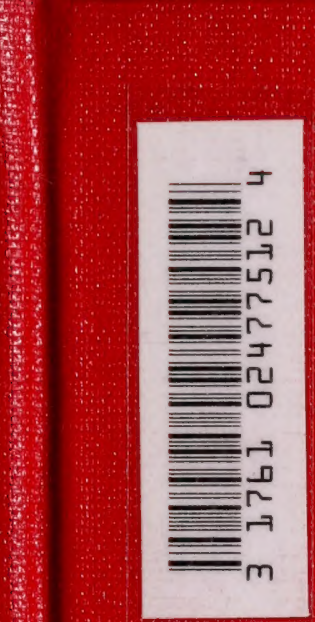


Digitized by the Internet Archive in 2007 with funding from Microsoft Corporation 


Forest Entomology

BY

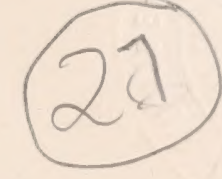

A. T. GILLANDERS, F.E.S.

WOODS MANAGER TO HIS GRACE THE DUKE OF NORTHUMBERLAND, K.G.

WITH 35I ILLUSTRATIONS
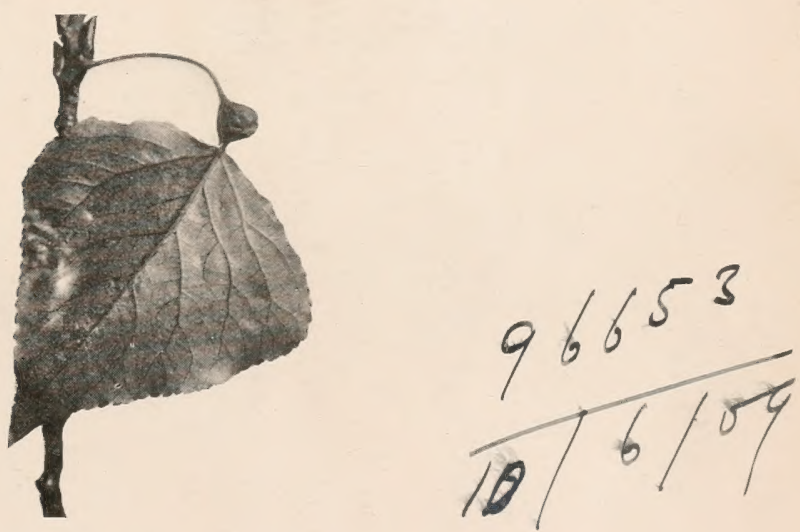

William Blackwood \& Sons

Edinburgh and London

1908

\author{
LIBRARY \\ FACULTY OF FORESTRY \\ UNIVERSITY OF TORONTO
}




$$
\begin{aligned}
& S B \\
& 761 \\
& 645
\end{aligned}
$$




\section{DEDICATED BY PERMISSION}

TO

HIS GRACE

THE DUKE OF NORTHUMBERLAND, K.G. 



\section{PREFACE.}

In submitting a book on a branch of Natural Science which has required any degree of research during its preparation, or which otherwise is intended as a guide for research, perhaps no one realises its shortcomings more than the writer. At least this is certainly the feeling of the author on the present occasion.

The book was begun in a very humble way. Having always had a strong inclination for Natural Science, and further for studying subjects associated with the scientific aspect of forest trees, I began as far back as 1887, while residing in Cheshire, to write papers on Forest Insects for the Warrington Field Club. To that district, with its Natural History clubs or societies, and the many excellent men I met. in connection with them, I owe a very deep debt of gratitude. I cannot in the present circumstances enumerate all to whom I am indebted for assistance in the present book, but my first teacher in Entomology was the late Mr Berry Kendrick of Warrington, who gave me most ungrudgingly all the help any one could possibly give to a beginner. Of the Warrington Field Club itself it is impossible to speak too highly as a Natural History society. Composed of some fifty members, 
original papers were given every fortnight during the winter months, often accruing from investigation during the summer months, and the members freely criticised the paper of the evening. This, though perhaps not always appreciated at the time, was in itself a most excellent school.

In a similar way I am indebted to the Manchester Microscopical Society for a great deal of ready help from its members. This Society, unlike the former, published the papers of its members, and I have therefore to sincerely thank it for publishing my papers on "Forest Insects," and, further, for kindly giving me the blocks prepared from my own negatives, some of which I have used for the present book.

I have also to thank the Chester Society of Natural Science for many extended courtesies given from time to time. The material for this book has been collected in Cheshire and Northumberland, but more especially the former county.

I am also indebted to the Country Gentlemen's Association, the Highland and Agricultural Society of Scotland, and the Royal English Arboricultural Society for publishing papers on Forest Entomology.

Turning from societies to individuals, it is almost impossible to acknowledge without being invidious those who have assisted me in the subject-matter of the volume. Two names may be mentioned. $\mathrm{Mr}$ R. Newstead, author of 'A Monograph of British Coccidæ,' gave me from time to time much assistance on Scale Insects. Mr A. Flatters, Manchester, has given me great help in microscopical manipulation, and has, in addition to the figures acknowledged with his name, photographed several specimens from my own microscopic slides, as, for example, the tiny Cecidomyia flies.

As regards the first works from which I derived considerable assistance, I may specially mention 'A List of Insects on 
Forest 'Trees,' by Mr S. L. Mosley, Huddersfield, and the splendid 'Mamual of Injurious Insects' by the late Miss Ormerod. Of the latter I cannot speak too highly, more especially as Miss Ormerod gave me very great cncouragement by correspondence.

As the period during which I have studied the subject has extended over twenty years, it is obvious that much original work has been done by many workers during that time. I have tried, so far as means or leisure would afford, to keep in touch with all original work. In order, therefore, that the sturent may get the full advantage of that, I have, whenever I found the work of others more suitable than my own, quoted from those writers. In most cases this has been done by direct permission of the author, but in all cases when giving an extract I have endearoured to duly acknowledge the same. In this advanced age of ours, knowledge, more especially Entomological knowledge, is no longer the property of any one individual. Hence all quotations are freely given as epitomised knowledge suitable for the student. They are given to obviate at first the necessity of consulting other works, and yet at the same time lie a guicle as to what other works he may consult for fuller information. It will be apparent that the majority of quotations are of a systematic nature. Hence the great difficulty in preparing the book has been to amalgamate the systematic with the economic, and so maintain a due proportion. On the one hand, if too many details of a systematic nature were given, the work would not only have been very much overladen, but the practical man would be impatient in reading it: on the other hand, if too few systematic details were given, it would not act as a guicle to fuller inquiries, or form, as designed, a suitable text-hook for students at agricultural and other colleges. The main 
feature which is attempted is recoynition of the insect from the damage, together with systematic characters and life-history details.

In studying the subject from the economic point of view, I have become convinced, from a prolonged study of the subject, that the economic stulent must of necessity stuly the systematic sicle ancl associate himself with systematic men. Hence, for example, I have added often, in extenso, extracts from valuaile works like Fowler's 'British Coleoptera, de. At the same time, the matter is so arranged that the begimer, or the practical man, may at first, if he chooses, skip them, and study the nature of the injuries, the life-history of the insect, and in some cases the remedies which may be adopted. If, however, the subject is to be thoroughly studied, the systematic points must be ultimately mastered.

With a view of making the work more reliable, I have submitted each chapter in proof to men who have specially studied particular sections or families of insects, and in all cases I am glad to count these specialists as personal friends. As the work embraces nearly all families of insects, this was considered all the more advisable, and though the changes made in the proof form by these specialists were comparatively few, yet in every case they were most important from the systematic point of view.

The following are the names of those who looked over the respective chapters in proof form-viz., Mr E. T. Connold; "Gall-Mites" and "Oak Galls"; Mr R. S. Bagnall, "Coleoptera"; $\operatorname{Mr}$ A. C. Forbes, "Scolytidæ"; Rev. F. D. Morice, "Saw-flies"; Mr R. Newstead, "Scale-Insects"; Mr J. Collins, "Lepicloptera"; Mr F. V. Theobald, "Aphididie" and "Diptera."

I have also to thank Mr J. F. Annand, Lecturer on Forestry, 
Armstrong College, Newcastle, for kindly looking over the MIS. previous to sending it to the publishers, and also for discussing many of the practical points with me.

I am specially indelited to Commander J. J. Wraller, R.N., Oxford, for kindly correcting the final proofs.

With reference to the illustrations, for the loan of blocks or electros I am indebted to Messrs Sampson, Low, Marston, \& Co., Ltd., for figs. 14, 16, 20, and 21; to Professor Miall for fig. 18 ; to Messrs L. Reeve \& Co. for figs. 39, 41', and 42; to the Ray Society for figs. 202 and 210, and also for granting permission to photograph figs. 21:;, 214, 2 $80,22.2$, 281,287 , and 311 ; to Messrs Healley Mrothers for figs. 175,221 , and 270 ; to the Proprietors of 'The Entomologist's Monthly Magazine' for figs. 157, 158, and 159. Mr W. R. Fisher has given me much encouragement from time to time, and I have to thank him for receiving from Messrs Bradbury, Agnew, \& Co., Ltul, the large number of blocksviz., figs. $47,48,49,50,60,61,78,79,92,121,126,127$, $163,164,238,239,240$, and 241 . I also owe thanks to Messrs Blackwood for figs. 45, 46, 72, 7:, 79, 101, 102, 104, and 245, from 'The Forester,' by Dr J. Nisbet. With the exception of the figures taken from the valuable German works, and acknowleilged under each figure respectively, all the others are original.

Finally, I beg to say that I submit the knowledge contained in the book with a feeling that I lave just about the necessary amount of knowledge to make a begimning rather than a finish; and I trust that the student will take up the sulject with the object of making a study of it on his own account, and verify each point by observation and rearing. In other words, the student must consider the work as an introduction only. Further, there is the most important point left 
to the last-viz., the study of German literature. The Germans are our great teachers in this branch of knowledge, and I have added many points and illustrations from German sources with the distinct object of showing their superiority, and inducing students to study their most valuable works.

Park Cottage, Alnwick,

May 1908. 


\section{CONTENTS.}

CHAP.

PAGE

PREFACE . . . . . . . . rii

INTRODUCTION . . . . . . . . 1

I. ERIOPHYIDE (PHYTOPTIDE) OR GALL-MHTES . . . 19

II. Coleoptera (BeEtles) . . . . . . 37

III. $"$-SCOLYTIDE (BARK-BEETLES) . . . 8.5

IV. HYMENOPTERA-OAK GALIS . . . . . 130

V. $"$-SAW-FLIES, ETC. . . . . 164

TI. COCCID

III. LEPIDOPTERA (MOTHS) . . . . . . 240

VIII. APHIDIDE (GREEN-FLY) . . . . . . 290

IX. DIPTERA (TWO-WINGED FLIES) . . . . . 339

X. PART I.-PSYLLIDE . . . . . . 363

II II.-CICADIDIE . . . . . . . 369

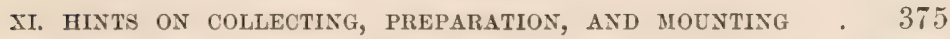

XII. INSECTICIDES AND. GENERAL REMEDIES . . . 387

XIII. BENEFICIAL INSECTS . . . . . . 398

XIV. LIST OF TREES WITH INJURIOUS INSECTS . . . 402

INDEX . . . . . . 417 



\section{LIST OF ILLUSTRATIONS.}

\section{INIRODUCTION.}

1. Eggs of Arctia menthastri.

2. Eggs of Bombyx neustria on birch

3. Typical forms of larve :

4. Typical pupal form of an insect.

5. Pupal case of Vanessa urticce

6. First emergence of Tortoiseshell Butterfly from pupal case

7. Emergence of Tortoiseshell Butterfly more fully advanced.

8, 9. Fully developed Tortoiseshell Buttertly

10. Typical mouth parts of insects

11. Compound eye of insect as seen under the microscope

12. Typical forms of antennæ .

13. Typical form of leg . .

14. Diagram of longitudinal section of an insect.

15. Horizontal section through the head of a worker bee

16. Diagram of the chief trunks of the tracheal system of an insect

17. Trachea of butterfly .

18. Food canal of cockroach

Diagrams of the heart of an insect

20. Female genital organs of the cockchafer
HIG.

21. Male genital organs of the

cockchafer . . 17

22. Eriophyes rudis

ERIOPHYID E (GALL-Mites).

23. Abortive swollen buds on hazel caused by Erioplyyes avellane

PAGF

24. Abortive swollen buds on birch swollen buts on

25. Abortive swollen buds on English yew . . 26

26. "Nail-galls" on leaf of lime-tree . . 27

27. Galls on leaves of field maple caused by Eriophyes macrochelus .

28. Galls on leaf of field maple caused - by Eriophyes macrorhynchus

29. Galls on leaves of common alder caused by Eriophyes lavis . .

30. Galls on midrib of the leaves of common alder caused by Eriophyes axillaris .

31. Galls on leaf of Wayfaringtree caused by Eriophyes tetanothrix

32. Malformation of the flower of ash caused by Eriophyes fraxini . .

33. Edges of hawthorn leaf rolled inwards by Eri- 
34. Surface of leaflets of mountain-ash injured by Eriophyes aucuparice.

35. Edges of leaves of blackthorn rolled inwards by species of Eriophyes

36. Dorsal surface and side view of Phyllocoptes carpini .

37. Galls on leaf of sycamore caused by Phyllocoptes acericola

\section{COLEOPTERA (BEETLES).}

38. Typical larvæ of beetles .

39. Head of Cicindela (magnified)

40. True wings of beetle

41. Typical beetle (upper side)

42. Typical beetle (under side)

43. Stag - beetles, male and female. .

44. Portion of ash timber injured by larvæ of stagbeetle

45. Young beech seedling, the roots of which have been destroyed by larvie of May beetle.

46. The common cockchafer or May beetle: feelers, chrysalis, \&c.

47. Melolontha hippocastani .

48, 49. Injury caused to beech saplings by Agrilusviridis

50. Ayrilus viridis .

51. Portion of dead hawthorn stem burrowed by larvæ of Priobium castaneum .

.2. Markings of larvæ of $E_{r} r$ nobius mollis on spruce pole

53. Clytus arietis (Wasp beetle)

54. Rhasium inquisitor.

55. Rhagium bifasciatum

56. Acanthocinus wdilis .

57. Saperda carcharias

58. Larva of Saperda carcharias

59. Injury caused to stem of aspen poplar by larvæe of Saperda populnea.

60. Melasoma populi: beetle, larva, and pupa
61. Injuries done by Melasoma populi .

62. Phyllodecta vitelline (Willow beetle). .

63. Willow leaf injured by larvæ of IVillow beetle

64. Leaf of balsam poplar injured by larvæ of Willow beetle.

65. Oak leaves rolled by Attelabus curculionides.

66. Attelabus curculionides .

67. Birch leaves rolled by $D e$ poraïs betulce $\quad$. $\quad 67$

68. Deporaüs betula . . 65

69. Otiorrhynchus picipes $\quad 69$

70. Otiorrhynchus sulcatus (Vine weevil).

71. Foliage of mountain-ash eaten by Phyllobius maculicornis .

72. Young spruce plants gnawed by Hylobius abietis . .

73. Hylobius abietis (Pine weevil), beetle, larva, and pupa 67 69

74. Cocoons of Pissodes pini on stem of Scots pine

75. Pissodes pini

76. Young pine-stem barked to show pupal-beds of Pissodes notatus . .

77. Beech leaves showing injuries done by larva and holes eaten by Orchestes fagi

78. Larval burrows of Cryptorrhynclues lapathi in alder stems . . 82

79. Cryptorrhynchus lapathi . $\$ 3$

80. Balanimus nucum . . S3

81. Portion of beech timber injured by Rhopalomesites Tardyi

\section{COLEOPTERA (SCOLYIIDE).}

82. Typical workings of "barkbeetles" . .

83. Antenna of Hylesinus crenatus 
84. Markings of Scolytus destructor in bark of English elm

85. Showing exit-holes of same

86. Scolytus destructor .

87. Markings of Scolytus muni in branch of apple

SS. Markings of Scolytusmultistriatus in bark of elm.

89. Markings of Scolytus intricatus on oak pole

90. Scolyius intricatus .

91. Markings of Hylastes palliatus

92. Hylastes palliatus .

93. Markings of Hylesinus crenatus

94. Hylesinus crenatus

95. Markings of Hylesinus fraxini

96. Hylesinus fraxini .

97. Markings of Hylesinus oleiperda

98. Hylesinus oleiperda

99. Markings of Hylesinus vittatus

100. Hylesinus vittatus

101. Shoot of Scots pine showing the entrance-hole and boring of a pine beetle.

102. Showing mother and larval galleries in process of formation

103. Portion of bark of Scots pine, showing two mother-galleries and larval workings of pine beetle.

104. Hylurgus piniperla

105. Markings of Phloeophthorus rhododactylus on gorse.

106. Markings of Phlceophthorus rhododactylus on broom

107. Phlocophthorus rhododactylus

103. Markings of Cryphalus abietis. .

109. Cryphalus abietis " 110. Showing "exit-holes" of Cryphalus tilice. .

111. Markings of Cryphatus tilioe on lime

112. Markings of Cryphalus fagi
113. Xylocleptes bispinus.

114. Mother-gallery of Dryo.

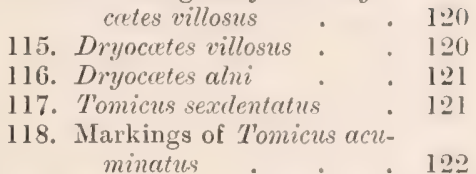

94

95

96

96

97

97

100

100

102

103

104

105

105

106

106

107

$10 \mathrm{~s}$

108

109

110

113

113

114

117

117

118

$11 \mathrm{~s}$

118

119. Markings of Pityogenes bidentatus (initial stage)

120. Fully developed markings of Pityorjenes bidentatus

121. Pityogenes bidentatus

122. Block of wood shown in perspective to illustrate the workings of the genus Trypodendron.

125

123. Workings of T'rypodendron lineatum

120

120

121

121

122

123

123

124

124. Trypotendron lineatum?

125. Markings of Trypodendron domesticum. . . 127

126. Xyleborus dispar (male) . 128

127. Xyleborus dispar (female) 12s

128. Burrows of Xyleborus dispar

129

HYMENOPTERA (OAK-GALLS).

129. Gall-fly of "oak-apple" and structural details . 138

130. Galls of Neuroterus lenticularis

140

131. Neuroterus lenticularis . 141

132. Galls of Spathergaster baccartum on male flowers of oak

142

133. Galls of Spathegaster baccarum on leaves of oak 142

134. Spathegaster baccarum . 143

135. Galls of Neuroterus fumipennis . . . 144

136. Galls of Spathegaster tricolor. . 144

137. Galls of Neuroterus lieviusculus

138. Galls of Spathergaster albipes... . 145

139. Galls of Neuroterus numismatis.

140. Gall of Aphilothrix radicis

141. Galls of Aphilothrix corticis

142. Galls of Aphilothrix globuli

143. Gall of Andricus inflator. 
1.4. Galls of Andricus cuvvator

169. Galls of Pontania salicis . 182

145. Injury done to leading shoot by gall of Andricus curverutor

170. Galls of Pontania bella

171. Galls of Pontania gallicola . . 188

146. Galls of Aphilothrix quadrilineatc

172. Galls of Pontania ischnocerus . . . .

147. Galls of Aphilothrix albopunctata

145. Gall of Autricus ramuli (cotton gall)

149. Galls of Aphilothrix fecundatrix . . .

150. Gall of Dryophanta scutellaris

151. Galls of Dryophanta longiventris

152. Galls of Dryophanta divisa

153. Galls of Biorhiza aptera .

15t. Gall of Teras terminalis .

155. Galls of Biorhiza remum .

156. Galls of Cynips Kollari (marble gall)

\section{HYMENOPTERA (SAW-FLIES).}

157. Thorax of a saw-fly: dorsal surface.

158. Lateral or side view of fig. 157 . . 167

159. Typical upper wing of saw-fly . . 168

160. Trichiosoma tibialis $\quad 173$

161. Cocoon of Trichiosoma after escape of fly .

162. Larve of Trichiosoma on hawthorn leaf

163. Lophyrus pini (Pine sawfly), male. .

164. Lophyrus pini (Pine sawfly), female.

165. Foliage of Scots pine eaten by larvæ of Pine sawfly. Injury done by first brood of the season

166. Pupal case of Lophyrus

167. Foliage of Scots pine eaten by larve of l'ine savfly. Injury done by second brood of the season

165. Galls of Eurra pentandree

173. Leaf of goat willow eaten by larve of Pontania salicis.

174. Larve of Croesus seplentrionalis on alder.

175. Croesus septentrionalis: insect and larvæ . . 186

176. Foliage of larch injured by larvæ of Nematus Erichsonii . . . 187

177. Nematus Exichsonii. . 187

178. Larvæ of Nematus Erichsonii . . . $18 \mathrm{~s}$

179. Pupal cases of Nematus Erichsonii . . . 188

180. Plank of silver fir injured by Sirex gigas . . 189

181. Sirex gigas (female) $\quad 190$

182. Sirex gigas (male) . $\quad 190$

183. Spruce timber injured by Sirex juvencus . . 191

184. Sirex juvencus (female) . 191

185. Sirex juvencus (male) , 191

186. Injury done to ash stem by hornet . . . 192

187. Hornet (Vespa Crabro) . 193

188. Galls on under side of leaf of dog-rose caused by Rhodites eglanteria.

189. "Moss or pin - cushion gall," caused by Rhod. ites rase . .

190. Seeds of Douglas fir injured by Mlegastigmus spermotrophus. .

176 191. Megastigmus spermotrophus (female) . . 196

192. Megastigmus spermotrophus (male)

177 | 193. Seeds of silver fir injured by Megastigmus strobilobius.

(U)CCII).E SCALE-INSECTS).

194. Cerataphis latanie (fringed aphis) on palm . . $\doteq 03$ 
195. Scale-like secretion of Aleurocles on leaf of tomato

196. Female scale of Aspidiotus

197. Male scale of Aspidiotus .

19S. Female scale of Diaspis .

199. Male scale of Diaspis

200. Female scale of Chionaspis and Nytilaspis . 207

201. Male scale of Chionaspis .

202. Pygidium, or anal segment, of Mytilaspis pomorum, showing dorsal and ventral parts, \&c. .

203. Male scales of Chionaspis salicis.

204. Female scales of Chionaspis salicis

205. Life-history of Chionaspis salicis.

206. Scales of Aspidiotus on leaf of Lapageria

207. Scale of $A$ spidiotus on leaf of Stephanotis .

20S. Scale of Aulacaspis rose on dog-rose

209. Female scales of $L$ canium caprece, "brown scale," on sycamore

211. Adult female Lecanium after treatment with potash $\times 20$.

211. Typical antennæ of female Lecrnium .

212. Male and female scales of Pulvinarice.

213. Male of Pulvinaria, species found on currant.

214. Male of Lecanium, species found on sycamore

215. Scales of Physokiermes abietis

216. Depressions on twigs of oak caused by Asterolecanium variolosum .

217. Pseudococcusacerison bark of hornbeam

21S. Antenna of Pseudococcus aceris.

219. Leg of Pseudococcus aceris 220. Rostrum of Pseudococcus aceris .

2:21. Cryptococcus fagi on beech 222. A pterococcus fraxini .
LEPIDOPTERA (МоTHS).

223. Smerinthus populi . . 24:3

224. Smerinthus ocellatus . $\geq \pm 4$

225. Timber of goat willow injured by larva of Trochilium bembeciformis .

226. Pupal case of T'rochilium bembeciformis . . 24j

227. Trochilium bembeciformis 24.5

229. Oak plank injured by larvæ of goat moth . 246

2:29. Cossus ligniperda . . $\mathbf{2 4 6}$

230. Larva of Goat Moth , 247

231. Pupa of Goat Moth a 247

232. Zeurera cesculi . . 245

233. Orgyia antiqua . . 249

234. Pupa of Puss Moth on twig of birch . . 2.51

235. Dicranura vimula . . 2.51

236. Pygera bucephala . . 252

217 237. Larvæ of Buff-tip Moth on twig of oak . . 252

217 238. Larva of Bordered White Moth . . . . 2.5t

217 239. Pupa of Bordered White Ioth. . 25t

240. Fidonia piniaria (male) . 254

241. Fidonia piniaria (female) 254

242. Foliage of lime-tree eaten by larvæ of Winter Moth 255

220 243. Leaf of wych elm eaten by larve of Winter Moth. 255

220 24t. Foliage of sycamore eaten by larre of Winter Moth 256

224 245. Winter Woth : male, female, and caterpillar . 256

224 246. Trachea piniperda. . 2.5

247 . Cone of silver fir partially eaten by larvæ of Dioryctria abietella . 25

248. Dioryctria abietella. . 259

249. Foliage of oak destroyed by larve of the Green Tortrix Moth

261

250. Foliage of hazel injured by larvæ of T'ortrix ribeana

264

2.51. Leading shoot of poplar injured by larva of Hedya ocellana . .

252. Shoots of English yew injured by larvæ of Batodes angustiorana.
265

266 
253. Shoot of holly injured by Peclisca ophthalmicance

254. "Leading" bud of Scots pine injured by larva of Retinia turionana.

255. "Leading shoot" of young Scots pine injured by larva of Retinia buolience

256. Retinia buoliana, male and female

257. Gall of resin on Scots pine caused by Retinice resinella

255. Retinia resinella

259. Hyponomeuta evonymellus

260. Web and empty pupal cases of Hyponomeuta evonymellu.s.

261. Leading bud of ash-tree injured by larva of Prays curtisellus.

26:. Young ash-tree "forked" by larva of Prays curtisellus

263. Prays curtisellus : its lifehistory after Judeich and Nitsche

264. Leaves of osier drawn together by larva of Depressaria conterminelle. .

265. Shoots of broom drawn together by larva of Depressaria assimilella.

266 . Tops of young larch-trees injured by larvæ of Argyrestlica levigatella

267. Leaf of lilac injured by the mining larve of Gracillaria syringella .

268. Normal foliage of larch .

269. Foliage of larch injured by larve of Coleophora laricella

270. Coleophora laricella: pupal ease and moth

271. Coleophora sp. on birch .

272. Typical blotch of Lithocolletis on oak leaf.

273. Injuries to foliage of holm oak by larvie of Lithocolletis messaniella

274. Foliage of laburnum injured by larvæ of Cemi-

ostoma laburnella

APHIDID E (GREen-FLY).

275. WVing of Aphis sambuci . 292

276. Wing of Schizoneura ulmi 292

277. Wing of Pemphigus pallidus. . 292

278. Wing of Chermes abietis. $\quad 292$

279. Terminal shoot of wild cherry injured by Myzus

cercesi. . . . 297

270

271

272

272

280. Melanoranthus salicis . 300

281. Eggs of Aphis cratogi on thorn . . $\quad 302$

282. Aphis-cratcegi. $\quad \cdot 302$

283. Aphis padi on bird-cherry 303

284. Aphis-sambuci . . 305

285. Chaitophorus aceris (special peculiar form) . .307

274 286. Eggs of Lachnus longipes on oak

311

287. Phyllaphis fagi . . 312

274 285. Foliage of copper beech (under side) covered with Phyllaphis fagi.

289. Leaves of wych elm rolled by Schizoneura ulmi.

290. Gall on leaf-stalk of poplar caused by Pemphigus bursarius

291. "Stem mother" of Pemphiqus bursarius

292 Larval stage of Pemphigus bursarius

293. Pupal stage of Pemphigus bursarius . .

294. Winged form of Pemphigus bursarius .

280

28:2

282

283

284

285

286

295. "Corkscrew" gall on leafstalk of poplar caused by Pemphigus spirotheca

296. Gall of Pemphigus pallidus on midrib of leaf

297. Galls of Tetraneura vilmi .

298. Gall of Chermes abietis .

299. Early stage of gall of Chermes abietis.

300. Winged forms of Chermes abietis on spruce leaves

301. Chermes laricis on bark of larch . 
302. Foliage of larch injured by attack of Chermes.

303. Chermes laricis on foliage of larch

304. Chermies pini on stem of young Scots pine

305. Chermes pini on terminal shoot of Scots pine.

306. Terminal shoot of Scots pine killed by Chermes pini . . . . 332

307. Chermes corticalis on branch of Weymouth pine

308. Chermes picex on bark of silver fir.

309. Hibernating winter forms of four species of Chermes.

310. Under side of oak leaf infested with Phylloxera punctata . . .

311. Apterous female, eggs, and larva of Phylloxera punctata

312. Winged form of Phylloxera punctata

\section{DIPTERA (Two-winged Flies).}

313. Leaves of Salix viminalis rolled by Cecidomyia marginemtorquens

314. Cecidomyia marginemtorquens (male)

315. Cecidomyia marginemtorquens (female)

316. Shoot of hawthorn injured by Cecidomyia cratcegi

317. Twig of yew injured by Cecidomyia taxi.

318. Shoots of Salix caprea injured by Cecidomyia rosaria

319. Cecidomyia rosaria (male)

320 . Section of willow stem showing injuries caused by Cecidomyia saliciperda.

321. Portion of bark and wood cut off to show the injuries of Cecidomyia saliciperde.
322. Leading shoots of a species of willow injured by Cecidomyia heterobia.

323. Twig of Salix caprea injured by Cecidomyia salicis.

3.511

324. Cecidomyia salicis (male). 325. Leaf of lime-tree injured by Cecidomyia tiliam volens.

326. Shoots of lime-tree injured by Cecidomyia tiliam volens. . .

327. Foliage of ash injured by Diplosis botularia

325. Edges of oak leaves folded by Diplosis dryobia . 3.52

329. Galls on leaf-stalks of aspen poplar caused by Diplosis tremulce.

353

330. Galls on upper surface of beech leaves caused by Hormomyia piliger.

354

331. Leaves of goat willow galled by Hormomyia caprect

332. Galls on broom caused by Asphondylia sarothamni

333. Asphondylia sarothamni .

334. Pupa of Asphondylia sarothamni

335. Gall on stem of bramble caused by Lasiopterca rubi

356

356

336. Galls on stems of willow caused by Agromyza schineri

337. Leaf of snowberry mined by Chromatomyia obscurella

338. Leaf of holly blotched by Chromatomyia iliris.

339. Bibio marci (males and females)

\section{PSYLLID Æ.}

340. Leaflets of ash injured by Psyllopsis fraxini

341. Leaves of box injured by Psylla buxi.

342. Young form of Psylla crateegi . 
343. Tip of hawthorn shoot injured by Psylla cratagi 314. Twig of alder injured by Psylla alni . . . 368

$$
\text { CICADIDA. }
$$

345. Typhlocyba ulmi

346. Typhlocyba ulmi

347. Young form of Typhlocybe ulmi
COLLECTING, PREPARATION, AND MOUNTING.

348. Simple arrangement for dissecting specimens under a magnifyingglass . . . 379

349. Proboscis of honey-bee 384

350. Tongue of house-fly . 384

351. Life-history stages of "Swallow-tail". Butterfly 


\section{FOREST ENTOMOLOGY.}

\section{INTRODUCTION.}

IT may appenr somewhat paradoxical to say that "Forest Entomology" differs from the "Entomology of the Forest." Under the latter heading the major portion of the science of entomology may be included, inasmuch as the student of general entomology, or the specialist of any particular group, will often find the forest one of his happiest hunting-grounds. This is due not only to the varieties of arboreal food and the varied forest flora, but to the game-preserving laws or customs continually furnishing carrion food, and demanding a varier cover for game-birds and feathered songsters, which doubtless act as sources of dissemination for many species of insects with comparatively poor powers of locomotion. With regard to "Forest Entomology," even in its widest sense we can only embrace directly all insects preferring an arboreal diet, and indirectly all other insects parasitic on arboreal-feeding insects.

As the field of natural history becomes broader and broader, natural science tends more and more towards specialisation; and while it is essential that the young student should gain a comprehensive view of kindred subjects, the adult who aspires to pose as a public instructor cannot make progress in any branch without limited concentration. Perhaps this narrowing is more essential in entomology than in many other branches of natural history.

The science of entomology may be studied from two different aspects-viz, from that of the collector, and of the economic entomologist or investigator.

The collector, who generally limits his work to one or two groups, 
tries ly ohservation and comparison to classify his captures according to the lifference in colour, size, and other variations. He also strives to enrich the local fauna by fresh captures. On the other hand, the economic entomologist seizes these data of the collector or systematic biologist, goes a step farther, and considers insects in relation to man, his person and property, either in so far as they affect his industrial products, his cultivated plants, or the wild plants of nature.

From a husbandry point of view, the science of economic entomology may be divided into three principal parts-viz., garden pests, farm pests, and forest pests. The last is obviously the most difficult to deal with.

Before any pest can be satisfactorily checked, it is indispensable to study the life-history of the insect-viz., the egg, the larva, the pupa, and the perfect insect,- - and then to deal with that stage in which the most practical results can be obtained.

Hitherto it has been customary to study only those insects which, by their numerical strength, have been injurious in the forest, but I renture to think it would be far more interesting and educational, either as an economic or a biological subject, to study all insects which prefer an arboreal diet. 'To carry this out, two methods of arrangement suggest themselves - viz., a botanical and an entomological. With regard to the former, it would be necessary to classify the respective trees, and then arrange those insects which feed on them. This method has been adopted by some American writers. It has, however, this drawback, that while several insects are fastidious as to their diet, others (except for the distinction between hardwoods and conifers) are general feeders. Several German writers follow an entomological method, and this course appears to be far more educational to the student of forest entomology.

As the forest is a field literally teeming with varieties of animal life, it may just he as well in passing to remind the practical husbandman and general naturalist that there are numerous creatures in the forest, under rotten bark and so forth, which are not in scientific language insects. Such creatures are snails, centipedes, spiders, and worms of various genera.

Hence two questions arise-viz. : (1) What relative position do insects occupy in the animal kingdom? and (2) What is an insect?

As regards the position of insects in the animal kingdom, natur- 
alists differ slightly in their arrangement; but it may be said that insects constitute a subdivision of the animal kingdom known as Arthropoda, which are characterised by having jointed limbs, and, as a rule, a distinctly divided body.

They rise in an ascending series in the following order-viz. :

ARTHROPODA (4 classes).

1. Crustacea - Crabs, Lobsters, \& c.

2. Arachnida . Mites, Scorpions, Spiders.

3. Mrriapoda . Centipedes and Millepedes.

4. Insecta . ... Insects.

In answer to the question, What is an insect? the general definition, with some common exceptions, is that an insect is a creature whose body is divided into three parts, has two antennæ, six legs, and, as a rule, passes through four stages of metamorphosis.

Accepting this general definition, it may be said that the creatures which, in point of anatomical structure and economic injuries, approach nearest to insects, are mites and spiclers; and as a rough-and-ready classification, it may be said that a mite is a creature whose body is of one piece, a spider two pieces, and an insect three.

The mites most injurious to vegetation are the Eriophyidæ (Phytoptidæ), or four-footed mites. Spiders do not affect trees directly, and therefore neel not be considered. We find a certain species of red-spider ${ }^{1}$ injurious to the foliage of ivy and other plants, sucking the juices from the leaves, and causing them to assume a sere appearance.

The whole realm of Entomology is divided into seven general or principal orders-viz., Coleoptera (beetles); Orthoptera (earwigs, crickets, grasshoppers, and locusts); Neuroptera (dragon-flies); Hymenoptera (ants, bees, and saw-flies); Lepidoptera (butterflies and moths); the Hesiptera, including the various species of bugs; and Diptera (two-winged flies).

The Hemiptera is subdivided into two principal divisions-viz, Hemiptera-Heteroptera, including the bugs; and Hemiptera-Homoptera, including Aphidæ or plant-lice, Cicadæ, Psyllidæ, and Coccidæ or scale-insects.

1 The so-called "red-spider"--the dreaded enemy of the gardener-is only a species of mite. 
With the exception of Orthoptera and Neuroptera, all the other orders are represented in forest entomology. Hence the necessity of versatility in entomological knowledge will be apparent.

Insects are further arranged into Families, Sub-families or Tribes, Genera, Species, and Varieties. There is, of

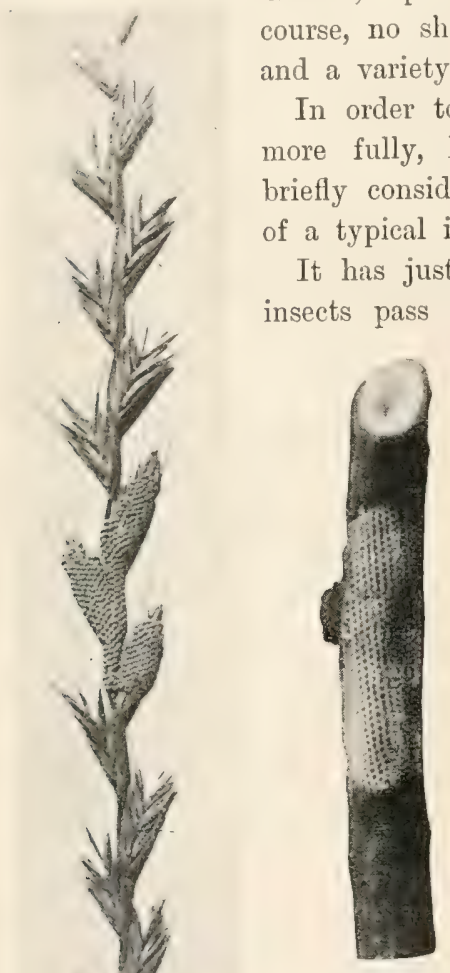

Fig. 2. - Eggs of the Lachey Moth (Bombyx neustria) on bireh twig. Found in Cheshire.
Fig. 1.- Eggs of White Ermine grass. (Photo by A. Flatters, Manchester.) phosis-viz., egg, larva, pupa, and perfect insect. When an insect passes through all these stages, the metamorphosis is said to be complete. When, however, it does not, - as, for instance, in the case of Aphidæ or plant-lice, - the metamorphosis is said to be incomplete.

Let us follow a typical example of a complete metamorphosis, commencing with the egg stage.

The eggs of insects are always deposited in the immediate vicinity of the food for the larve, as in figs. 1 and 2. In cases of many arboreal insects the eggs are often very difficult to discover. Sometimes they are concealed within the buds, in the midribs of leaves, the roots, bark, or other convenient places, according to the food of the larvæ. Insects adopt many devices to protect their eggs against weather and natural enemies, such as covering them over by a gummy secretion, the shedding of hairs, the formation of cocoons, and so forth. The (ugges of insects possess very strong powers of ritality, and frost gener- 
ally has very little effect on them. They vary very much in size, form, and markings. Some are smooth and spherical, others corrugated, sculptured, elongated, and tailed.

The structure and development, as seen under the microscope, form not only a very interesting study, but present many difficult biological problems. Amongst the higher egg-producing animals no eggr will develop without male fertilisation, but amongst insects there are many exceptions to this rule. In numerous cases eggs laid by virgin moths have been known to develop. Amongst saw-flies, certain generations of gall-wasps, plant-lice, and others, we have reproduction by virgin females. This law is known as parthenogenesis, or virgin reproduction without the intervention of a male, and a few special peculiarities will be considered under the respective families.

The morphological structure of the egr is somewhat complicated, more especially when we remember the philosophical writings of Weismann and others.

The term larva, caterpillar, maggot, or grub is generally applied to insects as they hatch out from the egg, and at this stage they generally differ in form and structure from the perfect insect. On the other hand, the term "nymph" is applied to the creature when it
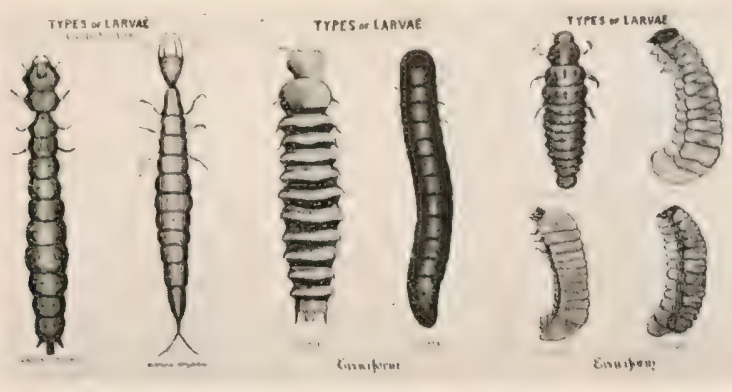

Fig. 3.-Typical forms of larre. (Flatters.)

bears a very strong resemblance to the perfect insect, as, for example, in the case of mites and Hemipterous insects.

The larva of a moth, on hatching from the egg, is usually a segmented body possessing six true legs. The caterpillar of a saw-fly has six true legs, like the larva of a moth, but has also several additional "prolegs," and consequently is easily distinguished. The maggrot of a fly is footless. Fig. 3 represents typical larvæ. 
In the case of the Aphididæ or greenfly, scale-insects, and plant-bugs, the young in the first stage, whether hatched from eggs or produced alive by the parent insect, resemble the perfect insect very much more than those of beetles, moths, and flies. But whatever shape and form they may take, the young insect in the first stage is always scientifically known as a larva. We have in forest insects all forms and classes of larve, and this variety is of great interest as a biological question. For instance, we find, as arboreal-feeding insects, active six-legged larvæ of a greenish colour, and harmonising with the foliage or lichens on the bark; while on the other hand we find the footless whitish grul, feeding within the wood. Thus we have two important factor's in the theory of evolution brought before us-viz., the absence and apparent absence of legs through disuse, and the harmony of colour to surroundings as a protection against natural enemies.

In the larval stage the insect feeds voraciously, and as a rule grows very fast. The skin of the creature, however, does not grow beyond certain limits, and when this stage is arrived at, the creature halts, as it were, throws off its skin, assumes a fresh coat, often of a different

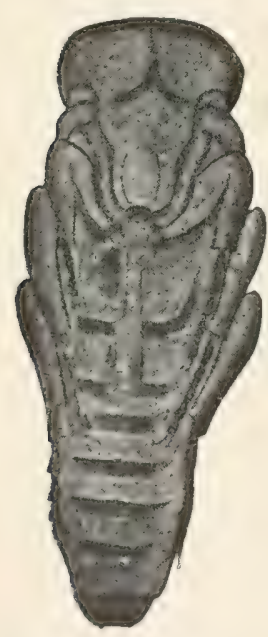

Fig. 4.-Typicul pural form of an insect. (Flatters.) colour, and again commences feeding. This process is known as moulting, and occurs several times during the larval stage until full srowth is reached. The duration of larval life in arboreal insects is very varied indeed. In some cases the period occupies only a few days, in others several years.

The pupa, or third stage of the life of an insect, is a period of rest or quiescence, when the insect takes no food. It is the period of quiet transformation, when the ugly crawling caterpillar is being transformed into the beautiful moth, or the carrion maggot into the swift airy fly. The pupal forms and habits of forest insects are very varied. Thus in beetles all the parts of the future insect are visible, saw-flies and moths form cocoons, and the two-winged flies form cases. Some descend into the ground to pupate, while others form hard cases on the food-plant. Fig. 4 may be considered, for general purposes, as a typical pupa.

The stages thus referred to-viz., egg, larva, and pupa-are the 
periods of growth and development. As soon as bursting from the pupal case takes place, the creature is then literally the perfect insect, inasmuch as there is no further change or development. It is well to bear this in mind, as it is a popular notion amongst certain people not conversant with natural history that small moths and flies are simply "young ones." Such, however, is not the case, for while there is often a difference in size amongst individuals, of the same species, it should be remembered that no growth takes place after full pupal emergence.

In demonstration of this, perhaps a typical case may be taken-viz., that of the Small Tortoiseshell Butterfly, Vanessa urtica. Fig. 5 represents the pupal case. In fig. 6 we have a representation of the first emergence from the pupal ease; in fig. 7 , which is later,

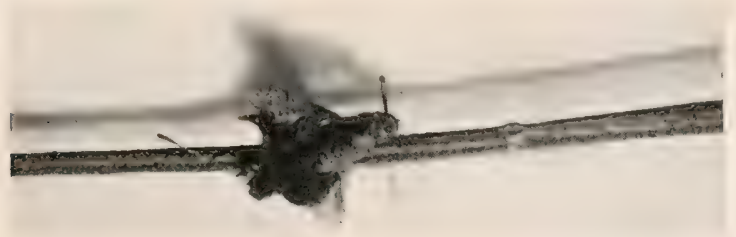

Fig. 6. -First emergence of Tortoiseshell Butter,iy from pupal case. (Flatters.)

the wings are slightly more expanded; and in figs. 8 and 9 we see a representation of the fully developed butterfly. The whole process

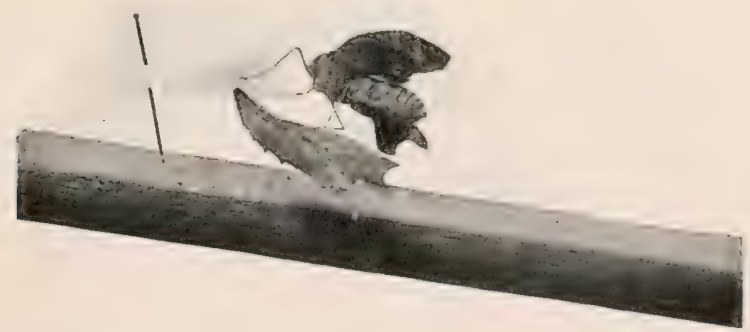

Fig. 7.--Emergence of 'T'ortoiseshell Butterfly more fully alvanced. (Flatters.)

of development, which is chiefly a question of wing expansion, takes at most only a few hours. 
In many cases where we have incomplete metamorphosis, the insect is injurious in all its respective stages, as, for instance, in Aphidæ and Cicadx. On the other hand, when the metamorphosis is complete, we find the insect injurious in larval and perfect stages, or

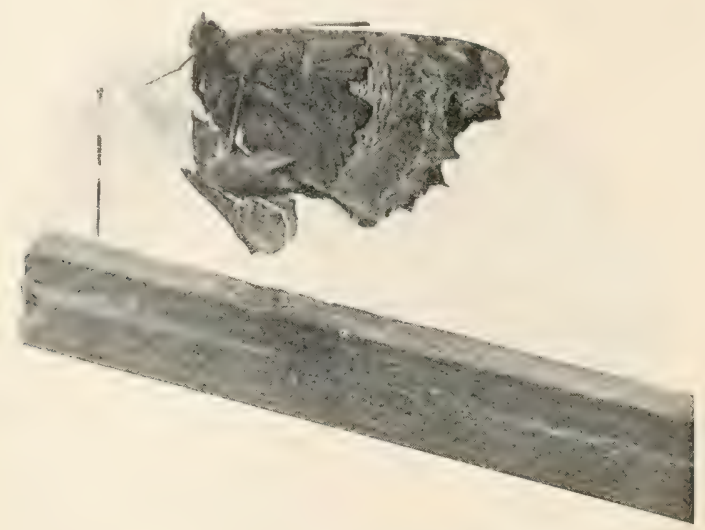

Fig. S. - Fully dereloped Tortoiseshell Butterfly. (Flatters.)

simply injurious in the larval stage alone. The perfect insect (or "imago," as it is termed in entomology) often takes no food whatever, except sipping water or juices, and the duration of life is often so short as to have become proverbial.

As a branch of economic entomology, the student of forest insects should strive to ascertain where and when egg-deposition takes place,

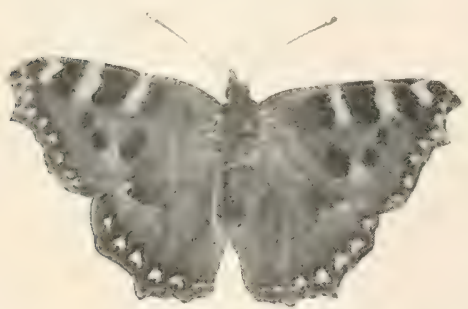

Fig. 9.-Fully developed Tortoiseshell Butterfy. (Flatters.) mind, that an insect is a creature whose body is divided into
three parts-head, thorax, and abdomen. As a biological subject,
insect anatomy and physiology is a very broad and interesting mind, that an insect is a creature whose body is divided into
three parts-head, thorax, and abdomen. As a biological subject,
insect anatomy and physiology is a very broad and interesting mind, that an insect is a creature whose body is divided into
three parts-head, thorax, and abdomen. As a biological subject,
insect anatomy and physiology is a very broad and interesting the egg stage, how long before the first moult and between the other larval moults, when and how long it remains in the pupal stage, and the time and appearnnce of the perfect insect-in short, a full life-history.

With regard to the structure of insects, it may be repeated, and must always be borne in
mind, that an insect is a creature whose body is divided into
three parts--head, thorax, and abdomen. As a biological subject,
insect anatomy and physiology is a very broad and interesting how long the insect remains in 
one, inasmuch as serial section-cutting and the highest powers of the microscope must be employed. This, though highly interesting in itself, is certainly not of vital importance to the young student of forest entomology. It is, however, indispensable that the salient features of head, thorax, and abdomen should in all cases be well studied, and in some special instances be committed to memory. It is upon these points that generic and specific characters depend. The advanced student with a fair amount of leisure would do well to study the internal anatomy of insects.

The head is theoretically composed of a number of pieces, but in general appearance is made up of one piece. On the under side it

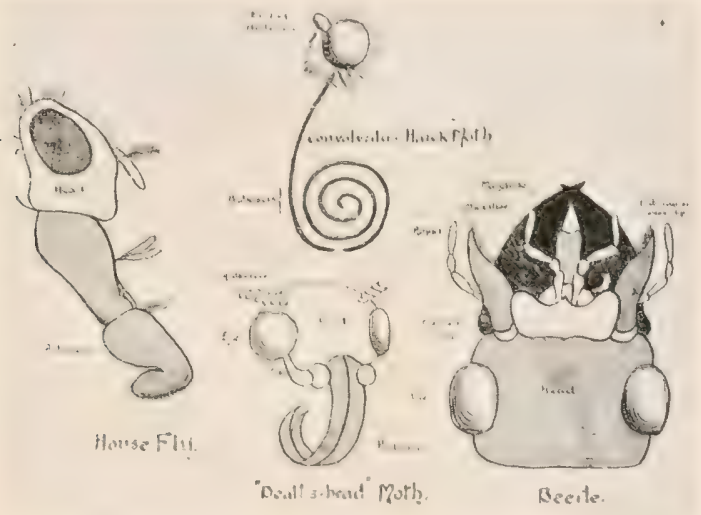

Fig. 10.-Typical mouth parts of insects. (Flatters.)

bears the mouth, which is adapted either for biting or sucking. The mouth arrangement separates the whole of the class Insecta into two principal divisions - viz., Mandilulate, or biting insects; and Hurste lata, or sucking insects. The biting mouth of the beetle and the trunk-like proboscis of the moth are cases in point. Fig. 10 represents typical mouth parts of insects.

The eyes in many cases form a prominent part of the head, and are of two kinds-compound and simple. The latter are termed ocelli. In some insects-as, for example, in the house-fly and hive-bee-the compound eyes cover nearly the whole of the head. The orbit of the eye is covered by a transparent skin termed the cornea. An examination under the microscope shows that the surface of the cornea is 
made up of a large number of six-sided cells, each of which is termed a corneal facet (fig. 11). The ocelli or simple eyes are placed between the compound eyes, or just in the midule of the forehead.

The antennæ, or horns, rise from the head. They are composed of several joints, and form good points for the discrimination of species. Any text-book of general entomology, or monograph of some particular group, will show that specific points very largely depend on the antennæ. This, for instance, is the case with the Aphididæ or plantlice. The joints of the antennæ have to be counted and compared. By a joint is meant not so much the division line between the pieces

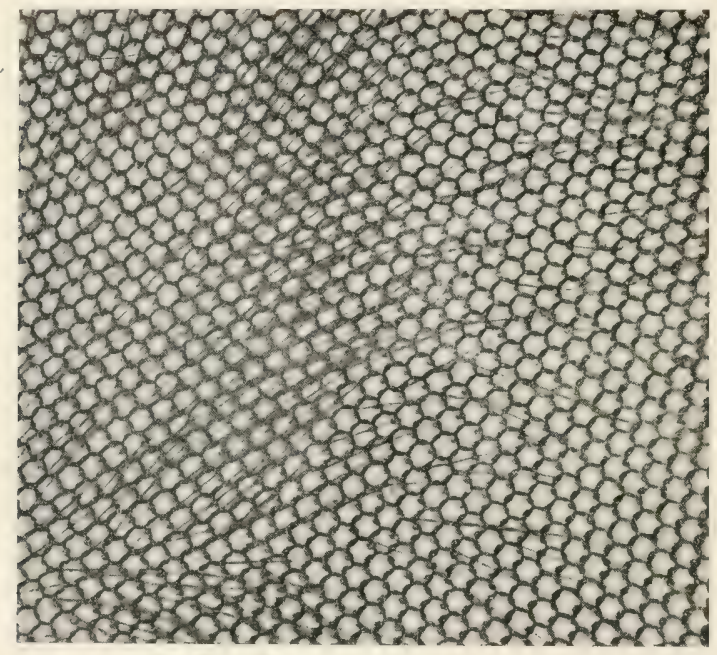

Fig. 11.-Compound eye of insect as seen under the microscope. (Flatters.)

as the actual portions themselves if separated at these lines. In counting joints we must begin from the head outwards, making sure the horn is properly and clearly separnted from the head. As a rule, the antenna is stouter at the junction with the head, and gradually tapers towards the other extremity: thus we say in a general way, from base to apex. The antennæ receive various designations, according to the structure, as, for example, in fig. 12. The physiological functions of the antennie are not fully understood, but they are supposed to be, to some extent, sense-organs.

The thorax or middle segment is theoretically composed of several 
pieces, and from this portion the wings and legs arise. It is further considered as being divided into three distinct portions - viz., prothorax, mesothorax, and metathorax. These segments vary in proportion in different insects, and they also vary in the respective stages of the life of an individual insect. The thorax and its component parts are of considerable importance in the discrimination of species, as, for instance, in the Hymenoptera.

The third segment is known as the abdomen, and is very variable in form, according to order and genus. It is generally composed of nine segments, and bears the organs of reproduction.

The wings, as appendages,
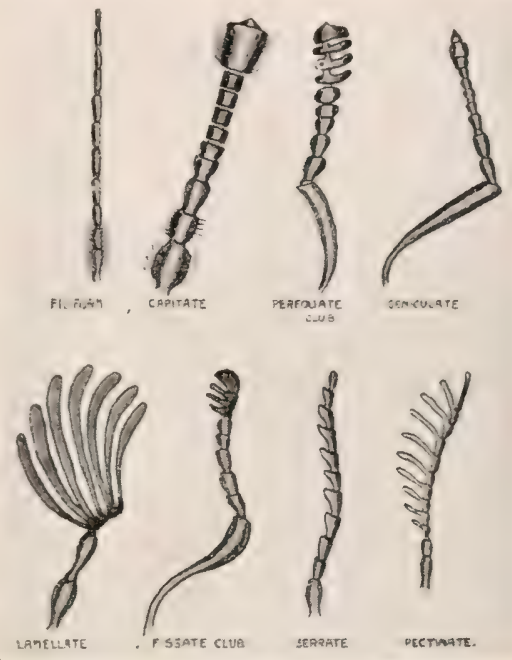

Fig. 12.-Typical forms of antennce. (Flatters.) are very important points in the discrimination of genera and species. In fact, some writers use the wings as a basis of elassification. So far as forest entomology is concerned, it is highly essential to make a detailed study of the structure of the wings of saw-flies, gall-flies, Aphididæ, and Diptera.

The structure of the leg is also of importance in the classification of species. If we separate a leg from the body of the insect and examine it, from the connection with the body to the tip, we shall find it is composed of several parts. The leg is attached to the body by a

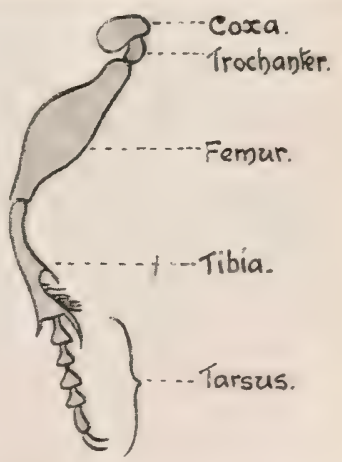

Fig. 13.-Typical form of leg. (Flatters.) joint called the coxc; next to this is a very small portion known as the trochanter, which serves as a sort of joint or hinge connecting the 
femur; then we have a long joint called the tibia; and finally, the joint called the tarsus, which is known as the foot. Fig. 13 is a representation of the different parts of the leg.

The foregoing characters represent the more important points as regarls external structure, but it is somewhat more difficult to deal with internal structure and function. To deal with too many details would simply embarrass the ordinary student, and at the same time the sulvject cannot possibly be intelligible to the student if too few points are presented.

The accompanying diagram (fig. 14), representing a longitudinal

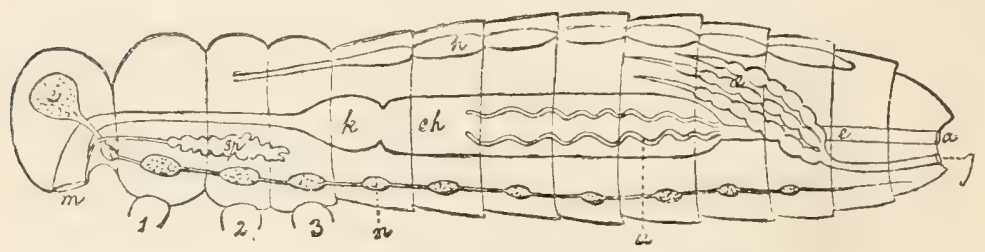

Fig. 14.-Diagram of longitudinal section of an insect, showing principal anatomical points of an insect. (From 'Text-Book of Zoology,' by Dr J. E. V. Boas.)

1-3, first and third pairs of legs cut awray; $a$, ants ; $c$, cerebral ganglion ; ch, mesenteron; $e$, proctodæum ; $g$, genital aperture; $h$, heart; $k$, crop; $m$, mouth; $n$, ventral ganglion; $s p$, salivary gland; $u$, malpighian tubule; $c e$, ovary.

section of an insect, shows the relative position of the more important anatomical points from a side view.

The nervous system of an insect resembles that of most other animals, inasmuch as the terminal seat of the nerve-centres is the brain, whence proceed other nerve-centres and nerves all over the

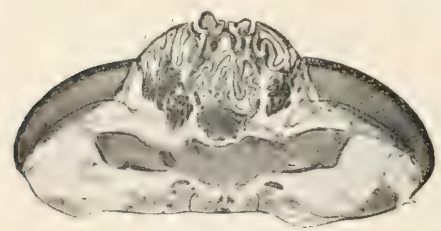

Fig. 15.-Horizontal section through the head of a worker bee, showing eyes and brain. (Section and photo by A. Flatters.)

body. The nerves receive impressions from the outside world, which react on the organism, and thus stimulate or restrain muscular action. Fig. 15 shows a photograph of a horizontal section through the head of a honey-bee.

The various convolutions of the brain should be noted; and as the development of these convolutions is indicative of intelligence, it is no wonder that the bee, in this respect, is considered as approaching nearer to man than any other animal.

The respiratory organs of an insect are composed of a system of 
tuhes, which are well represented in fig. 16. These tubes, or tracher, ramify throughout the whole of the body; and the air passes into them by means of special openings known as spiracles, which are situated alongside the body of the creature. These spiracles are somewhat complicated openings, inasmuch as they open to receive air, shut to maintain a supply, and again open for expulsion. The act of breathing, therefore, is somewhat after the nature of a bellows, inasmuch as air is received at a special opening and driven throughout the tubes. In addition to the function of breathing, it is obvious that the inflating of the tubes is associated with the machinery of flight. Fig. 17 is a photographic representation of a trachea from a butterfly.

The organs concerned with feeding and digestion occupy a considerable space in the bodycavity of many insects. From actual specimens this can only be understood by careful dissection and microscopical manipulation. The accompanying figure, however (fig. 18), taken from Miall and Denny, will convey a very good idea of these internal organs.

In the centre of the figure the food-canal is represented.

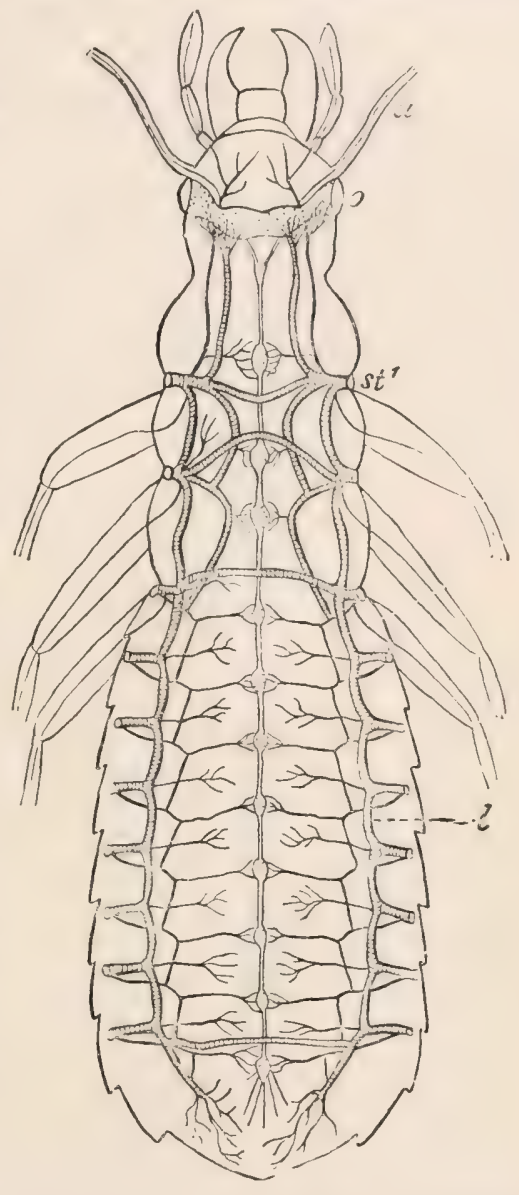

Fig. 16.-Diagram of the chief trunts of the tracheal system of an insect; the central nervous system is also shown.

$a$, antennæ ; 0 , eye ; st', anterior stigma ; $l$, longitudinal trunk. - After Kolbe. (From "TextBook of Zoology,' by Dr J. E. V. Boas.) At $s$ we have the salivary glands and reservoir which contain the saliva, which is not only beneficial in digesting the fool within the canal, but in some sucking insects is mixed with the crude 
sap of the plant before the juice is taken up by the proboscis. At $c$ we have the long crop, and below this we have the gizzard, which organism in some species is a favourite object for the microscope. Then we have a stellate arrangement of the cæcal tubes or blind tubes; and proceeding from this there is the stomach, which is simply a tube. At $k$ we have the kidney tubes, and then the small and large intestine, ending in the rectum and anus. In fig. 19

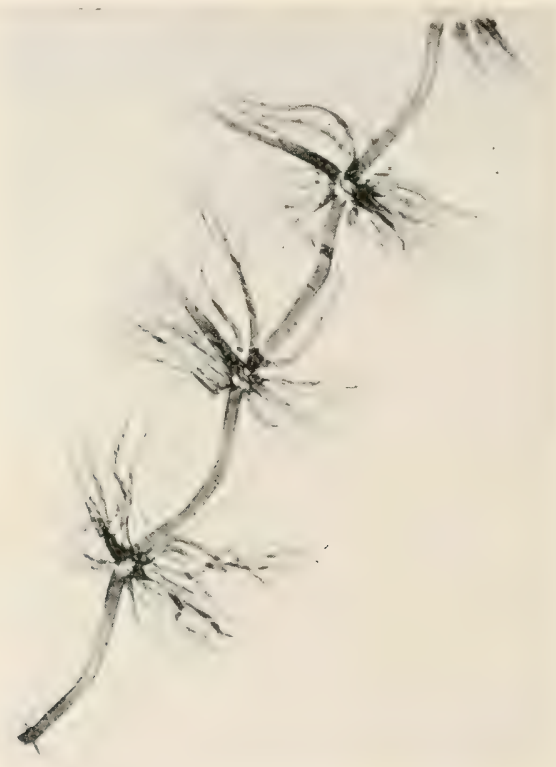

Fig 17.-Trachea of butterfly. (Flatters.)

we have a representation of the heart, which is a long muscular tube. separated by valves.

Having now considered the various structural details of an insect, it may be well to turn briefly to the reproductive organs, the functions of which serve to perpetuate the race. Insect reproduction may be either sexual or asexual. In the former, the union of two dissimilar cells is required-viz., a small-active (male) sperm cell (spermatozoon) with a large (passive) female cell (ovum) for the production of new individuals. In the latter class, female cells or 
eggs give rise to new individuals without the intervention of male (parthenogenesis).

The reproductive organs of insects may, according to instructions given in certain works on micruscopy, be carefully dissected from the abdomen, but the accompanying figures, together with the explanation, convey a very good idea of the reproductive organs of insects. The accompanying figures and explanation have been selected because they are not only large insects, but arboreal in their habits. It may also be noted that, as regards insects, the hive bee lias been carefully worked out in this respect, so that reference to any of the more important works on the bee would be found very helpful.

Genital organs. - "The female, as in other Arthropoda, possesses a pair of ovaries. Each consists of a varying number of tubules (ovarioles), which usually extend like fingers from the anterior end of the oviduct. Each ovariole is surrounded by a thin membrane, and is immature anteriorly, consisting of small homogeneous cells; farther back there are larger cells, young ova, lying

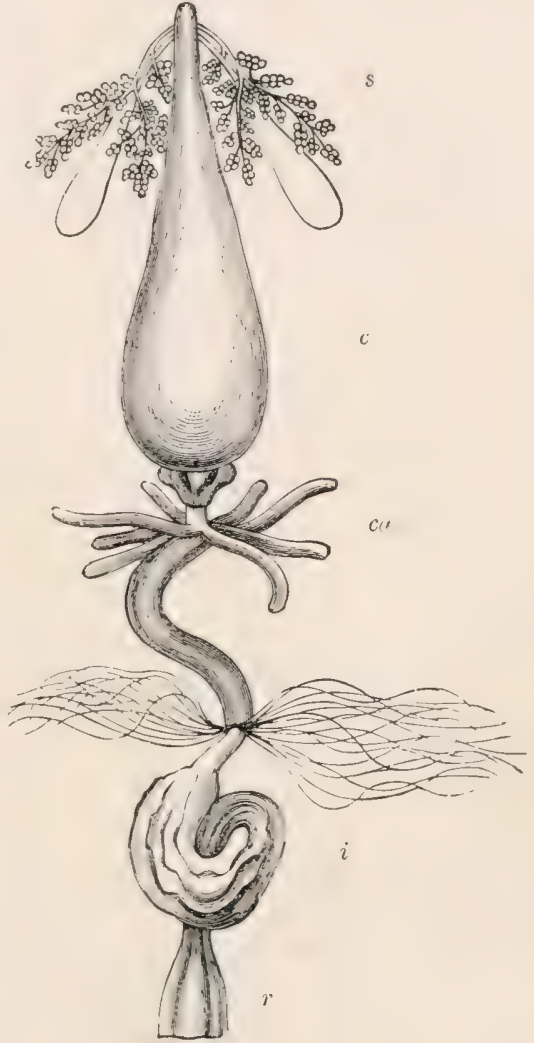

Fig. 18.-Food canal of cochroesh.

$s$, salivary glands and reservoir ; $c$, crop (the gizzard below it); cee, crecal tubes (below them the stomach) $; k$, kidney tubes: $i$, intestine ; $r$, rectum. Twice natural size. (From 'The Cockroach,' by Miall and Denny.) in the middle of the tube, and surrounded by smaller cells, which provide them with nutriment, and also secrete the shell (chorion) for the fully developed egg. The mature ova occupy the posterior ends of the ovarioles, and pass thence into the oviduct. When an 
exco passes into the latter, the corresponding portion of the ovarian tubule shrinks, and thus the egg next in front is brought nearer to the duct. The two oviducts unite to form an unpaired portion, the
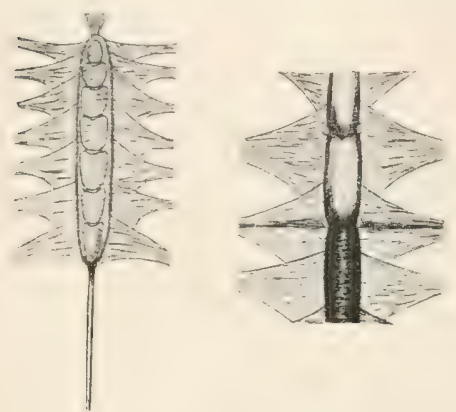

Fig. 19.-Diagrams of the heart of an insect. vagina, which opens ventral to the anus, either freely on the surface or into a cloaca, an invagination occurring at the hinder end of the body. There is usually an evagination of the vagina which serves as a receptaculum seminis, and one or a pair of accessory glands, which secrete either a sticky fluid to attach the ova to foreign bodies, or the mucus surrounding them (e.g., in insects

which lay their eggs in water). Sometimes there is also an evagination of the vagina to form the bursa copulatrix, into which the

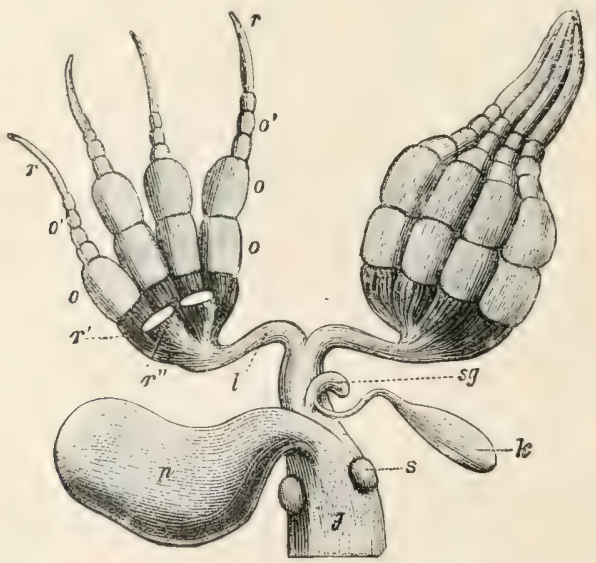

Fig. 20.-Female genital organs of the cockchafer.

On the right, the ovarioles are lying together in the natural position; on the left they are separated, and two are cut away. $g$, vagina; $k$, glands which open into the receptacula; 7 . oviduct; 0 , segments of the ovarioles, containing almost ripe ova; 0 , regions of the same, containing immature ova; $p$, bursa copulatrix, ; $r$, anteriur ; $r^{\prime}, r^{\prime \prime}$, posterior buds of the ovarian tubules; $s$, glands ; sg, receptacula ovorum. (After Boas.)

penis of the male is inserted in copulation. Not infrequently there is at the female aperture an ovipositor (Locusts), consisting of complicated knife-like or dagger-shaped laminæ, or a sting 
(Iymenoptera); or the last abdominal segments, which then are thin and elongate, and may be telescoped, serve in this capacity (Diptera and others). The chorion is often very hard, frequently covered with a delicate and regular seulpturing, and always provided with one or more openings, the micropyles, through which the spermatozoa may enter. The outer form of the eggs varies: it may be spherical, oval, discoid, rough, stalked, \&c.

"The male genitalia are for the most part a repetition of those of the female. There is a pair of testes, each consisting of several long seminal tules or shorter seminal pouches, situated at the end of the

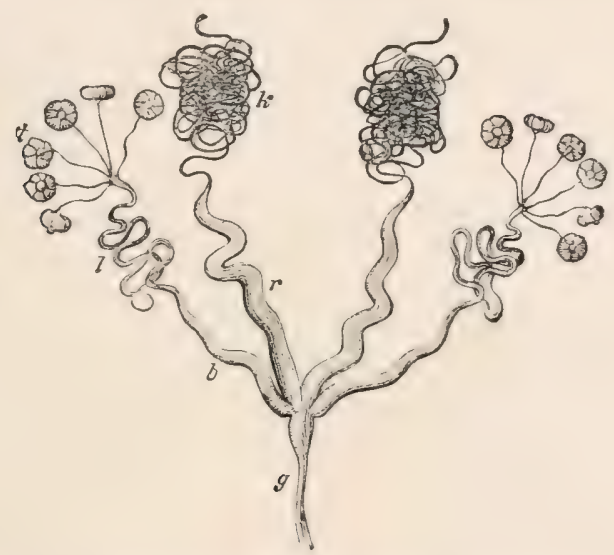

Fig. 21.-Male genital organs of the cockchafer (penis not drawn).

$z$, vesicula seminalis; $g$, vas deferens; $k$, glandular appendages; $r$, widened reginn of the duct of the sane; $t$, testis, consisting of six seminal pouches. (After Boas.)

vas deferens. The two vasa deferentia unite to form a single duct, which opens in a similar position to the vagina of the female. Each of the rasa deferentia widens posteriorly to form a vesicula seminalis. Special glandular appendages frequently open into these ducts, or into their common portion. There is a more or less complicated copulatory organ, an evagination of the body wall, through which the terminal portion of the seminal duct is continued, and capable of partial or complete retraction when not in use. In many it may possess hard chitinous portions, and lies hidden within the cloaca, from which it may be protruled during copulation." 1

1 Text-book of Zoology by Dr J. E. V. Boas, pp. 242, 243. 


\section{References to Literature consulted.}

Boas, Dr J. E. V. Text-book of Zoology. English transl. 1896.

Cambridge Natural History, The. 1899.

Carpenter, Geo. H. Insects, their Structure and Life. 1899.

Fisher, W. R. Forest Protection: Schlich's Manual of Forestry. 1907.

Kaltenbach, J. H. Die Pflanzenfeinde aus der Klasse der Insekten. 1874.

Köllar, V. A. Treatise on Insects Injurious to Gardeners, Foresters, and Farmers. 1840.

Nisbet, John. The Forester. 1905.

Packard, A. S. Insects Injurious to Forest Trees. U.S.A., 1890.

Taschenberg, Dr E. L. Einführung in die Insektenkunde. 1899.

Theobald, Fred. V. Insect Life. 1896. 


\section{CHAPTER I.}

\section{ERIOPHYIDE (PhytopTID ж) OI GALL-MITES.}

The Eriophyidie, or gall-nites, are so small in size (heing only visible when viewed under a very strong pocket lens or microscope) that we can only recognise them in the forest through the medium of their injuries. In other words, being practically invisible, the young student in forest entomology cannot associate the creature with its injuries, as in the case of most insects; and further, as the injuries caused by those creatures are in appearance so closely allied to the damage done by many species of parasitic fungi, the beginner may either overlook or misunderstand them. Perhaps, therefore, the best method of commencing the study of this group of arboreal mites is through the medium of a common horticultural species - viz., the currant-bud mite. In fact, it may be truly said that the study of gall-mites in this country has received special attention on account of the species on black currant having become a common garden pest in many parts of the country. The general appearance of this pest is only too easily recognised by the swollen buds, known in some localities by the graphic term "blind bud." The creature causing this widespread trouble has long been known by the name of Phytoptus vibis (Westw.)

The common garden pest referred to has its equivalent in the forest, producing "blind buds" and other abnormal growths on several kinds of trees. The latter may be various forms of galls on the leaves, rollings of leaves, or deformation of flower and fruit, \&c.

The abnormal growths arising from the action of gall-mites were at one time considered by botanists as a species of micro-fungi, and termed "Erineum." Frank gives a very interesting account of those abnormal hairs on the leaves, ${ }^{1}$ which are either caused by the gall-

1 Die Krankheiten der Pflanzen, Pd. iii. 1896. 
mites or otherwise associated with them. He says they were divided (where considered as nicro-fungi) into three orders-viz., Tahthrina, Fr., Erineum, Pers., and Phyllereum, Fr. The illustrations as given by Frank are suggestive of this leing rather an interesting microscopical study, inasmuch as we see the contrast of normal with abnormal hairs through the action of mite agency. In some cases the apparent cluster of hairs may, on examination, prove a genuine micro-fungus, so that, by careful microscopical observation, the student can be acquiring knowledge in a kindred subject.

With regard to the "blind bud" on black currant, it may be noted, as showing the history of the study, that the first authentic public announcement of the existence of the disease was made at a meeting of the scientific committee of the Royal Horticultural Society held on March 2, 1869 :-

"Specimens of a disease in shoots of black currant from the Rev. A. Fitch were then produced, Mr Berkeley remarking that the outer bracts were lyppertrophied, and in consequence the delicate divisions of the inner part of the bud were badly nourished, and death ultimately ensued. The chairman pointed out its probable analogy with the galls in hazel produced by a Cecidomyia, which was confirmed by I'rof. Westwood, who stated that the disease in black-currant shoots was proluced by an extremely minute four-legged Acarus."-_R. H. S. Journal,' New Series, vol. ii., pt. 3, 1870. ${ }^{1}$

With regard to the Eriophyide generally, it may be stated that $\mathrm{Mr}$ Andrew Murray was the first to collate the information concerning these mites in a general way, and he gives a very interesting account of them in his 'Economic Entomology.' 2

Within the last few years elaborate researches have been made by Dr Alfred Nalepa of Viemna, and to his writings all interested in the subject must refer. About forty-five species, arboreal and others, have been found in Britain. He has established various genera, families, and sub-families; but unfortunately he has seen fit to change the generic name Phytroptus to Eriophyes, and this term has been adopted by all writers on economic entomology.

The difference between a healthy and a diseased bud is very

1 "The Currant-bud Mite or Currant Gall-Mite," by R. Newstead, in Journal of Royal Horticultural Society, vol. xxv., pt. 3. 1901.

${ }^{2}$ Economic Entomology-Aptera : South Kensington Museum Science Handbooks. 
easily recognised. In the former the buds are comparatively small and pointed, whereas the latter are swollen and rounded. $A$ longitudinal section made in winter or spring through the centre of both classes of buds will show a difference of structure. In the case of the healthy buds - as, for example, in the currant-bud mite-the embryo leaves can be seen, and they are always close at the apex, while in the diseased buds the structural foldings of the leaf are broken up, and the apex always open. The same description holds good in forest trees infested by Eriophyidæ.

The life-history and microscopical characteristics of the genus Eriophyes form a most interesting study. It belongs to the sub-family Eriophyidæ (Phytoptidæ), - gall-mites of the order Acarina.

The mite is of a light yellowish colour, and varies very much in size according to species. Perhaps the size of the creature may be approximately put down as the $\frac{1}{200}$ to $\frac{1}{1000}$ of an inch in length, and it is obviously indistinguishable by the naked eye. Fig. 22 may be regarded as a typical mite.

The body is of a vermiform shape, and, like mites in general, is of one piece, and with few appendages. Hence a creature of such simple structure affords but few points for specific differ-

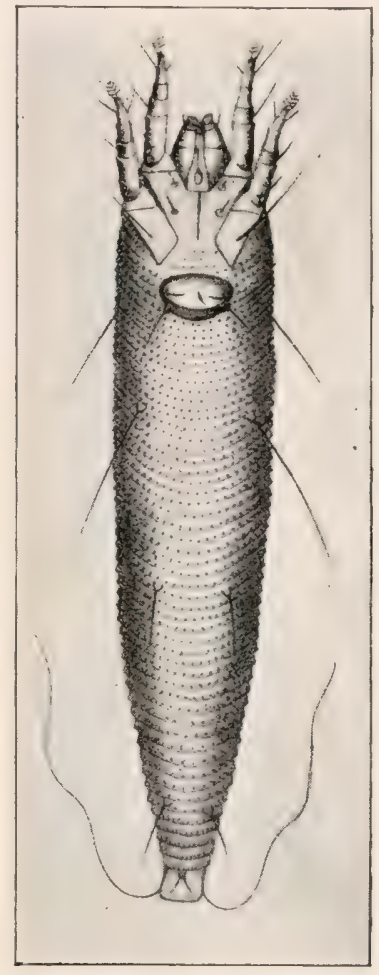

Fig. 22,-Phytoptus calycophthirus, Nol. (Eriophyes rudis, Canest.) (Photographled from Nalepa's 'Genera und Species der Familie Phytnpticla.' Wien, I $\$ 91$.) ences; nevertheless, Nalepa gives a full description of a typical mite, together with a detailed description of the respective species. $^{1}$

The form of the body is an elongated ellipse, narrowing towards the posterior end; and the cephalo-thorax is about the same breadth as 1 Das Tierreich, 4 Lieferung (Eriophyidæ). 1898. 
the abdomen. The head terminates in a snout-like projection, and the maxillary palpi are used as antennæ.

The group is known as the "four-footed" mites, and when viewed from the under side the four legs can be seen distinctly. The articulations of the legs, although well marked, are rather difficult to determine. The tarsus, or foot, is provided with a double claw : one half is terminated by a few fine bristles, called by the Germans "Fiederborste," or feather bristles, and the other half is a simple claw.

The abdomen is divided into a series of from 60 to 90 ring-like segments, according to species, and there are several hairs on the abdomen. These are variable in size, but should, as far as practicable, be noticed under the microscope, whether the dorsal, ventral, or side aspect of the creature is being presented for examination. The rings, hairs, and the regular or irregular markings afford good points for classification. At the extremity of the body are two very long hairs, and rather important claspers, which the creature uses as a means of anchorage. Doubtless, also, the hairs assist the mite in the act of locomotion.

The eggs are round or elliptical. There are two rather indistinct stages, larva and nymph. The species in the buds of black currant and hazel lend themselves for periodical examination, and the mites can be seen in their various metamorphic stages.

$\Lambda$ s regards the physiological functions of the mites, the following notes from $\mathrm{Mr}$ Connold ${ }^{1}$ may be quoted-viz. :

"The mites have no special respiratory or circulatory organs. The exchange of gases takes place through the body; nor is there any organ like a heart. The fluid, therefore, which is analogous to blood, moves freely and irregularly throughout the body. The nerves are in four pairs. The oesophagus passes throngh the brain ganglia.

"They are devoid of stomach, digestion taking place in the larger intestine. Salivary glands are wanting, and also Malphigian tubules.

"The skin is an exceedingly thin, colourless layer of chitin. Beneath it lies a network of branched cells, which contain slight colouring pigments."

From a botanical point of view, or as regards the injuries done to the host-plant, the mites may be divided into three great classesviz, those feeding within the buds, and consequently causing "blind

1. British Vegetable Galls, by Edward T. Connold, 1901, pp. 32, 33. 
buds"; those living in various forms of galls; and those causing malformations of flowers, fruit, or leaves. The last division presentis a very considerable variety, inasmuch as the leaves may be folded or puckered, and the leaf-veins enlarged in various ways.

As regards classification, Naleja divides the family into two suhtfamilies-viz., Eriophyinæ and Phyllocoptinæ.

I. Number of the back and belly half-rings almost equal; abdomen therefore similarly ringed; ventral side always, dorsal side as a rule punctured

Eriophyinæ.

II. Abdomen not similarly ringed; dorsal half-rings distinctly broader than the belly half-rings . . Phyllocoptinæ.

\section{SEB-FAMILY ERIOPHYINÆ.}

\section{Synopsis of the Genera.}

Abdomen without dorsal median furrow . 1, Genus ERIopHres.

Abdomen with dorsal median furrow . 2, Genus Moxocnetus.

\section{Species living in Buds.}

These may very easily be seen under the microscope, eating the vital parts of the bud. The infested bud, therefore, is transformed into an abnormally large swollen "blind-bud," which, instead of bursting into flower or leaf, becomes the dwelling-place and feetingground of many mites. Here we may again quote from the literature on the "Currant-bud Mite."

With regard to the actual number of mites tenanting a single bud, Newstead says of Phytoptus (Eriophyes) ritis :-

"The number of mites tenanting a single bud would vary accorling to the time of year. By desire of Mr Spencer-Pickering $I$ last year (January 9,1900 ) selected a medium-sized bud-gall, and in it counterl 2748 individuals; allowing for many individuals destroyed in dissecting the bud, I should put the number in round figures at 3000 . Larger buds would contain considerably more, and in March it would be safe to add half as many more." 1

1 "The Currant-bud Mite or Currant Gall-Mite," in Journal of Royal Horticultural Society. 1901. 


\section{Eriophyes aVellane (Nal.)}

The nut-tree mite is found in filbert and cob-nut plintations. The swollen and deformed buds can easily be recognised before the development of the leaves; and they are also afterwards conspicuous, as shown in the accompanying illustration (fig. 23).

The species living in buds of hazel lend themselves more or less to periodical examination throughout the whole of the year. Having examined them in February from young hazel plants, I found the

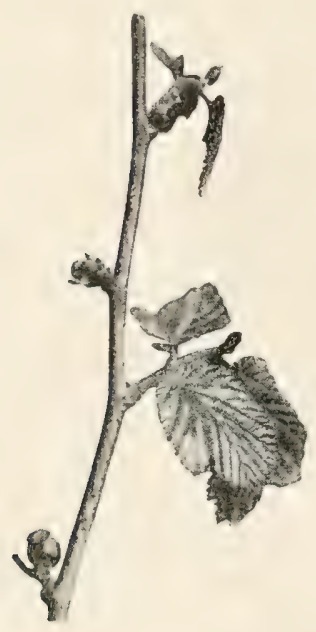

Fig. 23. - Abortive swollen buds caused. by Eriophyes avellanæ on hazel. enlarged buds, more especially the infested terminal bud, conspicuous as globular balls about $\frac{1}{4}$ inch in diameter. Numerous mites were found in all portions of the bud, from the outer scales to the centre. They were discovered in all stages-viz., eggs, larvæ, nymphs, and perfect mites. This species of mite is larger than the species found on the black currant. The eggs are whitish, smooth, and oval. The nymph is approximately about one-half or one-third the size of the perfect mite, and the four legs are stretched out in the direction of the mouth.

An examination of the swollen buds during May, when the leaves were half developed, showed the infested buds to be tenanted in all parts, and a few mites crawling along the leaf-stalks. They were in all stages - viz., full-grown mites, nymphs, and eggs.

In July another examination was made, and it was found that the mites were chiefly in the interior portion of the swollen buds. There were a few on the leaf-stalk and on the portion of the stem adjacent to the infested buds. At this time the swollen buds were quite half an inch in diameter, and the young buds for the forthcoming season were just formed. 
Eniophyes rudis, Canest., on the leaf-buds of Betula alba.

Synonymy of mite (Connold) :-

Phytoptus rudis, Canestrini.

Phytoptus calyeophthirus, Nalepa.

In fig. 24 two swollen buds on birch are represented. They were found in High Legh, Cheshire, and cut from the same branch, and in close proxinity to a "witches'-broom" - that peculiar bird-nest-like appearance seen on birch and hornbeam, of the growth and development of which Miss Ormerod gives a very interesting account, from personal observations made during 1876 and 1877 , while resident in the neighbourhood of Isleworth. ${ }^{1}$ There is no doubt, from the description and illustration given by her, and more especially from the appearance of the actual branch itself, seen in the South Kensington Museum, that the abnormal branch growths were heavily covered with swollen buds infested by Eriophyinæ.

I had, in consequence of Miss Ormerod's description, for a long time examined many "witches'-brooms," without finding a single "blind bud." The accompanying figure shows the

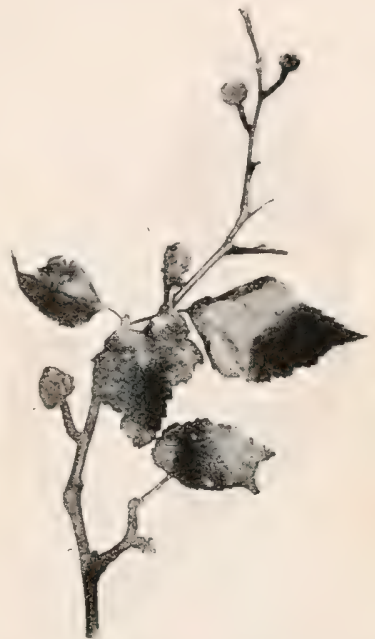

Fiv. -1. - - Lbortier surulen buds cansed by Eriophyes rudis an birch.

first infested buds I discovered in any way closely associated with a "bird's nest." 'The orthodox opinion as to the cause of "witehes'broom" or "bird's nest" is that it results from a fungus inhabiting the tissues, known as Exoascus.

With reference to "witches'-broom" being the result of fungal growth, Tubeuf, speaking of experimental infection, says :-

"In the case of the Exoasceæ, two points were cleared by the aid of artificial infection, - the penetration of spores into leaves of hostplants, and the production of witches'-brooms. Sadebeck, by means of infectious Exouscus epiphyllus on Alnus incana, has produced

\footnotetext{
1 Manual of Injurious Insects. Second edition.
} 
witches'-brooms artificially, thus proving that these malformations really originated from the mycelium of Exoascus." 1

As the cause of the "witches'-broom" is ascribed both to mites and fungi, it is suggestive of the adrantages and pleasures of original microscopical investigation. Still, these abnormal growths might have accrued from excessive development of adventitious buds, caused by the constant irritation of the Eriophyine without the presence of Exoascus.

I have found this species in several parts of Northumberland.

\section{Eriophyes psilaspis (Nal.) \\ Phytoptus taxi (Murray).}

This species (fig. 25) was first discovered hy Professor Sir Thiselton Dyer in the spring of 1875 doing immense damage to young hedges,

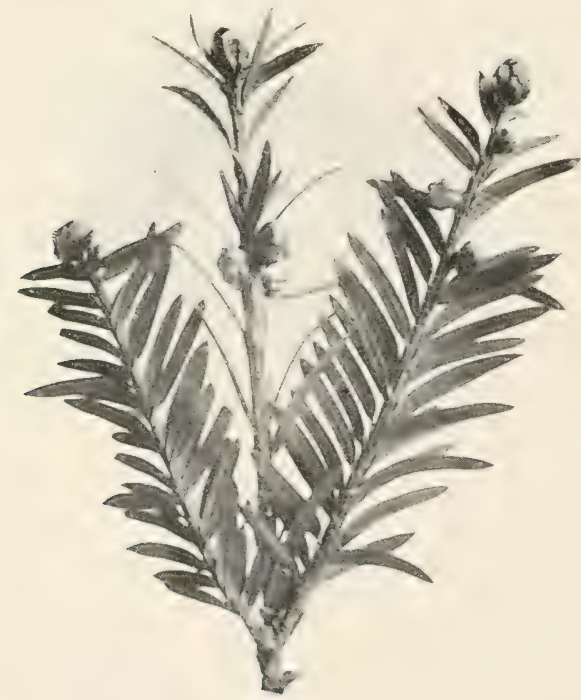

F'ig. 25. - Abortive suollen buds caused by Eriophyes psilaspis on Einglish yer. which damage had hitherto been ascribed to frost. I found it plentiful on the under side of the lower branches of a yew-tree at High Legh, Cheshire, from which the photographic illustration was taken. I have often found it very injurious to young yew-trees in the nursery-lines, and also occasionally on yew hedges.

As this species is certainly injurious, it is well to have recourse to some remedial measures. In the case of hedges, where regular trimming is resorted to, it would be well to burn all prunings; and as regards the young yew-trees in nursery-lines, it would be best to hand-pick the infested buds, say about the latter end of May, and burn them.

1 Tubeuf, Diseases of Plants induced by Cryptogamic Parasites. English edition, by W. G. Smith. 1897. 


\section{Species living in Galls.}

There are numerous species living in galls on the leaves of various trees, but the following are a few typical examples. They are not true galls, however, but simply pseulo-galls; and it is important to compare the structure of the psendo-galls of Eriophyine with the true galls of gall-forming insects. The former is simply an almormal thickening of the leaf, with an opening or passage leading into the pseudogall. The opening is surrounded by hairs, which doubtless act as a protection against the inroads of parasitic acari and other natural enemies. The true gall, on the other hand, is always closed, and the form variahle and immaterial. Some species of leaf-miner's (Lepidoptera) form conical galls or eases on the upper side of the leaf, but the passage communicates between the epiclermal skins, and has monfenin! through the under side of the leaf, as in the gall of Eriophyinax.

\section{Errophyes tilie (typicus) (Nal.)}

In fig. 26 we have represented what are popularly known as "nailgalls" on the leaves of the lime-tree-Titia enropcea. This is a very interesting species, inasmuch as nail-galls were first considered by Réaumur, the celebrated French entomologist, to be a special regetable formation accruing from the action of animal life; but in the absence of any description it is doubtful whether he saw the real tenant, or simply a parasitic lodger.

Mr Andrew Murray remarks: "Whether Réaumur saw them or not, at least no one else did for about 100 years after. About 1832 and 1834 , however, the publication of M. Duges' valuable papers on the

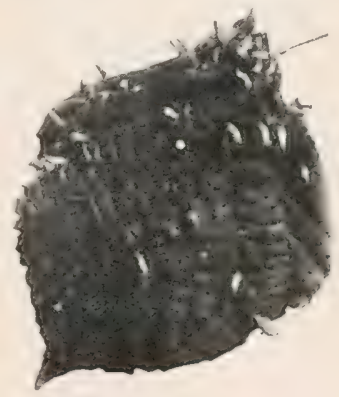

Fig. 26._- "Nail-galls" on leaf of lime tiser (Tilia eluroprea) rusurd by Eriophyes tiliat. classification of the Acaridæ, to which we have already had so often to refer, gave an impulse to their study, which led to fresh discoveries; and M. Turpin observed in the nail-galls of the lime leaf a quantity of very minute, semi-transparent, fleshy mites, of a new and hitherto unknown form, - a narrow creature with two pairs of small legs at its head, and some kind of sucker apparatus at its tail, on 
which it rests and raises itself, swaying about its body. He regarded it as a species of Sarcoptes." 1

Here is an account of the first true conception of the family Eriophyile, and the species under consideration is in consequence a most important one.

\section{Eriophyes Macrochelus (Nal.)}

To all lovers of natural history, no walk is more charming than a South Country lane, with its tall rough hedges and rich flora. The hedges are generally well stocked with the field maple (Acer cam-

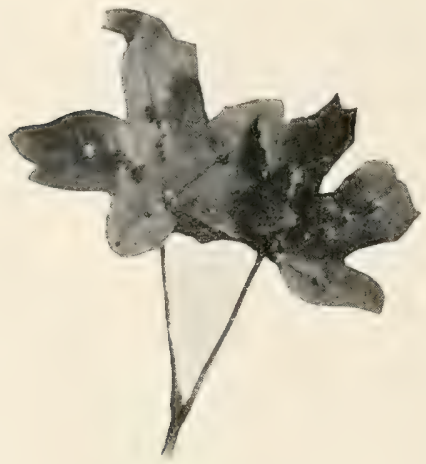

Fig. 27. - Galls on leaves of field mapte (Acer campestre) coused by Eriophyes maerochelus. and either on the veins or spread over the leaf. They appear quite early in summer, but may be considered fully developed in August. Fig. 27.

\section{Ertophyes macrorhynchus (Nal.) \\ Phytoptus myriadeum (Murray).}

This is the other species of gall on the field maple, and may easily toe recognised from the former species by being smaller in size, and much more crowded on the leaves. It is very abundant in southern England, but not at all common in the north or in Scotland. Fig. 28.

1 Economic Entomology-Aptera: South Kensington Museum Science Handbooks. 


\section{Eriophyes L Levis (Nal.)}

This species is found on the leaves of the common alder (Alnus glutinosa). The galls are found on the upper surface of the leaves, and are gregarious, often so abundant as to cover almost the entire surface of the leaf, generally glabrous, and very variable in colour. Fig. 29.

\section{Eriophyes axillaris (Con.)}

This species is also found on the leaves of the common alder, but they differ from the previous species, inasmuch as they are always found on the midrib, or in

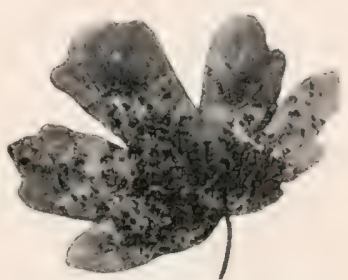

Fig. 28. - Galls on leaf of field maple (Acer campestre) caused by Eriophyes macrorhynchus.

the axils of the primary veins from the midrib. The galls are larger than the previous species, smooth, and varying in colour from

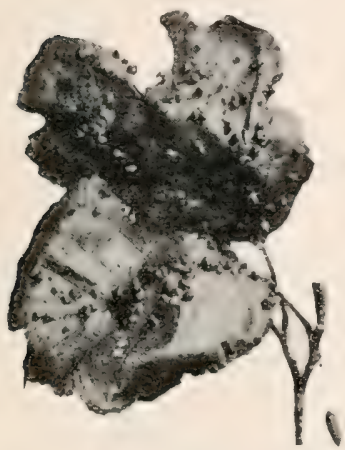

Fig. 29.-Galls on leares of common alder (Alnus glutinosa) caused by Eriophyes lævis.

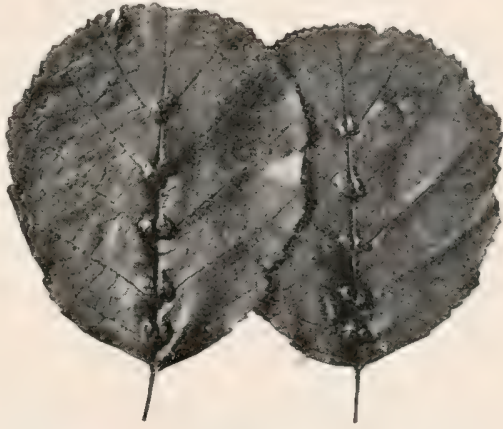

Fig. 30.-Cralls on midrib of the leares of common alder (Alnus glutinosa) caused by Eriophyes axillaris.

light-green to dark-brown, and always found in pairs. In section they are hollow, and lined with hairs. Fig. 30.

\section{Ertophyes tetanothrix (lavis) (Nal.)}

This gall is found on the leaves of Satix caprea. This species of willow is very common, and, as every botanist knows, very variable as regards the size and shape of the leaf. The galls of this species are generally found on the small-leaved variety, and on the upper 
surface of the leaf. A section of the gall, which is comparatively easily made, shows that the walls are very thick.

There are many other species forming galls on leaves of our forest

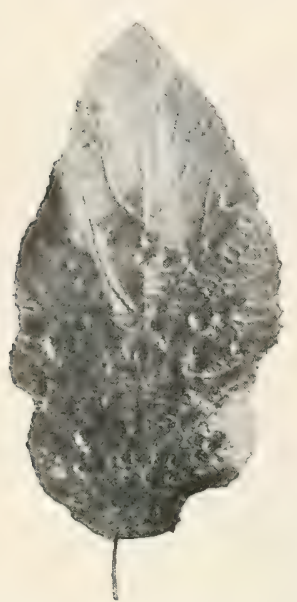

Fig. 31.- - cialls on leaf of Irinyfuring tree (Viburnum lantana) coused but Eriopliges tetanothrix.

trees and shrubs in many parts of the country, as, for exaniple, on the leaves of the "Wayfaring tree" (Viburmu lantana), fig. 31, which was photographed from a leaf taken in a Surrey lane.

\section{Species causing Malformation of Flowers, Fruit, or Leaves. ${ }^{1}$}

\section{ERIOPHYES FRAXINI (Karp).}

This species attacks the flowers of the common ash (Fraxinus excelsior), and gives rise to what may popularly be called deformed fruit, as the injuries are most commonly observed when the fruit is ripe. It is, however, more correctly a malformation of the flower, as the mites attack the flower, and by means of a symbiotic action give rise to the forms as seen in fig. 32. It is very local in some parts of the country, and sometimes peculiarly so to one tree in a whole district. It is very common in some parts of Northumberland and Berwickshire.

\section{Eriophyes tiliarius (Con.)}

This species attacks the flower-bracts of the common lime (Tilice europcea). Having only found this species once, which was in Northumberland, I give the following note from Connold, ${ }^{2}$ who has figured the species :-

"These galls begin to form on the margin of the bract as small elevations. The feeding of the mites causes the edge of the bract to rise upwards and curl over towards the midrib, producing a roll which sometimes extends 30 to $40 \mathrm{~mm}$. in length, and continues to roll

1 For a full and interesting account of "Gall-Mites" under similar classification to the above, see 'Die Krankheiten der Pflanzen,' Frank, vol, iii., 1896.

2 British Vegetable Galls, p. 170. 
over upon itself until the middle of the bract is reached. When thus affecterl, the bract may curve into a crescent shape, the roll itself

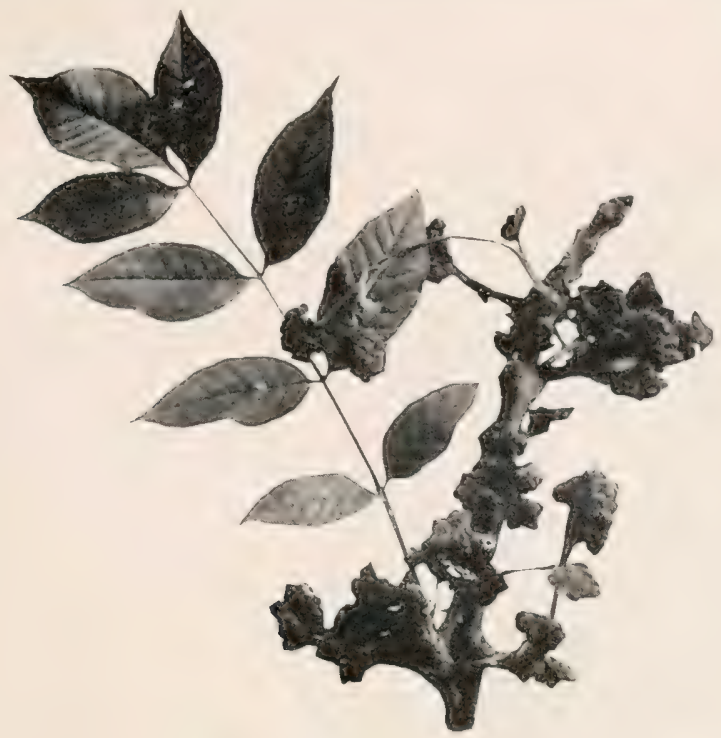

Fig. 32. - Malformation of the flower of ash (Fsaxinus excelsior) caused by Erioplyes fraxini.

forming the inner margin of the concavity, or it may be otherwise considerably distorted. No harm is done to the flowers, nor does the bract fall until the usual time, hence the mites are not destructive to the fruit."

\section{Eriophyes goniothorax (Nal.)}

This species is very common on the leaves of the common hawthorn (Cratcegus Oxyetcantha). On healthy trees and hedges we may only find an isolated affected leaf, but sometimes on an isolated bush in a wood we may find almost every leaf affected. The damage itself is easily recognised, as the outer edges of the leaf are rolled inwards,-

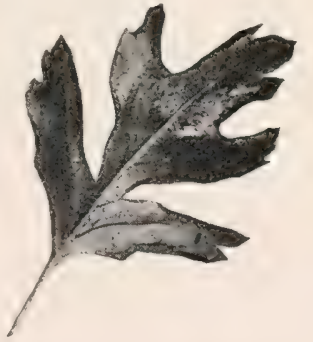

Fig. 33.-Edges of hauthorn lea, rollal inmols by Erioplyes goniuthorax. the roll itself being very slender, and of cord-like appearance. If fresh leaves are gathered, and kept in a box or on a table until they 
become slightly flabby, they can then be very easily opened; and if cxamined under the microscope, the mites can be seen in great numbers. Fig. 33 is a representation of a single hawthorn leaf rolled by this species.

\section{Eriophyes aucuparie (Con.)}

This species may be taken as a typical example of surface-injuries to leaves by gall-mites. The leaves are injured on both sides, but

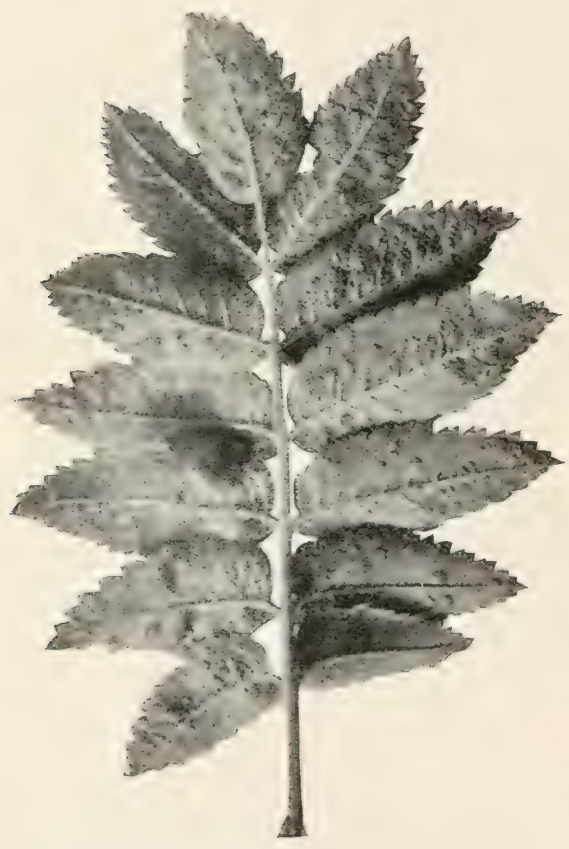

Fig. 34.-Surface of leaflets of mountain-ash (Pyrus aucuparia) injured by Eriophyes ancupariæ. the form of the leaf is not injured. Examples of this injury are very common in Northumberland, but so far I have not been fortunate enough to see the mite under the microseope. Fig. 34 .

Several other arboreal species may be found; or, in other words, many instances of malformation on leaves, flowers, and fruit may be recognised, which on microscopical examination will show Eriophyinæ. Those mites, however, may not always be the direct eause of the injuries referred to, inasmuch as the primary cause may be due to minute parasitic fungi, and the mites simply finding congenial association in the diseased spots. Hence the enthusiastic student will find this dual nature of parasitic disease a stimulus to encourage original investigation.

Several other species may be found rolling the leaves of our forest trees and shrubs, as, for example, the species forming rollings or small galls on the edges of the leaves of blackthorn (Prumus spinosa), fig. 35 . 


\section{Genus Monochetus.}

\section{M. sulcatus (Nal.)}

This genus contains a single species on beech, which is figured by Connule. ${ }^{1}$ "These most interesting galls do not appear to be common: they are very local where they occur. The affected leaves are situated on the new wood of the year. They are attacked while expanding, and instead of opening out into a flat blade, the primary offshoots from the midrib are caused to remain as nearly parallel as possible with it, and the areas which they enclose are pushed upwards, giving both sides of the leaf a deeply striated appearance. They continue to grow in length, and ultimately bend inwards, assuming a cymbiform

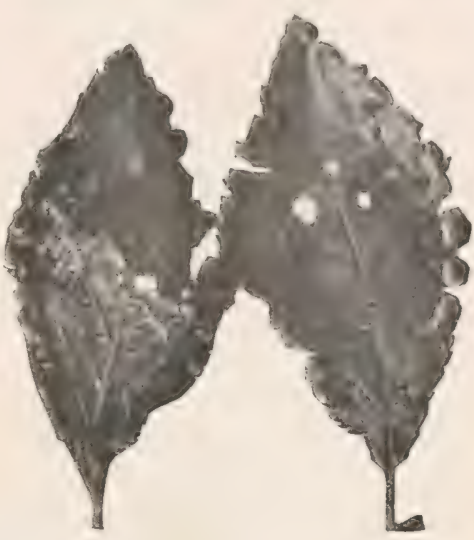

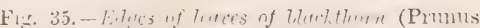
spinosa) rolled inuards by species of Eriophyes. shape. The edges of some meet and produce a pod-like growth. Owing to their excessive pilosity, they are like velvet to the touch."

\section{Sub-FAMILY PHYLLOCOPTINÆ.}

In connection with this sub-family, it may be mentioned that Nalepa gives several instances of Continental mites belonging to the respective genera of the sub-family, and associated with many of our forest trees. It is therefore possible that we have here, so far as systematic forest entomology is concemerl, a practically unworked field. Fig. 36, $a$, represents the dorsal surface, and $b$ the side view of Pliyllocoptes carpini Nal. ${ }^{2}$ The figures are specially given as showing the variety of structure in these minute creatures, and the suggestiveness of this field for original microscopical research.

The most familiar instance, however, is the species attacking the

1 British Vegetable Galls, p. 176.

2 From 'Beiträge zur Systematik der Phytopten,'von Dr Alfred Naleya. 1889. 
upper surface of the leaves of the common sycamore (fig. 37). It is now known by the name of Phyllocoptes acericola, Nal., and Connold gives the following synonymy-viz. :

Phyllocoptes acericola, Nal.

Volvulifex aceris, Amer.

Ceratoneon vulgare, Bremi.

Phytoptus aceris, Murray.

The galls are very common on the upper surface of the leaves of sycamore (Acer pseudo-platanus). In some instances they are very

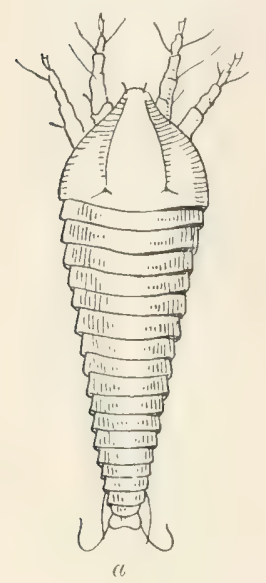

Fig. 36.-Phyllocoptes carpini. $a$, dorsal surface; $b$, side view. (Copied from
Nalepa.) thinly scattered over the leaf, in other cases quite gregarious. They are very beautiful in colour, varying from orange-yellow to purple. They appear soon after the leaves develop, and

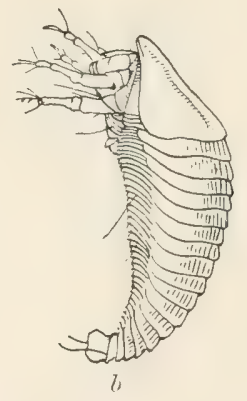
may be found throughout the whole summer season.

Such are a few typical specimens of arboreal Eriophyidæ living in buds or forming galls; and, as just stated, there may be many found on trees, but with the exception of two species-viz., those on hazel and yew-they are not very destructive, and certainly not to be compared with the species on black currant.

From the foregoing remarks it will be seen that the study of Eriophyidre is purely a microscopical one. The bases of classification are so minute, and the points of discrimination so difficult to determine, that the question naturally and suggestively arises whether we have the same or different species of mite doing several kinds of injury. As bearing on the specific differences of mites found on different food-plants, I may say, from practical and local examinations, that I have only once found Eriophyes ribis on black currant in Northumberland, near Newcastle-on-Tyne, whereas the species on hazel is about as common as in Cheshire, where E. ribis is a direful pest. Hence it would conclusively appear that the mites on the 
respective food-plants are distinct species, and therefore very fastidious as to food.

Mr Newsteal, Curator of the Grosvenor Museum, Chester, earried out a number of observations with regard to the species on black currant, and found that there was a succession of broods from February to September. He also discovered that when the buds shrivel up and become unable to support the mites, they migrate to the leaves and leaf-stalks, and enter the newly formed buds towards the end of July, where they remain until the following spring.

From preliminary observations I find that there is a slight difference between the habits of the species on hazel, compared with that on black currant, inasmuch as the "blind buds" of the former do not shrivel up so quickly as the latter. Consequently the swollen buds of hazel are teeming with life about the latter end of July, while comparatively few are on the leaves and leaf-stalks. The buds for the coming year were then formed, and the mites would be able to move from one "house" to the other without camping out during nature's building operations.

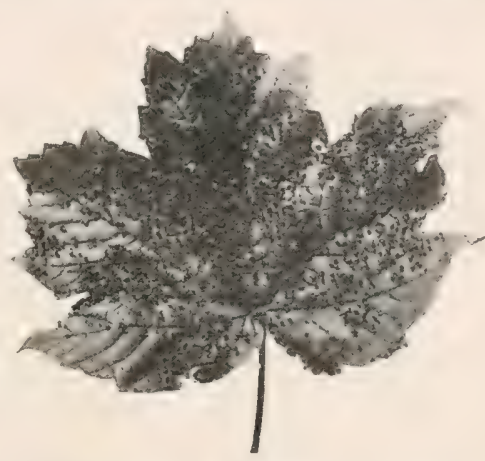

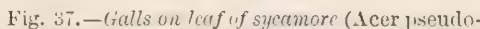
platanus) caused by Phyllocoptes acericola.

The life-history of those species living in galls is not so easily followed. For instance, I have examined the buds and twigs of a lime-tree, from the same branches which year after year produce galls on the leaves, without finding a single mite. Then, again, certain willow leaves are infested annually by a micro-fungus of the rust order, on the under side of the leaves, which invariably harbour those mites, and yet neither "leaf-galls" nor "blind buds" could be found on the tree whither the mites would be sujposed to migrate from the fungus excrescence, whose existence as a rust only lasts for a month or two.

On the under side of the leaves of some lime-trees a white growth is often found, which is known as a vegetable hypertrophy. This also harbours mites, and yet no nail-galls may be seen on the leaves of 
the same tree. Hence it may be concluded that the life-history of some "locally" resident species is more or less involved in obscurity. Conserpuently the following remarks are appended from an authority on economic entomology. Mr French says:-

"With regard to the life-history of these singular little animals, Mr. Crawford gives it as his opinion that there are two ways in which the mite survives the winter, when all leaves are shed: first, by hibernating among the hairs of, and in, the leaf-bud; and secondly, by forming colonies under the tender bark of the last year's growths, as I have found them in both situations. It may be the eggs are laid in the buds, as very young leaves, when still unfolding, have often very small galls, which are then of a pink colour. I expect, therefore, that the majority of the mites quit the leaves on the approach of their fall, to take up their winter quarters in these places. The mites that fall with the leaves would soon die, but their eggs might be blown about with the decayed leaves, and by chance alighting on pear-trees, colonise them. The wind, birds, and insects are doubtless the principal means of disseminating this pest in the summer time. The number of living Phytopti on an ordinary-sized pear-tree that is badly attacked must amount to thonsands, if not millions, so that, allowing for a most lavish waste of life, the chances of a few being carried alive to other pear-trees in the neighbourhood must be considerable." 1

\section{References to Literature consulted.}

Collinge. Black-Currant Gall-Mite. 1904.

" " " 1907.

Connold. British Vegetable Galls. 1901.

Frank. Die Krankheiten der Pflauzen, Bd. iii. 1896.

French. Insects of Victoria. 1891.

Iurray. Economic Entomology--Aptera.

Nalepa. Phytopti-Genera und Species.

" Das Tierreich. 1898.

Newstead. The Currant-Bud Mite. 1901.

Réaumur. Mémoires des Insectes. 1732.

Tubeuf. Diseases of Plants, \&c. 1897.

1 Insects of Victoria. 1891. 


\section{CHAPTER II.}

\section{COLEOPTERA (Beetles).}

OF all the families of Insects, with the exception of Lepidoptern, none appear so common, or so easily distinguished by the nonentomologist, as the Coleoptera or Beetles. They are easily recognised by their apparent absence of wings, though they are not wing. less, as the true wings are covered by two hard horny wing-cases known as elytra, which are spread ont during flight. The mouth is

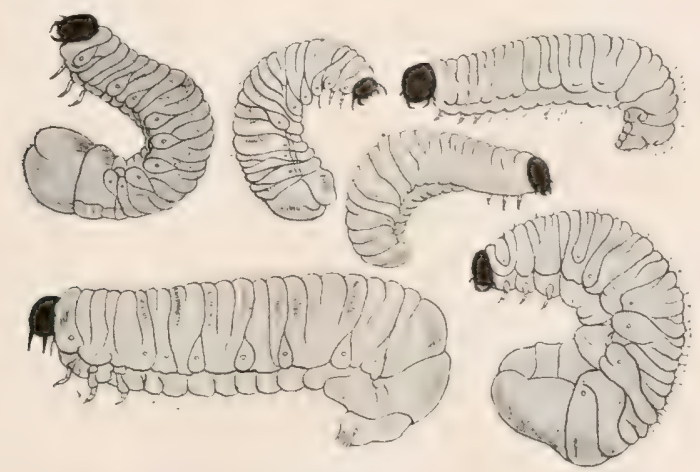

Fig. 38.-Typical larve of beetles. (From photo by A. Flatters.)

formed for biting, hence they are mandibulate; and the body, like that of all otner insects proper, is divided into three distinct portions - viz., head, thorax, and abdomen.

Beetles undergo complete metamorphosis, passing through the various stages of egg, larva, pupa, and imago or perfect insect. Fig. 38 represents typical larvæ of beetles.

The general student or collector of Coleoptera finds the forest a very happy hunting-ground, inasmuch as every portion of it is rep- 
resented by most of the respective families. Thus the ground underneath yields the various orders of "ground-beetles" or Adephega, while in the air above many species may be caught from time to time on the wing. Carrion-beetles may be found on "keepers' trees" and in dead carcases, while the bark of trees affords hiding-places for many species.

It is, however, from the economic point of view that the Coleoptera are really of special interest to the forester, inasmuch as the various parts of the tree become the feeding-ground of respective families and species of beetles. Thus the roots are attacked by the larvæ of certain

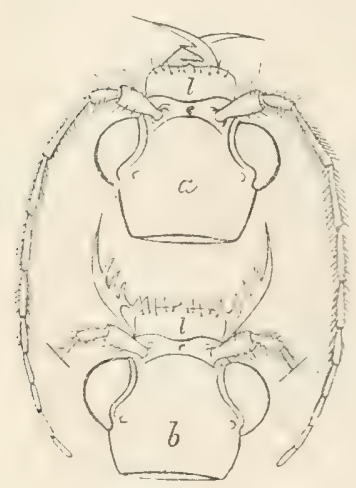

Fig. 39.-Head of Cicindela (magnified).

$t$, with jaws closed; $b$, with jaws open ; $l$, labrum; c, clypeus. (From Fowler's 'British Coleoptera.') species, the bark tunnelled and trunk bored by others, while some beetles are injurious to the foliage and shoots in both larval and perfect forms.

In order to understand the anatomy of beetles, ${ }^{1}$ it would perhaps be best to take a common ground-beetle, trisect it into its main divisions, - viz., head, thorax, and abdomen, —and then carefully note the general structure of each division and its respective appendages. This is also very important from a biological point of view, for undoubtedly if insect anatomy be generally considered, it will be found that there is not a difference in structure of the various orders, but simply a modification of similar parts. The anatomy of the mouth parts of the beetle affords a very good case in point.

Head.-Viewed from the top side, the eyes and antennæ are the most salient features. Fig. 39 shows all the respective parts : $l$ is the labrum or upper lip, which can be seen from the upper side. According to writers on beetle anatomy, the portion immediately behind this, $"$, is called the clypeus, c, or shield of the mouth, and behind this is the head proper, $b$.

In the Thynchophora the head is prolonged into a snout, called the rostrum, which is a true portion of the head, and in no sense a

I For full particulars of structure, the student is advised to consult Fowler's 'Coleoptera of the British Islands,' vol. i. 
trunk. On each side of the rostrum there is usually a groove into which the long first joint of the antenne generally lies when the insect is at rest. These grooves are called scrobes, and are useful characters in the deternination of the Rhynchophora. The anterior portion of the head is called the forfhear or front, and the central portion the vertex.

The antennce are very variable in the Coleoptera, and in many cases afford good points for the discrimination of genera and species. The eyes are generally very prominent.

The thorax, of course, can be easily recognised, but it must be remembered that the transverse division line as seen trom the upper surface does not represent the length of this segment, inasmuch as it projects on the under surface and extends under the abdomen. In other words, the under side of the thorax projects beyond the apparent divisional line, and the anterior portion of the abdomen therefore rests upon the thorax.

It is of importance to well understand the structure of the thorax, more especially in the case of Scolytidæ or "bark-beetles." The thorax proper is made up of three parts-the mothorax, mesothorad, and metathorax; and here again we must study the upper and under surfaces of those divisions. In the upper surface these divisions are known as pronotum, mesonotum, and metanotum, and the under surfaces the frosternum, mesostemum, and metasternum. As regards the upper surface, the visible portion of the mesonotum is known as the sutellum, which is a small but important triangular space, wedged in, as it were, between the elytra and thorax. From the under surface of the thorax we get the legs, and from the upper the elytra and wings.

The aldomen does not, as a rule, present many important features, either as to external anotony or as to points of classification. The last segment or pygidium is rather important, inasmuch as it contains the organs of reproduction. The legs spring from the thorax, and are attached to the body by a joint called the cora. The next joint is a very small portion known as the paiaroic (Fowler), and attached to this we have the strongest portion, known as the femur. The next portion is the tibia; and the last division is a most important oneviz., the tarsus. Tot only in beetles but in all orders the number of joints forming the tarsus must be noted. In the Coleoptera we liave the whole family subdivided, according to the number of joints in 
the tarsus, into four divisions-viz., Trimera, Tetramera, Heteromera, and Pentamera. This division is, of course, more or less arbitrary.

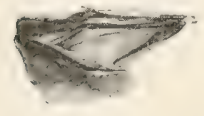

u

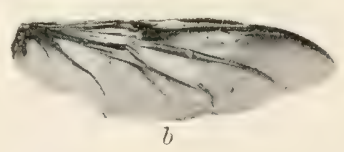

Fig. 40.-True wings of beetle. $u$, folded; $b$, unfolded.

The wings of beetles are rather peculiar, as what corresponds with the wings of other insects are the elytra or wing-cases. These have sometimes a very remarkable sculpturing, the use of which is unknown. In repose, these two elytra are very well fitted together: the junction line is known

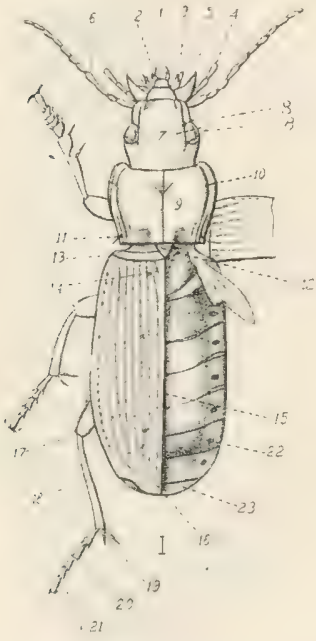

Fig. 41. - Typieal bectle: Pterostichus vulgaris, $L$. (male): upper side. (From Fowler's 'British Coleol'tera.)

1. Labrum.

2. Labial palpus.

3. Maxilla.

4. Maxillary palpus.

5. Mandible.

6. Antenna.

7. Front of head.

8. Supra-orbital setre.

9. Pronotum, ordinarily called "thorax."

10. Anterior lateral pore,

11. Angular pore.

12. Scutellum,

13. Basal fold of elytra.

14. Scutellary stria.

15. Suture of elytra.

16. Sutural angle.

17. Femur.

1s. Tibia.

19. Spurs of tibia.

20. Tarsis.

21. Onychimn and claws.

22. Stigma.

2:. PJgidium, as the suture. The wings proper, which correspond to the posterior pair of other insects, present a very variable structure, so far as the arrangements of nerves and cells are concerned. The size and general structure are compatible with the folding up under the elytra (fig. 40). In some forms they are considered apterous, but though in such cases the wings are never used, and the elytra sometimes soldered together, rudimentary wings may often be found.

Throughout the respective families various modifications of general anatomy present themselves. In the Rhynchophora or weevils, for instance, there is a prolongation of the mouth called a rostrum, which, as Canon Fowler remarks, is a true portion of the head, and in no sense a trunk.

Classification.-Notwithstanding the many works on Coleoptera, 
we have no fixed system of classification or method of arranging beetles. In catalogues they are generally grouped into families accorling to the number of joints of the tarsi : thus those "possessing five joints to all the tarsi have been termed Pentumera; those with five joints to the front and middle legs, and only four to the hinder, Hetermera ; those with apparently only four to all the tarsi, Tetrumere; and those with apparently only three to all the tarsi, Trimera." 1

In looking over a list of Coleoptera, the systematic student will obviously note that he enters the domain of beetles associaterl with forest trees deep down in his list. It is also, however, somewhat

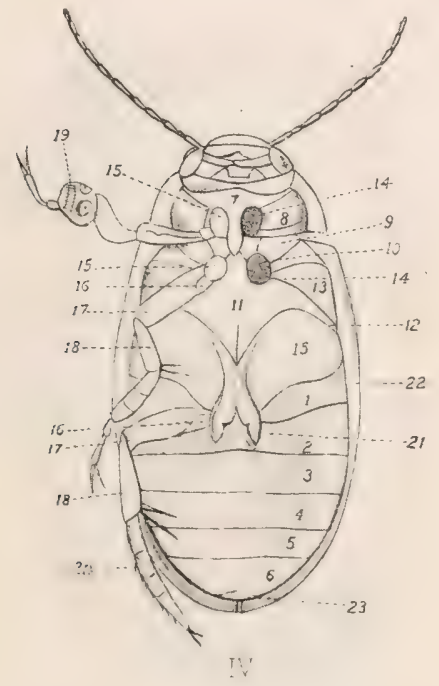

Fig. 42-Typical beetle: Dytiscus marginalis, $I_{\text {.. }}$ (male), under side (water-beetle). (From Fowler's 'British Coleoptera.')

1. Ist ventral segment of abdomen.

2. 2nd

3. 3rd " " " " ",

4. 4th ", ", ",

5. 5th ", ", ", ",

7. Prosternum, terminating "in prosternal process.

s. Episternum of prosternum.

ข. Episternum of mesosternum.

10. Epimeron of mesosternum.

11. Metasternum.

12. Wing of metasternum.

13. Episternum of metasternum.

14. Coxal cavities.

15. Coxæ (posterior pair very largely developed for the support of the swimming legs).

16. Trochanter.

17. Fenur.

18. Tibia.

19. Dilated tarsus or palette, and cupules of male.

20. Oar-shaped tarsus.

21. Coxal process.

22. Epipleura of elytra.

23. Gerital armature.

remarkable, so far as hunting-ground is concerned, that where the student in forest insects begins, the systematic man and the student of many forest insects might clam mutual association all along a considerable portion of the list. It is, however, only essential to select the more salient species, and in doing so many arboreal species will have to be omitted. On the other hand, so as to present anything like completeness, many species would have to he considered which are not of great importance from the purely economic point of view.

As regards the details of structure, the student would do well to refer to figs. 41 and 42, together with the explanation as given by

1 Rye, British Beetles, p. 41. 
Fowler. These points should be thoroughly mastered, as the ready discrimination of species from a systematic point of view will depend upon the same.

\section{FAMILY LUCANID里.}

Fowler says that "the three British genera of the Lucanidxe may be distinguished as follows:-

"I. Eyes more or less divided; ligula and maxillæ covered by the mentum; antennæ geniculate; posterior femora extending beyond margin of elytra.

"1. Eyes divided for scarcely half their diameter Lucanus, L.

"2. Eyes divided for nearly the whole of their diameter

Dorcus, $\mathrm{M} \mathrm{I}^{\circ}$ Leay.

"II. Eyes entire; ligula and maxillæ not covered by mentum; antennæ straight; posterior femora not extending beyond margin of elytra . . . Sinodendron, F."

\section{Ludanus cervus (Linn.)}

This large handsome insect, which may be termed the king of British beetles, is chiefly confined to the southern counties. It is of

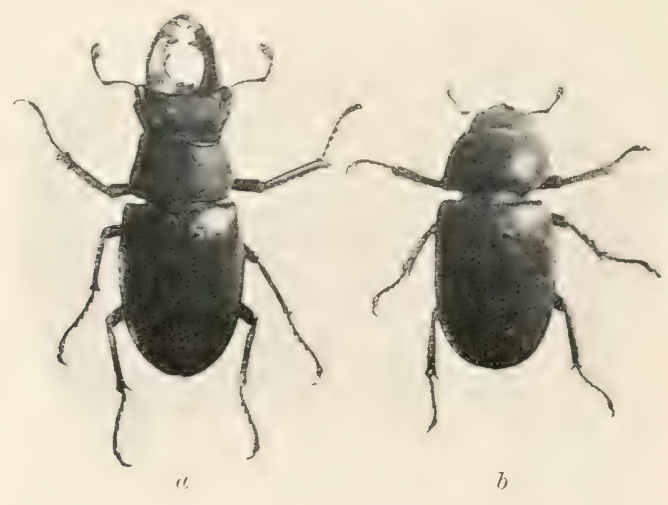

Fig. 43.-Stag-bectles.

$a$, male; $b$, female, slightly reduced.

a pitchy-black colour, with slightly. brownish elytra, and often meisures about two inches in length. The mandibles are very large, 
more especially in the males. In fact, these peculiar features ensily distinguish the insect; and this abnormal development of the male gives rise to its name of "stag-beetle," because the mandibles projecting in front of the head resemble the horns of a stag. Darwin says that the size and strength of the mandibles are of great advantage in fighting for the possession of the females. These insects fly during the evening, and rest on the stem, sipping at any juicy portion they can find. Fig. 43 represents the male and female insectś.

It is in the larval stage that this species is most injurious to timber trees, more especially oak and ash (though hornbeam is conspicuously mentioned by Kaltenbach, ${ }^{1}$ and alder and beech by Altum $^{2}$ ). The larva is white, with ferruginous head, nearly cylindrical, and of a soft fleshy consistence. It is said that they live for six years as larvæ, during which time they gnaw into the roots and eat the solid wood. In fig. 44 a piece

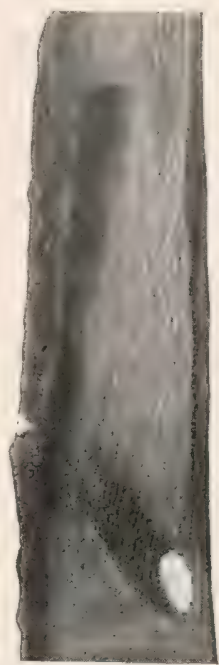

Fig. 44.-Portion of ash timber injured by laria of stag-beetle. of ash timber tunnelled by the larva of the stag-beetle is represented.

\section{Dorcus parallelopipedus (Linn.)}

To the beginner in entomology this species is suggestive of a small specimen of the female stag-beetle. At least, this was my incipient feelings when I first discovered this species under decayed bark in Gloncestershire several years ago. The larræ live in old decaying beech and several other trees. ${ }^{3}$

\section{Sinodendron crlindricum (Fabr.)}

This is another beetle which may be found in decaying wood. I have reared the beetle artificially, taken from decayed wood and fed on damp sawdust. I have also tracked the perfect insects by

${ }^{1}$ Die Pflanzenfeinde aus der Klasse der Insekten, p. 638.

2 Forstzoologie, vol, iii. p. 120.

${ }^{3}$ Commander J. J. Walker, R.N., informs me that he has seen several very large ash-trees in Cobham Park, Kent, completely destroyed by Doreus puralldopipedur. 
following up the frass at the bottom of a decayed standing tree, which betrayed the presence of males and females. My first discovery of this sort was in Acklington, Northumberland, July 3, 1902. Mr R. S. Bagnall pointed out to me that the sickly beech and holly trees in Gibside, Co. Durham, were very much injured by this species.

The beetle is shining black, about half an inch long. The male has a conspicuous hooked horn in front of the head. The female has also a slight horn, but it may require the aid of the lens to see it.

\section{FAMILY SCARABAID屟.}

Genus Melolontha.

This is exclusively an arboreal genus, inasmuch as it only contains two species, both of which are arboreal in their habits. Fowler gives the following specific characters-viz. :

"Two species of Melolontha are found in Britain; they may be distinguished as follows:-

"I. Pygidium elongate in both sexes, and gradually narrowed to apex; average size larger . . . M. vulgaris, F.

"II. Pygidium shorter, constricted at base, and very slightly widened at apex; average size smaller . . M. hippocastani, F."

The chief distinguishing character of the genus is in the structure of the antennæ, which are clubbed, and the club has seven lamellæ in the male and six in the female.

\section{Melolontha vulgaris, Fab. (Cockchafer).}

The cockchafer, otherwise known in this country as the May bug or May beetle, in Germany as the Maikïfer, and in France as Le Hameton, is injurious both in the perfect and larval forms. The fullgrown beetle feeds on the leaves of oak, elm, sycamore, and other trees, and the larvæ on the roots of grasses and young trees. In the nidland and southem counties of England the seedlings in nurserylines often are destroyed by the larvæ (fig. 45).

Its life-history, as given by all English entomologists, may be briefly told. The eggs are deposited by the female insect during the summer, underneath the ground, from six to nine inches below the surface. About thirty or forty are said to be deposited by a single insect. They hatch out in about six weeks, and during the first year 
attain the length of about 16 to $18 \mathrm{~mm}$. They live from three to four years in the larval stage, and when full-grown are about $1_{4}^{T}$ inch to $1 \frac{1}{2}$ inch in length, and about $\frac{1}{4}$ inch to $\frac{1}{2}$ inch in breadth. They have six legs, the figures of which in various works appear to show the third $n$ last pair as the longest, whereas they are considerably the short-

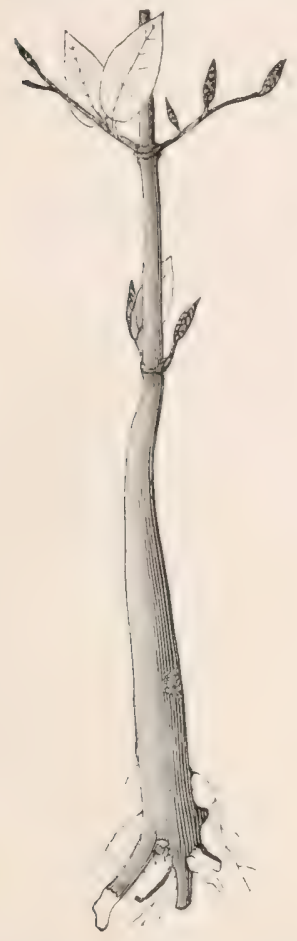

Fig. 45.-Young beech secdling, the roots of which have been destroyed by larva of May beetle (natural size). (From 'The Forester,' by John Nisbet.)
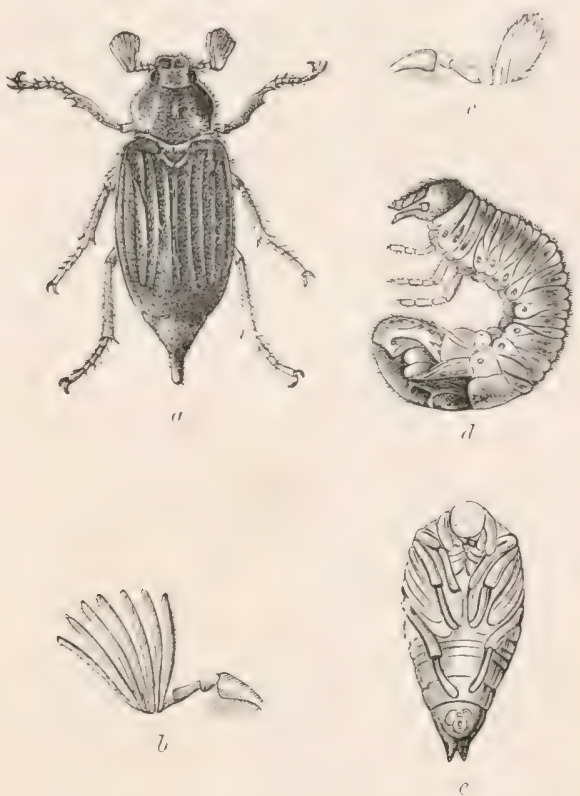

Fig. 46. - The common cockichafer or IIay beetle (Melolontha vulgaris).

$a$, beetle (male-natural size); $b$, feeler of male ( $i$ lamella - magnified four times); $c$, feeler of female (6 lamella-magnified four times); $d$, larva or grub (natural size); $e$, chrysalis (seen from below - natural size). (From 'The Forester,' by J. Nisbet.)

est, and the middle pair are a trifle longer than the other two. All the legs are more or less hairy. The jaws are porverful. They are a dirty white colour, with a ferruginous head, and become darker after being lifted out by workmen when trenching or levelling old "cops" or hedges. After feeding for three or four years the larva descends a trifle deeper, scoops out a recess, pupates in the autumn, and changes to a perfect insect in summer (fig. 46). 
The above account of the life-history may be only taken as regards England, or perhaps the north of France, as in Germany the cycle period is shorter in the south than in the north, thus showing that heat or geographical position is an important factor in life-histories.

\section{Preventive and Remedial Measures.}

This insect is injurious both in the perfect and larval stages, but more especially in the latter, and it is obvious that some remedial measures should be given. At the same time, it may be remembered that as this insect is so common and injurious in certain parts of the country, many practical men, according to local circumstances, have adopted their own respective methods of prevention and remedies. A few hints, however, may be given.

As regards the injuries done by the perfect beetle, they are of course entirely confined to the foliage, and the only remedial measures which could be adopted with any degree of success would be to place sheets under the most likely resting-places or feeding-ground of the beetles, and then to beat them on to the sheets, collect, and destroy them.

The larvæ, however, are much more difficult to deal with, and as they live for three years in the larval stage, it is highly essential that some practical methods should be adopted to lessen their attacks. From a forestry point of view, we have therefore to deal with them either in the young plantation or in the nursery. It is, of course, more difficult to deal with them in the former. In this case, before we can suggest any remedial measures, perhaps the most practical or effective way is to remember the nature of their life-history. It must be horne in mind that the female beetle prefers depositing her eggs on a grassy surface, as, for example, on an old pasture-fielt. If, therefore, it were practical to keep the young wood comparatively free from grass, it would obviously lessen the attacks, inasmuch as the females would not select the surface of the young woods for eggr-deposition. How far this could he carried out would depend largely upon local circumstances or conditions. If, for example, it were possible to have either a clean surface or, say, to cultivate potatoes between the plants, we should do much to lessen the attack, and at the same time be adopting a method which, in the case of portions of land planted for rapid landscape effect, would perhaps be the best means to adopt.

As regards the nursery from an estate point of view, we must 
remember that nurseries are of two kinds,-either temporary or permament. The former, as is well known from a practical point of view, is very advantageous; but in selecting a site for a temporary nursery we should not choose a spot adjacent to a wood which is known to be swarming with cockchafer beetles, nor should we, as far as possible, select an old pasture-field, unless it were found possible to cultivate it with potatoes or other root erops, which, from the nature of the working, would either facilitate the picking out of the grubs, or otherwise checking them in some practical way, prior to the eropping with young trees. As, however, the larvæ are quite as partial to the roots of young trees in the nursery-lines as they are to the roots of grass, we must adopt one of two methods,--either to make the surface of the nursery very distasteful to the female beetle as a spot to lay her eggs, or otherwise we must check or trap the larvæ themselves. With regard to making the ground distasteful to the female beetle for eggdeposition, we might regularly, from the beginning of May to the end of July, sprinkle the surface with parafin, sulphur, or in fact anything which would have a tendency to keep the female beetles off. With regard to collecting the larve in the nursery, without doing injury to the young plants a method of trap trenches might be adopted. If, therefore, the nursery plot is a comparatively large one, we might cut trenches at certain intervals, parallel with the lines, fill in those trap trenches with sods of grass, rolls of bark, weeds, partially decomposed turf, burned sods, layers of cow-dung, and such similar refuse as could be conveniently collected. From time to time those trenches might be turned up, the larve collected, and the materials replaced.

Another remedy for the larve is, of course, to periodically green-crop a portion of the nursery ground either for one or two seasons, as by so doing we should be able to pick out a great many of the injurious larvi; and in the case where the seedlings were to remain in the ground following such cropping, say for one season only, the nursery crop would be removed before any consideralle damage would ensue.

\section{Melolontha mippocastani (Fabr.)}

"The beetle (fig. 47) greatly resembles the common cockchafer, but is smaller, being only 20 to $25 \mathrm{~mm}$. long. Antennæ and legs darkbrown or black. Tail shorter, more abruptly tapering, and somewhat clubbed at its extremity. 
"Live-Thistr"y and economy.--In West and South Germany, similar to those of the common cockchafer, with which it swarms, but in smaller numbers. In East and West Prussia in the midst of great

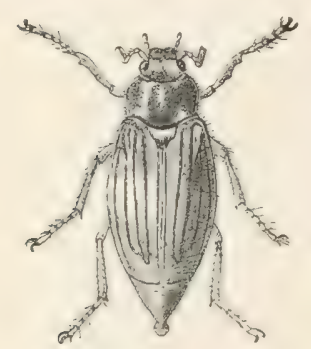

Fis. 47. - Melolontha hippocastani. (From 'Forest Protection, hy W. R. Fisher.)

Scots pine woods, this species alone destroys forests, the common cockchafer confining its attacks to agricultural lands. It does not merely attack horse-chestnut, as its name implies, but nearly all trees. The larvæ are highly destructive to young Scots pines three to six years old, but in their fourth summer they attack the roots of poles fifteen to eighteen years old, and even those of older trees. Season for swarming early (April). The eggs are laid eight to fourteen days afterwards, 10 to 14 inches deep in dry soil, but in moist soil only $2 \frac{1}{2}$ to 4 inches deep. The larvæ appear in.July, and pupate in August of the fifth year, about $1 \frac{1}{2}$ foot deep. The chafers come out in September and October, but remain underground till the next spring. A more northern insect than the common cockchafer; in Great Britain confined to Scotland and the extreme north of England." 1

\section{Genus AgriLus.}

This genus is probably more important in forest entomology than hitherto considered. There are five British species, and it would be well for the student to give them special attention.

\section{Agrilus viridis, Linn. (the Beech Agrilus). ${ }^{2}$}

As this is a south-country species, and one which I have not found, the following is copied from Mr Theobald:-

"Although rare, this beetle has been complained about as a pest amongst sapling beech-trees, whilst it is also said to attack birch, alder, aspen, and oak.

"The damage is done by the larve of this beetle, which burrow

1 Forest Protection, by W. R. Fisher (Dr Schlich's Manual of Forestry), vol. iv. p. 209, second edition, 1907.

2 'The Animal Pests of Forest Trees. 
between the bark and the sapwood, and form winding passages even into the wool, the tunnels increasing in size as the larvæ grow. Tow and again they completely girdle the stem, and then the upper part dies right away. As a rule, the bark over the passage splits and leaves behind a ragged crack, which is very characteristic of the damage done by this beetle. It appears to prefer weakly and unhealthy saplings, but sound ones may be attacked (figs. 48 and $49)$.

"The beetle (fig. 50) is about one-quarter of an inch long, and belongs to the family Buprestidæ, -long, slender beetles of usually metallic colour. This species varies from olive - green, - bluish - green, to blue-black ventrally; the apex of the elytra diverge, and are slightly dentate. They appear in June and July, and fly in bright sunshine. The eggs are placed on the bark of the saplings near the ground, usually singly, and exposed to the

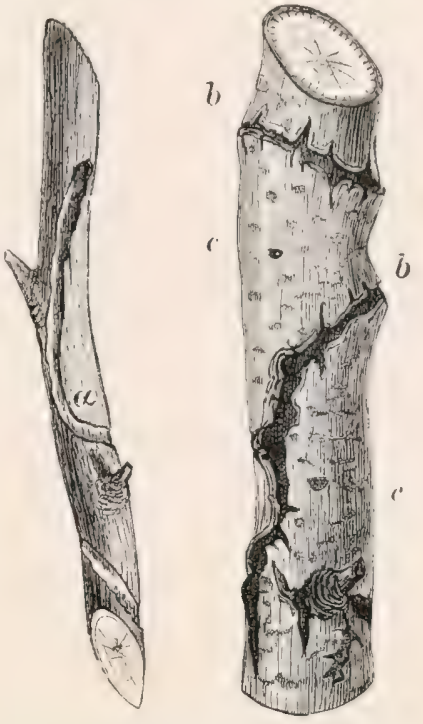

Figs. $4 \mathrm{~S}$ and 49. - Injury caused to beech sap. lints by Agrilus viridis, L. (uuturul siz). a, larval gallery, exposed by removal of the bark; l, old larval walleries, exposecl by rupture of the bark; c, trans verse oval Hight-holes of the imago. (From 'Forest Protection,' by W. R. Fisher.) sun. The larve appear in August ; they are white and legless, with broad first segment, usually somewhat flattened. They live in the trees for two or three winters, and pupate in April and May in the bark or sapwood, the cocoons being made of fragments of wood. The beetles emerge through holes which are oval below, straight above. They so seldom occur in this country that no further reference is necessary. Where it does do damage saplings should be smeared with clay, lime, and sulphur to stop the beetles egg-

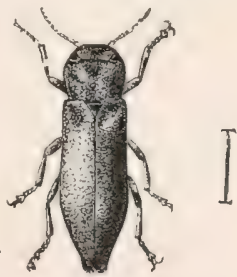

Fig. 50.-Agrilus viridis. (From 'Forest Protec. tion,' by W. R. Fisher.) laying, and all infested saplings should be pulled up and burnt early in May." 


\section{FAMILY ANOBIID君.}

The student of forest entomology, as a rule, finds his insects either on sickly or healthy living plants, but the members of this family are all found on dead wood, and are, therefore, apparently only indirectly connected with forestry, but they are nevertheless often very important as regards estate buildings. Perhaps the most familiar examples of the injuries of beetles belonging to this family are the "holes" or "worm-eaten" furniture in our cottages, and the injuries of a similar character done to timbers in our buildings. Again, in the forest proper, we find small holes in dead thorns, and also on those portions of old-standing trees where the wood is often dead on one side.

With regard to these injuries in roofing timber, it is rather remarkable that home-grown timber shoull be more seriously affected than foreign timber. Hitherto I have not found any special reason assigned for this. It may be that in home timber more of the sapwood is used than in foreign timber-for, as a rule, insects do not attack the heart-wood; or another explanation may be in the respective methods of seasoning.

There is nothing in the general appearance of the workings which can suggest any distinction of species beyond the size of the exit - holes.

Judeich and Nitsche ${ }^{1}$ consider this group important in forest entomology, and therefore divide it in the following manner, according to the damage done by the respective species:-

I. The larve inhabit the bark of old stems without particular injuries.

II. The larvæ live in still standing trees, whose timber they technically injure.

III. The larvæ inhabit the upper branches, and their injuries often cause death.

IV. The larvæ gnaw the young shoots, and thus destroy them.

V. The larve inhabit and destroy coniferous cones.

VI. The larvæ destroy comparatively old worked dry wood, planks, baulks in the wood stores, house utensils, furniture, \&c.

This hiological arrangement, though departing from the systematic, is a very convenient one to the forester of this country, more especially

${ }^{1}$ Forstinselktenkunde, vol. i. p. 343. 
as the insects themselves are not considered of primary importance, and it would be well, therefore, to give the respective insects which cause the particular injuries referred to in each division, but unfortunately we cannot get, owing to absence or rarity, the British species to fully coincide with the German arrangement in question.

In the first group Judeich and Nitsche give Anotium emarginatum, a species not recorded in Britain. These writers, however, say that it is not an injurious species, and only lives in the bark of old spruce-trees.

\section{Tribe anOBIINA.}

Fowler divides the tribe into the following genera :-

I. Elytra with punctured striæ distinct, at all events at sides; posterior coxæ distant.

1. Antennæ sub-contiguous at base, with the last three joints slender and long, especially in male Dryophilus, Chevr.

2. Antennæ distant at base, with the last three joints enlarged, evidently broader than preceding.

(1) Thorax not margined at sides . . Priobium, Mots.

(2) Thorax margined at sides . . Anobium, F.

II. Elytra without punctured striæ; posterior coxæ contiguous.

1. Tarsi with the fifth joint hroad; tibire stout Xestobium, MLots.

2. Tarsi with the fifth joint elongate; tibiæ slender

Ernobius, Thoms.

\section{Priobium castaneum (F.)}

This beetle is very common in Northumberland, in old dead thorn hedges. On May 26, 1905, I cut up a number of dead thorn stems from a heilge (fig. 51) and found several fully developed beetles, together with a few fully developed larve inside the stem. I laid aside a few pieces in a bag, and the beetles hatched out about the middle of June, or three weeks later.

The beetle is oblong, of a dull reddish-brown colour; antennæ and legs red; head fairly large, with prominent eyes; thorax lyoader than long, and narrower than elytra. The division between the elytra forms a deep furrow, and the longitudinal markings on the wingcovers are beautifully prarallel, so that uncler a strong lens it lowks like corduroy. Length about $4 \mathrm{~mm}$. 


\section{Xestobium tessellatum ( $\mathrm{F}$.)}

This insect, which is given as an example in the second group, is the largest of the British Anobiidre, and, according to Fowler, is recorded from many English localities, but very rare in Scotland.

The beetle is a large species, being about $7 \mathrm{~mm}$. long. The head is rather deeply sunk in the thorax, and the whole body is therefore

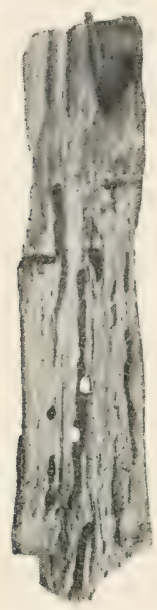

Fir. 51.-Portion of dead havethern stem bur rowed by larite. of Priobium castaneum. eylindrical and rather convex. The ground colour is dark-brown, but it is thickly covered over with a yellowish pubescence, and towards the abdomen there is an indistinct yellow band; antennæ reddish, legs dark-brown.

I am indebted to Mr Hereward Dollman for kindly sending two specimens.

The tribe Anobiina contains the species found in old wood in houses, and in dead wood generally. With regard to the former, the beetle popularly known as the "Death Watch" is perhaps the most familiar example. The poet says,

"The solemn death-watch clicked the hour she died,"

and this saying is simply the expression of a superstitious belief that the noise which the creature makes, and which is obviously most distinct in the stillness of night by a sick-bed, is associated with the supposed prognostication of a solemn death-warning. Several species are said to produce this noise, but the best examples are Anobium domesticum and Xestobium tessellatum.

\section{ERnobius Molis (L.)}

This species is very common in Northumberland, on larch and spruce palings or poles. It prefers very dry wood. I have hatched it from a spruce pole which had done duty as a flagstatr for several years. On finding larvæ under the bark in September, I cross-cut the pole into small pieces, and placed them in a lag, hung from the rafters of an open shed, and the beetles hatched out in intervals from the middle of June to the end of July. I have discovered then 
in large slabs which had done duty as a rustic covering on an important hut for six or seven years. The larve feed on the surfice wood, just below the bark, making irregular markings, as seen in fig. 52. They pupate below the surface of the bark, and often remain in their burrows after cutting out their exit-holes, or otherwise lodge in the burrows of the bark. In the middle of June they may be dislodged by gentle tapping, and thus collected freely.

The perfect beetle is from $3 \frac{1}{2}$ to $5 \mathrm{~mm}$. long, oblong, of a light ferruginous colour, and slightly covered with a pale pubescence. Eyes large and black ; antennæ slender.

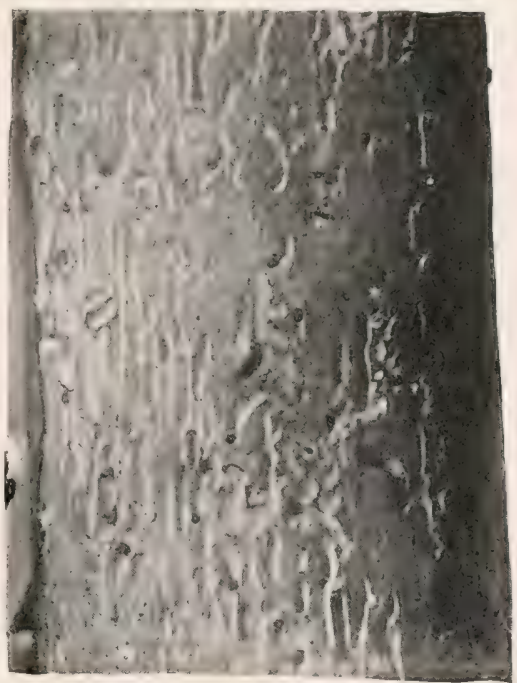

Fig. 52.-Marlings of larze of Emulins mollis on spruce pole.

Elytra rather long, with parallel sides; legs rather lighter in colour than body, and comparatively slender.

\section{LONGICORNIA.}

This group (so named because of the length of the antenne) is one which the general collector of Coleoptera is very anxious to get well represented in his cabinet. They are of special interest to the student of forest entomology, inasmuch as the larvæ are wood-feeders, feeding both in the living stem and on dead timber.

The larvæ are large, whitish grubs, and in many cases may be easily recognised in consequence of the prothorax being broader than the rest of the body. The head is, as a rule, comparatively small, and armed with strong mandibles and short antennæ. The legs, when present, are short or rudimentary, and locomotion is often assisted by fleshy tubercules which protrude from the body. 
Fowler ${ }^{1}$ divides the Longicornia into the three following families :-

I. Prosternum considerably produced in a blunt process behind anterior coxæ; thorax margined, with the sides armed with spines or teeth; labrum very small, usually connate with clypeus . . . . . Prionidæ.

II. Prosternum not, or scarcely, produced behind anterior coxæ; thorax not margined, with the sides sometimes armed with spines and teeth, but usually simple in one species; labrum free and distinct.

(a) Anterior tibiæ not grooved on their inner side

Cerambycidæ.

(b) Anterior tibiæ grooved obliquely on their inner side

Lamiidæ.

\section{FAMILY PRIONID压.}

\section{Genus Prionus.}

This genus contains only one species, and that species embraces the whole of the family of Prionidæ as represented in this country.

\section{Prionus corarius (Limn.)}

This handsome beetle is somewhat rare in this country, being chiefly confined to the south of England. The large larvæ bore into living oak-trees, and do considerable damage. There is only one British species, but several species are found in America, affecting various trees.

The beetle itself is about $1 \frac{1}{2}$ inch in length, of a dark-brownish colour, slightly shining, lighter below, robust antennæ, serrated in males, thorax black, comparatively square, and with spines at sides. It has the habit of fixing itself to the trunk, and flying at night. The female emits a very strong odour. The larvæ when fully fed are about 3 inches in length, of a whitish colour, and tapering considerably towards the anal end. At this stage they move towards the outer side of the trunk, and form a cocoon, whence the beetles emerge in July. 


\section{FAMILY CERAMBYCID压.}

The most salient characters of this great family of beetles are-body more or less eylindrical, with very long slender antennæ; larve called "borers," their bodies cylindrical, usually footless.

This great family includes a large number of species, many of which are wood-borers, and they are alike interesting to the general collector and student of forest entomology. The latter may often be able to hatch them, from larve in either fresh or dead wood, while the former may often enrich his collection with specimens found on the flowers of large umbelliferous plants.

The duration of the larval stage is very varied. They may, as a rule, live from one to three years, but instances are given of the perfect insects appearing from furniture which had been made of timber lying cut prior to using for several years. ${ }^{1}$

Aromia moschata, Linn. (Musk Beetle).

This species is so named because of the peculiar odour which it emits, which has been compared to the otto of roses. In the larval stage it is very destructive to willow-trees, and very often attacks lime-trees, but it is generally found in the rough stems of old pollarded

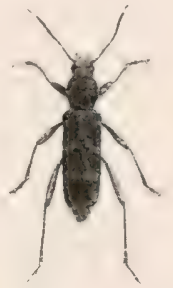

Fig. 53.-Clytus arietis (imisip) lectle), nutural size. (From photo by A. Flatter's.) willows, and, in fact, is said to be very common in all willow-growing districts.

The beetle is a very pretty and handsome insect, about an inch or more in length, with a strong spine on each side of the thorax. The colour varies from a rich sapphire to an iridescent peacock-green. In the male the antenne are $1 \frac{1}{2}$ time as long as the body; in the female, a little shorter than the body.

\section{Clytus arietis, Linn. (Wasp Beetle).}

This beetle (fig. 53) derives its common name from its general appearance, which resembles a wasp. The hody is rather more than half

I As the genera and species in this family, given as arboreal, are so comparatively few, it is not considered advisable to add generic characters. 
an inch in length, black, with bright yellow bands, beautifully marked behind the head and across the body. The general appearance is rather suggestive of designs for carriage decoration. The legs are rather long, and of a light terra-cotta colour. The antennæe are about lialf the length of the body, partly black, and partly the same colour as the legs.

This beetle is not an arboreal insect, in the true sense of the term, inasmuch as it does not attack living trees, but it is nevertheless a timber insect. In looking for arboreal insects we may come across it under the bark, and its appearance, habits, and specific characteristics justify the student of forest entomology placing it in his cabinet.

\section{Genus Rhagium.}

This genus is one which, though entirely arboreal, is not of very great economic importance in forestry. It is, however, one of those insects which it would be well to get familiar with, inasmuch as I have perhaps had more specimens of Rhanium bifasciatum sent me for identification, as being found in the forest, than any other class of insects. There are three species in the genus, two of which are very common in Northumberland - viz., $R$. bifasciatum and $R$. inquisitor.

The following, according to Fowler, ${ }^{1}$ are the specific characters :-

I. Antennæ very short; elytra rather strongly pubescent, without distinct oblique yellowish bands.

1. Head straight behind eyes; raised lines on elytra ceasing considerably before base . . . R. inquisitor, F.

2. Head narrowed behind eyes; raised lines on elytra continued almost to base . . . $R$. indagator, Gyll.

II. Antenne longer; elytra feebly pubescent, with two strongly marked oblique yellowish bands on each $\quad R$. bifasciatum, $\mathrm{F}$.

\section{Rhagium inquisitor (F.)}

The beetles may very easily be reared from the larvæ, which may be looked for in ash, oak, and other logs which have been lying in the woods until the bark has decayed and the sapwood dissolved into a black moist powder. The larvæ when full-fed are about an inch in length, pure white, with a light-brown head. If the Iarger-sized specimens are collected in February and Narch, and kept in the 
black material in a moist condition, they will develop into beetles about the beginning of April. Fig. 54 is from a photograph of the beetle.

\section{Rhagium bifasciatum (Fab.)}

This is a very common arboreal species in many parts of the country. In very warm days in July the beetle may be seen flying ahout amongst young fir woods, or lodging amongst the leaves of young Scots pines. During the summer months it may be fuund in the early morning, amongst the freshly cut sawlust, in the pit underneath the circular saw, where a portable sawmill is erected in a fir wood. During the winter and spring months the perfect beetles may also be found, together with many specimens of the larve, in old fir roots,

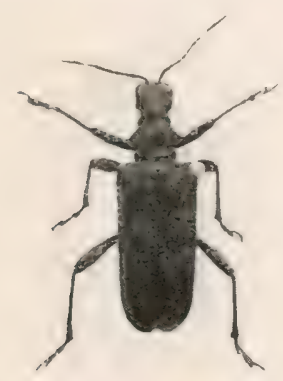

Fig. 54.-Rhagium inquisitor

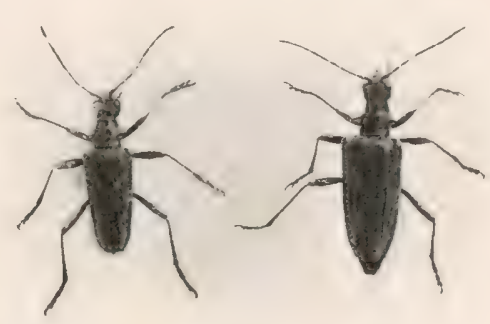

Fig. 55. - Rhagium bifasciatum
(natural size).

and more especially in roots where the trees have been blown down. I once found quite a colony in such a place in November, and as the beetles were fully dereloped, it is possible that they pass the winter in the perfect stage, after changing from the pupal stage in autumn, as so large a colony in one root could not be accounted for on the lines of hibernation. Another very happy hunting-rround for this species is in dead Scots pines which have been left standing until their condition is simply a mass of dry dust. I found quite a colony of the perfect beetles issuing from trees of this class on May 19, 1905, at Iyham, in Northumberland. After the exit from such trees, the stem shows so many holes that it looks like having been severely shot at with small bullets. As a rule, it cannot be considered an injurious insect, though in Cheshire I once found an oak log considerably destroyed by the larvæ of this species.

The perfect beetle (fig. 55) is shining and of a darkish mottled 
appearance. The conspicuous features of colour are two yellow oblique spots on each elytron-that is, four spots on the abdomen. The antennæ are a uniform brown colour. Legs black, with brown coxæ,-brown next the body and black next the femur, and the remainder of the leg brown. The thorax has very strong lateral spines. Length 15 to $22 \mathrm{~mm}$.

\section{FAMILY LAMIID压.}

From the systematic point of view, Fowler says, "The chief distinctive character of this family is found in the fact that the anterior tibie are obliquely grooved on their inner side : as a rule the palpi have the last joint cylindrical and pointed."

Fowler divides the family into twelve genera, the majority of which are associated with trees or timber, but two only may be consideredviz., Acanthocinus and Saperda, the former because of its peculiar appearance and structure, and the latter because of economic importance.

I. Femora distinctly clavate; thorax with lateral spines or tubercles. 1. Antennæ much longer than the body; upper surface smoother. (1) Antenne in male four times as long as the body; anterior coxæ rather widely distant; size large

Acanthocinus, Steph.

b. Antennæ 11-jointed . . Saperda, F.

\section{Acanthocines edilis (Linn.)}

The following description of this handsome insect is taken from Rye's 'British Beetles' :-

"Astinomus (Acanthocinus) cedilis is conspicuous for the enormous length of its antennæ, especially in the male. This also occurs at Rannoch, where it may be not uncommonly seen flying across the glades of the Black Forest with its long appendages streaming behind. It loves to settle on felled logs with its antennæ spread out like compasses, from which habit it is termed by the Highlanders 'Timberman,' a name curionsly enough applied to it in Lapland and Sweden, where it is common. If two males come within range they inevitably fight, for which reason, and also on account of their delicate structure, it is difficult to obtain quite perfect specimens. 
"The larva makes wide galleries and perforations in pine stumps, forming a niclus with coarse-gnawed fragments, near the surface, in which it changes to pupa. In this state the antennæe are turned downwarls, and recurved towards the middle of the head. It appears to be full-fed at the beginning of the summer, and after remaining two or three weeks in the pupa state, changes to the perfect state, staying as such in its nest until the following summer."

The bodly of the beetle is about $\frac{3}{4}$ of an inch in length, while the antennæ measure quite 3 inches.

Rannoch, or the "Black Forest," in Perthshire, referred to, is a

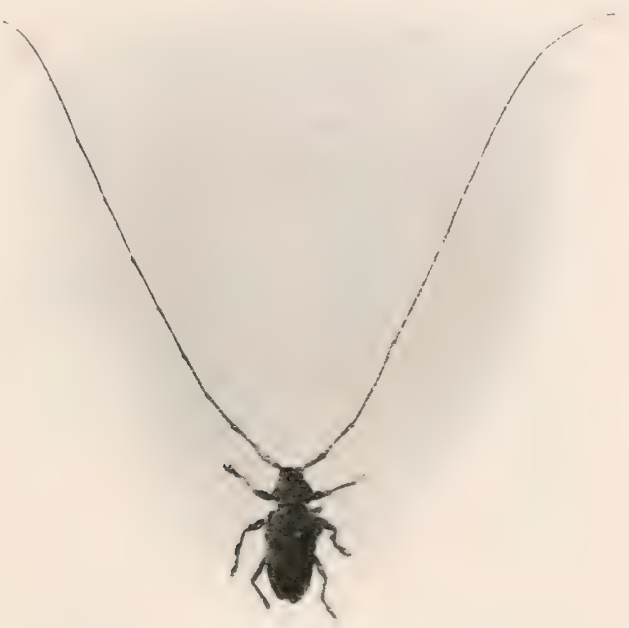

Fig. 56. -Acanthocinus ædilis (half natural size).

very happy hunting-ground for the entomologist. This is due to the fact that it is the remains of the old Caledonian Forest. Fig. 56 is from a photograph of the beetle.

\section{Genus Saperda.}

Head with vertical forehead. Larvæ without distinct legs, almost parallel-sided, and 11-jointed. Thorax longer than broad, witliout side spine. Genus exclusively arboreal. 


\section{Synopsis of the Species.}

Size large, elytra contracted towards the extremity, without any distinct patches; body covered with greyish-yellow hairs; legs dark

S. carcharias.

Size smaller, elytra cylindrical; thorax with yellowish side band; each elytron with four or five yellowish flecks . S. populnea.

I am indebted to friends for the specimens in my collection, but as I have not had any opportunities of studying this genus in the forest, the following account of the two species is taken from Professor Fisher's 'Forest Protection' (Schlich, vol. v., 1907 edition).

\section{Saperda carcharias, L. (Large Poplar Longicorn).}

Description.-Beetle (fig. 57) 23 to $30 \mathrm{~mm}$. long, grey or brownishyellow, dotted with many shining black points. Thorax short and

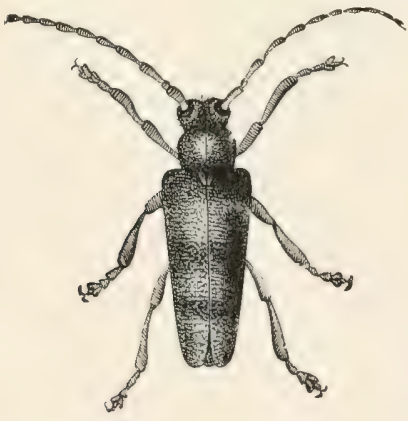

Fig. 57.- Saperda carcharias. (From ' Forest Protection,' by W. R. Fisher.)

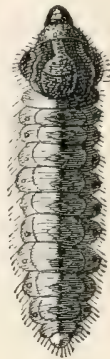

Fig. 58. - Larva of Saperda carcharias. (From 'Forest Protection,' by W. R. Fisher.)

cylindrical. Elytra with the shoulders prominent, narrowed posteriorly, and bluntly spined at the apex.

Larva extending up to $36 \mathrm{~mm}$. in length, without legs, cylindrical, yellowish-white, with the mandibles and segmental shields brown, the latter on the dorsal surface of segments $3-10$, and the ventral surface of segments $2-10$ (fig. 58).

Life-histor\%.-Season for flight: June and July.

The eggs are laid in June in crevices in the bark of poplars, especially near the ground. 
The larva emerge in July and August, and live and hibernate in the wood, pupating in May of the 3rd year.

The pupe lie head downwarls in a chamber blocked with a plug of wood-dust.

The imagos emerge in June of the 3rd year.

Generation biennial. The insect is rather common in a few parts of Great Britain, chiefly in the eastern counties.

Relations to the forest. - The larvæ bore into young, healthy poplars, and also into willows; aspen and black poplar up to 20 years old are specially attacked. Seedling trees are liable as a rule to be attacked from their 5th year, and suckers from the 3rd year.

The larvæ make vertical galleries, which reach the centre of the tree: these become gradually filled with wood-dust, which is forced out of the tree by the grubs through a bore-hole, and becomes heaped up at the base of the plants. The stem is attacked near the ground, and reacts by developing a large irregular swelling, the bark of which is fissured. Such perforated saplings are easily broken by the wind. This insect is chiefly of importance where poplars are grown on a large scale, as in France. It is sometimes associated with Sesic apriformio, Fabr., and Cossus ligniperda, Fabr.

The beetles in June and July eat roundish holes in poplar leaves, but this injury is unimportant.

\section{Saperda populnea, L. (Small Poplar Longicorn).}

Dexcription.-Beetle $8-13 \mathrm{~mm}$. long, greenish-grey to dark brown, covered with yellow-grey pubescence; thorax with three lines of pubescence; elytra with the median line, and a broad lateral stripe, and three or four spots on each side pubescent. Antenne blackish, and each segment up to two-thirds of the length of the antennæ with grey pubescence. Larva $13-15 \mathrm{~mm}$. long, yellowish, and resembling that of the preceding species.

Life-history. - The female deposits her eggs in May and June in cracks on the bark of young aspens, less commonly on other species of poplar, sometimes on willows. Seedlings of 2 to 6 years old and suckers are preferred.

Generation biennial. The larva hatches in July, bores through the bark, and eats a circular gallery round the sapwood. The stem, usu- 
ally one of the smaller branches, reacts by forming a gall-like swelling, which, however, is not found on willows. See fig. 59.

In the second summer the larva changes its course, boring upwards along the middle of the stem for about an inch. The flight-hole is

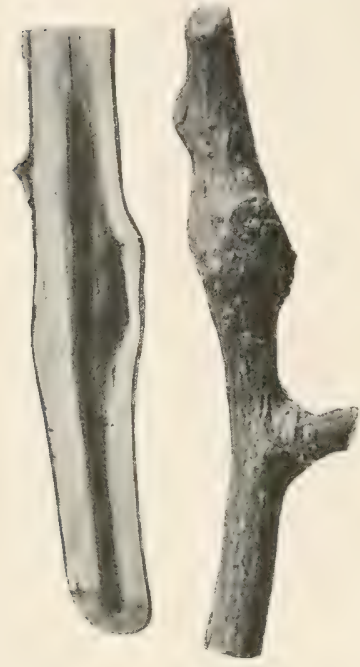

Fig. 59.-Injury caused to stem of aspen poplar by larve of Saperta populnea. circular, and situated on the swollen portion. Pupation in April of the third year.

This insect is usually found in open sunny places, and is not uncommon in the Midlands and south of England. It seldom kills the trees, but cripples the branches and prevents growth. Where it is abundant, hardly a branch can be found free from its gall. Fig. 59 is a representation of injuries.

\section{TRIBE CHRYSOMELINA.}

\section{Gemus Melasoma.}

There are three species in this genus, all of which are arboreal; but as two are very local, the species described may be taken as typical, and generic characters need not be given. Not having found the species considered, the following is taken from Fisher. ${ }^{1}$

\section{Melasoma populi, L. (Red Poplar-leaf Beetle).}

Description.-Beetle 10 to $12 \mathrm{~mm}$. long, of an obovate shape, blackish-blue, the elytra brick-red, their extreme tip black; thorax narrower than the elytra, its sides rounded, broadly raised and coarsely punctured; antennæe short, compressed, thickened towards the ends.

Larva 6-legged, of a dirty white colour, with many black spots, and two white lateral projections on the second and third segments.

Pupa sharply narrowed towards the posterior extremity, brownishyellow, with regularly distributed black spots and stripes.

Life-histor \%.-The season for flight is in May and June.

1 Forest Protection, 1907 ed. 
The of lays her yellowish-white eggs in clusters of 10 to 12 , in all 100 to 150 , on the under side of the leaves of young poplars. The larva emerge in June or July, feed openly on the leaves, and if disturbed exude a milky-white fluid, with an odour of bitter almonds.

Pupation takes place in July and August; the pupæ hang reversed from the leaves by their pointed end.

The beetles emerge by the end of August, and after October hibernate under leaves or moss, reappearing in the open in April.

Generation annual, but frequently double, when the beetles hiber-
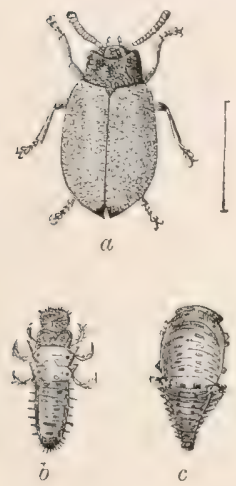

Fig. 60,-Melasuma populi. a, beetle; b, larva ; c, pupa. (From 'Forest Protection,' by W. R. Fisher.)

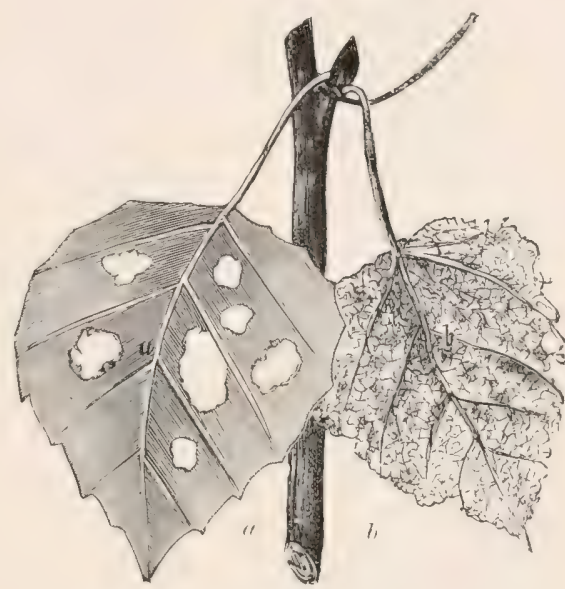

Fig. 61.-Injuries done by Melasoma populi. $a$, leaf bitten by beetle; $b$, leaf bitten by larvæ. (From 'Forest Protection,' by W. R. Fisher.)

nate; larvæ appear in May and June; pupæ 3-4 weeks later, new beetles 10 days later. Fresh larvæ in August, the second generation closing in the midille of September. Locally common in many parts of the British Isles, chiefly in South England.

Relations to the forest. - The insect, both in the larval and beetle stages (fig. 60), attacks young poplars and sometimes aspen shoots. Occasionally they are found in osier-beds, especially on Salix purpurea, L., and S. rutra, L., \&c. The larvæ attack the leaves, whicin are completely skeletonised, the parenchyma being eaten and the veins left intact. The imago eats holes out of the leaves (fig. 61).

The attacks last from June to August. 


\section{Gemus Phyllodecta.}

This is truly an arboreal genus. The beetles are usually of a bronze or metallic colour, oblong shape, parallel sides, rather long antennæ, elytra with beautifully punctured striæ.

Fowler gives the following specific characters-viz.

I. Punctured striæ of elytra irregular, colour blue

$P$. vulgatissima, $\mathrm{L}$.

II. Punctured striæ of elytra regular.

1. Forehead broadly excavated; antennæ longer; colour dark blue . . . . P. cavifrons, Thoms.

2. Forehead with a slight depression, not excavated; antennæ shorter; colour, as a rule, bronze $\quad$. P. vitellince, L.

The two species $P$. vulgatissima and $P$. vitellince are often confounded, and very difficult to distinguish by the practical man, affording, perhaps, a good case in point where the services of the systematic Coleopterist would be valuable.

\section{Phyllodecta (Phratora) vitelline (Kirby).}

This beetle (fig. 62), which is in many parts of the country popularly known as the willow beetle, is about one-sixth to one-eighth of

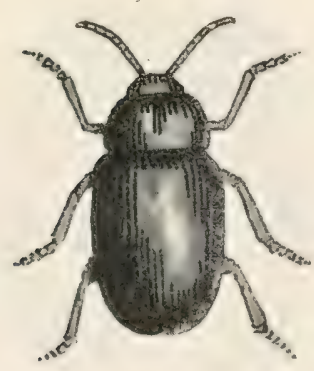

Fig. 62. - Phyllodecta vitellinæe (willi,w bectle), wrill mush cnlarger?. (Drawn by P. J. Brown.) an inch in length, of a bluish-black metallic colour, with a dash of bronze or green above and more below. The body is oval-shuped, with longitudinal punctured rows on the elytra.

The perfect insects hibernate in rotten wood and underneath the bark of trees, more especially such rough parts as those on Ontario poplar and the excrescences on ash caused by the fungus Nectria ditissima. In such places I have often found them in mill-winter. On the arrival of spring and the general appearance of vegetation they leave their sheltering places, and betake themselves to the osiers or poplars.

The female deposits her eggs in small clusters, generally six eggs in 
a cluster, on the under side of the leaves of willow, sallow, or poplar. Whether the female deposits more than one group, I am at present unable to say. The eggs very soon hatch out, and the larvæ do immense damage by eating the green portions, leaving only the vascular portion,-in fact, skeletonising the leaves, and giving the aflecterl portion of the plant a rery dirty-looking appearance (figr. 63 aml 64). They feed on the under side of the leaves, moving in straight rows like soldiers marching in single rank. They are rather larger than in the perfect state, and are of a dirty-looking colour.

The damage done to the willow, more especially the osier (Salix viminalis), is by no means confined to the larval stage. The perfect beetles do immense damage to the young rods by eating the tender portion of the extreme point,-in fact, eating the growing point; and as length is the main object of osier-growing, it is obvious the damage cannot be exaggerated. Damage of a similar nature to rods of the second year's growth likewise causes a great loss to willow-growers, inasmuch as the shoots throw out a number of small lateral branches, instead of increasing in growth by length. Hence they are very much depreciated in value.

Hitherto I have not been able to work out the full life-history of this insect. Some naturalists assert that it is double-brooded, but in all probability we have a succession of perfect insects appearing throughout the summer.

As regards remedies, the usual insecticidedressings of quassia, Paris green, \&c., would no doubt help to keep it in check, but I have found that the best way is simply to go over the

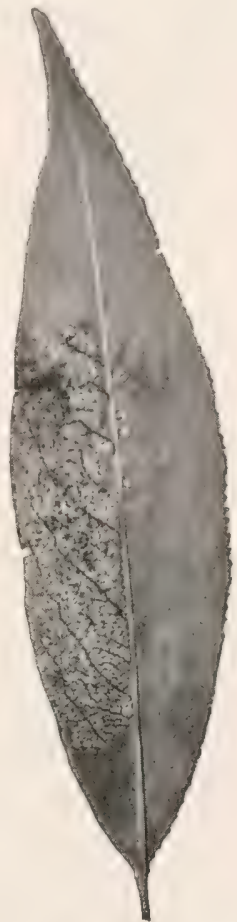

Fig. 633. - It illum linf injurat len liserer if uillow beetle (natural size). rows of twigs and shake the beetles into an old jar containing paraffin.

A very interesting account of the damage done to a large sewage farm in Lymm, Cheshire, will be found in Miss Ormerot's Manual; and my esteemed friend $\mathrm{Mr}$ J. Mort, who had then, and still has, charge of the farm in question, assures me that the beetles have all 
but disappeared as the result of anmually shaking them into paraffin. I can fully endorse this, not only from adopting the same method, but also on account of frequent pleasant per-

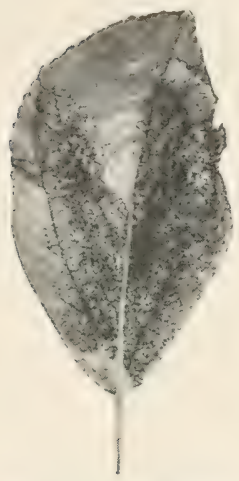

Fig. 04. - Leuf of balsum poples injural bulterew of willow beetle (re-
duced). sonal inspections of Lymm Sewage Farm along with Mr Mort.

\section{RHYNCHOPHORA.}

This section embraces a very large series of insects, both to the systematic student and the arboriculturist. As, however, the main distinguishing generic characters are given, it would be superfluous to give too many detailed sectional characters. In a general way (exclusive of the Scolytidæ) they may be characterised as "snouted" weevils. Many of them are easily reared from the larval stage, but it would be well for the enthusiastic student to collect this class of insects from palings, trunks of trees, stone walls, \&c., as by so doing he would not only gain a knowledge of the section, but many important points bearing on the life-history of arboreal species could be ascertained.

The family Curculionidæ contain certain weevils which are either injurious or otherwise interesting as forest insects, perhaps more especially those which cut and roll leaves in a peculiar manner, either for the benefit of the larvæ or the perfect insects.

To the systematic student of Coleoptera this is, comparatively sleaking, a very large family, and many species may be beaten from different deciduons trees, but the student of forest insects may confine his attention to the leaf-cutting and leaf-rolling species. With a view, therefore, not to overload the student in the details of classification, it is intended to give as few systematic characters as possible.

\section{Attelabus ourculionides (Linn.)}

This leaf-rolling beetle is very plentiful in some parts of the country. I have found it in Delamere Forest, Cheshire, at Newball in Lincolnshire, and also in the southern side of the county of Northumberlaud. As regards the date of appearance, I found it, together 
with the rollings, in the former place on June 15, 1895, and on June 20, 1896.

The work of the female beetle is very easily recognised in the form of "thimble cases," constructed by rolling up the oak (or, more rarely, Spanish chestnut) leaves (fig. 65). These are chiefly found on young shoots, growing as underwood. On unrolling the cases on the dates men-

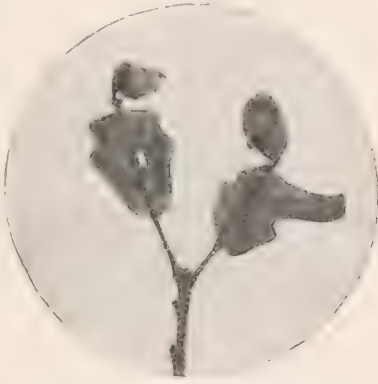

Fig. 65.-Oah-leaves rolled by Attela-

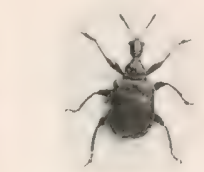

Fig. 66.-Attelabus curculionides (natural size). (Photo by $\mathbf{A}$. Flatters.)

tioned, a single egg was found in each case. The egg is a small spherical body, of an orange colour.

The perfect beetle (fig. 66) is about $6 \mathrm{~mm}$. long, of a bright rufous-brown colour; thorax and elytra smooth; legs all black and shining; antennæ black and 12jointed; head black, and eyes of a chocolate colour.

\section{Deporaüs Betulæ (L.)}

This species of leaf-rolling beetle is abundant in many parts of the country, but I have found it most plentifully at Kielder, Northumberland. The leaves (of birch) are cut much in the same manner as by the preceding species, but the case is rolled lengthwise instead of in a globular form (fig. 67). The rolled portion somewhat resembles a kind of paper bag used by grocers or

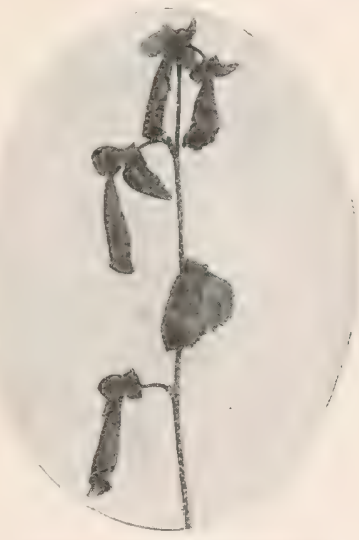

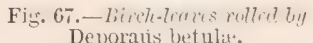
confectioners, and made by rolling a square-cut piece of paper round the hand. The chief injuries are done by the female insect: she interferes only with the vitality of a certain portion of the leaf. She hecrins rolling operations by making an incision on the outer edge of 
the leaf in the form of an $\mathrm{S}$ or ogee curve, until she reaches the midrib, over which she skips and cuts another $\mathrm{S}$ line, until she reaches the upper and outer edge of the leaf at ahout the same distance from the midrib as where she made the first incision. The rolled portion is partially weathered, and the other portion remains quite fresh. I have searched many of the cases, but hitherto

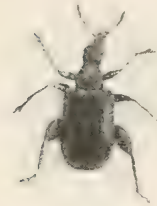

Fig. 68.-Denorauis betulie (enlarged). (Photo by $\mathbf{A}$. Flatters.) have not found any eggs as in Attelabus, though several perfect insects have been found sheltering within the folds.

The beetle (fig. 68) is about 2 or $3 \mathrm{~mm}$. long, of a black, shining, metallic colour, and striated. The beak is more or less widened at the tip end. The head is not narrowed into a neck behind the eyes. The antennæ are 11-jointed, and the beetle is on the whole a very pretty insect, though not so brilliant as the species of the closely allied genus Rhyncophora; but the metallic hue depends very much on the angle of light.

\section{Gemus Otionrhynchus.}

This genus is perhaps more important to the gardener than the forester, and the young student may get them in the first instance by collecting in the garden.

\section{Otionrhynchus picipes, Fabr. (Clay-coloured Weevil).}

This insect is most injurious in the perfect stage, and generally feeds at night on the shoots of various plants-viz., vines, raspberries, and strawberries in the gardens, and on thorns and other plants in the nursery and forest. I have only found it twice as a forest pest,-once doing much damage to several classes of young trees in the nurseries of Messrs Caldwell \& Sons, Knutsford, Cheshire, and also on young thorn hedges in High Legh, Cheshire. The latter case was accidentally discovered in the following manner. A farmer once applied to me for wire-netting as a protection against rabbits, which were, he said, eating the shoots of a recently eut-off hedge: the "cutting off" had been done the second year after planting. Knowing that the hedge in question was in the middle of a ploughed field, and where I thought no rabbits could be near, I at once refused the request pending a 
personal inspection. On arriving at the spot, I found the bark of the quicks badly eaten from the cut, half-way down to the soil. In vain I tried to persuade the farmer that it was insect and not rabbit damage; but on lifting the small clods of soil, the insects were found in great numbers, and so beautifully did the soil blend with the colour of the insect that only a practised eye could detect them. As a remedy we sprinkled paraffin on the soil, but a sudden change of favourable wet weather following a prolonged drought perhaps had better effects than the paraffin dressing.

The perfect beetle (fig. 69) is about 7 to $8 \mathrm{~mm}$. in length, or from one-fourth to one-third of an inch. The head and thorax are blackish in colour, and the elytra bearing to brown. This blending

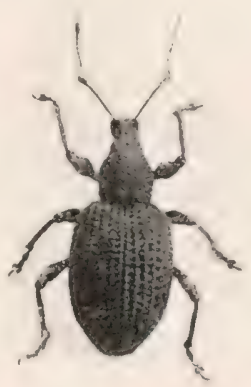

Fig. 63.-Otiornliyncluns picines (enlarged). (Photo by A. Flatters.) of black and brown gives it the appearance of clay, hence the name. Under the microscope the body has a scaly appearance. The legs are ferruginous, and the clubbed antennæ 12-jointed.

The larvæ live in the soil, and are whitish, legless, and somewhat hairy. The pupæ show all parts of the perfect insect.

\section{OtionRhyschus sulcatus (Eabr.)}

This beetle (fig. 70) is generally found in vineries, and is popularly known as the vine weevil. I once found it in Cheshire eating the young leaves of the common blackthorn. It is larger than the previous species, and of a dull black colour, varied with ochreous-yellow scales on elytra.

\section{Genus Strophosonus.}

This genus may be characterised by the eyes being extremely prominent, appearing in some species as if almost detached from the head. The head is also large and triangular. There are several species in this genus, but only two, namely, $S$. corplli and $S$. capitatu:
Fig. 70. - Otiorrhynchus suleatus (vine. weevil), natural size. (Plioto by A. Flatters.) 
(ohesus), may be considered as arboreal. The former is often recorded as doing considerable damage in this country, and the latter as being injurious to certain young trees on the Continent. It is, however, possible that the injuries of the latter species may have been overlooked in this country.

\section{Synopsis of the Species. ${ }^{1}$}

I. Elytra not fitting tightly into the base of thorax; scrobes slightly but plainly deflexed.

1. Elytra with the suture denuded at base, forming a black longitudinal patch at scutellum . . . S. coryli, F.

II. Elytra with the suture not denuded at base.

1. Erect hairs on elytra very distinct, if viewed sideways; thorax rugosely punctured . S. capitatus, De G. (obesus, Marsh).

\section{Strophosomus CORYLi (F.)}

Tarious accounts have been given of this beetle doing considerable damage by feeting on the foliage of lareh, oak, birch, \&c., in comparatively young plantations. It has also been recorded that considerable damage has often been done by it to several species of young trees in the nursery.

The insect, from a collector's point of view, may frequently be beaten from several species of young trees.

This beetle is from $\frac{1}{6}$ to $\frac{1}{4}$ inch in length, almost spherical in form, and of a uniform brownish-grey colour. The antennæ and legs are ferruginous, elytra with moderately punctured strix.

\section{Strophosomus capitatus, De G. (obesus, Marsh).}

This beetle is often found very injurious to the foliage of birch, and may be beaten in showers from young trees or coppice in early summer. The leaves are entirely riddled, so that where perfect foliage is an important point a slight depreciation ensues throughout the season.

The beetle is very much like the preceding species, but slightly smaller in size and very globular in form, - a character, however, very typical of the genus.

1 Fowler, vol. v. p. 189. 


\section{Polydrusus mitans $(\mathrm{F}$.}

I foumd this species very abundantly feeding on oak leaves of the epicormic branches at Reedsmonth, Northumberland, Nay 15, 1901. It could not be sail, however, that they were doing appreciable damage to the trees. Usually local, and not common.

The beetle is rather large and conspicuous, being from 7 to $9 \mathrm{mmm}$. in length, and the whole body is of a uniform coppery colour, and being rounded, the colour varies in detail as the result of refraction; legs and antennæe red, the club of the latter somewhat darker.

\section{Genus Phyllobius.}

This gentis contains a large number of species, most of which may be found in the forest. They are generally got in the early part of the year, and often do considerable damage to the foliage. As a rule, the species may be recognised by their more or less brilliant colouring. One species, viz., $P$. urtice (alneti, F.), is very common on nettles, and though not an arboreal species, might nevertheless be taken as a typical example of the genus. It is quite possible the specific distinction, as associated with forest trees, may hitherto not have been carefully recognised.

\section{Phyllobius maculicornis (Germ.)}

This beetle was discovered as doing considerable damage on recently planted trees of mountain-ash and

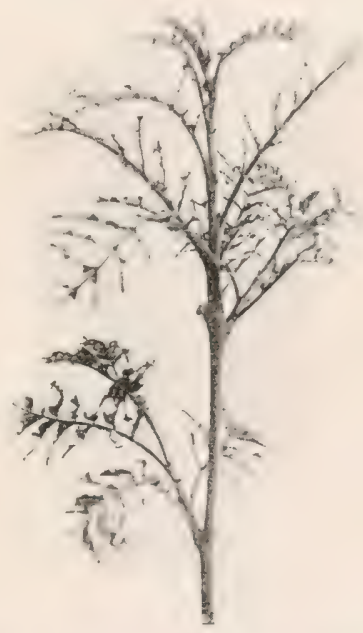

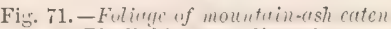
b.y Pliyllol, ius maculicornis. birch at Kielder, in Northumberland. In fact, the trees were quite defoliated as the result of their injuries.

On mountain-ash, fig. 71 is given as an example of the injury referred to by the beetle. 


\section{Hrlobius abietis, Fabr. (Pine Weevil). ${ }^{1}$}

This is considered one of the worst insect enemies the forester has to deal with; in fact, it may be said to be the most dreaded beetle.

From an entomological point of view, it is very closely allied to the genus Pisorles, and it may therefore be well to state that the chief reneric difference is that in Hylobius the antenme are inserted on the rostrum near its apex, while in Pissodes the antennæ are inserted
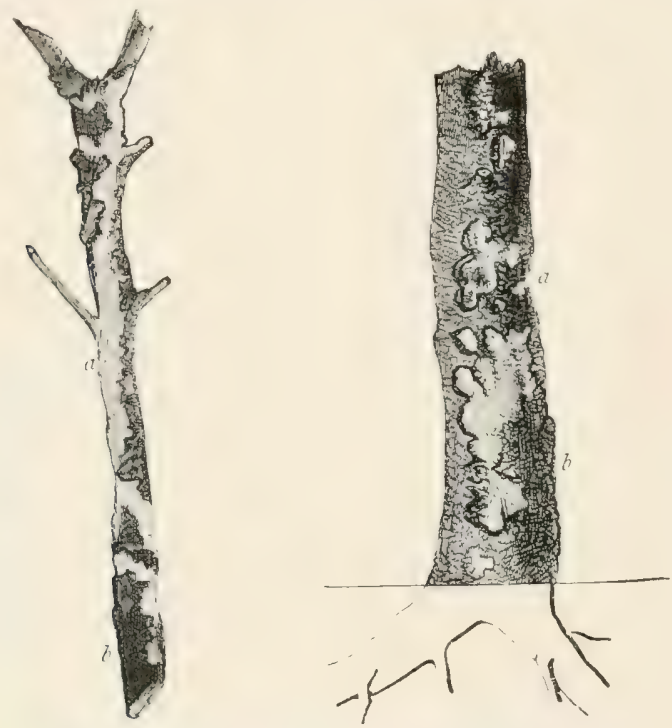

Fig. 72.-Foung spruce plants gnaued by Hylobius abietis. $a$, parts gnawed; $b$, parts still corered with bark.

about the middle of the rostrum. It is well to remember this important distinction, inasmuch as many specinens of Hylolius alnitis are very small in size, and may therefore, to the non-entomologist, be confounded with specimens of Pissodes pini, more especially when found in fresh sawdust, and apart from the respective injuries with which they are associated.

The pine weevil is injurious in the perfect state alone, chiefly to young coniferous trees from four to seven years old. Older coniferous

${ }^{1}$ As there is only one species in the genus, generic characters need not be givels. 
trees do not suffer so severely, but they have been known to attack young hardwoods, more especially when mixed with coniferous trees. They eat the tender shoots, buth bark and cambium, in such a mamner as to present an appearance of rabbit damage (fig. 72). In our cunntry the plants most used for planting are about three to four years old, and when such are attacked after being recently planted it is obvious they are not strong enough to resist the injuries, and the consequence is that many die off, and expensive replanting has to be resorted to. When the bark of older trees is eaten the injuries are not so severe. The weevil is especially fond of young shoots, and the vital cambium is therefore eaten with the bark.

The beetle (fig. 73) is a dull black colour, but brightened by several fairly large yellow spots on the elytra, which collectively form irregular bars. There are also a few yellow scales on the thorax. The rostrum is very stout, with the antenne inserted at the apex. Legs black, and femora armed with a strong stout spine. Length from 8 to $14 \mathrm{~mm}$.

As regards the life-history of this insect, it affords a very striking contrast to the life-history of some moths, as, for example, those which apjear and disappear within certain prescribed dates. The pine

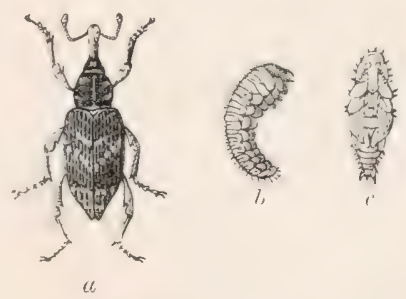

Fig. 73.-Hylobius abietis (pine weeril). $a$, beetle (natural size); $b$, larva (natural

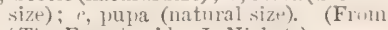
'The Forester,' hy J. Nishet.) weevil may, with special entomological knowledge, be found in all stages throughout the year. This fact, together with an unworked life-history, led to great diversity of opinion. Thus Altum, who carefully studied the species, maintained that a generation required two years for its complete development, while Eichhoff considered it more probable that there were two generations in a single year. This point has now been decided by Von Oppen, who has done very valuable work by working out its life-history from observations carried on under circumstances approximating to its natural conditions. As a result of his careful investigations, he found that the beetle was endowed with great vitality (extending over two years), and further, that it has the power of re-copulation and repeaterl ergdeposition. Hence this would account for the insect being found in all its respective stages at one and the same time. A single gener- 
ation, however, takes about fifteen months for complete development. The beetles swarm, or rather leave their winter quarters, about the beginning of April. These old beetles, therefore, deposit eggs on the roots of trees which have been felled about two or three years. The larvæ hatch out in about three weeks' or a month's time, and feed until about May or June of the following year. They then pupate for a short time, about three weeks being considered the regular period, and appear as perfect beetles about June or July. The late swarmers are comparatively harmless, as they soon hibernate under rough grass and heather, ready to do double duty the following year. The larvæ commence eating just under the bark, but do not reach the bottom of the bark and the surface of the wood until about the end of September. Then for the remainder of their feeding-period they make long winding galleries.

It may be noted that there is a common opinion that the insects lie for three years in the larval stage, and therefore it is advisable to give the ground three years' rest in consequence. The amount of rest is quite practicable, but $I$ am, from personal examination, of opinion that they rather prefer attacking the roots that have been cut for three years, and only live for a season in the larval stage.

\section{Preventive and Remedial Measures.}

As this is a very destructive beetle, it is advisable that, as far as practicable, the insect should be kept well in check.

As regards dealing with the beetle, the only remedy is collecting and destroying. Success in this respect will greatly depend on the method of local work and its associations. My own experience has been in connection with cutting a portion of a large tract of pure Scots pine every year with a movable sawmill in the wood, and also replanting a portion of the ground annually. At first the replanting was done on the heels of the cutting, and the result was that the plants were eaten off wholesale, and replanting had to be adopted. In the summer season the sawdust hole was carefully examined every morning and the beetles from the fresh sawdust destroyed. So much for beetle destruction. Now as regards the destruction of larvæ. In the winter season all branches accruing from the trees felled in summer were burned on the ground, and as many fires as possible made on the 
stools of felled trees. This had the effect of destroying the breedingplaces. When the fires were in progress they were greatly angmented by loose heather and other rubbish on the ground. This to some extent had the effect of reducing the congenial conditions for the hibernation of the prospective beetles during the coming winter; and finally, when the burning was completed, the land was temporarily fenced and stocked for three or four years with sheep and cattle. This had a remarkable effect, inasmuch as the bark was removed from the roots, thus utterly destroying the breeding-ground for the larvæ, and altogether improving the soil for the future planting.

It is obvious, however, that this method can only be adopted where fir woods are on a large scale. If, however, sudden replanting has to be done with coniferous trees, where a mixture of pine-trees had formed the previous crop, it would be well, if at all practicable, to uproot the pines, or otherwise render the roots unfit for breeding-places. Trenches might be made in the ground, and fresh sawdust scattered in them; or otherwise, lay pieces of fresh pulled bark on the ground, rough bark upwards, to act as traps for catching the perfect beetles.

\section{Genus Pissodes.}

This genus is very closely allied to the foregoing. The genus Pissodes contains two species in this country-viz, $P$. pini and $P$. notatus; but there are several species found on the Continent, and it may therefore be some inducement for British workers to keep a sharp look-out for additional species, together with their respective injuries.

So far as our present knowledge goes, it cannot be said that the Pissodes can be compared with Hylobius as regards forest injuries, inasmuch as the former in the larval stage confine their attacks to sickly trees, and in the perfect stage gnaw at the tips of young Scots pine trees, but are not injurious in any appreciable sense.

The structural details of the genus are well described by Dr. Stewart MacDougall : ${ }^{1}$

"The species belonging to this genus have a longish rostrum. Near the midlle of the rostrum the elbowed antennæe are inserted, their

1 "The Biology of the Genus Pissodes." Proceedings of the Royal Society of Edinburgh, vol. xxiii. 
long basal joint almost reaching the small, slightly-projecting eyes. The prothorax is narrowed in front, and its posterior margin, on examination with a lens, may show two slight excavations. The scutellum is round and raised. The elytra quite cover the abdomen. Femur untoothed, tibia straight, and with a curved hook at the point. The third joint of the tarsus is hroad and two-lobed, and the terminal fifth joint ends in two simple claws."

\section{Synopsis of the Species.}

I. Size larger: thorax short in proportion with the sides, more rounded; elytra with narrow transverse band behind the middle . . . . . . . P. pini.

II. Size smaller: thorax large in proportion with the sides, less rounded; elytra with a broad though not over-distinct transverse band behinil their middle. . . $P$, notatus.

\section{Pissodes PINI (Linn.)}

This species is very closely allied to Hylobius abietis, and to the young student very much like small specimens of the latter, inasmuch as both species may be found together in the mornings in the fresh sawlust pit underneath the circular saw. Where a temporary sawmill is erected in a Scots pine wood, it may be well to try and distinguish the two species. Is many specimens of $H$. atieti. are comparatively small, it is well, for the sake of distinction, to bear in mind that the chief difference lies in the position of the antennæ. In $H$. alietis, as already mentioned, the antennæ are inserted on the rostrum near its apex; and in the genus Pissodes the antennæ are inserted about the middle of the rostrum.

A part from the sawdust heaps, this species is found most abundantly in the larval stage. As a rule we may look for the larvie in dead standing Scots pine-trees from twenty to thirty years of age, more especially under the rough portion of bark. At times they may be found on cut trees lying on the ground, but not so plentifully as on dead standing trees. Nitsche gires spruce and Weymouth pine as food-trees. In the winter season the presence of the larvæ may be recognised by the bark being very much torn about, from the ravages of insectivorous birds in search of the larvæ as food. 
As the larve are always found on back-going or deal standing trees, this species camnot be considered as directly injurions. It would therefore appear, on first consideration, that the forest should not only be kept free from deal trees, but also that all heavily suppressed trees, showing distinct symptoms of death or premature decay, should be cut. This principle, however, pushed too far, would not be in keeping with first-class forestry, inasmuch as unbroken cimopy must be maintained throughout the period of growth, more especially in youth and middle age, and dying or recently dead trees are quite useful for estate purposes, provided proper creosoting be adopted. Fig. 74 is from a photograph of cocoons on dead standing trees underneath the bark.

The life-history of the genus has been most carefully worked out by Dr Stewart MacDougall, who proved from both observation and actual experiments that the dates of appearance of perfect insects were variable, as also the period of time required for larval and pupal duration itself. In Northumberland the perfect beetles emerge respectively most plentifully about the middle of July.

The female beetle lays her eggs in the bark, and the larvæ hatch soon afterwards. At first the larvæ move from the egg-chamber in

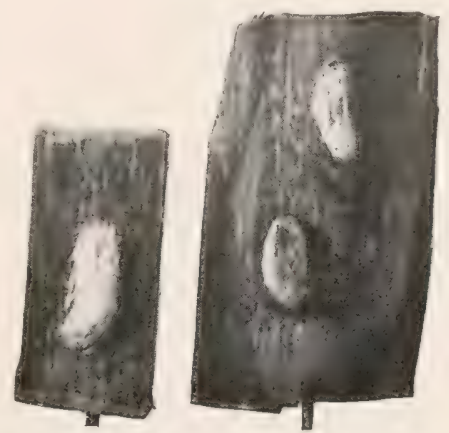

Fig. 74. - Cocoons of Pissodes pini on stem of Scots pine (reduced). different directions, forming a sort of star, but later on the markings appear in long, broad, irregular lines, generally running lengthwise with the stem.

The larval markings are, as a rule, most conspicuous on the bark. After the larva is fully fed it scoops out a chamber in the stem, and covers itself over with the scooped-out chippings. Each larva makes a chamber for itself, and those specimens which are fully fed in the autumn pass the winter in the larval stage, pupate in the spring, and appear as beetles during the summer. The chamber acts as a double means of protection, inasmuch as it minimises the attacks of insectirorous birds, and also shields the creature from injuries when the loose bark is removed from the stem. 
The larva is a white, fleshy, legless, wrinkled grub, with brown head and strong jaws. It generally is in a semicircular form, and about half an inch in length.

The beetle (fig. 75) is dark pitchy-brown in colour, and sparsely sprinkled over with yellow scales. The rostrum is longer than the thorax; antenure terra-cotta colour, with darker club. Thorax roughly punctured, with a distinct raised middle line; elytræ deeply punctured, broader than the thorax at its base. On each elytron there are four yellow spots, two in front and two behind the middle. Length about $\frac{3}{8}$ inch or 8 to $10 \mathrm{~mm}$.

\section{Pissodes notatus (Fabr.)}

It is very doubtful if this insect is so common as entomologists maintain. Fowler gives "Chat Moss, near Manchester; Sunderland, probably introduced in Scotch timber-laden

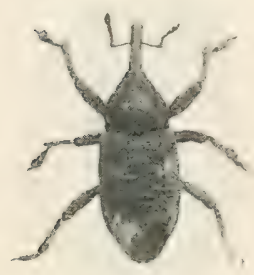

Fig. 75,-CPissodes pini (entarged). ships," 1 and "Scotland, rare Highlands, on Scotch firs Dee and Moray districts." 2 Personally, I have not found it in this country, but found it in Belgium, August 1905, near the roots of Scots pine stems from five to eight years of age. Fig. 76 is a very good representation of the cocoons. It often happens that in plantations of pure Scots pine from four to ten years of age, many plants die off, just as we wish them to be producing close canopy. Numerous suggestions have been given from time to time that the deaths referred to are due to fungi, but it is just probable that they die off in consequence of being badly handled in the nursery, or very badly planted by the notch method, and therefore having their roots twisted. I have examined many dead Scots pines of the type referred to in Northumberland with a view to finding $P$. notatus, but so far the search has been unsuccessful. Dr R. Stewart MacDougall found that imported German specimens were spreading in Scotland, so that it is probable we might have an attack through insects having been imported in pit-props or other materials.

${ }^{1}$ P. gyllenhali, Schön., and P. piniphilus, Hbst., are introduced.

2 It has been taken at Woking and Bournemouth by Commander Walker. 
As the senus Pissodes has heen so admirahly worked out by Sitewart MacI)ongall, I take the liberty of yuting the following conclusions, which have important biological and practical bearings:-

"1. The Pissodes have a remarkably long life in the imago stage. This long life is characteristic of both sexes.

"2. Copulation and egg-laying are not single acts which, once accomplished, terminate the life of the individual, but both may be often repeated. The same individuals which have paired and bred in one season may, after hibernation, still further proceed to a new' season's reproduction.

" 3 . Hibernation takes place in the month of November, and in a season of average temperature ends in March, in exceptionally mild weather even earlier.

"4. Egg-laying takes place in all months from April (in a very favourable season, even in Narch) to September inclusive.

" 5 . As adult beetles may be met with during all this period, the length of time necessary for individual development loses some of the significance that up till now has been assigned to it in relation to exterminative measures, because a comparatively limited flight-period being disproved, corresponding limited and

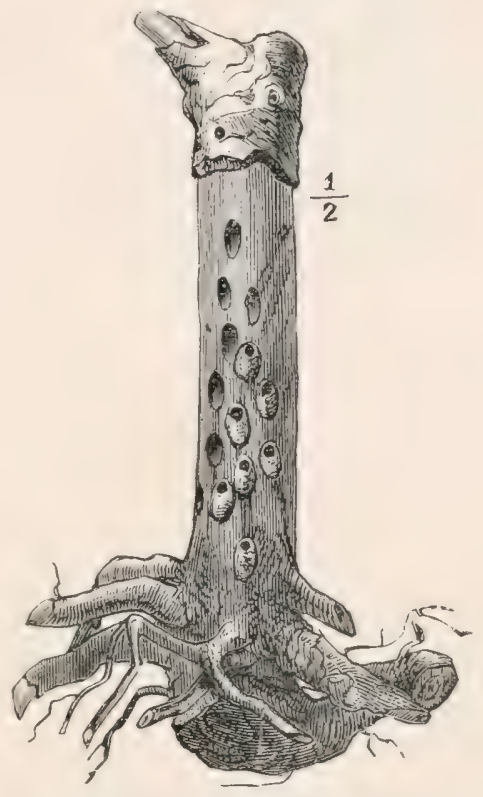

Fig. 76. - Young pine-stem barked to show pupatbeds of Pissodes notatus. (From 'The Forester, 'by J. Nisbet.) definite swarm-periods can no longer be relied on.

"6. Still, limiting our view to one cycle and the earliest-laid eggs of that cycle, the generation is typically a yearly one.

" 7 . As the first imagos issuing in the summer, as a result of eggs lail earlier in the same year, are not immediately able to proceed to an efficient copulation, but reruire some time for ripening, there is little likelihood of there heing in our climate two generations in direct descent in one calendar year."

As regards remedial measures, however, they are very simple, 
inasmuch as all attacked trees are generally in such a back-going condition that the forester should, as far as practicable, cut them out of the wood as soon as the attack is observed.

\section{Genus Orchestes.}

Antennæ distinctly bent, and inserted behind the middle of the trunk; head small, and the upper surface almost entirely occupied by the eyes, which are only separated by a narrow bend; thorax very small in proportion to the abdomen. Scutellum small but distinct. Elytra long, and well covering the pygidium ; femora strongly developed.

\section{OrChestes fagi (Linn.)}

The Orchestes fagi, or beech-leaf miner beetle, is, as its name implies, very destructive to the foliage of beech-trees. The most conspicuous portion of the damage is that done by the larvæ, which gives the tree the appearance of having suffered severely from late spring frosts. In fact, even practical men often erroneously attribute the injuries to frost. There is, however, this practical distinction between the two-viz., that frost generally shrivels up the entire leaf, whereas the injuries done by this beetle only affect one-half.

The beetle hibernates during the winter months under fallen leaves, in the crevices of bark, or, in fact, under any rough cover. It makes its appearance on the first warm days in spring, simultaneously with the opening of the leaves. It does not expose itself very much during the day, but in the night-time moves on to the young leaves, in which it euts small circular holes, giving the foliage the appearance of having been shot at. The female deposits her eggs in the midrib, and as a rule about half-way down. The eggs hatch in about ten days, when the larva immediately makes a straight cut across the leaf to the outer edge, but generally in the same direction as the lateral veins, so that it lands near the apex of the leaf. It then turns inwards, and eats a fairly large portion of the parenchyma, thus exposing the epidermal skins, and causing the large blotch referred to (fig. 75 ). The small, straight, larval track from the midrib to the outer edge is very important, inasmuch as its method is entirely confined to Coleoptera, and is a decided mark of distinction from the injuries caused by Hymenoptera, \&c. The larvæ are full fed in 
about twenty days. Then they pupate in a small white cocoon within the leaves, and come out as perfect insects in ahunt another fifteen days' time.

In 1904, at Alnwick, Northumberland, the egrs were deposited about 1st to 10th May, and the insects first appeared about June 24. On account of their pupating within the leaves, they are very easily hatched artificially.

The larva when full fed is about one-third of an inch in length, creamy white in colour, and has a rather flattish brown head.

The beetle is about an eighth of an inch in length, of a slaty-black colour, with grey pubescence, and rather coarse lines of punctures on the elytra. The legs and antennæ are bright brown in colour, and the femoræ of the hind legs are well

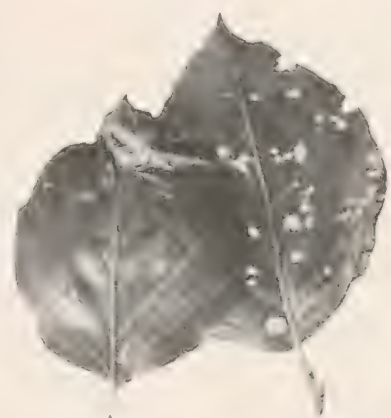

Fig. 77.--Deech leares slowing injuries done by laria and holes caten by weetle (Orchestes fagi). developed, which enables the creature to jumpl when startled, and this characteristic, together with the ample wings, which they can readily use, enables the creatures to get out of the way very rapidly.

The worst damage I have ever seen done by this insect was in Gibside, Co. Durham. This was pointed out to me by my friend Mr R. S. Bagnall. The foliage of the old beech-trees looked as if it had been riddled with showers of shot: not a single leaf had escaped.

\section{Orchestes Quercus (L.)}

This species is often found on oak leaves, and is red or brownishred in colour, and the body clothed with a silky yellowish pubescence. It is generally found on the leaves of suppressed or over-shaded trees, and if extremely abundant, imparts a yellowish tinge to the body of the foliage.

\section{Orchestes alni (L.)}

This species is somewhat variable in colour, and those specimens I have hatched out were from elm leaves collected in a Surrey lane. They were of the variety which had reddish elytre, with darkish head and thorax. 
This genus is well worth careful study, more especially as they prefer an arboreal diet; and having regard to their habit of pupating within the skins of the injured leaf, they can be very easily hatched artificially. The small size of the insects themselves, and the necessity of magnification for the discrimination of specific characters, give

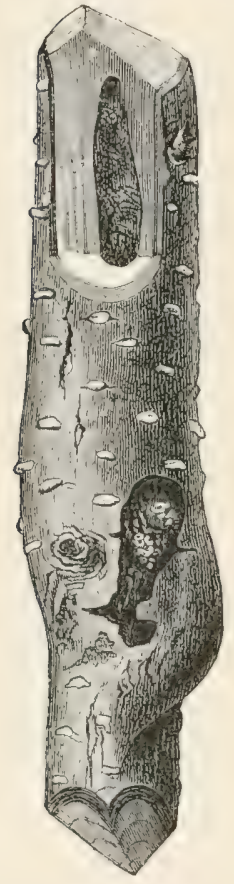

(l

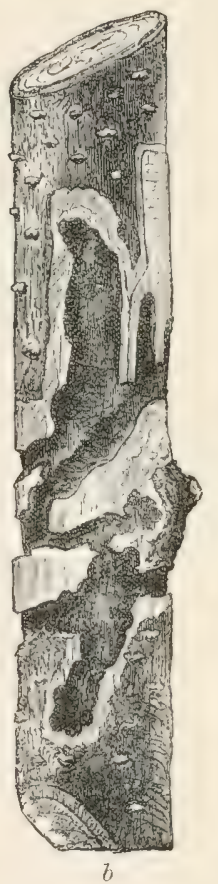

Fig. 78, $a, b .-$ Larvat Uurrous of Cryptorrhynchus lapathi in alder stems. (From 'Forest Protection,' by W. R. Fisher.) an additional interest to the study of the genus.

The student should make a careful study of the specific characters as given by Fowler.

\section{Gemus Cryptorrhynchus.}

Scutellum large and distinctepisterna of metasternum not covered by elytra and well developed. ${ }^{1}$

\section{CryptorrhyNCHUS LAPATHI} (Linn.)

This insect is often found in the south of England, doing considerable damage to alders of the black and white varieties, willows, poplars, and birch. It generally attacks alders in preference to the other trees, and prefers young trees from four to six years of age. $^{2}$ The insect is injurious both in the larval and perfect forms. The beetle eats the bark and sapwond of young shoots, and the larva gnaws under the bark, sometimes penetrating into the pith, thus doing considerable damage to the young stems--so much so, that they break off and die. Fig. 78, $a, b$, shows typical damage.

The beetle flies about the end of April or beginning of May. The larve are said to appear in about fourteen days after egg-laying, and

1 Fowler, vol. v. p. 328.

2 Commander Walker has always found it in and about osier-beds. 
the beetle emerges in autumn, and winters either in the galleries or under moss.

The beetle, fig. 79 , is from 7 to $8 \mathrm{~mm}$. long, and is very characteristically coloured. The prevailing colour is black, with a distinct variegated band of pinkish-red at the base of the elytra, and with a more or less distinct band across the middle of the elytra. The whole body is covered with rather coarse, imbricate, yellowish-white scales. The rostrum is stout, and can be folded into a depression under the thorax.

As regards remecties, it will obviously be the best means of extermin-

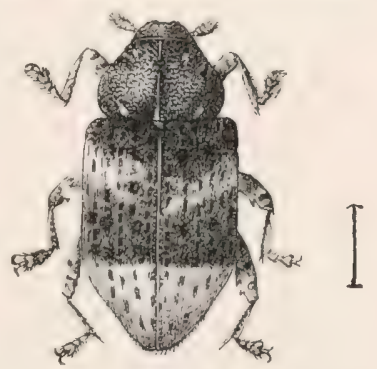

Fig. 79.-Cryptorrhynchus lapathi. (From 'Forest Protection,' by W. R. Fisher.) ation to cut down the infested shoots containing the larvæ or perfect beetles, and burn them.

\section{Genus Balaninus.}

This genus contains several species which are all arboreal, and therefore of special interest to the student of forest entomology. The species B. nucum may, however, be taken as typical of the genus. The most remarkable generic character is the very long, slender rostrum, which varies in length accorling to the species, but is often longer than the whole of the remainder of the body. The length of the rostrum enables the insect to pierce filberts, acorns, walnuts, \&c., in which they deposit their eggs.

\section{Balaninus nucum, L.}

It often happens that on eating filberts or hazel-nuts we either find a very large white grub, or otherwise a hollow shell con-

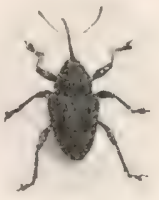

Fig. 80.-Balaninus nucum (enlarged). (Photo by $\mathbf{A}$. Flatters.) taining frass or powder. Those grubs are the larve of the nut weevil.

The heetle, fig. 80, is easily recognised by its very long snout (being longest on the female) and elbowed antennæ. The whole body is dark-brown in colour, but brightened by variegated markings and short depressed hairs. Length 5 to $7 \mathrm{~mm}$. 
The beetles appear early in spring, and may then be beaten from the bushes. The female bores a hole with her proboscis in the very young nut, and then deposits an egg. In a short time the grub hatches out, and feeds on the fleshy portion of the nut. When full fed in the autumn, the larva leaves the nut and pupates in the soil, appearing as a perfect beetle in spring.

When filberts or hazel-nuts are considered of importance as fruit, the pest may be kept in check by beating the perfect beetles into

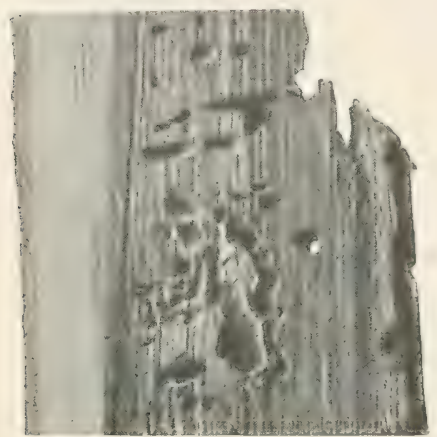

Firs. s1.-Fortion of luch timlur injured by Rhopalomesites Tardyi. a sheet or umbrella in spring; or the infested nuts, so far as they can be recognised, may be gathered before the escape of the larvæ and burned.

\section{Genus Rhopalonesites.}

\section{Rhopalomesites Tardyi (Curt.)}

This beetle is considered almost exclusively an Irish species. It is injurious to half-dead beech timber, and it may therefore be said that it considerably hastens its decay. Fig. 81 is a representation of the damage done to half-decayed beech planking. I am indebted to Professor Carpenter, I) ublin, for the specimen from which the photograph is taken. ${ }^{1}$

\section{References to Literature consulted.}

Altum, Forstzoologie, iii.

Carpenter, G. H. Entomological Papers.

Fisher, W. R. Forest Protection.

Fowler. British Coleoptera.

Judeich und Nitsche. Forstinsektenkunde.

Kaltenbach. Die Pflangenfeinde.

MacDougall, Dr R. Stewart. The Biology of the Genus Pissodes.

Nisbet. The Forester.

Nüsslin. Leitfaden der Forstinsektenkunde.

Ormerod, E. A. Manual of Injurious Insects.

Packard. Insects Injurious to Forest Trees. U.S.A.

Rye. British Beetles.

Theobald. The Animal Pests of Forest Trees.

1 Comparatively rare in England. Commander Walker has taken it at Plymouth, and has it from the Hastings district. 


\section{CHAPTER III.}

\section{COLEOPTERA—SCOLYTID E (B.LRK-BEETLES).}

Frox the point of view of forest entomology, one of the most important groups of insects is that of the beetles known as Scolytidie, inasmuch as they are practically all tre-feeders. As a general rule, they attack only dead, dying, or back-going trees, and therefore it is possible that, from a purely economic point of riew, their importance may have hitherto been over-estimated by many writers. At the same time, there are a few exceptions to this general rule. For instance, in one stage of its life-history Hylurgus. (Hylesinuss) pinipeinte, attiacks the healthy shoots of Scots pine trees; and Pityorfmess birtentatus. often attacks sickly and unhealthy young trees, and thus kills outright what otherwise would have recovered.

Many of the beetles are exceedingly small in size, which fact, coupled with their minute structural points, makes them of great interest to the working entomological microscopist.

In a general way the bulk of this family are known as bark-borers, and the Germans consequently call the whole group "Borkenkifer," or bark-beetles. But this is only a general term, for, as a rule, the majority bore deeper, and leave their impressions, or all-important markings, just under the bast, and immediately over the surface of the wood. Others, again, bore directly into the timber, but, as a rule, these wood-boring species confine their attacks entirely to the sapwood, and rarely penetrate into the heart-wood. Thus we have, in a general way, three divisions-viz., those which bore into the bark, those which work on the surface of the wood, and those which hore directly into the timber. So far as elassification is concerned, we cannot make any arbitrary dirisions, but the characteristic markings themselves are about as suitable data for the discrimination of species as it is possible to get. 
As the respective genera and species show variation in life-history and markings, it would perhaps be well for the student to study the salient features of a typical bark-beetle, as regards the formation of a brood, and its subsequent life-history.

With regard to the formation of the brood, there is one important point to be noted-viz., that some genera are monogamous, whilst others are polygamous. In the case of the former, the initial operations are always conducted by the females, whereas, in the latter, they are always made by the males.

Take a typical monogamous species. Both sexes hibernate during the winter months, but the female awakes first, and betakes herself to a suitable tree, where she scoops out a small chamber, and then takes a sort of nuptial flight, as it were, for she returns generally accompanied by the male, and copulation takes place either within the chamber or immediately outside it. The female then commences her work in earnest. She makes a straight tunnel, and deposits eggs right and left alternately. Her presence can always be recognised by the frass, or bore dust, made by the workings, which is deposited outside the burrow. The male is generally found just at the entrance of the burrow. As the female moves along, she often makes little bore-holes over her tunnel, for the purpose of ventilation.

In due time the larva hatch out, and moving along their respective galleries, which broaden according to larval growth, they finally scoop out a chamber, and then pupate. It is important to note, as we shall consider presently, that it is the particular angle made by the junction of the larval with the maternal galleries which gives the peculiar markings of the respective species. The fully formed beetle eats its way through the bark, which, after the swarming or flight periol, looks as if it had been riddled with shot. The holes made by the exit of the beetle can, however, by careful inspection, be distinguished from those made by the mother for ventilation, as the latter are always made over her own tunnel.

In those cases where the initial operations are conducted by the males, the excavation is a sort of circular chamber, where several females, generally from four to six, assemble, and within which copulation takes place. Hence it is called by the Germans "Rammelkammer," or brood-chamber. The females then make their respectire galleries, all radiating from the brood-chamber. The male very 
soon ifterwards dies. In nearly all cases the female dies at the ent of the burrow, after the deposition of eggs.

In a general way the appenrance of many species of insects is very much aftected by climatic conditions, and the Scolytida are especially susceptible to the influence of weather. Thus the first appearance of the hibernating species in spring depends on the warnth and sunshine. The weather also affects the swarming of the brood, and the colour of the beetle is therefore sometimes variable, as specimens which swarm soon after changing from the pupal to the perfect stage are light as compared with those fully developed specimens which, on account of unfarourable weather, have had to remain for a considerable time within the food-plant. The markings, too, are sometimes affected, as the perfect beetles, in their quarantine stage, often make markings beyond the pupal recesses.

These remarks apply to the markings of a typical bark-beetle; but the student, we repeat, must make a very careful study of the markings, because they are so definite in character that from them alone the species can always be determined.

It must also be borne in mind that there is a sharp and definite distinction between certain species which feed on conifers and others which feed on hardwoods, inasmuch as we never find coniferous feeders living in hardwoods and vire verst. This distinction, however, applies to species, and not to genera. For example, take the genus Cryphalus. Thus $C$. abietis and $C$. pirece feed on spruce and silver fir respectively, while $C$. fugi and $C$. tilice live on beech and lime.

The various parts of the tree itself also harbour different species, and therefore several species may be found on one tree. Take, for example, a comparatively young Scots pine tree. In the top twigs we may have Pityoyenes bidentatus, and in the smaller branches Hylustes palliatus. The stem may harbour Hylur!ns (Hylesinus) piniperda, and the root-surface Hylastes ater:

The mother-gallery is a-most important character, and no illustration is quite complete unless it is shown. The mother-gallery, as a rule, is either perpendicular or horizontal - that is to say, it is perpenticular when running in the same direction as the standing stem, and horizontal when running across the direction of the standing stem. The mother-gallery may be either single- or doubie-armed, and in working she makes one arm at a time.

A more detailed consideration of the galleries or markings may now 
be male, tilking the very lucid diagrammatical plate from . Judeich and Nitsche. In fig. 82, $\alpha$, we get a simple single-armed mother-gallery,
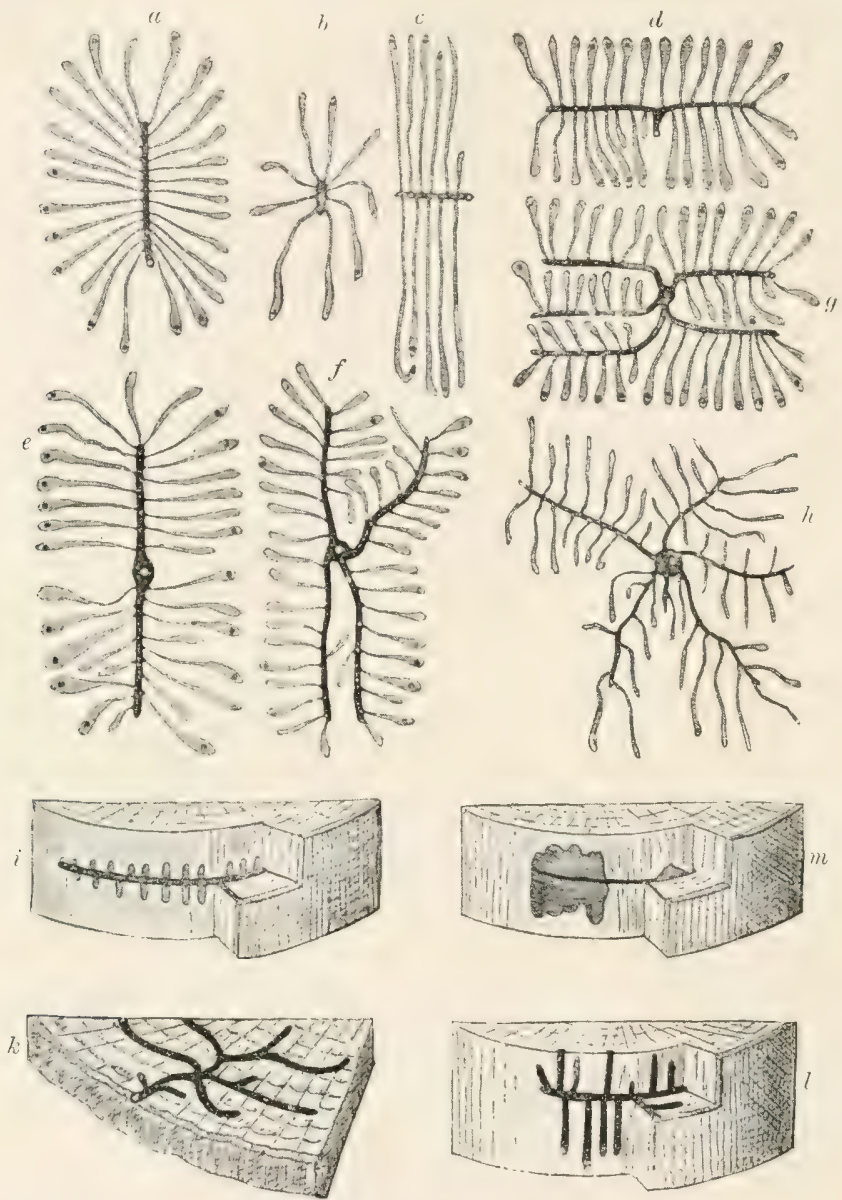

Fig. 82.-Typical workings of Scolytide.

$a$, Single-armed mother-gallery, showing equal larval galleries and pupal recesses; $b$, short mother-gallery and radiating larval galleries; $c$, single-armed short horizontal mothergallery and long right-angled larval galleries; $d$, double-armed horizontal mother-gallery with right-angled larval galleries; $e$, two-armed mother-gallery of a polygamous species; $f$, four-armed mother-gallery of a polygamous species; $g$, five-armed mother-gallery of a polygamous species; $h$, star-gallery of a polygamous species; $i$, ladder-gallery of a woodboring species; $k$, forked mother and larval galleries; $l$, an irregnlar ladder-gallery; $m$, a family gallery. Copied from Judeich and Nitsche.

with the larval galleries radiating slightly from the mother-gallery. 
If we take, therefore, the midlle of the mother-gallery as a centre, we shall see that the larval galleries, in a geometrical structure, somewhit resemble the stones forming $: m$ areh, inamuch as they all rimliate from a common centre. In fig. $82, b$, we have a very short mothergallery, with radiating larval galleries. In fig. 82, ", we have a singlearmed mother-gallery and right-angled larval galleries.

In fig. $82, d$, we have a double-armed horizontal mother-gallery, with practically right-angled larval galleries. In fig. 8., e, we have similar mother galleries of a polygamots species. In fig. 8.2, $f$, we have a four-armed mother-gallery, with right-angled larval galleries.

In fig. $82, g$, we have practically a repetition of $82, b$, except that the mother-galleries are horizontal.

In fig. $82, h$, we have a star gallery formed in a slightly different way, inasmuch as the circular central portion is made by the male, and the female galleries radiate from the male chamber, while the larval galleries again radiate from the mother-gallery.

In the foregoing it should be noted that all the young beetles finally leave (swarm) by gnawing new flight-holes; but in the remaining figures, as representing distinct wool-borers, the young heetles finally leave (swarm) through the old bore-holes.

In fig. $82, i$, we have a "ladder gallery" in wood, where the mothergallery is horizontal and the larval galleries perpendicular. The larval galleries are very short, as in Trypodendron lineatum.

In fig. $82, k$, we have forked mother and larval galleries, making collectively a sort of gallery of pipes, as it were, on a comparatively even plane, as in T. monographus. ${ }^{1}$

In fig. 82, 7, we have a representation of a horizontal mother-gallery and perpendicular larval galleries. It may be considered as illustrative of $T$. dispar.

In fig. $82, m$, we have a representation of a family-gallery, as in $T$. Saresenii.

The generations of the Scolytilx are very variable. In the German literature we note two or more broods per year of a species which only produces one brood in the north of England; and again we get some. times two broods per annum of a species in the south of England which only produces one brood a-year in the north. These variations are by no means universal, but the student must be careful to note them.

1 This species is not found in England. 
The general structure of the beetles themselves is somewhat peculiar. The most salient feature, which gives the Scolytidæe their particular form, is the shape of the thorax, which is nearly always of equal breadth with the elytra; and in several genera the thorax also acts as a sort of hood which covers the head, and thus, looking at the creature, the head itself is very often invisible. Hence, when looking at the beetle, it may be noted that the visible portions-namely, thorax and abdomen-present together a sort of oval or cylindrical form. In many species the elytra have anal hooks, which are occasionally of importance in determining species.

The uncler side of the abdomen is sometimes of considerable import-

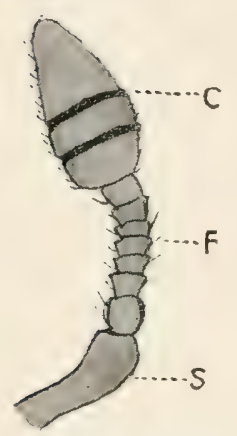

Fig. 83.-Antenna of Hylesinus crenatus. (Camera - lucida sketch.) ance, as one or more of the segments may have special projections, as, for example, in. Scolytus multistriatus.

As regards special structural details, the mandibles are stout, curved, or slightly toothed. The antennæ are short, inserted between the eyes, and form good points for the discrimination of species. They are divided into three parts - fig. 83 : the club (c), the funiculus (F), and the scape (S). In German literature these parts are known by the names of club, whip, and shaft respectively. The eyes are of special interest, inasmuch as they may be of one body deeply cleft in the middle, or otherwise distinctly divided into two parts. The legs should be carefully noted, as in many species they are too small for examination by a good lens, and form interesting objects when prepared as microscopic slides. They are, as a rule, short and stout in all the respective parts, with toothed femur and a five-jointed variable tarsus, which is terminated by a double claw.

The larve are fleshy white or yellowish white, with pale yellowish hearl. They are footless, and broadest at the heal, tapering towards the anal segment. The respective species cannot always be recognised by their structure, but many species may be distinguished by their habits and the nature of their galleries. The pupæ are, as a rule, pale white, and show all parts of the perfect insect.

To the physiological biologist this group may, on the principles of Natural Selection, be considered as of special interest as presenting 
some very suggestive points. For example, the white, fontless, tapering larve associate the thought of adaptability for tumnelling; ant the circular form of the body, the short antenne, buried head, and stout legs of the adult, eloquently proclaim the suitability for boring and clearing out the bore dust without injury to, or olstruction from, the appendages.

There is also another very suggestive problem-viz., the association of the male and female in the same burrow. It has been noted that copulation may take place outside the main entrance or, as a rule, just immediately insile the entrance, where a special chamber, known as the rhambre re copulatrid, is formed. After fertilisation the female makes a hurrow, in which she deposits eggs right and left in miniature recesses. The male remains behind, and either guards the female or the eggs against natural enemies, or clears out the frass or bore dust excavated by the female. In a single-armed gallery the sexes may therefore easily be determined by position, inasmuch as by following up the gallery from the entrance we come first upon the male, and afterwarls the female. Such is the method in a single-armed gallery; but in many cases the gallery is doulle-armed, and the female works one arm at a time, then retires and works the other arm. Now, why this doul,le arm? and why this second working shift? Is it possible that it may be for re-copulation? We know that in some insects this is an essential for reproduction, as, for example, in the case of Hylotine allietis, and it may be possible that such is the case in certain species of Scolytidæ. This is only a suggestive thought, but doubtless much may be learned by observation in this sphere of entomology.

As regards general measures for getting rid of the beetles, various suggestions have been offered; but seeing that, as a rule, they only attack dead or dying trees, it is obvious that the best preventive measure would be, either to keep the plantations as healthy as possible or to get rid of the dead and dying trees. Branches should always be burned, and, as far as practicable, when the insects are in the larral stage.

With a view to collecting the beetles for the purposes of scientific stuly, it is well to cut down certain trees or branches and leare them on the ground, to act as decoy stems or traps; and in searching for certain species it is often advisable to look on the under side of the branch and in places where the ground is rather moist,-moisture 
being often an essential condition, - though, as they are rather fastidious as to the amount of moisture, it would be useless to look for them in extremely wet places.

SCULYTID.E.

The family is divided by Fowler into the following sub-families -viz. : ${ }^{1}$

I. First joint of tarsi (or metatarsus) much shorter than the remaining joints united; sides of thorax not emarginate for the reception of the legss; eyes oblong or divided; head never broader than thorax . . . Scolytinæ.

II. First joint of tarsi (or metatarsus) almost as long as the remaining joints united; sides of thorax enmarginate for the reception of the legs; eyes round, subconvex; head broader than thorax

- Platypodinæ.

\section{SCOLYTine.}

This sub-family embraces the whole of the genera of Scolytidie, with the exception of Platypus, which is a genus containing a single species. The whole of the other species in the family are divided by Fowler into the three following tribes:-

I. Thorax not prolonged over the head, which is always in part visible from above, and is terminated by a short snout; thorax without any marked asperities on its anterior portion; third tarsal joint nearly always bilobed.

A. Abdomen strongly raised obliquely from near apex; thorax bordered at sides .

Scolytina.

$B$. Abdomen not, or only slightly, raised, as a rule regularly cylindrical; thorax not bordered at sides . Hylesinina.

II. Thorax prolonged over the head, which is sunk in the thorax when the insect is at rest, and is more or less globose; thorax almost always furnished with more or less distinct warty asperities in front; third tarsal joint simple

Dryocætina.

1 British Coleoptera, vol. $\mathrm{x}$. 


\section{TRIBE SCOLYTINA.}

\section{Genus Scolytus.}

The genus scolytus confines its attacks exclusively to the broarleaved trees of the forest or fruit-trees of the orchard.

The chief generic characteristics are: Knob of antemm large, larger than the whip; eyes longish and linear; boly smooth; therax much darker than the elytra.

\section{Synopsis of the Species.}

I. (1) Second ventral segment of alylomen without projection. Elytra shining, thickly punctured; third and fourth segment in both sexes furnished with a small tubercle. Mother-gallery perpendicular. Lives in elm . . . Scolytus destructor.

(2) Thorax very finely punctured, especially on the disc. Mothergallery long and perpendicular. Generally in fruit-trees.

S. pruni.

(3) Thorax very finely punctured, especially on the disc. Mothergallery short and horizontal; very long larval galleries. Lives in oak . . . . . S. intricatus.

II. (4) Second ventral segment with a strong horizontal projection. Perpendicular mother-gallery. Lives in elm, poplar, cherry, plum, pear, and oak . . . . S. multistriatus.

$$
\begin{aligned}
& \text { Scolytus Destructor (Oliv.) } \\
& \text { Scolytus Geoffroyi, Goetz (Eichhoff). } \\
& \text { " } \quad \text { " (Judeich and Nitsche). } \\
& \text { Eccoptogaster" scolytus, F. (Altum). }
\end{aligned}
$$

This beetle chiefly confines its attacks to elm-trees, and is therefore commonly known as the "elm bark beetle." It is a dreaded pest in elm-growing districts, as for example in many parts of the south of England and in the London parks. The perfect beetles appear ahout the midule of June, and the female commences her horing operations either in a newly felled trunk or an unhealthy tree. Previous to making the burrow proper, she makes a sort of pseudo-track in a deep furrow of the bark; and as the male appears about this time, it is 
doubtless during this initial horing operation that copulation takes place. She then makes her burrow proper, which is from 1 to 4 inches in length, and therein deposits from 100 to 160 eggs. This operation is said, as a rule, to take about three weeks to complete.

The markings are very characteristic, more especially when the mother-gallery is comparatively short. The mother-gallery is straight and single-armed (fig. 84). Taking, therefore, the middle of the gallery as a centre, it may be noted that the larval galleries do not quite

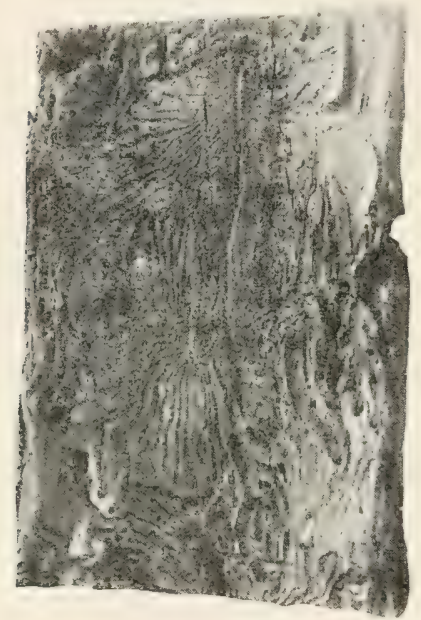

Fig. 84.-Markings of Seolytus destructor in bark of English elm.

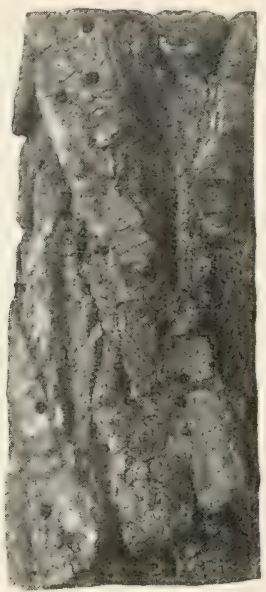

Fig. 85.-Showing "exitholes" of same.

run at right angles with the mother-gallery, but point slightly towards the extreme ends; and as we look towards either end of the mothergallery, it is noticeable that the angle becomes more acute, and consecuently the spaces between the extreme ends of the larval galleries widen. Hence if a line were drawn all round the extreme ends of the larval galleries, it would form an oval-shaperl figure, with the lines radiating from the centre to the outer edge. Fig. 85 shows the holes whence the beetles have emerged.

The beetle (fig. 86) is about $\frac{3}{16}$ of an inch in length. The thorax is black and shining, and the abdomen light-brown. The beautiful sharp contrast of colour is a conspicuous feature, and thus affords a rapid 
means of recognition. The thorax is linge, and the length exceeds the breadth. The antennæ and legs are ferruginous.

The larve are white, fleshy, footless grubs, with very strong chitinous head and wrinkled body. They are full-fed towards the end of July, and by the beginning of August perfect beetles may be fouml. Many of the larve pass the winter in cocoons, and aprear as perfect insects in May.

As this species is very destructive, the following practical remarks regarding prevention may be quoted :-

"One of the most important considerations, in regard to prevention of attack, is the removal of all centres of infestation, from which the beetles might spread to the sound trees.

"The possibility of clearing away or treating infested standing trees or infested limbs depends, of course, on local circumstances; but whatever care is exercised in other ways, it is very unlikely that much good will be done in lessening attack, so long as the inexcusable practice continues of leaving trunks of infested elms lying, with their bark still on, when containing myriads of these maggots, which are all getting ready shortly to change to perfect beetles, and to fly to the nearest growing elms. Such neglected trunks may be seen in our parks and rural woodyards

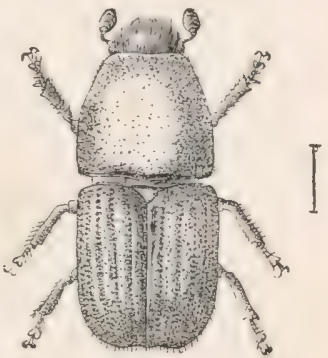

Fig. 86. - Scolytus destructor. (From 'Forest Protection,' by WV. R. Fisher.) all over the country, where, without difficulty (as I have myself often found), the hand may be run under the bark, so as to detach feet and yards in length from the trunk, all swarming with white Scolytus maggots in their narrow galleries.

"This bark, with its contents, ought never to be permitted to remain. Where it is loose, it may be cleared of many of the maggots by stripping it ofl and letting the poultry have access to it; or, if still partly adhering, it may be stripped from the wood by barking tools, and burnt. But if allowed to remain swarming with maggots, it is a tangible and serious cause of injury; and if our landed proprietors were fully aware of the mischief thus caused to their own trees, and those of the neighbourhood, they would quickly set rid of it." 1

1 Miss Ormerod, Manual of Injurious Insects, 1890. 


\section{Scolytus pruni (Ratz.)}

At first sight this species very much resembles the preceding, but it is smaller, and the sculpturing of the elytra is very much finer. The thorax is shining black, and the elytra ferruginous. Antemn and legs brown. Length $3 \frac{1}{2}$ to $4 \frac{1}{2} \mathrm{~mm}$.

This species is generally considered as exclusively belonging to the orchard, and living in plum, pear, or apple. Eichhoff, however, says that it has been found in hawthorn, mountain ash, and elm.

Several years ago I found in Cheshire very fine markings in a

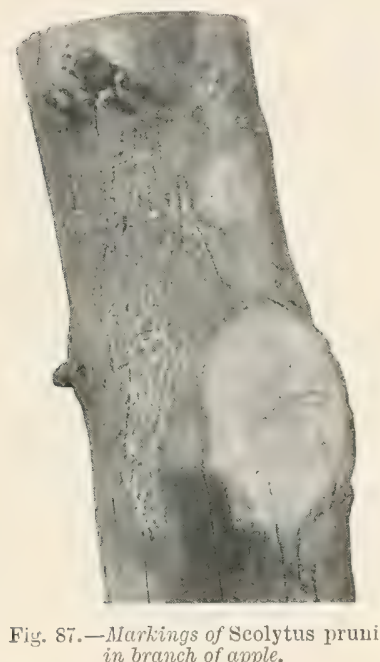

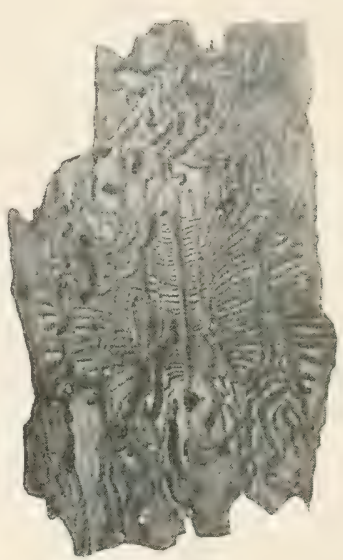

Fig. S8. - Markings of Scolytus multistriatus in bark of elm.

strong limb of wild cherry, which was doing duty as a fencing-post in a farmer's hedge, and I have since concluded that in all probability they were the markings of this species.

Fig. 87 is from a photograph of markings on branch of apple found in Gloucestershire. ${ }^{1}$

\section{Scolytus multistriatus (Marsh).}

Thorax black, shining, somewhat longer than broad; elytra pitchyred; antennæ and legs light-brown; elytra with close and finely

1 Commander Walker has seen an apple-tree apparently killed by this species at Wolvercot, near Oxford. 
punctured strix; abdomen thickly covered with hairs, and, viewed sideways, there is a strong horizontal projection on the under side of the abdomen, which is peculiar to this species. Length 2 to $3 \mathrm{~mm}$.

This species makes its galleries in thinbarked elm. 'The mother-gallery is from one to one and a half inch in length, and perpendicular with the stem. The larval galleries are approximately at right angles to the mother-gallery.

I found the piece of bark which produced the photograph for fig. 88 in Gloucestershire, and Mr MIorse, Leeds, sent me insects for description.

This species is said to be double-brooded.

\section{Scolytus intricatus (Ratz.)}

The species is said not to be at all common, and only once have I found any trace of its markings in Northumberland. Mr A. C. Forbes informs me that it is common in Wilts on oak limbs broken by wind. I found the specimen which supplied the photograph for fig. 89 in Belgium, on an oak stake, and just recently I found it fairly common at Newball, in Lincolnshire. The mother-gallery is horizontal and short, being about $\frac{5}{8}$ to 1 inch in length. The larval galleries run at right angles to the mothergallery, and are about 2 inches in length.

The beetle, fig. 90, is described by Fowler as being about " $3-4 \mathrm{~mm}$. long, black, shin-

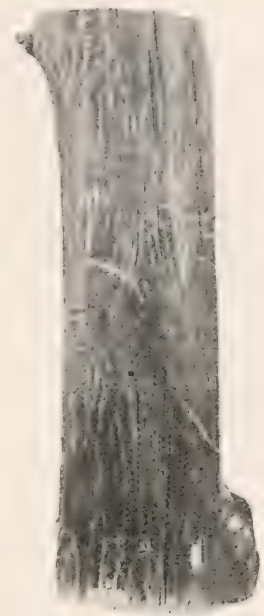

Fig. 89.-Markings of Scolytus intricatus on oak pole.

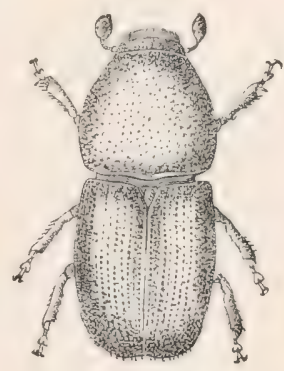

Fig. 90.-Scolytus intricatus. (From Fisher's 'Forest Protection.') ing, elytra duller, with the antennæ and legs ferrnginous, and the femora and elytra pitchy brown or pitchy red."

Altum cites a case ${ }^{1}$ where 50,000 oaks, 25 to 30 years old, were killed by this species.

\section{Forstzoologie.}




\section{'T'RIBE HYLESININA.}

The tribe Hylesinina is divided into the following genera by Fowler-viz. :

I. Eyes not divided; third tarsal joint nearly always dilated and bilobed.

(i) Funiculus of antennæ with seven joints.

1. Club of antennæ globose or ovate.

A. Anterior coxæ contiguous; first joint of the club of the antennæ very large, shining, the following very short. . . Hylastes, Er.

$B$. Anterior coxæ widely distant; first and second joints of the club of the antennæ large, almost equal, the following very short

Hylastinus, Bedel.

2. Club of antennæ compressed, oblong . Hylesinus, F.

(ii) Funiculus of antennæ with six joints.

1. Anterior coxæ narrowly separate; thorax with long villose hairs at sides; length $4-5 \mathrm{~mm}$. . Myelophilus, Eich.

(Hylurgus pars, Brit. Cat.)

2. Anterior coxæ rather widely separate; thorax evenly pubescent; length $2 \frac{1}{2} \mathrm{~mm}$. . Cissophagus, Chapuis.

(iii) Funiculus of antennæ with five joints.

Club of antennæ oval, nearly globose, formed of four joints, fitting closely together Xylechinus, Chapuis. (Carphoborus, Brit. Cat.)

Club of antennæ formed of three loose detached joints

Phlœophthorus, Woll.

II. Eyes completcly divided; third tarsal joint entire, not broader than the preceding; antennæ with a solid ovate club, and with the funiculus five-jointed . . Polygraphus, Er.

\section{Genus Hylastes.}

This genus is interesting to the collector, but not specially so to the forester. Fowler gives five and Barbey eight species. They can be readily distinguished by their general cylindrical appearance. The thorax is not broader than long, and has long, smooth, punctured lines, and the abdomen is practically uniform with the thorax. The 
whip of the antenne is seven-jointed, the club acorn-shaperl and not severely compressed.

There are two species, more or less generally distributed throughout the conntry-viz., H. palliatus and $I I$. ater-which may be considered as the more important arboreal species.

\section{Synopsis of the Species.}

Thorax not very long, and rugged at sides. Elytra distinctly regularly punctured. Centre line raised. In stems of spruce or Scots pine. . . . . . Hy. palliatus.

Thorax longer than broad, siles of pronotum almost equal and parallel. Centre line of thorax not raised. In stems of young Scots pine near the root. . . . . Hy. ater.

\section{Hylastes palliatus (Gyll.)}

The beetles hiberuate in dead trees, and appear about the latter end of Narch or beginning of April. They generally select sprucetrees which have been felled the previous winter, and it is best to look for them on stems of trees lying on the ground, especially where the branches have been cut off by the woodman's axe. If the woodman should have made a few false blows, and not have done his work very well, the imperfect result is an advantage to the beetle, inasmuch as the jagrged pieces form a sort of lolgment, and often quite a colony of twenty or even more beetles may be found in such places.

The larvæ appear about the latter end of April or beginning of May. The arrangement of the markings is very difficult to follow. At first the mother-galleries are perpendicular, but they often deviate, and the larval galleries may radiate in any direction. Thus we simply get a confusion of markings.

In comparatively large stems of spruce we generally find the markings made in the bark, but in branches of Scots pine we find them on the wood. Fig. 91 is taken from a Scots pine branch.

Eichhoff says that this species is double-brooded. This is so in some cases in Northumberland, and often the second brood remains fully developed within the bark, and swarms in spring. Again, I have found that this species is often single-brooded in Northumberland, so that as regards life-history the matter requires further elucidation. 
The beetle (fig. 92 ) is about 3 to $3 \frac{1}{2} \mathrm{~mm}$. long, and of a darkishbrown colour throughout. The interstices are deeply, but uniformly,

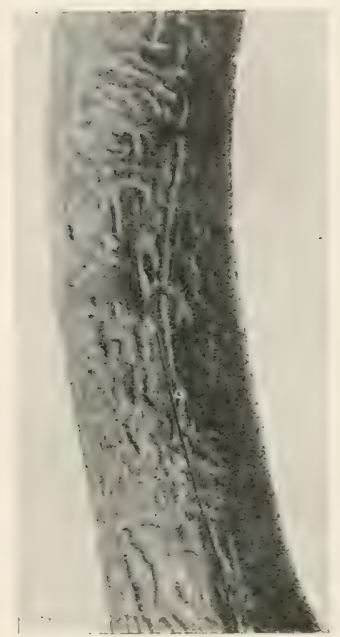

Fig. 91.-Markings of Hylastes palliatus on branch of Scots pine. punctured, and studded with warts, so that it is slightly rough in appearance.

\section{Hylastes ater (Payk.)}

This species is known as the black pine bast-beetle, and may be easily recognised by its uniform black colour and elongated appearance. I have found this species in Northumberland at Corbridge Fell. In the winter months it is fairly common under the comparatively thin bark of Scots pine logs of six to nine inches diameter (tops left lying on the ground after removing large stems), more especially on the under side where lying in a fairly moist position. The perfect beetles, on leaving their winter quarters in early summer, are very much attracted by the resin which exudes from the butt-end of the stem on newly felled Scots pine trees. Such embedded specimens are not much use for the cabinet, though they may to some extent be clarified by

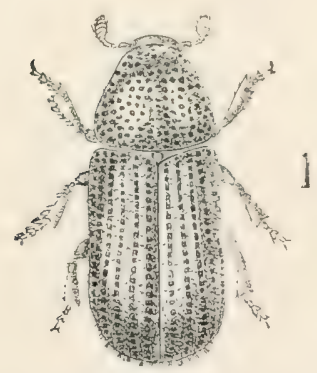

Fig. 92. - Hylastes palliatus. (From Fisher's 'Forest Protection.') immersion in turpentine. On July 3, 1907, I found a plentiful supply of this species at Corbridge Fell on a recently sawn stack of rails of Scots pine. They were moving about on the rails, but on attempting to bottle them they nearly all feigned death. The habits of this species would therefore appear to be somewhat different from the family, inasmuch as the beetles of this family generally pass their time within the food-plant.

As regards its true relation to the forest, the breeding-places proper are at the lower portion of the stems of young Scots pine trees from 6 to 10 years of age, more especially unhealthy trees, which are obviously going back, in consequence, perhaps, of the reaction from careless planting. 
The brood-gallery is very simple, of a slanting direction, and the larval galleries short and inconspicuous.

The bectle is elongated, cylindrical, black, shining, and smooth. Elytra with coarse crenate strix. Length 4 to $5 \mathrm{~mm}$.

\section{Genus Hrlesinus.}

This genus is a very important one to the student of forest insects, inasmuch as all the species are strictly artoreal insects, and the group) therefore has been termed "Hylesinidæ or wood-devourers." Three of the species feed on ash and one on elm.

\section{Synopsis of the Species.}

(1) Black or dark-brown, without scales. Size large. Mothergalleries single- or double-armed; short, and horizontal. Larval galleries very long and tortuous. Found in strong bark of old ash stems . . . . . H. crenatus.

(2) Variegated with greyish scales. Size smaller. Double-armed, fairly long mother-gallery, and right-angled or slightly radiating larval galleries. Lives in comparatively young ash stems or ash poles . . . . H. firaxini.

(3) Elytra black, with yellowish dorsal streak. Short horizontal mother-gallery; sometimes very long running larval galleries, at other times short crowded larval galleries. Lives in small branches of ash . . . . . H. oleiperda.

(4) Beautiful variegated colour. Size very small. Double-armed short mother-gallery; short larval galleries. Lives in elm.

H. vittatus.

\section{Hylesinus orenatus (Fabr.)}

This beetle is always recorded to have been found in ash in this country, though two or three German writers give instances of its being found in oak. It is also said to be widely distributed, but, so far as I ascertained, it was not at all common in Cheshire, though very common in Northumberland; and it appears to be common in Lincolnshire.

It is by no means clear that the eggs are always deposited in felled timber, though it may be looked for on recently felled old trees with 
rough bark, or on old standing trees which are considerably past their best. It often happens with trees of the latter character that one side of the stem presents bark harder and more nearly dead than the other, and the beetles should be looked for on the less vigorous side. The presence of a few exit-holes will often assist in revealing the abode of this species.

The life-history of this species is not quite so clear as one would wish. In some eases the generation is said to be double-brooded,

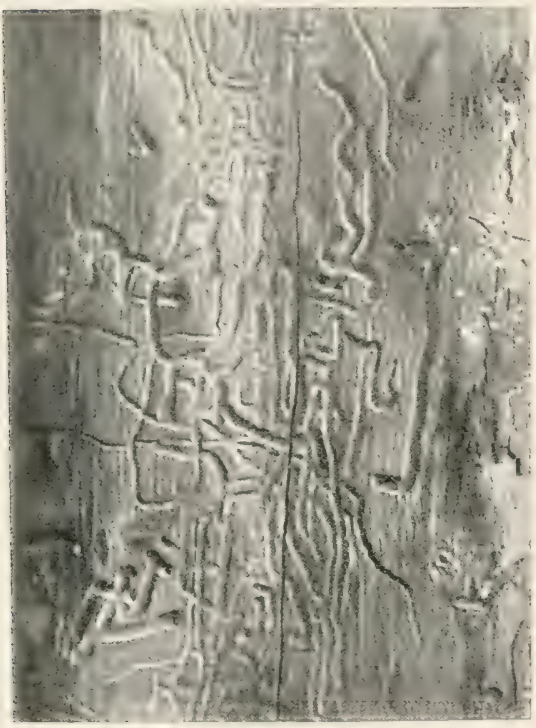

Fig 93. - Morlings of Hylesinus erematus ow a.h sto w ifter remomet of litil: whilst in other cases there are two generations in three years. The flight period is about the beginning of April, or about the middle of October. The female makes a short, bent, and deep gallery, which is, as a rule, doublearmed, but single-armed galleries are often found.

As a rule, the larvæ have no decided method of making galleries, and it is therefore very difficult to accept any particular markings as typical. This difficulty is intensified by their boring habits, inasmuch as you may find them either in the cleep bark or in the wood itself; therefore when the bark is removed the markings found on the wood are often only part of the workings. When, however, we do find the extreme length of the workings, they are generally about 6 inches long, and often at right angles to the mother-gallery. In consequence of the extreme length of the galleries, much harm may be done to very old trees, as these galleries may encircle the stem, and thus hasten decay. Fig. 93 is a representation of the markings of this insect.

The beetle (fig. 94) is about 4 to $5 \mathrm{~mm}$. in length, of a convex form, pitchy black throughout, somewhat shiny, and with comparatively long antennæ. The latter are often ferruginous in colour, with the shaft 
and whip clothed with long ciliate hairs. The elytrin are very coarsely striated, thus imparting to the insect a rather rough appearance. The legs are generally pitchy black.

The larvæ are long, legless, white maggots, with brown head and jaws. They pupate just immediately beneath the onter skin of the rough lark, so that in looking for the full-fed larve we must digg very lightly.

To prevent the spread of this insect, it is best to cut down all back-going old trees with very rough bark; and this is in keeping with good forestry, as an ash-tree, above all others, depreciates very rapidly in value if left standing after it has reached maturity.

\section{Hylesinus fraxini (Fabr.)}

This species is commonly known as the ashbark beetle. Miss Ormerod, in her valuable work, says: "The beetles are often attracted in large number by newly felled ash trunks, in the bark of which they propagate, and from whence the new brood spreads to

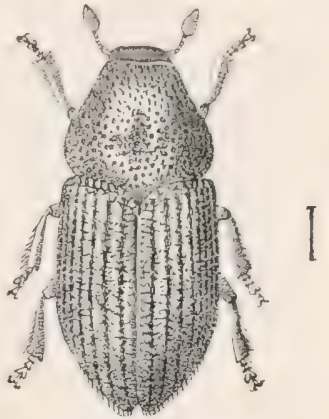

Fig. 94. - Hylesinus crenatus. (From Fisher's 'Forest Protection.')

the neighbouring trees, mainly attacking those that are sickly or decayed, or young trees, which they sometimes injure to a serious extent." So far as my experience and personal observations go, I have found that the beetles only attack very sickly or half-dead trees, but never healthy or young ones. When marking trees in Cheshire, I have observed the dead stinding trees had heen attacked by the beetle, but this had always been done just when the trees were in a half-dead condition.

The life-history of this beetle is very easily followed. About the end of MIarch or the beginning of April the beetles emerge from their winter quarters, and are attracted in considerable numbers to newly felled trees or poles. In Cheshire I always discovered this species on comparatively large stems, but in the south of England they are very common on poles. The female beetle generally appears before the male. She then commences to make a straight tunnel, and on the appearance of the male, copulation takes place. The female makes her tunnel perpendicular with the stem, deposits her eggs, 
and the male remains near the entrance. The mother-gallery, fig. 95 , is double-armed. The total length of the mother-gallery (including both arms) is about 4 to 6 inches when made in the stem, and about $1 \frac{1}{2}$ to $2 \frac{1}{2}$ inches when made on the pole. Mr A. C. Forbes, who has studied very carefully the life-history of this insect, ${ }^{1}$ found that the female first bores one half of the arm, and then proceeds to work the other half. The eggs are laid right and left, and are rather variable in number. When found on the stem of a comparatively large tree, they often amount to 120 , but when on

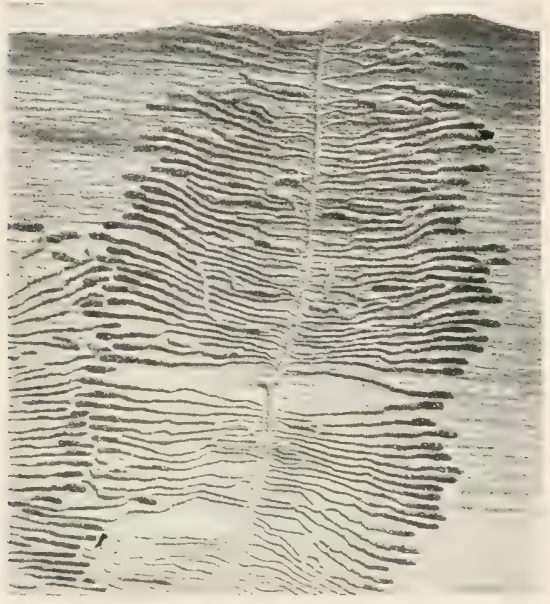

Fig. 95.-Markings of Hylesinus fraxiui on ash stem after removal of barl. the pole, half this number may be found.

The larvæ commence hatching out about the middle of April or beginning of May. At first they are of a slightly reddish colour, but the fully developed larvæ are white, with dark head and jaws, and tapering to a blunt point at the end. The larval galleries are about $1 \frac{1}{2}$ inch in length on the stem, and about $\frac{5}{8}$ to 1 inch long in the pole. The perfect beetles emerge about the first week in August, through individual exit-holes, and the bark consequently looks as if it had been riddled with shot.

The perfect beetles then betake themselves to healthy ash-trees or newly felled ash $\operatorname{logs}$, where they hibernate for the winter, and emerge in March or April. It is very questionable if they do any harm to the standing trees, as they simply bury themselves in the bark, though Judeich and Nitsche give a figure of "bark roses" resulting from the beetles hibernating, which in all probability is the work of the fungus known as Nectria ditissima following in the train of the bark puncture or wound made by the beetle.

${ }^{1}$ See Trans. High, and Agr. Soc. Scot., 1899. 
The beetle (fig. 96 ) itself is about $\frac{1}{3}$ inch in length, oval form, pitchybrown or ashy-grey colour; under side of abdomen covered with thick grey hairs; the antennæ and tarsi of a yellowish-brown colour.

Various remedies have been given for this insect pest, including the recommendation of planting on suitable soil, \&c.; but such advice is largely unnecessary, inasmuch as it only attacks felled logs or dying trees and poles, and all practical forestry insists on cutting backgoing ash-trees more quickly than any other species of tree, in order to prevent rapid depreciation of the timber.

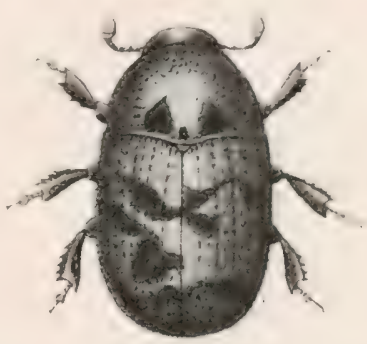

[Fig. 96.-Hylesinus fraxini. (From Barbey.)

Hrlesines oleiperda (Fabr.) ${ }^{1}$

This beetle is found on ash, but, in contrast to the preceding species, is always got on the small topshoots. It is, however, as a rule, a South Country species, the branches shown in fig. 97 being from a tree in Wiltshire. It is a species which hatches out very readily in confinement, so that the branches containing the larvæ may simply be put in a box in winter and left there until the beetles appear, about the end of July.

The mother-gallery is very short, being only about half an inch in length, and apparently only singlearmed. The larval galleries vary

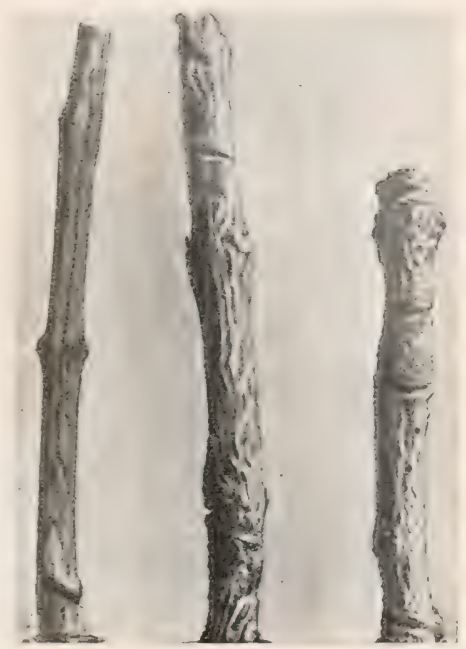

Fig. 97.-Marlings of Hylesinus oleiperda in sinall branches of ash. very much in length, being from half an inch to two inches. They are often crowded so closely together that every portion of the space becomes pitted with larval furrows.

1 I found the three species-viz., $H$. crenatus, $H$. fraxini, and $H$. oleiperdaall in Belton Park, Lincolnshire, July 1907. 
The beetle (fig. 98) is comparatively small, being about 2 to $3 \mathrm{~mm}$. in length, hluntly ovate, pitchy black, and covered with yellow bristles and hairs. The thorax is broad at the base, tapering towards the head. The wing-cases are marked with punctured lines. There is

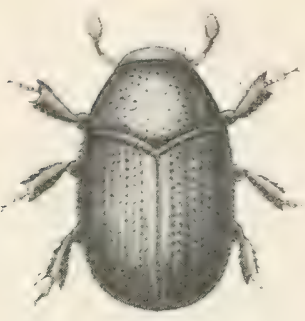

Fig. 9S.-Hylesinus oleiperda. (From Barbey.)

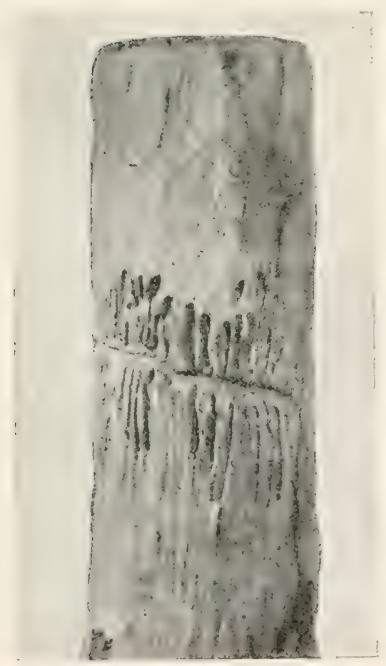

Fig. y. - Wurinus of Hylesimus vittatus in bromed of clm. an irregular yellowish dorsal streak between the two elytra. The legs and antennæ are yellowish.

The beetle derives its specific name in consequence of attacking the olive-trees in Italy. Fowler says the species has been found abundantly in beech near Frankfort.

\section{Hylesinus vittatus (Fabr.)}

This species is found on branches of elm. The specimens in my collection have been hatched out from branches received from Wiltshire, and judging from those hatched, the time for swarm. ing is somewhat variable. In 1904 the beetles did not appear until the end of June and beginning of July. In 1905 I found that a few had escaped by the end of April, and on cutting into the branch on May 6, I found perfect beetles in several burrows on one side of the mother-gallery, and active larvæ in the arms of the opposite side, hence one might infer that the flight period varies. It is possible, however, that the general time for swarming is just after midsummer. My friend, Mr A. C. Forbes, who has carefully worked up the fanily in the south of England, informs me that he never could find any workings until the beginning of August. It would seem that Eichhoff had not been able to work up this species personally, for he says that one person informed him that it swarmed on May 21, and another worker found it swarming in August. Hence he concludes, reasoning from analogy, that the 
species is double-brooded, whereas it was possibly due to erratic swarming.

It maty be noted that the larve work in the bast and on the surface of the wood. The bast is a lightishcream colour, and the frass from the larve is a deep dark chocolate.

The mother-gallery is two-armed, the total length being about $1 \frac{1}{4}$ inch. The larval galleries are at right angles with the mothergallery, and vary in length from $\frac{1}{4}$ to $\frac{1}{2}$ an inch. The workings are generally in comparatively small branches (fig. 99).

The beetle (fig. 100) is the smallest species of the group, and, viewed with a strong lens, certainly the prettiest. The form is more linear than any of the other species. The

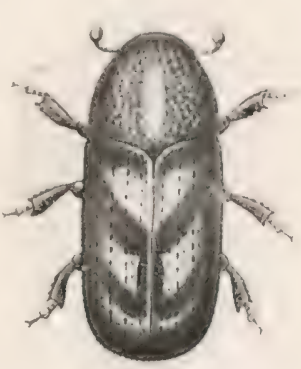

Fig. 100,-Hylesinus vittatus. (From Barley.) thorax is slightly grey, and the elytra are beautifully variegatel,so much so, that the colouring is suggestive of a moorfowl's egg. The antennæ are lightish-brown, and the whip portion is comparatively long. The legs are also light-brown.

\section{Gemus Hylurgus.}

Upper side of body clothed with scanty hairs; thomx long hairs at the sides. Eyes entire and longish. Whip of antenne threat-like and six-jointed; club ovate. First tarsal joint longest; third very broad. Elytra extremely punctured.

\section{Hylurgus piniperda (Linn.)}

Myelophilus piniperda, L. (Eichhoff and Fowler).

Hylesinus piniperda, L. (Judeich and Nitsche).

The above synonyms show that leading entomologists use different generic names. The practical forester of this country has always understooul it as Hylurgus, but Fowler adopts Myelophilus as the greneric term.

The genus contains two species, and Fowler ${ }^{1}$ gives the following key-viz. :

I. Second interstice of elytra flattened, and without tubercles at apex . . . . . . H. piniperda, L.

II. Second interstice of elytra nut depressed, and with a row of small tubercles at apex . . . H. minor, Hart.

1 British Coleoptera, vol. i. p. 419. 


\section{Hylurgus piniperda (Linn.)}

This beetle is very destructive to the young shoots of Scots pine, and has an interesting life-history. During the winter months many of the perfect insects hibernate in rough bark, or otherwise bore a hole in the bark of healthy standing trees, just enough for covering, but this winter burrow is in no way injurious to the standing tree. The burrows, however, on the stem of the tree may be best seen

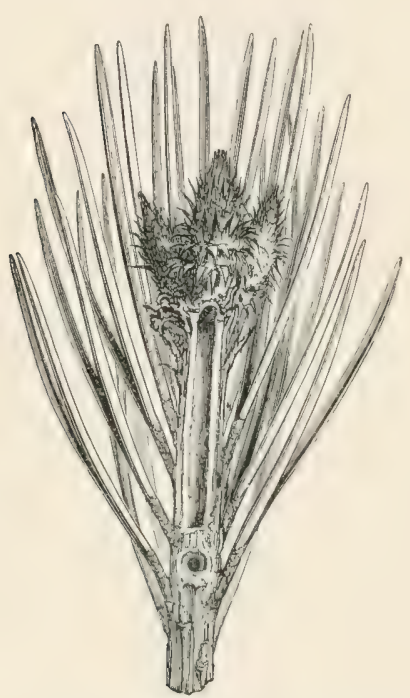

Fig, 101.-Shoot of Scots pine, showing the entrance-hole, and a slice removed to show the boring of a pine beetle. (From 'The Forester, by $J$. Nisbet.)

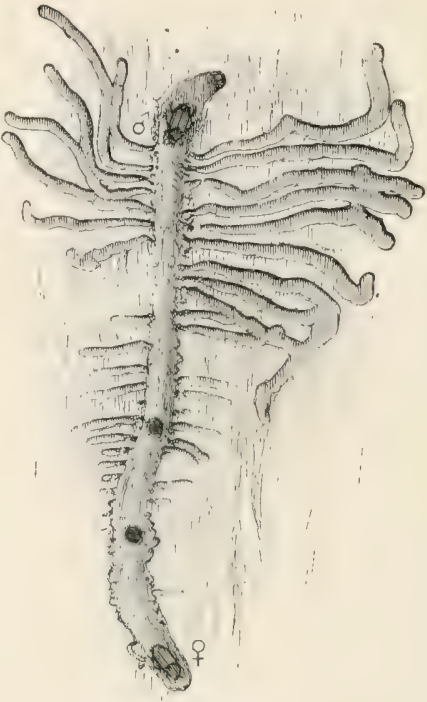

Fig. 102. - Showing mother and larval galleries in process of formation. (Frnm 'The Forester,' by 'J. Nisbet.)

months after the exit of the beetle. The exit-holes are clean-cut openings, surrounded by a fringe of hard resin, which has in consequence issued from the bottom of the excavation, as the boring has been sufficiently deep to reach the vital bast. A few of the beetles hibernate in the shoots, which fall with the buried insect in autumn (fig. 101). In early April or the end of March they withdraw from their winter-quarters and commence their breeding operations. The female beetle either selects a sickly standing tree or the stem of healthy trees which have been felled during the previous winter, and 
makes a slight burrow in the bark. Having scooped out a circular chamber, she then returns to the outer world, and re-enters the chamber accompanied by the male. In this chamber copulation takes place, after which the female proceeds to bore farther into the stem, almost at right angles to the first-scooped portion of the chamber. The main or mother gallery is therefore a straight line, with a hent at the bottom, or entrance, somewhat resembling a golf club (fig. 102). The total length of the mother-gallery is about three inches, and there are generally two or three air-holes directly over the gallery. In about ten or twenty days after the first eggs have been deposited the larvæ hatch out, and proceed to eat their way, more or less at right angles, to the mother-gallery. At first, therefore, the markings are very characteristic, as in fig. 102 ; but later on the larval markings are very much intermingled, as in fig. 103, which is a photograph from a portion of bark, and shows the intermingling of larval galleries from several adjacent broods.

At first the larval galleries are very fine and thread-like, but as the grubs enlarge the galleries widen, and pupation

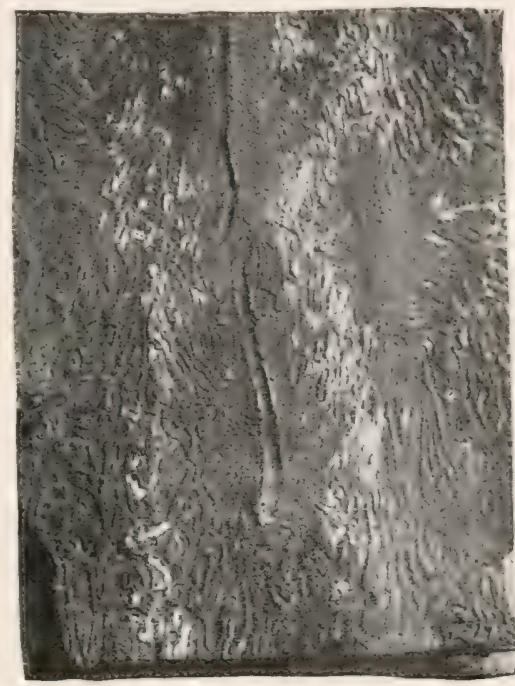

Fig. 103.-Portion of bark of Scots pine, showing two mother-yalleries and lerral "urlings.

takes place at the end of the larval gallery. It should be noted that both larval and mother galleries are always made in the bark, and never in the wood, though the frass always lies on the wood after the removal of the bark. Thus the beetle in question is a bark beetle.

The beetles escape from the pupal chamber by making direct exitholes, and thus the numerons flight-holes in the bark indicate that a new generation has escaped.

The beetles arising from the first-deposited eggs hatch out in about three to five weeks, generally towards the end of June, and these early hatched beetles, on quitting the galleries, deposit eggs in the 
bark of felled trees, preferring those trees which have been felled in late spring or early summer. But meanwhile the stem-mother has kept on depositing eggs, and beetles hatch out from the parent burrow throughout the season, but more especially in the autumn. Thus the perfect beetles arising from the second brood, together with the late swarmers just referred to from the original burrow, quit the bark practically simultaneously, and bore into the young leading shoots of the Scots pine branches, entering the pith, and thus damaging the shoots, so much so that they fall to the ground, and the beetles therefore may be found inside the pith of those shoots which so literally strew the ground of pine woods in autumn.

Some specimens leave the shoots to hibernate in the bark, and others remain in the shoots over winter, to come

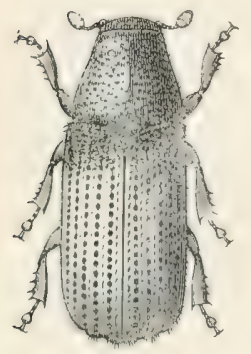

Fig. 104.-Hylurgus piniperda. (From 'The Forester,' by J. Nisbet.) out again in the following spring. The continual destruction of shoots gives the tree the appearance of being clipped or stumped, and the pruning habits have given rise to the insect being called in Germany the "woou-gardener" or "forester."

The perfect insect (fig. 104) is about $5 \mathrm{~mm}$. or $\frac{1}{5}$ of an inch in length, of a pitchy bronze colour, head and thorax approaching to black, legs same colour as body, with light tibiæ. The elytra, or wing-cases, are rough, and rounded over the sides, so that a transverse section of the abdomen would be nearly circular. The elytra should be carefully noted, and $\mathrm{D}_{\mathrm{L}}$ Somerville gives the following detailed description :--

"The elytra are lustrous, slightly pubescent, and traversed longitudinally by rows of fine punctures. The interspaces between the punctated rows are somewhat wrinkled, and each contains a row of hairy tubercles. These tubercles, in the case of the second interspaces on either side of the middle suture, are only present as far as the point where the elytra begin to bend downwards towards the apex; whereas in the other interspaces they are continued down the apical declivity to the edge of the elytra. This peculiarity is most marked in the male, though in both sexes it is quite observable with the unaided eye when the insect is held in a good light with its back towards the observer-that is to say, when the apical declivity is examined obliquely. Owing to the want of hairy tubercles in the 
two interspaces mentioned, these are seen to be smooth and lustrous, and appear like shining lines or shatlow grooves on the apinal declivity. This point is of much importance, for it is only by means of it that we can with certainty distinguish this insect from Hylesinus minori." 1

The larva is a white footless grub, with a light canary-coloured head. The middle portion of the grub is yellow, and the tail portion pure white. The pupa is whitish and shining, showing all the parts of the perfect insect.

\section{Preventive and Remedial Measures.}

Though this is certainly a very destructive insect, yet, in the absence of special damage by gales, it can be held in eheck by fairly good forest management. This consists largely in destroying the breeding-places, which, it must be remembered, are either in the stem of cut trees or in sickly standing trees. Much, of course, will depend on the felling season, and on the interval clapsing before manufacturing. If, say, the trees were cut in September and manufactured by March, no evil effects would accrue; but if they were felled in March and not cut up at the sawmills until September, it would be entirely to the advantage of the beetle. Hence, if cut during the latter period, various checks should be adopted. For instance, the bark might be partially cut off as in the custom of chipping the "four sides" of the log to lessen railway carriage, which would have the effect of so drying up the bark, or otherwise separating it from the log, to such an extent that the necessary conditions for propagation would be very much destroyed. If, however, the logs are not thus dealt with, then they should be barked at the sawmill from June to August, and all bark burned. Thus many larvæ and beetles would be destroyed.

If, on the other hand, we wish to lessen the breeding-places in standing trees, all sickly trees should be removed. But while the latter may be recommended on entomological grounds, we should bear in mind that "pure" woods of Scots pine should never be heavily thinned, but, on the contrary, an unbroken canopy should always he maintained. Another measure for eradication may be adopted in felling certain trees as catch or trap trees, and then burning the hark of the same.

From a practical point of view, it may well be asserted that the 1 Trans. High. and Agr. Soc. Scot., 1891. 
barking referred to would not pay; but having regard to the damage arising from the perfect beetle to the shoots of young trees, or where a nursery with young Scots pines is in the neighbourhood, it might be quite advisable to check the pest in this way. It often happens that young Scots pine plants in the nursery are injured by the beetle.

The very small tops and branches of Scots pine lying on the ground are not suitable for the breeding purposes of this insect, though they are used by other beetles. The larger branches, however, may be used for breeding purposes, and it is therefore advisable, both for checking the beetles and for the health of the crop, to keep woods entirely free from dead trees and all brushwood. Hence it may be seen that, so far as the health of the woods is concerned, it is not a good practice to leave the fresh or half-dead branches on the ground for cover. At the same time, it is only fair to note, in the interests of game-cover, that the perfectly dry dead branches which may at times be pruned off from the base of the stems of Scots pine are not used by beetles for breeding purposes.

\section{Hylurgus mixor (Hart.)}

This insect is considered by many coleopterists as purely a Continental species, though a few workers consider it a British species. Hence Fowler says it is rare, and gives Deeside and Braemar as districts.

The beetle is smaller than the preceding species, and may be recognised by noting the bristle-bearing tubercles continued on the second interstice of the elytra.

Not having found the species, I quote from Professor Fisher as regards the relation to the forest:-

" $H$. minor, Hart., chiefly attacks the Scots pine, but has also been found on the spruce. It prefers poles, but may attack 50- to 70-yearsold trees. The mother-galleries are large, regular, double-armed, and horizontal, with a rather long entrance-burrow, and groove the sapwood deeply. The injury which its breeding causes is therefore greater than that of $H$. piniperda, as the circulation of the sap is more endangered by these horizontal galleries. It is not, therefore, surprising that quite sound trees are killed by it, or, at any rate, become stag-headed.

"The larval galleries are short, not very numerous, and terminate 
in a deeply eut pupal chamber. This beetle, unlike the preceding species, is said not to confine itself to the borders of a pine wood, but to be found deeper in its interior.

" $H$. minor also bores into the pith of young pine shoots in the same way as $H$. piniperda." 1

\section{Genus Phlegophthorus.}

Antennal whip five-jointed; club of antennæe three-jointed and very distinctly divided; abdomen not raised towards apex.

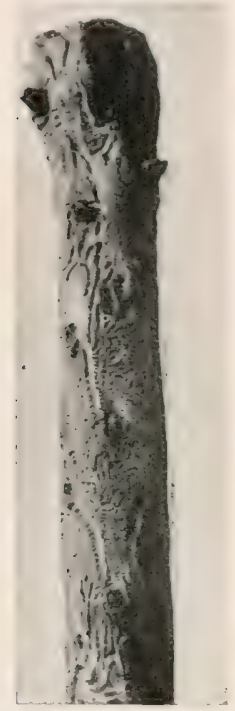

Fig. 105.-Markings of Phlceophthorus rhododactylus on gorse (whin) stem.

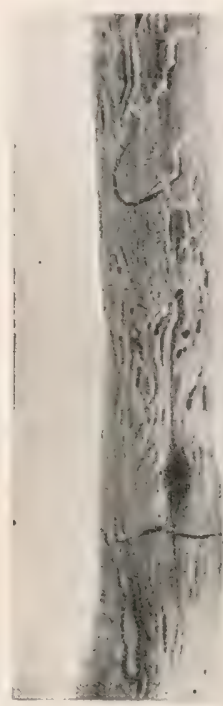

Fig. 106.-Marlings of Phloevplithorus rhododactylus on broom.

\section{Phlqophthorus Rhododactilus (Marsh).}

This is one of our smallest British wood-feeding beetles, and is found in gorse and broom stems. It is very common in Northumberland. Fig. 105 represents the markings on whin and fig. 106 on broom. The beetles may be looked for about the hegimning of April, more especially on half-dead gorse stems, - those stems, in fact, which were alive the previous year, but have been broken down ly the heavy snows of

1 Forest Protection, 1907.

H 
winter. They deposit their eggs in small irregular clusters, and the larvæ move about in all directions from the mother-gallery, so that

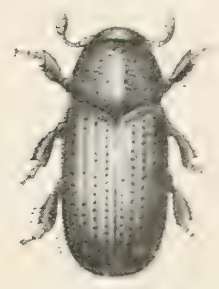

Fig. 107.-Pliloeophthorus rhorlodactylus. (From Barbey.) the markings are very irregular. These larvæ are transformed into fully developed beetles by early autumn, when some leave the broodplaces, whilst others remain at the far end of the larval galleries for the winter and leave the following spring. I have kept them in confinement over the winter, and they worked the same stem as they had done the previous year.

The beetle (fig. 107) is about $1 \frac{1}{2} \mathrm{~mm}$. in size, of a dull, blackish slaty colour, with slight greyish pubescence. The thorax is beautifully striated, and the body somewhat globular in shape. ${ }^{1}$

\section{Sub-FAMILY DRYOCÆTINA.}

This is rather an extensive tribe, and as the whole of the genera are practically arboreal insects, it is perhaps well to append the following synoptical key, slightly modified from Fowler -viz. :

I. Funiculus of antennæ with four or five joints, size variable.

i. Eyes entirely divided; club of antennæ without sutures. Beetles bore directly into the woody stem.

Trupodendron, Steph.

ii. Eyes entire or slightly emarginate.

1. Elytra clothed with scale-like pubescence, and sometimes with fine raised hairs in addition, not excavate at apex; scutellum very small; club of antennæ with distinct sutures. Beetles small, generally working in thin bark.

Cryphalus; Er.

2. Elytra without scale-like pubescence, glabrous or with outstanding hairs; club of antennæ orbicular and compressed.

1 There appears to be some confusion as regards the nomenclature of the two species of Phlocophthorus-namely, P. rhododactylus and P. Spartii. The insect known abroad as $P$. Spartii is given by Parbey as feeding on broom, and $P$. vhododnctylus as feeding on branches of the spruce. 
A. Base of thorax finely bordered; prosternum with a short process; size very small; club of antennæ divided by three constricting sutures into four joints . . Pitкoвntronts, Eich.

$B$. Base of thorax not hordered.

a. Club of the antennæ with the second joint crescent-shaped, and completely embracing the sides of the first joint, which is oval; scutellum rudimentary; elytra with reflexed portion dentate in the male, not dentate in the female

Xylocleptes, Ferr.

b. Club of antennæ truncate at apex, the basal joint being corneous, and the remaining joints lying within it; mentum broadly cordate, sub-mentum large and concave anteriorly . Dryocetes, Eich.

$b$. Elytra excavate at apex, which is horizontal or almost horizontal behind the apex of abdomen.

Tomicus, Latr.

b". Prosternum without or with a very short process between the anterior coxæ.

(a) Tibir almost linear, without furrows for the reception of the tarsi; apex of elytra with large teeth in the male, and with a strong impression on each side of suture in the female.

Pityogexes, Bedel.

(b) Tibiæ dilated, furnished with furrows for the reception of the tarsi ; apex of elytra without large teeth or deep impressions in the sexes.

Xrleborus, Eich.

\section{Gemus Cryphalus.}

The members of this genus are very small insects, and may certainly be overlooked by nearly all except the trained economic entomologist. Six British species have hitherto been recorded on poplar, lime, spruce, beech, \&c. They are all so very small in size that they cannot be seen to any advantage without the microscope or strong pocket-lens.

Fowler gives six British species, but as two are rather rare, we may confine ourselves to four species. As the beetles are exceedingly small 
in size,-from 1 to $2 \mathrm{~mm}$,,-the characters are entirely microscopical. The following generic characters may be given :-

Pronotum as broad as long, with small hump projecting in front portion. Elytra slightly hairy, conspicuously punctured, and well covering the abdomen. Whip of antennæ four-jointed; joints very small; club comparatively large; tibia broad, and toothed on outer edge.

The following are the specific characters, according to Fowlerviz. :

I. Club of antennæ with the sutures transverse, almost straight; body behind thorax, only twice as long as broad.

1. Eyes entire; thorax with four transverse rows of granules in front

C. tilice, Panz.

2. Eyes emarginate on their anterior border; thorax confusedly granulate.

$A$. Elytra with very short, scarcely visible, hairs; rows of punctures on elytra not very fine, and placed in somewhat impressed striæ - . C. abietis, Ratz.

$B$. Elytra with long raised hairs; rows of punctures on elytra very fine . . . . C. picece, Ratz.

II. Club of antennæ with the sutures strongly curved; hody behind thorax three times as long as broad; elytra without strix . . . . . . C. fagi, Nord.

\section{Cryphalus abietis, Ratz.}

This species is found on dead spruce hranches, - generally at knots of the branches. It is considered rare, but this arises probably from its being overlooked, for I have found it in the south of England, and again in the north-east of Scotland. Figs. 108 and 109.

Eichhoff says it is double-brooded, as the first brood swarmed in February and March, while snow was still on the ground, and the second brood appeared about the latter end of July.

I received a portion of a stem of young Douglas fir, heavily attacked by this insect, from Mr A. C. Forbes, Bowood, Wiltshire. As a rule, this tree is almost immune from insect attacks. 2Ir Forbes has again sent me an example of this species on Douglas fir from Cockle Park, Northumberland. 


\section{Cryphalus tiliz, Panz.}

This species confines its attacks to dead or dying branches of the lime, and is said to be extremely local. I am indebted to $\mathrm{Mr}$ Morse, Leeds, for the specimen as represented by photograph in figs. 110 and 111. He found it at Newnham, Gloucestershire, in Nay 1906. The mother-gallery is horizontal, and may be either single- or double-armed. The bark, at the selected portion of the branch, is exceedingly thin, and the female beetle bores just deep enough to skim the surface of the wood. The larval galleries run at right angles to the mother-gallery, but owing to the thinness of the bark, and the peculiar structure underlying the thin covering, it is with great difficulty that a specimen may be prepared for illustration.

All German writers say there is a double generation.

The beetle is small in size, oval, and circular if considered in section through the

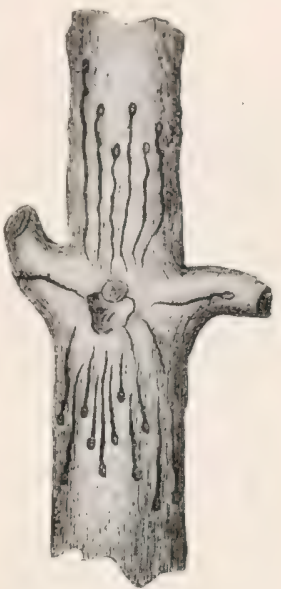

Fig. 108. - Markings of Cryphalus abietis. (From Altum.) body, pitchy brown, with reddish-brown antennæ and legs. Thorax broader than long, with small protuberances on the sides. Elytra with very finely punctured strix, but the general appearance is rough and scaly. Length 1 to $1 \frac{1}{2} \mathrm{~mm}$.

\section{Cryphalus piceie.}

I have not found this species. Fowler says it is very rare. Barbey says it lives exclusively on the silver fir (Weisstanne), though at the same time he gives two exceptions, one on the root of spruce and the other on the larch. He

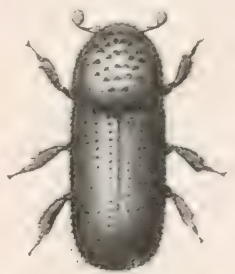

Fig. 169-Cryphalus abietis. (From Barbey.) also adds that it is a very deadly enemy of silver fir when associated with another beetle named Tomicus curvidens, Germ., and gives a very interesting account of the injuries. It would be well, therefore, for students in this group to keep a good look-out for this species (hitherto considered rare), more especially in the south of England. 


\section{Criphalus fagi, Fabr.}

This species is found generally on branches or snall stems, but is said to be very local. Mr Morse supplied me with the specimen from which the photograph is taken (fig. 112).

I only got one specimen from the branch, which was elongated, slender, and of a shiny, dull hlack colour.

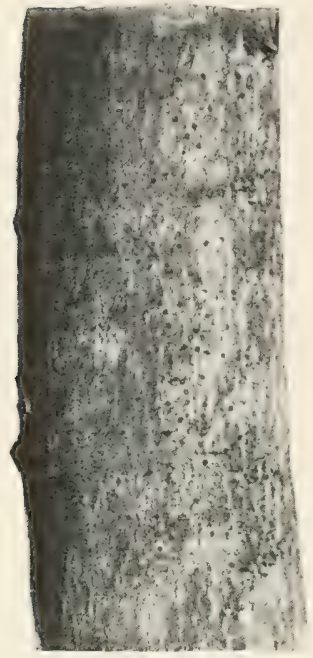

Fig. 110.-Showing "exitholes" of Cryphalus tilix in lime.

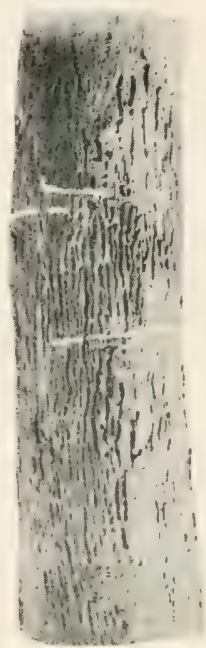

Fig. 111.-Markings of Cryphalus tiliæ on lime. The white horizontal lines are the mother. galleries.

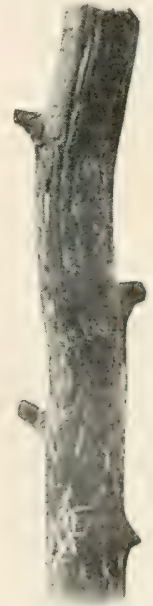

Fig. 112.-Markings of Cryphalus fagi on branch of beech.

Barbey says the chief character lies in the form of the antennæ club. ${ }^{1}$

\section{Gemus Pitrophthorus.}

Fowler says- "Genus as defined by Eichhoff presents the following characters: Antennæ with a five-jointed funiculus and an oval non-compressed club, which is constricted by transverse sutures dividing it into four distinct joints; thorax as long as or longer than broad, bordered at base and distinctly narrowed in front; elytra cylindrical, with simple rows of punctures, and with impunctate interstices; the apex is obliquely truncate, and presents a depression on either side of

1 Die Bostrichiden Central-Europas. 
suture; it is not armed with spines or teeth, but the raised sides of the apieal depression and the sutural margins sometimes possess a row of small setigerous tubercles." 1

\section{Pityofhthorus pubescenis, Marsh.}

'This is a very small species of beetle, which often follows in the train of unpractical planting of young Scots pine trees. There is an age of plant known in the trade as 2 yrs.-3 yrs., - that is, two years in the seed-bed and three years in the nursery lines; in other words, only once transplanted in five years. In this class the bill of mortality is a very high one, and the beetles prefer the dead trees of the class referred to, and may be looked for near the top of the stem, where the thickness of the stem is about equal to that of an ordinary drawing-pencil.

\section{Genus Xrlocleptes.}

Fowler remarks: "The genus may be known by having the second joint of the club of the antenne crescent-shaped, and completely enbracing the sides of the first; the funiculus is five-jointed; the scutellum is indistinct; and the apical portion of the elytra is strongly inflexed in the male and fully inflexed in the female." 2

\section{Xylocleptes bispinus (Duft.)}

This species is found on the dead stems of Clematis vitalba, and is, generally speaking, a South Country species. I am indebted to $\mathrm{Mr}$ Hereward Dollman for the specimens in my collection. He records them as being common at Ditching, in Sussex. ${ }^{3}$

According to Eichhoff, the mother-gallery is two-armed, and the insect has a double generation. The beetles pass the winter in the galleries, and appear in April or May. The first generation is developed by June or July, and the second from August till October. As the latter time is rather a prolonged period, it is probable that the late swarmers from the first brood may be confounded with the early swarmers of the second brood.

${ }^{1}$ British Coleoptera, vol. v. p. 433.

2 Ibid., p. 435.

${ }^{3}$ Commander Walker has found it abundantly in Kent, and sparingly in the Oxford district. 
The beetle (fig. 113) is elongated and cylindrical, of pitchy brown colour. The thorax is darker than the elytra, and longer than broad. Legs rusty brown colour, and the antenne and tarsi lightish-yellow.

In the male the apex of the elytra is much inflexed, with a tooth

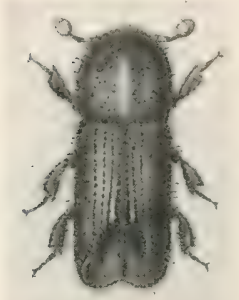

Fig. 113. - Xylocleptes bispinus. (From Barbey.) on each elytron, and the suture is so raised on the inflexed portion as to form a small keel.

In the female the apex is most feebly inflexed, and the extreme apical edges are rounded.

\section{Genus Dryocetes.}

The genus Dryocætes may be said to be of very minor importance, so far as economic forest entomology is concerned.

The whip of antenne five-jointed; elytra distinctly punctured, and covered with fine pubescence and smooth.

\section{Dryocetes villosus (F.)}

I found this species very plentifully in the rough bark of an old dead standing oak in Chatsworth Park, Derbyshire. I have also, more

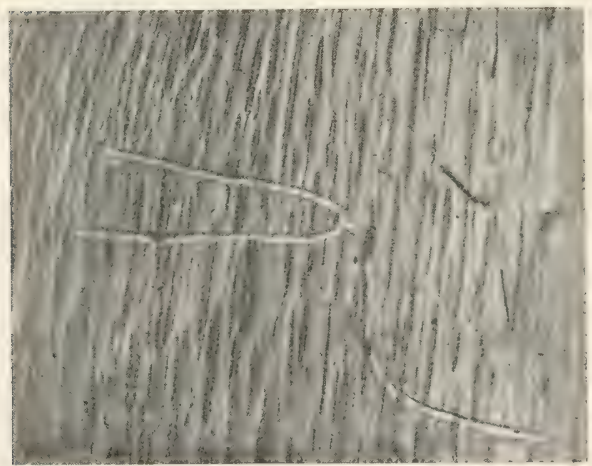

Fig. 114.-Mother-gallery of Dryocetes villosus in bark of oak:

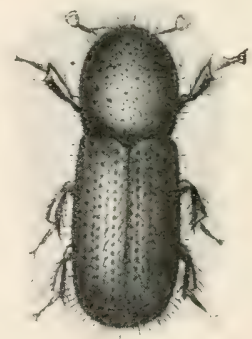

Fig. 115.-Dryocretes vil losus. (From Barbey.)

recently, had its markings pointed out to me by my friend Mr R. S. Bagnall, in Gibside, Co. Durham (see fig. 114). These markings were on an old dead standing oak. The beetle (fig. 115) is of a reddish- 
brown colour, and clothed with pale puhescence which might almost distinguish the species. Length $2 \frac{1}{2}$ to $3 \frac{1}{2} \mathrm{~mm}$.

The other two species of this genus, which may be overlooked, are D. alni (fig. 116) and D. coryli. The former is said to be found on beech, and the latter on dead twigs of hazel and hornheam, but both rare, especially the latter.

These two species are about the size and appearance of $P$. bidentutus.

\section{Genus Tonicus.}

The species of this genus are all feeders on coniferous trees, but some of the species are rather rare. They all make peculiar markings,- - so much so, that in consequence of the strongly marked patterns the species have been termed "typographers."

Some of the species are polygamous, and the main galleries can be traced from the starting - point $\mathrm{Or}$ breeding - chamber (Rammelkammer).

Fowler gives five species as British, but I have only found

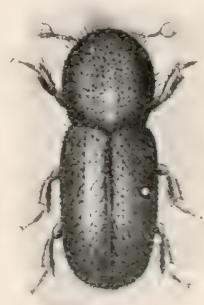

Fig. 116,-Dryocxtes alni. (From Barbey.)

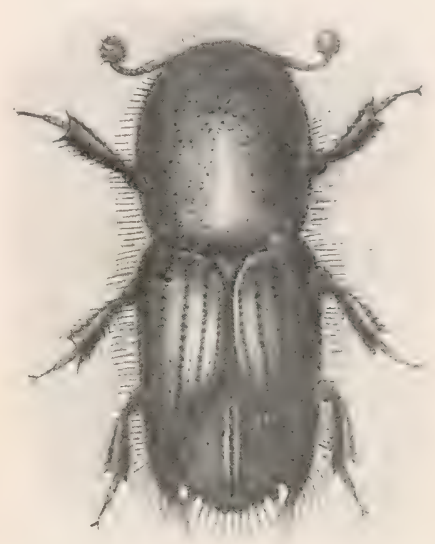

Fig. 117.-Tomicus sexientatus. (From Barbey.)

one in Northumberland-viz., T. aruminutus. It is perhaps the first record for the county, and I am obliged to Mr R. S. Bagnall for identification.

The principal generic characters are: antennæ whip five-jointed; thorax large, with a wrinkled little lump in front and punctured behind; wing-covers at the point pressed and toothed.

\section{Tomicus sexdentatus (Börn.)}

This is a large handsome beetle (fig. 117), pitchy dark-brown colour, 
pronotum smootl, and elytra deeply punctured ; abdomen covered with long hairs; and the apex deeply and obliquely excavated, showing teeth on each side. Antennæ and legs ferruginous. Length $5 \frac{1}{2}$ to $7 \mathrm{~mm}$.

Fowler gives as a habitat recently dead firs near London, and $\mathrm{Mr}$ R. S. Bagnall places it as an introduced species to Hartlepool. It is a very rare insect.

\section{T'omicus acuminatus (Gyll.)}

This insect is of a uniform terra-cotta colour, and slightly pubescent. Thorax longer than broad, and a slight depression in centre; the elytra fully cover the abdomen.

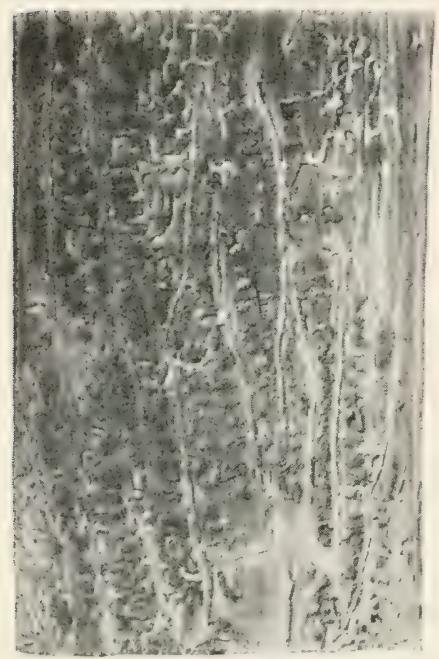

Fig. 118.-Marlings of Tomicus acuminatus on stim of Sirets pine after the berit: wers sinepind off. Eyes black; antennæ and legs yellowish.

The main characters, which are microscopical, are found in the toothed abdomen. There are three teeth on each elytron; the third tooth is the longest. In the female the third tooth is formed into a sort of hook, whereas in the male it is a sort of blunt forked spine.

This is by no means a common species, and I found it in Beanley Wood, Northumberland, July 1906. Fig. 118 shows the markings.

\section{Gemus Pityogenes.}

The genus Pityogenes, according to Fowler, contains three species, but $I$ have only one species, viz., $P$. lidentutus, which in many districts is very common. Barbey, who may be considered as a leading German authority, places $P$. bidentutus in the genus Tomicus, but I venture to think that Fowler's separation is a very good one, on the ground that in Pityogenes "in the males only the apex is excavate, and is fumished with strong teeth," and also that "the females have a deep impression at the apex of the elytra near suture." Under a strong lens this character is well maintained,- so much so, that the thorax has a quite "nipped"-like appearance. 
Pitrogenes bidentatus (Herbst.)

Pityogenes bidens (F'abr.)

This is a common beetle, but, being small in size, is very apt to be overlooked. Its breeding-places may be broadly divided into two classes-viz., on small dead fir-branches, and on sickly trees, say from 18 inches and upwards, which have been transplanted in the nursery-lines, or those which have been transplanted in young woods.

As regards the former class of foodmaterials, and as forming a commencement in the study of its life-history, it may be looked for amongst the small branches of Scots pine, chiefly on the under side of the branch, either where trees have been felled during the previous winter, or on branches which have been broken off by the wind. The small boreholes, together with the frass, reveal the abode of the insect. If the thin bark be removed carefully, we may find a starshaped marking, as in fig. 119. This is a typical beginning of the markings of this species. The central portion is scooped out by the male, where several females, generally from four to six, assemble, and after copulation each female makes her own gallery. The larræ arising from each respective female make their own particular design of markings, and this confusion gives rise to various irregular designs, such as shown on fig, 120. The same branches may harbour beetles the following year, but the markings are always best followed in recently cut branches.

As regards the sickly trees infested by

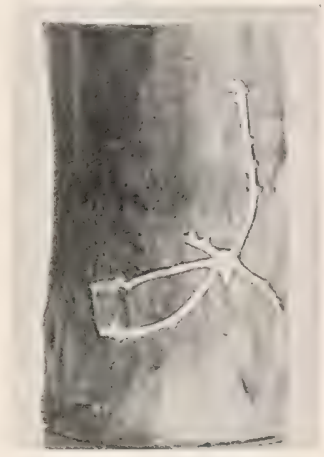

Fig. 119.-Marlings of Pity. ogenes bidentatus (initial stage).

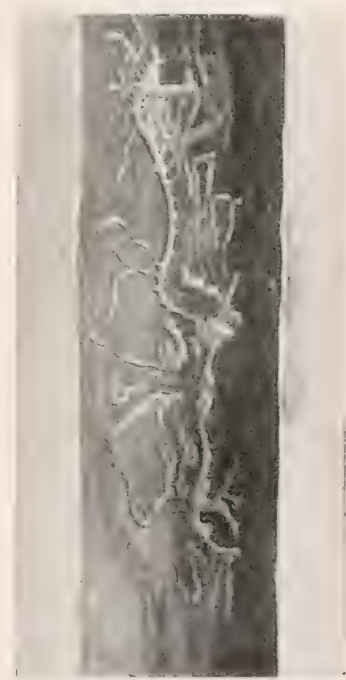

Fig. 120.-Fully developal mark: ings of Pityngenes bidentatus.

this insect, the principal damage is to pines, large transplanted Douglas firs, and so on. The transplanting of such class of trees, 
say from six to twelve years of age, is often rather risky, more especially if followed by a dry summer. Under such circumstances the bill of mortality is a heavy one, and the beetles are generally found on the dead or most sickly trees. It is just possible that, though the beetles are always found on dead or dying trees, they may be the means of partially killing several trees of the pine tribe.

It often happens that many transplanted Austrian pines hang, as it were, for one season, - that is to say, they make no growth, but simply remain green. If there be no insect enemies, the trees will recover the following year, but a severe heetle attack often kills what

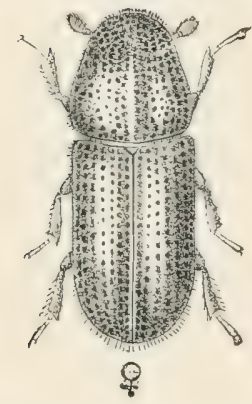

Fig. 121.-Pityogenes biden. tatus. (From Fisher's

'Forest Protection.') might otherwise recover. In the case of Douglas firs, the brown foliage emphatically declares the dead plants.

Altum ${ }^{1}$ relates that 100,000 seven-year-old plants were killed in one season by this beetle. In this country such an attack would be considered primarily due to, and afterwards accelerated by, the absence of healthy conditions, - that is to say, that the trees had been planted at the wrong season of the year, and on too dry a situation.

With regard to the life-history of the insect, I have found it in all its various stages throughout the whole year, and am therefore persuaded that Eichhoff's remarks regarding the respective broods are right-viz. :

"I. Spring swarm in May or June; larvæ in May, June, and July ; pupæ and imagines in July and August.

"II. Summer swarm from July till October; larvæ in July, August till October, and over winter; pupæ and imagines in September or October till May.

"III. Autumn swarm from August till October, larvæ over winter, imagines and swarms and broods in May and June." 2

The beetle (fig. 121) is from 2 to $3 \mathrm{~mm}$. long, pitchy black in colour, shiny, and covered with a very fine pubescence; antennæ and legs ferruginous; thorax constricted in front and punctured behind, and it has a sort of pinched appearance. The elytra have distinctly punctured rows. The male can be very easily distinguished by its having a projecting hook on each elytron.

1 Forstzoologie.

${ }^{2}$ Die Europäischen Borkenkäfer. 
As this beetle has proved a veritable pest on the Continent, and also occasionally in this country, it would be well to guard against its ravages. Perhaps the best preventive would be to remove or burn all comparatively young fresh branches which would come in groximity with any fairly large coniferous trees planted out, either in parks or villas, for immediate effect.

\section{Gemus Trypodendron.}

The beetles of this genus are entirely different in their workings from the sections hitherto considered. The Trypodendron motherbeetle bores directly into the stem of the tree for about $\frac{1}{2}$ to $\frac{3}{4}$ inch deep, directly towards the centre or pith, but when this depth is

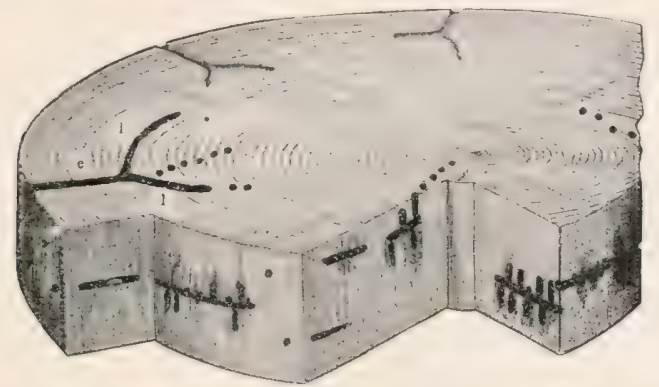

Fig. 122. - Block of wood shown in perspective to illustrate the workings of the genus Trypodendrou. (After Eckstein, and copied from Niisslin.)

reached she bends slightly round and then bores in a somewhat curved direction, parallel to the circumference of the tree, and always preferring the sap-wood. After she has taken the bend referred to she makes a sort of recess or basket, alternately right and left, of the main gallery, and places a single egg in each recess. In due time the eggs hatch out and make short galleries at right angles to the parent gallery. Each gallery points upwards or downwards. As regards space, each gallery altemates, and thus we get "ladder galleries" formed. When fully developed, the offspring creep out at the entrance made by the mother-beetle.

The accompanying figure, fig. 122, taken from Nüsslin, is a sort of perspective representation of an infested block, and gives a very good idea of how the insect bores into the stem.

The generic characters are: Eyes divided in two parts; knob of 
antennæ large and solid, longer than the four-jointed whips; thorax transverse or globose, with four projecting corners. Female with a convex forehead. Elytra ending abruptly, but without teeth.

The following are the specific characters, according to Fowler:-

"I. Apical declivity of elytra with a very distinet furrow on each near suture; elytra without distinct longitudinal streaks at sides; thorax black . . . . T. domesticum, L.

"II. A pical declivity of elytra without, or with an indistinct, furrow on each near suture; elytra with more or less distinct longitudinal streaks at sides; thorax more or less red, at all events behind.

i. Elytra with the punctured striæ moderately deep; club of antennæ subsecuriform, straight on one side, and somewhat rounded on the other. . T. quereus, Eich.

(signatum, F.)

ii. Elytra with the punctured striæ superficial; club of antennæ rounded on both sides and at apex T. lineatim (Ol.)" I

\section{T. LINEATUM (Ol.)}

This insect bores into spruce timber. It will bore into timber lying on the ground, which may have been cut during the winter, but

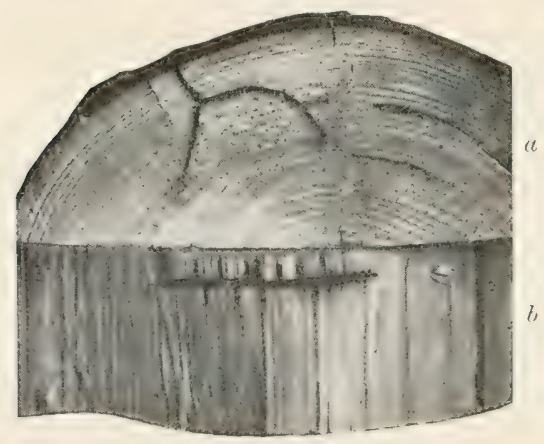

Fig. 123.-Workings of Trypodendron lineatum in spruce timber.

$a$, cross section of wood; $b$, longitudinal section.

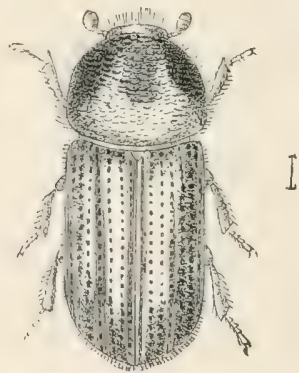

Fig. 121. - Trypodendron lineatum. (From Fisher's 'Forest Protection.')

by preference it attacks broken stumps-that is, standing portions of trees which have had two-thirds of their tops broken off by a winter gale. The female seems to be rather fastidious, as the material must

1 Fowler's British Coleoptera, vol. v. 
neither be too fresh nor too dry. She bores into the tree for an inch or more, and at about half an inch from the entrance commences to deposit her eggs. The larvie soon hatch, and bore at right angles to the tunnel of the parent, but in the longitudinal direction of the stem, either upwards or downwards; but the larvæ eat only a small portion of the timber, about twice the length of their own bodies, and they pupate in the recess thus formed. The perfect insect eats, ol rather makes, its way out at the hole in the stem made by the entrance of the female. Fig. 123 shows the workings of this beetle.

The beetle (fig. 124) is about 3 to $4 \mathrm{~mm}$. long, and cylindrical in form. The head is generally buried, as it were, in the thorax, which is blackish in colour. 'The elytra are yellowish-brown, with irregular black bands running along them. These bands are not always complete, but they are the salient feature distinguishing this from the species next mentioned.

I have found this species in two districts in Northumberland -viz, at Lyham, near Belford, in spruce, and in Scots pine, at Countess Park, North 'lyne; but it is by no means common in the county.

TRTPODENDRON DOMESTICUM

$$
\text { (Linn.) }
$$

This species bores in oak, beech, and birch, selecting the large limbs of trees which have been

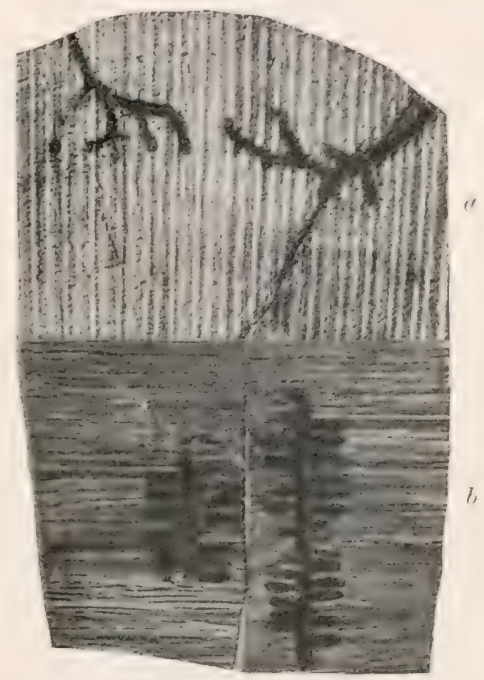

Fig. 125.-Marlings of Trypoleudron domestieum in oak timber.

$a$, cross section of wood; $b$, longitudinal section.

felled the previous year and left lying on the ground. Its presence may be very easily recognised by the amount of bore-dust lying on the surface. It should be looked for about the end of May or beginning of June, when many specimens may be found, as whilst at work it often appears on the surface of the trunk. Fig. 125 shows the workings of this beetle. In size it is about the same as the freceling species; but the prothorax is entirely black, and the elytra 
livid yellow over the whole surface, the irregular lines in the previous species being entirely absent.

Trypodendron quercus, Eich., is a species I have not found, but Fowler says it is fairly common in Sherwood Forest.

\section{Genus Xyleborus.}

The following are the chief characters of the genus, according to . Fowler :-

"Tibiæ broad, more or less serrate, and furnished with furrows for the reception of the tarsi, which are rather short; prosternum excised as far as the coxæ, and furnished with a very short process; thorax rough in front, and not margined behind; elytra without an impressed

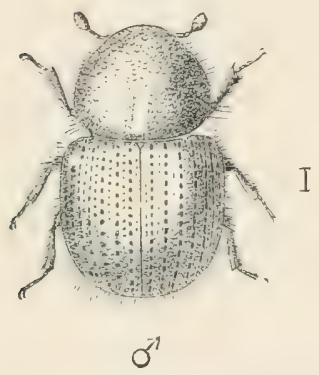

Fig. 126.-Xyleborus dispar (male)

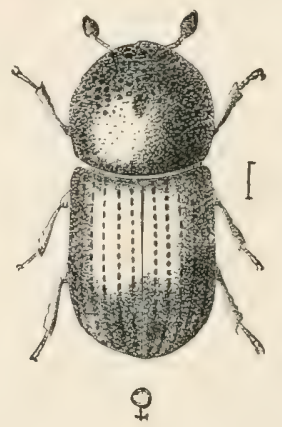

Fig. 127. -Xyleborus dispar ( female).

line along suture, with the apex not excavated but slightly reflexed, furnished with more or less distinct tubercles, which are sometimes almost obsolete; punctured striæ distinct, interstices closely and rather finely punctured in rows; eyes emarginate; the club of the antennæe has the sutures very slightly curved, and the funiculus is five-jointed." I

\section{Xtleborus dispar (F.)}

"Beetle, of 2 mm., o $3 \mathrm{~mm}$. long (figs. 126 and 127). Pitch-black, the antenne and legs testaceous-red. of short, convex, ovoid, and very hairy, with the thorax granular in front, punctured towards the base, with a smooth median line. The $q$ cylindrical, its thorax in front

1 Fowler's British Coleoptera, vol, r. 
strongly asperate. Elytra strongly arched at the declivity, with rows of deep punctures, and raised tuberculate interstices between them.

"The season for flight is in May. The q bores into several kinds of broad-leaved trees to lay her eggs, in preference below a branch, but never near the ground, attacking felled wood and young standing trees. Fig. 128 represents the workings.

"The larvæ appear in June, pupate in July in the secondary galleries, and the beetles emerge in August. They hibernate in the galleries, and there is only one generation. This beetle is not everywhere common on the Continent, and till recently it was regarded as one of the rarest British insects, but since 1891 it has been destructive in certain Glottcestershire fruit-orchards." 1

\section{References to Literature consulted.}

Altum, Dr Bernard. Forstzoologie. 1875.

Barbey, A. Die Bostrichiden Central-Europas. 1901.

Eichhoff, W. Die Europäischen Borkenkïfer. 1881.

Forbes, A. C. "The Bark-beetles of the Ash" —Trans. High. and Agr. Soc. Scot. 1899.

Fowler, Rev. Canon. British Coleoptera, vol. v. 1891.

Fuirst, Dr Hermann. The Protection of Woodlands. 1893.

Hopkins, A. D. Insect Enemies of the Spruce. U.S.A. Bulletin, No. 28. 1901.

Judeich und Nitsche. Lehrbuch der Mitteleuropäischen Forstinsektenkunde. 1895.

Nüsslin, Dr Otto. Leitfaden der Forstinsektenkunde. 1905.

Ormerod, Miss E. A. A Manual of Injurious

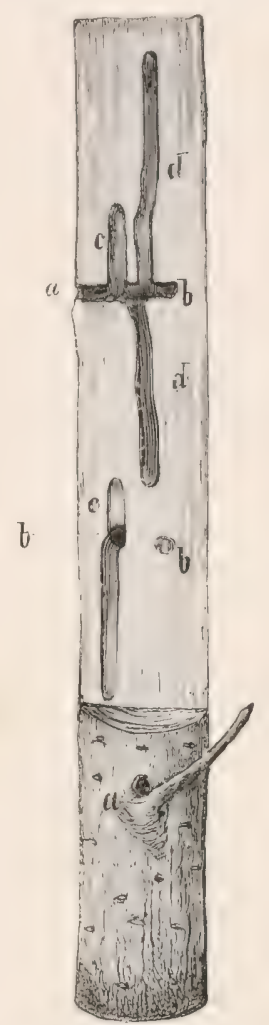

Fig. 128.-Burrous of Xyleborus dispar in an oak sapling (nat. ural size).

$a$, entrance-hole, usually under a twig; b, mother-galleries; c, conimencement of lateral galleries; $d$, completed lateral galleries, in which the larve lie. (Figures and explanation from Fisher's 'Forest Protection.') Insects. 1890.

Somerville, Dr W. "The Pine Beetle" (Hylesinus piniperda L.) - Trans. High. and Agr. Soc. Scot. 1891.

${ }^{1}$ Forest Protection, by W. R. Fisher: Schlich's Manual of Forestry. 1907. Cf. Miss Ormerod's report on this very interesting beetle, 1889, pp. 92-98; quoted in Fowler, vol. v. p. 448. 


\section{CHAPTER IV.}

\section{HYMENOPTERA-OAK GALLS.}

CosisIDERED entomologically, the subject of gall-forming insects is a very wide one, inasmuch as we find that certain insects belonging to the various orders, from Acarina to Hymenoptera, form galls. The galls on oak-trees are of special interest to the student of forest entomology, and also to the biologist.

Although the systematic study of galls is a comparatively modern one, many kinds of galls were known to the ancients, and several strange theories were from time to time propounded as to their origin and growth. As it was known that vegetable galls were tenanted by animal life, it was thought the plant contained a soul, able to impart life to the animal. Some considered that galls were stepping-stones from vegetable to animal life, while others thought egges were drawn up by the sap and ultimately developed into galls. Pliny, the Roman naturalist, knew that flies were produced from certain vegetable galls, but he associated many superstitions with his knowledge. For instance, he says that the events of the year were prognosticated as to the respective larvæ transforming into spiders, worms, or flies.

The first systematic writer on galls was an Italian physician, who gave an account of the galls of Italy and Sicily in 1686. The second writer recorded, on the subject, was Dr Derham, Canon of Windsor, who published his observations in the Boyle Lectures, 1711-1712. It is questionable whether he knew of the Italian writings, but it is said that when the two lists are compared the coincidence is very striking. Neither of these writings was known to Linnæus or Fabricius. Linnæus called the group Cynips, but comprised all species of Hymenopterous parasites with true gall-makers. Westwood, in 1839, working out the genus Cynips of Linnæus, termed the order Cynipidre, and gave some descriptive details. These, briefly 
consilered, are as follows: "Antenne 13- to 15-jointerl; wing few nervures; palpi short; head small and transverse; thorax thick. oval; abdomen much compressed; peduncle short; antenne insertel middle of face."

Hartig was the first to restore order and improve the classification. He separated the true gall-makers from the various species of parasites, and then subdivided the parasites into true parasites, incuilines or guest-flies, and commensals.

Thus a true parasite preys directly on the larva of the gall, and after undergoing its own metamorphosis finally kills its host. Inquilines or guest-flies prey on the substance of the gall, and, as a rule, indirectly kill the gall-forming insects. Commensals are generally found in large galls, living as lodgers in the sulsstance of the gall, but do not kill the insect.

These statements are corroborated by Ratzeburg in his 'Forstinsekten,' published in 18t4. Afterwards we find several workers in the field: Bassett, a Canalian, 1865; Riley, an American, 1873; Adler, ${ }^{1}$ a German, 1875 ; and Cameron of Manchester, 1892. The work of the last-mentioned writer was pullished by the Ray Society in 1892 .

Before dealing with galls from a purely entomological standpoint, it may be interesting, in view of the scientific importane of the sulject, to consider galls botanically, in so far as their morpholonical structure and origin are concerned. With regand to morphology, it must he borne in mind that a gall is not a structureless tumour, but a distinctly differentiated structure, and, as a subject, the histolngy of gall structure would prove an interesting study in itself.

Firstly, we have galls of cellular tissue, but with no differentiation of separate layers, as, for example, the currant gall or Syutheycuter barrarum. Secondly, galls similar to these, but containing an inner gall, as, for instance, the leaf-twisting gall cansed by Andricus surectur. Thirdly, galls developing vascular bundles throughout the cellular tissue, with distinct epidermis as well as differentiated inner galls, as, for eximple, the large root-gall caused by Aphilothric nocluli. Fourthly, galls, as, for instance, the marble gall, having a complicated structure.

1 This work was translated by Dr Stratton, and published by the Oxford Clarendon Press in 1894; and I beg to acknowledge my indebtedness to this important work for much of the foregoing, and also for many of the statements which follow. 
In support of the complicated structure of the marble gall the following may be quoted-viz. :

"If a transverse section of a young marble gall, $3 \mathrm{~mm}$. in thickness, be made at the end of June, it will be found, according to Beyerinck, to exhibit the following structure: a larval chamber surrounded by (1) a thin layer of primary nutritive tissue; (2) a thin layer of cells containing crystals; (3) a thin layer of primary starch cells; (4) the layers of the cambium ring; (5) a thick layer of large cells, rich in tannin and traversed by vascular bundles; (6) a layer of small meristematic cells; ( 7 ) colourless hypodermal cells; (8) epidermis with unicellular hairs containing red pigment in their cell contents." 1

The origin and development of vegetable galls, more especially those on the oak, is a subject which has puzzled eminent scientists. It was at first considered by naturalists that the Cynips deposited simultaneously with the egg a drop of irritating fluid, which caused the sap to flow round the egg, and thus a globular form would be the result. In other words, gall-formation was considered the result of chemical action. Darwin adopted this view, and says: "As the poisonous secretion of insects belonging to various orders has the special power of affecting the growth of various plants; as a slight difference in the nature of the poison suffices to produce widely different results; and, lastly, as we know the chemical compounds secreted by plants are eminently liable to be modified by changed conditions of life,-we may believe it possible that various parts of a plant might be modified through the agency of its own altered conditions." In the 'Origin of Species,' p. 572, he says: "When we see the symmetrical and complex outgrowths caused by a minute atom of the poison of a gall-insect, we may believe that slight changes in the chemical nature of the sap or blood would lead to extraordinary modifications of structure." In another work he says: "The complex and extraordinary outgrowths which invariably follow from the insertion of a minute drop of poison by a gall-producing insect show us what singular modifications result in the case of plants from a chemical change in the nature of the sap." ". This view, on the strength of the great naturalist, was adopted by sir James Paget, Prof. Riley, and others. From the fact that so "many eminent men have been puzzled with this subject, it is obvious that the question is a difficult one.

1 Adler, p. 163, written by Dr Stratton.

Animals and Plants under Domestication, p. 9. 
The two important factors at work in connection with sall-fomation are the activity of the vergetahle silp on the one hamd and the influence of the animal agency on the other. Botanically considered, gallformation cummot take place unless in direct contact with vital cells - that is, thrse cells specially set apart for growth anil derelopment. In the woody portion of the tree, from the root to the extremity of wery branch, there is a special zone of formative cells known as the cambium ring which plays the part of growth in the theatre of life. A section of leaf shows practically two layers of cells,-a layer of closely packed cells on the upper side, known as palisade cells in consequence of their resemblance to a paling fence; and a sort of double layer on the under sile, arranged in opposite direction to the palisade cells. The under cells of the leaf are considered to be those most actively associated with growth and assimilation. When exgs are deposited in a normal winter bud, before there is any differentiation of structure between the upper and under side of the leaf, we often find the gall structure on both sides of the leaf, but the preponderance of structure is always on the under side. This is noticeable in the case of Spathegaster baccarum. In order to fully understand the formation of gall structure on difierent parts of the tree, as associated with special cells, it is obvious that recourse must be had to section-cutting with the microtome, as well as to minute microscopical investigation. ${ }^{1}$

As gall-formation cannot take place unless in contact with special cells, it follows, therefore, that the insect must deposit the eggr with the greatest exactitude, otherwise abortive galls would be the result. In the artichoke gall, for example,-a species formed in buds,-we often find many abortive galls. This may be the result of an egg being deposited in a bud which had been previously pricked by another gall-forming insect, and the rital cells of the plant thus hecoming injurerl; or the premature death of the larval creature within the gall may have arrested the development of the gall. Considering, from the entomological side, the effect of the insect on the vegetalle structure, it has been proved that the wound resulting from egg-laying is at once healed up, and that there is, according to the species, a considerable lapse of time from egg-deposition to hatching. During this period the egg derives oxygen from the air, through the medium

1 For a full account of gall structure see 'Pathologische Pflanzenanatomie,' von Dr Ernest Küster. 
of the prolonged egg-stalk. Adler discovered that in two species gallformation commenced just as the larva was about to escape from the egg. It is, of course, difficult-in fact, in most cases impossible-to see the egg within the gall, but the same observer found that as the larva grew and fed, so the gall increased in size. In other words, no gall-formation took place until just immediately before hatching, but the growth of the gall proceeded simultaneously with the development of the larva. Hence it may be inferred that oak-gall formation is the result of the excitatory action of the larva acting in conjunction with the vitality of the vegetable cell. It must be borne in mind that this special method of gall-formation is only applicable to oak galls, as galls formed by some species of Hymenopterous insects, as, for example, in the case of the common bean-like gall-N'ematus yallicola-formecl on both sides of the willow leaves, is more or less of an amorphous structure, and practically fully developed before any embryological changes take place within the egg.

In consideration of the variety of gall-structure, and the comparative sameness of larval anatomy, the question may be asked, Is there a mechanical difference in the direct action of the larva or a chemical difference in the composition of the excitatory emanations? In other words, as the larvæ are exactly similar in structure and action, what are the factors which produce variations of structure, size, and colour? Thus in point of anatomical structure the larvæ of the Cynipidæ are practically identical, and, as previously remarked, the galls vary in size, colour, and complex structure.

The question of gall-formation, as considered in relation to the theory of evolution, is somewhat difficult to understand, but, at the same time, is extremely interesting to the philosophical scientist. Darwin somewhere in his writings remarks that if it could be provel that any one creature worked for the good of another creature, his theory would fall to the ground. Of course, this remark is only illustrative of the general principle of natural selection and the "survival of the fittest," and must not be confounded with the principle of altruism, as, for example, the care of the parent for the offspring. Now, in oak-gall formation, and all its complexity of morphological structure, we cannot believe that the oak would form these galls in a disinterested way for the grood of the insect, nor, on the other hand, as being of any advantage to the oak itself, considereil as a vegetable organism. The oak gall is, therefore, a distinctly differentiated struc- 
ture, apparently formed for the gool of the insect, which, as remarked, would be against the principle of the theory of evolution; and in riew, therefore, of the extreme interest of this question, I have talien the liberty of quoting the following on "Vergetable Galls" by IIr G. J. Romanes in 'Darwin and after Darwin.' Mr Romanes says-

"The other instance to which I have alluded as seeming at first sight likely to answer Darwin's challenge is the formation of vegretalle gralls. The great number and variety of galls arree in presenting a more or less elaborate structure, which is not only foreign to any of the uses of plant-life, but singrularly and specially arlapted to those of the insect-life which they shelter. Yet they are produced by a growth of the plant itself, when suitably stimulated by the insect's inoculation ; or, according to recent observations, by emanations from the borly of the larvie which develop from the egrs deposited in the plant by the insect. Now, without question, this is a most remarkable fact; and if there were many more of the like kind to be met with in organic nature, we might seriously consider whether the formation of galls should not be held to make against the ubiquitous agency of natural selection. But inasmuch as the formation of galls stands out as an exception to the otherwise universal rule of every species for itself, and for itself alone, we are justified in regarding this one apparent exception with extreme suspicion. Indeed I think we are justified in regarding the peculiar patholugical effect produced in the plant by the secretions of the insect as having been in the first instance accidentally beneficial to the insects. Thus, if any other effect than that of a growing tumour had been produced in the first instance, or if the needs of the insect progeny had not been such as to have derived profit from being encloserl in such a tumour, then, of course, the inoculating instinct of these animals could not have been developed by natural selection. But given these two conditions, and it appears to me there is nothing very much more remarkable alout an accidental correlation between the effects of a parasitic larva on a plant and the needs of that parasite, than there is between the similarly accidental correlation between a liydatid parasite and the nutrition furnished to it by the tissues of a warm-hlooded animal. Doubtless the case of galls is somewhat more remarkable, inasmuch as the morbid growth of the plant has more concern in the correlation -being, in many instances, a more specialised structure on the part of a host than occurs anywhere else, either in the animal or vegetable 
worli. But here I may suggest that although natural selection cannot have acted upon the plant directly, so as to have produced galls ever better and better adapted to the needs of the insect, it may have so acted upon the plants indirectly through the insects. For it may very well have been that natural selection would ever tend to preserve those individual insects, the quality of whose emanations tended to produce the form of galls best suited to nourish the insect progeny; and thus the character of these pathological growths may have become ever better and better adapted to the needs of the insects. Lastly, looking to the enormous number of relations and inter-relations between all organic species, it is scarcely to be wondered at that even so extraordinary an instance of correlation as this should have arisen thus by accident, and then have been perfected by such an indirect agency of natural selection as is here suggested.

"Again, quite independently, and still more recently, Mr Mivart alluded in 'Nature' (vol. xli. p. 41) to the difficulty which the apparently exceptional case of gall-formation presents to the theory of natural selection. Therefore I supplied (vol. xli. p. 80) the suggestion given in the text-viz, that although it appears impossible that the sometimes remarkably elahorate and adaptive structures of galls can be due to natural selection acting directly on the plants themselves, - seeing that the adaptation has reference to the needs of their parasites, - it is quite possible that the phenomena may be due to natural selection acting indirectly on the plants, by always preserving those individual insects (and larvæ) the character of whose secretions is such as will best induce the particular shapes of galls that are required. Several other correspondents took part in the discussion, and most of them accepted the above explanation. $\mathrm{Mr}$ T. D. A. Cockerell, however, advanced another and very ingenious hypothesis, showing that there is certainly one conceivable way in which natural selection might have produced all the phenomenia of gall-formation by acting directly on the plants themselves (rol. xli. 1).344). Subsequently, Mr Cockerell published another paper on the subject, stating his views at greater length. The following is the substance of his theory as there presented:-

"Doubtless there were intemal plant-feeding larvæ before there were galls; and, indeed, we have geological evidence that boring insects date very far back indeed. The primitive internal feeders, 
then, were miners in the roots, stems, twigs, or leaves, such as occur very commonly at the present day. These miners are excessively' harmful to plant-life, and form a cliss of the most destructive insectpests known to the farmer: they frequently cause the death of the whole or part of the plant attacked. Now, we may suppose that the secretions of certain of these insects caused a swelling to appear where the larvæ lived, and on this excrescence the larvæ fed. It is easy to see that the greater the excrescence, and the greater the tendency of the larvæ to feed upon it, instead of destroying the vital tissues, the smaller is the amount of harm to the plant. Now, the continued life and vitality of the plant is beneficial to the larvat, and the larger and more perfect the gall, the greater the amount of available food. Hence natural selection will have preserved and accumulated the gall-forming tendencies, as not only beneficial to the larvæ, but as a means whereby the larvæ can feed with least harm to the plant. So far from being developed for the exclusive benefit of the larve, it is easy to see that, allowing a tendency to gall-formation, natural selection would have developed galls exclusively for the henefit of the plant, so that they might suffer a minimum of harm from the unavoidable attacks of insects.

"But here it may be questioned, Have we proof that internal feeders tend to form galls? In answer to this I would point out that gallformation is a peculiar feature, and cannot be expected to arise in every group of internal feelers. But I think we can afford sufficient proof that wherever it has arisen it has been preserved; and further, that even the highly complex forms of galls are evolved from forms so simple that we hesitate to call then galls at all ('Entomologist,' March 1890). The paper then proceeds to give a number of individual cases. No doubt the principal objection to which $\mathrm{M} \mathrm{r}^{\circ}$ Cockerell's hypothesis is open is one that was pointed out by Herr Wetterhan-viz., 'the much greater facility afforded to the indirect action through insects, by the enormously more rapid succession of generations with the latter than with many of their vegetable hosts -oaks above all' ('Nature,' vol. xli. p. 394). This difficulty, however, Mr Cockerell believes may be surmounted by the consideration that a growing plant need not be regarded as a single individual, but rather as an assemblage of such" (vol. xli. pp. $559,560)$.

With regard to the insects producing oak galls, the transformations 
of the Cynipide are complete. They pass through four stages-viz, egg, larva, pupa, and imago (fig. 129).

The egg (fig. 129, a) is pyriform, with one end elongated, terminating as a prolonged penduncle. Adler supposed the function of this organism to be respiratory, it having long peduncles when deeply embedded and difficult of access to oxygen, and shorter when access is easy.

The eggs of the Cynipidæ are often laid in winter, thus contrasting
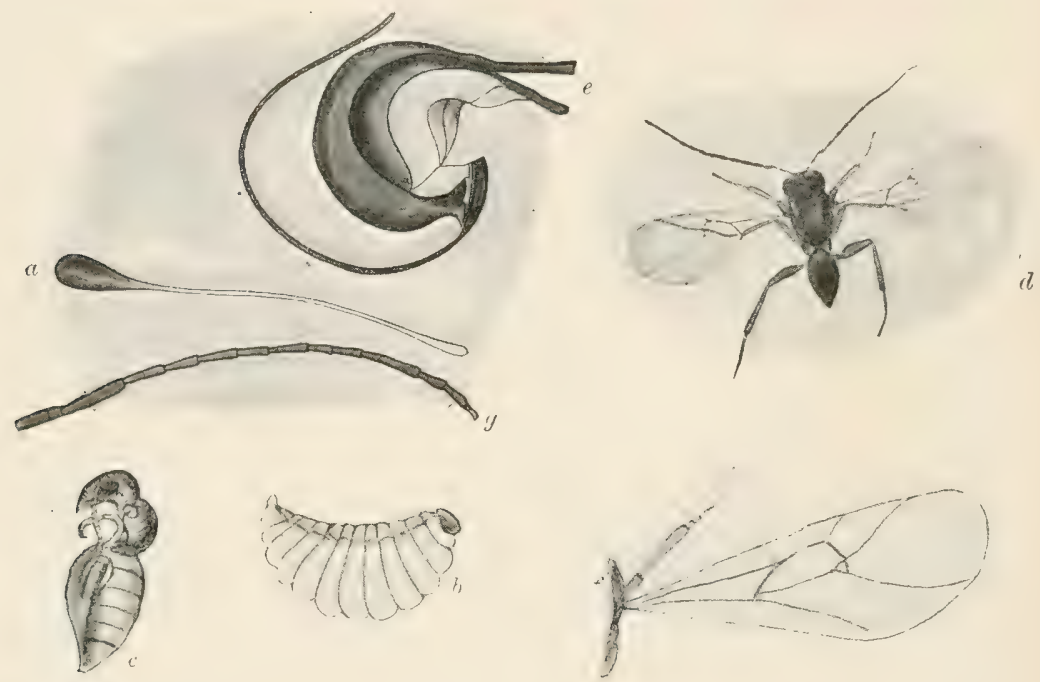

Fig. 129.

c. Egg of Cynips. (Copied from Adler and stratton.)

6 Larva of Cynips.

c Pupa of Cynips.

d Gall-fly, Teras terminulis (oak-apple). IIale. (From photograph.)

e Ovipositor of Neuroterus lenticularis. (From camera-lucida sketch.)

$f$ Wing of Spathegaster baccarum. (Froni photograph.)

$g$ Antenna of Spathegaster baccarum. (From camera-lucida sketch.)

with the eggs of many species of saw-flies, which are deposited when nature is active. There are other interesting points about the egg's which will be considered later on.

The larvæ are white, footless, and fleshy grubs, with thirteen segments $($ fig. 129,7$)$. There is considerable diversity of time regarting the larval stage.

In appearance the pupæ are similar to the larvæ, and some organs of the perfect insect are discernible. Fig. 129, $c$. 
The imagines, apart from the salient features to be considered under general anatony, present very few interesting halbit. They are inactive, take no food, but are known to imbibe water, and a most interesting point is the variation in the time of appearing:

The males differ from the females in having longer antennæ, and also have one or two more joints than in the case of the female (fig. $129,17)$. The female has a very large abdomen, and the precise shape of the alylomen ayain differs according to species, which depends on the form of the ovipositor (fig. $129,{ }^{\prime}$ ). It is to he remembered that we have two forms, the sexual and asexual or agamic, and that specific characters are not very distinct; therefore we have to rely on the galls themselves for the most important points of discrimination of species.

The following are the most distinguishing features, acenrling to Cameron ${ }^{1}:-$

"Cynipida.-Abdomen petiolated-i.e., not attached hy its entire breadth to the thorax.

"Alxhomen pedunculated, trochanters biarticulate, antenne 12 to 1 .) jointed and never elbowed, prothorax reaching to the insertion of the wings; wings without a stigma, and with 1 radial and 1 to 3 cubital cellules, the second when present being minute, usually triangular; the sub-costal cellule large, always present; the other cellules badly defined or absent; submarginal nervure absent; ablomen compressed, ovipositor originating close to the base of the abdomen, the borer usually semi-spiral, and with parts free; larvæ apterous, never spinning a cocoon ; eggss stalkel ; antenne in $f$ stouter than of; legs, claws simple in Cynips, cleft in some species of Andricus and Netroterus.

"Chalcididæ. ${ }^{2}$ - Wings having a stigma; no radial or cubital cellules; antennæ elbowed; prothorax not reaching to insertion of wings."

The details of a wing of Cynips, fig. 129, $f$, should be carefully studied, as the wings of the genuine oak-gall fly differ very much from the various species of parasitic flies which are associated with the Cynipidre.

1 Monograph of the British Phytophagous Hymenoptera, vol. iii. pp. 142, 147. Ray Society.

2 This family contains many of the parasites found in oak galls, therefore it is most important to recognise the contrasting points. 
Adler ${ }^{1}$ arranges the species in the four following groups-viz. :
I. Neuroterus.
III. Dryophanta.
II. Aphilothrix.
IV. Biotriza.

In attempting to give some detailed account of the various species of oak galls whereby the galls themselves may be recognised in the forest and the insects verified after hatching in confinement, it is obvious there are several ways open for adoption.

Tre might follow a botanical method and describe the galls on buds, leaves, fruit, and roots; or we might adopt an entomological course, and describe and compare the various species as found on the respect-

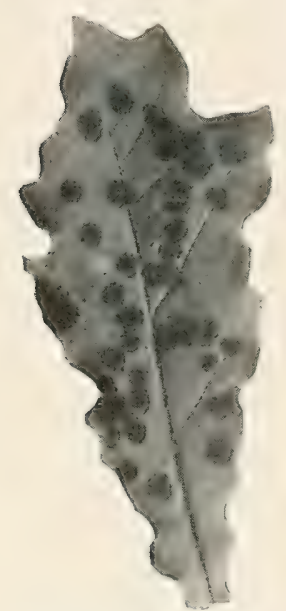

Fig. 130.-Galls of Neuro. terus lenticularis (oakspangle gall). ive parts of the tree. But we shall adhere to the arrangement of Adler, because we may then follow the commonest species and have a direct bearing on a most important biological law-viz., the alternation of generations.

Firstly, take

\section{Neuroterus lenticularis, $\mathrm{Ol}^{2}{ }^{2}$ (Oak-} spangle Gall).

This gall is very common throughout the country from July to September. The galls are scattered promiscuously on the under side of the leaves (fig. 130), are more or less circular, and develop in July from objects resembling pin-points. They are clothed with stellate hairs on the upper side, but smooth on the under side of the surface, pressing against the leaf and very slightly attached to the leaf. They are raised in the centre, tapering to thin edges on the leaf, and with the outer edge lying flat on the leaf. If specimens which lie on the ground over winter be measured in March, just before the flies hatch out, it will be found that they have the same breadth as in autumn, but have increased considerably in thickness. At this time of the year they will measure about $4 \mathrm{~mm}$. in breadth and $2 \frac{1}{2} \mathrm{~mm}$. in thickness.

1 Alternating Generations, p. 8. Translated by Dr Stratton. 1894.

2 The figures 1 and $1 \alpha$ represent alternating species. Thus 1 alternates with $1 a, 2$ with $2 a$, and so on. It should be noted also that the generations marked $1 a, 2 a, \& c$. , produce insects of both sexes, whereas insects in the generations marked 1, 2, \&c., are all females. 
Fly : colour black, shining, length about 2 to $2.5 \mathrm{~mm}$. The thorax is rather dull in appearance; abdomen shining and almost round in form when looked at from the side. The legs are of a lightish-brown colonr. The wings are iridescent and considerably longer than the body; antennie brownish, 15-jointed, the seven apical joints being mearly equal in size and much smaller than the bawal joints (fig. 1:31). The insects hatehed out in Northumberlind from March 2:3 to April 12, 1906, and only lived for about ten days within the glass case.

Prior to understanding the subject, a curious fact had often suggested itself to me as a problem difficult of solution-viz, if the insect appears in March, and lives only for a short time, where does it find leaves to deposit its eggs on for the next generation, seeing that leaves do not often appear until the end of May or beginning of June? The first thought which suggested itself was that the eggs were deposited in the buds, and when the leaves unfolded the galls would develop. Then the problem appeared more difficult, inasmuch as the spangle galls chiefly appear, not on the first developed leaves from the winter buds, but on leaves not appearing

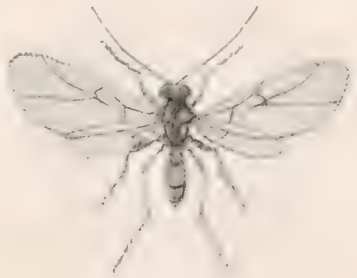

Fig. 131.-Neuroterus lenticularis. (Drawn by J. Patten, jun.) until July-in other words, on the young shoots which grew after the fly of the Neuroterus lenticularis must have been dead.

Dr Adler, before commencing to work out the subject, must have been likewise puzzled, and accordingly he commenced a series of experiments in 1875 . He grew a number of young oaks in flower-pots, hatched out the spangle-gall flies in March, and induced them to deposit eggs in the young oak buds, under glass, when the leaves unfolded and developed, tugether with the galls resulting from the previuns deposition of Cynip egys of the spangle-gall species. The galls, instead of being spangle galls, were another type-viz., Syuthegaster baccarum or currant gall (figs. 132 and 133). The galls were different, and the flies also, for they were sexual, males as well as fenales being found, whereas in the previons species the insects were all females. Adler then induced Sprithegaster baccarum to deposit eggs on the leaves, and obtained as a result the oak-spangle galls, - the galls on the leaves of the young shoots. Thus the oak-spangle 
gall-fly - Neuroterus lenticularis - deposited eggs in the bud and produced the currant gall; and the gall-flies of Sprothegaster baccarum or currant gall produced the spangle gall. In short, flies of the one species deposited its eggrs and produced the galls and flies of the other species. Thus Adler demonstrated to the scientific world what had only been previously guessed at-viz, the important biological law of the alternation of generations in oak galls. This is a very important biological law which is not uncommon amongst certain animals comparatively low in the seale of organisation, and is no doubt essential to the wellbeing and continuation of species. In view, therefore, of

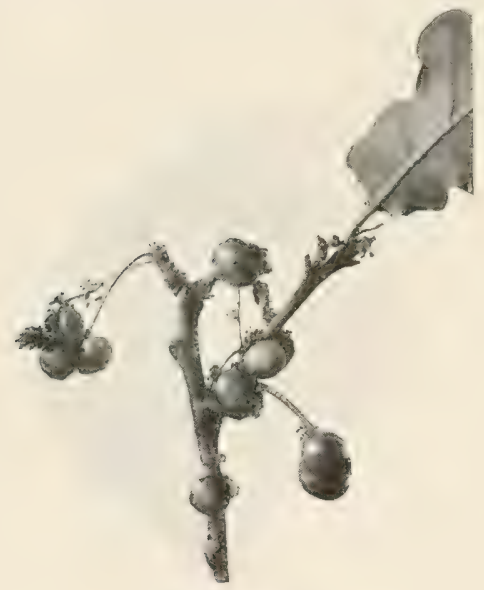

Fig. 132.-Gulls of Spathegaster baccarum on male flowers of ouk.

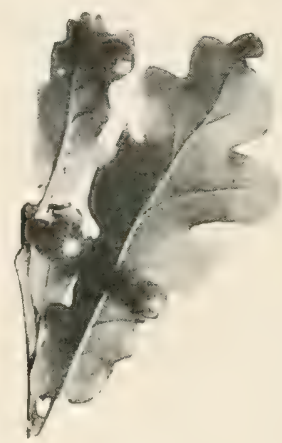

Fig. 133.- Galls of Spathegaster baccarum on leaves.

the biological importance of the subject, it may be well to contrast two important and to some extent allied phenomena-viz., Dimorphism and Heterœcism-as compared with alternation of generations.

Dimorphism means, two forms of the same thing. Thus certain chemicals and minerals crystallise in two forms, and are called Dimorphous, and if in three forms, Trimorphous. In animals we have seasonable dimorphism, as change of colour in winter or adaptation to environment; sexual dimorphism, as instanced by the difference between male and female in the peacock and pea-hen. In the lower order of plants and animals many instances might be given.

Heterœcism in animal and plant life means a change from host to host in order to complete a life cycle. Thus the tapeworm found 
in man passes its early stage in the pig, and the latter stage in man. Certain plant cliseases pass one stage on weeds and the other on trees. These are two typical instances from animal and plant life.

Alternation of generations is totally clifferent from these phenomena, inasmuch as two distinct generations alternate one with the other. In fact, this may be best understood when we say that the children never resemble their parents, but are always facsimiles of their grandparents.

Having mentioned two distinct genera resulting from alternating generations, the question arises, Are the two genera widely separated in point of general appearance or anatomical details? Adler considers they are, and accordingly adopts Neuroterus and Spathegaster as generic terms. But Professor Mayr of Vienna classifies the two genera as Neuroterus, and this classification is adopted by Cameron.

The main distinguishing features are slight differences in colour and in general stoutness, Neuroterus being stouter than Spathegaster. The abdomen differs in size and appearance, resulting from the size and shape of the oripositor (fig. 129, $e$ ), which must be viewerd in the relation of adaptation, a long ovipositor being necessary for penetrating buds, and a short one for leaves.

\section{1a. Spathegaster baccarum (Htg.)}

The galls are found on the flowers and leaves (figs.132 and 133). They are pea-shaped, smooth, glossy-looking, soft and succulent, of a greenish colour, but have often a few bright-red spots. They are situated on the under side of the leaves, but often penetrate through the upper side and rise slightly above it. The specimens found on the male catkins are generally smaller than those on the leaves, and slightly more reddish in colour.

The fly (fig. 134) has a black shining body, about $2 \frac{1}{2} \mathrm{~mm}$. in length,

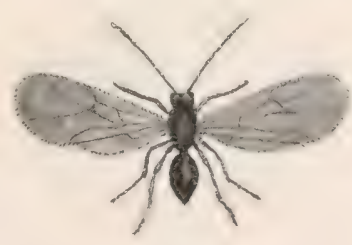

Fig. 134.-Spathegaster baccarum. antennæ brownish, 14-jointed in the male. The legs are yellow, with black coxw at the base. Tarsi 5-jointed; wings longish, broad at the apex, and about $8 \mathrm{~mm}$. in expanse. In a comparatively forward. 
season they may be found in the Midlands about the end of May, ${ }^{1}$ but more commonly in the middle of June. At the same season of the year as we find the spangle gall, two or three other species of Neuroterus may be found.

\section{Neuroterus fumipennis (Htg.)}

Gall on the under side of oak leaves, circular in outline, smaller in size and brighter in colour than the spangle gall (fig. 135); but the principal difference is that the spangle gall is raised in the centre and

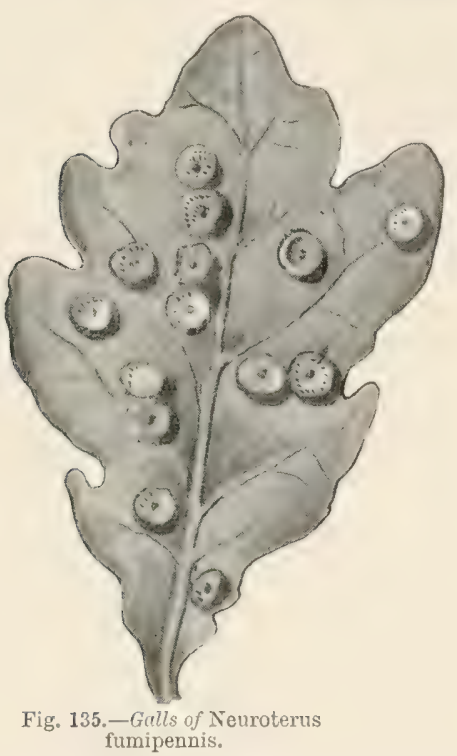

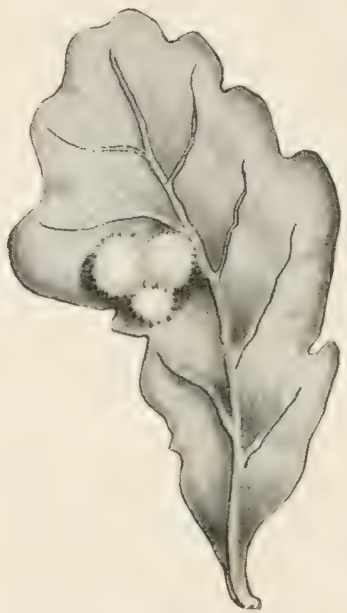

Fig. 136. -Gulls of Spathegaster tricolor. (Drawn by P. J. Brown.)

the outer edge lying flat on the leaf, whereas the species in question has the outer edge of the gall raised and slightly depressed in the centre. Thus the individual galls somewhat resemble a saucer.

According to Adler, larval development does not begin until March (liy the time Neurotrus lentiruluris has hatched), and the flies appear about the end of May. The same authority says this fly is easily distinguished from all the other species of Neuroterus. Size $2 \mathrm{~mm}$. Thorax dull black; base of abdomen orange; legs, including the femora, orange; wings, especially at the tips, smoky.

1 May 27, 1895, in Cheshire. 


\section{2a. Spathegaster tricolor (Htg.)}

The sexual species forms a pea-shaped hairy gall of light-yellowishgreen colour (fig. 136), appearing alout the end of June or heminning of July. They are found in elusters on the under side of the leaves. The hairs fall off when the gall matures, and then it may be mistaken for Spathegaster baccarum, which, however, is over by this time.

The fly is a very slender insect, the wings when spread out being comparatively long in proportion to the body.

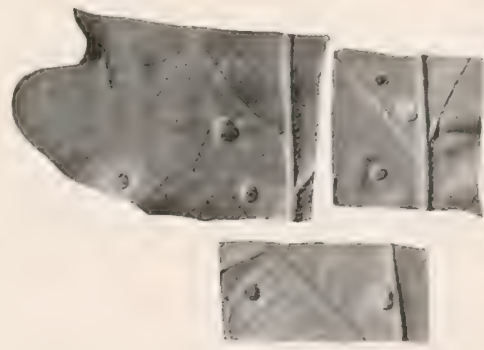

Fig. 137.-Galls of Neuroterus læviusculus. The body is about $2 \mathrm{~mm}$. long, and the expanse of wings $8 \mathrm{~mm}$. The body is black throughout, legs all yellow, and the wings rather cloudy. Males and females very much alike.

\section{Neuroterus Leviusculus (Schenck.)}

This gall (fig. 137) is very much like the two previous species in general appearance, but not so common or so numerons on the leaf. The form is similar, but in this species the gall is nearly smooth except on a well-defined knob in the centre, which is covered with hairs. I have not reared the fly, but found the gall fairly common both in Cheshire and Northumberland.

\section{3a. Spathegaster atbipes (Schenck.)}

This is the agamic species of $N$. leviusmulus, and I have only found it in one district-

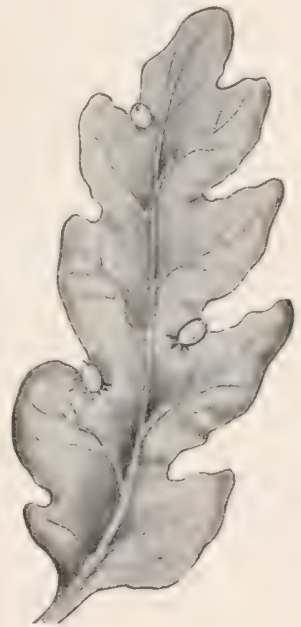

Fig. 138.-Galls of Spathegaster albipes. (Drawn ly P. J. Brown.) viz., at Pauperhaugh, in Northumberland, about the beginning of June. The gall of this species (fig. 138) is more or less oval, tapering to a blunt point, and of a slightly yellowish-green colour. The galls 
sit closely on the leaf, and they give rise to deep windings on the erlge of the leaf, which is said to be cansed through the gall originating on a rudimentary leaf within the bud.

\section{Neuroterus numismatis, Ol. (Button Gall).}

This gall (fig. 139) is very common in the autumn. It is very pretty, circular in shape, about $2 \mathrm{~mm}$. in diameter, hard, with a shallow depression in the centre. I have not hatched the flies nor found the alternate form-viz., $4 a$ Spathegaster vesicatrix (Schltdl.), 一 which are found on the under side of the leaf, and are rather incon-

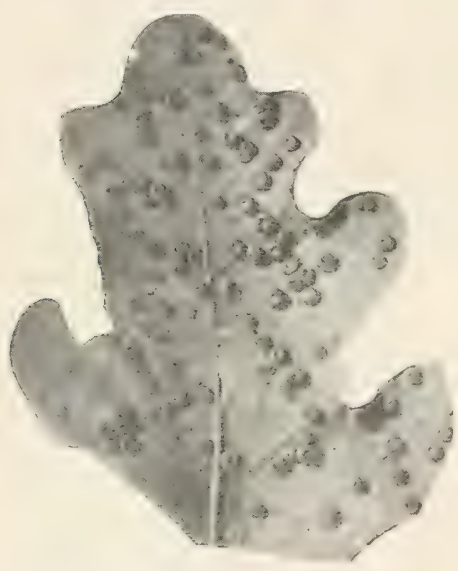

Fig. 139.-Gulls of Neuroterus numismatis. spicuous, as they are embedded in the substance of the leaf. ${ }^{1}$

There is another species in the group of which Adler was not quite sure about fixing the generation eycle. This is the gall of

\section{Neuroterus ostreus (Htg.)}

This is a very small gall, not larger than a leaden pellet, and always formed on the midrib of the leaves, and very slightly attached. It is very prettily marked, and the pale-yellowish colour brightened by red spots is suggestive of the markings of a miniature egg of some bird. It is common in September and October. From the early matured galls flies hatch out in October, but those not maturing until Oetober do not yield gall-flies until the following spring. I kept some in confinement, and they hatched out on April 25, 1895. The fly is about 2 to $2 \frac{1}{2} \mathrm{~mm}$. in length, of a bluck shining colour, with dull thorax, legs yellowish in slender portion and dark at top next to body; antennæ longish and slender, wings comparatively long.

As Dr Adler is not quite certain about the generation cycle of this species, it may be best to quote his own words - viz. : "I strongly suspect that the sexual generation belonging to Neuroterus ostreus

1 I have since received this species from $\mathrm{M} \mathrm{r} \mathrm{E}$. T. Connold. 
is to be sought for in Spathegaster arrilises," and this conjecture has since proved to be correct.

\section{$5 \alpha$. Spathegaster aprilinus (Gir.)}

The galls of this species are formed in buds, but the formation is so obscure as to be frequently overlooked. In fact, we should consider them abortive buds, and the best way to find them is to look for abortive buds just after the leaves develop. It should be noted that undeveloped buds, frequently found in oaks after the early flushing of the leaves, are due to the attacks of this species. In order to hatch those galls it is best to collect them about the end of April or beginning of May.

The fly is described by Adler as follows: "Length $2.5 \mathrm{~mm}$., black thorax, somewhat shining; scutellum wrinkled, abdomen shining, antennæ black, legs dark-yellow, coxæe and basal half of the femora blackish. Males and females similar in colouring."

\section{Gemus Aphilothrix.}

The second group, according to Aller, having alternate generations, is the Aphilothrix-Andricus Group. The genus Allituthri, includes a large number of gall-flies found only in the female sex. The genus Andricus yields the sexual form.

\section{Aphilothrix radicis (Fabr.)}

This gall (fig. 140) is found on the lower part of the trunk, or just on the horizontal portion of the root above ground. At first it

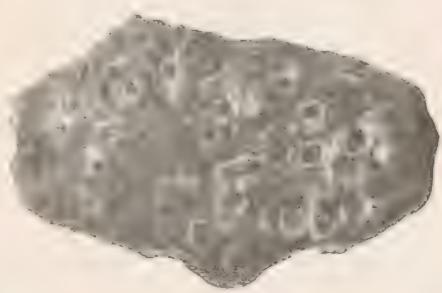

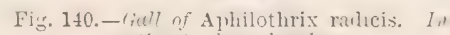
sectir uto shen chriateris.

appears as a large softish mass, but ultimately it becomes quite hard in the centre, and a section made in mid-winter will reveal a manychambered gall with a fully developed fly in each chamber. They hatch out about the latter end of April.

The fly is reddish-brown, with longitudinal stripes on the thorax. The abdomen is somewhat dark, and the thorax is covered with a fine silky pubescence. The antenna are dark-brown. Length from 5 to 
$6 \mathrm{~mm}$. The alternating species is $6 a$ Andricus noduli (Htg.), which makes galls in the woody portions of young shoots.

\section{Aphilothrix corticis (Linn.)}

The galls of this species are found inserted in the young bark which is formed where the stem has been injured, or in the tender bark which forms in the "healing over" process after a branch "has been sawn off (fig. 141). Sometimes they may be found in clusters,

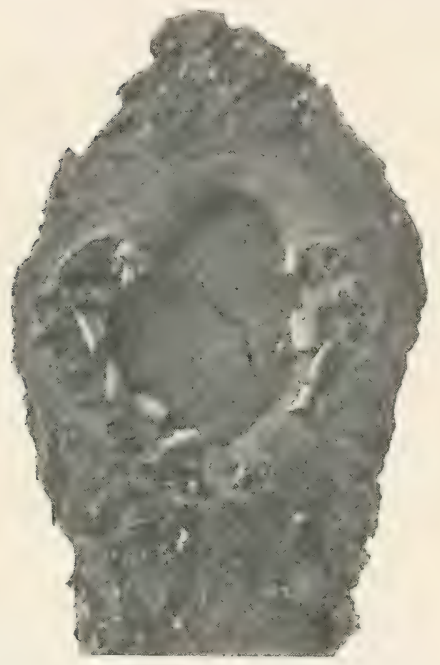
Fig. 141. - Galls of Aphilothrix corticis in por-
tion of bark "healed over by occlusion."

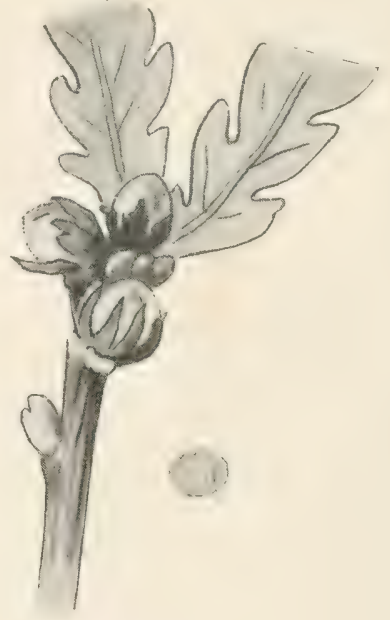

Fig. 142.-Galls of Aphilothrix globuli.

but as a rule they are distributed over the young bark. It often happens that the rim of under-hark surrounding the cut-off branch is very much torn, and this arises from birds tearing out the galls and lacerating the bark. The flies hatch out in Ime, and the alternating species, according to Adler, is $7 a$ Andrious gemiatus, a species found in the terminal buds.

\section{Aphilothrix globuli (Htg.)}

The gall (fig. 142) of this species is a beautiful green globular gall, formed in the bud for the coming year. It may be found in Sept- 
ember projecting from the bud-scales, and would perhins mensure about $\frac{1}{4}$ inch in diameter. I found it very common in Delamere Forest, Cheshire, but have not hatched the fly.

\section{8a. Andricus inflator (Htg.)}

This gall (fig. 143), which is the alternating species of A. gloluti, is origmally formed from a bul. In seneral aplearance it is somewhat like the thickened portion of that part of a tumip immediately above the bulb which is finally surmounted by the leaves. The gall proper is really within the woody portion, and during the year in which eggs are deposited growth is not perceptibly interfered with, but the next year the portion affected by the insect agency swells, and the adventitious buds formed thereon give rise to the tuft of leaves referred to. The galls are not very common, but may be looked for in June, and the flies emerge only in July.

"Fly-size 2 to $4 \mathrm{~mm}$. Head and thorax black,

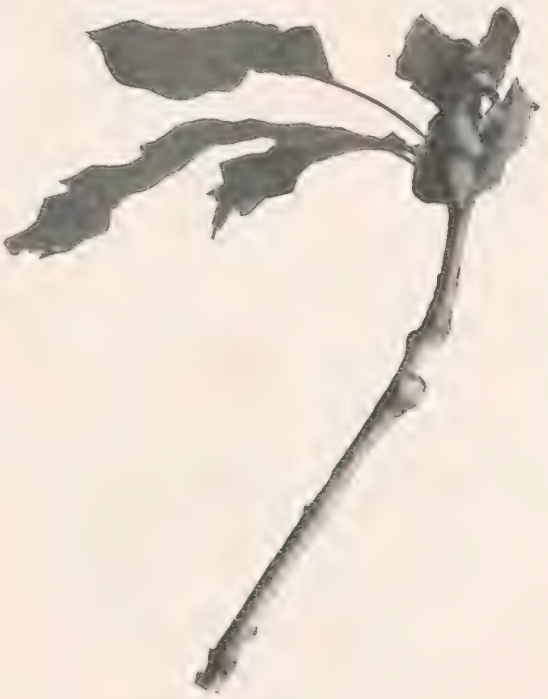

Fig. 143.-Gall of Andricus inflator.

slightly shining; abdomen in the female black above, red or ornge beneath,-in the male entirely black; legs orange, but the posterior tibiæ and coxæ dark; antennæ dark, pale at the base."-Adler.

The next gall to be considered is very common in the sexual form, but not so general in the agamic stage. The latter is, according to Adler's classification, Aphilothrix collanis (Htg.), and the furmer, ANdricus curvator (Htg.), or the leaf-twisting gall.

The gall of (9) ApHILothrix collaris is formed upon a bud, and, being concealed, may easily be overlooked. Adler says: "In Sept- 
ember and October the gall becomes loosened and falls to the ground, and a few may remain, but only inquilines and parasites are reared from those adherent galls." The flies are said to be difficult to rear from the galls, as after the galls are mature a year and a half passes before the appearance of the flies.

\section{9a. Andricus curvator (Htg: $)^{1}$}

This alternating generation with Aphitothrix collaris is a very common gall, and may be found about the beginning or middle of

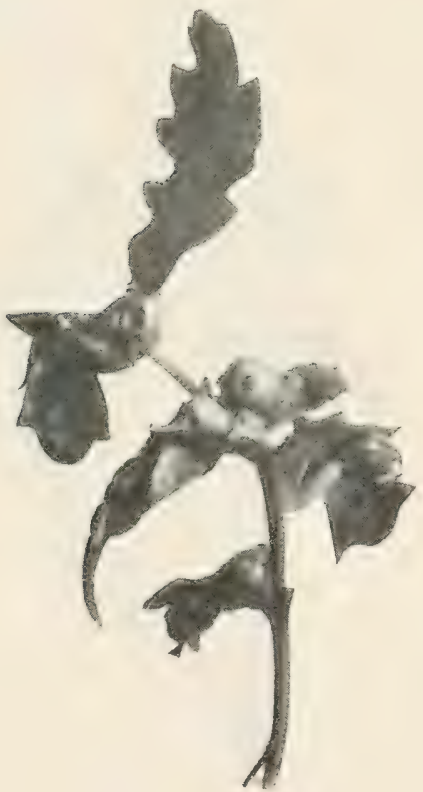

Fig. 144.-Galls of Andricus eurvator.

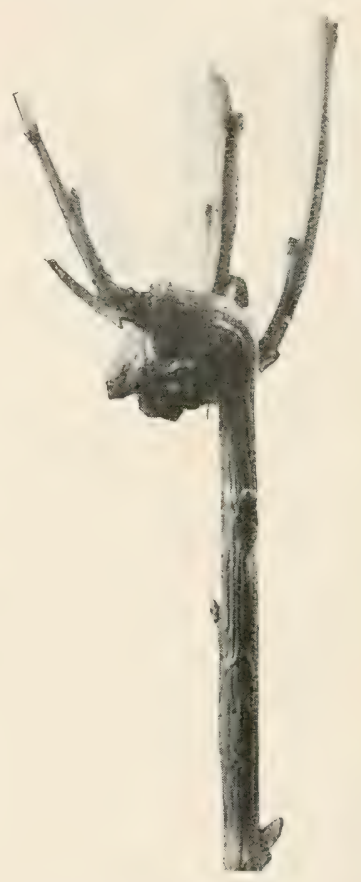

Fig. 145.-Injury done to leading shoot by gall of Andricus curvator.

June. The galls are formed on the ribs of the leaves. They form irregular thickenings of the leaf-surface, and cause the leaf to twist inuards (fig. 144). Sometimes we find the extreme tip of the twig affected by the gall-formation, and, as a consequence, a swelling takes place where the terminal shoot bends, and grows at right angles

1 From this point the alternation of generations is not followed. 
to the more upright twig. The portion thus affected selinom does any more good, but, when this occurs on minor twigs, the tree is not appreciably injured (fig. 145). When, however, several galls are (n one leaf anil very abundant on a young tree, the leaves are arrested in their development, and the result in the aggregate woukd diminish growth and earse disfiguration. The gall itself is an irregular swelling, of a green colour, and pod-like in structure. When opened, the central cavity is comparatively large, and contains a small brownish seed-like porl, which is the imner wall, wherein is found the larval form

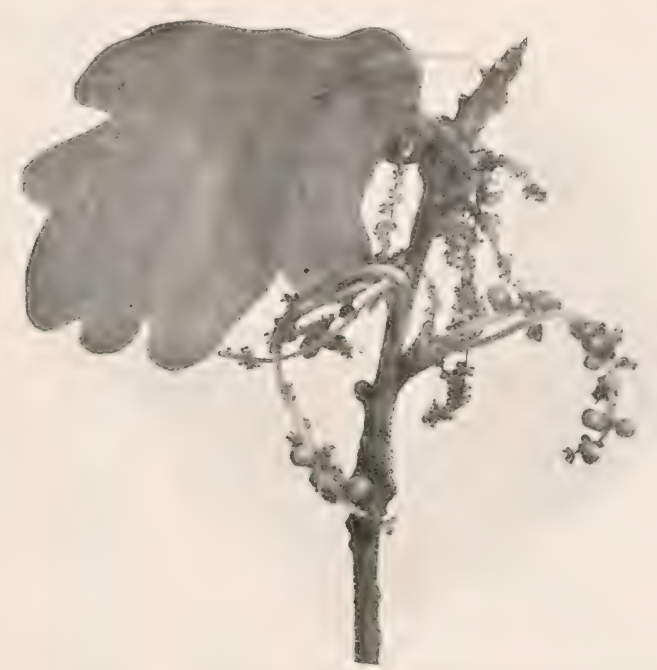

Fig. 1to.-Galls of A philothrix quadrilineata on flowers of oal:

of the gall-11y. 'This inner gall is not attached to the wall of the outer' gall. The galls may be looked for in May, and the flies appear in . Ine.

The fly is about 1.5 to $2 \mathrm{~mm}$. in size. Body and antennæ shining black; legs lighter in colour; wings more or less hyaline.

The two following species of the Aphilothrix group are not associated by Adler as connected with the alternation of generations, but are nevertheless more or less common.

\section{Aphilothrix quadrilineata (Htg.)}

The gall of this species, fig. 146, is found on the flowering catkins about the end of May or beginning of June. It is very small in size, 
and may not inaptly be compared to a miniature rifle-bullet with longitudinal ridges added on.

I have not succeeded in rearing the fly, which Adler says is very difficult, and does not appear until the following April. It is very common in Alnwick parks.

\section{Aphilothrix albopunctata (Schltdl.)}

The gall of this species is a very pretty little object, and is formed in the bud (fig. 147). It somewhat resembles a small acorn. It is green, spotted with red, and is about 5 to $6 \mathrm{~mm}$. long. The larvæ are

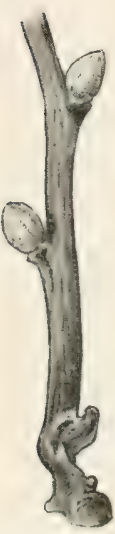

Fig. 147.-Galls of Aphilothrix albopunctata. gregarious, and the gall is not chambered. The galls were very common in High Legh, Cheshire, and were found in May. The flies hatched out about June of the same year.

\section{Andricus ramuli (Linn.)}

This gall is known as the cotton gall, as it occurs on the flower and resembles a ball of cotton-wool (fig. 148). The hairs are interwoven so as to form a sort of felt. The galls itre many-chambered, or polythalamous. This is by no means a very common gall. I have found it twice, - once in Wales, in June 1901, and again in the Alnwick parks, July 1898. The flies hatch out in July.

\section{Aphilothrix fecundatrix, Htg. (Adler). Andricus fecundatrix, Mayr (Cameron).}

This gall is known as the artichoke gall. It very much resembles a hop-flower, with imbricated scale. At first it is of a green colour, but becomes brown with age. In collecting those galls when mature much care is necessary to obtain the imagines. The real gall is a small acorn-shaped body within these scales, but so very loosely 
attrched that, if not careful, our hop-like galls may be nuthing else but empty husks (fig. 149).

\section{Dryophanta Group.}

The galls of this group are always found on the under side of the leaves, and in order that we may verify the galls in the forest, it may

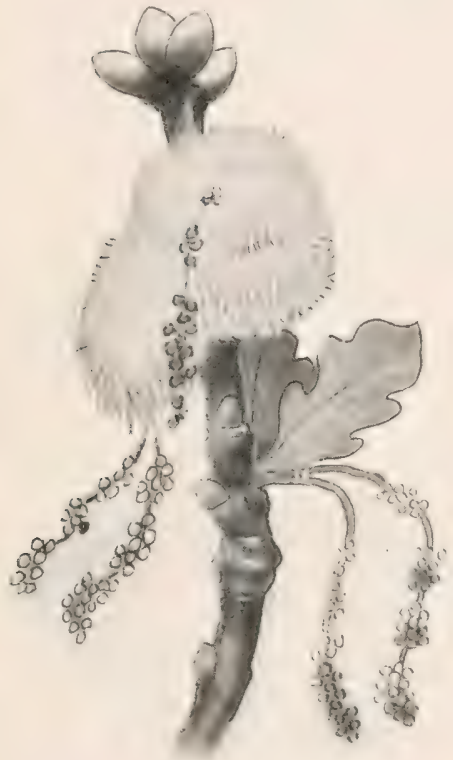

Fig. 148. - Gall of Andricus ramuli (colton gall). (Drawn by P. J. Brown.)

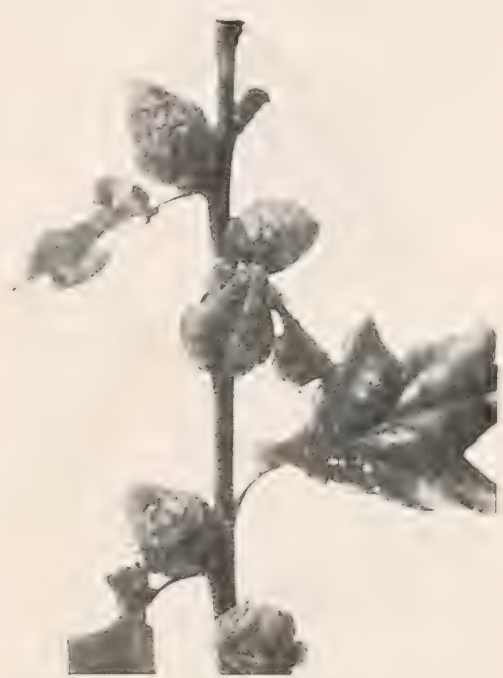

Fig. 149.-Galls of Aphilothrix fecunclatrix (artichole gall).

be better to confine ourselves to the group and not to the cycle generation.

Dryophanta scutellaris, Htg. (Adler).

Dryophanta folii, Mayr (Cameron).

This is known by the graphic name of "cherry gall." It is comparatively large, about the size of a small cherry or marble, and always springing from the veins of the leaves, more especially the midril). It is slightly attached to the vein. The colour varies from light-green 
and yellow to red on one side. It is fairly common in some parts of the country, but is more or less local (fig. 150).

\section{Dryophanta LONGIVENTRIS (Htg.)}

This gall (fig. 151) is somewhat like the previous species, and is also found on the midrib of the leaves. It is brilliantly coloured with red

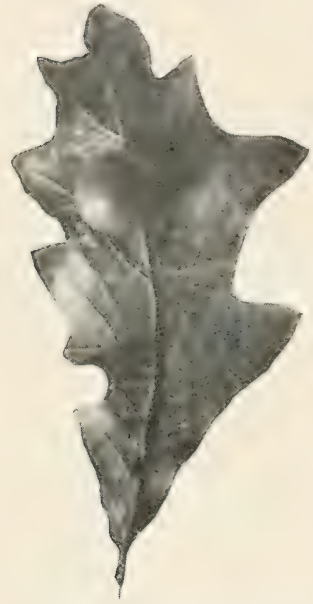

Fir. 150.-1irll of Dryophanta scutellaris (cherry gall). and white stripes, and its rind may be either smooth or slightly corrugated. It is fairly common in some parts of Northumberland.

\section{Dryophanta divisa (Adler).}

The galls are about the size of a small pellet or buck-shot, and are found thickly studded on the under side of the leaves, springing from the veins (fig. 152). They may be looked for from June to October, and at first they are of a bright-red colour, but they gradually change to a light-brown towards maturity. The surface is smooth, with a slight depression in the centre. The structure is hard and woody, with a comparatively thick wall and small single larval chamber.

From a dozen to twenty may sometimes be found on one leaf.

The flies hatch in October and November, and are about 4 to $5 \mathrm{~mm}$. long. Antennæ dark - brown;

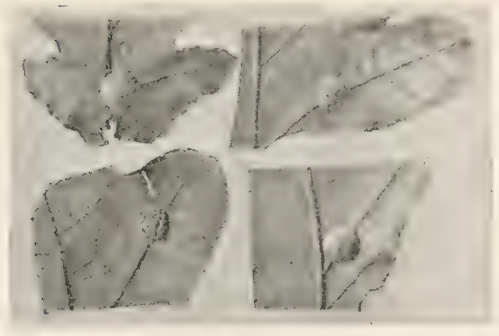

Fig. 151.-Galls of Dryophanta longiventris. head and thorax brown; abdomen black, and legs of a lighter brown than body; wings longer than body.

\section{Biorhiza Group.}

The first to be considered in this group is BIORHIZA APTERA (Fabr.) The galls of this species are found on the roots of the oak, sometimes on the smallest tips, at other times on strong roots. The galls may 
very often be found by workmen when trenching or uprooting trees in winter. They are of a coffee-brown colour, and vary in size, but the average is about the bulk of a common pea (fig. 153). They are generally procured in clusters, which very much resemble the honeycombs of the moss-bee, Bombus muscorum. Adler says that, after many observations, he found that the flies issue in December and January, but adds that other observers found the time of their appearance rather variable. This last remark I can quite endorse, inasmuch as galls found by workmen in February did not hatch until well on in spring. In this case there is no mistaking the species or confounding with parasites, inasmuch as the specimens are all apterous.

The fly varies in size from 4 to 7 mm. long, wingless, with a rather slender thorax. The form is somewhat spider-like, and the whole body of a uniform brownish colour.

With regard to the alternate form, Adler made many observations, and found that the

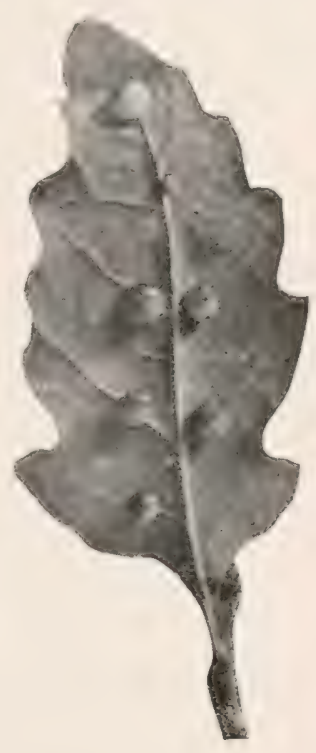

Fig. 152.-Galls of Dryophanta divisa. eggs deposited by Biortiza aptera result in the formation of the well-known oak-apple.

Adler watched the egy-laying process rery closely, and found that the insect did not deposit the egg immediately after making the incision, but acted on the principle of "one thing at a time," inasmuch as she carefully pricked the buds and then returned to deposit the eggs in previously prepared-channels. In this way he found that

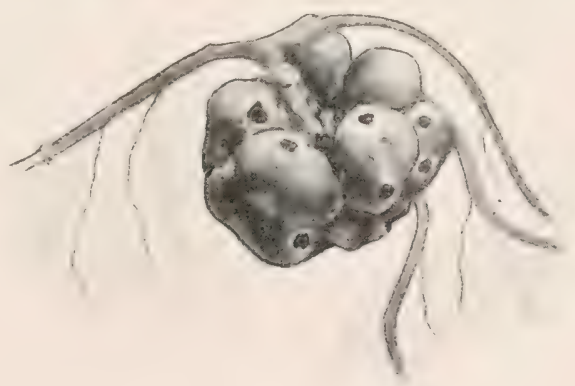

Fig. 153.-Galls of Biorhiza aptera. on January 27, 1878, the fly deposited 582 eggs during 87 hours. Towarls the end of May these galls were fully rleveloped oak-apples. 


\section{Teras terminalis (Fabr.)}

The gall of this species (fig. 154) is the well-known oak-apple or King Charles apple, which is worn by country boys in the south of England on the 29th May. When first the oak-apple appears, it is of a very beautiful scarlet colour. On making a longitudinal or transverse section, we find that the interior of the gall is manychambered, and the outside soft, spongy, and rich in tannin.

The gall matures in June, and the flies emerge in July. This being

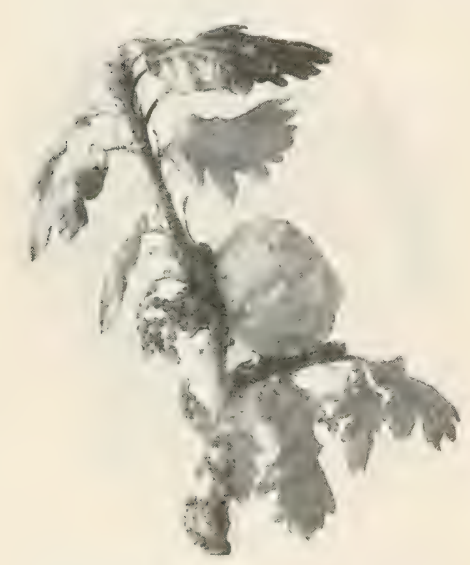

Fig. 151.-Gall of Peras terminalis (ock-apple). the case, and considering that the gall is abundant and common, it is very easily reared.

With regard to the $\mathrm{fly}$, I have made from microscopical observations the following notes:-

Length of body $2 \mathrm{~mm}$.; breadth or expanse of wings $5 \mathrm{~mm}$.; wings slightly pubescent, with short hairs; head and thorax brownish ; abdomen considerably narrower than thorax, blackish, shining, egg-shaped, and pointed; eyes black and shining; three terminal joints of antennæ more slender than the other joints.

The males are paler than the females, and always winged, but the females have often rudimentary wings.

The alternate generation between Biorhiza aptera and Teras terminali: has been demonstrated by Adler and corroborated by Heyerinck, and yet notwithstanding this there are apparent natural difficulties to fully realise the same correctly. First of all, we have the agamic generation Biortiza aptera living on the roots and always apterous. But the next generation is often found on the tops of comparatively tall trees, and the question arises, How do the apterous flies in a natural state reach the topmost boughs to deposit their eggs?

We have seen that apterous insects are often born amongst oakapple flies. This might be considered advantageous in assisting the insect to deposit its eggs on the roots. The apterous flies on the oakapple are the exception, but the apterous flies from the root galls, so 
far as hitherto ascertained, are a rule without any exception. Tet another point is noticeable-viz., that galls appear on certain levels, certain zones of height; and here we find the apterous flies, in order to reproduce the next generation, have reached the highest zone.

There is a special entomological interest attached to the oak-apple gall, inasmuch as the list of parasites reared and given by Cameron is quite a little study in itself. The interest is intensified on account of various species appearing throughout the whole year.

\section{BIorhiza ReNum (Htg.)}

This is a kidney-shaped gall, as the name implies (fig. 155). It is not very common, but when found is generally abuntant on the under

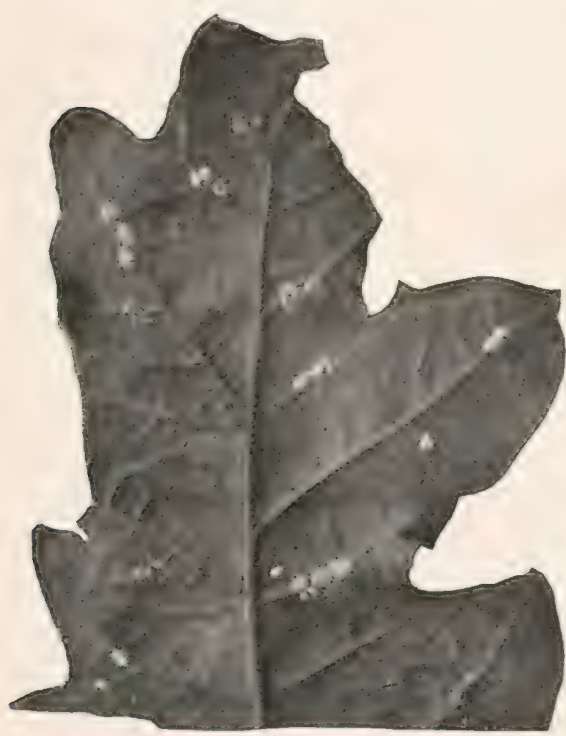

Fig. 155. - Galls of Biorhiza renum (kidney gall). side of the leaves, and arranged in rows attached to the veins. It is found in September and October, but though I found it several consecutive years in a Cheshire lane, I yet failed to rear a single fly, which is described as wingless, and of a brownish-red colour.

By experimental breeding Adler found the fly alternated with TrigonASPIS MEGAPTERA (crustalis), which is found on adventitious buds on old oak stems near the roots. The gall is about the size of a large pea, of a beautiful pink colour, soft and succulent. This gall may be first observed towards the latter end of April, and by the middle of May we find it fully matured, and the insects hatehing out. It is very generally distributed thronghout the country, but is not always equally abundant every year. Thus in 1893 it was very common, but comparatively rare in 1894 and in 
1895, and again fairly abundant in 1896 . In $1897 \mathrm{I}$ found one as late as May 23 in Cheshire, and it hatched out next day. It may be found either singly or in masses, and each gall is single-chambered.

The perfect insect is one of the prettiest of the gall-flies. The head and thorax are black, and abdomen of a bright shining appearance. The wings are considerably longer than the body, and the general appearance handsome and slender. Haring observed that the fly from B. remm on the leaves was apterous, contrasted with long-winged flies

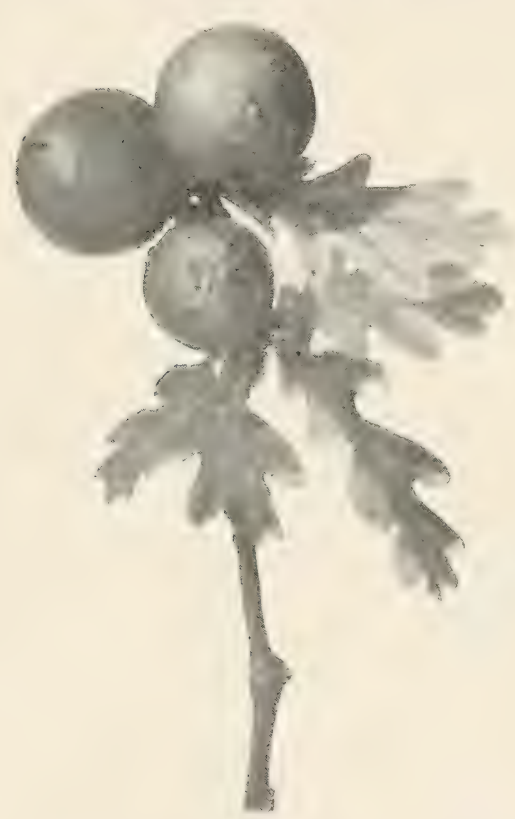

Fig. 156. -Galls of Cynips Kollari (marble gall). from Trigonaspis megapteru, it may be observed in passing that the apterous flies deposit their eggs on adventitious buds on the stem from one to three feet from the ground.

There is another curious point wortlyy of notice. Cameron gives Trigonaspis megapter a as the agamic form, and Biorthiza renum as the sexual. Adler, on the other hand, gives Trigonaspis megapterce as the sexual, and Biorliza renum as the agamic form. Cameron describes the male of Biorhiza renum, and Adler describes the male of Trigonaspis megapter'a under the synonym of Trigonaspis crustalis, Htg.

Perhaps the inference which might be drawn from this apparent contradiction is, that while the various families of insects appear to be well worked by leading authorities, it is nevertheless essential in practical entomology that all points should still be verified.

\section{Crnips Kollari (Htg.)}

The next and last species I shall deal with is the very common one known as "marble galls" or Cynips Kollari,-often very abun- 
dant on oak bushes and young trees. This gall is now widely distributed over the British Isles (fig. 156). It is often called the 1)evonshire gall, from the fact of its first appearing in that county and causing great alarm.

The galls are from $\frac{3}{4}$ inch to 1 inch in diameter, and, as a rule, almost a perfect ball. In some cases two galls coalesced, but in the centre one grub may only be found. As a rule, the gall may be perfectly smooth, but in some cases it is warty. At other times they may be found dwarfed in size and shrivelled, but when such is the case they are generally chambered, and inhabited by parasites, - thus contrasting with the true larval chamber, which is normally single and smooth.

The fly appears at various times, according to locality, from the latter end of April to beginning of June. As the fly is very easily hatched out, and being of a fairly large size, the following detailed description from Adler and Stratton may be given-viz. :

"Fly. - Length 4 to $6 \mathrm{~mm}$.; whole body reddish-yellow; looked at from abore, the head appenrs widened behind the eyes; cheeks half as long as the eyes, without wrinkles; antennæ filiform, thirteenjointed, second joint longer than thick, third joint the longest, twelfth and thirteenth joints partially united. Thorax brown, covered with short hairs; parapsidal furrows complete; scutellum with two thickly haired foveæ at its base; metanotum black, vertical, overhung by the scutellum. Abdomen smooth and shining; second segment covering half the dorsum, very dark above, with two large hairy spots; the other segments fringed with silky hairs. Ovipositor long and spiral. Venter exposed. Wings as long as the fly, hyaline, finely haired; ratial cellule open at the margin, clongate, with the areolet opposite its base; basal abscissa of the radius angled; cubitus opposite to, but not reaching, the michlle of the transverse basal nervure; legs yellow, margin of the fore tibiæ fringed with short depressed hairs; hind coxæ broad; claws bifid." 1

\section{Stroptionl Table of OAK Galls.}

With a view to readily ascertain the name of any gall, it may be considered advisable to arringe them according to the respective parts of the oak-tree on which they may be found.

${ }^{1}$ Adler and Stratton, p. 164. 


\section{On the Leaf.}

A. On the under surface of the leaf.

Currant gall found either singly or in groups-green or tinged with red-soft, succulent, smooth, about $5 \mathrm{~mm}$. diameter. In May and June; soon shrivels up after escape of fly

Spathegaster baccarum.

Pale, about $4 \mathrm{~mm}$. diameter, soft, in clusters and hairy. July

Spatheyaster tricolor.

Cherry-like gall, softish, generally singly but sometimes in clusters. July and October . . . . Dryophanta scutellaris.

Smaller than previous species; harder, and beautifully marked with reddish stripes. July to October. Dryophanta longiventris.

Like a small pellet, smooth, beautifully spotted. August to October

- Neuroterus ostreus.

Kidney-shaped, often in clusters on veins. September and October Biortiza renum.

button-like gall, conspicuously depreseed in centre, surface like silk velvet, light-brown colour. Autumn - Neuroterus numismatis.

Covered with stellate hairs, raised in centre, flat at outer edge, spangle gall. Late summer and autumn. Neuroterus lenticularis.

Not covered with hairs, nearly smooth, white or yellowish, outer edge turned up. Late summer and autumn Neuroterns laviusculus.

Centre of gall concave, edges conspicuously turned up

Neuroterus fumipennis.

B. On the margin of the leaf.

(1) No inner gall.

Smooth, spindle shaped, causing fairly deep indentations of leaf Neuroterus albipes.

Smooth, red-ribbed, and leaf on which it is found often looking as if abruptly cut . . . . . Aphilothrix marginalis.

(2) With an inner gall.

An irregular globular swelling, outer surface hard, lightish-yellow colour. - Andricus curvator. 


\section{In Buds.}

Polythalamous; very large, spongy, apple-like. In terminal buds, or often on lateral buds on terminal shoots. May and June

Teras terminalis.

Monothalamous. In April and May, on trunks of old trees, generally near the ground, like a round drop of sealing-wax

Trigonaspis megaptera.

Like marbles on twigs or young trees in nursery; green from July to September, and light-brown throughout the winter; either singly or in clusters

Cynips Kollari.

Spindle-shaped, with long peduncle. July and August

Aphilothrix callidoma.

Ovoid, green, spotted, smooth, hard . Aphilothrix albopunctata.

Gall wholly enveloped in leaf-scales . Aphilothrix fecundatrix.

Gall very thin, and to all appearance only an undeveloped bud. In April and May . . . . . Spathegaster aprilinus.

Globular, green, projecting from bud scales in September and October .

Aphilothrix globuli.

Terminal twig inflated with a tuft of leaves, growing from the inflated portion .

Irregular swellings on twig. . . . Andricus noduli.

\section{On Roots.}

Polythalamous; soft when young, woody when mature. At base of trunk, or on strong roots, on surface of ground. October and winter . . . . . Aphilothrix radicis.

Monothalamous, but often in irregular clusters on rootlets of old trees. October and winter . . . . Biorhiza aptera.

\section{On Bark.}

On young bark around a pruned branch, when cut off close to stem. Early summer

Aphilothrix corticis.

\section{On Flowers.}

Large mass of woolly hair, resembling a ball of cotton-wool. In June and July . . . . . . Andricus ramuli. 
Spherical, smooth, and soft currant-like mass. May and June Spathegaster baccarum.

Ovoid, slightly ribbed on sides like miniature rifle-bullet Aphilothrix quadrilineata.

Note.-In the above synoptical table I have largely followed the arrangement of Adler, but I have given only those species I have collected, with the exception of Aphilothrix callidoma, which I received from Mrr Connold of St Leonards-on-Sea.

\section{Oak Galls: Their Economic Interest and Teachings.}

With regard to oak galls, or the Cynips, considered as an insectpest, the only species I have ever found so numerous as to cause appreciable damage was Cynips Kollari. This was in a plot of transplanted oaks in a nursery in Cheshire, and the galls were so abundant that the whole of the trees had to be burned.

Though individually the species of galls are not, as a rule, so numerically strong as to be looked upon as a pest, yet collectively they give rise to injuries which retard the longitudinal growth, and, in many cases, "prune" the tree into shapes and forms exactly the opposite to what practical forestry requires - as, for example, see fig, 145. Hence they have important associations in practical forestry, as well as interesting biological teachings.

There is no tree more difficult to train into a straight pole than the oak, and it is just possible that this is often due to the effects of the gall insects; therefore the best preventive against the injurious effects is to be found in careful cultivation in the nursery and young plantation. The evil practice of selling by height, irrespective of age, has had disastrous results on the sylvicultural growing of oak. Thus it often happens that nurserymen, having height in view, allow seedlings to grow for three years prior to transplanting, and then after transplanting allow them to stand for three or four years in the nursery-lines, then again transplant, and finally sell individually over several consecutive years. But if the nursery work is bad, the method of planting out by the purchaser is sometimes worse; for we often see large oaks planted out in a "mixed" plantation, and towering three or four feet above the more hardy species, which were planted under the name of "nurses." Apart from the excellent 
method of sowing the acorns direet, the better sylvicultural method, and one which will overcome gall insect-pests, is to transplant in nursery-lines good seedlings at one year old, because at this age we get a better root in proportion to the top than at two years. 'Then if growth is vigorous in the nursery-lines, transplant the very best specimens only the following year into the mixed woul, together with the more hardy nurses, or otherwise in a young wood, where the nurses have been planted as an ameliorating species in advance. The remainder of the oaks in the nursery-lines, which will obviously improve as the result of "quartering," may also be planted out in the young wood during the following year.

Of course it must be borne in mind that the above remarks apply only to planting extensively, and under the protection of wirenetting.

\section{References to Literature consulted.}

Adler and Stratton. Alternating Generations : A Study of Oak Galls and GallFlies, 1891.

Cameron, Peter. A Monograph of the British Phytophagous Hymenoptera. Vol. iv. Ray Society. 1893.

Cameron, Peter. Galls of Mid-Cheshire. Manchester Mic. Soc. 1891. 8 pp., $1 \mathrm{pl}$.

Fitch, E. A. The Galls of Essex. Trans. Essex Field Club.

Gardeners' Chronicle. Articles on Galls from 1854.

Lubbock, Sir John. Origin and Metamorphosis of Insects. 1876.

Mosley, S. L. Yorkshire Galls. Naturalist, Sept. 1892.

Romanes, G. J. Darwin and after Darwin. Pt. I. 1892. 


\section{CHAPTER V.}

\section{HYMENOPTERA-SAW-FLIES, Етс.}

Coxstoeren as a division of entomology, perhaps no class of insects is more important than the Hymenoptera. To the student of insect anatomy and physiology they are, as a whole, the most highly differentiated and organised creatures in the insect world. The student of mental phenomena finds in this group instances of rare intelligence and instinctive forethought, often surpassing anything in the animal kingdom; and the humble but patient observer who studies life-histories will also find abundant scope in this important division. When we remember that this order embraces (besides many others no less distinct in their structure and their habits) saw-flies; gall-flies, ichneumons, ants, bees, and wasps, the truth of the above assertions will be apparent.

To the student of forest entomology they present a fairly wide field, inasmuch as saw-flies and gall-flies may be considered as injurious insects (though not always to any great extent), and ichneumons, on the other hand, may be considered as beneficial insects.

To some extent, therefore, in a general way, the student must study the salient features of the whole order, but unfortunately at the present time entomologists are by no means agreed as to classification either as regards the whole order or some of the most important sections.

As regards the special study of Hymenoptera in its relation to the forest, it may be said that on beating trees and bushes many larvæ of several species may be found, and by breeding the same a good representative collection might be obtained. This, however, would be too general for forest entomology, and it is better, therefore, to confine our studies to the more destructive or general species.

The Hymenoptera have by some been divided into Terebrantia and 
Aculeata, according as the ovipositor of the female is modified into a "boring instrument" or a "sting." But this distinction is often hard to maintain, and also appertains only to one sex, which is unsatisfactory. Another division-viz., into Sessiliventria and Petiolata, according as the abdomen is attached to the thorax over its whole width, or at one point only by a narrow and stalk-like first segmentis not open to the above objections, and is here adopted.

The Sessiliventria are also called by English writers "Saw-flies," and by German "Blattwespen " (i.e., leaf-wasps). Such Ilymenoptera as are of special interest to the forest entomologist belong mostly to this division, and I have therefore thought it worth while to call attention to the further classifications which have heen introduced into it by specialists, and to indicate some of the writings on the subject which are likely to assist such students as desire to master it to a greater or less extent.

The most useful complete works dealing with the saw-flies of large areas as a whole are-

Kriechbaumer's collection of Klug's writings on Blattwespen (Berlin, 1884); Hartig's 'Families of Leaf and Wood Wasps' (Berlin, 1860) ; Thomson's 'Hymenoptera Scandinaviæ,' vol. i. (Lund, 1871); Andre's 'Species,' vol. i. (Beaune, 1879); and (for British genera and species) Cameron's Monograph, \&c. All these works, however, are beginning to get old; and since their appearance much new light has been thrown upon the group by a very able and original German naturalist (Pastor F. W. Konow), who has published a vast number of short articles and revisions of particular genera, and is now issuing a monograph (on the very largest scale) of the saw-flies of the whole world. Consequently several names of species, and even genera, hitherto in common use are destined to be superseded before long, and some may be said to be already out of date. A series of papers by Mr Morice now appearing in 'The Entomologist's Monthly Magazine,' entitled "Help-notes," \&c., has for one of its chief objects to inform English students of the alterations in the British list (at present resting mainly on Cameron's work), which seem to be required in consequence of Konow's researches hitherto; and also to facilitate the study of the subject, by fresh tabulations of generic and specific characters, which the writer hopes will generally suffice to guide collectors to a correct determination of the specimens taken by them.

In view, therefore, of the importance of Morice's "Help-notes," I 
beg to give at considerable length some of his "notes," together with his illustrations, as I know of nothing more helpful to the student who wishes to make a thorough study of the insects in question.

"The head is nearly always broader than long, and generally about the same breadth as the thorax. The eyes are large, and ocelli are also present. Behind the ocelli there is a quadrangular space, bounded latterly by distinct furrows, known as the vertical area. The spaces bordering the compound eyes are the ortits. The space containing the ocelli, and reaching to the insertions of the antenne, is the frons, and part of this space surrounded by furrows is called the pentagonal area.

"Looking at the face and below the antennæ we see the clypeus and labrum. The space between the eye and base of the mandible is termed the gena.

"The back of the head, facing the thorax, is the occiput. Between the occiput and the compound eye lie the tempora.

"The details of the thorax, which furnish many very important characters, can hardly be made clear except by diagrams. I give therefore now an outline camera-lucida sketch of the thorax in Tenthredo mesomela, L., viewed from two aspects-(fig. 157) dorsally, i.e., from above; (fig. 158) laterally, i.e., from the side :-

$a$ (in both figures), pronotum.

$6 b$, tegulæ.

$c$, middle (or front) lobe of mesonotum.

$d d$, side lobes of mesonotum.

$e$, scutellum (or better, perhaps, scutellum mesothoracis, to distinguish it from $f$ ).

$f$, postscutellum (better scutellum metathoracis).

$g$, propodeum or median segment (the central slit in this is what Cameron calls the blotch).

$h h$, cenchri (the space between them is the metanotum).

$k$ (in fig. 158), prosternum.

$l$, mesosternum.

$m$, metasternum.

$n$, mesopleura.

$o$, metapleura.

рpp, coxæ.

"Note. - The unlettered areas in fig. 157 are parts of the meso- and meta-thor:x, which are seldom, if ever, referred to in descriptions, and I therefore ignore them. The shaded space indicates a very deep impression between the meso- and meta-thoracic regions.

"I may add that-

the pro-thorax includes the areas $a$ and $k$;

the meso-thorax includes the areas $c, d$, and $e$ in fig $157 ; n$ and $l$ in fig. 158; 
the meta-thorax includes the areas $f$ in fig. 157, $o$ and $m$ in fig. 158; the propoleum (, $\mathrm{in}$ both figures) is an originally abdominal sungment, transferred to the thorax in pupation.

"The thorax of a saw-fly can easily be broken up into its three constituent parts of pro-, meso-, and meta-thorax. If the front and midlle coxre are seized in two pairs of pincers and pulled alpart, the pro-and meso-thorax part company. Similarly, by tearing the middle coxæ away from the hind coxæ, the meso-thorax can be separated from the meta-thorix. The so-called propodeum, though theoretically an abdominal segment, is so fimly attiched to the meta-thorax that when the abdomen is broken off $(e . g$. , in a dried specimen by

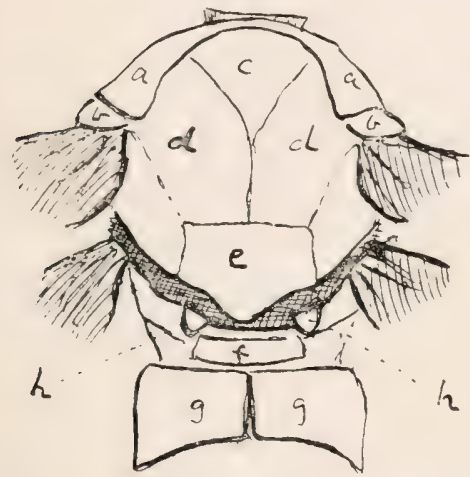

Fig. 157.-Thorax of a saw-fly: clorsal surfacei.e., as seen from abore. (Sketch hy Rev. F. D. Morice. From 'Entomologist's Monthly Magazine.')

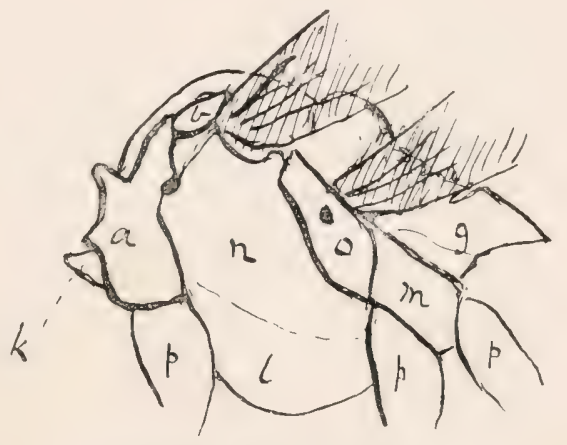

Fig. 158,-Lateral or side view of fig. 157.

pushing it roughly downwards), the propodeum always remains with the thorax.

"In fig. $157, h, h$, the 'cenchri' are two singular organs with some resemblance to little tegulæ. They are always present in Tenthrerlinidæ, but I cannot find that their function has as yet heen discovered. They belong to the meta-thorax, and mark its base.

"Pegarding the neuration of a saw-fly's wing, the first thing to he done is to realise the course of the longitudinal nervures $=$ the 'veins,'- the thick single lines. It will be seen that they are much longer than the transverse = the 'nerves.' 'They are also more uniform throughout the whole group, and much less liahle to vary abnormally in individual specimens. We commence with them partly 
on this account and partly because they divide the wing into areas named from them, and from these areas again are named most of the (transverse) 'nerves' and the 'cells' or divisions of the areas bounded by them.

"Starting from near each other, and near the base of the wing, five main 'veins' run, all more or less in the direction of its apex, but radiating apart, like the fingers of an extended hand.

"The first pair start at $a$ and $b$ : these are the costa and the subcosta. The costa follows the actual margin of the wing, and the sub-costa runs nearly parallel to it for about half the length of the wing, when it bends upwards and unites with the costa at $f$, just before the stigma (the shaded area in fig. 159).

"From $d$ and $e$ start another pair, the brachius and the humerus.

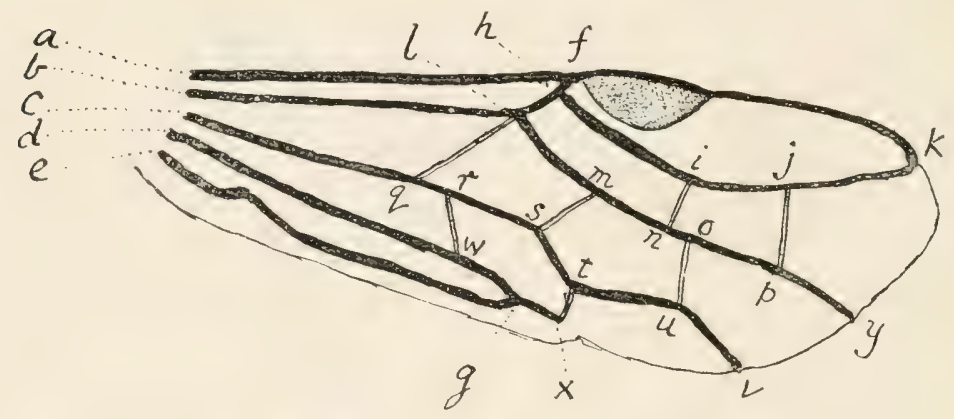

Fig. 159. - Typical upper wing of saw-fly. (Sketch by Rev, F. D. Morice. From 'Entomologist's Monthly Magazine.')

These run both somewhat parallel to the lower margin of the wing, but neither of them coinciding with it. Again, for about half the total length of the wing, the humerus turns upward and joins the brachius at $g$ (just as at $f$ the sub-costa joins the costa). The brachius is continued a little farther to $x$, and there disappears.

"The fifth of these 'veins," starting at $c$, is called the merdius. It runs at first straight along the middle of the wing (equidistant, therefore, between the two pairs described above) for half its length. Then it bends downwards as though to join the brachius, but at $t$ turns suddenly off, resuming its horizontal course, then (at $u$ ) is again deflected, and reaches the margin at $v$.

"Besides the above five main veins, we have two which may be called subsidiary. They are confined to the superior (apical) quartes 
of the wing, and have the appearance of branching out of the subcosta. One leaves it just before its junction with the costa (at a point about 7 ), and, bending first down and then a little up, finally joins the costa (on the margin of the wing) at its apex $l$. This is the radius. The other-called the cubitus-leaving the sub-costa earlier (i.e., nearer its base) at $l$, bisects, roughly, the area between the radius and the apical portion of the medius, and so proceeds not always in so straight a line as the figure shows to the point !/ on the margin.

"Thus we have in all five main and two subsidiary longitudinal nervures or 'veins,' and these divide the wing into longitudinal areas or 'fields,' as follows.

"Between the costa and the sub-costa is contained the intercostal field. Between the brachius and the humerus is the humeral fiehl, familiar to all students of saw-flies under the name of the "lanceulate cell.' Then between the sub-costa and the medius lies the medial field, and between the medius and the brachius the brachial field. (A certain similarity in form and size will probably have been noticed by the reader between the intercostal and humeral fields and the medial and brachial fields respectively. This will help him perhaps in forming a mental picture of the neuration as a whole.)

"Next we have the radial area lying above the radius, and the cubital area below the radius and above the cubitus. Between the cubitus and the apical half of the medius comes a continuation of the medial area, which, if regarded as distinct from it, may be called the discoidal field. That part of the wing lying below and as it were outsicle of the neuration system-i.e., that which is bounded inferiorly by the actual inferior margin of the wing and superiorly by the humerus as to its basal half, and by the medius as to its apical portion-is called the anal field.

"Owing to the disappearance of the brachius without reaching the margin, there is no complete longitudinal line of division between the brachial and anal areas. But for practical purposes the transverse nerve, $f x$, may be regarded as separating them.

"We come now to the transverse elements of the neurationKonow's 'Nerven' sensu restricto.

"Often (though not in my figure) the radial area is crossed by one, very rarely by more than one. Then the radial area is said to be 'divided,' or, as some authors express it, 'there are two radial cells.' 
Similarly, the cubital area shows, practically without exception, either, as here, two, or perhaps more often three, nerves connecting the radius with the cubitus $(i n, j p)$. These, as crossing the cubital field, are called the cubital nerves (1st, 2 nd, \&c.), and the divisions into which they cut up that field are the cubital cells. (Three seems to have been the original number of the cubital nerves. Where only two appear, either the first or second of the original three has vanished. Thus in Emphytus the first has gone, leaving only the second and third; whereas in Dolerus the two surviving nerves are the first and third, the second being absent.)

"Although these radial and cubital transverse nervures give, both as to their number and direction, obvious and easy characters for distinguishing both genera and species, they are unluckily liable, as already mentioned, to considerable variation,-_disappearance, duplication, displacement (within certain limits), irregular (atavistic) reappearance, \&c., in particular specimens, or even in one wing of a specimen and not in the other; so that it is very unsafe to trust wholly, or even chiefly, to them in 'determinations.'

"Very much more constant and trustworthy are the characters to be drawn from the three nervures which cross the median field-viz, lq (perhaps the most important nerve in the whole wing), the discoidal nerve, $m s$, and on the medial nerves (1st and 2nd), the two latter being better known probably to English readers as the 1st and 2nd 'recurrent,' and the former as the 'basal.' The characters of these nerves can hardly ever mislead us, and are of the utmost consequence in determining not merely genera or species, but families and tribes, - such characters, e.g., as whether the discoidal nerve strikes the sub-costa close to the origin of the cubitus (as in fig. 159), or considerably before it (i.e., between the points $b$ and $l$ in that figure), or whether it strikes (e.g., in $L y d a, \& c$.) not the sub-costa at all, but the cubitus; and again, whether the discoidal and 1st medial nerves are convergent (upwards) or sub-parallel, whether the two medial nerves are received in the same cubital cell or in two different ones, \&c. The importance of these points for 'determination' will appear abundantly when we come to construct our future tables. Two more transverse nerves only appear in my figure-viz., $r, w$, the areal nerve (called by Thomson rather oddly nervus transcersus ordinurius, and by Mr Cameron-e.g., see his Tables of Species for Emphytus-the transverse median), and $t, x$, the anal nerve. Of these the former is 
the more important, its direction and the point at which it is received in the cell above it giving several useful characters.

"We have now, I believe, dealt with all the nervures which are regularly present in the upper wing of a silw-fly. But certinin others which appear only in particular genera or families are for that very reason especially useful for 'determinations.' 'Thus, between the costa and sub-costa may lie a 6 th longitudinal nervure, and this maly ultimately either run simply into the sub-costa somewhere near l, or he forked at its apex into two branches, one joining the sub-costa and the other the costa. Or, in the same region (the intercostal field), there may be a transverse nerve stretching from the sub-costa to the costa, either before or after the point where the former receives the discoidal nerve. Or, as in Arye, the costa, instead of lying wholly on the margin of the wing, may quit it just before its apex, and bend down to meet the radius, this cutting off from the rest of the ratial area a little subtriangular apieal cell (cellula radiulis aprenticulata). Lastly, in the humeral area ('lanceolate cell') we have a number of important characters for determining genera depending partly on the presence or absence of transverse in that field, and partly on certain modifications in the structure of the humerus itself, especially in its basal part. These characters we have now to examine.

"It will be seen by reference to fig. 159 that the humerus (quite near its base) shows a strong inclination to unite with the brachius, long before it ultimately does so, at \%. Generally this inclination is, if we may say so, suddenly checked : the humerus, though approaching very near the brachius, starts off at a tangent, and gradually recedes to a respectful distance from it, hefore taking the final curve by which it ultimately reaches it. Sometimes, however, the inclination is not checked: the humerus continues its approach to the brachius till it actually reaches it, and so the two veins for a while coincide,-it may be only for a moment or for a considerable distance,-but always separate again, so as to enclose a spindle-shaped space between them before their final point of union. Again, sometimes the humerus, without quite reaching the brachius at the (sub-basal) point alluled to above, all but does so, and throws a 'short perpendicular' nerve across the narrow interval which separates it from its companion rein. Yet again the humerus, soon after its origin, seems to vanish and presently to reappear emerging from the brachius, though it has never been seen to join the latter. Lastly, sometimes-though never, I 
believe, in conjunction with any of the phenomena described abovean 'oblique cross nervure' runs over (the apical portion of) the humeral area, cutting it into two divisions, the apical one 'completely enclosed,' and very much smaller than the other."

\section{TENTHREDINID AE (LEAF - WASPS).}

This family is known in Germany by the name of "Blattwespen " or Leaf-wasps, and the designation answers our purpose very well, inasmuch as the larvæ are always injurious (in very varying degrees) to the foliage of many species of forest trees, but more especially to Scots pine, larch, thorn, willow, and poplar. They are, however, only injurious in the larval stage.

The classification, for the purposes of the present work, of this family is somewhat difficult, for two reasons-(1) I need only to deal with a few genera and species, taken as it were here and there from the whole family; and (2) the publication, now slowly proceeding, of a very important German monograph of the saw-flies of the world has already caused the abandonment in many cases of generic and specific names hitherto employed in British works, and will doubtless yet more disturb our present nomenclature within the next few years.

I propose, therefore, to adopt the following merely provisional division of the insects into three sub-families, according to Konow, as follows-Cimbicides, Lophyrides, and Nematides.

\section{CIMBICIDES.}

\section{Gemus Trichiosoma.}

The following are the generic characters according to Morice ${ }^{1}$ -

"Claws simple; hind femora generally toothed conspicuously beneath ; very pilose, brown-looking insects, with abdomen fuscous or black above (but sometimes more or less rufescent at the apex and beneath).

\section{"Synopsis of British Trichiosoma.}

1. Abdomen black, not bronzy; dull, closely and rather coarsely punctured, and clothed right up to the apex with long, loose, grey, sub-erect hairs. (Attached to the birch) T. LUCorum, L. 1 'Entomologist's Monthly Magazine' for Aug. 1903. 
Abdomen at least slightly metallic, somewhat shining, puncturation finer and more remote, hairs on apical segments shorter . 2

2. Abdomen rufescent beneath and often at the sides. (Attached to willow) . . . . T. Silvatica, Leach.

Abdomen bronzy-black throughout . . . . 3

3. Tibix, at least in + , black or lark-brown. (Attached to hawthorn)

T. tibialis (Steph.)

Tibire yellow. Apical segments of abdomen clothed with longer hairs than the last species. (Attached to willow)

T. Latreillei, Leach."

This synopsis is extremely interesting from a collector's or naturestudent's point of view, but for practical purposes any species which the local collector may find most abundantly may be taken as a type of the other species.

\section{Trichiosoma tibialis (Steph.)}

This species is generally attached to hawthorn, and the pupal cocoons may generally be found on the twigs of switched hedges, more especially on twigs near the base of the hedge. As a rule, however, the cocoons are opened by insectivorous birds. The collector, therefore, should try as far as possible to gather these cocoons in the early autumn, and place them in a jar for hatching purposes. When this is done, the flies are

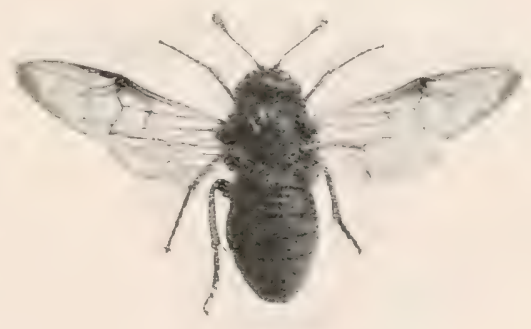

Fig. 160. -Trichiosoma tibialis. very easily reared, and they hatch out from the middle of March to the end of April. Fig. 160 is from a photograph of this species, and fig. 161 is a representation of the pupa.

It is best, in rearing flies from the larval stage, to try and collect, as far as possible, the fully developed larve, as when the larve are collected at an early stage they do not feed readily in confinement, and a great proportion of them die off. Fig. 162 is a representation of the larvæ on a hawthorn leaf. 
It should be noted that, from a systematic point of view, the species attached to hawthorn has hitherto been known as Trichiosoma lucorum, but modern classification associates the latter name with another species which is attached to birch-trees.

This species is in every way an interesting forest insect, but in no sense whatever can it be termed an injurious insect. The large

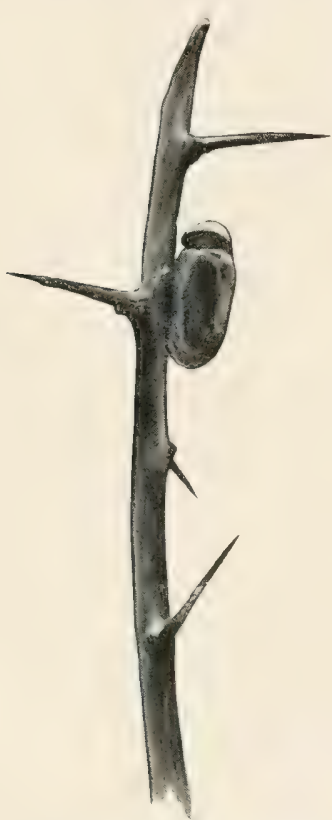

Fig. 161.-Pupe of Trichiosoma

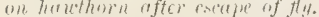
(From drawing by P. J. Brown.) and somewhat pretty larva may often be found on thorn hedges, when we are quietly searching for anything of an arboreal interest.

The larva (fig. 162) when young has a greyish - white appearance, largely due to a powdery covering, which appears dusted over the body. As it gets older the colour is a blend of green with light yellow, with a yellowish face and black eyes. It may be looked for in July. It is not a voracious feeder.

The pupa (fig. 161) is a hard brown cocoon, $\frac{7}{8}$ inch to 1 inch long, and $\frac{3}{8}$ inch to $\frac{1}{2}$ an inch in breadth. It opens by a lid for the exit of the perfect insect. It may be looked for during the winter months on thorn hedges, more especially towards the bottom of the hedge.

The perfect insect may be seen hovering in thorn hedges in March and April. It may be mistaken by the uninitiated for a bee. It is a brownish colour, head, thorax, and abdomen hairy. Antennæ dark-brown. Legs a lightbrown. The wings are clear. Length 6-10 lines.

The genus Cimbex is very closely allied to Trichiosoma, but in a general way the former may be distinguished from the latter as being less hairy. For practical purposes we may group the two genera together; and Judeich and Nitsche, though giving different generic characters, adopt this method for general description. 


\section{LOPHYRIDES.}

\section{Genus Lophyrus.}

The species belonging to this genus are relatively very small. The males are smaller than the females, and have double pectinated antennx; and the larger females have single (but slightly) pectinated antennx. In this country only two species have been recorded, but in Germany eight or ten species are mentioned. All the species are arboreal in their habits, and hitherto recorded as feeding on the foliage of Scots pine. It would be well for the student of forest insects, more especially those living in Scotland, to keep a sharp look-out for unrecorded species. They are double-brooded during the year, and therefore lend themselves for rapid results as regards observation.

\section{LOPHYRUS PINI}

(Linn.)

In consequence of the immense damage done to young Scots pine plantations, this insect may be classed as a veritable

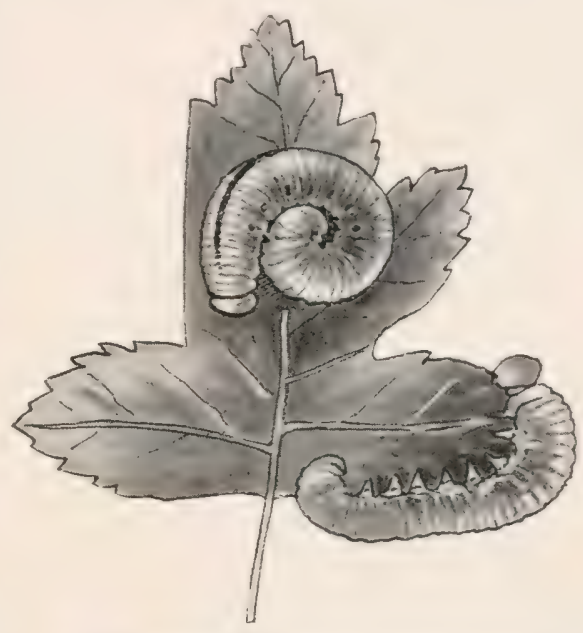

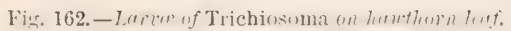
(From drawin: by P. J. Brown.)

forest pest. The larvæ live sociably, and have voracious appetites, so much so, that the lealing shoots are quite defoliaterl, giving the twigs the appearance of having been clipped with a pair of scissor's; and wherever such wholesale damage is to be gauged by area, it is obvious a severe visitation is in reality an alarming pest.

The saw-flies appear in early summer, but the time seems to vary in localities. Thus in Cheshire $I$ often found the females lodging amongst the leaves about the end of May, whereas in Northumlerland the males (which generally precede the females) appeared on July 4, 1901. This was from specimens I had kept from an autumn 
brood over the winter. Of course it is possible that this may be by no means considered the first appearance in the county, or in fact any reliable guide as to dates for the country generally, as (fortunately) it is not very plentiful in Northumberland.

The females deposit their eggrs on the leaves, and the larvæ hatch out in from two to three weeks.

The larvæ, when full fed, are about $25 \mathrm{~mm}$. long. The general colour of the body is a light yellowish-green. The head is lightbrown. At every pro-leg are two black dots, and often black dots are conspicuously scattered over the body.

The pupæ, or rather the pupal cases, are very hard and brown. The male puparia are about $10 \mathrm{~mm}$. long by 5 broad. The female
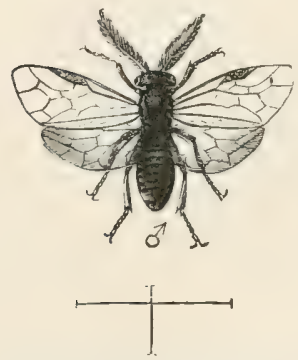

Fig. 163.-Lophyxus pini, Pine saw-fly (male). (From "Forest Protection," by W. R. Fisher.)

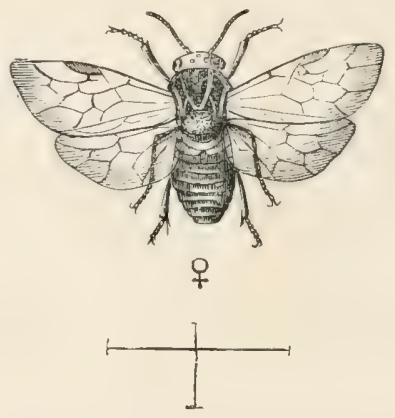

Fig. 164.-Lophyrus pini, Pine saw-fly (female). (From 'Forest Protection, by W. R. Fisher.)

puparia are about $15 \mathrm{~mm}$. long by about 7 broad. The perfect insects escape by a lid, but if the pupa has been parasitised, the parasite simply escapes by a minute cireular opening.

The male (fig. 163) has a wing expansion of $15 \mathrm{~mm}$. ; body black, legs testaceous, with black femoræ; antenne doubly pectinated. The female (fig. 164) has a wing expansion of $20 \mathrm{~mm}$. The head and thorax are darkish-brown, and singly serrated antennæ. The middle portion of the abdomen is strongly banded black, while the portions above and below this black band are, on careful examination, double bands of yellow mixed with black. The upper wing has one radial and four cubital cellules.

Life-history. - As before stated, the life-history is somewhat variable. In a general way it may be said that the female (which 
is very sluggish) cuts slits in the leaves with her saw-like ovipositor, and lays her eggs in the slits. These hatch out in abont two or three weeks' time, feed on the leaves of last year's terminal shoots (at this stage they often eat about half of the leaves-see fig. 165), and pupate in July. A portion of those larvæ hatch out in August, and thus we get a second brood from a portion, while others remain in the pupal stage (fig. 166) until the following spring. The larva

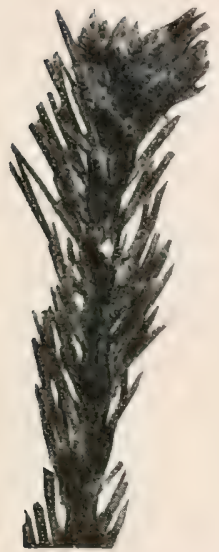

Fig. 165.-Foliage of Scots pine eaten by larva of pine saw-fly. Injury done by first brood of the season.

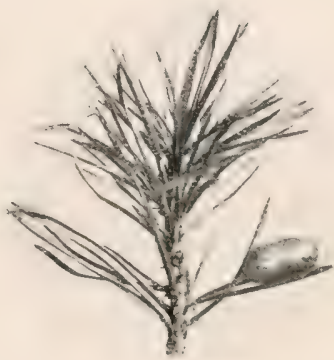

Fig. 166.-Pupal case of Lophyrus pini (pine saw- $f(y)$.

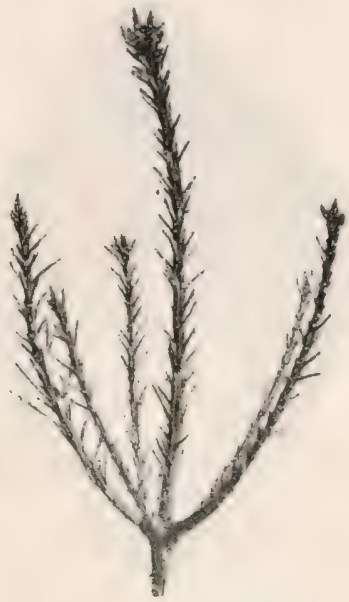

Fig. 167.-Foliage of scots pine eaten by larve of pine saw-fly. Injury done by second. brood of the season.

issuing from the second brood eat the foliage of the current year (see fig. 167).

In Northumberland the first male of the second brood appeared on September 1, 1904, and the females about a week later.

As this is a very troublesome pest, it follows that some specific remedies ought to be given. Keep the young woods in very good health, and encourage all birds which would open and pick the pupæ from their cases.

The larve might be collected by chipping off infested shoots and letting them fall into paraffin. The cocoons might also be collected, as far as practicable. For the perfect insects smeared traps might be laid against the young trees in April. It should 
be remembered that it is amongst the very young plantations that most damage is done.

\section{LOPHYRUS RUFUS (Klig).}

Miss Ormerod writes ${ }^{1}$ regarding this species :-

"I have also had observations, with specimens during this year, of much injury being done by the caterpillars of the Lophyms mius of Klug on three or four thousand acres of young Scots fir in Argyleshire. These caterpillars are of a greenish dusky grey, with black heads, a fine lighter line along the back, and a dusky line above the spiracles. The abdominal sucker feet and abdomen below yellowgreen. The specimens sent me on the 10th of June had spun their cocoons by the 23rd. The flies may be looked for from August onwards. The females are reddish; the males black, with abdomen beneath and legs red. It was observed that trees ten feet high were not so seriously attacked as those from two to six feet high."

\section{NEMATIN止 (NeMATIDES).}

This sub-family is of considerable interest in forest entomology, inasmuch as a great many of the species are arboreal feeders. Many of them are amongst the first insects to appear on the wing in spring. On a sunny day single specimens may be seen flying for a short distance, and then lodging amongst grass or other harbourage. They can then be very easily placed in a chip-box or bottle. They may also be collected from the flowers of sallow, which forms a sort of general food for spring insects. As regards feeding habits, they may be divided into two principal classes-viz., those whose larvæ feed on the foliage, and those which form galls chiefly on willows. They are injurious in the larval stage only.

As regards size, they range from very small to medium-sized insects, perhaps from 2 to $12 \mathrm{~mm}$. They are for the most part smooth, shiny, and rather soft-bodied, variously coloured, with 9 -jointed antennx, usually elongate, slender, and tapering; anterior wings, with simple, seldom-divided, radial cell. Hind wings always with two discal cells, and with completely enclosed lanceolate cell.

\footnotetext{
1 Manual of Injurious Insects, 2nd edition, p. 255.
} 


\section{Table of Genera. ${ }^{1}$}

Anterior wings with simple radial cell.

Lanceolate cell widely contracted in the middle.

Second and third cubital cells each receiving a recurrent vein.

Third to fifth, sometimes sixth and seventh, antennal joints of the male with a more or less prominent branch at the tip; antennæ of the female somewhat compressed, and with sharp projection at tip of basal joints

Cladius, Illig.

Joints of antennæ without projections at tip; third antennal joint curved at the base, in the male with a short, blunt fork beneath, and in the female with a sharp projection

Trichiocampus, Htg.

Lanceolate cell petiolate.

Third transverse cubital wanting . . Euvra, Newn.

Third transverse cubital present.

Claws bifid, clypeus usually emarginate.

Tip of the eighth dorsal segment of the male with a small, blunt, more or less awl-shaped projection; antennæ of female filiform, small species 2 to $5 \mathrm{~mm}$. long; stigma often having clear base; sheath often pointed at tip; gall inhabiters . . . Poxtaxia, Cost.

Eighth dorsal segment of male broader, obtusely pointed, or not at all produced at tip; antennæ distinctly tapering toward tip; stigma not lighter at base; sheath not pointed at tip; body more robust.

Last ventral segment of male obtusely triangularly produced at tip; sheath of female of the usual form; posterior tibie simple.

Mesonotum and pleuræ shining; antennæ long and slender, usually lighter coloured beneath; head, viewed from the front, almost round; labium but slightly projecting; sheaths usually narrow and delicate . . Pteronos, Jur.

1 Adapted from 'Revision of the Nematina of North America,' by C. L. Marlatt. Washington: 1896. In this table three or four genera are omitted, as they are not, so far as hitherto-recognised, associated with forest insects. 
Last ventral segment of male excavated at tip, not obtusely triangularly produced; sheath of female very broad, or the posterior tibiæ and tarsi thickened.

Posterior tibiæe and tarsi very broad and flattened . . CResus, Leach.

Posterior tibiæ and tarsi not flattened.

Posterior tibiæ and tarsi thickened, tibiæ externally with longitudinal furrow

Holcocneme, Knw.

Posterior tibiæ and tarsi simple; sheath very thick and stout. Nematus, Jur.

Clypeus truncate.

Pentagonal area more or less distinct; eighth dorsal segment carinated, sub-produced; sheath simple; elongate species

LygeONeMATUS, Knw.

Genus Cradius.

This genus, which is now known to systematists as Trichiocampus, is a part only of the old genus Cladius. The name Cladius is still kept for C. pectinicornus, \&c. It has the third joint of the antennæe curved, and the species on Lombardy poplar has an orange-red abdomen.

\section{Cladius (Trichiocampus) viminalis (Fall.)}

This insect may be found in the larval stage on the leaves of Lombardy poplar. The larvæ feed in company on the under side of the leaves, generally from three to five in a row, each larva touching its neighbour, and all keeping in perfect line. The larvæ are a beautiful light-orange colour, with dark hear, and clothed with strong hairs. There are also rows of black flecks across the rings. Length from 15 to $22 \mathrm{~mm}$.

The female insect has black head, thorax, and antennæ; abdomen light-yellow; legs in all parts light-yellow. Wings with light-brown veins and stigma. The male is similarly coloured, but the antennx are dark-brown. Length of female $9 \mathrm{~mm}$.; spread of wing about $18 \mathrm{~mm}$. Male $6 \mathrm{~mm}$. ; spread of wing $13 \mathrm{~mm}$. 
Eudra (Cryptocampus) pentandre, Cam.

Large woody galls are formed by this insect on willow-stems, generally of the species Satix pentendre. This insect is not at all common, and certainly very local. Although the attacked bush is often very valueless either from an esthetic or an intrinsic point of view, yet the galls are often so numerically strong as to do great vital injury to the btsh itself. An infested bush, from its extremely local habits, becomes quite an interesting object.

The galls themselves may be first noticed near the extreme end of the twigs, being an enlargement on the twig (see fig. 168), about the end of June. During the early summer months the galls are of a close woody structure, but towards the autumn they are more or less hollow, and contain a comparatively large amount of dirty black frass. Several larvæ are found within one gall. It may happen on inspection that each larva is enclosed within a cocoon. This condition I found on January 5, 1900, but it must not be inferred that the larvæ are fully fed, as the cocoon may be either for protection or shelter.

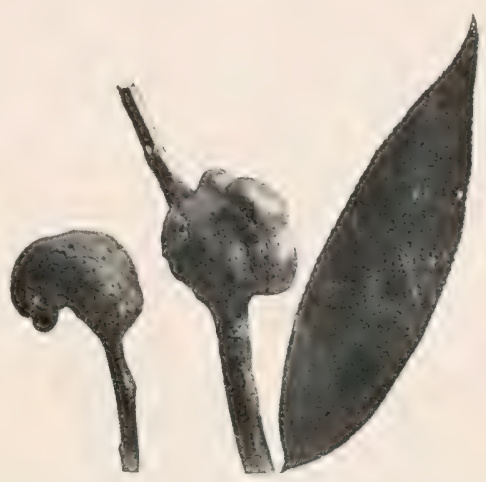

Fig. 168.-Galls of Euura pentandræe on shoots of Salix pentandre.

The larve commence making their pupal cocoons about the middle of April, for by April 28, 1900, they were all in the pupal stage.

The larvæ when full fed are about 8 to $9 \mathrm{~mm}$. long, of a uniform slaty-whitish colour, with darkish hearl. The six true legs are well developed, and there are six pairs of thoracic legs.

The flies hatch out from the 9 th to the 15 th of May. The length of the body is about, 2 lines. Expanse of wings 6 lines; antennæ 9 -jointed. Body wholly black; legs brown, with darkish trochanters.

\section{Pontania salicis (Christ.) Nematus bellus, Zad.}

The galls are formed on the leaves of Salix caprece (goat willow). It is generally most abundant on hilly districts. In some seasons it 
is very common at Kielder, Northumberland. The galls are on the under side of the leaves (fig. 169), and as a rule a single specimen is found on each leaf, though at times two galls coalesce together. They may be either glahrous or slightly hairy, and as a rule the galls

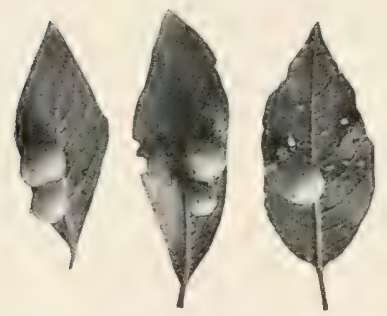

Fig. 169.-Gulls of Pontania salieis on locters of balix capreit. which coalesce generally develop miniature warts. The colour is greenishyellow, with small reddish spots, and the average diameter from 6 to $8 \mathrm{~mm}$. It may be looked for from July to September.

Each gall contains a single larvæ. The grub is very active, and the frass is found within the gall. As the larvæ pupate in the soil, it is well to gather the galls fairly early for artificial breeding. The flies hatch out about the beginning of May (May 9, 1905).

Female. - Head and thorax black; antennæ dark-brown; abdomen black, with yellowish bands at division of segments.
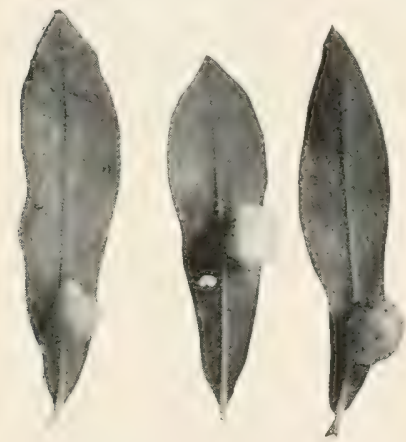

Fig. 170.-Galls of Pontania bella on leaves of Salix viminalis. Under side of abdomen yellow and black. Legs pale, testaceous. Wings hyaline. Stigma dark-fuscous.

Nale.-Colour very much as in female. Smaller in size, and antennæ stouter.

\section{Pontania bella (André).}

The galls of this species (fig. 170) very much resemble those of the preceding, except that they are always found on S. viminalis, which is perhaps the most important distinction to the practical man.

The insects are also very much like those of the previous species; but they hatch out much later in the season-viz., about the end of June. 


\section{Pontania proxima, Lep.}

This species was sent by my friend Mr Forgan, Bowood, Wiltshire, in stems of golden willow. No swellings: only indication is small hole in stem. Larvæ bore in pith. This hatehed May 14, 1902, in confinement.

Fly.-Head, body, and antennæ black. Legs more or less testaceous. Wings black. Antennæ 7 -jointed. Larva, white body, brown head, $\frac{5}{16}$ inch in length.

\section{Pontania Gallicola (Steph.) \\ Nematus vallisnerii, Htg. \\ Nematus gallicola (West).}

In almost every country ramble the leaves of Huntingdon willows may be seen covered with the bean-shaped galls cansed by $\mathrm{A}$. yallimald. The galls (fig. 171) are always formed on both sides of the leaf. They are of a rosy colour, and therefore contrast with the green leaf. A section of the gall, together with a description of its development, would be interesting. In the centre of the gall we get the parenchyma of the leaf so enveloped by the gall that this green substance becomes the food of the larva.

There are two broods in the year. By collecting the galls fairly early in autumn, before the larvæ quit them for pupation, they may be

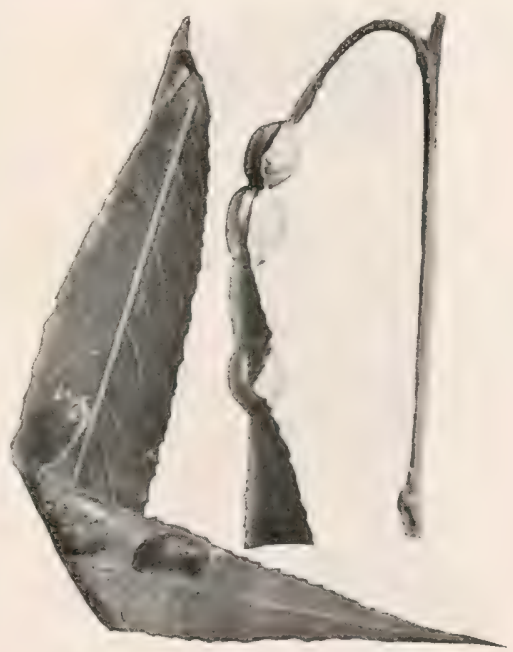

Fir. 171. - Galls of Pontania gallicola on Huntingdon willow. easily hatched out artificially. They quit the galls, and form small leathery cocoons. The flies appear about 9 th May in Northumberland. The second brood is said to hatch out in August. 
Pontania ischnocerus (Thom.)

Nematus ischnocerus, Th.

I have only found this species at Kielder, Northumberland. Cameron gives three localities-viz., Rannoch, Braemar, and New
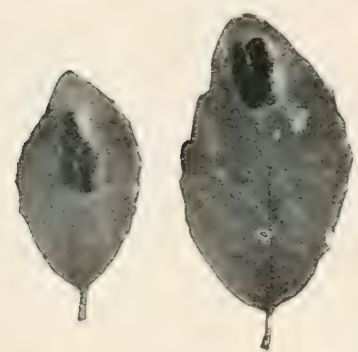

Fig. 172.-Galls of Pontania ischnocerus on species of Salix. Galloway. Fig. 172 is a representation of the galls on the leaves of a species of Salix. This species cannot in any way be considered as an important forest insect, except in so far as it is of interest in a collection.

\section{Gemus Pteronus.}

This genus contains a number of species which have been selected from the old genus Nematus, as regards structure and lifehistory peculiarities. Perhaps the best plan for the student to master the same from a typical species is

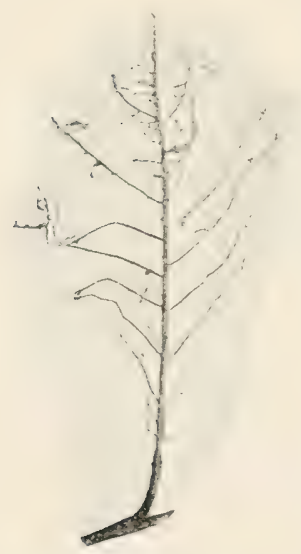

Fig, 173.-Leaf of goat willow (Salix caprea) eaten by larve of Pontania salicis. to work out the life-history of the gooseberry saw-fly, $P$. ribesii, Scop., hitherto known as Nematus ribesii. For specific characters the systematic student is advised to refer to the "Synoptic Table of British Pteronus," by Rev. F. D. Morice, in the 'Entomologist's Monthly Magazine' for June 1906.

\section{Pteronus salicis (Linn.)}

It often happens that in our early summer or late autumn rambles we find bushes of Salix caprece defoliated by sawfly larvæ, as in fig. 173. In this case the insects proved to be $P$. salicis, as identified by Rev. F. D. Morice.

The perfect insect has black antennæ, black or dark-brown stigma, and in both sexes a bright orange-coloured abdomen.

The insect is double-brooded, and can be very easily hatehed out. 
Creesus septentrionalis, Leach (Cameron). Nematus septentrionalis, L.

This species is said to be very commion in some parts of the country; and Cameron says the larve feed on poplar, aspen, birch, willows, hazel, and mountain ash. I have not, however, found it on any of these plants, but in Cheshire it was very common on, and sometimes quite injurious to, alder. Fig. 174 is from a photograph on alder.

The perfect insect may easily be recognised by the peculiar Hattened formation of the tibire and tarsi (fig. $175 \mathrm{~A}$ ), and black colour of the hind legs. Head and thorax black, abdomen black and brown, antennæ as large as the body. Wings hyaline. Spread of wings 16 $\mathrm{mm}$. in male and $24 \mathrm{~mm}$. in female.

The larvæ (fig. 175 B) are bluishgreen, with black head; head, extreme end of abdomen, and prolegs quite yellow; one or two rows of black dots along the body. Length about $30 \mathrm{~mm}$.

The perfect saw-fly is a black and light-red insect. In both sexes head, thorax, and anal portion of

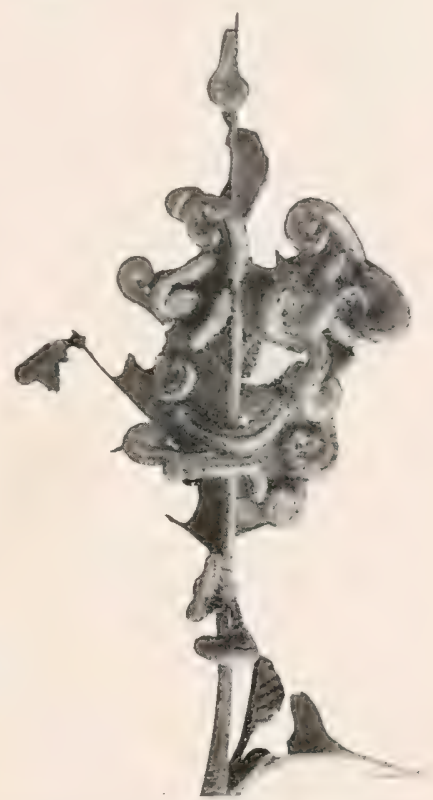

Fig. 174.-Larve of Crosus septentrionalis on alder. abdomen black; remainder of abdomen light-brown. Wings hyaline; stigma in female black, in male light-brown. Length of male $7 \mathrm{~mm}$.; span of wings $16 \mathrm{~mm}$.; female $11 \mathrm{~mm}$; span of wings $24 \mathrm{~mm}$.

I have not worked out the life-history of this species, but Judeich and Nitsche say there is a double generation, the flies appearing in May and August. It is very probable that this may be so in the south of England, while in the north of Scotland there may be only one generation a-year. It is not very common in Northumberland. 
Nemates (Holcocneme) Erichsonit, Htg. (the large Larch Saw-fly).

This insect, though fairly common in some parts of this country, is not even mentioned in any Lnglish literature relating to forest entomology. Cameron writes: " Erichsonii does not appear to be a common species. I have only seen a specimen taken by the Rev. T. A. Marshall, of which I did not know the locality. Mr Dale records it from Glanvilles Wootton." In German literature Judeich and Nitsche, ${ }^{2}$ and also Nüsslin, ${ }^{3}$ only slightly refer to this species. Packard ${ }^{4}$
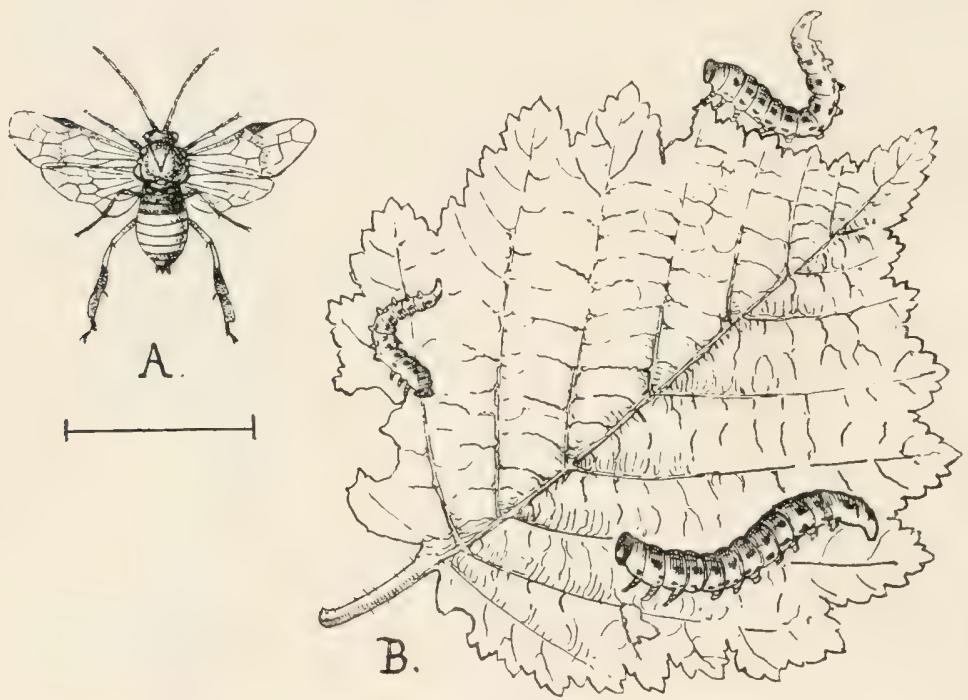

Fig. 175.

A, Crocsus septentrionalis: B, Larve of Crasus septentrionatis. (From F. V. Theobald's 'Ani mal Pests of Forest 'Trees.')

reports it as being injurious in some parts of America, and it is also recorded as being injurious in Canada. ${ }^{5}$ In 1906 it appeared in considerable numbers in Cumberland, so much so that the Board of Agriculture requested Dr R. Stewart MacDougall to inspect the injured

1 Monograph of British Phytophagous Hymenoptera, vol. ii. p. 51.

2 Forstinsektenkunde, Band i., seite 661.

3 Leitfaden Forstinsektenkunde, seite 359.

* Fifth Report of the United States Entomological Commission. Forest Insects, by Packard. 1890.

5 Canadian Entomologist, Nov. 1884. 
plantations and report (see 'Jommal of the Board of Agrienlture,' October 1906). I had in the same year found this species sparsely distributed in Northumberland. As this hitherto rare species has sullenly appeared as a destructive insect, it affords a good case in point of the necessity for the student being well grounded in general entomology.

The damage done by this species consists in defoliating larch-trees of virrious ages (see fig. 176 ); and as the injury is dlone whilst the trees are vigorous, it is obvious that the increment is not only aplrecialily affected, but the health of the tree may be considerably impaired. Is the larch is very susceptible to disease, it is important that everything be done to obviate injuries of all sorts.

Dr MacDougall thus describes the insect: "Adult.-The adult

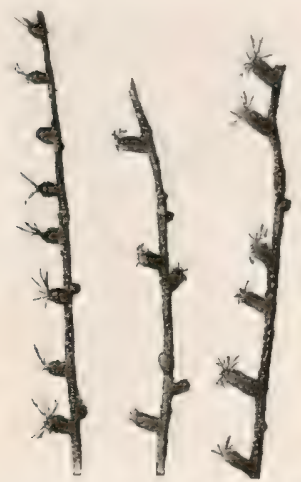

Fig. 176.-Foliage of lareh injured by larece of Nematus Erichsonii.
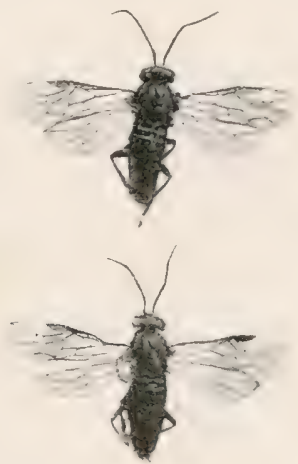

Fig. 17\%.-Nematus Erichsonii.

saw-fly measures up to $\frac{3}{8}$ inch, or a little over, in length, and in spreal of wings just less than an inch (see fig. 177). The ground colour is black. The head and thorax are black; the first joint of the abdomen is black; then follow joints coloured red, the end of the abdomen again being black. The mouth parts, the two front pair of legs, except at the part next to the thorax, and the upper parts of the femora of the hind legs, are reddish or reddish-yellow. The tibix are yellowish or pale in the upper parts. The antennæ are nine-jointed and somewhat thick, and taper towards the apex. With a lens the hear and thorax are seen to be sparsely and finely pubescent, and the thorix is markedly punctured. The wings are glossy, and slightly clouded below the stigma. 
"Egg.-The egg is longish oval, and measures just over a millimetre in length. It is white in colour.

"Lavva.-The full-grown caterpillar measures three-quarters of an inch, or a little over, in length (see fig. 178). It has a round, black, hairy head, with a single ocellus on

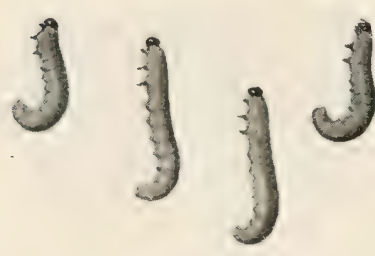

Fig. 178. - Larve of Nematus Erichsonii (slightly reduecd).

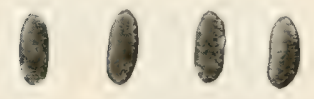

Fir. $179--$ Pupet cosfs of Nematus Erichsonii (slightly reducul). each side. On the upper surface, all down the back, the colour is greygreen; the sides are lighter; the under surface is yellowish-green. If one uses a lens, there will be seen on the abdominal segments transverse rows of minute warts with spines. The spiracles along each side are brown. The legs number twentyviz., three pairs of thoracic legs, which are black, and seven pairs of abdominal legs, which have the colour of the under side of the body. The head is followed by twelve segments or joints: 1, 2, and 3 are thoracic joints, and each bears a pair of legs; 4 to 12 inclusive are abdominal joints; 4 has no legs; 5,6 , $7,8,9$, and 10 have each a pair of legs; 11 has no legs; and 12, the last joint, carries a pair of legs."

Fig. 179 is a representation of the pupæ.

Lygenonemetus saxeseni, Htg.

Nematus abietinus, Ch.

This insect, though often a very great pest on the Continent, is not, as a rule, very abundant in this country.

The injuries may, however, be recognised from the leading shoots of branches of spruce from twenty to sixty years of age being defoliated. This species has been recorled as being rather injurious in Cumberland, and I have found it fairly common at Kielder, in Northumberland.

The larva may be beaten from the spruce branches during the summer months. It is about half an inch in length, and of a uniform green colour, very much resembling a spruce needle. The eyes are black.

As regards the perfect insect, I have so far not been successful in hatching it, though several have pupated all right, and therefore 
cannot give any description. It would be well, therefore, for the student to work it out, more especially as it is not mentioned by Cameron except as a synonym; and the assumption that the abovenamed insect is the one responsible for the damage on spruce is based on the description given by German writers, together with correspondence from Mr Morice.

\section{SIRICID屟 (WOON-WASPS).}

As reginds forest insects, this family is represented by the genus Sirex. The injuries are chiefly done by the larvæ to back-going standing trees, and timber of a secondary class is therefore further depreciated by the larval borings. The trees which are attacked are Scots pine, silver fir, spruce fir, and larch.

The genus Sirex is represented in this country by two species ${ }^{1}$ -viz., Sirex gigas, Linn., and $S$. juvencus, Linn. There are three species in Germany - viz., S. juvencus, S. gigas, and S. spectrum.

\section{Sirex GIgas, Linn.}

This fine insect often attracts considerable attention in estate timber-yards, where logs of Scots pine, spruce, silver fir, and larch

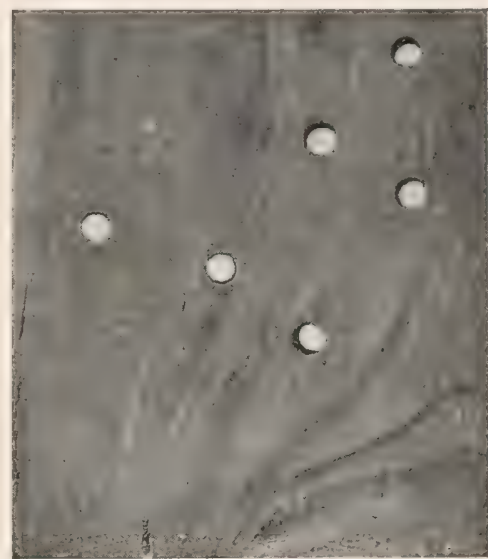

Fig. 180.-Plunt of silew fis (Abies pectinata) injured by Sirex gigas.

are cut up, more especially where the cut logs have been either lying for some time in the yard, or where sickly or previously blown trees (which were unfit for sale) have been brought to the sawmill yard.

This insect is credited with being a very destructive species, but this appears to be an exaggeration, inasmuch as it always attacks sickly timber. Fig. 180 is from a photograph of injuries done to a plank of silver fir (Abies pectinata).

1 There is a third species-viz., $S$. noctilio-but it is very difficult for the practical man to distinguish it from S. juvencus. All three occur in England, but systematic men consider that juvencus is evidently far rarer than noctilio. 
The female Sirex, which is armed with a long ovipositor, lays her eggs in Scots pine and silver fir trees which are either sickly or injured. The full life-history does not seem to have been worked out, either by German or' English entomologists, but it is said that the larvæ attain their full development in about seven to eight weeks, but that they live from two years in the larval stage, and appear as perfect insects the third year. They make a sort of rough semicircular route, at first boring deeply into the wood, and then turning towarls the ontside, in fact often just immediately within the bark. Although the perfect insects do not appear until July, both sexes may often be found within the logs in November as perfectly developed insects. One of the best consignments of those insects I ever

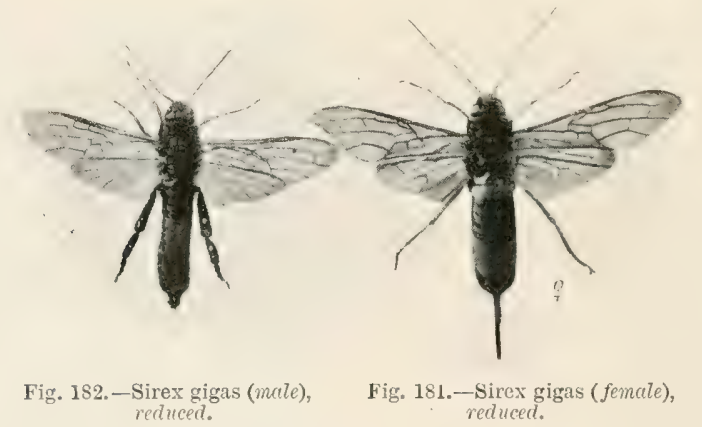

had sent was captured by a miner issuing from props within the coal-pit.

The tarce are whitish and soft. The head is scaly, and armed with strong jaws, and there is a blunt hook at the extremity of the tail segment. They are about $1 \frac{1}{4}$ inch in length, and about $\frac{1}{4}$ to $\frac{3}{8}$ inch in diameter. I have never found any pupal stage except as tightly packed forms of the perfect insect.

The female (fig. 181) is usually $1 \frac{3}{4}$ inch in length from head to extremity of ovipositor, and about $\frac{1}{4}$ to $\frac{3}{8}$ inch in breadth. The antenne are filiform, yellow, and 18- to 25-jointed. The head is black and hairy; eyes and ocelli black. There are two yellow portions behind each eye. The thorax is wholly black and hairy. The abdomen is made up of nine joints, the colour being banded of yellow and black.

There is a black velvety band across the middle of the abdomen, on either side of which there is a yellow band, the abdominal segment 
heing terminated by the ovipositor. The wings are over two inches in expanse, and the legs are yellow.

The male (fig. 182) is smaller than the female, and with comparatively long antenna. The abdomen is flattish and brown throughout, except the first segment, aljoining the thorax, which is black. The absence of the ovipositor is of course the salient point in quickly determining the sex. The legs are also darkish-brown.

\section{Sirex Juvencus, Linn.}

The habits of this insect are almost identical with the preceding species. There appears, however, to be a difference of opinion

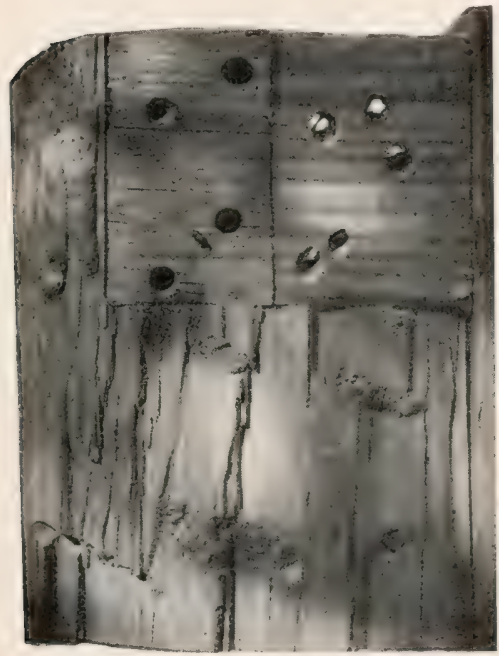

Fig. 183.-Spruce timber injured by Sirex juvencus. $a$, shows transverse section of timber; $b$, shows longitudinal section of timber.

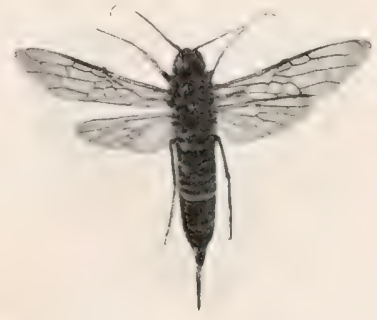

Fig. 184.-Sirex juveneus (female), reduced.

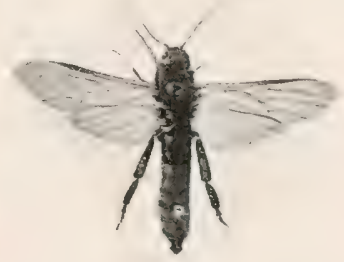

Fig. 185.-Sirex juvencus (male), reduced.

amongst various writers as regards the trees upon which they are found, and it is possible either species may be general feeders on the trees named; but so far as my observations go, I should say Sirex jucencus on spruce and larch, and Sirex !riygs on Scots pine and silver fir. Fig. 183 is a representation of injuries done to the timber of spruce.

The larvæ are narrower and more elongated, and more of a dirtywhite colour.

In general outline the female (fig. 184) resembles that of Sire. 
gigas, except that it is smaller, and the antennæe and entire body of a shiny metallic or steel-blue colour. The legs are also darkish.

The male (fig. 185) resembles the female except in being smaller. The thorax and first thoracic segment are steel-blue. The legs are darkish, with the segments flattened.

\section{MISCELLANEOUS HYMENOPTERA.}

As the section of this order known as Phytophagous Hymenoptera is so large that it would require practically a lifetime for the student to grasp, it is obvious, having regard to the size

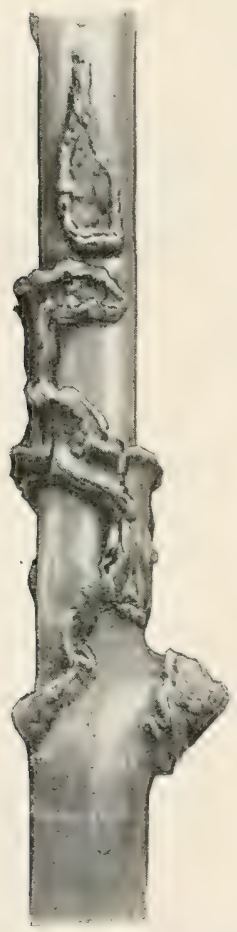

Fig. 186.-Injury done to ash stem by hornet. (Drawn by P.J. Brown.) of the field in forest entomology, that any attempt to give correct systematic classification in its entirety would overload the chapter. It is therefore deemed advisable to give the following insects as "Miscellaneous Hymenoptera," without any attempt at classification.

\section{Vespa Crabro, L. (Hornet).}

When one sees a hornet's nest, or rather the hornets moving in and out of their nest in a hollow of a tree trunk, they may be considered as belonging to the realm of the general entomologist, rather than to the student of forest entomology. In this country they are confined to the south of England, and do damage to young stems of ash and alder. In Germany, where they must in some places be very numerous, Dr Altum gives a very detailed description of the damage they do to various forest trees, much after the illustration given. I received a damaged young elm from Newmarket, discovered by Mr Bond, Lambton; and Mr Forgan, Bowood, Wilts, kindly forwarded me specimens of young ash-trees which were considerably damaged, of which fig. 186 is an illustration.

Fig. 187 is from a photograph of a hornet kindly sent me by $\mathrm{Mr}$ A. Cameron, forester, Longleat, Wilts. 


\section{Rhodites eglanterie, Htg.}

The galls are found on leaves of dog-rose (Rese ranina), generally on under side of leaves, but also on upper surface and sometimes on leaf-stalks. They are very pretty spherical galls, about 3-5 mm. diameter, with beautiful blending in colour of yellow, green, and red, having a small attachment to leaf, and with a large inner cell.

They may be looked for from July to September, but may be very easily overlooked. The galls, when

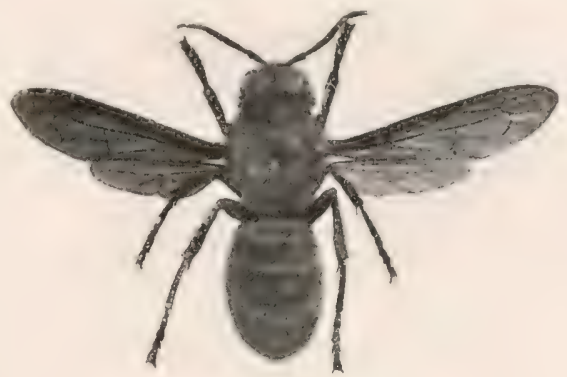

Fig. 187.-Hornct (Vespa Crabro). fully developed, fall to the ground. The larva pupates within the gall. Fig. 188 is a representation of the galls on the under side of the leaf.

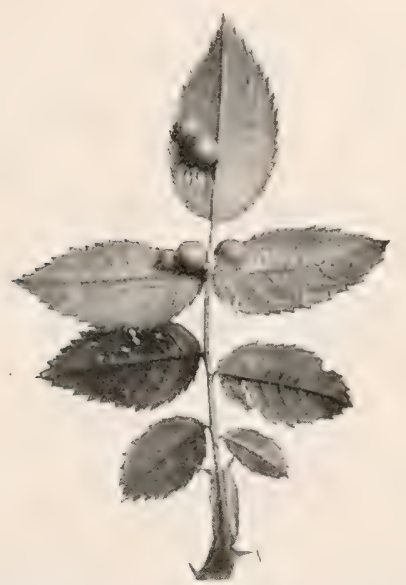

Fig. 185.-Galls on under side of leaf of dog-rose (Rosa canina) caused by Rhodites eglanteriæ.

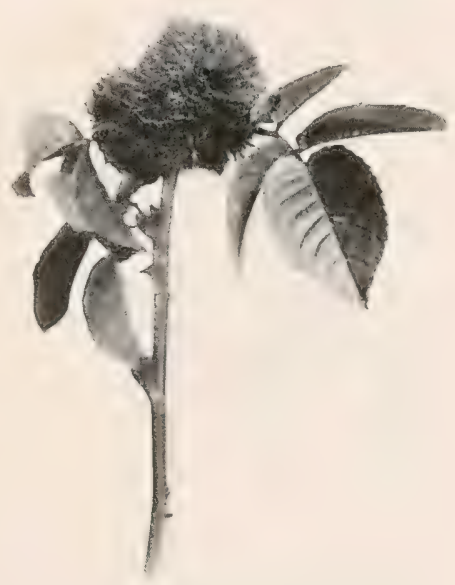

Fig. 189.-" Moss or pin-cushion gall," caused by Rhodites rose.

\section{RHODITES ROSE, Htg.}

This insect, through its oviposition, causes the familiar growths on Alog-rose (Rosa cunina) known as "Robin's pin-cushion," "Moss galls," "Bedeguar galls," \&c. This gall (fig. 189) is common in every lane, 
and may be considered one of the most remarkable gall-growths arising from insect agency, which causes modification in the vegetable organism. It may originate either from a bud or leaf. First of all, we get a very sudden "moss-gall," and each hair is a beautiful feathered structure. Later on we get a conglomeration of woody cells, varying in number from three or four to thirty or forty. Each cell contains a single grub; the interior is smooth and clean, and the outside hardy and woody. The growth is complete by the end of August, and the first flies appeared in confinement June 9, 1901, Northumberland, and again on July 9, 1906.

\section{Megastigius spermotrophus, Wachtl.}

This insect, both in point of damage and structure, is entirely different from all the other genera and species belonging to the order Hymenoptera which we have been hitherto considering.

It is the only known hymenopterous insect directly injurious to the seed, and it belongs to the sub-order Petiolata, which are characterised by a constriction between thorax and abdomen. To this order belong the bees, wasps, and ruby flies, and a large series known as the Parasitica, of which a very large number of examples may be found from parasites bred from the various species of oak galls. In fact, Cameron gives species of Megastigmus as parasitic on several species of galls.

This insect has been very fully worked out by Dr R. Stewart MacDougall, ${ }^{1}$ by whose kind permission I herewith give the following notes from his valuable paper.

The damage was first discovered by Mr John Crozier, forester, Durris, near Aberdeen. So far as Scotland is concerned, Durris may be almost called the home of the Douglas fir, and therefore $\mathrm{Mr}$ Crozier wrote in the following terms to Dr MacDougall :-

"The insect has, for some years back, been causing a serious loss to our stock of Douglas fir seed. I noticed its presence on coming here nine years ago, but it had no doubt been in the estate before that time. Seed was plentiful, however, and as the damage was comparatively trifling I did not pay much attention to the fact. Now, however, it has assumed a more serious aspect, as the seed

${ }^{1}$ Transactions of the Royal Scottish Arboricultural Society, 1906. Vol. xix., Pt. I., p. 52. 
on many of the older trees from which I formerly collected my supply, in good years amounting to over 300 bushels, is not worth the trouble of gathering. I have raised some millions of plants on this estate, but unless this pest can be kept in check, it will be impossible to keep up the stock from home-grown supplies."

Fig. 190 is a representation of injuries done to the seeds of Douglas fir (Preurlotsuga Doumlasii). The small holes show the exit of the insects, and the seed is therefore totally injured.

Dr MacDougall gives the following deseription of the insect:-

"This insect, Megastigmus spermotrophus, was first received by Wachtl, of Vienna, in 1893, and was described by him as a new species. In the spring of 1893 Wachtl got some specimens of Megastigmus insects that had issued from the seeds of the Douglas fir. From these specimens Wachtl described the male and female of the species, which description I now give, in translation, from
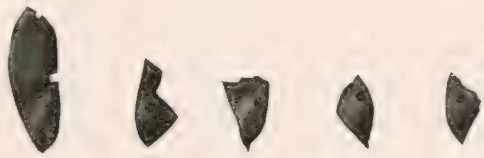

Wachtl's paper:-

"'The female (fig. 191) is loam-yellow; the vertex of the head and the forehead to the base of the antennæ are red-brown; the central part of the face

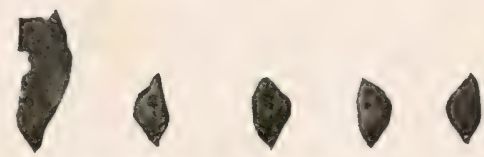

Fig. 190.-Seeds of Douglas fir (Pseudotsuga Douglasii) injured by Megastigmus spermotrophus (slightly reduced).

(epistome), the inner edges of the eyes, and the palpi, yellow; the ocelli red-brown, each edged with black, and sometimes connectecl with one another by means of black lines; never, however, is the entire inner surface of the ocellar-triangle dark-coloured; the eyes during life are shining coral-red, after death red-brown; antenna hlackish-brown, the scape, and the part between the scape and the flagellum, reddish-yellow; the pronotum with a more or less broad yellow band at the hind edge; the scutum of the mesonotum generally red-brown; the outer side of the shoulders and the furrows of the parrapsides yellow; the surroundings of the bases of the wings to a slight extent black; the diaphanous wings finely black haired; the knob or club of the ramus-stigmaticus longer than broad, elliptical and black; the coxe of the fore-legs yellow; the pulvillus on all the legs black; the compressed abdomen reddish-brown on the upper 
side, with a larger or smaller black-brown or black spot at the base of the first segment, and becoming paler at the edges. This spot is sometimes wanting; on the other hand, the end of the body and the under surface of the abdomen are somewhat light-coloured; the sheath of the ovipositor is intense black.

"All the flagellum joints of the thirteen-jointed antennæ are longer than thick, and become gradually a little less towards the apex of the antennæ; the first joint is the longest, the others practically agree in length; the three-jointed club is egg-shaped, and as long as the two foregoing joints taken together. The central part of the face is obliquely wrinkled, the forehead longitudinally

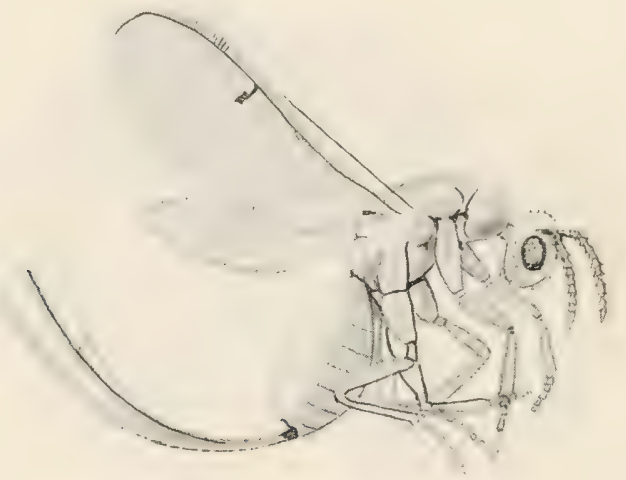

Fig. 191.-Megastigmus spermotrophus (female). (Drawn by P. J. Brown.)

wrinkled; the vertex of the head, the prothorax, the mesothorax, and the scutellum are transversely wrinkled; the post-scutellum, outlined by a fine deep line, is glossy and smooth except at the base and along the longitudinal middle line, where it is finely puncturer ; the metanotum is finely punctured, with a prominent longitudinal keel in the middle, and in the case of most examples, with a transverse ledge at the limit of its front third; the hind margin is glossy smooth, without sculpture. The face, mesonotum, all the coxæ, the tibire and tarsi of the fore-legs and the middle and hind legs, are white haired; the vertex of the head and the forehead, the thorax, especially both sides of the furrows of the parrapsides, the scutellum other than the post-scutellum, the femora of the fore-legs and the 
hind edges of the segments of the abdomen, are beset with longer or shorter black bristles. The ovipositor is as long as the body. The body length of the female measures from $3.25 \mathrm{~mm}$. to $3.5 \mathrm{~mm}$. (= roughly $\frac{1}{8}$ to $\frac{1}{7}$ of an inch).

"The male (fig. 192) is ormnge-yellow; antemne reddish-brown; the pronotum has, in the midlle of the front edge, a black transverse patch, which is somewhat elongated behind, in streak-like fashion, in the direction of the middle line, sometimes resolved into two sputs or reduced to two points; the scutum of the mesonotum is reddish-yellow, and provided in front with a black-brown spot, paler behind, which sometimes only shows through the hind end of the pronotum more or less clearly; the bases of the wings and the metanotum are black; the tarsi of the forelegs, as well as the middle and hind legs, are reddishyellow; the strongly compressed abdomen is brownish-red above, with a black longitudinal patch at its base, gradually narrowing behind and becoming paler at the edges.

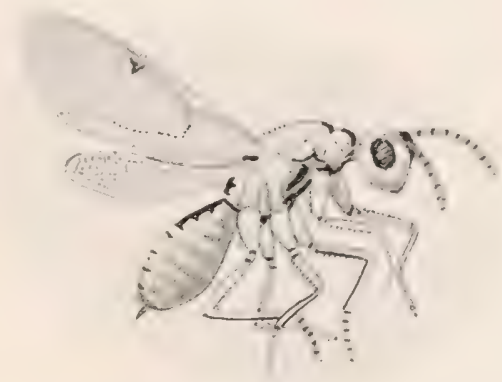

Fig. 192.-Mesastigmus spermotrophus (male). (Drawn by P. J. Brown.) Sculpture, hairing, ic., as in the female. The hody length of the male measures from $275 \mathrm{~mm}$. to $3 \mathrm{~mm}$. (= $\frac{1}{9}$ to $\frac{1}{8}$ of an inch).'

"So far as I know, the larva has not till now been described. It is whitish in colour, and legless. The segments are well markerl, and indeed the general appearance, including the wrinkled and eurled form, is strongly reminiscent of a weevil grub. The marked horny head of the weevil grub, however, is absent. Instead, in the megastigmus larva, each of the two chitinised gnawing jaws is somewhat sickle-shaped, the two jaws together reminding one of a pair of callipers. The apex of each jaw is pointed, and on the concave side is provided with marked teeth. These gnawing mouth-parts are rect or yellow-brown in colour."

As regards the life-history of the insect, it of course hatches out quite freely in confinement. Each infested seed contains a single larva, and when the fully developed insect emerges from the seed 
there is nothing left but an empty husk. The insects hatch out freely in May and June, and no loubt the insect contains only a single brood in the year. As the female flower or cone of the Douglas fir is very open in the scales, the female insect can have no difficulty in depositing an egg in each seed.

Having regard to the recognised value of the Douglas fir as a tree, and to the unrecognised value as a shade-bearer, it is imperative that this insect should, as far as possible, be kept in check. There is, of course, no way of dealing with the perfect insect in the open wood, and therefore remedial measures must be taken with the seed. Hence Dr MacDougall's remarks may be given in full :-

"The cones should be gathered as soon as ripe (the latter half of October), and should at once be subjected to such treatment as will permit of the seed being abstracted. This seed should without delay be fumigated with bisulphide of carbon. The method is as follows :-

"Place the material to be treated in an air-tight receptacle. Pour the bisulphide of carbon into a saucer or saucers, or such shallow dish, and lay these on the top of the material. Close the receptacle. The bisulphide of carbon vaporises, and as its fumes are heavier than air, they sink down through the material. The receptacle should be kept closed for forty-eight hours. One ounce of bisulphide of carbon will do for $100 \mathrm{lb}$. of seed, or one ounce for every 50 cubic feet of airspace. The treatment should be administered in not too cold a temperature. Bisulphide of carbon fumes, being poisonous, should not be inhaled by the operator, nor should a light of any kind be brought near. If it is desired to store the cones during winter or longer, these must be similarly fumigated directly they are gathered.

"The results to be looked for from fumigation are-

"1st. The germinative capacity of such seeds as have not been infested is not interfered with.

" 2 nd. In infested seed, where the larvæ may not have made much progress in the destruction of the reserve in the seed, the larva will be killed, and the seed may germinate.

" 3 rd. In infested seeds, where the contents have been altogether or much destroyed by the larvæ, and which therefore would not have germinated, the larvæ will be killed, and the issue of the next year's brood of adults prevented. 
"The light seed blown through by the fan at cleaning time should be burnt at once, and where there has been attack, this will probibly account for many of the pests."

As an insect-pest the Megastigmus is a very good case in point, as showing that forest entomology is a very large and imperfectly worked field. Though the insect harl not been noticed until about 1897 or so by Mr Crozier, still it has, no doubt, been in the country for a very long period. At the same time, it is quite likely that its numbers have been cunsiderably increasel with imported seed from Westem North America. It is possible that it may be very abundant on other estates throughout the country, either as an insect-pest where the seed of IDouglas fir is available, or otherwise adapting itself as a parasite, either on oak-galls or other suitable hosts.

\section{Megastigmus strobilobius, Ratz.}

Referring to the remarks on the previous species, and the probability of other species of Mryustigmus: in the country, I received in the early spring of 1906 a few seeds of silver fir containing larvæ from Mr A. C. Forbes, of the Armstrong College, Newcastle-on-Tyne, who had received a single cone from Longleat, Wiltshire. Fig. 193 is a representation of the injured seed.

On July 15 three female insects emerget, and the specimens were quite distinct in colour and other characters from the previous species, and I made the following note :-

Three specimens, all females. Black marked with yellow, vertex of the head black. Central portion of face yellow. Eyes red-brown. Antennæ blackish-brown (entire length); whole pronotum black. Tings hyaline black. Fore-legs, coxa, and tibia yellow, tarsus blackish. 2nd

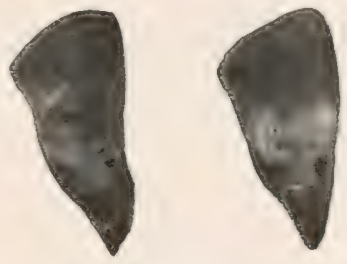

Fig. 193.-Seeds of silver fir (Abies lectinata) injured by Mlegastigmus strobilobius. and 3rd pairs of legs yellow throughout, or darkish coxa, and other parts yellow. Abdomen on dorsal surface black, with yellow markings; under surface yellow.

In 'Forstinsektenkunde,' by Judeich and Nitsche, there is a note to the effect that Wachtl should not have priority for the 
discovery of a Megastigmus species as a conifer-seed enemy, as Borries had pointed out to Judeich by letter in 1887 an insect of the genus Torymus - viz, massive females, but no males, of Megastigmus strobilobius, Ratz.

\section{References to Literature consulted.}

Cameron, P. A. Monograph of the British Phytophagous Hymenoptera. 3 vols. Ray Society.

Cameron, P. A. "The Galls of Mid-Cheshire"-Manchester Microscopical Society. 1892.

Carpenter, George H. Insects : their Structure and Life. 1899.

Judeich und Nitsche. Lehrbuch der Mitteleuropüischen Forstinsektenkunde. Berlin. 1895 .

MacDougall, Dr R. Stewart. Megastigmus spermotrophus, Wachtl.

MacGillivray, Prof. Alexander Dyer. A Study of the Wings of the Tenthredinoidea, a Super-family of Hymenoptera. Washington. 1906. (This is a most excellent work.)

Marlatt, C. L. Revision of the Nematina of North America. Washington. 1896.

Morice, Rev. F. D. "Help-Notes towards the Determination of British Tenthredinidx" -Entomologist's Monthly Magazine for Jan, 1903.

Nüsslin, Dr Otto. Leitfaden der Forstinsektenkunde. Berlin. 1905.

Ormerod, Miss. Manual of Injurious Insects. 2nd edition. 1890.

Trail, Prof. James W. W. The Gall-making Hymenoptera of Scotland (exclusive of those that live on Oaks). 1888. 


\section{CHAPTER VI.}

\section{COCCID $Æ$ (SCALE-INSECTS).}

THere is perhaps no class of insects more puzzling to the practical husbandman, the economic entomologist, or the biologist who is anxious to gain a general knowledge of insect structure and lifehistories, than the Coccidæ or Scale-Insects. The student must rely almost entirely upon the microscope for the accurate determination of these insects, which from their minute size present exceptional difficulties. Even for general field-work it is necessary to have recourse to a strong pocket-lens; as to the naked eye, they may be confounded with lenticels-as, for example, those on birch-twigs. They may also be mistaken for certain micro-fungi on leaves or stems of various plants.

In the Introctuction it was emphatically asserted that concentration in the study of forest entomology was indispensable, inasmuch as almost every natural order was represented, and thus as a branch of forest science, to the forester in particular, general versatility in entomology was impossible. Scale-insects, however, are to some extent an exception to this rule. The arboreal-feeding species of this important family are comparatively few, and therefore, in order to thoroughly understand the salient characteristics, it is necessary to glean information from all available sources. In other words, in order to thoroughly understand the special part, it is essential to make a general study of the available whole.

But though the arboreal species in this country are comparatively few in numbers, the forester, or student of forest entomology, can always obtain an abundance of material from various plants cultivated under glass - the amateur greenhouse often being a happy huntingground.

Temperature and climatic conditions are important factors in the distribution and regulation of scale-insects. Hence warm greenhouses 
afford several important advantages to the student. Thus where the temperature is, comparatively speaking, perpetual summer, we find several broods occurring throughout the year, as well as the creatures in their various stages of metamorphosis. In the forest, on the contrary, many species are not only local in area but sparsely distributed, and all are single-brooded. In hothouses, through importation, plants are collected from various parts of the world, and thus, to some extent, we get in private greenhouses and public botanical gardens an approximate epitome of the scale-insects of the world. It is therefore evident that, in order to understand the life-history of many scales originally imported, but now acclimatised to our glasshouses, recourse must be had to foreign and colonial literature. Not only is it advisable to study the literature relative to foreign scales, but it is essential to study the microscopical structure of the foreign scales themselves which are to be found on our imported plants and fruits. And as the dead females answer best for microscopical examination, greengrocer's stalls may be looked upon as a very happy hunting-ground-more especially at a time of the year when life is dormant, and when the working entomologist may use his microscope as an instrument for original research in a comparatively fresh field.

But the study of foreign scales and the literature bearing on them has, in addition to its charms and pleasures, a very practical bearing, inasmuch as we find that some species are quite cosmopolitan in distribution. We also find that many species which are practically identical to the naked eye, and likewise in point of damage, prove on microscopical examination and in their life-history to be quite distinct. As regards the value of such knowledge bearing on the discrimination between foreign injurious senle-insects and the apparent introduction of any particular injurious species into this country, as recognised only from naked-eye characters practically identical to the casual observer, one important case may be cited-viz., the San José scale (Aspidiotus perniciosus) from California, as compared with the scurvy-bark louse (Aspidiotus ostreceformis) of this country. The former is a sub-tropical insect, and would not likely withstand the rigours of a Western climate. In fact, it has not even established itself under glass in this country.

In the year 1898 it was thought the San Jose scale-insect had established itself in this country, and so much was the scare felt 
that the Board of Agriculture invited Mr Newstead to give evillence before a special committee meeting at the House of Commons. $d$ s the result of previous studies, he was able to dispel all fears, and subsequent experience has amply justified his opinions.

As showing the wile geographical range of certain scale-insects and their adaptability to varied food-plants, one species, namely, the common mussel-scale (Mytilaspis pomorum), may be cited. Newstead says: "It occurs as a pest in almost every part of the world where the apple is cultivated-in Europe, North and South, the Lnitul States, New Zealand, Australia, North Africa, and probally miny other places."

The Coccila or seale-insects belong to the order Hemiptera, which is subdivided into two principal divisions-viz., Hemipteri-ILeteroptera, which includes the bugs; and the Hemiptera-IIomoptera, which includes $A$ phidide, Cicadæ, Psyllide, and Coccide or scale-insects. The last are broadly distinguished from other families by the wirlo or merting which they spin to protect their bodies. Hence the Germans call them by the expressive term Schildlüuse (shield-lice).

Having often found that intelligent practical men designate scale-insects as a "very low form of life," it may be well to show their close relationship with other families which are grouped together in the same suborder. As in point of structure and lifehistory they are very closely associated with other families of the sub-order, it may be well, even at the risk of repetition, to present the more salient features of each family as an educational advantage to the clearer discrimination of the relationship which exists between them. All the insects of the natural order Hemiptera are characterised by the

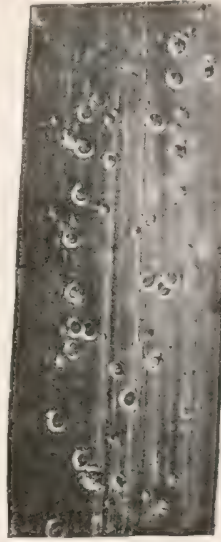

Fin. 194. - Cerataluhis latanie (fringed aphis) on palon. Known to horticulturist as the "black-seed scale." possession of suctorial mouths, and therefore belong to that great division of Insecta known as Haustellata.

The Aphidide or plant-lice are soft-bodied insects, usually green, with long, rather slender legs, and not formed for leaping. They oceur in two forms-winged and wingless. The beak (proboscis), or feeding-organ, is often very long, and the tarsus two-jointed. One 
species of this family is often mistaken for a scale-viz., the fringed aphis (Cerataphis latanice), known to horticulturists as the "blackseed scale": it occurs on palms, orchids, \&c. (see fig. 194).

The Psyllidæ very much resemble the Aphididæe in general appearance, but their legs are formed for leaping. The wings are clear, the antennæ conspicuous, long, nine- or ten-jointed, and the eyes large and prominent. The tarsus is two-jointed.

In general appearance the Aleyrodidxe are the nearest approach to the scale-insects, more especially so in their nymphal or pupal

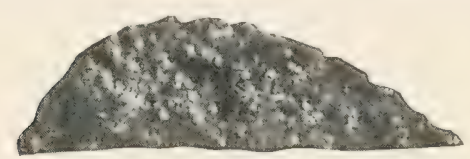

Fig. 195.-Scule-like seretion of a leurodes on leaf of tomato. stages. Their bodies are of an ivory-white colour, scaly-looking in appearance; both sexes are winged, and the tarsi two-jointed. They often deposit a scale-like secretion on plants (see fig. 195).

Aleyrodidre are found on tomatoes, \&c., in greenhouses, and on ivy, lime, and hazel in the woods.

The closely allied Coccide are broadly distinguished from the other families of the Homoptera just referred to by the following characteristics-viz. In the females by being naked (Lecanium), clothed partly with secretion and partly with moulted skins (Diarpince), or clothed with white meal-like secretion (Dactylopius), and with wax-like plates (Ortheria). The tarsus in all the British species but one ${ }^{1}$ is composed of a single joint; there are also two foreign genera in which the tarsi are two-jointed.

The larva are minute, and very active when young, usually naked, and the sexes are inseparable in the first larval stage.

The female undergoes a semi-complete metamorphosis, is apterous in all stages, has generally a well-developed rostrum, and, accorling to the genus, the legs may be present or absent.

The adult male undergoes a complete metamorphosis, and may be winged or apterous. It has no mouth or feeding-organs, but possesses six legs, eyes, and antennæ.

It is important to bear in mind that both sexes secrete a varying quantity of waxy, homy, mealy, or resinous substances for the formation of their shield-covering or scule, and that these secretions or coverings vary in form and colour. In fact, those differences are so

\section{${ }^{1}$ Excretopus formiciticola, Newst.}


clearly pronounced that they afford valuable data, not only for the distinction of sex, but for the separation of the various sul)-families and genera. These remarks are applicable to the "scales" of both sexes, but more especially to the male scale or puparium.

Naskell ${ }^{1}$ gives the following microscopical characters :-

(1) The presence of only one joint in the tarsus, or fourth joint of the leg, in males and females.

(2) A single claw terminating the leg in males and females.

(3) Two wings and two halteres in the males.

(4) Two or more eyes or ocular tubercles, in addition to an ordinary pair of eyes.

With regard to the classification of scale-insects, it would be quite superfluous under "forest entomology" to give all those sub-families at present known in the British Isles, but the following genera, according to Newstead's Monograph, are arboreal in their habits:-

\section{Symopis of Sub-FaMilies. ${ }^{2}$}

\section{Males with Simple Eyes.}

A. Abdomen of female terminating in a compound segment forming a definite pygidium. Anal orifice simple.

(1) Insects with a separate covering seale (puparium) composed partly of moulted skins (exuviæ) and partly of secretion. Adult females without legs; antennæ rudimentary ; mentum monomerous

Diaspinæ.

B. Abdomen of female without definite pygidium. Anal orifice setiferous.

(2) Females with a posterior extremity cleft; anal orifice closed by a pair of dorsal plates. Larvæ with prominent setiferous lobes within the anal cleft . . . Lecaniinæ.

(3) Adult females with cleft extremity and anal plates, as in Lecanium. Larvæ with abdominal lobes, as in Dactylopiinæ . . . Hemicoccinæ.

(4) Abrominal extremity not cleft, usually with a pair of more or less prominent setiferous lobes at margin. Abdominal extremity of larvæ similar

Dactylopiinæ.

1 Scale-Insects of New Zealand.

2 From vol. i. p. 67. 


\section{DIASPIN平.}

The sub-family or group Diaspinæ may be defined, from a purely entomological point of view, as insects covering themselves by a shield or scale composed partly of discarded skins and partly of secreterl matter. Two very common scales-viz., the species on ash, \&c., and the species on fruit-trees known as mussel scale - are very good examples of this sub-family. As there are, however, other forms of scale belonging to this group, it is often somewhat difficult to determine to what genus the scale really belongs. The first point to note is the form of the scale-whether it is linear or circular. But this in some cases is not always quite sufficient, as the male scale, or puparium, must be looked for to determine the genus. Hence the following characters may be given-viz. :

Female scale circular (fig. 196); male scale circular (fig. 197)

Aspidiotus.

Female scale circular (fig. 198); male scale lineur (fig. 199)

Diaspis.

Female scale linear (fig. 200); male scale linear (fig. 201)

Chionaspis and Mrtilaspis.

These are most important points to remember, inasmuch as it is sometimes impossible to determine the genera until a male scale is found.

In fig. 196, which represents a female scale of the genus $A s$ pidiotus, $a$ represents the first larval moult, $b$ the second larval

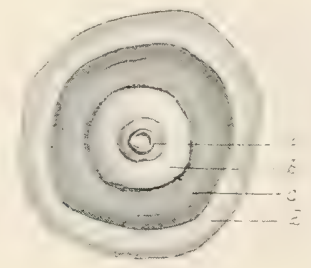

Fig. 196. - Female scale of Aspidiotus. $a$, first larval moult ; $b$, second larval moult; $c$, portion representing sub-lying body of female; $d$, outer secretionary portion of scale.

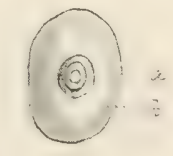

Fig. 197.-Male scale of Aspidiotus.

$a$, larral moult; $b$, secretionary portion.

moult, $c$ the underlying female, and $d$ the outer "scale" which is spun by the insect, and thus attached to, but extending beyond, the 
ear-shaped (pyriform) and white, with exuvix at the anterior xtremity. Under a pocket lens the two larval moults may be istinctly recognised. The male puparium is elongate, and composed Imost entirely of a pure white secretion, with the yellowish larval loult at the anterior extremity.

\section{Chionaspis salicis (Limn.)}

The scales of this species are very common on ash, willow, and ther trees. In some parts of the country, notably in mid-Cheshire, ve find young ash-trees from six to eighteen years $\mathrm{f}$ age, and osiers from four years and upwards, ompletely covered with these scales. They are omparatively small, and if accurately measured would probably be about $.75 \mathrm{~mm}$. in length.

A cursory examination shows that two forms of scale appear on the stems -the male form (fig. 203) and the female form (fig. 204). Sometimes ive find both sexes on the same tree, at other times only females are found. In those cases where the male form preponderates, a whitish appearance is presented, as in fig. 203, where the male seales, or
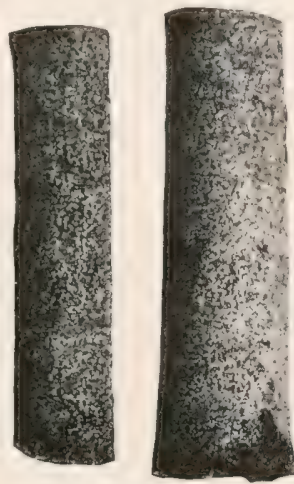

Five. 203. - Male scales of Chionaspis salicis on bark of a young ashtree.

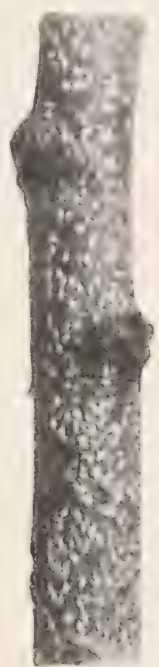

Fig. 204.-Female scales of Chionaspis salicis on stem of a five-yearold balsam poplar. puparia as they are called, entirely cover the bark of the young stem. Those two forms, as seen collectively by the naked eye in figs. 203 and 204, and individually magnified in fig. 205 ( 7 and 3), represent the male and female forms of Chionaspis salicis.

If we lift a perfect female scale any time during the winter months, turn it over, and examine the under side with a lens, or as an opaque object with an inch objective, a considerable number of beautiful red eggs will be noticel (fig. $205(4)$ ). In my younger days, when working in the woods, I have often rubbed my thumb-nail 
against the bark infested with Chionaspis, and sincerely designated the squashed eggs as "blooil." Subsequent research with the microscope has yielded many happy hours with what was originally crushed in a careless and thoughtless manner. These eggs are of a chocolate colour in autumn, just after oviposition, but become

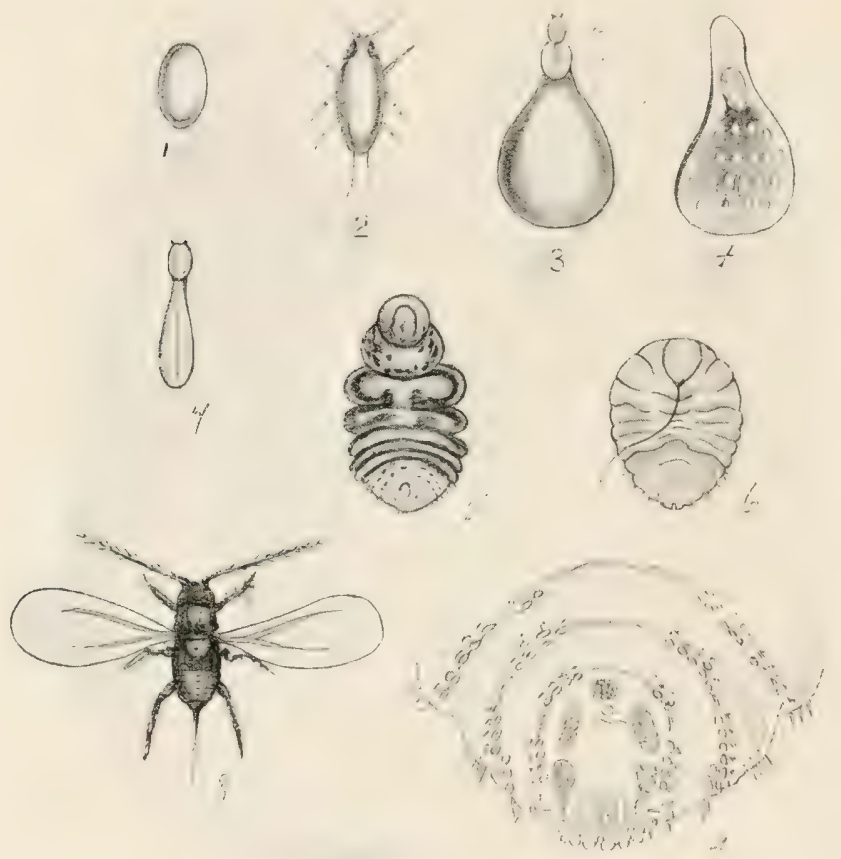

Fig. 205.-Life-history of Chionaspis salicis.

1, egs; 2, larva; 3 , dursal surface of female scale- $(a)$ first larval moult, $(b)$ second larval moult; 4 , under surface of female seale, showing dead female and eggs; 5 , fully developed female at period of fecundation; 6 , form of female scale at period of egg-deposition; 7 , male scale or puparium ; 8 , fully developed male; 9 , pygidium or anal segment of female as seen under $\frac{1}{4}$-inch objective.

lighter during the winter months. Now let us follow the development of these eggs. Fig. 205 (1) represents a single egg. The larvæ hatch out in Cheshire about the beginning of May, and by the middle of that month the infested stems may be recognised at a considerable distance, on account of the numerical strength of the larvæ, imparting quite a red colour to the stem. These larvæ (fig. 205 (2)) are at first 
very active, and measure approximately about the $\frac{7}{100}$ of an inch in length. They possess six legs (the tarsts being single-jointed, and terminated by a claw and knobbed hairs), comparatively long antemn of five or six joints, two eyes, and two very long transparent hairs at the posterior end of the body. Under imperfect magnification the sergmentation of the abdomen camnot be clearly traced; lience I at first hastily, but erroneonsly, concluded that "the posterior legs spring from the abdominal part, which is a unique feature in insect anatomy." 1 In the course of two or three days they assume a quiescent state, and inserting their beaks (proboscis) into the bark of the tree, suck up its juices. As soon as the larvæ assume this habit they enlarge consirlerably, and the legs and the antenux disappear beneath the body. After the larva has grown for a short time it casts its skin, and it is after the first larval moult that the sexes are determined. The female scale develops into the form shown in fig. 205 (3), and the male as shown in fig. $205(7)$.

Now let us follow the development a little more fully, and first with regard to the female. After the first larval moult, which is represented by fig. $205(3 a)$, the creature develops and again moults, the second larval moult being shown by $b$ in the same figure. Up to this stage the creature protects itself by means of cast-off skins, but the female now commences to further protect herself by means of a covering or "scale," which is spun by minute organs known as "spimnerets," and represented in fig. 205 (9). After the second larval moult the metamorphosis of the female insect is complete. The full development is shown by fig. $205(6)$, from which it will be seen she is simply an inert slug-like creature made up solely of body and mouth.

The rostrum or mouth serves the double function of feeding-organ and anchor, but in the latter capacity it is further assisted by the long hairs, or "setre" as they are termed. And sometimes when the females are loosened from their host-plant by birds, they may be seen dangling in the air attached by the "setre" alone.

Prior to the deposition of eggs, which takes place in September, the body entirely fills the orisac, but as the eggs are deposited the hody gradually shrivels until it ultimately occupies but a very small portion at the upper or anterior end of the scale. The female dies shortly after the egrgs are deposited, and during the winter months the dead female and the eggs may be found under each scale.

\footnotetext{
${ }^{1}$ British Naturalist, Feb. 18.94.
} 
If a microscopical examination of the female be made in the winter months, the well-developed rostrum will be observed, but a special examination of the anal segments forming the pygidium (fig. 205 (9)) shows five groups of spinnerets and other important structures.

It is well to bear in mind that the pygidium yields the main characters which form the principal basis for the discrimination of species. The anal lobes, hairs, and other characters, requiring the highest powers of the microscope, are all taken into account by the specialist. Hence at this stage it may be as well to give detailed characters of the female and pygidium of this species, as given by Newstead in his Monograph :-

"Adult female (fig. 205 (6)) elongate ovate; cephalic, thoracic, and abdominal segments strongly defined, the former being distinctly trilobate. Colour dull crimson; cephalic extremity dull orange, mottled with crimson; pygidium bright orange; the dorsal spinnerets indicated by a double semi-elliptic series of dull crimson marks. Eyes black. Rudimentary antennæ normal. Each of the three free abrlominal segments with about nine large tubular spinnerets at the margin, of the same character as those of the pygidium; and the last segment presents a few stont, spiny plates. Pygidium (fig. $205(9)$ ) has five large groups of circumgenital glands.

"Dorsal tubular spinnerets, short and cylindrical, are in twelve distinct series, forming three incomplete arches. Within the first series, and immediately behind the lateral circumgenital glands, are usually three other tubular spinnerets; anus and vaginal opening opposite. The median and second pair of lobes are well developed; the former have the margins rounded, or faintly and roundly serrate or dentate; the second pair are bilobed, the anterior lobule very small, and both have the margins rounded; third pair are also diviled or bilubed, the posterior lobule usually dentate, the anterior lobule very minute, and sometimes both are wanting. There is a spine-like projecting pore between the median and second lobes; an angular one immediately posterior to the third lobe; and there is a third midway between the latter and the last group of plates. Two long spines at the base of the anterior lobule of the second pair of lobes. Of the plates, there is a short one between the median and second lobes; six others, long and spine-like, are arranged in three pairs, and followed by a group of four or five others."

It ought to be laid down as an axiom that only the full-grown 
female should be examined for specific points, as the spimerets and other microscopical characters are not fully developerl till after. Hhe second laveral moult; and no doubt in a general way specific errors have occurred, and are likely to do so, by several workers examining the same species in two distinct stages.

The male seale (fig. 20.5 ( 7 ) ) liffers from the female (fig. 20.5 (6)) ly having only one larval moult, by being lighter in colour, felterl, more linear, and carinated. The perfect male (tig. 20.5 (8)) contrasts with the female, inasmuch as it has two wings (though apteruus specimen: are often found), six legs, and two antenne, two eyes, and no mouth or feeding-organ. The male generally appears about the first week in July, and only lives from about three to seren days, but during that short space of time he has obtained the sole object of his existenceviz., the perpetuation of his species.

The genitoires are large in proportion to the size of the creature, varying from about one-third to one-half the length of the whole insect. We here see the adaptation to environment in the abnormal development of the penis-sheath requisite, considering that the female is stationary and helpless, and covered with a shell; while we note in her the absence of eyes and legs-both useless uncler an opaque shell. Hence we have a beantiful illustration of the elaboration of one part and the degeneration of others.

It may be as well to remark that previous to the publication of Nerstead's Monograph this species was known as Chiond.ppis ficurini, Sign., but this and several other so-called species have been sunk as synonyms of $C$. salicis.

In order that the student may thoroughly understand the lifehistory and structure of this important arboreal insect, it may be advisable to give a short epitome of the foregoing description, as illustrated by "figs." in figure 205. In fig. 1 we have a single egg. The eggs are found in winter as represented in fig. 4 , and hatch out in May. Fig. 2 represents a larva which is active for a short time; fig. 3 represents the dorsal surface of a fully developed female scale : $"$ is the first and $b$ the second larval moult. The sexes cannot be distinguished till after the first larval moult, and fig. 7 represents the male scale, showing the remains of only one larral moult, together with the secretionary portion; and fig. 8 represents the fully developed male, which appears in July, and copulates with the female, represented in fig. 5. It should be specially noted that at this period the female is 
relatively small and of a peculiar form: this stage of development is known in Coccid study as the period of fecundation. After the act of impregnation the female changes her form, as represented in fig. 6 . This change in form is due to the body being filled with eggs, and up to the time when the eggrs are deposited this stage is termed the period of gestation.

Thus, in a female Diaspid scale we have several stages-viz., the egg, larva (first and second moult), period of fecundation, and period of gestation; and in the male we have egg, larva (one moult), pupa, and winged stage.

\section{Genus Mrtilaspis.}

This genus, of which we have here only one species to consider, may be distinguished from Chionaspis by the mussel-shaped scale of the female. The scale is highly rounded, of a uniform light-brown colour, and the second larval moult is completely corered by secretion.

Male puparium rare, elongate, siles parallel, and there is a faint hinge-like depression towards the middle. It somewhat resembles the second stage female.

\section{Mrtilaspis pomorum (Bouché).}

This scale-insect is unfortunately only too well known as a garden pest. It infests apple, pear, and plum amongst our fruit-trees, and hawthorn, mountain ash, cotoneaster, and wild-rose amongst our forest trees and shrubs. Its common name "mussel-scale" is a very appropriate one, inasmuch as it resembles, when magnified, our common mussel of the sea-shore. The scale differs from that of Chionaspis in being more elongate, less circular, of a brown colour, and about an eighth of an inch in length. It is built up in the same manner as the ash-bark scale, but the first larval moult is yellow. Plant after plant may be found so thickly covered by the female scales as not to be able to get a pin-point down without touching them (not only covered with, but killed by, the scales), and yet not a single male scale is to be found. Hence the species was almost considered as parthenogenetic, and Mr Maskell silys, "Male unknown in New Zealand and Europe, doubtful in America." It was not until July 1896, after nine years of observation, that Newstead discovered the male on broom at Bearstead in Kent. As the male had hitherto been unknown, this was rather an important find. It may even now be 
considered as analogous to some species of $A_{\text {phide, in which males }}$ have only been found after an interval of several years, otherwise the sex may have been determined (as sexes of insects often are) by the food-plant. With regard to finding it on certain food-plants, Newstead remarks, "IIere in England, however, I have met with it freely on Cytisus and Vaccinium, and sparingly on heath."

Its habits are much the same as the Chionaspis on ash, \&c. At the end of August or early in September the female lays her ergs, which remain under the scale during the winter. They are white, and hatch out in Cheshire about the end of May, but not until the middle of June (June 16, 1900) in Northumberland. The males, when found, have appeared in July.

Newstead gives the following detailed description of the pygidium -viz. "Pygiclium (fig. 202) with five groups of circumgenital glands, subject to great variation in number. Dorsal tubular spinnerets, small and cylindrical, are arranged in three series,- the first, opposite the lateral ventral glands, form a long scattered hand terminating near the anus; intermediate series in a single row forming an incomplete arch, with an outward lateral series extending from the middle almost to the margin ; third series following the articulation of the pygidium with the segment. On each side of median lobes along the margin are six tubular spinnerets, of which the second and third, and fourth and fifth, are arranged in pairs. Anus a little in front of the anterior group of ventral glands. Vaginal opening almost central. Nedian lobes almost as broad again as long; lateral margins usually straight; posterior margin centrally lobate, with one or two notches on either side. Second and third pair of lobes small, almost touching, have their margins rounded and entire or bluntly and irregularly dentate. Plates long and spine-like, usually one median and four lateral pairs." 1

\section{Genus Aspidiotus.}

Female puparium more or less circular, and either raised or comparatively flat in centre. Exuviæ central or conspicuously to one side of centre. Secretionary covering often very thin. Females show great variation in the character of the pygidium. Hence, from a microscopical or specific point of view, it is advisable to study every available species on different host-plants.

Male puparium circular, but much smaller than the female scale.

1 Newstead, vol, i. p. 196. 


\section{Synopsis of Arboreal Species. ${ }^{1}$}

A. Pyndium with four, rarely with five, groups of circumgenital ylands.

(1) Short serial group of lateral dorsal pores absent. Puparium reddish-pink in the young, smoky-grey in the old examples. On oak .

Zonatus.

B. Pygidium always with five groups of circumgenital glands.

(2) Serial group of dorsal pores present. Puparium flat, convex grey with a darker central zone. Hitherto found on fruittrees

C. Pygidium with club-shaped glands.

Ostreæformis.

(3) Groups of tubular spinnerets connected, with pores on both surfaces of pygidium ; circumgenital glands almost continuous. Puparium bright-fulvous. On holly .

Britannicus.

\section{Aspidiotus zonatus (Framenfeld).}

This insect is found on oak, but, so far, it has been rarely recorded. One of the first discoveries was by myself at Agden, in Cheshire, Sept. 1892. It has been found fairly often in Cheshire, but never occurs in any great numbers.

Is regards life-history, the egg-laying takes place early in May, and the larvæ hatch soon afterwards. As soon as the first larval moult takes place, the sexes not only assert themselves, but they separate, the males moving on to the leaves, and fixing themselves to the midrib and veins, and the females congregating on the stem. But though separated, it is, after all, only in the metamorphic stages, inasmuch as it is only for the requirement of pupal development on the part of the male. As the males emerge from the puparia on the leaves with fully developed wings, it is obvious they have no distance, or difficulty, to move from the leaf to the stem for nuptial rites and associations.

\section{Aspidiotus britannicus (Newstead).}

This is a species which, so far, has only been found on holly and a species of fern cultivated under glass in the immediate neighbourhood of London. The scales are circular, of a dusky-brown colour, and on the slightest disturbance fall readily from the leaf. The males can be distinguished from the females by the smaller size of the scale.

1 Modified from Newstead's Monograph, vol. i. 
As the two preceding species are not very common except in one or two special localities, it would be well for the student to stuly the habits and structure of an easily procurable and closely allierl species -viz., Aspidiotus ostreceformis on plum, apple, pear, and cherry. This species is very common in many parts of the country.

In the event of this species not heing procurable, the stulent may find several species of Aspritiotur under gliss, as in fig. 206 on Lapageria, and fig. 207 on Stephanotis.

\section{Genus Diaspis.}

This genus has a circular female puparium, and the remains of the larval moults lie between the centre of "scale" and its outer edge.

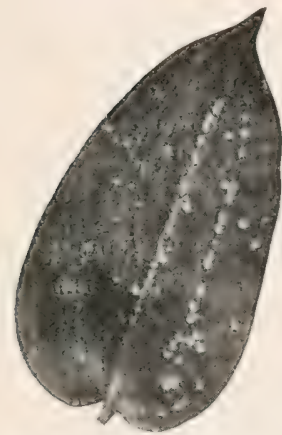

Fig. 206.-Scale of Aspidiotus on leaf of Lapageria.

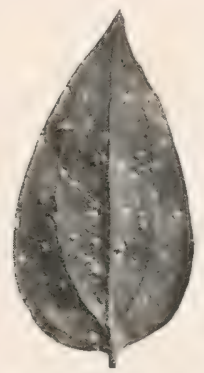

Fig. 207.-Scale of Aspidiotus on leaf of Stephanotis.

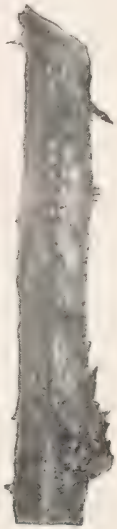

Fig. 208.-Sicale of Aulacaspis rosie on clog-rose.

The puparium of the male is elongated and strongly ridged, closely resembling the puparium of Chionaspis.

In this genus proper we have no arboreal species, and the species on wild-rose, long known as Diaspis rostr, has been named Aularmspis. (Diaspis) rose by Cockerell, and Newstead has, somewhat reluetantly, adopted the change.

\section{Aulacaspis (Diaspis) ROSæ (Bouché).}

This scale (fig. 208) is found on the dog-rose (Rosa canina), and sometimes on species of Rubus (bramble). It is fairly common in 
some districts, and entirely absent in others. I have, for instance, never taken it in Northumberland. It is generally found on the stems of very old plants, and then ofter so abundant as to completely cover the bark.

The female scale is of circular form, slightly convex, and from 2 to $3 \mathrm{~mm}$. in diameter. The central or larval exuviæ generally lies between the centre and the outer edge of the scale. It is of a dull canary colour. The exuviæ of the second moult is yellowish-brown, and the scale proper is a dirty-white-looking colour. Collectively, they give a sort of drab colour to the infested stem.

Prior to the deposition of the egg, the body of the female is of a dull orange-crimson, and the pygidium, which is rather conspicuous, is a bright orange. The body, though elongated, has a slight leaning towards a rough circular outline, and the front portion is almost a perfect semicircle. The outline of the boly shows the segmentation very elearly.

The male scale is elongated, and very much resembles the puparium of Chionaspis. It is of a whitish colour, and the exuvia varies in colour from bright-yellow to red-orange. If examined carefully, it will be seen that the white portion possesses three linear ridges, the centre one being more raised than the other two.

The male of this species, and also the male of the genus Diaspis, resemble the male of Chionaspis, both as regards the form of the scale and the perfect insect. The body is crimson, and the wings whitish. The eyes are black, anil the antennæe long and slender, with very delicate hairs. The legs are yellowish, and slightly pubescent.

There is an important point in connection with the life-history of this species, as compared with the genus Chiond:ypis, and the advice given by Linnæus, "Observe and compare," is very applicable to the stucly of scale-insects. It has been noted that the larva of Chionaspis hatch out early in May, assume a quiescent stage after a few days' active existence, and that eggs are found undemeath the scale from September to May. The active larvæ and eggs of $A$. rose, on the other hand, are found throughout the year. I have found active larve, together with eggs and females, in November of one year, and also in January of the following. Newstead says that the eggs are deposited in August, and that there is only a single brood in the year; and the apparently abnormal character of eggs and active larva being found together shows that where egg-laying extends over a consider- 
ahle period, the respective stages of the metamorphosis are often variable in point of time, resulting in an irregular appenrance of the adults.

IIitherto I have dealt with a group of insects which spin a covering or secle, in addition to using cast-off larval moults, to protect their bodies. Now we come to a group in which the actual body of the female is transformerl into a covering or "scale" for the protection of eggs and larvæ. This group is known as the Lecaniinæ, of which fig. 209 represents a typical example of a Lecanium scale found on sycamore.

The scales of the genus Lecanium, or "brown scales" of the gardener, are found on sycamore, hawthorn, hazel, and other plants. They have a general resemblance to brown dead buds. If a few of these scales are placed in a glass-covered box about the middle of July, we should find that towards July 25 or so the box would be literally swarming with small chocolate-brown colourer active larvæ. They are very small mite-looking creatures, measuring about $\frac{1}{100}$ of an inch in length. These small mite-like larvæ are the first stage of the "brown scules" referred to; and as there is a great difference in size and apparent

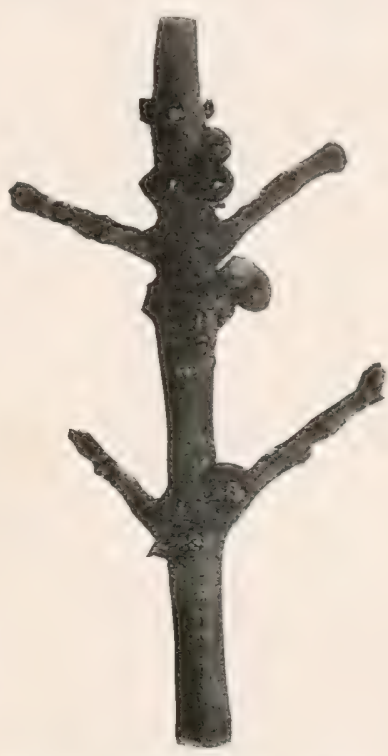

Figr. 209.-Femele saeles of Lecanium calprea, "brown scule," ont syemmint. structure between the small active larve and stationary brown deadlike scales, it would be well for the student to study the development of a Lecanium scale.

Under the one-inch objective the structure of the larvæ will be seen to resemble that of the larve of Chionaryis. In their natural state they move about very actively for a time, and then settle down and begin to imbibe the juices of the plant.

As it is rather difficult, more especially for a beginner, to follow out the life-history of a Lecanium on a forest tree, it is best to have recourse to stove or greenhouse specinnens, and get a plant which is 
badly infested with "brown scale." For example, a comparatively small specimen of Croton will often serve the purpose. In order to understand the structural details, it is best to prepare and mount a young adult, and examine it under the inch objective. It is then advisable to carefully look for all the characters found in fig. 210. In the first place, see the mouth and sucking-tube, as at $a$ and $b$.

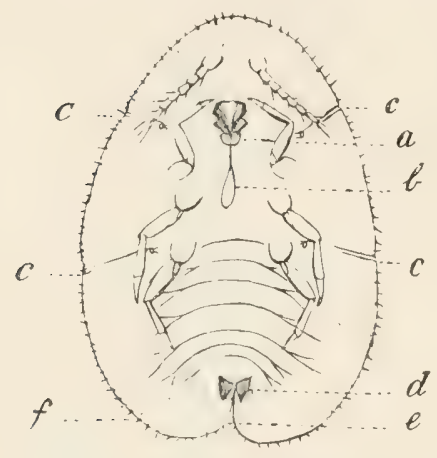

Fig. 210.-Adult female Lecanium after treatment with potash $\times 20$.

(', mentum ; 7, rostral filaments, forming the sucking-tube; cccc, ventral channel leading to spiracles; $d$, anal plates or lobes (dorsal); $e$, anal cleft ; $f$, marginal syines. (From Newstead 's 'Monograph of the British Coccila.' Ray Society.)

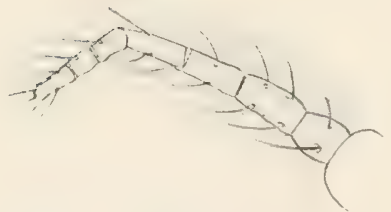

Fig. 211.-Typical antennce of female Lecanium. The antennæ (fig. 211) should be well studied, as the number and relative lengths of the joints often afford important points in classification. At $c c c c$ we get the openings leading to the spiracles or stigmata, and these structures may be carefully studied. At $d$ we find the anal plates or lobes; at $e$ the anal cleft; and at $f$ the marginal spines. All these structures are clearly displayed in the young adults. The legs, like the antennæ, should also be carefully noted under the field of the microscope.

But while the microscopist thus gains a general idea of the structure, the fully developed "brown scale" is nevertheless a puzzling organism to the practical man. Perhaps it may be best understood by adopting an illustration. In view, therefore, of making it intelligible, it is to be hoped that a very homely, if not grotesque, simile may be used. Most people are conversant with the tortoise-a creature moving along with short legs and hard body. Now suppose this creature was born with fully developed legss, but after one or two "moults" the body developed, say, fifty times its infantile size, while the legs remain the same as at birth, and also as a natural consequence the creature became absolutely helpless from such abnormal development,-we should have exactly an analogous case to the development 
of a brown scale. If, therefore, the fully developed creature be boiled and mounted according to instructions given, we shall have a more or less circular form, representing the outer edge of the scale, and the internal appendages as represented in fig. 210. As already stated, the body is transfurmed into a covering for the egrss and larva. Thus, speaking generally, the eggs are contained in the enlarged body, and when the larvæ hatch out, they may often be found in a group underneath the scale.

When this stage of development is attained, the female is sometimes apparently, and often in reality, dead. In either case it shows, on the part of nature, a very beautiful arrangement. The modification of form and structure for the prospective requirements of her own progeny is a beautiful adaptation; but when we consider that the dead body of the female is transformed into a protective covering for the offspring, it shows a form of altmis.m, - the application of that law which reveals a struggle for the life of others, and which is in itself, certainly, a very beantiful adaptation indeed.

In studying those creatures in a natural state, from an arboreal point of view, it would be best to mark a badly infested plant for examination, and make regular visits to the same. If, therefore, the attacked portion be examined during autumn, it will be ascertained that the small larve are somewhat difficult to find. They have, of course, lost the activity of early youth, together with (to the naked eye) characters and their appendages. They are now transformed into small scales, measuring perhaps approximately about or $\frac{1}{30}$ of an inch in length, comparatively flat, and in colour harmonising well with the food-plant. They are to all appearance lifeless, and in this comatose state pass the winter. At the same time it must be remembered that before winter sets in the larvæ will have passed through their first moulting stage. In spring, glassy elongated puparia of the male may be found (see fig. 212), and if collected in late spring or early summer the perfect insect can be hatched artificially.

After copulation, the females develop rapidly until they measure about $\frac{1}{8}$ to $\frac{3}{15}$ of an inch in diameter. As males are not always found associated with the female scales, it is quite possible they may at times be parthenogenetic.

In Cheshire the females reached maturity by July 1 . If a number of specimens are placed under glass about the time referred to, it will 
be found that some of the scales will soon appear perforated, and the case swarming with small Hymenopterous parasites. Hence, probably, the harmony of colour in the early stage was a means of protection against natural enemies.

The salient characters of the sub-family Lecaniinæ, according to Newstead, ${ }^{1}$ are: "Adult females either naked or covered with secretion, forming a test or ovisac. Abdomen in all stages with a more or less defined cleft, and on the dorsal surface at the base of the cleft are two more or less triangular lobes or plates. Legs and antennæ generally retained, but a few forms are apodous, and have rudimentary antennæ. Mentum generally monomerous or dimerous. Males generally possessing wings, either with or without caudal filaments. The puparium of the male is generally of a glassy nature.

"Larve with large setiferous anal lobes, placed within the posterior" anal cleft."

\section{Synopsis of Genera (arboreal).}

A. Females naked. Ovisac behind and partly beneath the posterior extremity of the body

Pulvinaria.

$B$. Females naked-no ovisac.

(a) Females retaining legs and antennæ. Old adults hollow beneath . . . . . LECANIUM.

(b) Females without antennæ and legs; body with two internal pouches. . . . . Physokermes.

\section{Genus Pulvinaria.}

The male scale of this important genus cannot be separated from the male scales of the genus Lecanium or "brown scale." In the younger stages we cannot distinguish the female scales of the one genus from the other. The adult species are, however, quite distinct. We may define the adult female Lecanium as a brown scale proper, and the adult female Pulvinaria as a brown scale with a white ovisac attached to the scale itself, and extending behind and beneath the insect proper.

\section{Pulvinaria vitis (Linn.)}

The specific name of this species would suggest that it may be looked for only in the vinery. Such, however, is not invariably the

$$
{ }^{1} \text { Vol. ij, p. } 5 .
$$


case, for though under glass it may be found on vines and peaches, out of doors it may be found on rarions trees-viz., hawthom, hirch, hazel, willow, alder, cotoneaster, and others.

Before the publication of Newstead's Monograph this species wats known by a number of synonyms, accorling to the respective foolplant-viz., Pulvinaric letula, $P$. salicis, $P$. populi, $P$. persicce, \&e. It is therefore very helpful to find these specific names have now been sunk as synonyms of $P$. vitis.

Whilst I have found it sparsely distributel on the various trees enumerated, I might just add that the most common part of an old tree to find it is on the young bark formed by occlusion either after pruning or where the stem had been previously stripped of its bark by accident.

If this scale be found just as the eggs are deposited (at the period of parturition), the smooth, white, plump ovisac, together with the overlying seale of chocolate-brown colour and slight corrugations, makes a very pretty object. But soon, however, it changes. The scale grows darker, while the outer edges of the body curve inwards and upwards, becoming detached from the orisac, and only fixed to the food-plant by the cephalic area. At this stage, also, the dermis is very heavily wrinkled.

The antennæ are generally composed of eight joints, though at times there are only seven. The legs are ordinary, with simple digitules to the tarsus.

\section{Pulvinaria vitis, var. ribesice (Signoret).}

So far as the naked-eye characters of this insect are concerned, it very much resembles the preceding species, but as it may often be found in districts where $P$. vitis does not exist, it would be well to study its life-history and microscopical characteristics.

Fig. 212 is from a photograph of this species on Rities sanfuineum, found at Lyham, Northumberland.

Newstead gives a very full and interesting account of it, and the following is his summary-viz.:

"We find that there is but one brood in a year. The larvæ hatch in June and the early part of July, the first moult taking place from the middle of July onwards; the second moult is in August, when a sexual difference is first observed. Pupation takes place towards 
the end of August, the males appearing in September. They then fertilise the females, when the latter moult again for the third time. Hibernation commences shortly afterwards, and the insects remain dormant until the spring. Egrg-laying takes place at the end of April and throughont the early part of May. In all probability the periods here set forth may vary slightly, according to the season."

The male (fig. 213), copied from Newstead's Monograph, is described as dusky reddish-crimson or blackish-crimson in colour, with black eyes;

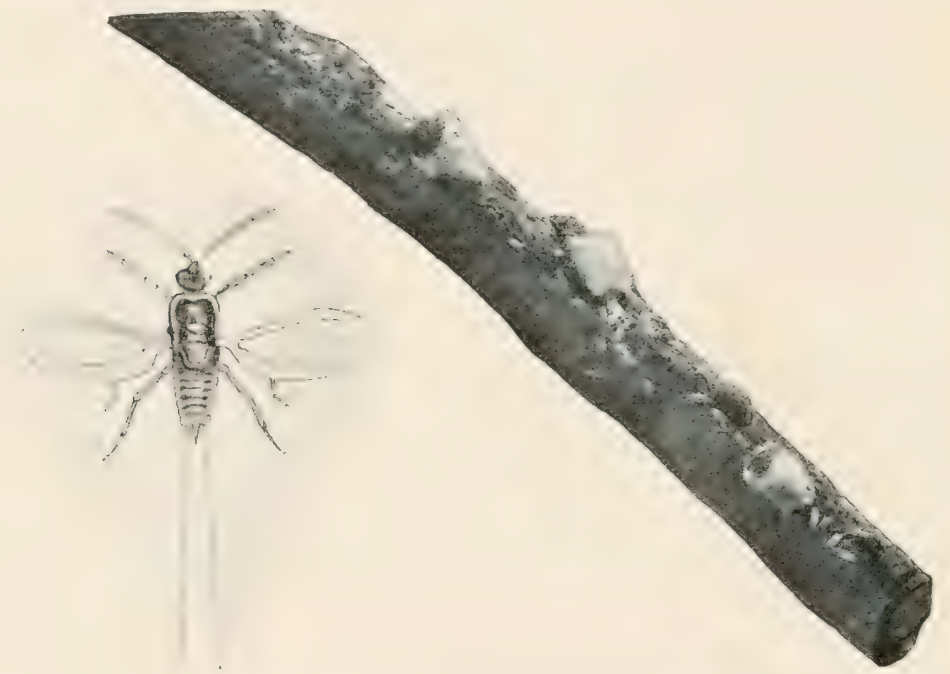

Fig. 213. - Male of Pulvinaria. Species Fig. 212.-Mate and female scales of Pulvinaria on flower. found on flovering currant. ing currant, Ribes sanguineum (natural size).

long, slender, and ten-jointed antennx. 'Two very long caudal filaments at posterior end. Length, including caudal filaments, 2 to $3 \mathrm{~mm}$.

Having in a general way referred to the characters and life-history of the genus Lecanium, it may now be best to give the salient characters of the arboreal species, according to Newstead.

\section{Genus Lecanium. ${ }^{1}$}

Adult females, some low, convex, others hemispherical abore, hollow beneath at the period of parturition.

1 Adapted from Newstead's British Coccidx, rol. ii. 


\section{Synopsis of arboreal species.}

1. Adult female highly convex, sometimes hemispherical, and more or less rugose . . . persice and var. coryli.

2. Aclult female with a delicate marginal fringe, and usually with a dorsal fusiform swelling, Coxa one-third the length of the tibia . . . . . ciliutum.

3. Adult females more or less hemispherical, spheroid, or oblatespheroid.

(a) Dorsum with conspicuous tubercles; anal lobes rounded . . . bituberculatum.

(b) Dorsum rounded, with two to four short, deep, irregular grooves radiating from the anal cleft; sides of body comparatively smooth. Legs and antennæ short

caprece.

\section{LeCANIUM PERSIC,e, var. coryli (Linn.)}

I have only found this species in the adult stage-viz, on Cotoneaster miciophylla, growing in a cemetery near Leamington, Warwickshire. The colour is bright reddish-brown, more or less hemispherical, of a very uniform pattern and size.

\section{Lecanium ciliatum (Newstead).}

I found this scale fairly common on oak-coppice shoots at High Legh, Cheshire. The female may be first recognised, about the latter end of May or beginning of June, by the conspicuous fringe which surrounds the body. This is the period of fecundation, and it may be compared to a large specimen of "mealy bug" we find in greenhouses. The whole body is covered with a whitish farinose secretion, including the two anal lobes which project beyond the body.

As this stage of the life-history of the species in question cannot be called a starting-point, though in all probability the student may also recognise them in the forest at the same stage, the following note as regards life-history is taken from Newstead:-

"'The larvæ hatch towards the end of July. At least one moult takes place before winter, and the insect grows to some extent before libernating. In spring (March) the female appears, and is then about 
$3 \mathrm{~mm}$. long, bearing upon its back the singular square-shaped excrescences, which are composed partly of secretion and partly of the effete skin of the previous moult. The latter is not cast off, but splits or divides into squares, and these, as the insect grows, become more and more widely separated. In May another moult takes place, the newly cast skin carrying with it the marginal fringe and all the old exuviæ and secretion. After the final moult the insect grows somewhat rapidly," and the period of fecundation is therefore reached.

Later on the female at the parturition period assumes a chestnutbrown colour, with a highly convex swelling in the central area. The whole scale retains slight traces of the original waxy covering, with a shining surface and a fringe of delicate hairs at the outer margin of the scale.

The antennæ usually consist of eight joints, but this number is not always constant, as seven is often found. The legs are comparatively short, with unusually well-developed coxæ.

\section{Lecanium bituberculatum (Targioni-'Tozzetti).}

The adult female scale of this species is a large, brown, highly convex scale, with two pairs of sub-dorsal shining tubercles projecting considerably beyond the contour of the scale. It is found on hawthorn hedges, more especially in the eastern and southern parts of England, but it is very local. It has several characters which go to determine it as a distinct species, but these are of more importance to the specialist in scale-insects than to the general student of forest entomology. It is, however, one of the most beautiful and best marked of all the British species.

\section{LECANIUM CAPREA (Linn.)}

This insect may be called the common brown scale of the forest, as it is found on quite a variety of food-plants-viz., hawthorn, apple, elm, sycamore, oak, alder, willow, hazel, lime, horse-chestnut, laurel, wild sloe, \&c. (see fig. 209). Careful observation and comparison of similarly aged specimens will show that this scale varies very much in form according to the food-plant. Thus on elm and horse-chestnut the insects are smooth and spherical, while on lime and hawthorn they are more flat, slightly elongated, and wrinkled. During life the 
colour is of varying crimson shades, but after death the colour is invariably chestnut-brown.

The antennæ are variable, and may be composed of six, seven, or eight joints. It is, however, possible that eight is the typical number, but two or more joints may be so fused together as to lose all trace of segmentation.

It is also considered that parasites have a peculiar influence in determining the form of the scales.

The insect not only varies in colour during the period of parturition, but even more so during the period of fecundation. Hence the variety of form in the two stages has given an endless number of specific synonyms, and coccidologists and general entomologists must be grateful to Newstead for placing them all under one species.

With regard to the life-history of this species, I found that the larve of insects from sycamore hatched out, in confinement, on May 25th. This was in Cheshire, and the specimens having been kept in a warm room, it is possible that this was rather early.

The larvæ move about quite promiscuously for a time on leaves and shoots, but early in the autumn they all betake themselves to the shoots and moult. They pass the winter in a comatose state, and the sexes assert themselves in early spring; but there is generally a

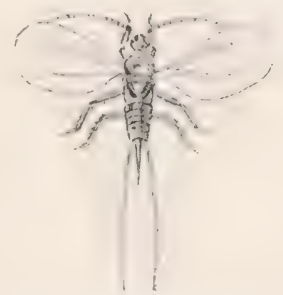

Fig. 214. - Nale of Lecanium. Species found on sycumore, It, tugal liurel, goat willow, dec. preponderance of females, and in some cases males cannot be found.

In Cheshire Newstead found that males hatch about the end of April or beginning of Nay, but in Northumberland I found, after keeping puparia for two days in a cool room, that males appeared on May 23 in 1901 . Allowance must be made for the lateness of the north, but it would seem as if twenty days to a month elapses from the appearance of the males to hatching of the larva. The student will be well repaid by following out the life-history of a Lecanium, as it is in some respects a typical example of how variable in point of time larval development and emergence may be.

Newstead thus describes the male (fig. 214): "Pale crimson, with the head, thoracic bands, and apodema crimson-black; abdomen, legs, 
and antennæ paler and dusky. Eyes and ocelli black, shining, and of the latter there are four dorsal and six ventral. Caudal filaments comparatively short. Halteres pale red, turned back over the thorax when the insect is at rest. Wings rather short, and suddenly widened at base. Stylus nearly as long as the abdomen."

I have found this insect sparsely distributed on all the food-plants enumerated. As a veritable pest, however, I have found portions of hedges near the city of Chester, and also in other parts of midCheshire, killed outright by this insect. It is also somewhat remarkable that I always found this scale most injurious where the hedges were either cut twice in one season or on cottage-garden hedges cut only once in a season, and more especially where the cutting was done very early in the autumn.

\section{Genus Physokerues.}

The larvæ and early stages are quite identical with Lecanium. After this, however, the structural details differ from Lecanium, inasmuch as in Physokermes the body at egg-deposition is composed

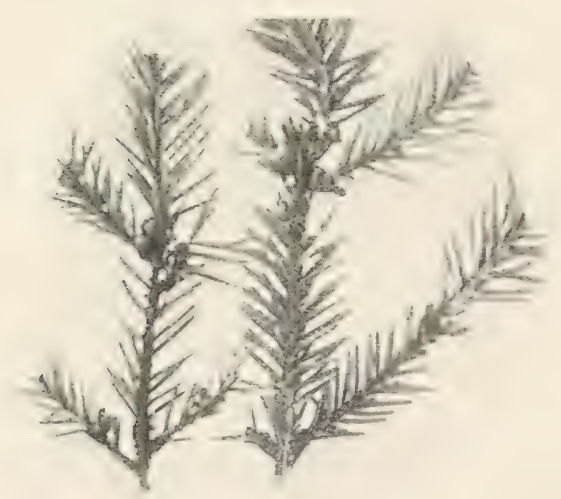

Fig. 215.-Scales of Physokermes abietis as found in the "forkings" of the young tecigs of common sprnce. of two chambers, both of which are filled with eggs; and also in the adult scale no traces of antennæe or legs are found.

\section{Physokermes abietis (Geoffrey).}

This insect is always found on spruce (Abies excelsa). The scale is very much like a Lecanium in general appearance. It may be looked

for on the younger twigs of spruce, and more especially in the "forkings" of the young twigs (fig. 215). The colour, generally a dull chestnut, harmonises well with the food-plant, which may be a means of protection against natural enemies. Newstead says he has hatched from this scale a chalcid parasite, Encyrtus scaurus, Walk.; a 
small beetle, Brachytarsus varius; and a small dipteron, Diplosis latibulorum, Winnz.

The life-history somewhat resembles that of a Lecanium, but the anatomical structure is altogether different and quite unique. Newstend says the eggrs may be found in the pouches at the beginning of June, and the larve hatch towards the end of July. This observation was made in Cheshire, and therefore differs from notes I have made here in Northumberland-viz., to the effect that on August 2, 1900, I found eggs, and on September 1, same year, I also found egrss, and placed the insect containing them in a small box, but the observation was neglected until September 21, when the larve from those of the latter date which had hatched out were all dead. The larvæ hide themselves rather effectually on the young twigs during the winter months. Hitherto no males have been found. The creature has an internal double-chambered marsupial ponch, into which she places her eggs for incubation. This peculiar structure can best be seen by embedding the body in paraffin wax and making sections by means of a microtome. Legs, antennæ, and other appendages are not foumd after boiling the body in potash, but a peculiar rough tesselated surface can be seen after the chitinous body has been prepared for microscopic examination.

I found this species very plentifully at Pollok, near Glasgow. As a rule, it is very common on sickly specimens which are considerably injured by Chermes alietis. In healthy spruce-trees no appreciably ill effect accrues from the presence of this scale, but the more weakly trees, which act as shade-bearers, are often killed ontright by this species and the associated Chermes.

\section{SUB-FAMILY DACTYLOPIINÆ.}

"Adult females active or stationary, naked or covered with mealy, cottony, waxy, horny, or glassy secretion.

"Antennæe and legs either well developed, rudimentary, or entirely absent. When present, the last joint of the antenne is usually much longer than the penultimate. Anal lobes generally small or rudimentary.

"Larvæ, exhibiting anal lobes and setiferous anal orifice, similar to those of the adult female.

"The females of this division are distinguished chiefly by the 
character of the anal lobes, which, although varying in degrees of development, are always present.

"In Dactylopius the ovisacs are usually formed of loose, white, flocculent secretion, often quite devoid of form, and aggregated in masses on the food-plant.

"In Cryptococeus the ovisacs are also felted, and often so thickly packed together as to completely cover the bark of the tree.

"The males are characterised by the comparatively short and somewhat complex structure of the genital armature.

"The male puparia are generally felted." 1

\section{Synopsis of the Genera.}

A. Adult females stationary, enclosed in a glassy or horny fringed ovisac (test) . . . ( (I.) Asterolecanium (1).

$B$. Adult females active, covered with mealy secretion, not enclosed in ovisac.

(a) Female antennæ of eight joints - (II.) DactrLopius (2).

$B B$. Adult females enclosed within ovisac at gestation.

(a) Female antennæ of nine joints . (III.) Pseudococcus (3).

(b) Female antennæ of six, rarely of five or seven, joints

(IV.) Ripersia (4).

C. Adult females stationary, living from the earliest stage within the ovisac ; antennæ and legs rudimentary or absent.

(a) Anal orifice of adult female with four spiny hairs

(V.) Cryptococcus (9).

(b) Anal orifice of adult female with six long hairs

(VI.) Antonina (7).

$C C$. Antenne and legs present; anal orifice with six flattened hairs

(VII.) Apterococcus (8).

$D$. Anal lobes of adult female very large, body with long marginal or dorsal spines . . . (VIII.) ErIococous (5).

$E$. Body of adult female with numerous short conical spines

(IX.) Grunococcus (6).

The above "synopsis" is copied in full from Newstead's Monograph, vol. ii.; and though all the genera are not arboreal in their habits, it is important that the student, more especially a horticultural student, should study at least a typical species from each genus.

${ }^{1}$ Adapted from Newstead's Monograph. 
The arboreal genera are: Asterolecanium, Pseudocoscus, Criptococcus, and Apterococcus. With the exception of Asterolecanium, these genera are, so far as our present knowledge goes, exclusively arboreal.

The remaining genera - viz., Dactylopius, Ripersia, Antonina, Eriococeus, and Gymmococeus-are, as regards food-plants, very varied indeed. Thus Dartylopius ("mealy-bug"), of which five species are at present known, may feel on numerous greenhouse plants, grasses, or sea-pinks; Ripersia on a hothouse fem, on Stephanotis, roots of grass, and even subterranean birds'-nests; Antonina on bamboo; Eriococeus on gorse, grasses, or heath; and Gymnococcus on stovehouse plants.

\section{Gemus Asterolechnium.}

The females of this genus are completely enclosed in a sac of opaque or semi-transparent waxy or glass-like secretion. This ovisac is usually termed a "test," and the margins are generally furnished with a fringe of waxen rods or plates.

The adult females are apodous, and the antennæ are either absent or rudimentary.

\section{Asterolecanium variolosum (Ratz.)}

This is a species which I found very common in Cheshire, on the tips of the young oak shoots. The female scale adheres very closely to the young twig,- - so much so, that she actually causes a depression to be formed, and where they are numerically strong, often kill the twig. The appearance presented may be compared

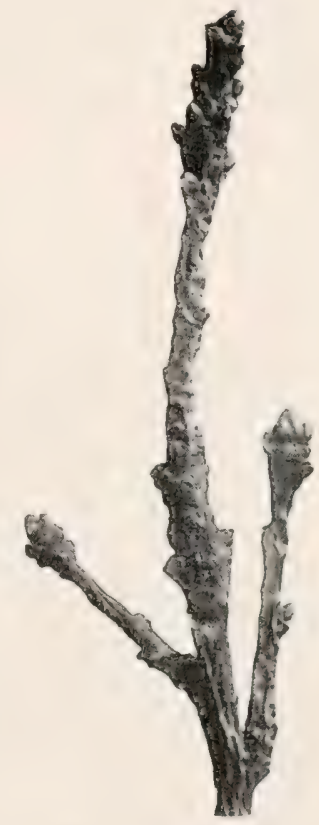

Fig. 216.-Depressions on twigs of oak caused by Asterolecanium variolosum (nut: ural size). (if the simile is not considered too grotesque) to the features of a person who has suffered severely from small-pox (fig. 216). The ovisac is made up of a "test" or scale, which is of a circular shape, and around the lateral sides a curious fringe may be seen under the microscope. The colour of the scale varies according to age: thus 
in summer it is green, and in winter brown. Underneath this seale or "test" may be found the actual body of the insect, but in the living specimens it is almost inseparable from the scale, hence it is best to select dead specimens for microscopical examination.

After treatment with potash, details of structure can only be seen under high powers, of which the salient features are spinnerets and rudimentary antennæ.

\section{Genus Pseudococcus.}

The genus Preudococrus is decidedly arboreal, and in many respects resembles the mealy bug, more especially in the larval stage.

\section{Pseudococcus aceris (Signoret).}

In fig. 217 a typical example of this scale is represented on hornbeam. To the naked eye this scale appears as a small white speck

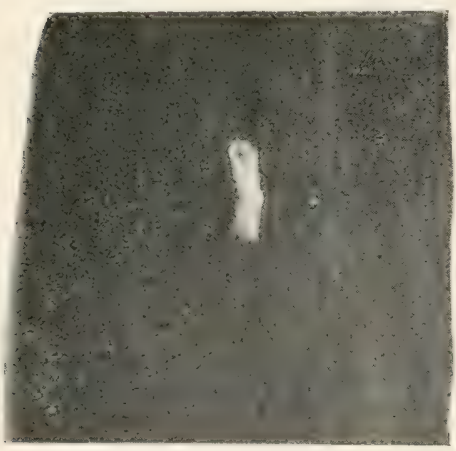

Fig. 217.-Psembecoens aceris on bitrk of horubcen (nuturel size). on the food-plant. It is found on various forest trees and shrubs, including sycamore, hornbeam, mountain ash, elm, oak, and gorse or other plants. On the last-named food-plant it is sometimes very thickly coated on the spring leaves, and at other times only sparsely distributed. Though never so numerically strong as to be considered a pest, it has nevertheless an interesting life-history. The female insects, as seen in the illustration, should be looked for towards the end of May or beginning of June. They may be then placed in a box, together with a very small portion of the host-plant upon which the insect rests. The larve hatch about the middle of June, and they are mere pin-points in size, and of a light-yellow colour. The antennæe at this stage are composed of six joints, the terminal joint being as long as three succeeding joints. They have large prominent eyes, of a brown colour, with just a slight tinge of 
blue. The legs are similar to those of other coceil larra. The borly at first sight appears to be in one piece, but the abdomen is segmented and fluted, each flute terminating in a single hair.

The species illustrated on hornbeam, on which I tried to make a few observations, was taken from a tree in my garden in High Legh, Cheshire. I found the larrie hatched out about the middle of June, but I failed to discover their presence again until September. It is true that the bark of the particular tree in question was very much covered by the alga known as Protococos viridis, and would thus

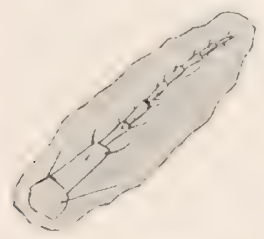
provide ample shelter and covert for the creatures. By that time they had enlarged considerably,

Fig. 218. - Antenna of Pseudococens aceris. (Camera-lueida sketch.)

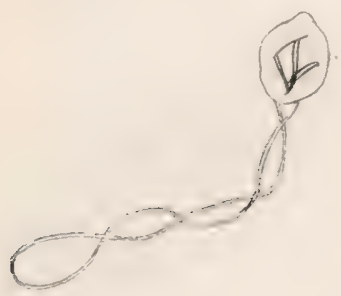

Fig. 220.-Rostrum of Pseudococcus aceris. (Camerd-lucida sketch.)

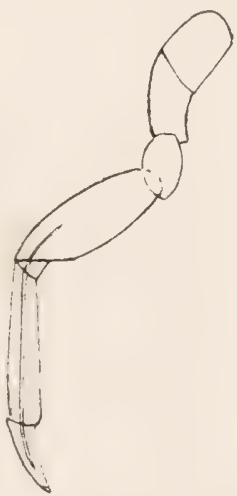

Fig. 219.-Leg of Psendocnceus aceris. (Camera-lucida shetch.)

and could be found in comparatively large numbers swarming on the lower region of the trunk. At this stage they are still larva, but the sexes then assert themselves and separate. The males remain in the south or lee side of the trunk, and the females go higher up, on the branches, generally in the cleft. According to observations made daily with this species, on a laburnum-tree, Newstead says the females reawaken in March, a few days hefore the males, descend the trunk, copulate, and return to the branches. This seems all the more remarkable inasmuch as the males have wings and well-developed legs, and could easily move in the direction of the female residence. In May the females spin their cocoon, which 
takes about three days. The eggs are laid during the construction of the cocoon, and the larvæ hatch out, as previously mentioned, about the middle or end of June.

I found larve of this species very plentifully in thorn hedges at Prestbury, Gloucestershire, Sept. 10, 1906. In general appearance they very much resembled the "mealy bug" of greenhouses. They were yellowish, with a white dusty covering over the body. The parent scales with their ovisacs were situated on the twigs, but the young larvæ in question were congregated in a streak along the midrib of the leaf, and generally on the upper side.

The female can be easily detached from the ovisac without the aid of a lens. The body is simply an ovate sac of a yellowish colour. If the body be boiled in potash we get rather an interesting object. The antennæ are composed of nine joints (fig. 218), of which the second is usually the longest, but the antennæ are often variable. The legs and the outline of the rostrum can also be clearly traced. Fig. 219 represents a camera-lucida sketch.

Fig. 220 is a camera-lucida sketch of the rostrum.

\section{Gemus Criptococcus.}

"Adult females stationary, living within a felted ovisac. Antemme rudimentary. Posterior pair of legs rudimentary ; anterior and intermediate pair absent. Anal legs normal. Larva with anal orifice, as in the adult female. Antennæ of five joints." ${ }^{1}$

\section{Cryptococous fagi (Barensprung).}

This insect is very common in many parts of the country, and is, in fact, one of the most dreaded pests of the arboriculturist. At the same time, it may be noted that it often confines itself to comparatively small areas, or to isolated park trees. In general appearance the trunks and larger branches of beech-trees infested with this pest present the appearance of a shower of snow having frozen. This pest has been graphically termed the "felt scale" by Miss Ormerod. Fig. 221 is a representation of this scale on beech.

Where the pest is but sparsely distributed on the stem little damage acernes; but it is sometimes found about a quarter to half an

1 Newstead, vol. ii. p. 214. 
inch in thickness, and when such is the case the bark separates from the stem, and the tree ultimately dies in consequence.

This insect confines its attacks exclusively to the beech (Fagus syleutica), and, by reason of its whitish appearance, must not be confounded with the various species of Chermes ( $A_{\mathrm{p}}$ hide) on larch, silver

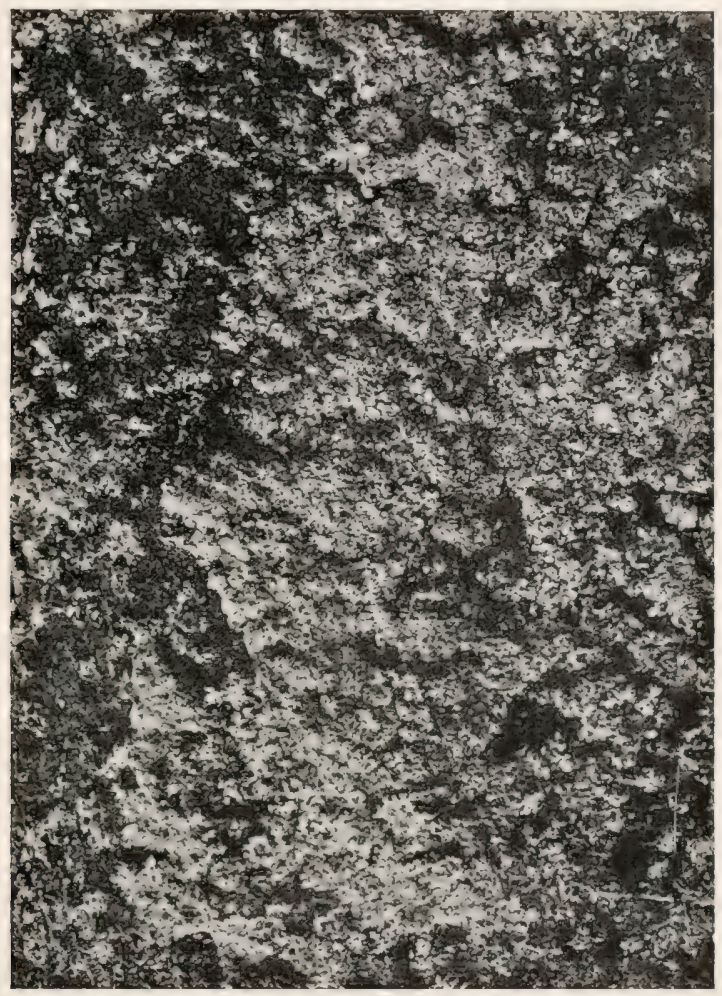

Fig. 221.-Cryptococcus fagi on bech. (From F. V. Theobald's 'Animal Pests of Forest 'Trees.')

fir, Weymouth pine, \&c. It should also be noted that the "copper beech" is all but immune from this insect-pest. In fact, I have occasionally seen cases where the copper beech was grafted on the common beech, of the pest appearing fairly thick on the stock or common beech portion, and the copper beech portion above having only here and there the smallest possible specks on it. 
On moving the white covering about midsummer, the insects may be found in all their respective stages.

The adult female is of a sulphur-yellow colour, about half a line, or $\frac{7}{25}$ of an inch, in length, convex above and below. The creature is both wingless and legless, and has, therefore, no power of locomotion. The mouth-organs are placed on the under side of the body, and are composed of long hair-like appendages, forming mouth or suckingtube and anchorage. She covers her body with the white waxy secretion, which is impervious to rain, and here she lives, lays her eggs, and dies.

The larvæ, in shape and appearance, very much resemble other coccid larvæ, being active and yellow in colour. The eyes are rather conspicuous, and of a purplish colour. The antennæ are five-jointed, and terminated by a forked bristle. The legs are short and stout.

As a rule, they are found under the living or dead bodies of their parents or in the same felted mass, for the larvæ also secrete a white waxy covering, thus adding to the white materials, and also aiding in the destruction of the tree. Occasionally the larvæ move to the fresh portions of the bark, secrete a covering over their bodies, and thus spread the injuries over the trunk.

The eggs are also of a lemon-yellow colour, and comparatively large for the size of the insect.

As regards the life-history of this insect, it may be said that much may jet be done by the inquiring and observant student, inasmuch as eggs, larve, living and dead female, may at various periods of the year be found all huddled together. However, it is possible that the majority of the eggs are deposited in July, and that some hateh out in the autumm months and pass the winter as active larve, whereas the majority hatch out in spring and soon after evolve into fully developed females.

At various seasons of the year I have often found very active specimens of acari amongst the insects.

Considering the alarming spread of this pest, preventive and remedial measures ought to be taken in order to save many specimen trees in pleasure-grounds, parks, the neighbourhood of rillages, and forests generally.

Some years ago, as a remedy, I tried a solution which proved very successful. To make it, take about half a gallon of soft water, boil, and dissolve about $1 \mathrm{lb}$. of soft soap and about $1 \mathrm{lb}$. of common soap; 
ard a handful of sulphur, one pint of parafin, and alwut the same quantity of turpentine. Then add about four gallons of soft water to this mixture. Churn well with a syringe, and when cold, store away in a stoppered barrel to prevent evaporation. Apply with a whitewash brush about May, just as the larvæ are hatching out, but hefore application chum well with the syringe, to ensure the mixture of the ingredients. ${ }^{\mathrm{I}}$

I did not measure out the ingredients in exact proportions, but took care not to add too much paraffin and turpentine. I have, however, in practice, been fortunate enough to have been associated with healthy beech-trees in Northumberland, and therefore have not had an opportunity of putting this mixture to the test on a large scale, but all those who have tried it maintain that it answers well. In fact, I had several portions of beech bark sent from various parts of the country showing the good effects accruing from the application of this mixture.

A most interesting remedial measure has been brought under my notice at Blagdon, in Northumberland. With an inch augur bore three holes at about equal distance right into the centre of the trunk, about three feet from the ground, and shoping slightly towarls the root of the tree. Into these holes place as much flowers of sulphur as can be conveniently got in, and then cork them firmly up with a plug of soft wood. This should be done in the autumn, and will be found successful. It was first adopted about thirty years ago, and the trees which were then operated on are now in comparatively good condition.

Though this remedial measure may he adversely criticised ly many mractical men, nature would seem to surgrest some analogous form of treatment by inference from the copper beech being all but immune, and also from the fact that certain species of fruit-trees are immune from American blight and scale-insects.

From an able and interesting leaflet of the Board of Agriculture the following insecticides for this pest are recommended :-

(1) Paraffin emulsion.-Mix equal proportions of soft soap, dissolved in boiling water, and paraffin, and chum them up by means of a force-pump or syringe. When required for use add twenty times its bulk of water, and again churn.

1 This has been adopted by the Board of Agriculture. See Leaflet No. 140, Remedy "No. 2." 
(3) Caustic alliali wash.-Dissolve $1 \mathrm{lb}$. of commercial caustic soda in water, then $1 \mathrm{lb}$. of crude potash or pearl ash in water. When both have been dissolved, mix the two well together; then add $\frac{3}{4} \mathrm{lb}$. of soft soap, stir well, and add sufficient water to make up to ten gallons. Caution.-Do not mix in painted vessels of any kind.

\section{Genus Apterococcus.}

Adult female stationary, living within the ovisac. Legs persistent. Antennæ six joints. Male apterous. Antennæ seven joints. Male puparium felted.

\section{Apterococcus fraxini (Newst.)}

In some parts of the country this scale is fairly common. I found it frequently in Cheshire, and again in some instances in Northumberland. As a rule, it is gener-

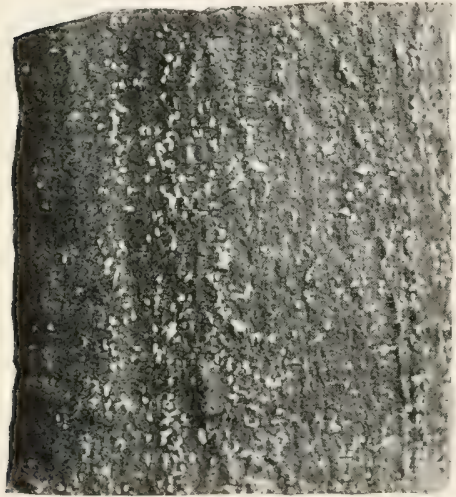

Fig. 222.-Apterococcus fraxini on bark of ash. ally found on isolated trees, or otherwise extremely local on hedgerow trees. It is found on trees of varying ages, from fifteen years upwards, hut most abundantly on trees from thirty to forty years of age with comparatively smooth bark. When it is found on old trees, it is sparsely scattered in the fissures of the rough bark. The general appearance of this scale somewhat resembles the genus Dactylopius or mealy bug, inasmuch as the bark is spotted with numerous white specks (fig. 222). If an individual sac be examined during the winter months, it will be found to contain two or more female insects.

The adult female is of a bright-red colour, somewhat globular in shape, with six-jointed antennæ, short legs, and very long rostral filaments. A microscopical examination of a prepared female insect, under high power, reveals special rings of spines surrounding the anal orifice, and a few tubular spinnerets on the dorsal surface.

The male is apterous, of a bright-red orange colour, with black 
eyes. The antenne show seven and sometimes eight joints, and at the junction of the third and fourth joint a curious ball-and-socket arrangement may be seen. The genital armature is comparatively short. The males appear in consilerable numbers during ()ctober anl November, and during the day may be seen actively moving on the bark.

I found the larve hatching out in Derbyshire about the latter end of June 1906, and about a fortnight later of the same year in Northumberland.

\section{References to Literature consulted.}

Cockerell, T. D. A. Notes on the Geographical Distribution of Scale-Insects. Smithsonian Institute. 1895.

Comstock, J. H. Report on Scale-Insects. 1881.

Douglas, J. W. Some British and Exotic Coccidæ. E. M. M. 1891.

Fuller, Claude. Articles in Australian Papers.

Howard, L. O., and Marlatt, C. L. The San José Scale. U.S.A. Bulletin, No. 3. 1896.

Hunter, S. J. Scale-Insects Injurious to Orchards. University of Kansas, Lawrence. 1898.

Lea, A. M. Scale-Insects. Western Australia. 1898.

Lewis, Richard. Papers on Scale-Insects.

Lounsbury, Chas. P. Coccidæ or Scale-Insects. Cape of Good Hope. 1907.

Maskell, W. M. Scale-Insects of New Zealand. 1887.

- Various papers from 1883.

Morgan, A. C. F. Scale-Insects. Portugal. 1888.

Newstead, K. Monograph of the British Coccidre. Ray Society. 2 vols. 1900-1902.

Newstead, R. The Injurious Scale-Insects and Mealy Bugs of the British Isles. Journal of the Royal Horticultural Society. Also separate papers from E. M. MI. 1891.

Quaintance, M. S. American Aleurodidæ. 1900.

Sulc, Karl, Studie o Coccidech. 1895.

Tryon, Henry. Scale-Insects. Queensland. 1898. 


\section{CHAPTER VII.}

\section{LEPIDOPTERA (MотнS).}

The Lepidoptera are undoubtedly the most favourite order of insects, and, as far as ornament is concerned, they are the highest in the insect world. The majority of entomologists begin their studies with the Lepidoptera. They are very interesting in breeding, from the larvæ being associated with special food-plants, and more especially in watching their development from the egg stage.

As regards the association of this order with arboriculture, it is of course obvious that it is somewhat difficult to know what species to adopt or reject, inasmuch as some of the rarest species are exclusively arhoreal feeders, and on the other hand, some of the most direful forest pests belonging to this order may only appear in certain localities at very long intervals of years. Perhaps, therefore, the best method will be to simply give the more general species, with as few details of generic and specific characters as possible, because the student will find more available books on Lepidoptera, and probally more assistance from local naturalists, than in any other order of insects.

With reference to general characters, the Lepidoptera have four wings; body and wings covered with scales, which are usually variegated in colour; venation more or less straight and without cross veins. Imago with mouth only fitted for sucking, which is situated at the extreme end of a long coiled proboscis, capable of protrusion. The metamorphosis is complete, but abrupt; the larva has a large head and strong mandibles; the pupa often has the antennæ adpressed, and cemented to the borly; and the full development of the moth takes place within the pupal case.

The head is in a large part made up of the compound eyes, the simple eyes or ocelli which are usually concealed by the antennæ, and the proboscis or trunk. 
The prothorax is small, the mesothorax large, and the metathorax small.

The abdomen varies according to sex. In the female it may be said there are seven segments forwally and six segments ventrally. But one segment is concealed ventrally, and other two segments are molified in connection with the ovipositor, thus making in reality nine segments. In the male the abdomen is also composed of nine segments, and as a rule is more slender than in the female. At the extremity the anatony is sonewhat complex, but the general design shows two terminal claspers.

The legs are long, slender, and covered with scales. The tarsi are five-jointed, and terminating with two small claws.

The vings of the Lepidoptera are a remarkable feature of this order, inasmuch as they owe their beanty to the often exquisite blenting of colour which adorns their surface. This delicate colour is due to the arrangement of minute scales, which overlap one another after the manner of slates on the roof of a house. They form very fine oljects for microscopical mounts, and the young collector must always remember their delicacy, as the slightest touch of the finger will at once destroy the beautiful pattern of the wing.

A detailed study of the wings is of very great importance to the specialist in Lepidoptera, and requires, as a subject, a good deal of consideration to thoroughly understand. The most salient features are the size and form of the scales, the arrangement of nervures, the comparative size of the wing-cells, and the development of the wings during the pupal stage.

The egg shows great variety in structure, and also in the manner of deposition. In some cases the eggs are large, naked, and exposed; in other instances they are beautifully coated over with a substance bearing so close a resemblince to the food-plant that it is with great difficulty they can be found, while in other cases it is scarcely possible to discover them at all. There is also great variation as regarls the interval of time hetween the deposition of the exgrs and the hatching out of the larvæ. Thus, some hatch out in the autumn and feed for a short time, and then hibernate for the winter; while many, on the other hand, pass the winter in the egg stage, and hatch out only slightly in advance of the development of the fool for the larve.

The lance of arboreal-feeding Lepidoptera show considerable 
diversity in apparent structure. They are generally composed of a head and thirteen divisions or segments of the body. Those feeding on the surface of foliage have generally well-developed legs, and clothed with hairs, while those feeding within the tissues of the plant are either footless or with partially-developed legs and smooth surface.

In the mupe there is also great diversity as regards form and habit. In some, all parts of the future perfect insect are visible, while others are enclosed in a silky cocoon. Some bury themselves in the soil, while others pass their pupal stage within the leaf or other portions of the food-plant. From a structural and evolutionary point of view, the complex changes taking place within the pupal stage of a Lepidopterous insect are most remarkable, and would require a long and detailed study to thoroughly understand.

The mouth of a Lepidopterous imago presents a great change from the mouth of the larva, inasmuch as the one is adapted solely for sipping and the other for biting and masticating its food. As regards special structure, the mouth of the fully developed insect is somewhat difficult to understand, but the principal feature is a tube or proboscis which is rolled up when the creature is at rest, and protruded when it wishes to sip nourishment, as may be readily seen by the collector when the moth is enjoying his prepared banquet of "sugar." The proboscis, and the exact mode in which it acts, present many suggestive questions. Thus the length of the proboscis is adapted to the needs of the creature, inasmuch as the essential food often lies at the bottom of a floral vessel which could be reached in no other way except through the medium of a long tube. On the other hand, a short tube is often recognised on the mere surface-feeding moths, and still further in many species the mouth is atrophied, and minute anatomical investigation shows that the stomach is in a correlated condition.

With reference to classification, it is obviously unnecessary, having regard to the few species selected as arboreal Lepidoptera, to give too many details of the larger-sized sub-families. Students, however, as a general rule, may divide the order into two principal sections-viz., Macro-Lepidoptera and Micro-Lepidoptera. The former deals with the larger-sized species, and the latter with the smaller or very tiny creatures.

In the smaller-sized moths or Micro-Lepidoptera it is essential in 
some sections to give considerable attention to generic characters, as in certain eases the whole genus may not only be arboreal in habits, but as the characters are minute, microscopical examination of the salient features is indispensable.

\section{Sierinthus populi (Linm.) (Poplar Hawk-Moth).}

This moth, as the name implies, is found on the poplar. It is not so abundant as ever to be considered a pest, though fairly common as an entomological specimen. The larva lives on Lombardy and hlack Italian poplars. The moth appears about midsummer.

The eggs are deposited on the upper side of the leaves. They are

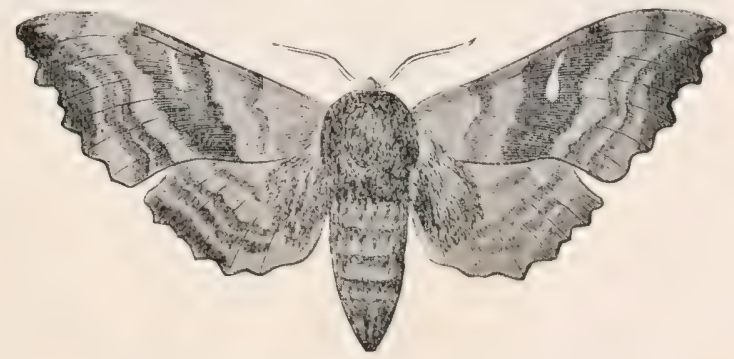

Fig. 223.-Smerinthus populi (Poplar IFavk-Moth).

large and nearly globular, pale green in colour, and glued singly to the leaves. The embryo may be seen before hatching.

The larvæ hatch out about the beginning of July, and the long caudal horn projecting from the last segment is quite a conspicuous feature. As development proceeds the horn is less conspicuous, but stripes, spots, and markings on the lateral segments may be noticed, and after the respective moultings the larve develop a short, stout, yellow, caudal horn, and it is interesting to note the changed markings in comparison with the green colour of the leaf.

The moth, fig. 223, is a large heavy insect of a stone-grey colour, with a whitish spot on the fore wings and a brick-red blotch on the hind wings. The wings are notched at the margins, and the venation is fairly conspicuous. The body is soft and velvety-looking. The antennæ are serrated in the 0 , nearly filiform in the + . 


\section{Sierintuus ocellatus, Linn. (Eyed Hawk-Moth).}

The life-history and habits of this moth very much resemble the preceding species, and the larva is said to generally feed on the willow and apple, though I have found it feeding on the leaves of the black Italian poplar.

The moth, fig. 224, is more beautiful than the preceding species, and receives its specific name in consequence of having a large eye-like spot on each of the hind wings. The fore wings present a beautiful,

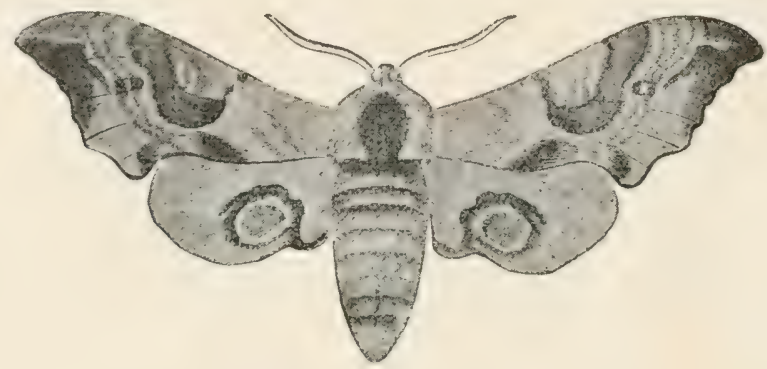

Fig. 224.-Smerinthus ocellatus (Eyed Hauk-Moth).

glossy, velvety appearance, which renders the veins less conspicuous than in S. populi. The hind wings are of a delicate rosy tint.

\section{Trochilium (Sesia) bembeciformis, Hub. (Hornet Clear-wing of the osier).}

The larve of this species are generally found in the base of stems of the goat willow (Salix caprea). The holes which show whence the perfect insects have escaped are often the first conspicuous indication of the damage. Such holes, however, are not always a sign that all the moths have escaped, for if a few cuts be taken from such stems and placed in a box, say in April or May, we may anticipate moths emerging at the proper time for two consecutive years. The dates on which I found them appearing in Northumberland were July 10, 1901, and July 10-14, 1902. Fig. 225 shows a longitudinal gallery, and cross section of several galleries.

The larva is whitish, a little over an inch in length; head brown, tapering considerably behind; legs dark-brown and small. 
The pupa is of a bright chestnut colour, with the wing-cases and antenne rather long and free from the body. In the in-

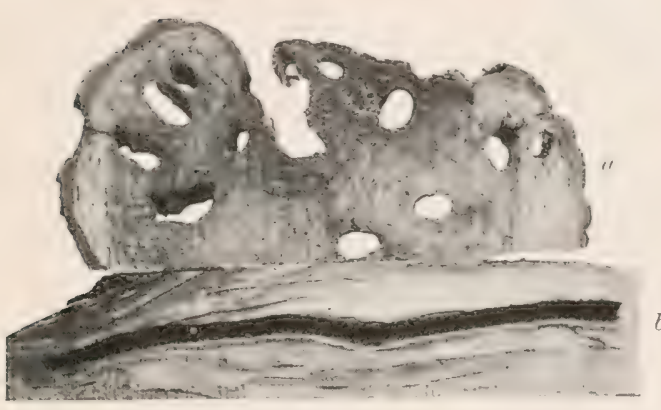

Fig. 225.-Timber of goat willow injured by larve of Trochilium $a$, cross section. $\quad b$, longitudinal section.

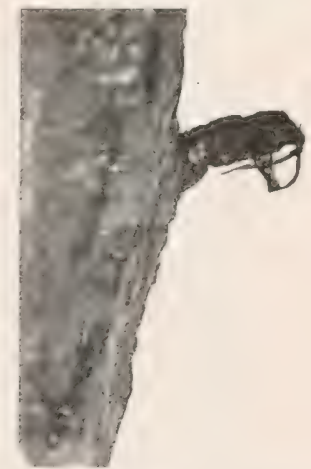

Fig. 220.-Pupal case of Trochilium bembeciformis projecting from trunk: after the escape of the noth.

terior of the wood it is encased in a strong cocoon of white silk and gnawings of wood. After the moths hatch out, the empty pupal cases may be found lying in the hatching-box, or otherwise projecting from the stem, as in fig. 226.

The moth, fig. 227, has a wing expanse of $1 \frac{1}{4}$ to $1 \frac{1}{2}$ inch. Wings transparent, costal edge dark orangebrown, and nervures dark-brown, Head dark-brown. Abdomen darkbrown, with conspicuous yellow bars

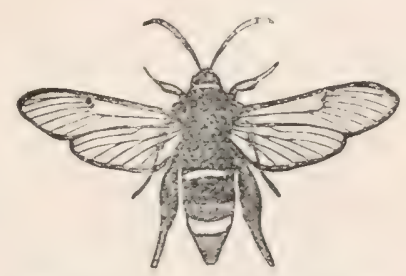

Fig. 227.-Troclitium bembecformis (Hornet (latr-II'in!! "if the osior). across the abdomen. Antennæ black, rather short and stout. Legs an orange-brown.

\section{Cossus ligmiperda, Fab. (Goat Moth).}

The larvæ of the goat moth are often very injurious to various species of trees, as, for example, oak, elm, ash, willow, and poplar. In Cheshire I twice hatched it from oak gate-posts. It may be termed a south-country species, as it generally does not occur north of York- 
shire, and it is said to be most abundant near London. Fig. 228 represents the injuries done to an oak stem or plank. I am indebted to

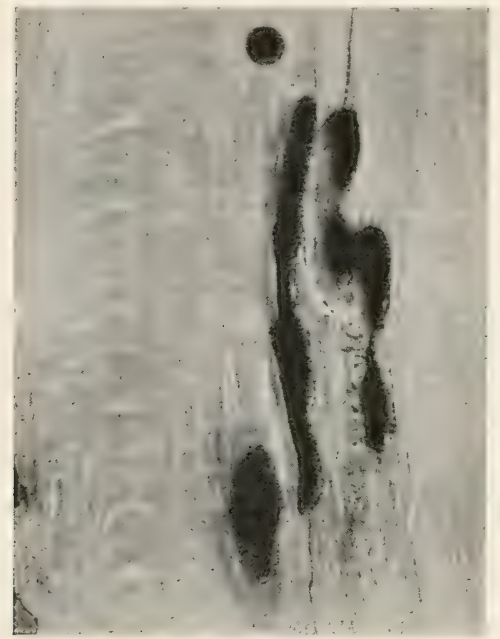

Fig. 228. - Oak plank injured by larve of Goat Moth.

Mr E. G. Wheler, of Claverdon Leys, Warwick, for this specimen.

Mr F. V. Theobald says :-

"The goat moth larvæ are the cause of the damage, for they are not only large but ravenous creatures, which tunnel right into the heart of the hardest wood, and in from six to ten years a large tree is completely killed by them, the whole trunk becoming a honeycombed mass. As many as two hundred have been formd in a single tree. If once a tree is struck by this pest, it continues for years (usually until it is destroyed) to be a breeding-ground. It is quite erroneous to say they only attack sickly trees: perfectly sound and healthy ash and

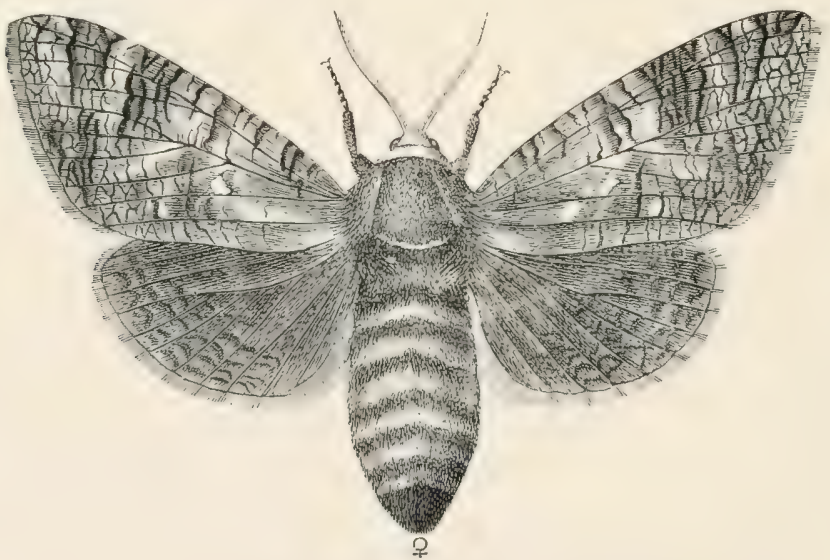

Fig. 229.-Cossus ligniperda (Goat Moth). (From 'The Forester,' by J. Nisbet.)

elm have been observed to be attacked and eventually killed, and then the larvæ traced to the nearest tree that is unalfected. Nor are 
solitary trees and those along wood borders only infested, for I have found trees killed by the goat moth in the heart of dense woods.

"Infested trees may easily be told by the holes in the trunks, the dying limbs, the wood chips thrown out of the holes, and the rough and gnarled appearance of the trunks. Infested trees are said to be easily recognised by the foul odour they emit: this I have failed in every case to notice, and some 150 trees that have been infested, and have succumbed to the attack, have been examined." 1

The moth, fig. 229, is a very large insect, with pectinated antennæ in both sexes. Head reddishbrown; fore wings ashy-grey colour, mixed with a dash of brown, and hind wings more of a smoky-grey. The sexes are somewhat similar, but the female is much the larger, being sometimes $3 \frac{1}{2}$ inches across. The moths appear in June and July, and at once deposit their eggs in the crevices of the bark.

The larva, fig. 230 , is from 3 to $3 \frac{1}{2}$ inches in length, rather smooth and shining. Head small, shining black, the body flesh-coloured, and the legs yellow. They live for about three or four years in the larval stage, and observers have recorded that it frequently has the habit of wandering from its food-plant and pupating in the soil. When it does pupate in the stems of trees, it makes a cocoon with chips and frass.

The pupa, fig. 231, is very stout, slightly curved with rings of sharp spines, and rather prominent wing-cases. The colour is a dark red-brown.

Collectors sometimes get the moth at "sugar."

\section{Zeuzera .escela (Linn.) (Leopard Moth).}

The larva of this moth is destructive to various

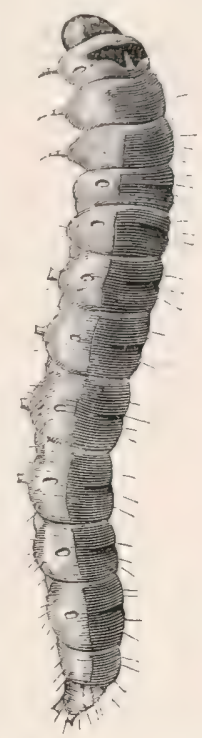

Fig. 230.-Lfiret "f limet Hoth. (From 'The For. ester,' hy J. Nisbet.)

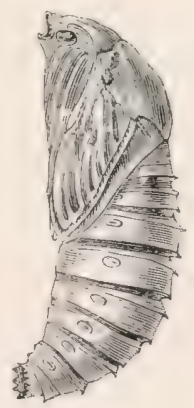

Fic. 231.- P'uper of Foat Butl. (From 'The Forester,' by J. Nisbet.)

species of trees-viz., poplar, horse-chestnut, ash, elm, sycamore, birch, willow, hawthom, and several species of fruit-trees. It may

1 The Animal Pests of Forest Trees. 
be found feeding in the trunks, branches, or twigs. It is said to live from two to three years in the larval stage.

The larva is about $1 \frac{1}{2}$ to 2 inches in length, yellowish-white colour. Head rather small, blackish-brown; second segment has a broad dorsal plate. Each segment of the body has black spots, so that the entire larva has a spotted appearance.

The moth, fig. 232, is very handsome. The ground colour of the wings is white, semi-transparent, with many large blue-black spots. Antennæ black; abdomen grey or blackish.

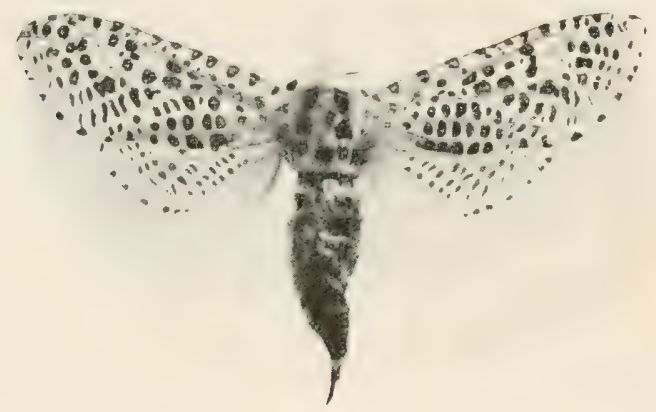

Fig. 232.-Zeuzera xsculi (Leopard Moth).

The expanse of wings is about $2 \frac{1}{2}$ or $2 \frac{3}{4}$ inches in the female, but the male is rather smaller.

It appears on the wing from the end of June to the beginning of August.

Mr A. Gallie, Ringwood, Somerley, sent me a sample of damage done to young trees by the larra, which bore into the stems, and then they snap off.

Orgyia antiqua, Linn. (Common Vapourer Moth).

This is a moth which may be almost termed a universal feeder, inasmuch as the larvæ may be found on almost every tree and shrub. I have, however, not found it so numerically strong as to be considered a serious pest, though I found it very abundant in Delamere Forest, Cheshire, June 1895. 
The caterpillars, fig. $233 a$, are very noticeable from their peculiar tufts and bunches of hair. It is quite parti-coloured-a mixture of brown, grey, pink, yellow, \&c. The head is black, and behind the head two very long feathered bristles project, after the manner of antennx; the segments are brightened with red spots, hairy bristles project from the segments, and four conspicuous yellow tufts spring from the dorsal surface.

The pupa, fig. $233 \mathrm{l}$, is very stout, swollen in the middle, shining dark-brown, hairy, and enclosed in a small cocoon within the balls of leaves.

The male moth, fig. $233 c$, which flies in the day, is of varying

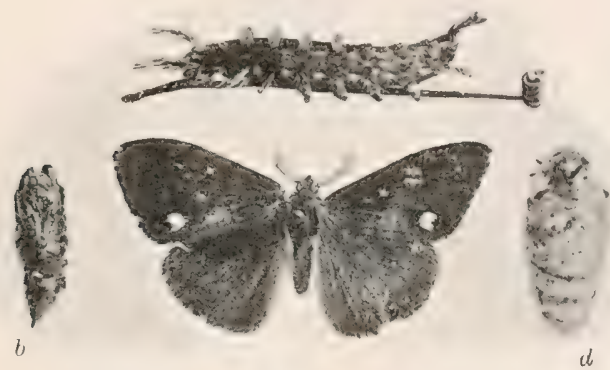

Fig. 233.-COrgyia antiqua (Common Vaponer Moth). $a$, larva ; $b$, pupa ; $c$, male ; $d$, female. (Photo hy A. Flatters.)

shales of hrown or chestnut, and with a white half-moon-shaped syot near the lower outer edge of the fore wing. The antennæ are short and pectinated.

The female, fig. $233 d$, is almost wingless, having short abortire wings, and of a uniform grey colour.

\section{Dicranura (Cerura) vinula, Linn. (Puss Moth).}

The caterpillars of this moth are sometimes very injurious to willow and poplar. I once found them eating hazel in Cheshire, and reared several moths from the caterpillars. I have had them reported from several places in the east coast of Scotland, and the reported injuries coincide with the following account from Miss Ormerod:-

"In 1885 especially, I had notes from MIr J. Low, forester on the 
Rothes Estate, Fife, of the caterpillars being at work in the middle of summer on Balsam poplars, from some of which they had entirely stripped the leaves. These trees had been planted in the previous spring, and were from four to five feet high, and in another instance the rapidity with which the caterpillars devoured the leaves was specially mentioned. During the present year a very curious instance was reported to me from Lincolnshire, in which the little trees were so young and small that the quantity of woody material and bark removed by the caterpillar for its cocoon had so weakened the slender stem that the young poplar plant had broken off. In the specimen sent me, the slender stem was completely bared of bark for some little distance from the hard cocoon, and the young plantation was reported to be practically destroyed." 1

From the species above mentioned which I hatched out, I found that the eggs were deposited about July 1. The eggs were brown, circular, and about $2 \mathrm{~mm}$. in diameter.

Buckler gives the following description, viz. :-

"The eggs are laid either singly or two or three near together, on leaves of poplar, sallow, or willow. (I fancy poplar, any kind, is preferred by the larvæ, when they have the choice.) The egg is button-shaped, convex above, nearly flat underneath, fairly round, with a small pit at the apex, varying from $1.6 \mathrm{~mm}$. to almost $2 \mathrm{~mm}$. in wide diameter, slightly more than $1 \mathrm{~mm}$. high, the shell hard, glossy, but finely pitted all over, colour rich warm brown above, more smoky beneath, the central pit blackish, but ringed with yellowishwhite. There is a pale variety of the egg of a buff tint, the central pit still blackish, with light ring." 2

The larva, when full fed, is large, stont, and smooth. It may be easily recognised by the position it assumes, of arched body and forked tail, which, in fact, may be termed a fighting attitude. The fourth segment is surmounterl by an angular hump, head black, and often partially withdrawn within the body. The prevailing colours of the caterpillar are brown and yellow, the former an angular portion along the back, and the latter conspicuous when viewed from the side.

The pupa is enclosed in a very hard shell-like cocoon, which may be found on the trunk of the food-tree, or, in fact, on any adjacent

I Manual of Injurious Insects.

2 The Larvæ of British Butterflies and Moths. (Ray Society.) 
object. When glued on the stem, they display most excellent examples of protective resemblance (fig. 234).

The moth, fig. 235, is a very large handsome insect, antennæ pectinated in both sexes, very broadly so in the male. The female is the larger insect. It is of a greyish colour throughout, and the body is downy and soft in general appearancehence the name. Wings partially transparent, showing the venation, but more covered near the base, where there are several dark spots.

\section{Pygera buceptiala, Linn. (Buff-tip) Moth).}

The larve of this moth often do considerable damage to various forest trees by feeding on the leaves of elm, oak, and other trees. In some cases oak-trees have been quite defoliated, but as a rule the damage

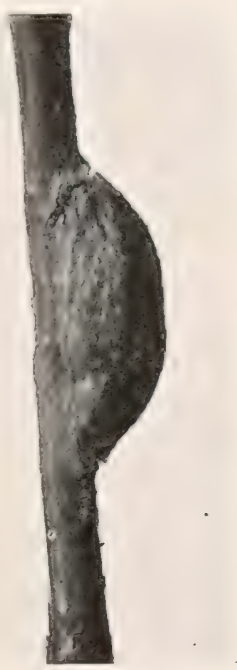
is easily recognised in early autumn, which Fig. 234.-Purce of Puss Moth consists of a defoliated bough, standing on twig of birch. out quite conspicuously from the otherwise fully foliaged trees.

The moth, fig. 236, appears in May and June, and the eggs are laid

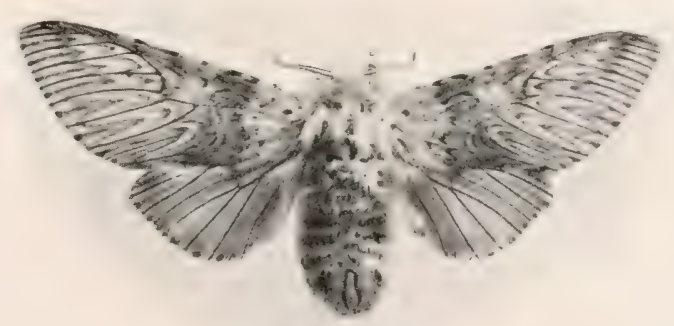

Fig. 235.-Dicranura vinula (Puss MIoth).

in patches on the under side of the leaf. The moth may be found resting in repose during the day, with the wings folded narrowly across 
the body, and the pose so beautifully harmonises with a dead twig that it may, in fact, be easily overlooked. There is a conspicuous buff-coloured portion at the extremity of the wings-hence the name.

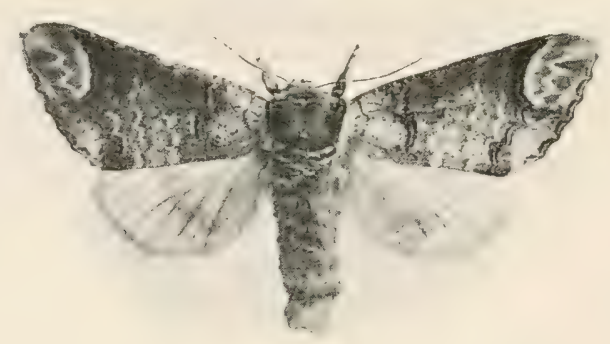

Fig. 236. - Pygara bucephal เ (Buff-tip Moth).

The fore wings are of various shades of pearly grey or silvery grey, with mottled whitish markings. In fact, the wings may be briefly described as sparkling with silvery powder of a frosty appearance.

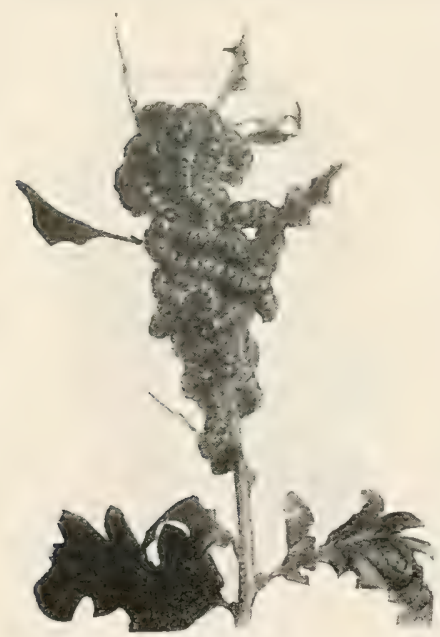

Fig. 237.-Larve of Buff-tip Moth on twig of oak:

The hind wings are whitish stonecoloured in appearance. There is a conspicuous raised crest on the thorax.

The caterpillars, in their very young stage, feed in company, but after the first larval moult they separate into parties of eight or ten, but do not move far from their birthplace-hence the damage is all done in one place. When resting, however, from feeding, they reassemble in comparatively large groups, as seen in fig. 237. When full-grown they are about $1 \frac{3}{4}$ inch in length, rather soft and limp. Head black, body downy. The prevailing colour is a mixture of yellow and black. In the first three segments behind the head those two colours are blended in squares, but on the other segments 
the darkish colour is in fairly large patches, and the yellow colour in longitudinal lines. The yellow colour prevails to such an extent as to brighten the whole body, and thus the caterpillar is a very pretty creature.

As this is often a very injurious insect, it is at times essential to adopt some remedial measures. This can best be clone in the caterpillar stage, by shaking them down on a spread sheet, or otherwise collecting the larvæ and placing them in paraffin.

The pupæ may in some cases be kept in check by spreading gas lime or hot lime round the roots of a previously infested tree.

\section{FAMILY GEOMETRINA.}

The family of moths known as Geometers are of considerable importance in forest entomology, inasmuch as many species may be realily recognised on the foliage of trees by the peculiar habit of the larvæ, known as "looper grubs." This peculiar habit arises from the method of the larva walking in the form of a "loop." A short observation of the creature will give a rapid demonstration. The larva of a "looper grub" has six well-developed true legs in the fore part of the body, and four well-developed claspers at the abdominal end of the body. When at rest the creature may be perfectly straight, but when it wishes to exercise locomotion it brings up the claspers against the true legs, and thus the greater portion of the boty rises upwards in the form of an arch or loop. Then the creature adheres by the abdominal legs, and projects the whole body forwarl, and again draws the claspers against the true legs, thus making the loop and moving the length of its own body forward each time.

The moths are not quite so easily recognised, but as a general rule they have well-developed wings (though in some cases the females are partially wingless), and the wings are generally folded ridge-wise when at rest.

Fidonia pintaria, Linn. (Bordered White Moth).

This moth is very common in Northumberland during the summer months. In the Scots pine woods they fly very abundantly amongst the heather and rough herbage. The larva is not particularly con- 
spicuous in the foliage to the naked eye. The caterpillars may be beaten from the foliage in September and October.

The eggs are deposited on the needles of the Scots pine.

The caterpillars are lightish-green in colour. In the early stages they may be compared to thread-like worms, beautifully harmonising in colour with the foliage. When full-grown they change in colour, but still harmonise with the foliage. The prevailing colour is sea-green, with a whitish longitudinal line down the back, and a yellow line along each side of the body, running parallel with the dorsal line. The caterpillar (fig. 238) is from $1 \frac{1}{4}$ to $1 \frac{1}{2}$ inch in length. They are full fed about October. They pupate in the soil.

The pupa (fig. 239) is light dark-brown in colour. It may be noted

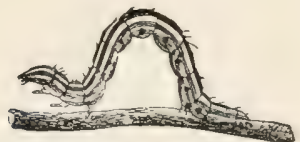

Fig. 238. - Larea of Bordered White ifoth. (From 'Forest Prutection, by W. R. Fisher.)

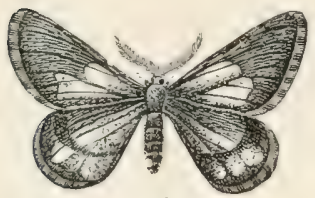

ठำ

Fig. 210.-Fidonia piniaria (male). (From 'Forest Protection,' by W. R. Fisher.)

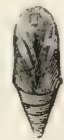

Fig. 239.-Pupa of Bordered White Moth. (From 'Forest Protection, by W. R. Fisher.)

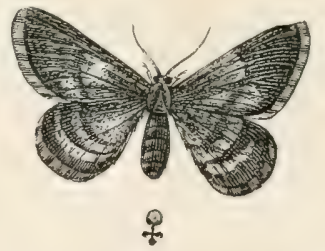

Fig. 241.-Fidonia piniaria (female). (From 'Forest Protection,' by W. R. Fisher.)

that in this insect the pupal period is of comparatively long duration, and Altum points out ${ }^{1}$ that full-fed caterpillars and pupa are subject to being attacked by several natural enemies, both fungi and insects.

The male moth (fig. 240) has very strongly pectinated antennæ, whilst those of the female are quite simple. The body is slender, whitish-grey, and approaching to yellow at the extremity. The prevailing colour of the wings is a mixture of dark-brown and white. The apical portion of the fore wing - a space about equal to one-half of the wing-is a brown-black colour, and the remainder of the wing is practically white, with brown streaks. The under wings are of a similar colour, but the white portion is more mixed with the brown colour, and sometimes roughly divided into white and brown spaces.

1 Forstzoologie. 
Thie female (fig. 241) is, as a rule, slightly larger than the male, being a little over an inch in expanse of wings. In colour both sexes are very unlike, the female being of a nearly uniform orangebrown tint above.

Both sexes fold their wings erect when in repose.

\section{Chemitobia brumata, Linn. (Winter Moth).}

To the fruit-grower in many parts of Lugland this is a dreaded pest. It is also a most injurious forest insect, inasmuch as it feerls on several species of hardwood trees. In nursery-rows, in early summer, young

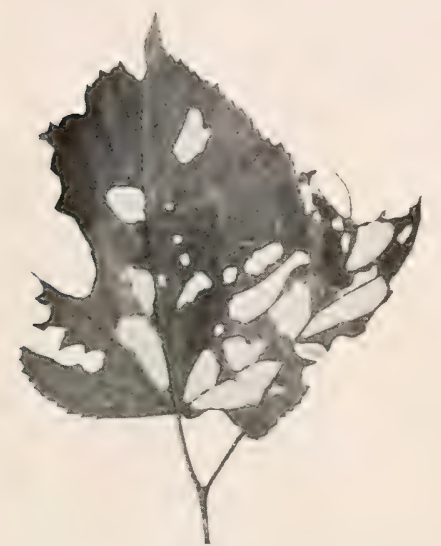

Fig. 242.-Folicge of lime-trec caten by larve of Winter Moth.

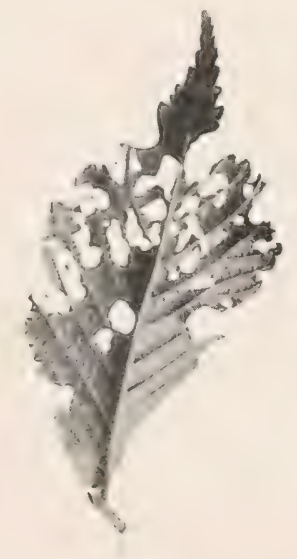

Fig. 243.-Leaf of wych elm eaten by larve of Winter Moth.

lime-trees-more especially those of a comparatively large size which lave just been transplanted the previous spring-are often defoliated by the voracious larvæ of this species (fig. 242). The foliage of the wych elm and sycamore, also, is often much destroyed by the larve of this species (figs. 243 and 244). The injuries done to the foliage are very similar to the ravages of certain species of Tortrices, and it is therefore very important, for purposes of verification, that the moths should be reared from the larval stage.

The moths appear about November, hence the name of "winter moth," and the males fly about in the evening. The males are winged, but the females are furnished only with abortive wings, which are practically useless in the service of flight (fig. $245 \mathrm{~B}$ ). 
The male moths (fig. $245 \mathrm{~A}$ ) have a wing span of about 1 to $1_{4}^{1}$ inch. The fore wings are of a light brown-grey colour, and marked by several faint transverse bands or bars. The hind wings are a pale greyishwhite colour. The antennæ are simple, and the body very slender.

The abortive wings and body of the female are of an ashy-grey colour. The fore wings are brightened by irregular white markings. The colour harmonises very beautifully with the lichen covering the bark of the trees, on which it may be found. The abdomen is very large in proportion to the thorax, and thus the creature when at rest may, as Miss Ormerod remarks, be mistaken for a spider.

I have not found the eggs on the trees, but have examined them

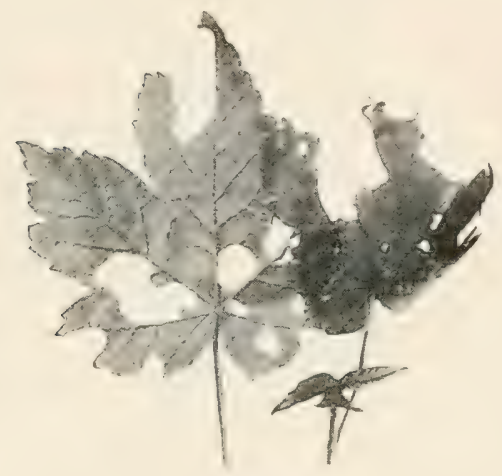

Fig. 214.-Foliage of sycamore eaten by larve of Winter Moth.

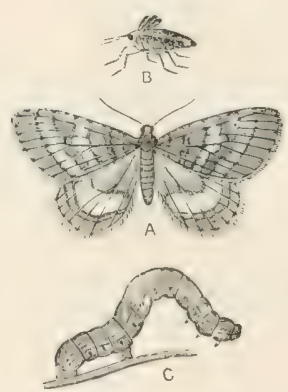

Fig. 245.-Hinter Moth (natural size). A, male; B, female; c, caterpillar. (From 'The Furester,' by J. Nisbet.)

when deposited in confinement. At first they are a light-green colour, and later on they change to a beantiful light-orange. Prior to hatching they are a dark-green colour, from the colour of the encased caterpillar, and after hatching the empty shells are glassy and transparent. The approximate measurement would be about $\frac{1}{64}$ th of an inch in length, oval, blunt at both ends, and beautifully pitted over the surface. The hatching-cases were placed in a cool shed, and the eggs hatched very irregularly. The first larve were recognised on February 10,1905 , and a few appeared every week until the beginning of April, when the bulk then hatched out. At first the larvæ are of a dirty-green colour, with dark heads. When full fed they are about an inch in length, green, with a dark dorsal line, and three yellow stripes along each side, and a dark-brown head. 
The pupa is a light-hrown colour, and slightly encased in a very louse flimsy cocoon. In this species the pupal stage is a comparatively long one, and some specimens do not appear till the following spring. There is only one generation during the year.

As regarls remedies, when the insect is rery destructive to young trees or special trees in a prark, the method adopted hy fruit-rorowers may with advantage be copiet. This consists in intercepting the female moths from climbing up the trees to deposit their ergss. The fruitgrower simply ties a bind of grease-proof paper around the stem of the tree, and then smears the paper over with tar and cart-grease or other viscous substance, into which the female becomes embedded, and therefore cannot extricate herself. This prevention, however, is often overcome by the insects, inasmuch as the male frequently performs the apparently chivalrous action of carrying the female $i$ in crij. to the tops of the trees.

\section{Hrbernia defoliaria, Clerck. (Mottled Umber Moth).}

The larvæ of this moth are often very injurious to various species of trees, as, for example, hornbeam, white-thorn, hazel, oak, and sycamore. The worst attack I ever saw was in Sherwood Forest, Iay 26, 1896, when the larve were actually hanging by threads in shoals from the trees.

Newman thus describes the caterpillar: " "The head is rather large, and not notched on the crown; the body is uniformly cylindrical, and without humps ; the head is without gloss, and brown; the body has a broad dorsal area, of a clear brown colour: this area is bounded on each side by a very distinct, but narrow-waved, black stripe, and is also adorned with grey markings, which are particularly conspicuous at the interstices of the segments where they approach the black houndary stripe; below the boundary stripe the bouly is bright yellow; the spiracles are white, and the regrion surrounding each spiracle brown; the belly is greenish-yellow; legs and claspers pale. A beautiful but very abundant caterpillar."

The moth appears in October. The female is wingless, and the male has large wings and pectinated antenne. The fore wings are of light-hrown colour, usually with two dark-brown bands. The hind wings are paler, and have a dark spot in the middle of the wing.

1 British Butterflies and Moths, p. 105. 
Trachea piniperda, Panz. (Pine-Beauty Moth).

This is the only species selected from the very large family of nocturnal moths generally known as Noctuæ. There are other species of arboreal habits belonging to this group, but this will probably be sufficient for the purpose of this work.

This species is exclusively an arboreal one. The larvæ feed on the twigs of Scots pine trees, and may be beaten from them in June

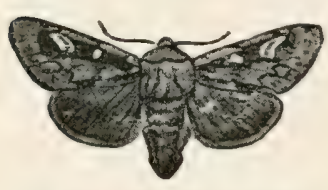

Fig. 246.-Trachea piniperda (Pine-Beruty Moth). and July. In colour the larva has a palebrown head, and the body varies from dark-olive to rich oil-green. It has five longitudinal white stripes. It is not often recorded as being numerically strong, and therefore cannot be considered as a pest.

The moth, fig. 246, appears in April, and may be found adhering to the bark. The antennæ of the male are serrated and those of the female simple. The head is compara-

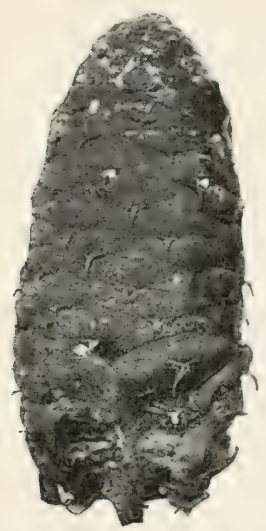

Fig. 24\%.-Cone of silver fir (Abies pectinata) partially eaten by larice of Dioryctria abietella. tively small. The fore wings are of a bright reddish-brown colour mixed with orange, and the hind wings are grey-brown.

\section{Dioryctria abietella, Zinck.}

The larvæ of this species are injurious to the cones of the spruce fir (Picea excelsa) and silver fir (Abies pectinata), fig. 247. As the larvæ live within the cones during the latter part of summer and early autumn, the affected cones may not at first be recognised. When very much eaten, as represented in fig. 247 , they are of course easily noticed, but in the early stages of the injuries it is best to collect the cones and lay them out singly on a clean floor or on a paper, and then select those from which the frass may be seen escaping. They may then be put aside in a vessel, and wait till the perfect insect appears in the following July.

The larva is of a dirty reddish or greenish colour, with darkish back and slightly side-striped. Head and shield brown. 
The moth (fig. 248) may be described as follows: Fore wings long and narrow, glossy dark-grey, with several wavy black transverse lines. Basal and first lines preceded by a white fascia ; first line very distinct on costa; second line angulated and bordered on its outer margin with a white line; an indistinet shaded grey line between it and the hind margin; a pale central spot on disc of wing. Hind wings concolorous. Length 22 to $25 \mathrm{~mm}$.

This species belongs to the

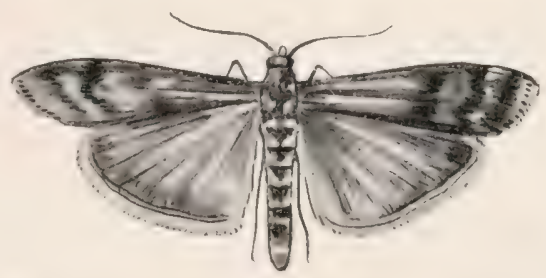

Fig. 248.-Dioryctria abietella (full size), (Drawn by P. J. Browı.) family of Crambites, and typical moths of the same may be seen flying, or rather leaping on the grass fields, in a summer evening walk.

\section{FAMILT TORTRICID压.}

The moths of this family are comparatively small, and some naturalists have proposed for systematic considerations, as regards external anatomy, to merge it with the Tineidr. This suggestion, however, has not met with much support, and from an arboreal point of view the two families should be considered as quite distinct. The name Tortricilæ refers to the general habit the larve of those moths possess of rolling up leaves, or twisting and distorting shoots and buds. The mode of rolling leaves by small larvæ has been much diseussed, and is probably due to definite operations of the larvæ, together with assistance derived from silk threads spun by themselves. These silk threads are rolled round the leaves, and they harden and contract from exposure to the air. After the leaf is thus bound by the tiny thread, the roll is still further perfected by the growth of the vege. table organism accruing from the interference of the caterpillar agency acting within the prescribed limits of the silken thread.

As a great many species of this family are arboreal fecters, a larce field for investigation is presented to the student of forest insects. The prospective interest is still further intensified, as their life-history is involved in considerable obscurity, more especially in the egrg stage, inasmuch as the moth often effectually conceals her eggss. The injuries are done just when growth is most active, and it is obvious, 
therefore, that this must have a very appreciable effect on the increment.

The imago stage is, as a rule, of short duration. Many examples may be found on the wing from March to November, but the majority of arboreal species are most abundant from May to July.

The general characters of the imago may be given as-head tufted with hairy scales, often partially hiding the eyes; the compound eyes usually large and spherical; antennæ invariably simple, and never so long as the anterior wings; thorax usually short; abdomen moderately stout in both sexes, more especially in female, and often terminated by a tuft of bristles in the male.

The larva is from $\frac{1}{2}$ to $\frac{3}{4}$ inch in length, usually with sixteen feet, head and shield horny, and the anal segment generally has a horny plate on the dorsal surface. The duration of life and habits vary according to the food of the species. Thus, for instance, those living on the foliage of deciduous trees must be fully developed prior to the fall of the leaf, or even before the leaves become too hard, while those feeding under bark can live comfortably throughout the winter months.

The pupa is either enclosed in a cocoon or web spun by the larva. The abdominal segment is often armed with minute spines. The pupal stage, like that of the larva, is also very variable.

\section{Tortrix viridana, Linn. (Green Tortrix Moth).}

There is perhaps no species of insect whose injuries are more conspicuous than those of the green Tortrix, or oak-leaf roller moth. Often as early as the end of May, or beginning of June, the larvæ are so abundant as to almost completely defoliate the trees. As this occurs just at the time when the tree is actively growing, it is obvious that in consequence of defoliation the loss of increment is enormous. By way of revenge, as it were, the tree subsequently produces a crop of late green shoots - Lammas shoots, as they are termed, - and though to some extent amendment may be made, yet it is just possible that there may be such a physical difference between the spring and autumn formed cells as to cause technical depreciation of the timber.

It is generally asserted that this species confines itself entirely to the oak. Such, however, is not always the case, as I have often bred it in comparatively small numbers from hazel and ash. It has been 
asserted by several German writer's that when the oak does not yield sufficient food for the larve, they often leave the oak, and complete their full development on other species of trees-viz., lime, ash, beech, mountain-ash, maple, and other species of hardwoods. I have never found it on Turkey oak.

It is also worthy of note that while generally distributed over the

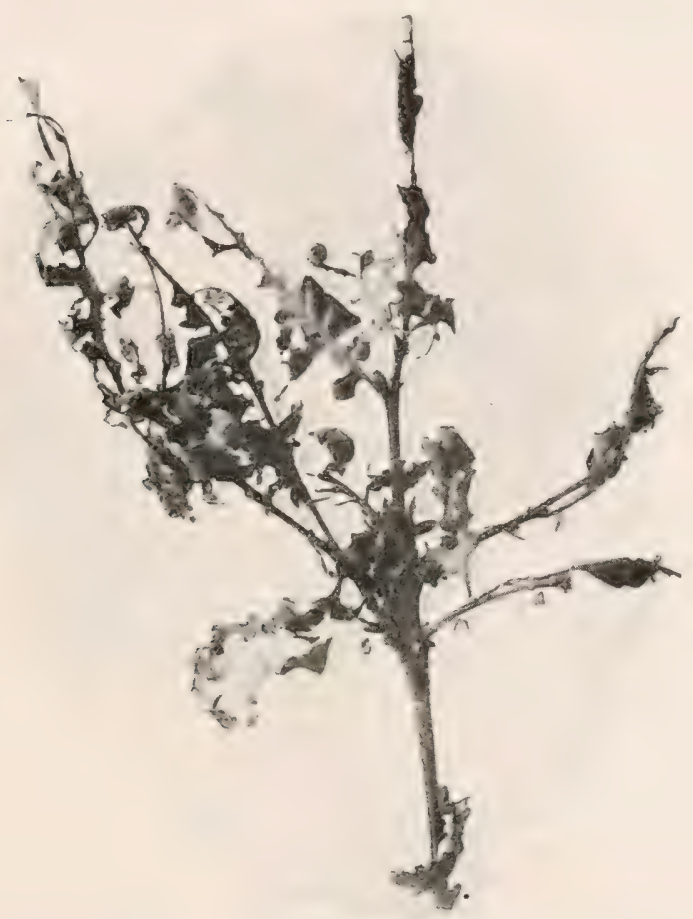

Fig. 249. - Foliage of oak destroyed by larve of the Green Tortrix Moth.

country, it is not a common species in Northumberland. One or two woods, however, on Tyneside are often badly attacked, and in Co. Durham it is frequently very common. Fig. 249 is a photograph of an injured oak-shoot.

The eggs are laid the season preceding the larval attack. They are doubtless deposited on the immediate vicinity of the buds, but opinions differ as to the precise spot, and I have not actually discovered them. 
The larvæ are a slaty colour. The head is a dark-bronze colour, a shade darker than the body, but not so dark as the shield of the head. On each segment may be found four minute black spots, which become more pronounced as they get older. When full fed they measure about $\frac{11}{16}$ of an inch in length. They curl up the leaves for shelter, feed most voraciously, and when disturbed lower themselves by a slender thread.

The pupa is of a uniform dark-brown colour. Pupation takes place in the folds of the leaves, and the moths appear in swarms about the end of June.

The moth is easily identified, as it is the only pure green Tortrix we have. The fore wings are pure green, hind wings grey. Head, antennæ, and body yellowish-white. Wing-span about 22 to $24 \mathrm{~mm}$.

This species, as has been asserted, is very injurious to the oak, but it should be noted that it is more injurious to the pedunculate than the sessile variety. As regards the discrimination of those two varieties, practical men as well as botanists do not quite agree; but it may be said that distinct types are easily determined. The partiality of the insect for the pedunculate variety was pointed out to me by my friend Mr J. F. Annand in the Chopwell Woods, Co. Durham. In this case the pedunculate variety was entirely defoliated, whereas the sessile variety was untouched. This peculiarity is noted by Mr Elwes, in his magnificent work on 'The Forest 'Trees of Great Britain and Ireland,' in the following remarks :-

"Another peculiarity of the sessile oak is referred to in a letter from the Hon. Gerald Lascelles to Mr Stafford Howard, in which he says: ' $I$ doubt whether there is much difference between the timber of the sessile and pedunculate oaks, but I think that the sessile is straighter and cleaner in growth, and one thing is certain, that it is almost immune from the attacks of the caterpillar (Tortrix virildana) which so often destroys every leaf on the pedunculate oak in early summer. Whether this does any real harm or not is a mootpoint, but I think it must be a check to growth, and that the trees would be better without it. I have seen a sessile oak standing out in brilliant foliage when every tree in the wood around was as bare of leaf as in winter.'

"Mr J. Smith, in the paper above referred to, pp. 29, 30, confirms Mr Lascelles' observations, and says that in 1888 , which was the 
worst year for these caterpillars that he remembered, he passed through a wood composed of Q. sessiliftora in which, though it had been attacked hy the caterpillars, they had left off, evilently either poisoned or starved. He also quotes a resident in the Forest of Dean, who, writing in 1881, says: 'It was strikingly evident last summer that the Q. robur pedunculata, or old English oak, was attacked by blight (? caterpillars) more severely than Q. r. sessiliflora;' and Mr Baylis, who now has charge of Dean Forest, writes to me on the subject as follows: 'I can confirm the statement that the larva of the green oak moth defoliates $Q$. pertunculata very much more than Q. sessitiflora, and I think the reason is this: the latter is the first to come into leaf, and the leaf has time to get fairly tough before the caterpillax has reached its most destructive stage, which is about the time that $Q$. pedunculata is coming into leaf. I have frequently noticed this fact, that the oak with more decided pedunculate characters is almost invariably attacked rather than the other.'"

As regards remedies for this species, it is most difficult to know what to suggest, and it therefore afforils a very good case in point as showing how difficult it is to cope with a real forest pest on a large scale.

\section{Tortrix Ribeana (Hub.)}

This species is a general feeder on many kinds of trees, and fig. 250 on hazel may be taken as a typical example of its injuries. The foliage is often entirely eaten by the larve of this species. At first they riddle the leaves very much indeed, and take alvantage during the day of the uneaten portions of the under side of the leaf for shelter. Finally, they often denude the trees of the entire foliage, and pupate in the soil.

The larva and moth of this species are often very variable in colour and markings, and as there are several species doing similar damage, it would be well to verify the respective species by hatching out the moths from larvæ making injuries on hazel after the manner of the illustration given.

\section{Penthina pruniana (Hub.)}

It often happens that isolated specimen thorns on lawns, and also patches of trimmed thorn hedges, show almost complete defoliation 
about the end of May and beginning of June. This is due to the voracious feeding larvæ of Penthina muniana. The larvæ commence feeding just as the foliage develops, so that the infested patch remains naked until the larvæ pass into the pupal stage-about the middle of June.

The moth may be looked for about the beginning of July lodging amongst the foliage, and with a little patience may be easily hoxed during the daytime.

The moth has fore wings blackish for two-thirds of their length, a

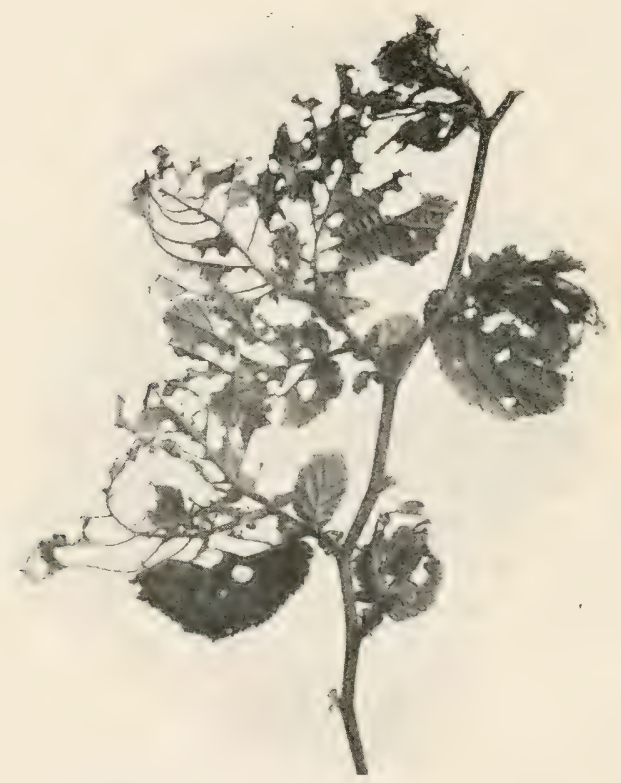

Fig. 250.-Foliage of hazel injured by larve of Tortrix ribeana.

space before middle of wing white, between basal patch and central fascia, sometimes crossing the wing, but always distinct on inver margin; apical third white, clouded with grey, with about four small tooth-marks on costa; hind margin dark-grey. Expanse 18 to $20 \mathrm{~mm}$. All the species of this genus have similar markings, and are not easy to determine; but the short broad form of the wings will separate it from its allies. 


\section{Hedya ocellana, Fib.}

This species is very common in many parts of the south of England, and the larva is injurious to numbers of trees. Mr L. T. Connold sent me the specimen from which fig. 251 is taken, as showing typical injury to the variety of white-leaved poplar known as Populus argentea. It will be noticed that when the larva injures the leading shoot, as seen in the illustration, considerable damage is done to young woods.

\section{Batodes angustiorana, Haw.}

It often happens that many of the extreme twigs on the common yew are dead throughout the early part of summer, and having the appearance of being damaged by frost. This, however, is the result of the larva of this species. The larva hibernate during the winter in cocoons of hair and leaves of the yew-tree. They eat

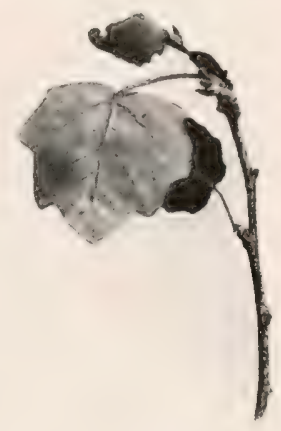

Tif. :-5.-- Leculing shoot of

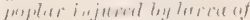
Hedlya velluha. the woody portion of the twig, and thus cause it to wither (fig. 252). In early summer they may be beaten from the yews.

The larva is about half an inch in length, of a green or yellowishgreen colour, with black markings on the sides, and having a dorsal line of a lightish-yellow colour.

The pupa is about 3 lines long, and of a pale-brown colour.

The moth has fore wings brown with reddish-brown markings, the basal bloteh reaching dise of wing; central fascia broadest on inner margin, gradually narrowing to costa, and oblique by crossing the wing. On its outer margin on the costa is a pale-yellow spot. Then follows the ocellated blotch which extends to the anal angle; in the middle of it are some darker scales. Hind wings uniform dark-grey. Description from a $q$ specimen. Expanse 12 to $16 \mathrm{~mm}$.

\section{Pedisca occultana, Dougl.}

I have only found this insect once, and that was an attack on Pimes cembra in Northumberland, on plants which had been purchased preceding the attack from a public nursery in the Midlands. 
The plants in question were from 3 to 4 feet high, and the injuries consisted in the top shoots being arrested in their development. Every practical man knows that conifers in general make but a very short leading shoot the year following transplanting, and that in the early stages of growth the whorl of lateral branches stands erect and surrounding the leading shoot. In this particular case the injuries inflicted by the larvæ resulted in not only eating the young leaves,

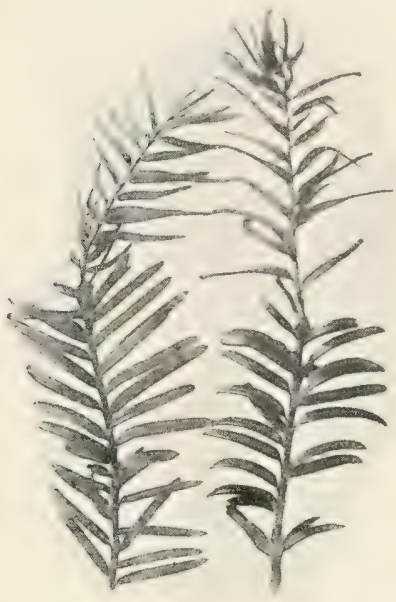

Fig. 252.- Shoots of English yew (Taxus baccata) injured by larve of Batodes angustiorana.

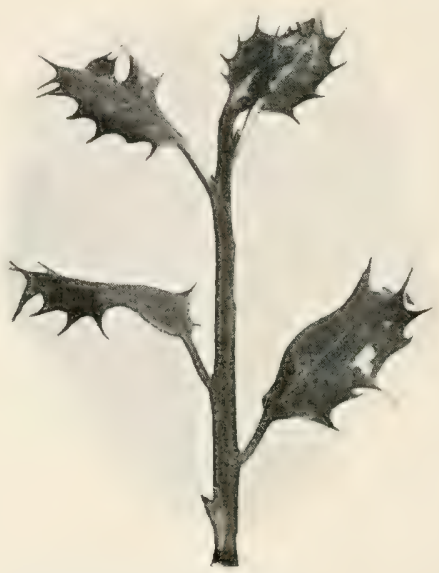

Fig. 253.-Shoot of holly injured by Prdi=ca ophthalmicana.

but in soldering the whole of this whorl together, so that in many cases the leading shoot and lateral branches were either very much weakened or otherwise killed outright.

\section{Pedisca ophthalmicana, Hub. ${ }^{1}$}

If the holly hedges are examined about May or June, it will be found that the leaves of the terminal shoots are often drawn together by a small silken thread, thus forming a sort of rosette (fig. 253). It will be found that each rosette is tenanted by a single small caterpillar, and in many cases they are very abundant on hedges

${ }^{1}$ It is possible there are several closely allied species doing similar damage, so that implicit conficience should not be placed in the name of this species from the damage alone. 
which are switched or clipped annually. The rosette is not conspicuous until the larva is nearly full ful. It is of dirty-green colour, with black head and shield.

The pupa is about 4 lines long, of a rich brown colour, and slightly shining.

The imago appears about the end of June or beginning of July. The fore wings are of a dark smoky-grey colour. The hind wings are of a light-green colour. Eyes intense brown, and with a velvety appearance. Antennæ dull brown. Abdomen shining grey colour. Length about 6 to 7 lines.

This species cannot be regarded as very injurious, yet it does a considerahle amount of damage to the surface of the hedge, inasmuch as, being often numerically strong, it apprecially affects the growth of the shoots. As the surface is the all-important point in an ornamental hedge, it would often be well to check this pest by simply cutting or nipping off the tender shoots while they contain the larve, and either burning or throwing them into a bucket containing paraffin. This operation, though rather tedious, would have the effect of reducing the number of perfect insects, and therefore diminishing the attack for the following year.

\section{Stigmonota Regiana (Zeller).}

If the loose projecting bark on very old sycamore-trees be lifted up during the winter months, small cocoons, sometimes quite a number together, may be recognised. In each cocoon there is a small larva, of a dirty - white colour, and about 4 or 5 lines long.

The pupa is about $3 \frac{1}{2}$ lines long, and of a light-amber colour.

The imago, which appears in June or July, is about 6 or 7 lines in expanse of wings, and when unfolded is certainly very pretty. The prevailing colour of the fore wings is chocolate, whilst on each wing there is a semicircular patch of yellow, which, when the wings are closed, forms a beautiful circle in the middle of the folded wings. The effect of this marking is somewhat lost when the wings are spread out.

This species cannot on any account be considered injurious. It is quite possible, however, that the action of the larve causes the old bark to fall off sooner than it otherwise would do. 


\section{Gemus Retinia.}

The genus Retinia is found amongst fir-trees, and in certain localities some species are quite dreaded enemies. In fact, it is possible that a consulting entomologist may receive more specimens of Retinia buotiana than almost any other insect for identification. This species, being fairly well distributed, may be studied as a type form of the genus. It is very easily hatched out artificially, more especially as it is generally full fed before it asserts itself.

Lepidopterists recognise seven or eight British species, but the following is a synopsis of the important species:-

(a) In buds of Scots pine, with brownish-grey fore wings

R. turionana.

(b) In leading shoots of Scots pine, with yellowish-red fore wings and silvery cross lines . . . $\quad R$. buoliana.

(c) Forming a gall of resin as a larval chamber. Fore wings dark brown-green, with grey dusty covering . $R$. resinella.

(d) Making a "running" side destruction of leading shoot of larch or Scots pine. Fore wings brown, with dark-buff tip

R. duplana.

Retinia turionana, Hb. (Pine-bud Tortrix Moth).

This species has only once come under my observation as a pestviz., in Delamere Forest, Cheshire. The infested pines were from ten to twelve years of age, and the injuries were in the leading bud, as shown in fig. 254.

The moths hatched out early in June. They were from 16 to $18 \mathrm{~mm}$. in expanse of wings. The fore wings were of brownish-grey colour, with transverse lines. The hind wings were whitish. Head and thorax ferruginous, and abdomen grey.

The larvæ are a yellowish-red colour, and rather less than half an inch in length.

Retinia buoliana, Schiff (Pine-shoot Tortrix Moth).

The habits of the larva are very much like those of $R$. turionana, except that in buotiana the leading bud or whorl of buds are not arrested in their early development, and therefore all begin to 
grow at the same time; but the centre one soon droops and finally dies, in consequence of the centre of the shoot being entirely destroyed

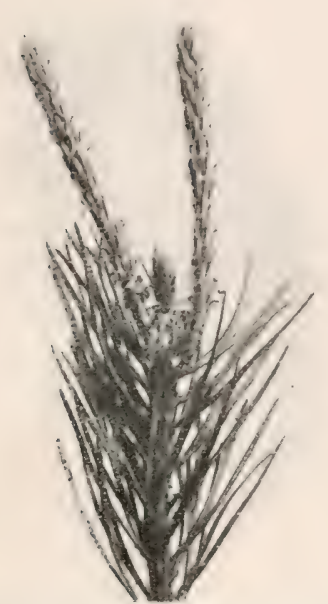

Fig. 254.- "Leading" bud of Scots pine injured by larva of Retinia turionana.

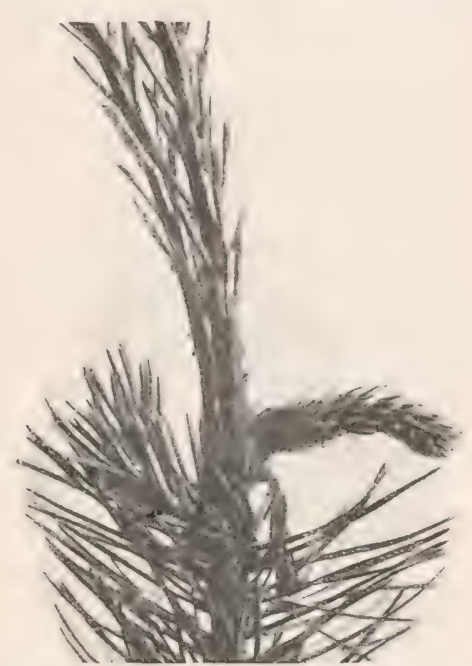

Fig. 255.- "Leading shout" of young Scots pine injured by laria of Retinia buoliana.

by the larva. Fig. 255 represents a photograph taken from a twoyear Scots pine plant in the nursery-line. The affected shoot, which contains a single larva, is lying to the right, and the normal shoots are very vigorous, but they are not shown in full length. In addition to injuries being done in nursery-lines, we often find young Scots pines and Austrian pines from six to ten years of age very much destroyed by this species. As a rule the injured shoots die, but a few exceptional cases are found on young trees with distorted or deformed leading shoots, accruing from the damage done by this insect.

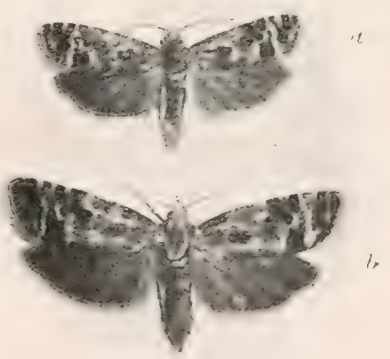

Fig. 256,-Retinia buoliana. $a$, male; $b$, female.

The moth (fig. 256) is from 18 to $22 \mathrm{~mm}$. wing span. The fore wings are of yellowish-red colour; the red is brightened by silvery 
cross-lines, which are very variable in pattern. The lind wings are of a uniform dark-grey, being fringed with light pale-grey ciliæ. Head and thorax a pale-yellow colour; antennæ brownish; eyes black; abdomen dark-grey.

The larva is from 6 to 7 lines long, dark-brown in colour. Head and thorax black; legs small and black, very sluggish.

The pupa is about 5 lines long. The head, thorax, and wing-cases are a dark-brown colour, and the abdomen a light-chestnut colour.

As regards the life-history, the moths appear about the end of July, and deposit their egres at the tip end of the shoots. The larvæ hatch out late in summer, and gnaw the side of a bud, so as to cause a flow of resin, which covers the caterpillar over for the winter, and here they hibernate. In spring they wake up, attack the leading bud, giving rise to the injuries already referred to, and feed till about the latter end of June or beginning of July. They pupate within the infested shoots, and the pupal stage lasts from ten to fourteen days.

With regard to remedies, very

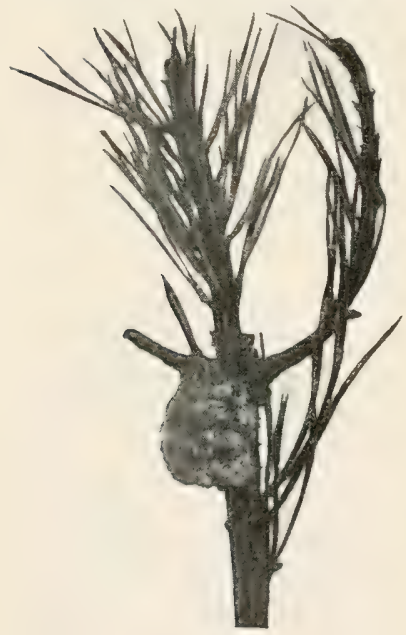

Fig. 257.-Gall of resin on Scots pine caused by Retinia resinella. little can be done except pick the injured shoots, together with the incased larva or pupa, about the middle of June, and then destroy the same. This would have the effect of diminishing the attack for the following year. The moths may be found lodging in the young shoots, and if collected shortly after hatching out, egg-laying might be checked.

Retinia resinella, L.

This insect is said to be confined to certain localities in the north of Scotland, and the only time I have ever seen it in numbers was in

Belgimm in 1905. There is no mistaking it when seen, as it is simply a large gall of solid resin on the shoots of Scots pine at a spot representing what practical men would term the commencement of the growth the year before last (fig. 257). This spot at once suggests an 
important factor in the life-history of the insect-viz., that the gall takes two years to reach maturity. The generation is therefore a liennial one. The eggs are laid in May, just under the whorl of buds, which are bursting, or about to burst, into the growing shoots. The caterpillar bores into the pith, and this being the most active period in the life of the plant, eauses the growth of a hollow gall resinous mass, about the size of a pea, and in this abode the larva passes the winter. In the following spring the larva continues feeding, but meanwhile the gall rapidly increases in size to that of an average gooseberry. A section of a gall shows that it is divided into two chambers by a strong vertical partition: in one the larva lives and pupates, and the other contains its excrement. The pupal period is very short, and the moth flies about Nay - the generation thus extending over two years.
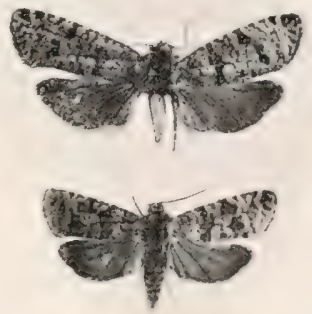

Fig. 25s.-Retinia resinella.

It generally attacks trees from six to ten years of age, but, as a rule, the injury to the forest, or even to individual trees, is very trifling.

The moth (fig. 258) has a wing expanse of 16 to $18 \mathrm{~mm}$. Head, antenne, thorax, and abdomen dark brown-green, or lightish grey dusty covering. Fore wings dark black-brown, with shining grey transverse lines; hind wings grey-brown; fringes pale.

The larva is about $11 \mathrm{~mm}$. long, and of an orange-brown colour.

\section{FAMILY TINEÆ.}

\section{Genus Hrponomeuta.}

In many parts of the country, more especially in lanes, we often find bushes defoliated and covered with a sort of net, in the interior of which are a large number of small larvæ of the genus called Hyponomeuta. They are popularly known as the small "ermine moths," but they are comparatively large for "micros." 


\section{Hyporomeuta evonymellus (L.)}

The genus contains a number of species. The one generally found in the north of England is H. evonymellus. It is found on bird-cherry and spindle-tree, and the conspicuous feature of the

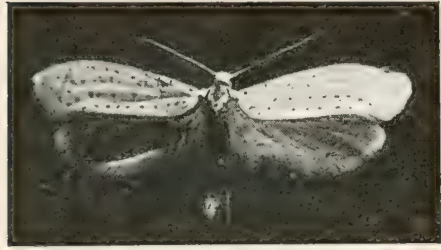

Fig. 259.-Hyponomeuta evonymellus. damage is the defoliation of the bushes, together with the gauzelike spun webs, which protect the gregarious larvæ.

The moth (fig. 259) measures about $\frac{3}{4}$ inch from the tip of the wings. The upper surface of the wings is a lustrous white colour, and shows five rows of black spots (over forty in all). The hind wings are dark-grey. The head and antennæ are white, eyes black, and abdomen grey.

The caterpillar is about $\frac{3}{4}$ inch in length, and of a yellowish-grey

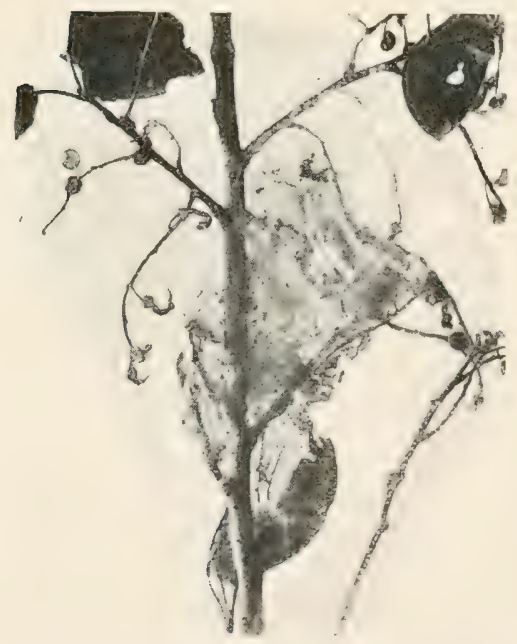

Fig. 260. - Webb and empty pupal cases of Hyponomeuta evonymellus. colour. The head is black, and there are black spots on the segments.

After the caterpillars are full fed they congregate within the web, and pupate in a mass, for the mass of pupal remains may be found even in the following year, reminding one of the empty cases of the wasp or honey-bee. (Fig. 260.)

As regards the life-history of this species, I have only made observations in Northumberland. The moths appear about the first week in July. They deposit their eggs in clusters on the twigs, just immediately below a bud, and they are most beautifully concealed by a lelicate covering, the colour of which hamonises with the tiny stem so well that it is only after a most careful search they can be 
found at all. So far I have not been able to ascertain the approximate date at which the larve emerge from the eggs and betake themselves to the opening buds, but they do not assert themselves on the foliage until well on the middle of May. By this time the leaves are well developed, and thus aftord plenty of food for the larva, which live gregariously, and spin a veil-like web over the colony. They are full fecl by the middle of June, and the pupal stage completes their life-history.

As this species is in many eases very injurious, and as its host-plant, the birl-cherry or hackberry, has some claims as an ornamental tree, on account of its beatiful white flowers, it would be well in very bad cases to adopt some remedial measures. It is obvious that we could only apply remedial measures in its larval and pupal stages.

As regards checking the larve, they may be (1) shaken down from the trees during the day on to a sheet, or (2) hand-picked by cutting off the web containing the larve, or (3) they may be sprayed with a parafin emulsion. With regard to the last method, the following note is taken from the Board of Agriculture leaflet, No. 65 :-

"The Board know of one ease in Perthshire where, in an extremely severe infestation, the proprietor, dissatisfied with the result of a paraffin spray, made up a strong solution of an arsenical sheep-dip, and by this means killed thousands of caterpillars. The caterpillars that had not been killed, or which on disturbance had let themselves down from the web by their threads, collected at the foot of the trees, and were easily destroyed. Great care, however, had to be exercised, as any leaves touched by the material turned black and dropped off."

With regard to checking the pest in the pupal stage, this can best be done by simply cutting off the webs when they are in the cocoon stage; but as this stage is a comparatively short one (about ten days or a fortnight), no time would have to be lost in order to make it effectual.

\section{Prays curtisellus, Don. (Ash-bud Moth).}

This species seems to entirely confine itself to one food-plant-viz., the common ash (Fraxinus excelsior), and is certainly very injurious indeed to plants in the nursery-lines from three to six years of age. It attacks the terminal bud, and thus causes the young ash to fork, a fenture we do not by any means wish to see in young ash plants. 
Kaltenbach says ${ }^{1}$ that he "never found the larvæ in free-standing or healthy ash, but more abundantly on young over-shadowed or thickstanding small trees." The result of the larval damage first asserts itself in the terminal bud, which does not develop along with the lateral ones (fig. 261), and as time goes on the leading bud dies, and we have a forked young tree, as in fig. 262. As soon as the leaves begin to grow the larva leaves the bud and bores itself into the leafstalk, and in consequence the leaf-stalk, together with the leaves, wither and die off. One larva goes from stalk to stalk, and thus kills several of them. After the larva is full fed it spins itself into a

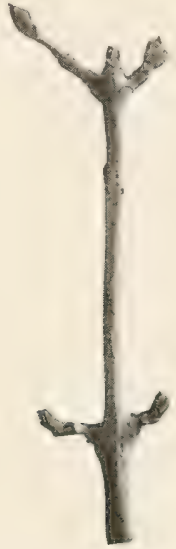

Fig. 261.-Leading buel of young ash-tree injured by larva of Prays curtisellus.

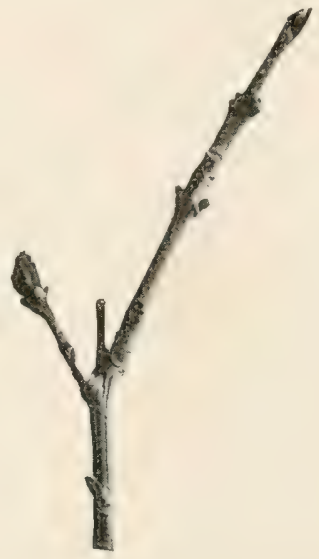

Fig. 26"-Young ash-tree "forled" by larea of Prays curtisellus.

silken cocoon, pupates, and appears in the imago form about July 1. Specimens sent from Chatsworth, Derbyshire, and those in Northumberland, hatch out simultaneously.

The moth is a pretty whitish-grey insect. Head white and hairy; eyes black; thorax white; abdomen brown-grey. Fore wings whel closed showing a white line in centre, and brown at sides, a kind of magpie colour. Fore wings when spread, whitish with brownish patches. Hind wings brown-grey with light fringe. Wing span 14 to $17 \mathrm{~mm}$.

Larva with black head, and neck shield; body of a dirty ashy-grey culour, streaked with reddish-green, tapering at both "ends, and the

1 Die Pflanzeufeinde aus der Klasse der Insekten. 
belly dark-green. Length $12 \mathrm{~mm}$. Viewed with a lens, the colour very much resembles a healthy young ash stem.

Pupa dark-brown in fore part, and latter part of a very light, greyish-yellow, enclosed in silken threads.

As regards the life-history of this species, I find there is a great difference between the account given by Judeich and Nitsche, as seen from fig. 263, and what I have found in Northumberland, inasmuch as the species is double-brooded in Germany, and only a single gener-

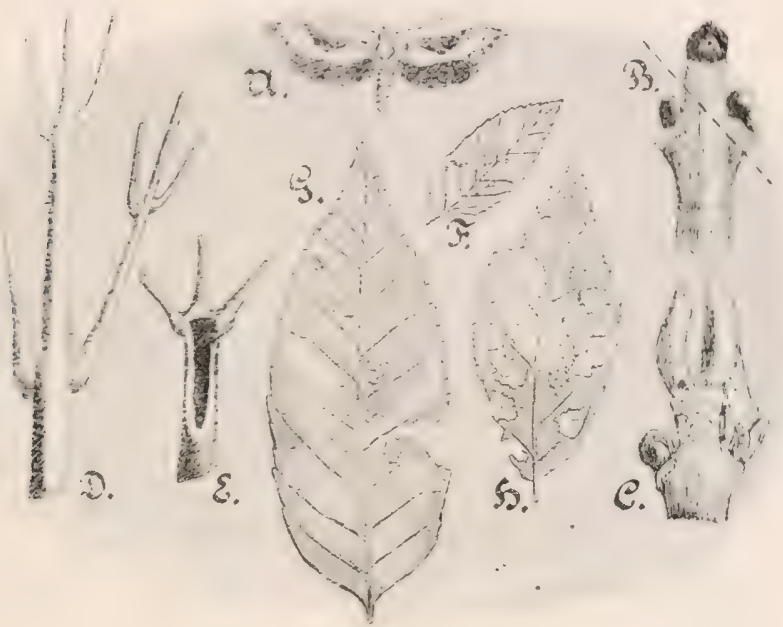

Fig. 203.-Prays curtisellus.

$a$, moth ; $b$, bud injured in autumn by young larva; $c$, the young larva has left the bud in spring and spun a protection for itself; $d$ and $e$, the young shoots destroyed by spring larve; $f, g$, and $h$, leaves eaten by summer larvie-i.e., larvæ of second brood. Copied from Judeich and Nitsche.

ation in a year in the north of England. It is, however, possible that the species may be double-brooded in the south of England, and it will be well, therefore, for students in forest entomology to verify this. Hence the illustration from Nitsche may be very helpful. In the accompanying illustration it will be seen that the spring brood destroys the leading shoots and the leaf-stalks, as seen in $d$ and $e$. The larvæ of the second brood eat the leaves, as seen in $f, g$, and $h$, and then deposit eggs in the leading buds.

With regard to remedies, it is scarcely possible to do anything except collect the larvæ when they are feeding in the leaf-stalks. 
This could easily be done in the nursery-lines, and also in a young plantation, though it would obviously be more practical in the nursery. Pruning by checking the worst of the double shoots should be done during the summer following an attack, as an ash is a tree which is very much depreciated in value if allowed to become forked.

In glens or valleys where ash has been planted in a very congenial position, much good may be done by cutting down the young damaged trees to the ground and allowing them to spring up again, which in sheltered spots they do very rapidly.

\section{Genus Depressaria.}

The genus Depressaria is the largest of the sub-family Gelechiidæ, numbering just over forty species. They are remarkably characteristic from the broad flat appearance of the moths in repose. Wings two and a half times as long as broad, tip rounded, hind margin nearly parallel to anal angle; hind wings nearly as long as fore wings,

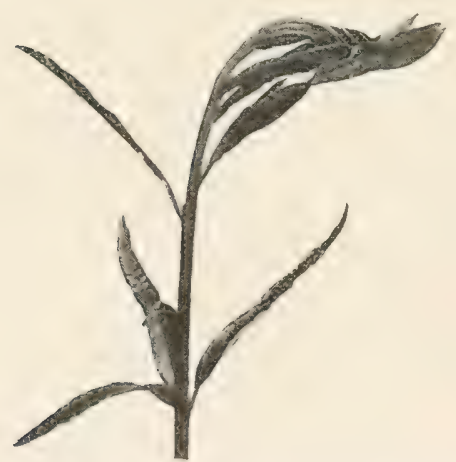

Fig. 264.-Leaves of osier (Salix viminalis) drat'n trigether by lared of Depressaria conterminella. with the hind margin indented near anal angle ; palpi long, ascending, curved, and often furnished in middle with dense tufts of scales.

\section{Depressaria conterminella, Zeller.}

Fore wing reddish-ochreous; base of wing pale yellow, rather sharply defined. A pale ochreous spot on dise, and near it an oblique, crescent-shaped, black streak. A series of short black marks along the costa; hind margin before cilia narrowly bordered with a black line. Head and often thorax pale ochreous; hind wings uniform dark-grey. Length 18 to $20 \mathrm{~mm}$.

If osier-beds are examined during the latter end of May, it will be found that many of the leading shoots present the appearance shown in fig. 264. If the whorl of leaves be unfolded, it will be found that a small wriggling larva has been protecting itself within 
the folded leaves and injuring the leading bud and shoot. This is the larva of Depressaria conterminella.

It should be noted that several species of Lepidopterous larve do similar damage, so that the injury represented in fig. 264 should not be taken as solely due to the species given. The species in question, however, was most injurious in Cheshire to osier rods (Satix viminalis). I am obliged to Mir J. Collins, Oxford, for the identification of this species.

\section{Depressaria assimilella, Tr.}

If an inspection of broom be made from March to the beginning of May, it will be found that the twigs are often very much drawn together, as in fig. 265. If the twigs are separated at the points where they overlap, it will be found that a small brown larva lives within the folds, and has injured them very considerably. This is the larva of Depressaria assimilella.

The moth appears in June and July. The fore wings are of a pale ochreous colour, and about 9 lines in expanse. The antennæ are dark-brown.

It cannot be said that this species is of any great economic importance, but it often happens that broom is grown for ornament or covert purposes, and in such cases the insect may be considered a pest. In order to effect remedial measures it would be well to top the broom

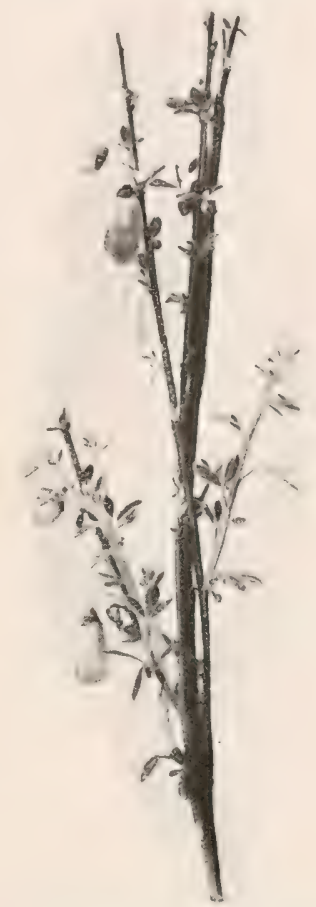

Fig. 265. - Shoots of broon trawn together by lurve, of Depressaria assimilella. while the creature is in the larval stage, and burn the prunings. When broom is cultivated it is well to prune off the tops in any case, either in early autumn before the frosts appear, and thus prevent the winter winds from blowing the bushes about, or after the spring frosts and prior to the vigorous growth of early summer. Thus the adoption of practical work is a remedial measure against the pest. 


\section{Genus Argrresthia.}

Stainton ${ }^{1}$ gives the following characters for this genus-viz., "Imago, head rough; the face smooth; no maxillary palpi; labial palpi rather short, the terminal joint blunt or slightly pointed; fore wings elongate; hind wings lanceolate, with long fringes.

"The insects of the genus Argyresthia are distinguished by their position in repose, as the hind pair of legs are laid alongside the body, which is elevated at a considerable angle, the insect's head being

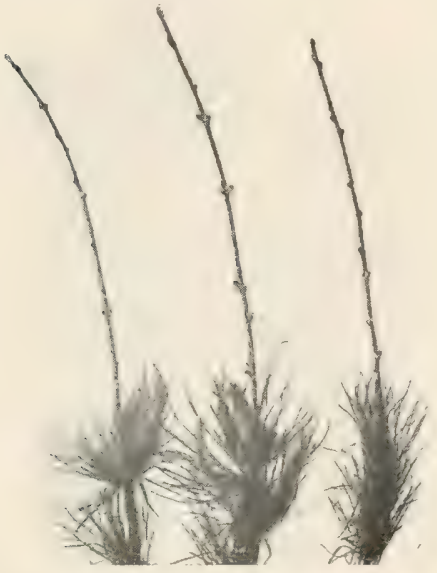

Fig. 266.-Togs of young lurch-tices injued by larece of Aryresthia livigatella. almost in contact with the substance on which it rests."

\section{Argyresthia LæVigatella}

(H. Sch.)

In all probability this is a forest insect which has escaped attention for a considerable time. The first record of it in this country is given by Dr Somerville and Mr John Bennett so recently as July 1907.2 The insect was not difficult to determine, from its damage to the larch, as a very good figure is given by $\mathrm{N}$ isslin; and though not hitherto recorded in this country, it is just possible that it may have been overlooked, owing to the close resemblance of the damage accruing from the pineweevil (Hylotius abietis). At all events, I now find the creature fairly common in Northumberland, and that I mistook the injuries as suggested. The larval action is that the leading shoot is killed, as shown in fig. 266.

Dr R. S. MracDougall gives the following deseription of the insect: ${ }^{3}$ -

"Moth.-The moth is very small, measuring only 4 to 5 millimetres (less than one-fifth of an inch) in length and 10 to 12 millimetres in spread of wings. The fore wings are silver-grey and silky, with a

1 Manual of Butterflies and Moths.

2 Quarterly Journal of Forestry, vol. i., No. 3.

3 Journal of the Board of Agriculture, vol, xiv., No. 7. 
gloss like lead; the fore edges are somewhat darker; the fringes of these fore wings are grey or brownish-grey.

"The hind wings are dark-grey, and not so glossy. The face is white; the base of the antenne is white, and the rest of the antemne dark and light-ringed. There is a tuft of hairs on the head; the colour of the hairs is given differently by different Continental authorities,-in my own specimens the colour is yellow. The abdomen of the moth is dark-grey.

"Caterpillar:-The larva is pale yellow when young, but later is pale grey with a dash of red, and is dark striped towards the hind end of the back. The heal and the three front pairs of legs are black. The length, 6 to 7 millimetres.

"Pupa.-The pupa is dark-brown, with a black head; its hind end is distinctly pointed."

As regards the life-history of this insect, the moth appears in the latter end of May or beginning of June. The eggs are deposited in the lower part of the shoot of the current year. The egg soon hatehes, and the tiny caterpillar bores below the epidermis. Meanwhile the shoot develops, but when winter overtakes the larva it hihernates in the hollow marle by itself. In early spring it awakes, and commences eating where it left off, with the result that the shoot is very much weakened, and thus the injury not only arrests development but finally kills the twig, as shown in fig. 266 , which was photographed in the latter end of June 1907.

The caterpillar is full fed about the end of April, so that the pupal stage is comparatively short.

As regards remedies for this pest, it is perhaps well to remember that the creature has only been recently recognised in this country, and therefore the full extent of the damage is not thoroughly understood. If the damage be done to twigs on trees from ten to twenty years of age, little could be effected; but if (as I have from preliminary observation discovered) on young trees the second year after planting, something might be done. One rarely sees larch plants in the nurserylines affected. The inference, therefore, is that weakly shoots are selected, as dead twigs are obviously a necessity for the final transformation of the creature. Hence the greater vigour accruing from careful planting would to some extent act as a check. When, however, the young shoots are attacked, the dead or dying twigs in the recently planted wood should be recognised as early as possible in 
April, and then, together with the larva or pupa in the shoot, cut off and burned. This method is apparently tedious, and when the leading shoot is removed considerable disfigurement ensues, but as a tree the larch has wonderful recuperative powers of taking a lead from a side branch, so that the labour would be well repaid.

\section{Gracillaria syringelila, Fab.}

This species is often very injurious to the foliage of lilac (Syringa vulgaris). The larve live gregariously within the epidermal skins of the leaves, and cause very conspicuous blotehes, as seen in fig. 267.

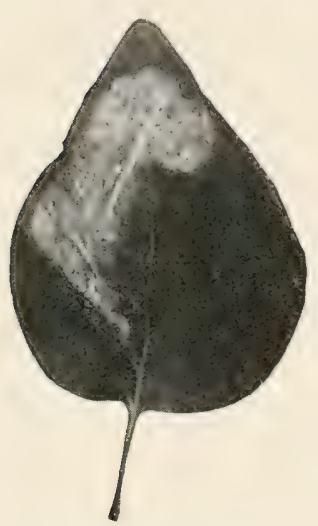

Fig. 267.-Leaf of lilac (Syringa vulgaris) injured by the mining larve of Gracillaria syringella.

Mr Collinge has worked out the lifehistory of this species, and the following account is given by him: ${ }^{1}$ -

"The observations and experiments were made on nine trees about five feet in height and growing five or six feet apart.

"The moths of the first brood were noted on May 24, rather later than in 1904 . The eggs were noticed on both the upper and under surfaces of the leaves a few days later, 27th and 28th, and the caterpillars hatched out on June 4. They at once made their way into the leaves, and commenced to feed upon the soft parenchymatous tissue between the upper and lower epidermis. The largest number found in any one leaf was thirteen.

"Sometimes the whole of one side of the leaf was tunnelled; in other cases the basal half was blistered before the apical; whilst in others the blisters were irregular and scattered over the leaf.

"The young larvæ are almost transparent and glossy; a little later they have a faint yellowish tinge, with a narrow median green line, caused by the green chlorophyll in the intestine. After feeding in the leaf for about three weeks, they creep out on to the surface and commence to feed on the epidermis, the leaves rolling up laterally or from the apex. About ten days later they become full fed, and are slightly over a quarter of an inch in length, with a prominent brown 1 Report on the Injurious Insects and other Animals (Midland Counties), 1906. 
head. Ilere they remain for about ten clays, then leaving the rolled leaves and pupating in the axils of the leaves or branches, or even leaving the trees and crawling to fences, \&c. After fourteen or sixteen days the moths of the second brood make their appearance, and the life-cycle is again repeated, the pupal condition continuing through the winter.

"Preventive and Remedial Measures.-Picking oft" the leaves had but very little effect. Spraying with paraffin emulsion in May proved beneficial. There were very few blistered leaves on the two spriyed trees, whilst the remaining seven showed little else but blistered ones.

"Spraying with soda and potash in January killed or injured many of the pupe, but as these trees were near a fence, many of the larve hat left the trees, and were pupating in crevices and cracks in the fence."

\section{Genus Cotieophora.}

Hitherto this genus has not received such special attention from economic entomologists as to assure us that the habits given by naturalists are over-reliable. At all events, it is a genus that would well repay special attention.

The perfect insects appear from the end of May to the beginning of August. The larve hatch out in autumn, and in the early stage many species feed as leaf-miners, and after mining the leaves the individual larva forms a small case, within which it passes the winter in the larval stage. In the spring they recommence feeding by sucking the juices of the leaves, and each larva makes a larger case for itself in which it lives and pupates. The larva never moves out of its case, and never exposes its body beyond the anterior (or true) legs, which are used in walking.

In the perfect insect the head is smooth, and the antennæe are always erected in repose. The antennæ are slender, the basal portion smaller and covered with seales. The anterior wings are smooth, narrow, elongated, and pointed with long ciliæ. The posterior wings are very narrow, and fringed with long ciliæ.

\section{Coleophora laricella, Hub.}

The larve of this species are very injurious to the foliage of larch in spring, - so much so, that on account of the invisibility of the 
insect, and the conspicuousness of the damage, the injury is often attributed to frost. The general appearance, however, very much resembles the action of frost or singeing by fire, inasmuch as the leaves are half withered up, and practical foresters have therefore often associated this appearance with the commencement of "larch disease." It is, however, possible that this insect may play a very important, though inlirect, part in connection with the larch disease

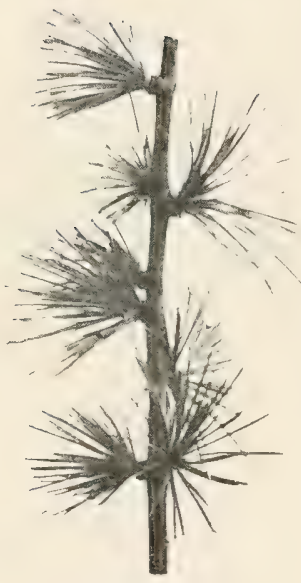

Fig. 268. - Normal foliuge of

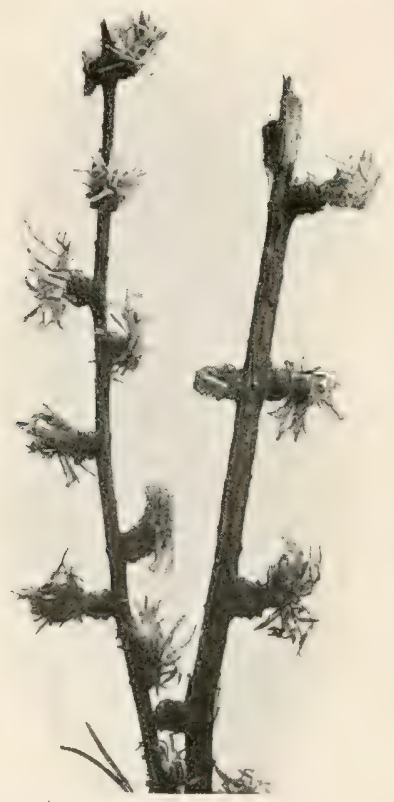

Fig. 269.-Foliage of lurch injured by larve of Coleophora laricella.

fungus (Periza Willkommii). The fungus is most active in spring months, and as the injuries caused by C. laricella on the foliage, together with the obvious effect of checking the rate of growth, have a tendency to reduce the plant below prar, it follows that the fungus is materially assisted in its action, and can therefore do greater damage. Fig. 268 represents the normal foliage, and fig. 269 the injured shoots.

The small caterpillars which do this damage hatch out in July, and feed on the leaves of young trees from six to thirty years of age, but as a rule they are most destructive to trees of the latter age. At first 
the very tiny larve bore into the leaves or suck the juices. The damage is done from apex to base, for about half the length of the leaf. The injured portion shrivels up, is light in colour, and therefore very conspicuous. Meanwhile the larvæ, when resting, bury themselves in the midule of the cluster of leaves, but they soon ehange their mole of protection, as each indivilual larva forms a case for itself out of the injured leaves. At first the case is very lightly coloured, but it becomes darker with age. The interior is lined with silk. When the caterpillar is feeding, the case stands erect, with the head of the larva downwards. The larve go on feeling in this way throughout the season, so long as nourishment remains in the leaves, and then hibernate for the winter. Nany of them go into cracks and crevices of the bark, or bury themselves amongst the lichens. A considerable portion of them lay themselves quite flat on the twigs, and butt against the natural ridges of the young twigs. The light-coloured cases harmonise well with the light-coloured bark. In this way they pass the winter, being perfectly immune to the effects of frost. As soon as the young larch

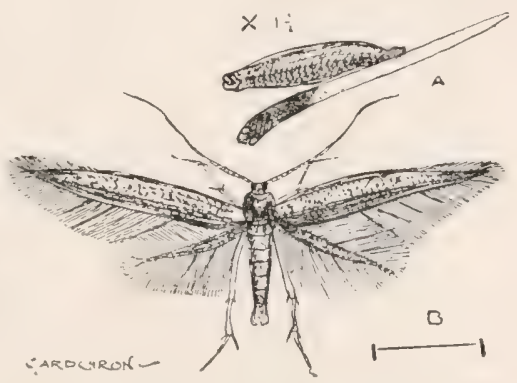

Fig. 270.-Coleophora laricella. (From F. V. Theobald's 'Animal Pests of Forest Trees.')

A, pupal case ; B, moth. needles burst forth in spring the larvæ wake up, carry their cases back to the needles, and commence feeding in real earnest, thus giving rise to the characteristic withering already referred to. The larvæ now grow very rapidly, and the original cases become too small. The tiny caterpillar then makes a fresh case.

The larvæ are a dark red-brown colour, and still darker head. Only the anterior pair of legs are at all moderately developed, and, with the exception of one anal pair of pro-legs, with which they fix themselves in the case, the pro-legs are also but poorly developed. There is a black plate on the anal segment. The larva is about $5 \mathrm{~mm}$. long.

The pupa is small and brownish-black.

When the wings of the perfect insect are expanded they measure about 4 or 5 lines across. The head and anterior wings are grey, the posterior wings of a paler grey, and the abdomen of a blackish grey. (Fig. 270.) 


\section{Coleophora fuscedinella, Zell.}

This species is, as a rule, very common on alder, and is termed the alder-bud moth, in consequence of the larve feeding on the buds and destroying them prior to forming its case, and then on the leaves.

\section{Coleophora sp.}

Some years ago I received from my friend, Mr Elder Cholmondeley, Cheshire, a quantity of birch twigs which had been utterly destroyed by a species of Coleophora. So far this species has not been definitely identified. Fig. 271 is a representation of the damage, and the

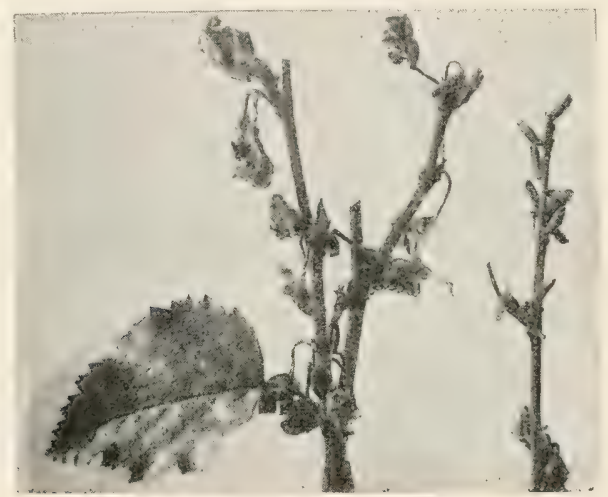

Fig. 27I.-Coleophora sp. on birch.

normal leaf at the bottom was added for the purpose of identification. The larvæ were very injurious, as the twigs were stripped of their entire foliage. After the larvæ had made their final cases, they destroyed the foliage by boring a hole into the leaf from the upper side and entirely eating the contents of the leaf, which lie within the two epidermal skins. Taking the hole as a centre, the larva eats all round the same, thus making a circular patch, but, as a rule, always keeping itself attached to the case by means of its anal hooks, and on the slightest approach of danger drawing itself within its case. Sometimes it goes on feeding within the epidermal skins away from its camp, but, as a rule, it moves to a fresh spot, after eating the circular patch referred to, and then going on a fresh spot, until finally the whole of the green portion of the leaf is destroyed.

The imagines are considerably larger than the species on larch. 


\section{LiTHOCOLIETIS.}

This genus is very common on the leaves of several forest trees. The larva mines the leaves of trees and shrubs, sometimes simply creating a flat blotch on the under side of the leaf, at other times making the blotch in such a manner that a pucker is produced either on the upper or under side of the leaf. The larva never quits the mine. Some species make no cocoons; others, cocoons of various kinds.

The perfect insects are very small in size. They have a rough hend and smooth face. The antennæ are rather long, but not so long as the anterior wings.

The larvæ have only fourteen legs and one pair of ventral pro-legs.

The pupa is either naked or enclosed in a cocoon, and in the former the wing-cases are quite free.

As regards artificial hatching, many species can be picked up in autumn, as the blotches appear quite conspicuous on the fallen leaves. They may be collected and placed on the ground in a canvas bag for the winter months. In early spring they may be removed from the bags and placed in glass cases. The imagines appear in May.

\section{Lithocolletis messanielia, Zeller.}

The larvæ of this species are very injurious to the foliage of the evergreen oak (Quercus $i(e x)$. In the evergreen oak we find several distinct varieties of the tree, and it may be said, though the injuries of this species of moth are practically identical so far as the physiology

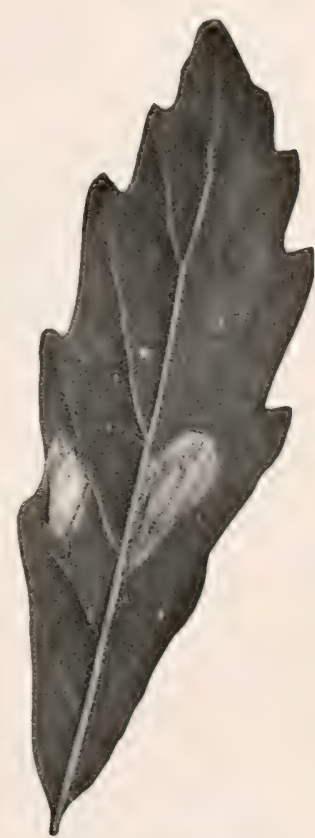

Fig. 272.-Typical blotch of Lithocolletis on sirecies of evergreen oak. of the damage is concerned, yet the general appearance of the damage itself is somewhat different. In the case of the holm oak proper, the leathery leaves are blotched "brown" and withered-looking. In the case of the other variety, the injuries are not so conspicuous on the upper surface, and on the under surface we get a delicate white patch, and prior to the eruption of the skin it looks as if a very fine piece of tissue-paper had been pasted on the under side of the leaf (fig. 27:2). 
The first time I found this species in abundance was on a holm oak (fig. 273) close to Checker House Station, when walking with the Manchester Microscopical Society to Sherwood Forest, and after finding the respective stages of the insect I made the following note:-

"May 9, 1896. - Leaves considerably damaged; effect of damage shown on both sides of leaves, but most conspicuous on under side. Larva mines between under epidermis and thick fleshy part of leaf. The parenchymatous part of leaf not eaten, therefore upper surface appears brown and leathery, but not showing 'thin' as under side.

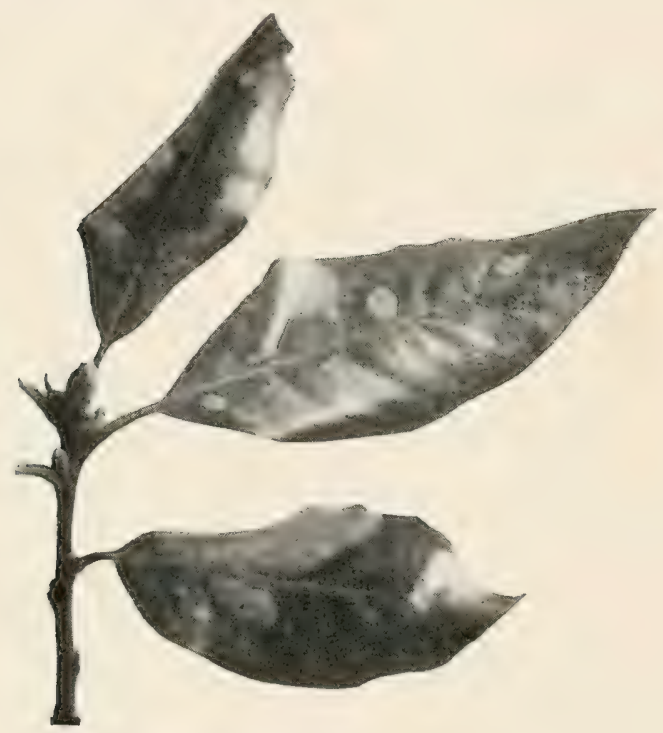

Fig. 273.-Injuries to foliage of holm oak (Quercus ilex) by larve of Lithocolletis messaniella.

"Lavva.-Full fed are rare to find at present,--now principally pupæ. Length $4 \mathrm{~mm}$. When young flattish, and round when fullgrown. Colour of first four segments white, with darkish head; remainder of segments saffron colour. The six thoracic legs short, and first pair longest. Pseudo-legs not very conspicuous.

"Pupa. $-5 \mathrm{~mm}$. long; dark-brown colour. Passes pupal stage in leaf. Very active, wriggling about at posterior end. Antennæ nearly full length of chrysalis. The projection beyond attachment, and active anal end shows irregular 'forked' end. Side view shows pura has pointed horn and bent awl-shaped. 
"Imago.-Length about $4 \mathrm{~mm}$. to $4.5 \mathrm{~mm}$. Fore wings saffron colour, folded ridgewise. Under wings fringed." 1

This is rather a difficult species to check. However, one surgestion may be male. As regards the holm oak, every gardener dislikes it as a lawn tree, in consequence of its shedding its old leares, about the ent of April or beginning of May, just when every place is tidy and spring work very abundant: hence the hatred to the tree. It would The well, therefore, to burn all the leaves as soon as they fall off, or, if desired, the trees may be shaken to bring them off. Provided the fall is in April, many moths would be destroyed, but it is olovions that if not done till May the moths would have hatehed out, and the burning operations consequently useless.

There are several other species of Lithocolletis found on forest trees, but none of them can be considered as injurious, though they are, of course, interesting from a collector's point of view.

$L$. salicicolella causes blotches on the under side of the leaves of sallow bushes. The injured leaves may be looked for in September and October. The insect may also be found in May, so that there are two broods in a year.

$L$. coryii is found on the leaves of hazel bushes. The blotch starts from the midrib, and the tip portion of the blotch is a sort of pucker, so that it is seen from the upper side. Imagines in May and August.

L. carpinicolella is found on the leaves of hornbeam.

$L$. faginella is found on beech.

\section{Cemiostoma laburnelua, Heyd.}

This species is responsible for the blotches caused on the upper surface of the leaves of the laburnum (fig. 274). This species is very common in many parts of England, so much so that it is scarcely possible to examine a laburnum-tree without finding its leaves heavily blotched with a dirty green-whitish appearance. This is caused by the larvæ mining the leaves. It is not so abundant in Scotland, more especially as we proceed northwards, as it is in England. Again, it may be mentioned that it is far more common on the English variety of laburnum (Cytisus Lalnurnum) as compared with the Scotch variety (Cytisus alpinum). The latter variety has very

\footnotetext{
1 Trans. Manchester Microscopical Suciety, 1896.
} 
much larger leaves, and a brighter green bark, in younger stages, than the former.

If we examine the sheltered side of a laburnum-tree, or any adjacent palings, about the latter end of April or the heginning of May, we are sure to see a brilliant, little, white moth, with a few yellowish markings towards the apices of the wings. This is the imago of C. labumella. It measures about 31 lines across the expanded wings. The head and face are white, and the antenna fuscous. The anterior wings are white, with yellow spots or bars across. The posterior wings are also white, with long cilix. The thorax is white, and the abdomen pale-grey. The legs are also white. Then carefully examined under the microscope, this tiny moth is a

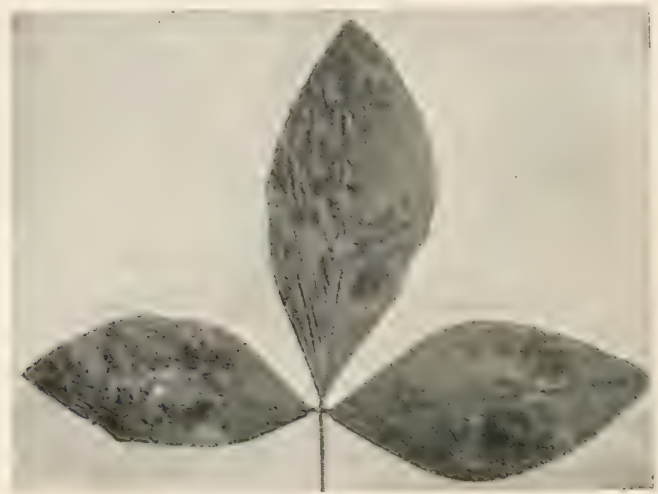

Fig. 2-4. - Foliage of laburnum injured by larve of Cemiostoma laburnella.

very beatiful object,--so much so, that it seems to vie with the rich colours and brilliant markings of tropical insects.

The larra is about 3 lines in length, of a pale greenish-white colour, with sometimes a bright-green dorsal line,-due, of course, to the food taken from the green colouring under the leaf.

The pupa is encased in a white cocoon, pointed at both ends.

The life-history may be thus briefly described: The moths appear during the latter end of $A$ pril or beginning of May, and deposit their egrgs on the under surface of the leaf, generally near the millrib. There are two brools in the year. In the first the larve are full fed about the early part of July. Then they leave their feeding-ground on the upper surface of the leaves and mupate on the back of the 
leares, more especially on the younger leaves, which have been forming throughout the summer season. The pupe are lons whitish ohjects, pointed at both ends, and encased within a very heantiful white cocoon. About the beginning of August, or after about ten days to a fortnight in the pupal stage, the moths appear. This brood deposits eggs in the same way as the moths of the second brood which appeared in spring. The larvas feed as lefore, on the newly formed leaves. They are full fed about the middle or latter end of October, when the eaterpillars let themselves down by a slender silken rope to the sroumd, where they pupate, and appear as perfect insects about the latter end of April or beginning of May. About the latter" end of October the tiny larve may be seen on a sunny day dangling from the laburnum bush. They may be collected and put in a small box, as this species hatches very well in confinement.

\section{References to Literature consulted.}

Carpenter, G. H. Various papers on the Injurious Insects of Ireland.

Collinge, W. E. Reports on the Injurious Insects observed in the Midland Counties.

Kaltenbach, J. H. Die Pflanzenfeinde aus der Klasse der Insekten.

Köllar, V. A Treatise on Insects injurious to Gardeners, Foresters, and Farmers.

Meyrick, Ed. A Handbook of British Lepidoptera.

Newman, Ed. Natural History of British Butterflies and Moths.

Ormerod, E. O. Manual of Injurious Insects. 2nd edition.

Stainton, H. T. A Manual of British Butterflies and Moths.

Theobald, F. V. Various papers on Economic Entomology.

Wilkinson, S. J. The British Tortrices. 


\section{CHAPTER VIII.}

\section{APHIDID E (GREEN-FLY).}

THzocgrot the whole country no class of insects is more universally distributed or more deserving of the appellation "injurious" than the Aphididæ or "Green-fly." The term blight is adopted for the destruction aceruing from this class of insects, which are individually small in size but collectively most injurious. They are to be found on almost every plant, and are soft-bodied insects, with comparatively long legs which are hut poorly adapted for leaping. They are always found in two principal forms-viz., winged and wingless; and the largest are never more than a quarter of an inch in expanse of wings.

The body of the aphis is pear-shaped. The head, which is small in comparison with the rest of the body, has two compound eyes, and in the perfect stage ocelli or supplementary eyes are often present,a feature which is well worth special consideration from a physiological point of view. During the larval stage the eyes are very conspicuous. In fact, they are often quite obvious in the embryo stage, before the larvæ quit the eggs. They vary in colour from ruby red to brown or even black.

The beak, which is always an important organ in insect structure, is peculiarly adapted to the destructive demands of the creature, and just shows that all insect anatomy is a modification of similar parts to meet the needs of the creature. The beak proper is composed of three joints, which vary in length according to genus and species. Thus in the Stomaphis, a species living on oak, the beak is longer than the body, while in the genus Chermes it is very small indeed, the mouth being alapted to the food-plant. The former lives on oak deeply furrowed; the body reposes on the outer hard bark, while the long proboscis is a necessity to reach the bottom of the narrow fissure, where the juice can only be found. On the other hand, the 
short-beaked Chermes lives on smooth hark, on which the slightest tap would yield the necessary juice.

The antenne are from three- to seven-jointed, and form good points for classification. They are very variable in length according to genera, and are also variable in the larve as comprared with perfect insects of the same species. Hence it is essential in the discrimination of genera to know that we are dealing with adults.

The wings are thin, and of a beantiful transparent irideseent colour, folled rilge-wise over the body, hut possessing poor powers of flight. In the wing of a typical aphis (fig. 275) the cubitus or post-costal nervure gradually expands into a semi-coriaceous stigma, whence proceed the veins of the wing. Fig. 275 is a camera-lucida sketch of the wing of Aphis sambuci, and may be considered as a very good example of a typical wing.

The following is an explanation of the characters :-
a. Cubitus or post-costal nervure.
1. Costal cell.
b. Posterior marginal.
2. Basal cell.
c. Costal nervure.
3. First discoidal.
d. Cubital nersure.
4. Second discoidal.
e. First furcal.
$f$. Second furcal.
5. Infra-marginal.
$g$. Second oblique.
6. Marginal.
h. First oblique.
7. Second cubital.
i. Insertions.
8. First cubital.
k. Apical marginal.
l. Stigmatic.
p. Hooklet.

The above is adapted from Buckton's Ionograph, but in that work the wings of Siphonophora are used as a typical case.

The third vein, counting from the body of the insect, is twice forked in the tribes of Althitime and Lartume (fig. 275); once forked in the tribe Schizoneurince (fig. 276); and not forked in the tribe Pemphigince (fig. 277), and also in Chermesince (fig. 278). In the lower wing of the typical aphis the post-costal vein gives off two oblique veins only. The wings are carried vertically when at rest, with the costal vein downwards. In the foregoing sketches we have typical wings represented, and the student would do well to study the wing venation of the family, more especially as it is not infrequent to find different venation on each side in some forms. 
The abdomen is composed of several rings, and is capable of much distension, this being dependent on the amount of food taken. The

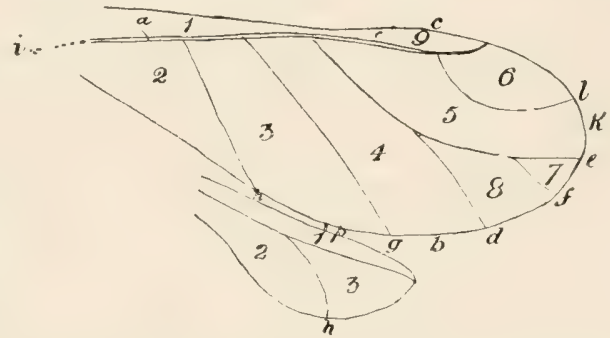

Fig. 275. -Wing of Aphis sambuci, with third vein twice forked.

number of rings or somites is variable. On the sixth segment many genera have two important tubes or appendages, called cornicles,

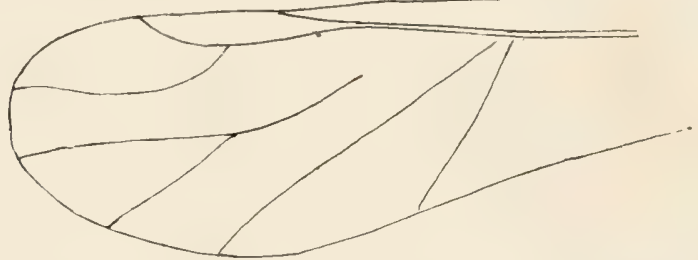

Fig. 276. - Wing of Schizoneura ulni, with third vein once forked.

which serve for the exudation of a liquid substance known as "honey dew"; others have none.

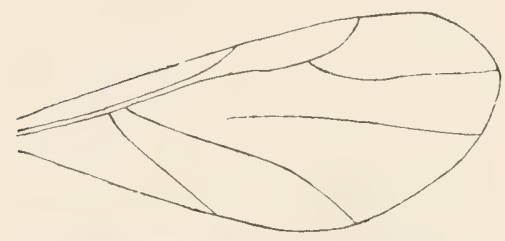

Fig. 277.-Wing of Pemphigus pallidus, with third vein straight.

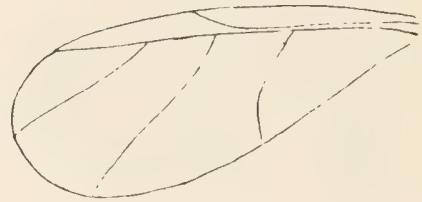

Fig. 278. - Hing of Chermes abietis, with third vein straight.

The honey-dew itself is a substance which has given rise to a good deal of interesting thought and speculation. It is of a saccharine nature, and is consequently sought after by other insects, more 
especially ants, which not only sip the juices but extract the honeydew from the aphis by squeezing it from the cornicles. I liave often observed ants doing this on the aphides on elder.

The honey-dew is very injurious to vegetation, for not only does it have a tendency to choke up the stomata or breathing-pores of the leaves, but the injury is still furthur increased by the honey-dew forming a lodgment for soot, dust, and dirt.

The tail, though not an important appentage in the discrimination of genera or species, must not be forgotten in generic distinction, inasmuch as it is long in some, and short or entirely absent in others.

The life-history of an aphis presents many interesting points, either considered biologically or as evidenced by the mysterious appearance and disappearance of the so-called "blight" or "green-fly."

The aphis generally appears in numbers simultaneously with the green foliage. The first brood of the season originates either from a female which has hibernated during the winter months, or from eggs -that is, grenerally true eggs, resulting from male fertilisation. In the former case, the "stem-mother" (Stamm-mutter), as the Germans call her, very much resembles the queen wasp, inasmuch as she is the mother or founder of a whole summer's colony. As a rule, she is considerably larger and less active than any of her offspring.

The eggs of Aphididx may sometimes be seen in autumn as small white specks on the stem, though generally they are green-brown or bottle-green. They become dark in winter, and, of course, are not so conspieuous as in the autumn months.

The brood arising from eggs which had been deposited in autumn, or from the "stem-mother" in spring, give rise to insects which are generally all females. These may be found in two forms - viz., winged and apterous. In many genera, when but a few days old, both forms are capable of giving birth to living young. Each individual insect produces from 90 to 100 progeny, and so on until about twenty generations are produced in a single season. Hence it will be seen by a progressive calculation that the numerical strength of the progeny produced by a single insect certainly becomes appalling, and the number just given is under rather than over the average.

In order to realise the numerical strength of aphis reproduction, Professor Huxley made some remarkable calculations, and has therefore put them in his own inimitable way. He calculated that if an 
aphis weighs $\frac{7}{100}$ of a grain avoirdupois, and a stout man not more than two million grains, - about twenty stones, - then the tenth brood formed (exclusive of all the preceding broods, supposing that the multiplication had been altogether unchecked by the various causes which generally influence it) will exceed in weight five hundred million men, or about one-third the entire population of the globe. 'This calculation is made on the assumption that each individual member could turn the scales at $280 \mathrm{lb}$, and also that each aphis is capable of producing only twenty young, whereas, according to Latreille, the average rate of production of a viviparous aphis during the summer months is twenty-five per day,- - but this is greatly in excess, as far as this country goes.

Fortunately for vegetation, the aphis has several natural enemies to keep the enormous reproduction within bounds. Heavy rains act as a check, but, entomologically considered, the small Chalcididee, Hymenopterous parasites which pass their metamorphic stages in the interior of the aphidian bodies, are of inestimable value in keeping them down. Throughout the summer months the dead bodies of the Aphididæ may be found adhering to the food-plant. These bodies are mere chitinous shells, with a small hole whence the tiny Hymenopterous parasites have emerged. Ladybirds, horse-flies, Chrysops, and birds are natural enemies.

At the end of the season the last brood for the year is generally composed of males and females. In certain species males have not been discovered for a few years. But investigation seems to show that sooner or later males will appear-verifying what Andrew Knight said in 1799 regarding self-fertilisation, viz., that it is a "law of nature that organic beings shall not fertilise themselves in perpetuity." Subsequent research has borne out this statement in other animals. It is well known to every entomologist, collector, or economist that the number of insects depends very considerably on the conditions of the weather and the supply of food. The Aphidide are certainly more susceptible to those external inflnences than any other class of insects. Should the weather suddenly become colder, a great number of winged specimens will appear, as they do also in the event of the food-supply becoming scarce.

It is neither by chance nor latent ability that apparently apterous individuals suddenly become winged, but apterous specimens give birth to young which develop wings. Hence the change from wing- 
less to winged specimens is the result of the short period necessary for the ushering in of a fully developed fresh broot, which will adapt themselves to natural changing conditions. In other words, the newly born brood will move to new quarters either in search of food or warmth. And here comes in a very common but erroneous notion -viz., that the sudden appearance of "blight" is due to "east winds." Now the fact is that the proverbial east wind has simply assisted the winged aphis, which, after all, is but poorly adapted for locomotion, to move from his native land to "fresh fields and pastures new."

Winged forms are known at an early age as apterous larvæ, the "pupal" stage being that period when the wings are half-grown. Some species pass through these metamorphic stages before their life cycle is complete. Thus apterous larve, semi-winged pupæ, and winged imagines may be constantly found throughout the summer season on the food-plant.

In many species both apterous and winged females produce living young, but, according to Jiuckton and other observers, the pupæ never give birth to young. There are two classes of females apart from apterous and winged ones-viz., ovipurous and viviparous, the first reproducing themselves by egrs, the second by living young. It is asserted by many practical workers that the oviparous never becomes viviparous, or vice versa, the same individual aphis never producing eggs and living young.

The difference between the deposition of eggs and the production of living young on the part of the respective female insects would appear to be simply a question of time and stage of reproduction, but it affords a subject for actual investigation by dissection and serial section-cutting, in order to ascertain the morphological difference between oviparous and viviparous organs.

To the student of forest entomology it is not only essential to make a detailed study of the life-history of the various species as found on trees, but it is indispensable to study the species found on almost every plant, inasmuch as we get migratory species and dual or multiferous food-plants of certain species. Thus, for example, we gret the hop aphis, the larch and spruce aphis, mealy plum aphis, together with root and trunk forms constantly changing from food-plant to food-plant. It is therefore obvious that this is a good case in point, showing that it is most essential for the economic entomologist to 
become, as far as possible, well acquainted with the structural details of the systematic student.

As regards terms for the family or sub-families, Buckton says"The Aphides have the following synonyms:

Aphides, Linnæus.

Aphidee, Curtis, Westwood.

Aphidina, Burmeister, Walker, Hartig.

Aphidince, Rondani.

Aphidide, Passerini.

It is therefore rather difficult to know what precise term to adopt for the family or sub-family."

The family APHIDID\& may be divided into six tribes-viz, Aphidinæ, Lachninæ, Schizoneurinæ, Pemphiginæ, Chermesinæ, and Rhizobinæ.

The following are the principal tribes and genera which are arboreal in their habits :-

Tribe Aphidinæ.-Upper wings with cubital rein twice forked; lower wing with two oblique veins. Antenuæ long, with seven joints: 7 th joint long, 3rd usually longest.

The following are the principal genera belonging to this tribe which are arboreal in their habits-
Myzus.
ApHIS.
Drepanosiphum.
Chattophorus.
Melanoxanthus.
Callipterus.

Tribe Lachninæ (woolly). - Wings same as in Aphidinæ. Antenuæ six joints, 7 th rudimentary. Genera-

$\begin{array}{ll}\text { Pterocallis. } & \text { Stomaphis. } \\ \text { Phyllaphis. } & \text { Dryobius. }{ }^{1} \\ \text { Lachnds. } & \end{array}$

Tribe Schizoneurinæ.-Upper wing, cubital vein once forked; lower wing with two oblique veins. Antennæ six joints, 7 th rudimentary; 3rd ringed; 4 th often ringed. Genus--

\section{Schizoneura.}

Tribe Pemphiginæ (gall-forming).-Upper wing, cubital vein not forked; lower wing with one or two oblique veins. Antennæ short, six joints; 7 th rudimentary. Genera-

Pemphigus. Tetraneura.

1 The above is adapted from Buckton, as it is rather difficult to reconcile his classification: see vol. i. p. 94 and vol. iii. p. 11. 
Tribe Chermesinæ (kermes, a red dye).-The grenera of this tribe are varied in their habits, inasmuch as they are coccus-like, bark-feeders, gall-makers, or wool-spinners, and sometimes subterranean. GeneraChermes. Phylloxera.

Tribe Rhizobinæ.-The genera of this tribe are root-feelers, and hitherto have not been much investigated in the forest. There is a species very common on the dead leaves of Seots pine which may he found throughout the whole of the year, hut hitherto I have not discovered any name for it.

In giving an account of the more common and destructive genera and species of arboreal Aplintide, it may be suggested to the student that much raluable information on the havits and structure of these insects might be gained by studying many species of the genus Siphonophora, which are found on many varieties of plants. Thus, for example, Siphonouthera roser is abundant on roses; S. ruti on raspherry ; S. arellum on hazel; and various other species of this genus are found on our common plants.

\section{Tribe APHIDINÆ.}

\section{Genus Mrzus.}

The chief generic characters are antemme about equal to the length of the body. Cornicles long, tail prominent. Wing venation much the same as in a typical aphis.

\section{Mrzus cerasi (Fab.)}

This species is very common on wild cherry or gean of the forest, as well as on the cherry of gardens and orchards. The damage done by the insect is very easily recognised. The injured shoots form a sort of rough rosette of leaves (fig. 279), and the absorbing action of

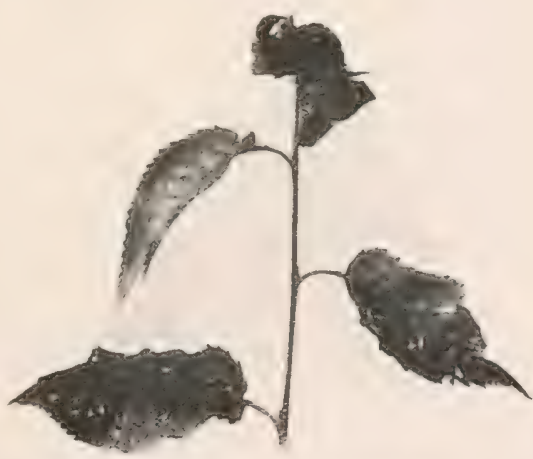

Fig. 279.-Terminal shont of wild clerry injural by IIyzus cerasi.

the insects, coupled with the exudation of honey-dew, add a sort of sooty appearance to the damaged shoot. 
The apterous viviparous female is wholly black in general appearance. Antennæ not conspicuously long. The abdomen is of a very shiny black colour. The cornicles are rather long. The eyes are a darkish-brown colour.

The winged viviparous female is wholly and conspicuously black, with rather long antennæ and broad wings.

It is somewhat difficult to prescribe a remedy for this species. It has been suggested to eut off the infested shoots or rosettes and destroy the same, but as the leading shoot is the portion generally attacked, this would obviously destroy the young tree, so that it would be better to adopt some spraying measure, or otherwise shake the aphides into a vessel containing paraffin.

\section{Genus Drepanosiphum.}

Rostrum short; antennæ very long, third joint longest; seventh joint very delicate; enrnicles large; tail inconspicuous. Wings long and narrow; cubital vein twice forked.

\section{Drepanosiphum platanoides (Schr.)}

This is a common aphis which lives on sycamore, and may be found simultaneously with the appearance of the foliage. It simply injures the plant by sucking the juices, and does not cause any malformations.

The egrgs of this species may be found very plentifully on the bark of sycamore during the winter months. They are black in colour, and, when abundant, their glossy appearance on lichen and Protococcus viritis renders them conspicuous to the naked eye at some distance.

The larvæ are found on the young leaves just as the latter are bursting. When hatching they are of a bright-green colour, with very long antemne and conspicuously red eyes. In general appearance the body is so slender that the creature may be said to be all "legs and arms."

The pupal form, or stage between larva and winged insect, is very variable both in colour and general appearance.

The winged insects are also variable in colour, but the prevailing hue is bright green. The head is rather flat, the eyes are very prominent, and being of a golden-green colour, contrast very strongly 
with the head and hodly. The antemme are black, long, and slenter, and consequently liable to injury. There are two vertical black markings and five or six transverse bars on the abdomen, as well as similar markings on the under side. The legs are variable in colour. The tail is short and not very conspicuous. The cornicles are comparatively long.

This is altogether a handsome-looking aphis, and is suggrestive of a lobster. It may be shaken in showers from the leaves. This species, however, is so very variable in colour that Buckton gives several varieties in both larval and perfect forms.

About the middle of April, just before the winged insects appear, large apterous specimens, very much larger than the general larve, and of a mahogany colour, may be found. Contrasting with the larve just referred to, it may be observed that in proportion to the size of the body, the antennæ, cornicles, and tail are all comparatively short. The abdomen is large, warty, and bristly. At first sight this insect may be taken for a "stem-mother" or for some other species, but if kept in confinement for a few days it will be found to be a bloated parasitised form, whence parasites are hatched.

It has been asserted by several observers that the larvæ of this species always assume wings, and that consequently the wingless specimens never give birth to young. In other words, only the fully developed female, which in this case is the winged specimen, gives birth to young. I have not fully verified this, but so far as my observations go, I am inclined to endorse this view.

The apterous oviparons female may be found in the autumn on the under side of the leares, just before they fall. It is easily recognised by its darkish colour and elongated abdomen prolonged into a tail. The eyes are bright red.

This insect rather lends itself to a study of ovarian characters.

\section{Genus Melanoxanthus.}

As this genus was founded by Buckton, it is best to give his own description :-

"Body elliptical, rather flat, vertex flat between the antennæ.

"Antenne short. The third joint double the length of the fourth. The serenth equal to the sixth. Frontal tubercles inconspicuous.

"Nectaries short and pear-shaped, with trumpet-like mouths. 
Prothorax marked by two lateral teeth. Abdomen oval. Legs strong and short.

"Tail inconspicuous or none. Wings moderately long. Stigmatic veins with their apices reflected."

In this genus it would be well for the student to carefully study the generic characters, inasmuch as the genus may be confounded with Lachnus.

\section{Melanoxanthus salicis (Linn.)}

This insect may be found very abundantly on the two-year-old shoots of the common osier (Salic viminalis). They are gregarious in their habits, and may be found clustering on the rods they select. The attacked rods may

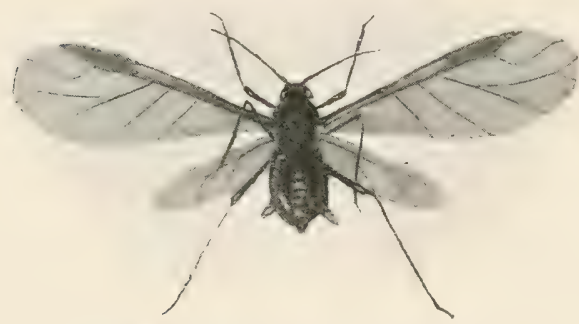

Fig. 280.-Melanoxanthus salicis. (From Buckton's 'Ionograph of British Aphides.' Ray Society.) be afterwards known by the deposition of a white mealy substance on the infected portion of the stem. They are very common in Cheshire about the latter end of June.

The apterous female is a very large insect. The body is of an oval shape, and of a sooty greyish-black colour. Along the dorsal surface there is a faint median line of rudely diamond-shaped spots of a greyish-heliotrope colour, and also similar spots on the abdomen. The two largest spots are situated near the middle of the body. The basal half of the antennæ is of a terra-cotta colour, and the apical portion is blackish or dark brown. In proportion to the size of the body, the antennæ are comparatively short, the third joint being the longest. The legs are slightly pubescent, and similarly coloured to the antennæ. The cornicles are small and of a brightorange colour. The rostrum is fairly long, but appreciably longest in the young stage. The tail is not very long or conspicuous.

The pupa is somewhat similar to the above, except that the thorax is a more slaty colour.

The winged viviparous insect (fig. 280) is very large, but not so 
plump or oval as the apterous specimens, and the spots are not so pronounced.

On the whole, this is a very pretty aphis, the spots giving the entire body a very bright-looking appearance.

Mr Theobald in correspondence says-

"The curious staining of the wood where they have been is interesting. I have found them in masses over a foot long in IIunts and Kent."

\section{Genus ApHis, Linn.}

The genus Aphis, according to Buckton, contains 45 species, and it is a very important genus. In the first place, the name Aphis to a novice in entomological knowledge is very apt to be confounded with the whole family of Aphididx, and may therefore in a general sense be used to refer to every individual species. As there are 45 species in the genus, with food-plants ranging from the small weed to the tall trees, it is obvious that some care must be taken in tabulation.

As regards the main points in the genus, Buckton gives the following-viz. :

"Rostrum moderately long, the last joint skittle-shaped, and as long as the preceding. Antenne shorter than the body. Frontal tubercles none or rudimentary. Seventh joint setaceous, and as long as the third. Cornicles cylindrical, and equally thick throughout. Cauda short, sometimes hardly visible. Legs moderately long. Wings generully shorter than the preceding genera, but veining similar."

\section{Aphis crategi (Kalt.)}

In several districts in Cheshire during the season 1893-94 very much damage was done to young thorn hedges and young quicks by the Aphis cratceni, young thorns in many cases being lilled outright. There is no mistaking this pest. In consequence of growth being arrested, the shoots are comparatively short, the leaves curl up, and in general appearance the infested plants look as if the leaves and young shoots are covered and killed with fresh soot (fig. 281).

If infested plants are examined during the winter months, the topmost portions will be found studded with dark-brown eggrs. These eggs hatch out as soon as the leaves burst, and throughout the summer the insect pest in all its various stages may be found. 
It is very variable in colour and appearance. Hence Buckton remarks that "it is exceedingly difficult to reconcile the descriptions of various insects named Aphis cratregi by authors."

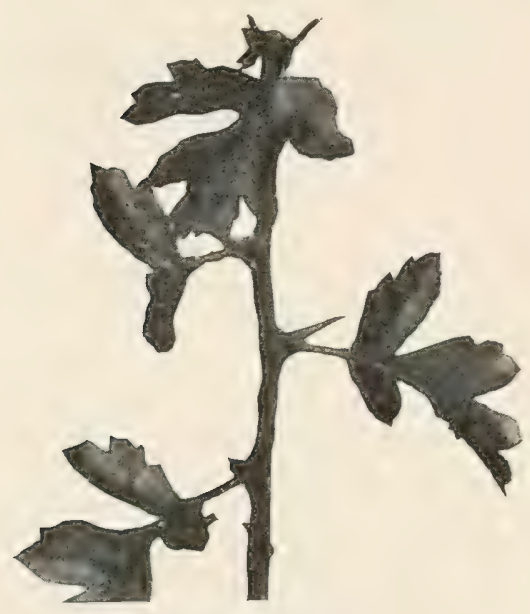

Fig. 281.-Eggs of Aphis cratægi on thorn in nursery-line.

The apterous viviparous female is a bright-greencoloured insect with brown eyes. The antennæ are shorter than the borly. The third and seventh joints are the longest. The comicles are comparatively long, cylindrical, and equally thick throughout. The tail is short but conspicuous.

The pupa in many respects resembles the apterous specimens, but on the whole is very much smaller in size.

As I have not made any deseriptive notes on the winged form (fig. 282) when examining the living insect, and mounted specimens lose all colour, I append Buckton's description :-

"Head, neck, ring, thorax, and its lobes black, head broad and convex, abdomen shining brightgreen, with the same marked carin-

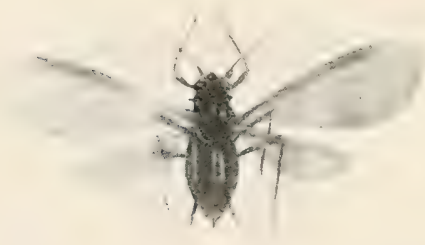

Fig. 282.-Aphis cratæyi. (From Buckton's 'Monograph of British Aphides.' Ray Society.) ation and minute pore marks of the larvæ. Cornicles long and straight, colour olive-green, antennæ and legs ochreous, pale, and hairy. Rostrum reaches to the second coxa. Tail conspicuous and green. Eyes bright red."

With regard to remedies for this pest, we must either kill the insect in the stages of its metamorphoses or destroy the eggs. The insect form may be considerably checked by syringing the foliage with a mixed solution of soft soap and quassia chips. On the other hand, the eggrs may be got rid of, so far as young hedges are concerned, 
by simply "cutting down" the young thorns and burning the prumings. In transplanting such thoms previously cut down, care nust be taken to lift plants with the best possible roots, and encourane as much as possible by attention and good manacrement. This flan I have adopted with considerable success. However, under ordinary circumstances, it is certainly not advisable to cut down ruicks the same year as they are planterl, inasmuch as the shoots produced are not so strong as from those grown for a season prior to cutting off. When the young thorns are cut off the same season, or, perhaps, rather the same day, as they are planted, they are exposed to considerable risks. In the first place, the shoots are weak, and not able to withstand insect attack, as for example the aphis on the shoots during the summer, and also privr to the commencenent of growth by the clay-coloured weevil (Otiorrhynchus sulcatus). The shoots, being comparatively weak, are more apt to be destroyed by rabbits or choked by weeds. Hence it is better to cut off the second year, wherever this method coincides with good local husbandry.

If young thorns in nursery-lines are very badly attacked with this species, and if such attacked quicks are not strong enutgh to go ont, or otherwise not convenient to put out, it would also be well to cut them down in the nursery-lines, burn the tops, and dig in manure between the rows, so that a strong bushy thorn may be produced by another year.

\section{ApHIS PADi (Reaum.)}

This insect is very common on the young shoots of Prunus padus (birdcherry). Fig. 283 shows the injuries, or rather the gregarious habits, of this species; but later on in the year, say

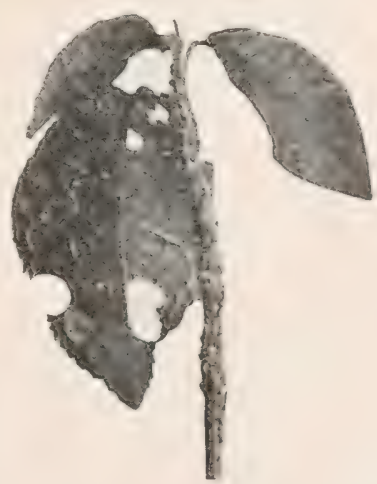

Fig. 283.-Aphis padi on bird-cherry. about the middle of July, nearly every terminal twig of the birdcherry bush has been killed. It is therefore evident that severe injuries accrue from this species, as the development of the bush has to depend upon growth being produced in the latter end of the season.

The apterous viviparous female is of a yellowish-green colour, somewhat variegated with oval stripes, and more or less stained with a 
coloured mealy powder. Eyes black; antennæ, legs, and comicles yellow, the last being rather dilated at the base.

The pupa is of a greenish or black colour. The prothorax is partially green, varying to light olive, and the abdominal portion is of a shining black colour. Eyes and cornicles black; antennæ and legs olive-green.

In the winged viviparous female the whole body is of a shining black colour, and brightened here and there with lightish spots. Antennæ, eyes, and legs lightish-brown. Wings rather large, with somewhat conspicuous dark stigma.

\section{Aphis euonrusus (Fabr.)}

This insect causes the shoots of Euonymus europous to form a sort of rosette, very much after the manner of the shoots on wild cherry. The insects eluster under the rolled leaves, and both apterous and winged forms are either a very dark-brown colour or otherwise wholly black.

\section{APHIS Hederæ (Kalt.)}

This insect is often found very plentifully on ivy, and clusters of them may be discovered during the winter months where the position is rather warm. It is dark-brown or blackish colour, and it is said that the species found on holly is precisely the same insect.

\section{Aphis abietina (Walker).}

This insect is often found very plentifully on spruce from May onwards throughout the summer. The apterous form is a brightgreen colour. The abilomen is somewhat elongated, and the cornicles rather long. The eyes are red. The winged form is rather small, and also of a light-green colour. The colour of this insect is somewhat variable, but it is easily recognised from being associated with the spruce, and by the seven-jointed antennæ and the forking of the wings.

During the winter months the apterous females of this species, which give rise to the summer's brood, may be found amongst the leaves of spruce-trees. 


\section{Apus viburni (Schr.)}

This is another species causing the tip shoots to form into a rough rosette of leaves on Vilurmum opulur, and the shining l)lackish insects may be found underneath the leaves.

\section{Aphis sambuci (Linn.)}

This insect is very plentiful on the young shoots of elder. They are very gregarious, and often cluster two or three deep, and thus form a sovering from three to six inches in length on the shoots.

There are many species of the genus Aphis on forest trees and shrubs, but they may be all recognised as belonging to this genus from their structure, and in nearly all cases the specific name coinciles with the name of the host-plant. Hence the specific name of the insect may be almost anticipated; but this species is a migrant, and does not live all the year on elder. Fig. 284 is an illustration of the winged female.

\section{Genus Chaitophorus.}

As this genus may be confounded with Drepanosiphum, it is well to give full characters of

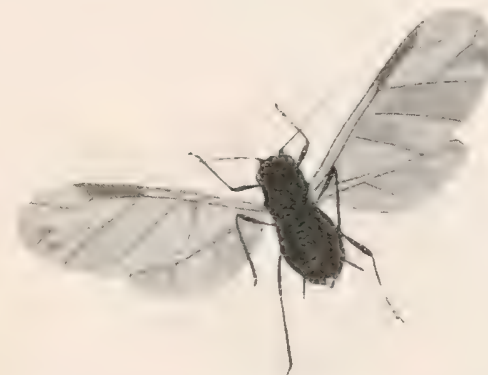

Fig. 284.-Aphis sambucl. (From Buckton's 'Monograph of British Aphides.' Ray Society.) the same, according to Buckton. Rostrum fairly long; head with tufted bristles; antenne much as in Aphis, and short compared with Drepanosiphum, very hairy; abdomen studded over with tubercles, each of which is surmounted with a tuft of bristles; cornicles very short, and in mounted specimens projected at right angles to the abdomen. Legs comparatively short and hairy. Wings veined as in Aphis.

\section{Chattophorus aceris (Linn.)}

An aphis is found on the sycamore which may be readily confounded with Diepanosiphum platanoides previously described. This 
is Chaitophorus aceris or "hairy aphis." It is common in many districts, but I first discovered it in Sherwood Forest on May 25, 1896.

The general difference is that this species is more hairy, and is altogether smaller. The antennæ, legs, wings, and cornicles are all respectively shorter. The abdomen is studded over with tubercles, and each tubercle is surmounted by a tuft of bristles. The legs are comparatively short, and the wings are veined as in Aphis.

There is a unique interest attached to this species on account of its special dimorphic forms. Its peculiar and interesting life-history may be briefly told. During the winter months the apterous oviparous female, which is the foundress of next year's broods of insects, may be found in the crevices of the bark, together with the dark shining eggrs she had deposited in the crevices of the bark. From those eggs, which hatch in spring, we get the apterous viviparous females, which are comparatively small, of a greenish colour, and produce lightyellowish or darkish larvæ. The latter are rather variable in detailed colour.

The pupæ are smaller than the apterous viviparous females, and have rather lightish-coloured legs and dark-coloured wing-cases.

Arising from this brood there are two varieties of winged viviparous females. The first variety to be considered is one with black head and thorax and greenish abdomen, which is ornamented with a few cross-bars. The cornicles are small and black, and the whole insect more or less hairy. The second variety is rather larger than the first, with comparatively larger wings, and the creature is more pilose than the former variety.

It is, however, with regard to the young produced by those two varieties of female insects that the chief interest is attached. The first variety produces normal insects, which in turn give birth to other insects, and so on throughout the summer season. The second variety produces a class of insects so distinct, and differing so much from all other Aphididie, that it has not only received several synonyms, but a suggestion has been made to relegate this variety to a separate family, between Coccidæ and Aphididæ. I found several specimens on the common sycamore in Sherwood Forest, and tried to induce them to live in Cheshire, but without success. They are born in the early part of summer, and live until autumn, never moving from their early habitat or respective leaves, and, with the exception of moulting, undergoing 
no metamorphoses. In addition to these characteristies, the creature develops a strange morphological structure, inasmuch is peculiar flabellæe are attached to its dorsal surface. In short, it is a peculiar form of neuter gender, and contemporary with ten or twenty parthenogenetic generations (fig. 285).

I have found it common in Northumberland, on the under side of the leaves of the purple varieties of sycamore, and also on Acer colehicum rubrum. As the green colour of this creature contrasts with the species of those plants referred to, it may be fairly easily recognised, though it must be remembered they are only mere pin-points in actual size, and often difficult to find.

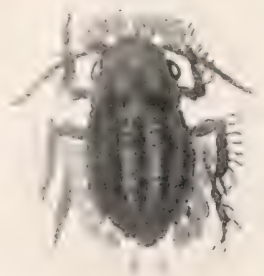

Mr Theobald informs me that it is common in Cambridge, Deron, and Kent.

\section{Genus Callipterus.}

This genus is rather important in forest entomology, inasmuch as the species are all arboreal in their habits. Hence it may be well to state the generic characters as given by Buckton-viz. :

"Rostrum stout, short, does not reach to the second coxæ.

"Antennæ very long, often tipped with black; third joint much the longest. Seventh joint variable in length, but rarely less than the sixth.

"Head large, vertex flat, frontal tubercles none.

"Cornicles very short.

"Legs moderateily long; longest in the males.

"Wings generally ample, iridescent, usually clouded with pisment at the extremities of the veins. Stigmata long. Stigmatic cells trapezoidal.

"Abdomen: in some species the apterous females are hirsute. The last abdominal ring is provided with two anal valves or papillie."

In habits of life, however, they are quite distinct from other genera belonging the tribe, as those hitherto considered are all gregarious, while the Calliptera, especially in the winged stages, are more or less solitary. When they approach anything like gregarious habits, it 
will generally be found that they are the progeny of a single parent, congregated, as it were, together before leaving "home."

\section{Calitipterus betularius (Kalt.)}

This species is very abundant on birch-trees, more especially birch coppice, during the summer months, and great numbers of it may be beaten from the foliage. The winged specimens are rather sluggish in their motions, and do not take willingly to flight.

The apterous viviparous female is linear in form ; the body is almost entirely green, with slight yellowish colouring in the anterior parts. The head is slightly covered with hairs; eyes red; antenne are very slender.

The winged viviparous female is of a light pea-green colour, and more smooth on the body than the apterous specimens; antennæ very long and slender, and of a slightly brown colour. The third joint is very long. The middle portion of the thorax is yellow-orange spotted with brown. The front portion of the thorax is of a light-yellow colour; eyes beautiful light chocolate; legs uniformly light green, except the tarsus, which is dark brown. Wings moderately long and clear; stigmatic portion yellow ; veins dark brown, and slightly clouded at the tips.

\section{Calitpterus quercûs (Kalt.)}

This species is found fairly common under oak leaves. The apterous oviparous female is a light-yellow colour. Antenne shorter than the body. Eyes brown. The winged viviparous female is of a palegreen colour, leaning towards yellow. The antennæ comparatively long, and the joints marked with a blackish colour, - a character which is well maintained in mounted specimens.

The young of this insect are at first very small and light-coloured, with conspicuously darkish or reddish eyes. These characters can be very well ascertained with the aid of a pocket-lens against the leaf as a background.

The more common species which may be looked for are the following - viz. : Callipterus coryli, Goetze, on hazel; Callipterus carpini, on hornbeam; and Callipterus castanere, Buckton, on sweet chestnut. 


\section{TrIBE LACHNINÆ.}

We now approach the second tribe of the family, known as Lachnine. The venation is the same as in the preceding tribe, but the antennæ are six-jointed. This character as revealed by the microscope is important to the systematist. To the economic entomologist, however, there is no general character as revealed by the injuries in the forest which can suggest a marked line of classification. The term Lachmus means "woolly," and this character is well pronounced in the genus Phyllaphis, which is often very abundant on beech; but unfortunately many members of the genus Lachnus have no wool.

\section{Genus Pterocallis.}

The characters of this genus may he described as rostrum short and stout; antennæ shorter than in Callipterus, the difference in length being specially conspicuous in the apterous form ; six-jointed, but the sixth joint has a break in the middle, which might on indistinct examination be mistaken for a seventh joint. Cornicles small and stout. Wings shorter and narrower than in Callipterus, and most heantifully clouded; hence the term Pterocallis is derived from the Greek, and means beautiful wing.

Buckton describes three species as belonging to this genus, all of which are arboreal in their habits-namely, Pterorallis alni, on alder; $P$. juglandicola, on the walnut-tree (Juglans regia); and $P$. tilia, on various species of lime, which, however, is so abundant on the ordinary lime-tree (Tilia exropea) that it may be taken as typical of the genus.

\section{Pterocallis tilia (Linn.)}

The apterous viviparous female is of a uniformly lightish-yellow colour, with most beautiful light-red eyes. The antennæ, more especially in the young stage, are light and dark, the basal portion of each joint being light in colour, and the apical portion of the same joint being very dark. The contrasting colours therefore make the antennæ rather beautiful objects.

The winged viviparous female is of a uniformly light colour on the under surface of the body, and on the upper surface she is of a yellow colour, with short dark bands reaching half-way across the 
abdomen. The thoracic portion of the body is also yellow, with two Iongitudinal dark bars on the lower portion of the thorax. The legs are variable in colour: the first two pairs are of a yellowish colour, with darkish tarsi. In the hind pair, the portion adjoining the body is also a light-yellow colour, and the middle portion of the whole is conspicuously black, and the tarsal portion light brown. Eyes same as in apterous form. The wings are comparatively long and narrow; veins light brown, and broadly clouded at their apices.

\section{Genus Lachnus.}

This genus is rather interesting from a sylvan point of view, inasmuch as the species are all arboreal feeders. According to Buckton, one species lives on willow, while the others prefer the oak or coniferous trees.

As regards the leading points which characterise the genus, it may be said that the rostrum is very long and slender; antennæ sixjointed ; small cornicles; inconspicuous tail ; very long legs and large wings, with the cubital vein twice forked.

Perhaps the most conspicuous species are L. pini, on Scots pine, and L. lonifipes, on oak, - the former, from the damage done to young Scots pine in early spring, and the latter, as conspicuous by the egres in autumn.

The insects are very heavily bodied, and the winged specimens are but poorly balanced for flight.

\section{Lachnus pint (Linn.)}

This species is found on Scots pine (Pinus sylrestris), and is fairly common, more especially in smoky districts, where the young trees do not thrive over-well. During the winter months the eggs, which are comparatively large and black, may be found seattered amongst the leaves or on the bark of the shoots.

In late spring or early summer, when the insects hatch out, they make their way to the very tips and there congregate themselves, and when an attempt is made to collect them they become very active in their motions.

The apterous form is very large, of a dull brownish-grey colour, black eyes, slender antennæ, long legs, and the body rather hairy, but 
soft in structure. In mounted specimens the rostrum is often very conspicuous, and as a rule the front pair of legs are much more prominent than the antennx.

The winged specimens are much the same in colour as the above. They may be beaten from Scots pine trees throughout the summer, and as the wings are often folded flat over the body, they might be mistaken by a beginner in entomology for a species of ant.

\section{LACHNus LONGIPES, DUfour.}

This species is found on oak, and often on young shoots from oak stools. The eggs, however, as represented in fig. 286, are the most conspicuous. They may be looked for in late autumn or during the winter months.

In early summer the apterous viviparous females may be found in masses on the shoots of oaks which grow as suckers from the stools or stumps of previously felled trees. They are fairly large in size, of

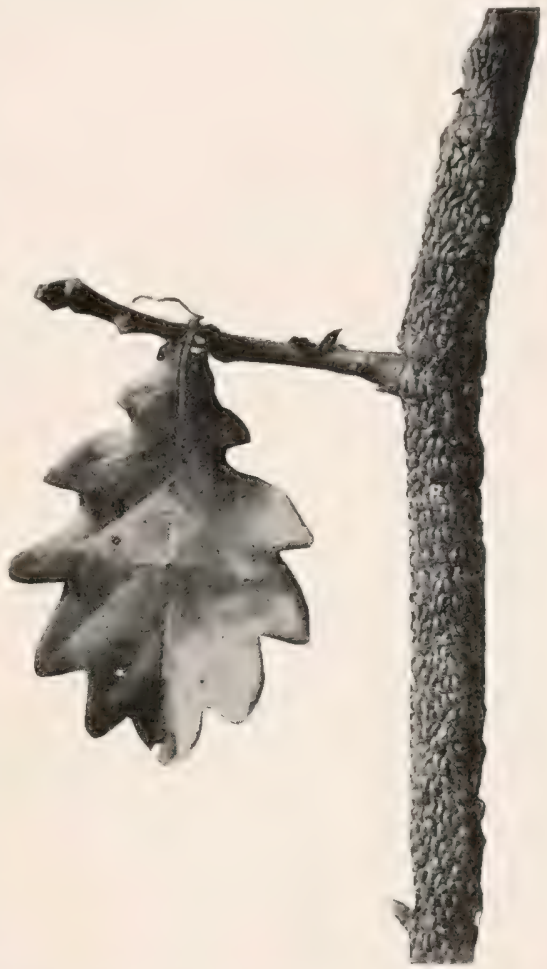

Fig. 256.-Eggs of Lachnus linngipes on oak. Photograpled in winter; leaf added for identification. oval form, and of a uniformly deep-brown colour. Eyes black, and cornicles small.

\section{I,ACHNUS VIMTNALIS (Fonsc.)}

This species is found fairly common in some parts of the country on willow or osiers, and very harmful to willows and osiers in parts of South England. Wasps are greatly attracted to where they occur. 
It is apt to be confounded with Melanoxanthus saticis, one of the most salient points of difference being the joints of the antenne.

The other species described by Buckton in his Monograph are L. picex, which is said to be very abundant on silver fir and also on spruce near London; L. pinicolus, on larch and Scots pine; and L. mucrocephalus, on spruce.

\section{Gemus Phyllaphis.}

The following generic characters are from Buckton :-

"Rostrum very short.

"Head convex, smooth.

"Antennæ moderately long, the third joint about double the length of the fourth; the fifth and sixth joints equal, the sixth furnished with a representative nail.

"Cornicles hardly visible, and lying flat to the body.

"Cauda almost obsolete.

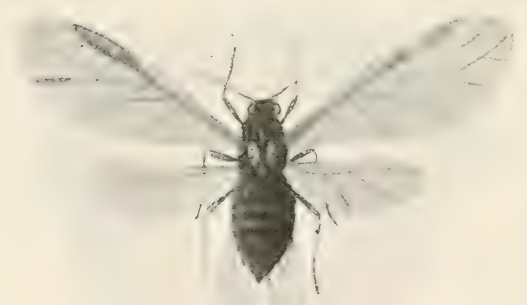

Fig. 287.-Phyllaphis fagi.

"Body furnished with long flocks of wool-like fibre of a waxy nature.

"Wings long and broad. Stigma long and trapezoidal. Nervures not clouded.

"Legs moderate in size."

\section{Phyllaphis fagi (Linn.)}

During early May the leaves of beech-trees may be found covered with a white woolly coating, produced by insects known as Phyllaphis fagi. In some cases large beech-trees are so badly attacked as to he partially defoliated in midsummer, and this being the growing season, the increment of the tree must be appreciably affected.

The apterous female is a light-green or yellowish colour. The general colour is, however, rather variable, as the abdomen is marked with spots or bars. The cornicles are rather small, and the joints of the antennæ are about equal thickness throughout.

The winger female (fig. 287) is best examined by first dissolving the 
white fluffy matter, but this, unfortmately, rather spoils the colour. The general colour is yellowish-green, with darkish legs and antennæ.

Fig. 288 is from a photograph of the leaves of copper beech; and there is only one species in the genus which confines itself exchusively to the beech.

In the older writings of 'The Transactions of the (Royal) Scrittich

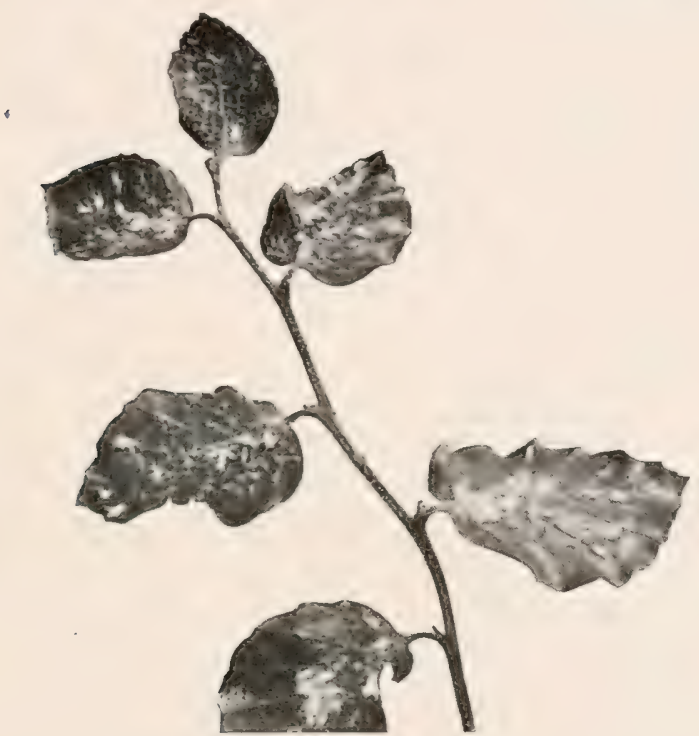

Fig. 285.-Fotiage of comper bech (under side) covered with Phyllaphis fagi.

Arhoricultural Society' several accounts of this insect are given under the name of Chermes fagi.

This species is particularly harmful around the London area.

\section{Genus Stomaphis.}

As this genus, according to Buckton, contains only a single species, namely, S. quercês, which is said to be comparatively rare in England, it may be well, for the advantage of students, to simply give the following generic characters according to Buckton-viz.

"Head and eyes small. Antennæ slender, moderately long, sixjointed, third joint the longest, the sixth as long as, or longer than, 
either the fourth or fifth, the aborted seventh joint longer than in Lachmus.

"Cornicles very inconspicuous.

"Legs shorter than in Lachmes, and less stout. Tarsus biarticulate, tail none, rostrum very long in the apterous females, but shorter in the winged forms."

I have not found Stomathis, and therefore only give the generic characters.

\section{Genus Drxobius.}

The following generic characters are taken from Buckton :-

"Rostrum rather long and thick, projecting beyond the poststernum-much longer in the young.

"Antennæe slender, six-jointed, with an unciform process in the sixth joint. Third joint more than twice the length of any other, the fourth and fifth joints about equal--the sixth less than half the length of the fifth.

"Cornicles conical, and very short.

"Cauda inconspicuous and rounded.

"Legs, the first two pair moderately long, the hinder pair disproportionately long; tarsus composed of two distinct joints.

"Wings moderately long in the males, but very short in the viviparous females. Stigmata rather long; cubital and first furcal veins issue from the same point, which is at some distance from the cubitus. The membrane of the upper wings variegated with brown, smoky fasciæ."

Buckton in his Monograph describes three species, but they appear to have been found either on the Continent or in the south of England; and as I have not found either of the species myself, I must simply refer the student to the generic characters.

\section{TRIBE SCHIZONEURINÆE.}

This tribe contains the dreaded "American blight" found on fruittrees, and the damage done to stem and roots is unfortunately only too well known to require description.

The species belonging to this tribe differ in two ways from insects belonging to the previous tribe, both as regards the structure of the insects and the nature of the injuries. 


\section{Genus Schizoneura.}

As regards the structural details, the following seneric characters are given by Buckton-viz. :

"Liostrum moderately long in the aulult, much longer in the young.

"Antennæ with six articulations, omitting the terminal unciform process.

"The first and second joints very short, the third much the longest, and in all cases either ringed or enpped; the fourth and fifth about equal, and also usually ringed; the sixth joint rather shorter than the preceling, and ending with a rudimentary joint, a small tubercle sometimes separating the two parts.

"Cornicles rudimentary or none; legs short. Tarsi furnished with two claws. Body either powdered with a mealy substance or furnished with wool-like tufts.

"Wings moderately long, cubital, with a single furcation, and in

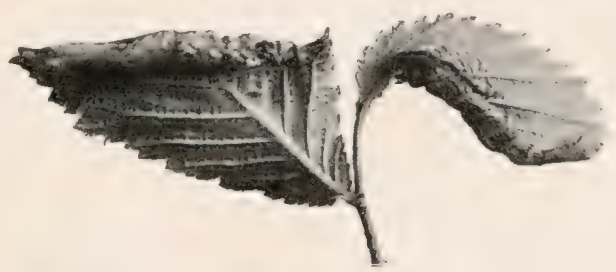

Fig. 289.-Leaves of wych elm rolled by Schizoneura uImi.

most species springing at some considerable distance clear from the cubitus. The post-costal nervures of the hind wings nearly straight, and giving rise to the usual two oblique veins."

Irith regard to the damage, it may be noted that in this tribe we find a reaction of the vegetable organism against the insect attack. In other words, we get gall structure and its modification. The various figures given by Réaumur and others would seem to suggest that those features have been recognised for a very long time.

The arboreal species chiefly confine their attacks to the foliage. The curling of the leaves of elm (fig. 289) is a very conspicuous feature throughout the country. If the curl arises from the gnawing of one stem-mother, then a single straight roll of half the leaf is the result, but if the same leaf is seized by more than one stemmother, then the deformed leaf assumes various distorted shapes. 


\section{Schizoneura ulmi (Linn.)}

The arboreal species most injurious in this country and throughout Europe is the Schizoneura ulmi (Linn.), and the most injurious arboreal species in America is known as Schizoneura americana (Riley). ${ }^{1}$

The description given by European writers was suggestive of the two species being identical; but Professor Riley, on closer examination, found that the two species differ from each other in their methods of damage and structural details, thus showing that while we may deplore specific hair-splitting, hasty grouping is far from commendable.

Riley maintained that, considered as a psendo-gall, the chicf difference in the two species is that the stem-mother of $S . u 7 m i$ attacks the upper side of the leaf, and the injured leaf in consequence rolls over; whereas the stem-mother of $S$. americana attacks the under side of the leaf, and the injured portion rolls under. This observation was based by Prof. Riley on a specimen sent from England by Mr Buckton, but it certainly does not coincile with our own species, $S . u m i$, inasmuch as the queen-mother attacks the under side of the leaf and rolls under (fig. 289).

Hence it is evident that we must have recourse to foreign literature, for though the various species may be more or less local, the genus may often be cosmopolitan. A more comprehensive view of the genus will give a better grasp of the species.

The queen-mother may be found about the middle of May. She is apterous, of a dark-olive colour, mottled with dark-bluish tints, like the gloss on black grapes. The creature is considerably larger than any of her offspring, which may be found either along with her or after her death. The body is slightly covered with a cottony exudation arising from a series of pores on the back. In comparison with the body, the head and thorax are very small. The antenne and legs are short, hence the creature is very helpless. The antenne are composed of six joints, the third being nearly half the entire length. It is highly probable that those stem-mothers hatch from eggs laid the previous autumn.

The winged specimens may be found very plentifully by the middle of June in the rolled elm leaves. The body of the female is wholly black in colour: the eyes are also black. The third joint of the

I Insects Injurious to Forest Trees. Packard, U.S.A. 1890. 
antenne is very long, being considerably longer than all the other joints put togrether, and beautifully ringed. The wings are molerately long; and the cubital vein is but once forked, which is an important point in generic classification.

\section{TRIBE PEMPHIGIN.Æ.}

Closely allied to the preceling group are the Pemphiginæ or gallforming aphicles. The insects live sociably, but instead of rolling leaves, form galls, - growths which, from a structural point of view, may be considered ligher in the scale of organisation than rolled leaves. The curious abnormal growths, eaused by insects belonging to this tribe, appearing on the leaf-stalks or midribs of leaves, often displaying beautiful colours, have received a great deal of attention from various workers. The galls themselves, differing from one another in aplearance and position, give rise to specific characteristic distinctions, apart from the structural points of the respective insects themselves.

In comparing the characters of the two genera, it will be ascertained that the rostrums are alike, and the antenne similar, viz., six-jointed; but the sixth joint in Pemphiginæ is larger than in Schizoneurinæ. It is, however, in the wings that the most salient structural difference may be recognised. The cubital vein in Schizoneurinæ is forked once, whereas in Pemphiginæ it is not forked, but in both genera the cubital vein is unattached to the cubitus.

\section{Gemus Pemphigus.}

The following are the generic characters according to Buckton:"Rostrum as in Schizoneura. Antennæ short, with six joints, omitting the nail-like process. Third joint about equal to the three following taken together. The third, fourth, and fifth joints commonly ringed; the sixth joint longer than that of Schizoneura.

"Cornicles wanting.

"Wings with no furcated cubital vein,-this vein, as in the last genus, being unattached to the cubitus; stigma large and trapezoidal; the two oblique veins usually start from the same point. The postcostal nervure of the lind wing somewhat angular, from which angle the two oblique veins spring.

"Legs short, particularly in the apterous forms." 


\section{Pemphigus buraraius (Hart.)}

This species is found on the leaf-stalks of poplar (fig. 290), chiefly on the black Italian species, the black burry poplar, and also on the

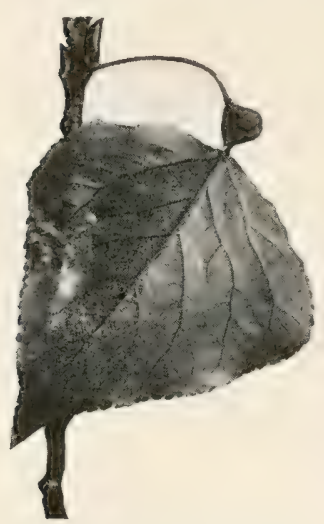

Fig. 590.- ciall on leaf-stalli of poplar caused by Pemphigus bursarius. young woody twigs of the Lombardy poplar. The gall is smooth, globular, highly coloured, and with an opening at the side. In July or August the leaves, with galls on the foot-stalks, having fallen prematurely, may be picked up, and the insects found in all their respective stages of metamorphoses.

The stem-mother (fig. 291) is larger than any of her progeny. The legs are short, and the creature comparatively helpless. The antennæ are four-jointed, and the cornicles absent.

The larva (fig. 292) is of a very lightgreen colour.

The pupa (fig. 293) is of a pale-green colour, with a slight mealy dusting, and shows signs of wings at a very young stage. The antennæ are longer than in the green aphis, but the joints are not easily distinguished.

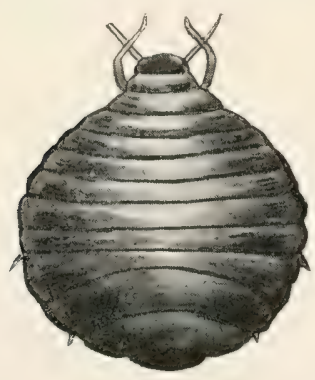

Fig. 291. - "Stem-mother" of Pemphigus bursarius. (From camera-lucida sketch.)

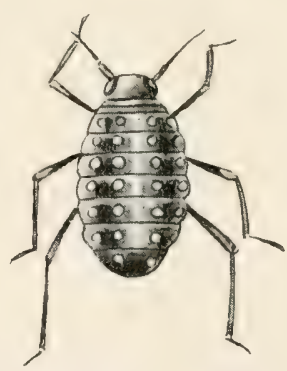

Fig. 292.-Larval stage of Pemphigus bursarius. (From camera-lucida sketch.)

The winged viviparous female (fig. 294) is black, and the body and wings are dusted over with a white powdery matter. The antennæ are six-jointed, the third joint being the longest; and the third, fourth, fifth, and sixth are ringed. Buckton says the sixth joint is smooth, 
but in the specimens I examined this joint was ringed like the others.

Common and harmful in Kent.

\section{Penphigus spirothece (Koch).}

This species, like the preceding species, is also found on the leafstalks of poplar of the black Italian species (fig. 295), but it makes a corkscrew-shaped gall. It is far from common, and very locally distributed. While living in Cheshire, I only found but one tree, growing on a bank alongside a brook, which annually yielded me a good crop of galls. The queen aphis punctures one side of the leaf-stalk to obtain nourishment, and the stalk in consequence bulges on the opposite side. The gnawing and bulging causes the stalk to form a corkscrew - shaped gall, where the stem-mother and her

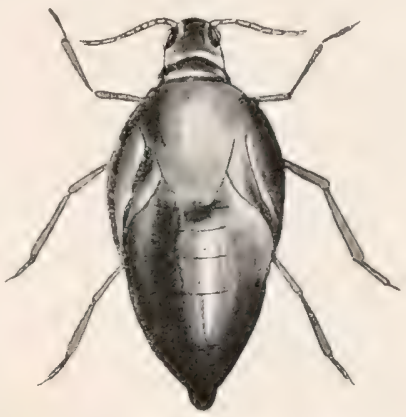

Fir. 293. - P’uprol stump of Pempligus bursarius. (From camera-lucida sketeh.) progeny find a home and shelter in the folds. As the fully developed insects are about to escape the galls become more elastic, and

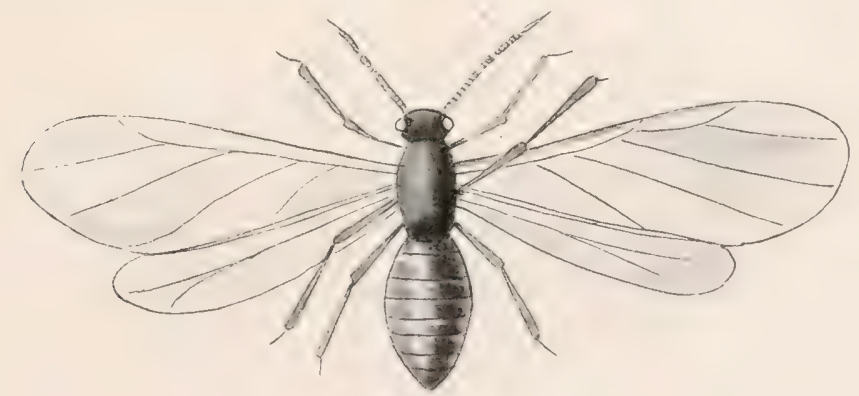

Fig. 294. - Winged form of Pemphigus bursarius. (From camera-lucida sketch.)

open easily. The gall is of a dull-green colour, and may be lnoked for from June to September.

The most abundant crop of those galls I have ever seen was at Peterborongh, on the Lombardy poplar. 
The insects are smaller than those in the preceding species, and differ in a few minor specific points.

\section{Pemphigus palimdus (Haliday).}

In fig. 296 an illustration is given of $P$. pallicus, which forms galls on the midrib of wych elm. The specimen from which the photo-

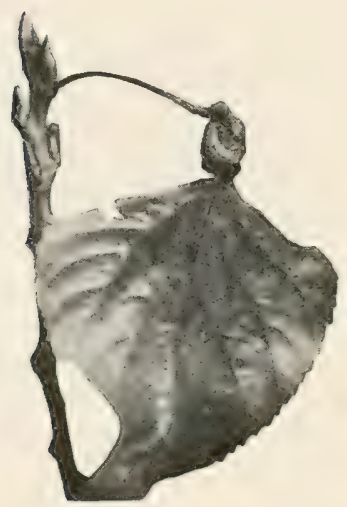

Fig. 295. - "Cortiscrewe" gall on leaf-stalk of poplar caused by Pemphigus spirothecæ.

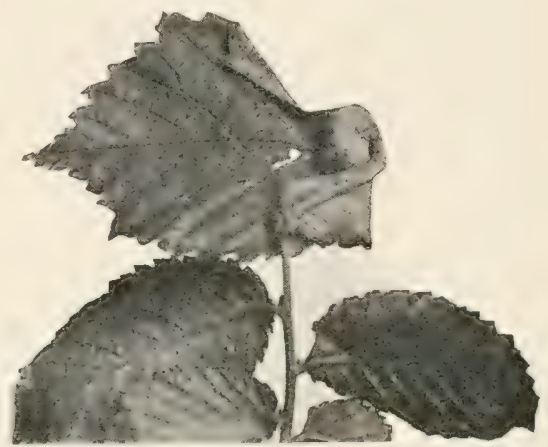

Fig. 296.-Gall of Pemphigus pallidus on midrib of leaf of wych elm.

graph was taken was found in High Legh, Cheshire, where it was very common.

The fully developed insect is somewhat variable in size. The head and thorax are black; abdomen yellow; eyes red; antennæ darkishbrown.

\section{Tetraneura ulim (De Geer).}

Closely allied to the Pemphigns, and belonging to the same tribe, is the genus Tetraneura, with a single species, Tetraneura ulmi.

The galls of this species are found on the upper side of elm leaves (fig. 297) about the middle of May. They are nearly one-fourth of an inch in length. I have frequently found the galls projecting from the folded portion of the leaves injured by Schizoneura ulmi. Thus we get two species very closely allied entomologically, and practically united botanically. The entrance to the galls of Tetraneura is well closed, and guarded by hairs which doubtless act as a protection against parasites. 
As compared with the preceling genus, the rostrum is companatively short, the antenne short and six-jointed. The wings are similar to those of Pemphigus, "except that there is only one oblique vein in the lower wing."

The gall attains its full size prior to the complete development of the insect. The antenne are four-jointed, the rostrum rather long in eomparison with the berly, and legs slightly hairy. Colour tark oak, and the insects very sluggish. It is very harmful to isolated elms, killing the leaves -in many parts of the country.

\section{TRIBE CHERMESINÆ.}

Perhaps in the whole realm of forest entomology there is no tribe of insects which presents such peculiar difficulties as the Chermesinæ, inasmuch as it is most difficult to present the biological importance, as revealed by the present state of our scientific knowledge, and the

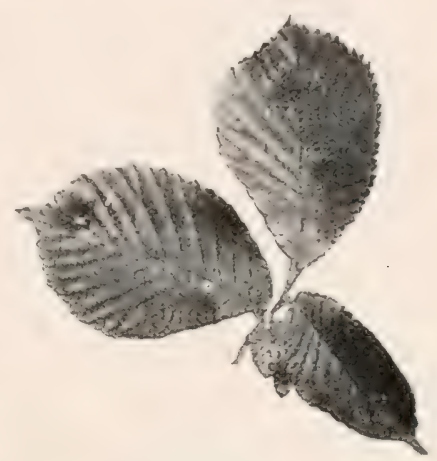

Fig. 297.-Galls of Tetraneura ulmi on learcs of elm. exact discrimination of our so-called species in such an amalganaterl form as will be correct to the scientist, and also intelligible to the practical man. In other words, we have, in this group, two problems to face-viz., the alternation of a species from host-plant to hostplant, and on the other hand the determination of the so-called species on their respective host-plants as associated with their own peculiar injuries.

First, let us consider the alternating generations as given by Juleich and Nitsche, ${ }^{1}$ and more recently by ${ }^{\text {Tiisslin }}{ }^{2}$ from Cholodkorsky. In the former, two classes are given-viz., (1) Continuation or remaining on spruce, with clear parthenogenetic reproluction; (2) partly emigrating from the spruce to the larch, with parthenogenetic or sexual reproduction. In the latter, which has heen carefully worked out by Cholodkovsky, the gist of it may be summed up as follows:-

Typically the Chermes show five generations and an exchange of host-plant. The principal host-plant is always the sprnce; but only

1 Forstinsektenkunde.

2 Leitfaden der Forstinsektenkunde. 
one generation, the 3rd or emigrans generation, belongs exclusively to conifers other than the spruce (such as Scots pine, lareh, and silver fir). This change of conifers referred to other than spruce is known as the intermediate conifer (Zwischenkonifere) only in so far as the former brings about the transport of the species, through the laying of eggs on the intermediate conifer, in order that they may return to the spruce. Now this is a most important point, as it elearly implies that this alternation is for the welfare of the species, though, as it were, on the part of the insect, not altogether optional, but periodically (not annually) compulsory for the welfare of the species. This shows that it must have been difficult to discover and ratify by those Continental workers, and even difficult for the student in this country to verify.

The following is a short account of the alternation as given by Niisslin : ${ }^{1}$ -

"The 1st generation (foundress) is a parthenogenetic female, wingless, with three-jointed antennæ, confined to the spruce and producing the spruce gall. The 2nd generation (migrans alata) acquires wings after the fourth moult, receives at the same time five-jointed antenna, compound eyes, and three simple eyes. It develops in the gall on the spruce, and flies usually to one of the 'intermediate conifers,' where it lays its eggrs on the needles. From these eggrs springs the 3rd generation (emigrans), which resembles its ancestor of the 1st generation (the foundress). It remains on the alternate host (the "intermediate conifer') for hibernation, and lays eggs there in spring. From the eggrs emerge either forms resembling the parent (exuluns) or the 4th generation (sexupara), which in every respect resembles the generation hefore the last (its 'grandmotherly generation'), the migruns alat", only it remains smaller, and is less prolific. From the beginning it is independent (freilebem ), and after the first moult varies somewhat. It lives and develops on the needles of the 'intermediate conifers,' and flies back to the spruce, where it lays eggs on needles. Out of the esgs come the two different forms of the 5th generation (sexules) - the leaner males and the stouter females. Both are rather small, but do not diminish in size, and have four-jointed antennæ. The female, after pairing, lays in midsummer a single fertilised exgr on the spruce, from which emerges the hibernating foundress. The fivefold cycle requires, therefore, two years and two different coniferous species for its completion.

1 Leitfaden der Forstinsektenkunde. 
"According to what has just been said, we have in the Chermes cycle only three principal (chief or leading) forms-viz. :

1. The parthenogenetic (non-sexual or asexual) wingless form.

2. The parthenogenetic (non-sexual or asexual) winged form.

3. The sexual generation with male and female.

"But in reality the number is increased, as each of these forms varies more or less in the $3-4$ moulting stages. Especially does the appearance of the insect change between the first and the lant stage of the parthenogenetic winged form (mirpans aluta)."

The question of how to form a precise recognition of the different species, and the various stages of the same species, is somewhat diffieult to determine. It would be advisable to boil and stain the respective mother Chermes, as found on different food-plants, and compare their minute structure, such as chitin plates, wax glands, antenne joints, legs, and so forth, together with the colour of the eggs and general habits of the creatures.

Second, as regards the so-called species, it would perhaps be well to consider them separately in the usual way, both as to their relation with other closely allied insects and the damage on different trees. Hence they may now be considered in the ordinary manner of genus and species.

\section{Genus Chermes.}

This genus is exclusively arboreal, and the respective species are confined to conifers. They come near to the Coccidæ or Scale-Insects in point of anatomical structure, and nearer in general appearance of damage than any other tribe in the whole family. Thus the snowy appearance presented by the felt scale on beech, and the white fluffy matter on the stem of silver fir and Weymouth pine, are to the naked eye practically identical. The difference between the two families can only be decided by microscopical examination, and in fact, between the respective species of this genus, can only be decided by the most eareful microscopical examination.

In structure the genus Chermes is characterised by the upper wing having three oblique non-furcated veins, and the under wing a single oblique vein. The antenna are normally five-jointed. The rostrum is very short, being used exclusively as a feeding-organ, and not specially for anchorage. The creature develops three or more long 
hairs, or setro as they are termed, by means of which it maintains a hold on the bark. In this respect it very much resembles the Diaspinæ, or scale-insects, on the ash, alder, willow, \&c., as in both families the creatures may be seen dangling in the air, after they have been detached from the bark by birds or other natural enemies. There are no cornicles. The parthenogenetic females secrete wax, and for the most part show, on careful examination, clearly marked chitinous plates.

\section{Synopsis of the Species.}

Producing comparatively large galls on the terminal and lateral shoots of the spruce (Picea excelsa). The shoot often extends beyond the gall . . . . . C. abietis.

Producing comparatively small, hard, close galls on the terminal buds of twigs of spruce, and always arrest subsequent growth . . . . . . C. strobilobius.

Producing a white covering on the stems or foliage of comparatively young larch-trees . . . C. laricis.

Producing a white covering on the twigs or branches of young Scots pine or Austrian pine . . . C. pini. Producing a white covering on the branches or stems of Weymouth pine . . . . . C. corticalis.

Producing a white covering on the stems or foliage of silver fir (Abies pectinata) or Abies Nordmanniana . C. picece.

\section{Chermes abietis (Linn.)}

This is a gall-forming species on the common spruce (Picea excelsa), the gall being in appearance like a pine-apple or pseudo-cone of Scots pine (fig. 298), each abortive shoot terminating in abortive leaves.

The structure of the gall varies, as in some cases it surrounds the young shoots, and arrests or retards future growth. At other times it may be found on one side of the shoot, thus doing only partial damage. When the leading shoot is attacked, the young tree is often very much injured.

The "stem-mother" hibernates during the winter months at the extreme top of the young shoot, just immediately below where the pseudo-gall will be formed next year. They are, however, very difficult to find, as they are not only surall but beautifully concealed. 
Shoots in close proximity to the old galls of the previous year are the most likely to yield specimens.

The first appearance of the gall may be looked for, according to season, about the middle of April. 'This is recognised by a small white speck at the tip of the shoot (fig. 299), in which the mother Chermes may be found depositing her eggrs. On examination about a month after recognising the white speck (ny dates were April 20 and May 18, and the locality Cheshire), the mother Chermes was still surrounded hy egrgs, although none were hatched. Neanwhile the cottony down had increased in quantity, the young

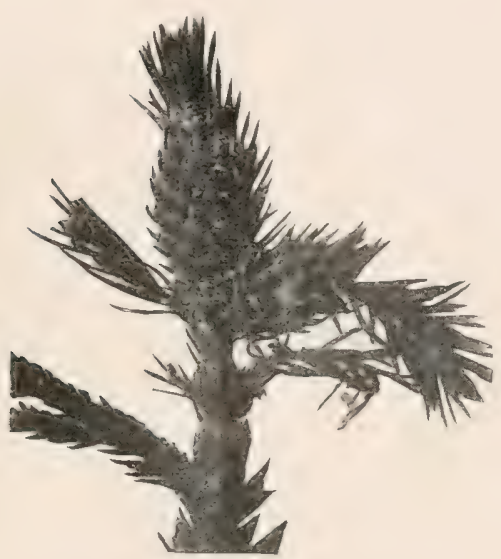

Fig. 298. - Gall of Chernes abietis on spruce.

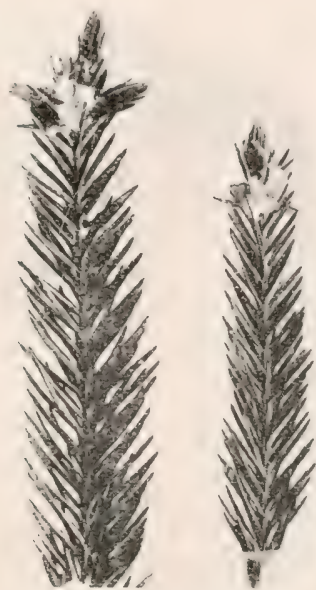

Fig. 299.-Early'stage of gall of Chermes abietis on spruce.

shoots had grown from $1 \frac{1}{2}$ to $2 \frac{1}{2}$ inches in length, and the pseudocone or gall itseif from ${ }_{8}^{3}$ to $\frac{1}{2}$ inch in length, whence arose deformed leatlets about $\frac{1}{8}$ inch in length.

It is probable that constant irritation causes the gall formation in question.

The young larve are hatched outside the pseudo-gall, which begins to enlarge before the larvæ are hatched out, and it is not quite clear how the vegetable structure reacts against the insect attack; but the gall slightly opens at the slits, and the young larve creep in. Afterwards the gall closes up, and the transformations take place within the gall. It is computed there are about 2000 inhabitants to each gall. 
Buckton remarks: "It is not quite clear' if the queen-mother dies outside of the developing gall, leaving thus the young which hatch from the eggs to enter those chambers alone, or whether she accompanies them in their retreat."

From the middle of June to the end of August the winged specimens may be found emerging from the gall. They are very sluggish in their movements.

The "pupal" form presents a reddish-brown-coloured creature, whose body appears "all made up of a piece." The eyes are of a darker brown colour than the body. The antennæe and legs are short, and the wing-cases slightly greenish; but specimens differ very much in colour. As might be expected, the insect is more or less covered with a resinous exudation.

The winged imago is of a golden brown colour, which deepens very much with age. The head is broad, and the eyes dark brown. The antenne are short and five-jointed, the last three joints being peculiarly straight on one side. The prothorax is comparatively broad and large. The abdomen is oval-shaped. Specimens mounted for some time show the abdominal segment to have a rather broken outline, and ending in a short ovipositor. The wings are comparatively broad, and vary in colour from a light to delicate greenish tinge. 'The venation is typical of other Chermesinæ.

About the middle of September many insects will be found depositing egrgs on the leaves, as seen in fig. 300. In some cases an insect is found on almost every leaf. The hear of the insect points towards the base of the leaf, and she generally places herself fairly near to the base of the leaf. After depositing the eggs the female dies, but the dead body is so placed that it forms a protection for the eggs. It should be noted, however, that the egrgs are not thrust outside the body, as Ch. laricis, but on the contrary the ovisac is slightly extended and placed bodily on the leaf prior to the death of the creature.

These insects just referred to are, according to alternating generations, probably the return generation from the intermediate conifer.

\section{Chermes strobilobius (Kalt.)}

It is quite possible that this species has, in this country, been hitherto confounded with Ch. abietis. The structural features, as 
illustrated by Judeich and Xitsche, do not show any stroner salient points of difference, and in the absence of knowledge on the part of the student regarding verifieation of the alternating stike, it would be well to recognise the difference in the structure of the galls. In (. stroblitulius we find the galls smaller, globular in form, and in colour resembling the unripe fruit of the wild strawberry. The develop-

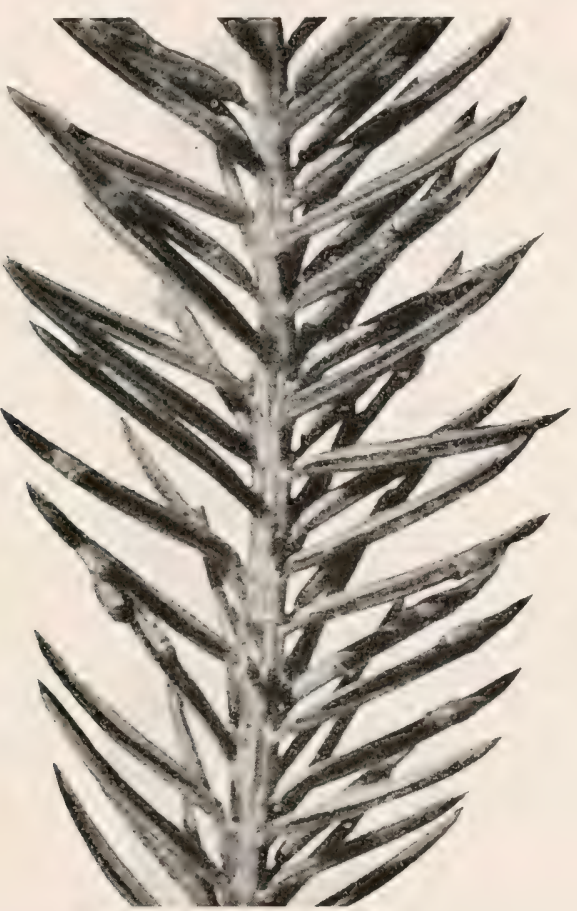

Fig. 300.-Winged forms of Chermes abietis on spruce leares (entarged). Found in autumn. This stage should be carefully studied, as it probably may be the sexupurc stage.

ment of the gall is such that leaves do not project beyond the gall. In the German literature it is said that there is a marked difference as regards the "over-wintering" (ubemintern) of the two species, inasmuch as in C. abietis the stem-mother (Funtutric) passes the winter at the base of the bud, whereas in $C$. strobilobius the creature winters in the top of the bud. It is therefore suggestive that the initial action of the respective insects produces the variation of gall structure. 


\section{Chermes laricis (Hartig).}

This and the remaining species of Chermes differ from the preceding, inasmuch as abietis is gall-forming, and those about to be considered protect themselves by a woolly covering. The evidence of the presence of alictis cannot in a general way be recognised by the naked eye until we find a white speck in late spring. This speck reveals the abode of the queen-mother. With regard to Chermes lavicis, on the other hand, considered as a distinct species, the queen-

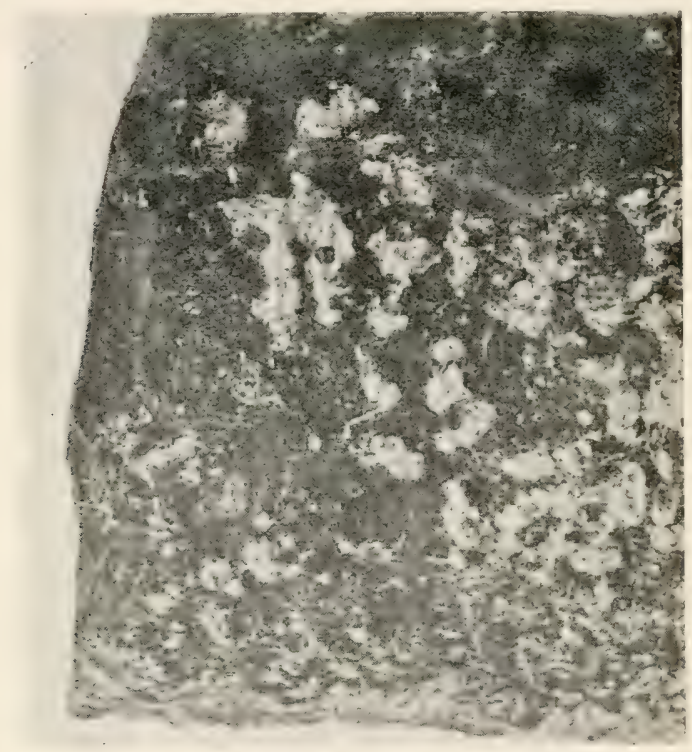

Fig. 301.-Chermes laricis on bark of larch.

mothers may he found throughout the whole of the winter months on the stems of young infected trees, their presence being indicated by the cottony covering on the stems $^{1}$ (fig. 301). This is no doubt the main harbourage, but many specimens may also be found hibernating just underneath the leaf-scales. ${ }^{2}$

${ }^{1}$ Mr Theobald, in correspondence, says : "You cannot trace a single one on the stems in South England, where laricis swarms. The trunk aphis is found in Lincolnshire. There is no doubt it is different, and that there are two allied species."

2 The two forms-viz, those on buds and those on bark-are probably quite distinct. The latter is termed $C$. viridis by some entomologists. 
In Cheshire, by ahout March 25, the queen-mothers may he found just beginning to make "a move." At this time they are very small, and much resemble the lavere hatehed ont from egress later on in the season.

If the infested trees be examined about three weeks later, it will be found that the tufts of leaves have grown from alwut a quarter to three-quarters of an inch in length. The queen-mother Chermes will be found at the base of the leaf-buds, surrounded by eggs. Her body is now very much enlarged, and of a dark-brown colour, with conspicuous rows of tubereles and slightly dusted with cottony down.

The antennæ are very small, and partly hidden. They are three- or four-jointed, but the joints are not easily determined by the inch objective. The rostrum is short and stiff, with very long attached setæ. The legs are short, and naturally not seen outside the bodily circumference. The tail is short, but is used by the insect in arranging her eggs, with which she ultimately becomes halfburied.

The eggs are greenish in colour, glued together by a resinous turpentine, and further attached to each other and to the plant by delicate threads.

The larral forms which hatch from the eggs are mere pin-points in size, and a

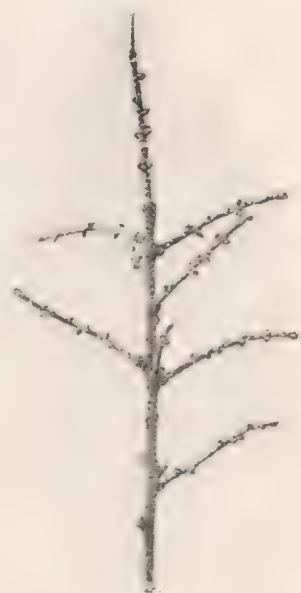

Fig. 302.-Foliage of larch arrested

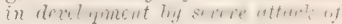
Clowrmes in torly summi:

darkish colour. They spread themselves all over the tree, and do immense damage by sucking the juices of the plant. When numerically very strong, as in some local spots, they entirely defoliate, or rather retard the development of the folinge-so much so, that the severely affected trees may appear quite naked when others are in full leaf (fig. 302).

Later on during the summer the green leaves are heavily dusted with white-so much so, that they would appear as if covered with a slight shower of snow (fig. 303). If each speck be examined individually, it will be found that it is composed of mother and egrs covered by the white exudation. 


\section{Chermes pisi (Koch).}

This species is found on Scots pine and Austrian pine. The white specks are generally found on the stems or branches of young trees, and also on the shoots (fig. 304). To follow out the life-history of this insect, the dark-brown queen aphis should be looked for in May; and by June she is covered with brownish-yellow pedunculated egrss,

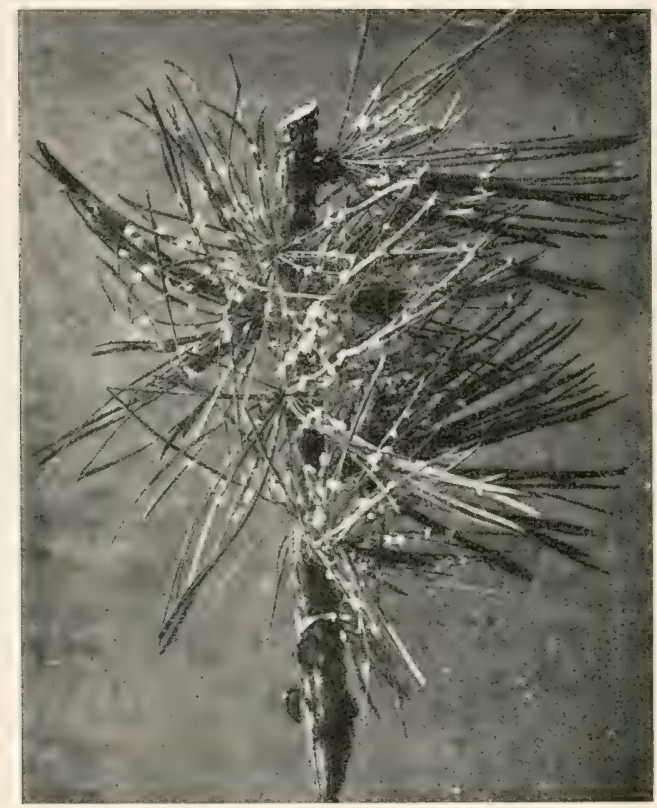

Fig. 303.-Chermes laricis on foliage of larch.

which soon hatch out into very active larvæ. The insect protects herself with long white silky filaments.

In early spring the white cottony matter covers the young shoots, as seen by fig. 305 . It will also be observed that in this case, which is purely a typical example of severe damage, the shoot is considerably bent as compared with unattacked shoots, which are perfectly straight. In many cases, however, healthy trees recoyer from attacks of this kind and no serious injuries accrue, but, on the other hand, as will 
be seen from fig. 306, many of the young shoots die from the attack. This fig. was photographerl from a plantation which was not in a very good state of health. If, as a rule, the health of the crop is fairly good, the trees "throw off" the attack, and no appreciable damage is done.

\section{Chermes corticalis (Kalt.)}

This species is very common in the south of England on Weymouth pine, and is said to do very great injury to the trees. It has

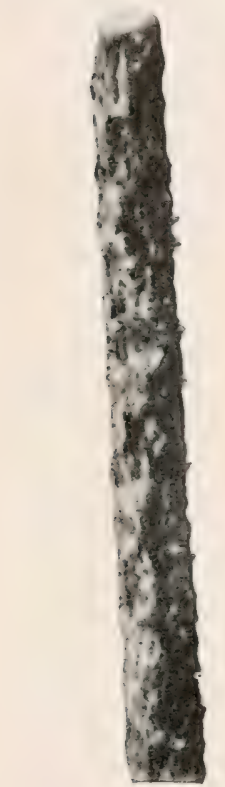

Fig. 304.-Chermes pini on stem of young Scots pine.

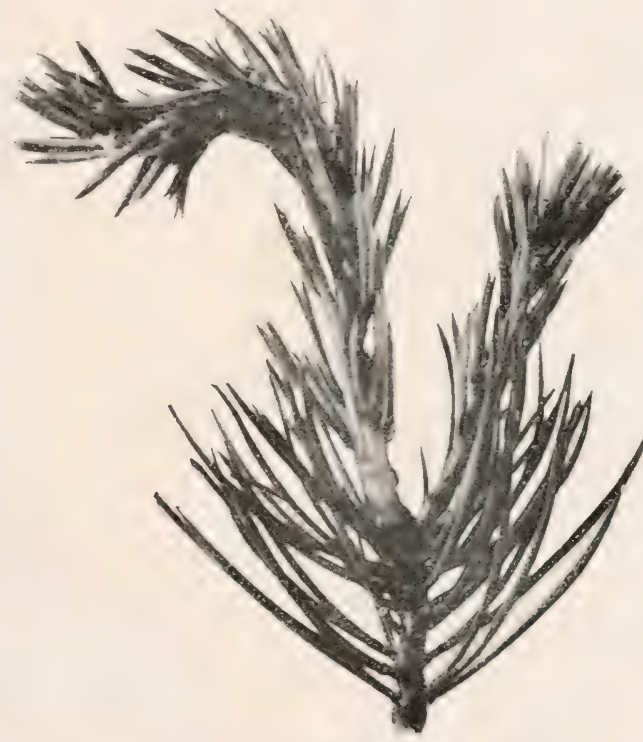

Fig. 305. - Chermes pini on terminal shoot of Scots pine.

been notably sent me from the sandy soils of Surrey, and I have found it bad on one tree in Kent. Fig. $30 \tau$ is taken from a branch of Weymouth pine in a garden in Cheshire. I have not found this species in Northumberland, so that I am unable to give any description of the creature. 


\section{Chermes pice. (Rtzb.)}

The bark-louse of the silver fir (die Tannenrindenlaus of the German) is very destructive to young silver firs, comparatively young specimens of Abies Nordmanniana, and even fairly old trees of Abies nobitis. Fig. 308 is taken from the bark on a silver fir tree of ahout

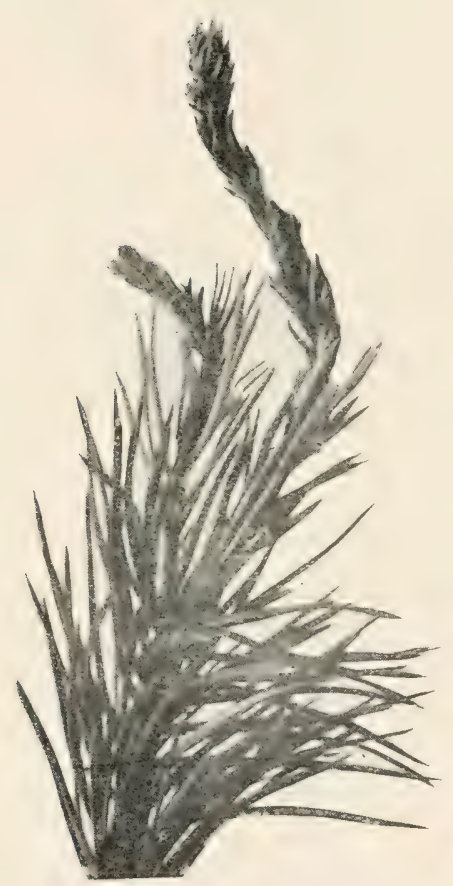

Fig. 306.-Terminal shoot of Scots pine killed by Chermes pini.

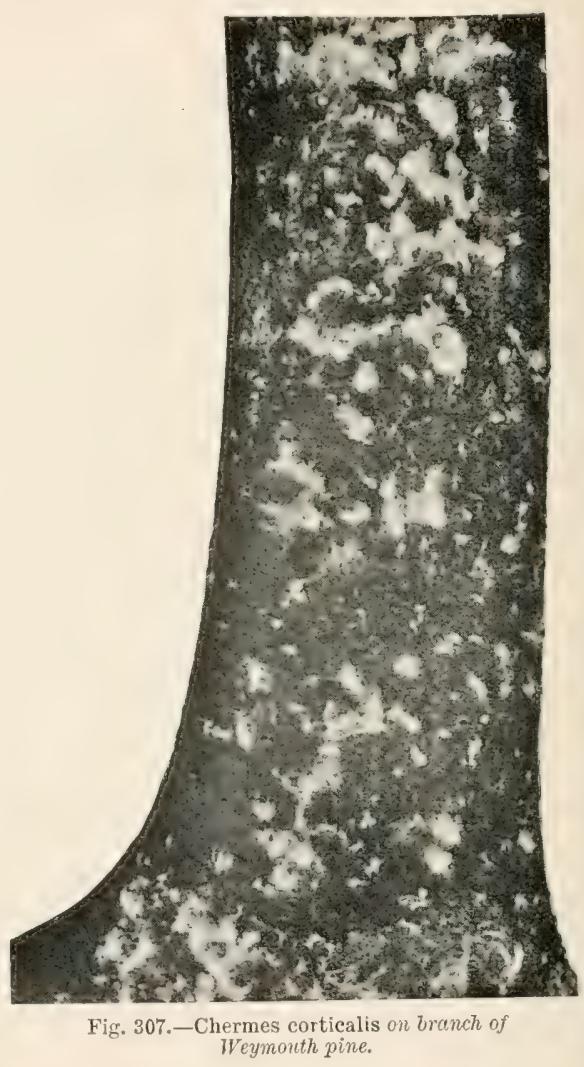

thirty years of age. Specimens of young silver fir trees in nurserylines are often killed outright by this insect.

It is to be hoped that the above account of the genus Chermes will show that they are of very great importance from an entomological point of view, and that much subsequent study is required in order 
to fully clear up the life-history of this hitherto partially studied genus. The aspiring student should therefore collect the various species of what hitherto has been termed stem-mothers on different trees, boil them in caustic potish, and stain with Crawshaw's nilgenta penny dye, as recommended for scale-inseets, and try to verify the various minute points of structural difference as shown in fig. 309 from Juleich and Nitsche, carefully noting and tabulating the results of his observations. Such a method would obviously be highly interesting and important, as in searching for the various anticipated alternating stages of the same insect on different trees, confirmation of the same creature changing from hostplant to host-plant would obviously be ratified.

\section{Importance of the Gexus Chermes - in Forestry.}

This genus is exclusively arboreal, and should be specially studied from a practical and scientific point of view. To the scientist the various species of insects change from one tree to another, and thus our so-called species are simply various stages of the same insect. But the practical man, often indifferent to specific distinctions, recognises the injurious effects on certain trees, and thus prefers to identify the species as coincident with the food-plant. Thus Chermes laricis

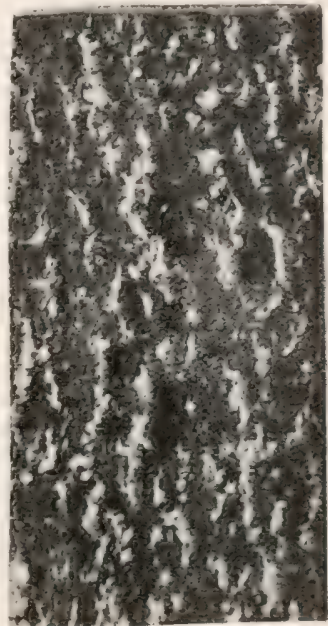

Fig. 308.-Chermes picex on berli of sileer fir. may often be found very injurious to young larches of from ten to fifteen years of age, more especially on those trees growing in hollows or in damp spots: Chermes abietis on spruce-trees which are not growing in suitable places, and often in young spruce-trees in the nursery-lines; and Chermes picece is often found on young silver firs in the nursery, and on young trees of $A$. Nordmanniana. C. strobilobius is perhaps more destructive to young trees in the wond, especially those too much overshaded and not thriving well. The dearl galls adhere very closely to the twigs, and can often be seen after the infested tree is partially dead. 
Now the question is, how are we to deal practically with those pests, having regard to recognised systems of "mixing" with those very trees which act as host-plants in the alternation of the species? Much has yet to be learnt from good sylvicultural conditions, careful work in planting with well-rooted plants, and also from experiment and observation. Take, for example, a suggestive case in point-viz., the growing of young silver firs. On many estates very fine examples of old silver fir trees can be found, and the modern forester with his high-class sylviculture cannot grow it. Without giving any definite opinion, much might be done in the younger stages by growing under shade of hardwoods in the nursery-say, plant a row of hardwoods,

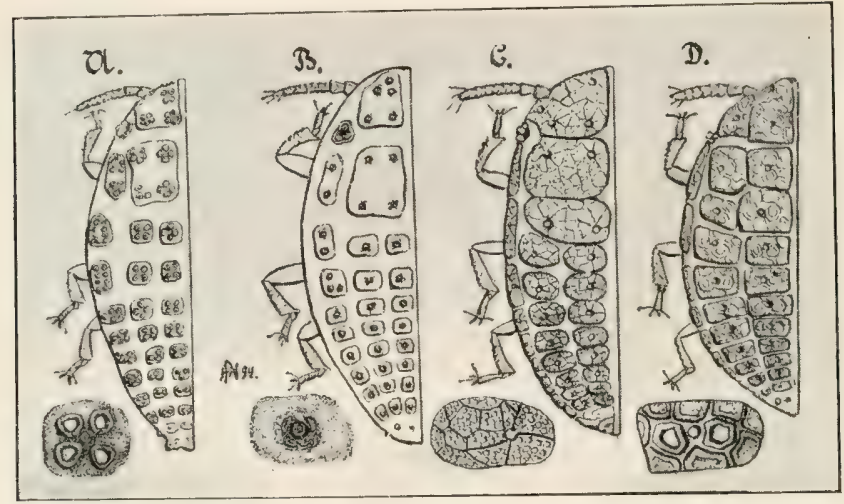

Fig. 309.-Hibernating winter forms of four species of Chermes.

A, C. abietis ; B, C. strobilobius; C, C. coccineus; D, C. siliricus; together with a highly magnified single chitin plate of each species. Copied from Judeich and Nitsche.

two or three rows of silver fir, and again a row of hardwoods, and so on throughout the nursery plot. Perhaps, also, an exception may be made to the general rule of much transplanting in the nursery. 'This tree should not be too often moved, but plants should be specially carefully taken up when they are lifted. Again, when transplanted in the forest, the silver firs should not be planted in the open, but as shade-bearers in late filling up, or otherwise solely as underplanting.

Then as regards the injurious effects of $C$. alietis as compared with C. strobilobius, it may be said, so far as real injuries are concerned, that the former is often injurious in the nursery-lines, more especially to those plants standing in the rows for three consecutive years, and 
the latter, as remarked, on young trees. As regards remedies for C. abietis in the nursery, this is a very good case in point where good husbandry is advantageous both to the seller and purchaser. I general saleable age of the spruce plints is five years-namely, two years in the seed-bed and three years in the rows, - 2 yrs. 3 yrs. of the nurseryman. When transplanting from the seed-bed they are, of course, placed very thickly in the rows, and if they do well, are useful stuff as 2 yrs. 2 yrs., but when unsold the nurseryman must either leave the crop as it is or otherwise compromise matters by interlining. "The latter method does not give relief between plants, and the consequence is that they are afterwards weakly--much to the advantage of the Chermes. Again, three years in the nursery-line is conducive to bal roots, which, coupled with the depreciation from the insect attack, means a very poor class of plant to the purchaser.

Hence, in order to maintain health and vigour, the practical remedy is, at the end of two years, transplant again for another two yearsprovided, of course, the seller could secure purchasers who recognise that quality and not cheapness is the essential of success. By doing so on suitable soil, we should get a better plant, and thus lessen the attack of the Chermes. This could always be done on private estates.

Another point in connection with the planting of spruce in the young woods associated with Chermes may be mentioned-viz., that in some parts of the count,!y the spruce should not he planted in the open amongst the more harly species, but used more as an after-plant for filling up. In the latter case it will thrive better, and though attacked by $C$. abietis, does not suffer to any appreciable extent, inasmuch as on vigorous plants the galls are often considerably on one side of the shoot, and thus the subsequent growth overcomes the attack.

Another point in connection with Chermes and practical forestry may be mentioned-viz., that it has been asserted by some observers that the mother Chermes on lareh inomulates ${ }^{1}$ the tree with the spores of Peziza, which is the fungus causing the well-known "larch disease." Hence it would obviously appear that a mixture of spruce and larch would favour the insect, and consequently be conducive to the spread

${ }^{1}$ It is just possible that the wounds caused by the insects form suitable sporebeds, just as apple canker will develop in the wounds of S. lanigera; and can only do so in wounds. 
of larch disease. So far as the mixing of spruce with larch is concerned, this theory does not square with actual results, inasmuch as many instances of the "mixture" referred to may be seen throughout the country, where, with spruce as an undergrowth, the larch is practically free from disease, and likewise a very good commercial crop. On the contrary, it is just possible that the under-crop of spruce in a lareh plantation, acting as a soil-protector, may have proved a great stimulus to the larch crop, forming greater increment. But while improved sylvicultural conditions may do much for the prevention of insect or fungoid diseases, it must not be inferred from the above remarks that spruce is the best mixture with larch, though it must be borne in mind that larch is not a suitable tree to grow as a pure crop. ${ }^{1}$

It might again be noted that this genus is, in general appearance, practically identical with several other insect damage. Thus, for example, Chermes corticalis may be common on Weymouth pine, and Ciryptococess fayi abundant on adjacent beech-trees; but the one is an Aphis and the other a Scale-two quite distinct insects. Now this is very important to the entomologist; but it is often of far more practical importance to the owner of trees, inasmuch as the imperfectly trained entomologist is apt to make wrong deductions and prescribe erroneous remedies. For example, I once knew of an expert entomologist advising a linded proprietor to cut down Weymouth pines as a remedy for the injuries of Cryptococcus fagi on beech, - a most absurd remedy, seeing that the two insects have no connection whatever.

\section{Genus Phylloxera.}

Hitherto only one species has been found in this country, and the generic characters may be characterised by moderately long rostrum in the winged form, their jointed antennæ, eyes small, legs very short, and tarsi apparently single-jointed, with a double claw and pad. In this respect they come very near in structure to the Coccidæ or "scale-insects." As regards the wings, they are decidedly of aphidian structure, inasmuch as we get a well-marked cubitus, whence spring their straight veins.

1 These remarks may be criticised by practical men, but in some cases the success of this "mixture," as showing the absence of "larch disease," can be seen in certain parts of the south of England. 


\section{Philloxera punctata (Licht.)}

The damage aceruing from this insect is often very conspicuous in a general way, and, except to the searching eye of the naturalist, the insect itself may be easily overlooked. During the latter half of the summer the oak leaves begin to take a very sere colour, and thus we often hear it remarked that the drought is playing havoc with the foliage, or that winter is setting in early. Now the cause of this is due to our aphis, Phylloxera punctata, - a creature closely allied to the dreaded pest of France, and found abundantly on the under side of the oak foliage (fig. 310).

The yellow spots are caused by the mother aphis and her egrgs or progeny, which surround her in concentric circles. The mother has a very long ovipositor, by means of which she arranges her eggs.

The queen-nothers may be looked for carly in June or latter end of May under a very small pucker, which might be mistaken for the beginning of some species of gall.

The female (fig. 311) in the centre of the yellow spot is a comparatively small creature, with flask-shaped body of an amber-yellow colour spotted with red. Head rather broad; eyes small; thorax hardly separable from abdomen, which terminates in an obtuse ovipositor; antennie three-jointed.

Prior to hatching from the eggs, the

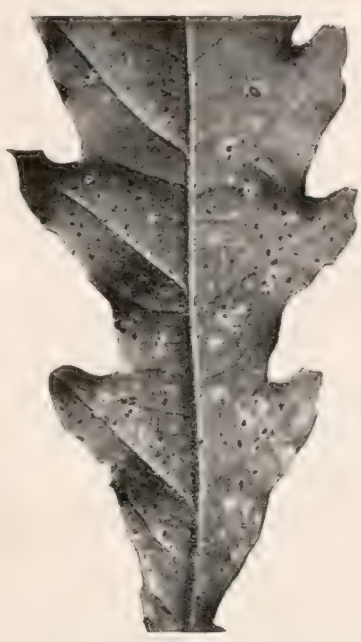

Fig. 310.-Under side of oak leaf in. fested with Phylloxerd punctata.

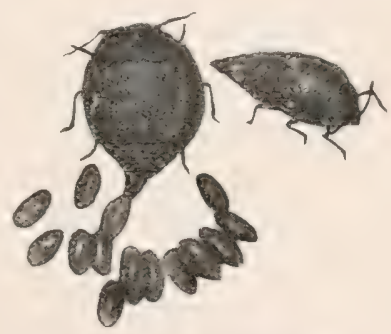

Fig. 311.-Apterous female, eggs, and laria of Phylloxera punctata. eyes of the larvæ are very conspicuous. When first hatched they
are of a yellow colour, with scarlet eyes and white antenuæ and legs. It is said they moult four times before assuming the "pupal" stage. They are of a long oval form, of a gamboge-yellow, becoming darker with age, and variegated on the abdomen. The legs are short. 
Fig. 312 is a representation of the winged form.

My observations of this insect were made in Cheshire, where it was quite harmful. I have never found it in north Northumberland,

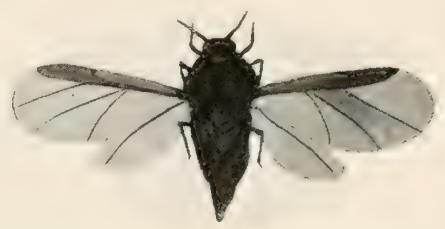

Fig. 312.-Winged form of Phylloxera punctata.

but it is often met with in the south of the county, just on the borders of Durham.

\section{References to Literature consulted.}

Buckton, G. B. Monograph of British Aphides. Ray Society. Judeich und Nitsche. Forstinsektenkunde. Nüsslin. Leitfaden der Forstinsektenkunde. 


\section{CHAPTER IX.}

\section{Diptera (Two-winged Flies).}

From an entomological point of view, the order Diptera is very important, inasmuch as it is, to a large extent, an unworked fielu, requiring a good deal of careful study, and having admittedly an unsettled question of classification. Tiewed by the economic entomologist, it traverses a very wide field. Thus we lave the troublesome flea, the annoying house-fly, and the irritating summer-evening midge. There are several species which feed on cirrion or decayed regetables, and destroy obnoxious matter, both in the animal and vegetable kingdoms, and a number of species which take an active part in disseminating some of the most direful diseases. From a husbandry point of view, the familiar names of warble-fly, onion-fly, carrot-fly, Hessian-fly, and many others, suggest the importance of the subject. In the forest they are, as a general rule, not so destructive as some of the insects previously dealt with, but their small size, minute characters, and interesting life-histories suggest them as interesting studies to the microscopist, the general biologist, and the practical man.

The structure of the Diptera can be best made out by taking a house-fly as a typical insect. The chief character is, of course, the "two-winged" structure. They are sharply marked off from all other orders of insects by the reduction of the hind-wings to mere knobs, "balancers," or halteres as they are termed. The whole mechanism of flight is entirely dependent on the two wings, but it is patent that the creatures bound through the air with greater ease, more graeefulness, and apparently, as it were, more command of will, than any other group of insects.

The head is usually very convex in form, large eyes, and with so slender and flexible a neck that the head all but turns round on a pivot. The order shows that there is great diversity and modifica- 
tion of mouth-parts. Thus the house-fly takes its food by a sucker arrangement; and the equivalent of mandibles and maxillæ, \&c., of other insects are modified into organs for piercing in the mosquito. The antennæ of the order vary much in length and structure.

The legs are usually very slender, and vary much in size. The legs of the house-fly and "daddy-long-legs" are cases in point. The feet end in two claws and a sort of pad. The wings are also variable, and the venation requires the greatest attention, so far as detailed studies are concerned.

The abdomen is generally made up of eight segments, indicated by numbering from the base- that is, the part attached to the thorax. The last or anal segment is of peculiar shape, and contains the generative appendages, and consequently the sexes are very easily determined in many tribes of the Diptera. These characters are, of course, variable, but in the male they may be either a sort of double forceps with central penis, or lamellæ and penis sheath. In the female the last segment is prolonged into an ovipositor or vaginal sheath, and has two basal lobes. ${ }^{1}$

With regard to classification, the order may be divided into two sections-(1) Orthorrhapha and (2) Cyclorrhapha.

(1) The larra in this section has a more or less perfectly developed chitinous head, and the pupa escapes by a $T$-shaped rent in the larval skin.

(2) In this section the larva has no chitinous first head, but is quite acephalous, and the pupa escapes from the larval skin by a circular opening.

The Orthorrhapha are divided into two sub-sections-viz., the Nematocerc and the Brachycerc, the former having threadlike and many-jointed antennæ, the latter having the antennæ composed of two or three segments with a lateral bristle or arista.

The principal families of Diptera which eause injuries in the forest are Cecidomyiidce, Phytomyzidce, and Agromyzidce.

The first-named is numerically considered the strongest, and the following characters of the family are given by Mr Theobald : ${ }^{2}$ -

1 The student who wishes to pursue the special structural details of Diptera would do well to consult a very detailed chart by the Rev. W. J. Wingate, in the 'Transactions of Nat. Hist. Soc. of Northumberland and Durham,' vol. ii., 1906.

2 An Account of British Flies, by Fred. V. Theobald, pp. 50, 51. 1892. 


\section{FAMILY CECIDOMYID里,}

"Ocelli often absent. Thorax with no transverse suture. Antennæ long, composed of many segments (10-36). Wings with only few nervures. Coxæ not elongated, femora not thiekened, no spurs on tilire. Delieate midges or gall-flies whose larve are provided with an anchor process beneath the head end.

\section{Genus Cecidomyia.}

"Antennæ long and moniliform or cylindrical; generally verticillate, 13-36 joints. Wings hairy, and have densely pubescent margins. Three or four longitudinal veins. There are two types of wings. In the first type the third vein is forked, thus representing the third and fourth veins, which have united for most of their length. In some rare cases this fork may become obliterated. In the second type of wing the four veins are separate and simple. We must note in these insects a curions longitudinal fold between the second and third longitudinal veins, present in most Cecidomyidæ."

The following are the more important as regards arboreal insects -viz. :

$$
\text { "Cecidomyia, Lw. }=\left\{\begin{array}{l}
\text { Dasyneura, Rid. } \\
\text { Rhabdophaga, Westw. }
\end{array}\right.
$$

"Same number of joints in the $\hat{\delta}$ antennæ as in the $q$. The joints may be pedicelled or sessile. The second longitudinal vein reaches the margin of the wing before its tip.

$$
\text { "Diplosis, Lw. }=\left\{\begin{array}{l}
\text { Phytophaga, Rd. } \\
\text { Bremia, Rd. }
\end{array}\right.
$$

"The antennæ of $\hat{\delta}=26$ to 27 joints; that of the $q=14$ to 15 . The joints are pedicelled. The second longitudinal vein reaches the margin beyond the tip. The joints of the antenne of the of double the number of those of $q$.

\section{"Hormomyia, Lw. = Angelinia, Rd.}

"This sub-genus is distinguished by the gibbose thorax, which is often drawn over the head. The second longitudinal rein ends as in the preceding sub-genus. Wings without lustre. 


$$
\text { "Asphondylia, Lw. }=\left\{\begin{array}{l}
\text { Crlindrocera, Lioy. } \\
\text { Phyllophaga, Rd. }
\end{array}\right.
$$

"Antennæ with short hairs of equal length; joints cylindrical and sessile; no verticils. Same number of joints in $\hat{\delta}$ and $q$. Second longitudinal vein reaches the margin of the wing, beyond its tip. Wings shiny."

As the insects in the family are so very small in size, it might be best for practical purposes to consider them according to the injuries they inflict on the respective arboreal food-plants-viz. :

(1) Foldings and rollings of leaves.

(2) Galls on leaves.

(3) Galls on stems or stalks.

(4) Various injuries or deformities of shoots, \&c.

It is, however, not practicable to attempt reconciling this arrangement with systematic classification.

Hitherto this family has not been very carefully studied in forest entomology, and the chief points for the discrimination of species are very minute, so that recourse must be had to the microscope. The main points are, the "breast-bone" in the larval stage —an "anchor process" found on the first thoracic segment; the venation of the wings; and the genitalia of the males.

By stupefying the insects with chloroform we can very easily examine with the inch objective. It is necessary to do this, however, in order to carefully note all the characters, more especially as they change colour rapidly after deatli, and they are most fragile to mount as microscopic slides.

\section{Cecidonita (Dasyneura ${ }^{1}$ ) marginemtorquexs, Wim.}

This insect is found on the common osier (Salix viminalis), and forms galls on the edges of the leaves, - often on both sides of the leaves, - and rolled from the base to nearly the apex (fig. 313). These galls or foldings are on the under side of the leaves, and rolled towards the milrib. The rolled portion of the leaf is generally smooth, and of varying shades of colour, from pale-green to purple and chocolatebrown. The galls appear early, and may be found from June to

1 The generic names given in parentheses are those usually adopted at the present time. I am indebted to Mr Theobald for this improved arrangement. 
October. It is quite possible there are several broods, as I have hatched them out in confinement in Northumberland from the bexinning of July to the end of October; and as the larve pupate within the galls, artificial hatching is very simple, provided we see that they are in the pupal stage prior to being placed in a glass-covered box. lyy stupefying the insects with chloroform we can very easily examine them with the inch objective.

Male.-The body and antenne are darkish-brown colour; antennæ 15- to 16 -jointed, as long as the body. The thorax slightly reddish; abdomen yellowish-brown; wings covered by darkish hairs. The
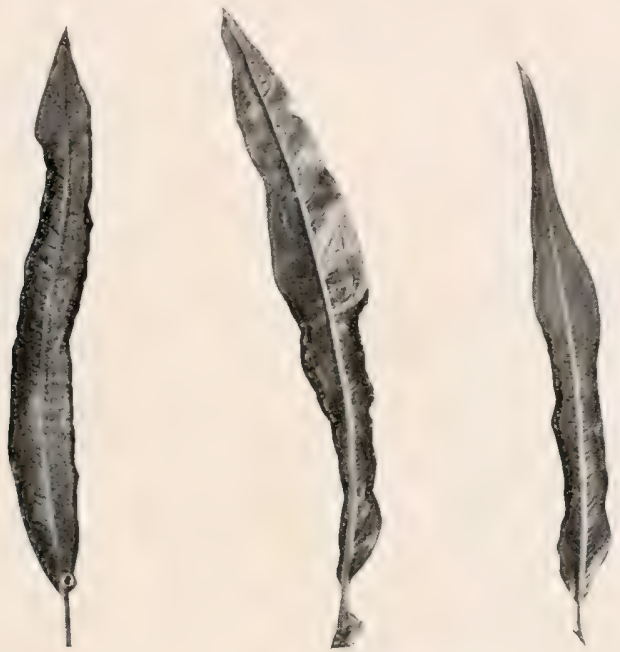

Fig. 313.-Leaves of Salix viminalis rolled by Cecidomyia marginemtorquens.

legs are of a lightish colour, and slightly tinged with red at the joints. Length 1 to $1 \frac{1}{2} \mathrm{~mm}$. (Fig. 314.)

Female.-The body is of a dark-grey colour, with rather comparatively longish halteres. Face light-grey; the wings are clear, but hairy, more especially at the edges. Eyes large, deep velvetyblack. The head and thorax black, with stiffish erect bristles; abdomen dark-grey above, light-grey beneath. The antennx lightgrey, with a darkish tinge throughout. The legs are light in colour; oviduct long and slender. Length 1-2 mm. (Fig. 315.)

The conspicuous difference between the antennæ of the nale and 
female, together with the small size and fascination of getting good mounts, make this an interesting microscopical object.

\section{Cecidomya (Dasyneura) crategi, Winn.}

This species is found on the common thorn, but more especially on clipped hedges. The gall (fig. 316) is often a common and familiar roadside object. It is formed of a tuft or rosette of leaves on the tips of the young shoots, and generally on shoots at the top of the hedge, which grow after the previous year's cutting. There is generally only one gall on the top of each shoot, but they are often found

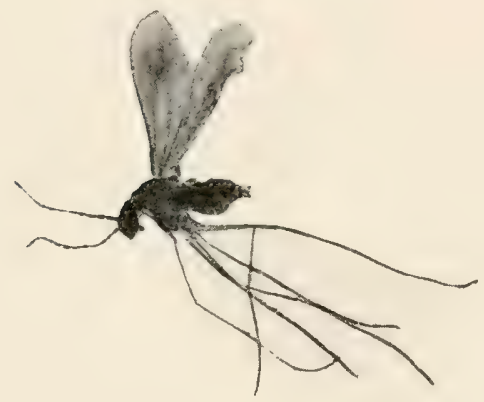

Fig. 314.-Cecidomyia marginemtorquens (male).

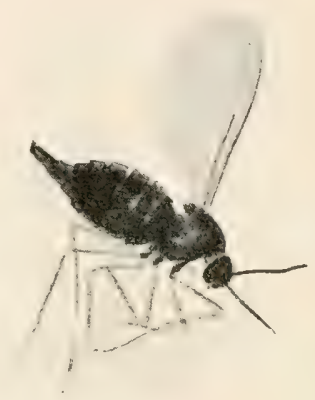

Fig. 315,-Cecidomyia marginemtorquens (female).

so numerous that scarcely a twig is left untouched. The larvæ live gregariously within the cluster of the deformed sessile leaves. Each leaflet is thickly studded with short, stiff, blunt, erect hairs, which provide protection for the larvie.

"Imago black, with yellowish palps. Antennæ 16-jointed in of, 15-jointed in + . Oviduct long, and yellow at the tip. Sides of thorax and metathorax flesh-coloured. Abdomen flesh-coloured, with black bands. Halteres white. Wings hyaline; black pubescence and costa. Second long. vein bends forward at its junction with the transverse veinlet, then, passing in an almost straight line, joins the costal a little distance from tip of wing. Length, $\frac{3}{4}$ lin." 1

${ }^{1}$ An Account of British Flies, by Fred. V. Theobald, p. 67. 
Cecidomyia (Dasyneura) taxi, Inch.

This species is found on both the English and Irish varieties of yew. It forms a cone-shaped gall of tufted leaves (fig. 317). There is only one larva in each rosette, and it lives and pupates within the gall. The imago emerges either in the last week of May or first week in June. This species is difficult to rear artificially, therefore it is important to place them in confinement about May 20 or so; and as the galls shrivel up very quickly, it is advisable to gather fresh specimens every two or three days about the date mentimed. So far as this species is concerned, dates are important,

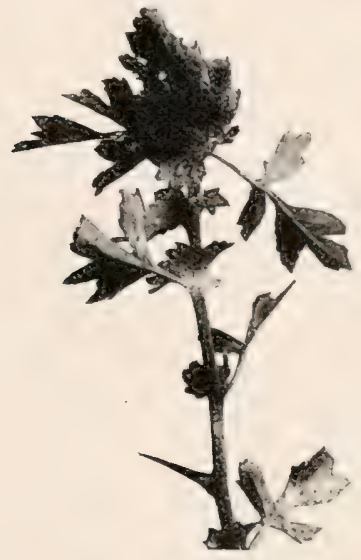

Fig. 316.-Shoot of hawthorn hedge injured by Cecidomyia cratæegi.

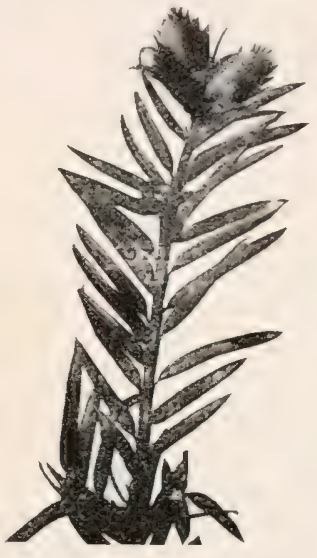

Fig. 317.-Twig of yew injured by Cecidomyia taxi.

having regard to the difficulty of rearing. I have gathered them for artificial hatching about the middle of Nay, and they have all shrivelled up so much that they never hatched; and again I have gone to the trees about June 10, and the "bird had fled," leaving the empty pupa-case on the extreme tip of the rosette.

IMale-Antennæ 15-jointed; joints verticillate pilose; basal joints rell, others light-grey. Eyes large, black; thorax orange beneath, dorsum black. Halteres bright orange; abdomen light-grey, with dorsal orange streak; genital armature light-brown; wings light-grey, slightly hyaline, legs of a uniform light-grey, anterior pair slightly orange-coloured.

Female-Antennæ light uniform grey, very pilose, 18 -jointed. 
Thorax light yellowish-orange beneath, above pilose dark. Wings as in male; abdomen orange, with paler oviduct, and covered with

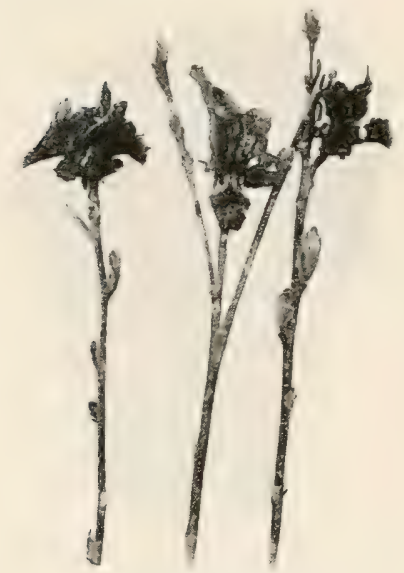

Fig. 318.-Shoots of Salix caprea injured by Cecidomyia rosaria.

black hairs; legs uniformly darkbrown, with greyish pubescence.

Cecidomyia (Rhabdophaga) rosaria, Lw. (Willow Rose-gall Midge).

The galls caused by this insect (fig. 318) are fairly common in Northumberland, more especially in the hilly districts, where there is an abundance of scrub of the goat willow (Salix caprea). The galls may be found throughout the winter months after every leaf has disappeared, and as many of the larvæ pupate within the gall, it is well to collect them when dry for artificial breeding. The insects appear about the middle of May, and deposit their eggs in the terminal shoots. The gall very soon forms, as I have found it by the first week in June. The gall itself is simply a rough rosette of leaves formed in consequence of growth being arrested.

Adult insect, female.-Expanse of wings about $6-8 \mathrm{~mm}$. Anten-

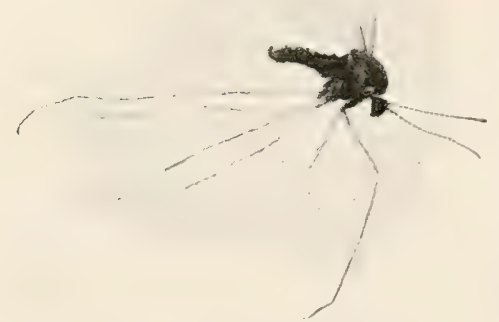

Fig. 319.-Cecidomyia rosaria (male). næ lightish, inclining to grey on upper side. Thorax greyish, very hairy. Abdomen flesh-coloured, telescopic portion of segments very elastic, other portions dark and hairy, under side uniformly flesh-coloured, with greyish silken hairs. Eyes black, wings greyish, veins dark-grey. Halteres light. Legs greyish, with red foot.

Wale--Antennæ greyish-black, and joints very hairy. Eyes black. Base of wing flesh-coloured. Thorax darkish grey, hairy. Abdomen uniformly grey, and hairy. Legs same as in + . (Fig. 319.) 
Cecinomia (Rhaiborhaga) salictperda, I) uf. (Willow-wood Midge).

This species injures the stems, from two years old and upwards, of several speeies of willow, and can therefore be realily distinguisher from $C$. salicis, which confines its attacks to young twigs. In figs. 320 and 321 we have a representation of the damage done to a species from Kew Gardens. Fig. 320 represents a cross section of the stem, showing the depth of the injuries; and fig. 321 repre-

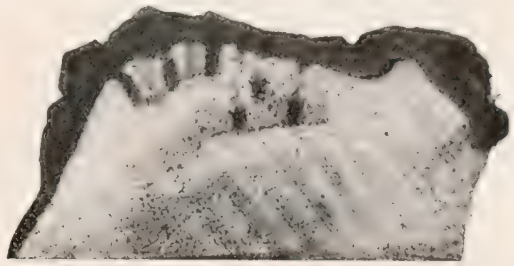

Fig. 320.-Section of willow stem showing injuries caused by Cecidomyia saliciperda.

sents the damage as revealed by a very thin shaving or "slab" taken off.

As I received the specimens after the insects had hatched, I give the following account from Dr R. Stewart MacDousall : 1

"This is a tiny fly, 2 to $3 \mathrm{~mm}$. long (the female is a little larger than the male), with head and thorax black or blackbrown, and with black hairing. The wings are milky white, with whitish hairs.

"The eggs, rounded and orangeyellow, measure $0.40 \mathrm{~mm}$. in length.

"The larva is rounded at both ends, or somewhat spindle-shaped. It has a well-marked anchor process, and on magnification little projections can be seen on the edge of the body, and warts on the top of the body.

"The pupa is bright yellow, the linit of the wings reaching to ring 4 and the feet to ring 8. At the base of the antennx two brown horns can be seen.

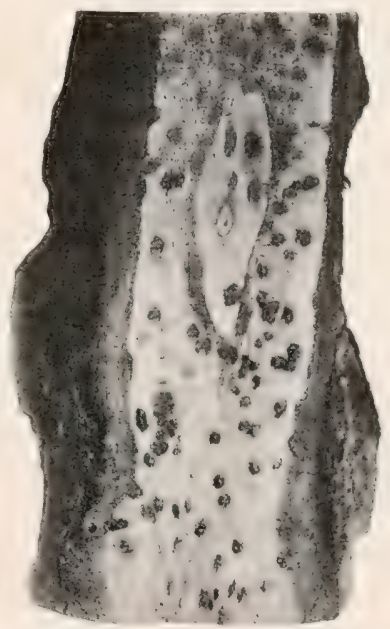

Figr. 321,-Portion of bark and mand cut off to slemen the injuries of Cerei. domyia saliciperda.

"The females lay their eggs on Salix alba, S. fragilis, S. caprea, S. purpurea, S. viminalis, and exceptionally on white poplar.

\footnotetext{
1 Journal of the Association of Economic Biologists.
} 
"The parts chosen for egg-laying are most commonly about two years of age and more, with twigs up to three inches in diameter.

\section{"Life-7istory.}

"The female does not bore (her ovipositor is too weak), but lays her eggs in chains or rows on the bark. 'The larvæ bore into the bark, but by the time they enter below it the cambium has already made the first layers of wood. Owing to the irritating presence of the larve, the cambium gives rise to irregular streak-like growths, through which the pests make longish excavations; the galleries are irregular. Between the larval galleries the wood is normal in condition. It is possible that the larvæ may not really need to bore in, as the activity of the cambium, with its wood formation, may be sufficient to enclose them.

"For a time the bark stretches, accommodating itself to the increased thickening, so that only spindle-shaped swellings show; but ultimately it ruptures and hangs down in shreds. For pupation the full-fed larva betakes itself to the periphery, pupation taking place under only a thin external layer, which is easily broken through by the two horns of the pupa. The empty pupa skin, with its 'forehead horns,' may be seen jutting from the round hole until the weather removes it. The bark from which flies have issued may be seen riddled with small holes.

"There is one generation in the year, the larvæ tunnelling from June or July till the next April, May, or June.

\section{"Measures of Preservation and Remedy.}

"1. Cut off and bum infested shoots before issue of the brood. A very observant forester will recognise the swelling before rupture of the bark, and should remove it. Another sign of larval presence is the poor leafage. The cut-away parts must not be left lying, else development and issue may be completed.

" 2 . Streak over with tar the places attacked, as though the pupa may push its way through, and the fly will be caught in the sticky material."

Cecidonyia (Rhabdophaga) heterobia, Lw.

This species, which gives rise to the malformations as seen in fig. 322 , is, I have found, often very closely associated with C. marginem- 
torquens. Both species were found in the nursery. C. marginemtorquens: was in great evidence on the leaves of Salir rimimalis, but no terminal buds were infested. (On the other haml, the tominal buds as represented in the figure were infested on the species of willow known locally as the Wentworth seedling golden willow, and some of the leaves were rolled as in Salix viminatis (fig. 322), but not to any appreciable extent.

The male is about 5 to $6 \mathrm{~mm}$. in expanse of wings. Colour blackish on back, and grey on belly side. Eyes black. Antennie

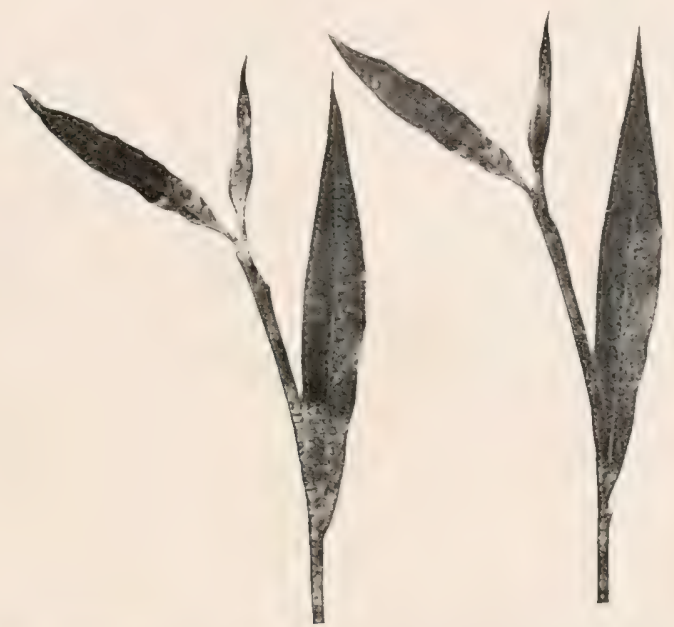

Fig. 322. -Leading shoots of a species of willow injured by Cecidomyia heterobia.

darkish-brown. Palpi lightish-grey. Thorax clothed with greyish hairs. At base of wings a yellowish-orange. Wings hyaline, and clothed with greyish hairs. Veins dark-grey. Legs lightish-grey. Abdomen uniform dark-grey. Gentalia dark-brown.

\section{Cecidoniyia (Rhabdophaga) salicis, Schrk.}

(Willow-twig Midge).

The gall which is formed by this insect is found on various species of willow throughout the latter part of the summer and winter. The gall is formed by the gregarious larve feeding upon 
the pith, and thus causing the woody cells which surround it to swell out, as in fig. 323 . The galls are always found on the twigs

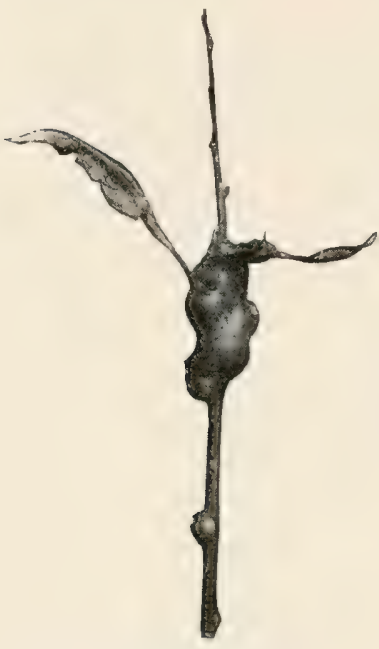

Fig. 323,-Twig of Salix caprea $i n$ jured by Cecidomyia salicis. of the tree or bush, and between the internodes.

The perfect insects hatch out about the middle of May (May 10, 1905, in Northumberland), and deposit their eggs in the twigs of last year's shoots. The larvæ soon hatch out, and by their united action, which creates a form of symbiosis, stimulate excessive growth at the affected part. The larvæ feed right on throughout the winter, and pupate within the gall about April. The exit of the flies may be recognised either by the flightholes or by the empty pupal-cases projecting from the gall.

The fly is about $6 \mathrm{~mm}$. in expanse of wings. Eyes black. Antennie dark. Wings hyaline, and at the base they are of a light vermilion colour. Halteres white on the knob portion, and same colour as wings at base. Thorax darkish, with two yellow-grey longish strips. Abdomen variable in colour, sometimes dark

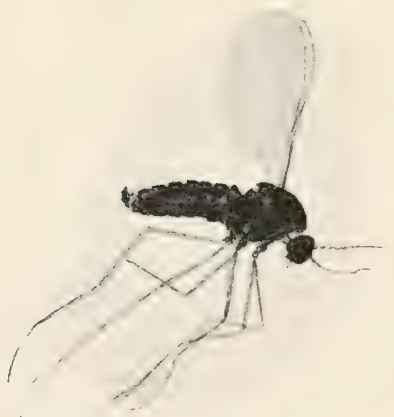

Fig. 324.-Cecidomyia salicis (male). above and red below, but as a rule darkish-grey above, and light with a covering of silvery-grey hairs below. Fig. 324 is a representation of the male.

The larvæ and pupæ are of a light-yellow or orange colour, and, as a rule, from 12 to 30 are found in a single chamber.

Cecidomyia (Dasyneura) tiliam volENs, Rubs. (= C. SAlicis, Schrk.)

This species forms galls on the terminal shoots of lime-tree branches and the base of the leaf-stalk, about the size of a pea. The leaves are deformed and disfigured, and growing with the point of the shoot 
spoiled, but are found principally on shoots growing as suckers from old stem. (See figs. 325 and 326.)

Larva yellow-orange colour, $2 \mathrm{~mm}$. long. Head long, thin, and pointed, footless. Has habit of anchoring anal end, raising head, and making a motion or two in the air, then placing head to tail end, thus making body a sort of loop, and then giving a high and clear leap off the table to a distance of two or three inches. Mr Theobald says:

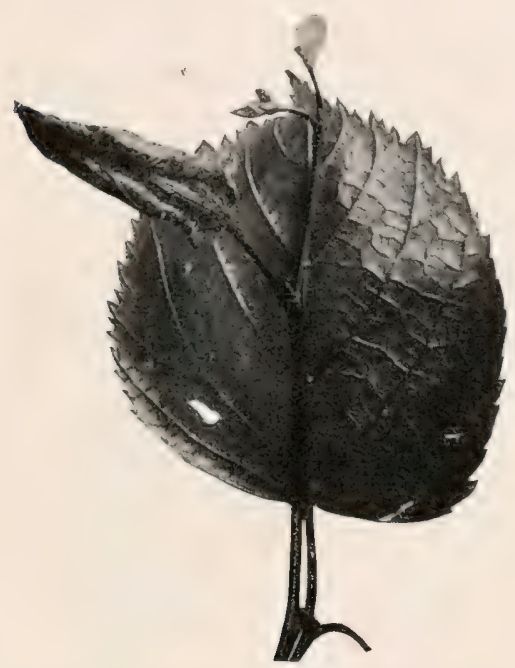

Fig. 325. - Leaf of lime-tree injured by Cecidomyia tiliam volens. A normal leaf is placed behind the injured leaf for identification.

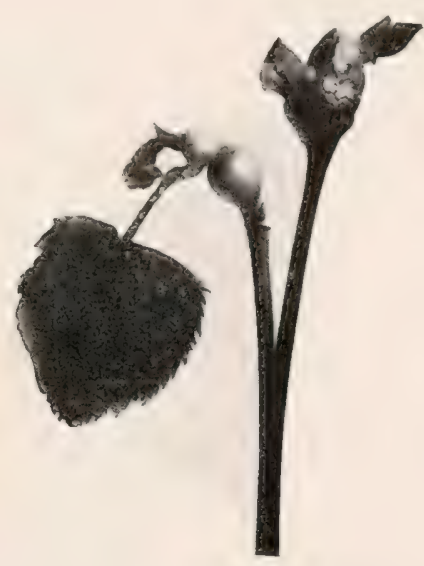

Fig. 326.-Shoots of lime-tree injured by Cecidomyia tiliam rolens.

"I have found this very harmful on clipped and trimmed limes used as 'blinds' in suburban gardens."

\section{Diplosis (Clinodiplosis) botularie, Wtz.}

This species is shown by the photograph (fig. 327). The larvæ live in a sort of pea-pod-shaped recess formed by rolling the leaf inwards, and stimulating the growth of the leaf in thickness. The larvæ secrete a liquid and, as it were, half swim in it. They are white with a central streak of green in the body. It is said they fall to the earth, pupate, and appear as flies in the following May. I found them very common at Bellingham, in Northumberland, about 
the midule of June every consecutive year, but have not succeeded in hatching the insect.

Miiller, in 'Gardener's Chronicle,' 1870, gives the following description of this insect: "It. is reddish-yellow, with a white beak. Its thorax shows three narrow, short, pale-brown streaks; the poisers are pedunculated and whitish; in the segments the abdomen is brown, each segment with a fine brownish lateral streak ; the head border of the segments beneath is fringed with long whitish hairs. The six legs are long and slender, brownish, and clothed with a white pubescence. The wings are comparatively large, and sparse greyish hairs, and suffused with a weak iridescent violet; their veins are brownish.

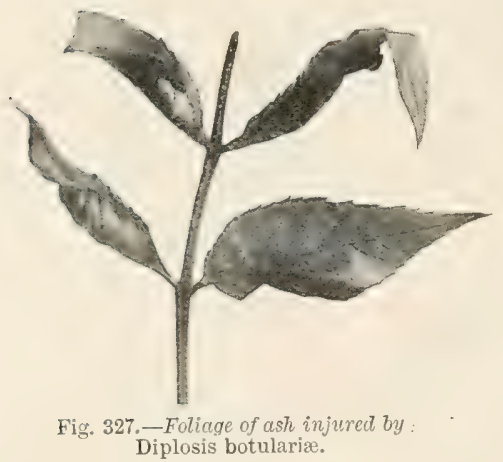

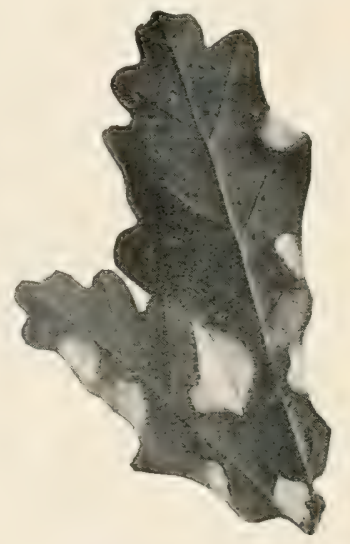

Fig. 328.-Edges of ouk leaves folded by Diplosis dryobia.

The feelers are brownish, 26-jointed in $\hat{\delta}$ and $14 \mathrm{in} q$. The latter furnished with a short ovipositor."

\section{Diplosis (Macrodiplosis) dryobia, Lw.}

This species causes the leaves of oak to fold over, as depicted in the illnstration (fig. 328). The folded portion is of a light-yellow colour, and the larve live within the folded portion. They pupate in the ground.

I found this species very common in Cheshire in the hedges. It often happened in that part of the country that young oaks grew up in the thorn hedges, and were of course switched with the thorns, and this species was generally found on the foliage of those hedge oaks. 


\section{Diplosis (Harmandia) tremule, Wtz.}

Theobald says: "The larvie of the 'aspen gnat' seem to form two kinds of galls : the first are formed on the leaves of Populus tremulitthese are red galls, the size of a pea; the second kind is the wellknown gall formed on the leaf-stalk: each gall is inhahited by a single larva, which pupates in the ground (Winnertz)." I

I found what I now suspect to have been the first form, in June 1897 , in High Legh, Cheshire, but the latter I have never found, and am indehted to Mr E. T. Connold for the form as shown in fig. 329.

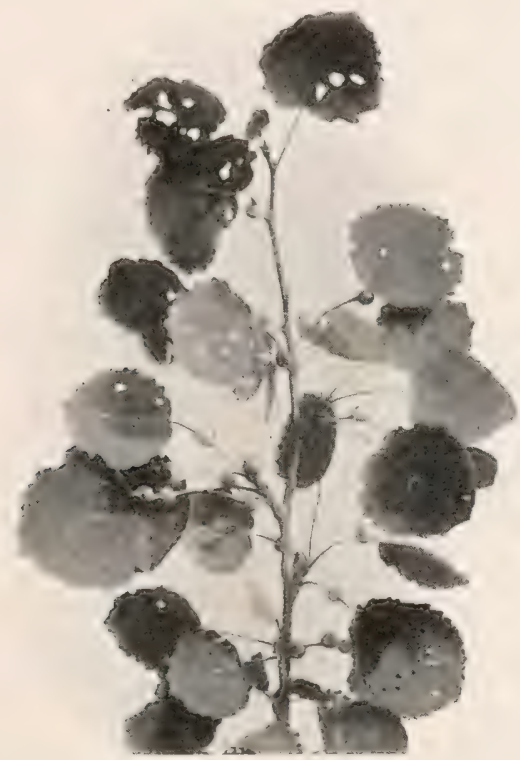

Fig. 329.-Galls on leaf-stallis of aspen poplar caused by Diplosis tremula. (From plioto by E. T. Connold.)

Theobald thus describes the fly: "Imago-dorsum blackish-brown, with two rows of whitish-yellow hairs; abdomen dark-brown, with thin flesh-coloured incisions and white hair. Posterior half of serenth ring and the rest of the abdomen flesh-coloured; $\hat{3}$ genitalia hlack; f yellow. Wings large, grey, with thick blackish-grey hairs, third longitudinal vein hending in an almost straight angle to the posterior edge; 1 to $1 \frac{1}{2}$ lin."

1 An Account of British Flies, by Fred. V. Theobald, p. 75. 


\section{Hormomyta (Oligotrophus) piliger, Lw.}

The larva of this insect cause galls on the leaves of the beech (Fagus sifleatica). The galls (fic. 330) are pilose, more or less gregarious on the upper surface of the leaf, but as a rule generally arranged near the midrib. The colour is somewhat variable-at first yellowish, then gradually deepening to various shades of red or brown. They may be found from the beginuing of July right on to the end of the summer. The larvæ pupate within the gall.

\section{Hormonyia (Oligotrophus) caprex, Wtz.}

This is a pustule-forming gall, as it were, inasmuch as it may be compared to an eruption arising from a sting on the midrib of the

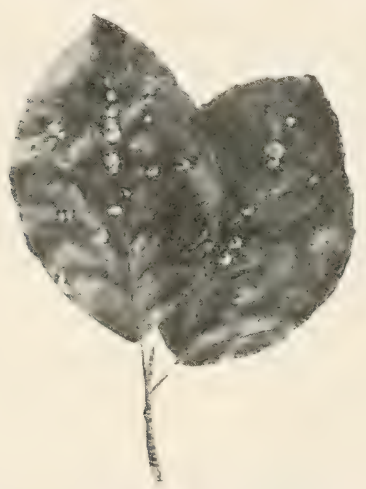

Fig. 330.-Galls on upper surface of beech leaves caused by Hormomyia piliger.

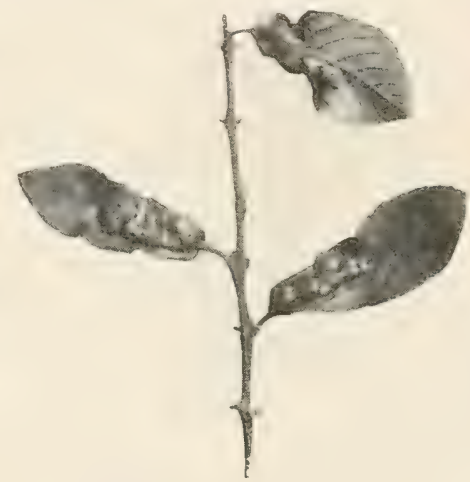

Fig. 331.-Leares of goat willow gailed by Homomyia caprex.

leaves of Salix caprea (fig. 331). The midrib itself is more or less conspicuous, while the gall is sinnly the adjoining portion of the leaf, transformed into a hard woody structure. The colour varies from pale-green to pale-yellow. It may be found from June to October. The larvæ pupate in the sround, and the flies emerge during the spring.

\section{Hormomya (Mikiola) fagi, Hartig.}

The gall is formed on the upper surface of the leaf, and is a glabrous cone-shaped structure about $4 \mathrm{~mm}$. high. The colour varies from green to yellow, and reddish. It may be found from 
July to September. When fully ripe it falls to the ground, where the larve pupate, and the flies emerge the following spring. I have found it in Alnwick parks, but it is not so conspicuous on the leaves as C. pitiger:

\section{Asphondia sarothami, Lw.}

This insect is important from a collector's point of view, but may easily be overlooked, as the galls formed by the larvæ very much resemble the unopened flower-buds (fig. 332). They are larger in size, and comparatively hard in the outer structure, being lined with a greyish pubescence, and containing a single larva. The metamorphosis takes place within the gall.

The flies (fig. 333) hatch out from the beginning to the end of June, and in order to follow out the development they may be looked for about the first of May, as they are then in the larval stage. The pupal stage is comparatively short.

As compared with the Cecidomyia, the flies are very much larger, and the venation of the wings more distinct. Body dark-grey, head dark, and wings brown and hairy. Antennæ of female 13- or 14 -jointed, the three joints at the tip being very small in size.

Fig. 334 is a photograph of the pupal form.

\section{Lasioptera rubi, Heeg.}

The larvæ of this insect cause gralls on the stems of the common bramble (Rubus finticosus)

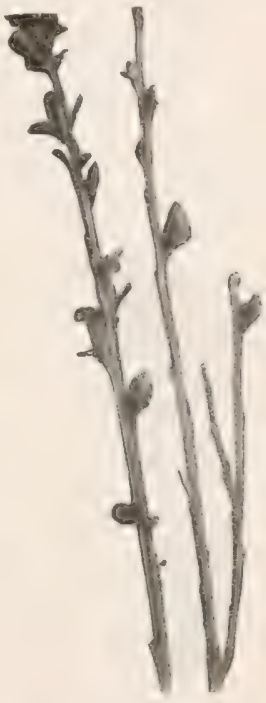

Fig. 332.-Galls on broom cersed by Asphondylia sarothamni. (fig. 335), and it is of course more interesting as an entomological specimen than a forest insect. I have only twice found it-once in Cheshire, and very plentifully near Ville la Villiers, Belgium. It is, however, said to be very common in some parts of the south of England. It is harmful to raspberries, forming galls on the canes as on the bramble. The size of the galls is very variable, inasmuch as the gall may be simply a slight excrescence.

With regard to the description of the species, Theobald says: "In their habits they resemble the Currommitr., infesting plants much in 
the same way. The larvæ are much the same as in the Cecids, having the same peculiar reddish hue and curious 'breast-bone."

The larvæ live in excrescences on the stems of various Rubi, and metamorphose in the galls. They appear in May.

Imago.-Brownish-black; antennæ of of black, shorter than the

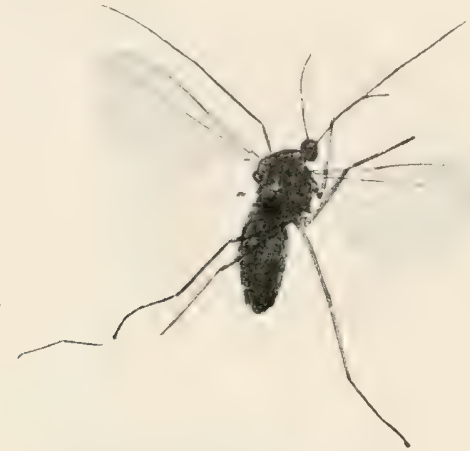

Fig. 333.-Asphondylia sarothamni.

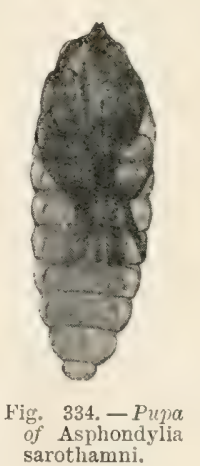

head, 22 -jointed. Palpi white; head white and brown. Thorax deep black with a silvery white band around the edge in front, with two pinkish or golden stripes partly along the top; seen in certain

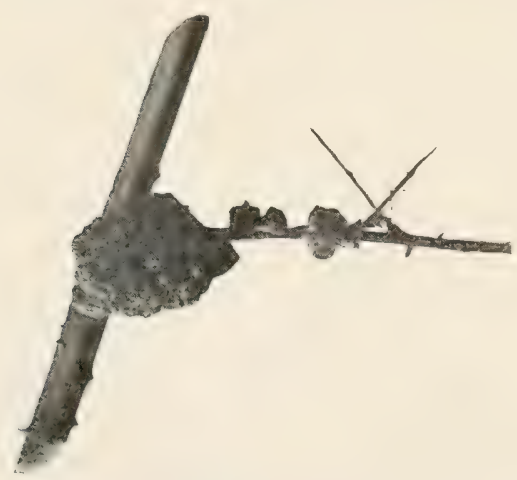

Fig. 335.-Gell or stem of bramble caused by Lasioptera rubi. lights, in others the centre of the thorax is black; scutellum tawny. Abdomen black, with four silvery bands slightly broken in the middle. $\mathrm{Ab}$ domen and of genitalia covered by white hairs. Legs also covered by silvery hairs and scales. Wings clear; costa thick and dark, in the middle a white spot; root of costa also pale. of resembles of, only the antennæ are 24-jointed. Ovipositor yellowish-white; long; no lamellæ. There are beautiful scales on the venter of the abdomen as well as the legs. After death the colours turn browner, and the white hairs less silvery. 


\section{Cecidonyia (?) PICEe, Henschel.}

In the spring of $1906 \mathrm{I}$ began to dissect a number of cones of the common spruce, with a view to looking for the larva of Meastinnus. In one batch the cones showed a number of light orange-colonied larrax. These were put aside in gliss jars, and from May 13 to May 20 the jars simply swarmed with specimens of Cecidomyia. Tieference to avilahle English literature has failed in siving any account of this species, hut the more important. German text-books give twi species-viz., C. picere as living in the seeds of the common spruce, and C. abietiperda, Hensch., as living in the shoots of spruce. The species in question would appear to coincide with the former. A careful dissection, however, showed that not only many of the seeds were eaten by the larvæ, but also a very large proportion of them had hollowed out the thicker portion of the bracts.

\section{FAMILY AGROMYZID压.}

The larvæ of this family are said to mine leaves and do other damage, but I have not hatched out any of those insects.

As regards family characters, Theobald states: "No

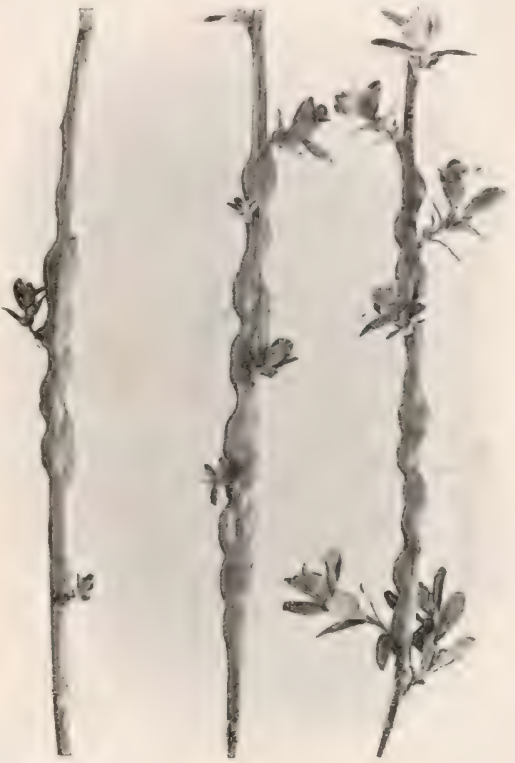

Fig. 336.-Galls on stem of species of willow caused by Agromyza schineri. (From photo by E. T. Connold.)

costal bristles. First longitudinal vein short, the auxiliary connected with it at tip; posterior transverse vein far distant from the borler. Front with strong bristles. Border of mouth with vibrissa on each side. Third joint of antenne rounded, terminal bristle bare or pubescent."

Agromyza schiveri, Gir.

This species is found on willows, and I am indebted to $\mathrm{Mr} \mathrm{E}$. T. Comold, st Leonards-on-Sea, for the photograph as shown in fig. 336. 
The gall is formed, through the agency of the cambium, on the side of the twig. Growth is complete in September; the larva pupates in the ground, and the fly emerges in spring.

\section{FAMILY PHYTOMYZIDÆ.}

In this family the larvæ are leaf-miners, and, so far as the species to be considered are concerned, they pupate within the leaf. The puparia are barrel-shapel. According to Rev. W. J. Wingate, there are several genera and species in the north of England, but as regards identification of species and association with damage I have only hatehed two species.

As the species on snowberry leaves makes markings very much after the manner of the larve of several micro-lepiloptera, it would be well for the student not to be over-sanguine in naming insects from markings without verification by hatching. It would be well to bear in mind, also, that in those species where pupation takes place within the epidermal skins of the leaf, specimens should not be placed within the hatching-box until the creature has reached the pupal stage.

Chromatomyia obscurella, Fln.

Phytomyza xylostei, Kalt.

The leaves of snowberry (Symphoricarpus racemosus) are often thickly covered over with white trailing galleries, as in fig. 337. In fact, in several parts of Northumberland in some patches this species is so common that it was almost impossible to get a leaf without markings.

The insect causing this damage has a double generation in a year. The first generation appears in spring, probably in May, and the larval markings appear in June. At first the larva moves very irregularly around a common centre, but afterwards it "mines" more rapidly, making long winding galleries. The larvæ pupate within the leaf, and the flies appear in the last week in July. The flies of this brood immediately deposit eggs on the leaves which have developed during the summer, and the larve make similar markings to those of the first generation, and pupate within the leaves, which of course fall to the ground in autumn.

The flies, which are like small house-flies, are matt black. Eyes dark red, wings hyaline. 
Chrovatomya ilicis, Curtis.

Phytomyac ilicis, Kalt.

(Holly Leaf-miner.)

In many parts of the country this pest, known by the name of the Ifolly Leaf-miner, is very alumdant. In fact, it is ruite the exeepinn to find specimens of the common holly, Hodgkin, and a few other varieties, to be quite freo from it. (Fig. 338.)

The flies are very easily hatehed out by artificial means, if the infested leares on shoots from the previous year are gatheret, after the larva has changed to the pupal stage, by the latter end of April or

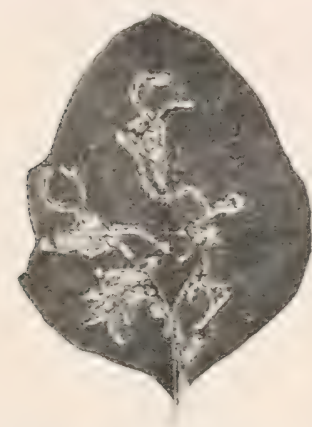

Fig. 337.-Leaf of snouberry minced by Chromatomyia obscurella.

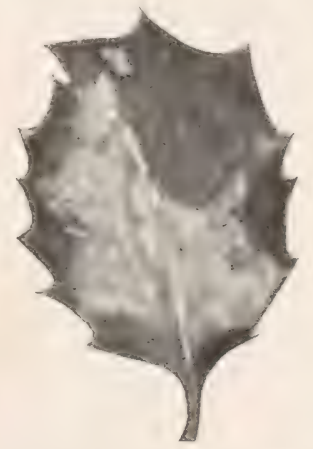

Fig. 33s.-Leaf of holly blotelied by Chromatomyia ilicis.

beginning of May. In Northumberland the flies hateh out in the first week of June.

In general appearance the fly resembles a small specimen of the common hothe-tly. Expanse of wings, $3 \stackrel{1}{y}$ to 4 mm. Eyes of a shining chocolate colour. Body, as a rule, entirely black and hairy. Wings hyaline; veins black; halteres waxy white. Under side of abdomen sometimes sliglitly yellow, and on upper sile of abdomen there are frequently narrow whitish bands across the segments.

The full-grown larva is about $3 \mathrm{~mm}$. long, white and footless, and the juparium is rather shorter, barrel-shaped, and of a leathery colour and texture.

As regards the life-histury of this species, I have several times tried to work it out, and so far as my observations go, they coincide with the following description from Mr Collinge, the University College, Birmingham :- 
"Early in June the female fly deposits her eggs on the under side of the leaves; so far as my observations go, only a single egg is placed on each leaf, and on the midrib close to the leaf-stålk. In seven or eight days the larra hatches out, and makes its way into the ressels of the midrib, and then commences to slowly travel forwards. In September, October, or November it leaves the vessels, and tunnels its way into the soft green tissue of the leaf, forming galleries which give the leaf a blistered appearance.

"By the following April the larva is mature, and it now bites through the epidermis in order to provide an exit for the fly. Like many other flies, it retains its last larval skin as a protection for the thin, white, pupal case. The puparium is of a flattened oval form, and marked by a number of regular transverse segments - the original segments of the larval skin. Within this is a second skin, which is the true pupa."

As regards any remedial measures against this pest, it is certainly very difficult to suggest anything which would be at all practical. $\mathrm{Mr}$ Collinge advocates spraying the foliage with paraffin near the time of the flies hatching out, so that the bushes may be made offensive to the females about to deposit their eggs. Spraying with diluted paraffin as a check against egg-laying is often productive of good results in some garden and farm crops, but it is obviously more difficult to carry out in practice in the forest.

As the damage is always on the leading shoots, all prunings done in autumn or winter to hedges or bushes should be burned. It may, however, be remarked that only judicious pruning of trees or bushes is intended, as the clipping of hollies into certain stiff forms is quite an objectionable feature. Healthy hollies sher their leaves in spring, and those may be burned; but this would not in any way check the pest, inasmuch as the blistered leaves on the ground have discharged their parasitic pests a year or two prior to falling off.

\section{FAMILY BIBIONID压.}

The members of this family, many of which are of a good size, are mostly black, or black and yellow. No one can fail to find several species along the banks of our streams or in damp woods from May till September. Larræ phytophagous, on living plants, rotting vegetable matter, dung, \&c. 
Bibio marci, L. (St Mark's Fly).

This insect is known as a dung-fly, and has never been considered as a forest insect. Its connection with forestry was introiluerd to me through Mr Thring, Boughton Kettering, who sent me samples of oneyear seedling ash very much eaten on the thick portions of the rout. The damage varied in alprearance, and was therefore suggestive of heing the work of different insects. Mr Thring kindly sent me sume larre on ash seedlings. They changed into pupæ near the end of March, and hatched ${ }^{*}$ out tlies (fig. 339) about the berginning of May, which were ilentified by Rev. W. J. Wingate, Bishop Auckland, as Bithin marci. Judeich and Nitsche say they are not of much importance in
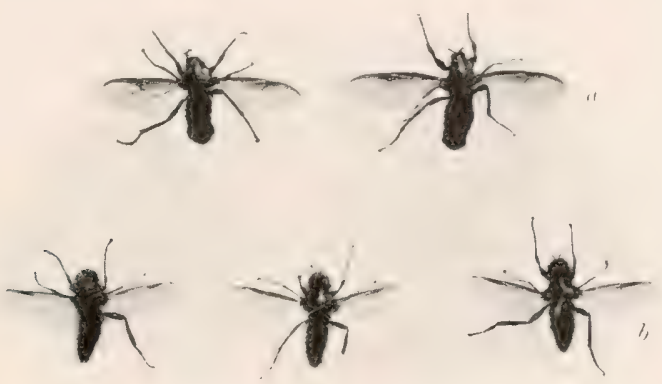

Fig. 339.-Bibio marci. $a$, females; $b$, males.

forestry; but the roots in question were very much injured, and $\mathrm{M} r$ Theobald informs me that they are often very injurious to the roots of hop and other plants.

\section{References to Literature consulted.}

Binnie, Francis G. On the Asphondylix of the Glasgow District. Nat. Hist. Soc. Glasgow. 1876.

Cambridge Natural History. Insects. Part II. 1899.

Collinge, Walter E. Report on the Injurious Insects of the Midland Counties. 1904-6.

Collinge, Walter E. The Life-history of the Pear Midge. 1905.

Frank. Die Krankheiten der Pflanzen. 1896.

Gardener's Chronicle, various articles from. 1870. 
Judeich und Nitsche. Forstinsektenkunde. 1895.

MacDougall, R. Stewart. Proceedings of the Association of Economic Biologists. Vol. i., Part I. 1905.

Niisslin. Leitfaden der Forstinsektenkunde. 1905.

Theobald, Fred. V. An Account of British Flies. 1892.

Theobald, Fred. V. Various miscellaneous writings.

Verrall, G. H. A List of the British Diptera. 1901.

Wingate, Rev. W. J. A List of Durham Diptera. Transactions of the Natural History Society of Northumberland and Durham, vol. ii. 1906. 


\section{CHAPTER X.}

\section{Part I.}

P S Y L L I D Æ.

Coxstoered as a distinct group, this family of insects is very easily overlooked, even by workers who have a fair knowledge of economic entomology, inasmuch as they may be mistaken for the Aphididie or green-fly on the one hand, and the Cicadidre on the other.

The following may be taken as the chief characteristics of the group: Head produced in front, but somewhat broad; eyes-large and prominent; three ocelli present, one close to each eye and the third in the middle of the forehead. Antennæ inserted in front of the head, usually ten-jointed, with two large basal joints, the remainder of the joints filiform, and terminated by a slender forked bristle.

The thorax is well developed. The wings, when at rest, are folled roof-wise over the body. As the wings are nearly all equally clear, they may be termed four in number, and not elytræ and wings. The venation of the upper is very simple. The subcostal vein passes obliquely across the wing, ending in a small indistinct stigma, and dividing the whole wing into seven distinct open cells.

The front pair of legs are rather shorter than the other two pairs. All legs are well formed for leaping. The tibix in the second pair of legs are somewhat longer than in the first pair, and still longer in the third pair. In the hinder pair the tibir have a few blunt spines at the apex. The tarsi are two-jointed, and terminated by a distinct claw. In the hinder pair of legs, the second joint of the tarsi, like the tibire, have also a few blunt spines. There is a very noticeable peculiarity in the adult insects on the food-plant-viz., that they take to flight very reluctantly from approaching danger, and seem to depend almost entirely on their leaping powers as a means of escape. 
The abdomen should be carefully noted, both as fresh or prepared specimens, as the genital segments are so clearly defined that the sexes are very easily determined, more especially if a side view be presented.

The development of the creature, from its early larval stages to the winged insect, forms a most interesting study, and should also be examined both as fresh and as prepared specimens. The former will show the wax cells, the latter the structural features. Witlaczil describes four distinct larval stages from embryo to imago, and the student will be well repaid by following up the development.

As regards classification, it may be noted that Dr Franz Löw, in his paper "Zur Systematik der Psylloden, 1878," divides the family into four sub-families - viz., Liviinæ, Aphalarinæ, Psyllinæ, and Triozinz. So far, however, as forest insects are concerned, the subfamily Psyllinæ are the most important.

The Psylline are again divided into two genera-viz., Psyllopsis and Psylla. In the former genus we have two species on ash-trees, and in the latter there are several species found on different trees.

\section{Psyllopsis fraxinicola (Fürst).}

If the foliage of our large ash-trees be beaten over an inverted umbrella during the summer months, we shall find a very large number of green Psyllidie, amongst other insects. These are Psyllopsis fraxinicola. They cannot be said to be injurious to the foliage to any appreciable extent, inasmuch as they simply suck the juices, and do not deform the leaves in any way whatever.

The whole body of the insect is of a pale-yeilow colour, the tips of the antennæe and the claws of the feet being often darkish-brown. Length $3 \mathrm{~mm}$.

\section{Pstllopsis fraxini (Linn.)}

In early summer the foliage of the young ash-trees in the nurseryrows is often rolled up, as shown in fig. 340 , the main characteristic feature of the damage being that the whole of the compound leaf is injured. Sometimes a single compound leaf springing from the stem may only be affected, and at other times the damage is so bad that almost the whole foliage is injured. As this injury appears most conspicuous just when the plant is most active, it is obvious that the growth must be appreciably affected. A careful examination will 
show that the individual leaflets are rolled towarls the centre in a somewhat ollique manner. The natural green colour of the leaf is substituted by large brownish mottled streaks. As long as the injureul foliage is attached to the plant, the leaflets are comparatively stiff; but if removed from the stem, they soon get as flabby and tender as tissue-paper.

If the leaflets are unfolded we find a large quantity of "cottonwool," protecting larve and eggs. This diversity in the phases of development is therefore suggrestive of the adult insects subsequently appearing at varying dates.

As regards larre and pupre, it is difficult to determine where the one stage ends and the other begins, except that after one or two larval moults the wing-cases are more fully developed, and the latter stages may therefore be termed pupæ.
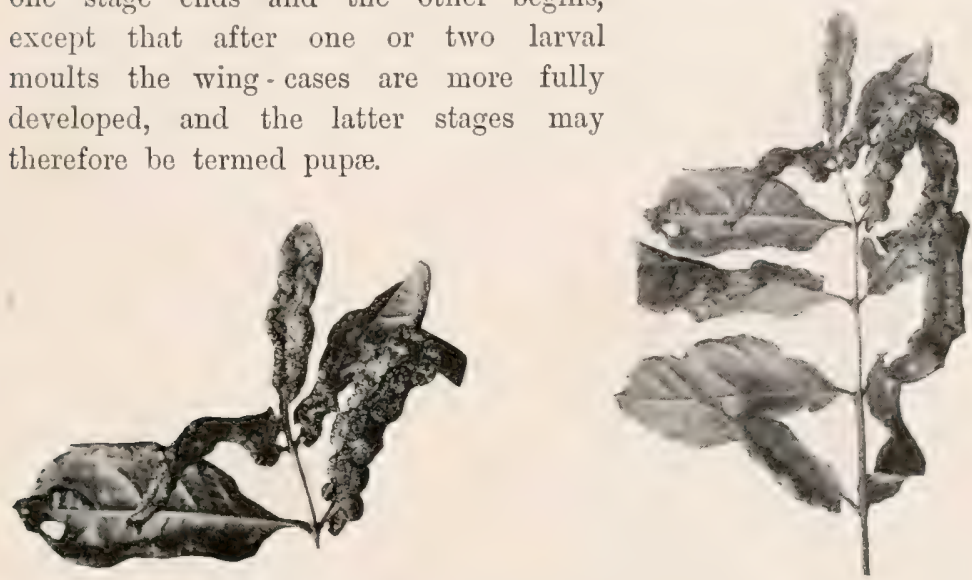

Fig. 340. - Lectfets of ash injured by Psyllopsis fraxini.

The adult insect is somewhat variable in colour. The head is a reddish-yellow, with dark projecting eyes. Thorax a variable yellow with black markings; abdomen black above and yellow below. Antenne ten-jointed, long and slender joints, becoming smaller towards the apex; last joint very small, and terminated by a forked bristle. Wings, smooth in cells, veins, and even edges. Clouded at edges. Legs a reddish-yellow. Length $2 \frac{1}{2}$ to $3 \mathrm{~mm}$.

The clouded wings and brown markings of the body are quite characteristic features of this species, inasmuch as the colour of the insect harmonises in a very wonderful degree with the chocolatepinkish colour of the leaflets. 
The life-history of this species does not appear to have been worked out, but it would well repay any one to follow it out.

As regards any remedial measures, it would perhaps be best to collect (by clipping off) the individual injured leaves while they remain in the young stages, and such clippings should be burned. In its younger stages the ash is a tree which is somewhat difficult to grow to perfection in the nursery, but more especially in the young woods. Hence it is well to encourage vigorous growth. The seedlings should be transplanted at a year old and grown for two years in the nursery-lines, and then either transplanted in the nursery or otherwise in the young woods, under the protection of wire-netting, and if possible also under the sheltering influences of more hardy species planted in advance. If they are transplanted in the nurserylines as one year, two years old, or say 18 to 24 inches in height, they should be quartered the following year--that is, the best plants should be taken out, and so thin the crop that "spindling" is prevented in those which remain. The latter class should then make very useful trees for park planting, where a method of systematic groups at regular intervals, for continuity of effect, is the object in

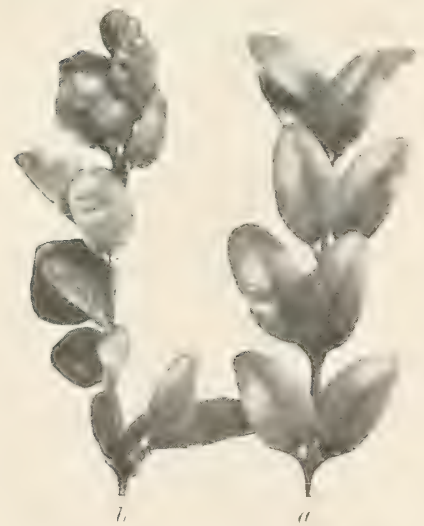

Fig. 311.-Leaves of box injured by $a$, normal leaves; $b$, injured leaves. view. If, on the other hand, two-year seedlings are transplanted in the nursery, then it is often advisable to grow for one season and cut the plants down the following year close to the ground, taking eare that only one good, strong, vigorous shoot will spring up. Attention to these practical points, together with any improvement on them, is the best antidote against any appreciable damage accruing from the injuries of the insect in question.

\section{Psylla buxi (Limn.)}

'This insect in its larval stages, and also in its early adult stages, causes the leaves of the box to curl up, so as to give rise to a sort of pseudo-gall, as seen in fig. 341 . Fig. $341(a)$ represents the normal twigs of box leaves, and fig. $341(b)$ shows the "galls" caused by the insects. 
The adult insects may be beaten from box plants, especially those with rolled leaves, in showers throughout the summer monthis, and odil specimens can also be beaten from box-bushes during the winter months.

An examination with the pocketlens will at once give the impression that the bodies of the tiny insects appear "to have been made" out of box leaves. In other words, the colour of the insect, as compared with the box leaves, is about the best possible mimicry in the whole realm of forest entomology.

The prevailing colour of the insect is sea-green. Head and thorax palegreen; antennæ varying in colour from yellow to brown. Wings hyaline; abdomen green; legs yel. lowish-green, with darkish tarsi. Length $3 \frac{1}{2} \mathrm{~mm}$.

\section{Psylla crategi (Schr.)}

The injuries caused by this insect are not of very much importance, and they are very apt to be overlooked. They may be found either on a hawthorn-tree or otherwise on a switched thorn-hedge, but more especially on the latter. Just as the young shoots begin to grow the larve of this species (fig. 342 ) seize hold of the extreme tip of the shoots and fasten themselves to it gregariously all round the tiny twig. The result is that, through

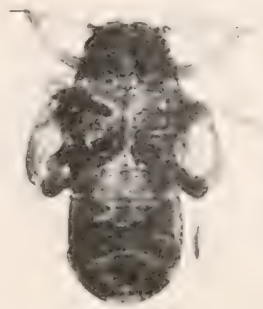

Fig. 342.-Young form of $\mathbf{H}$ sylla cratargi on shoot of hewethorn.

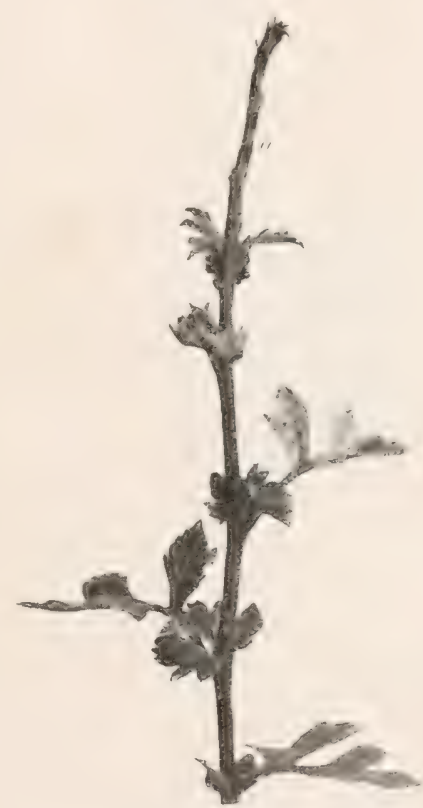

Fig. 343.-T'ip of hauthorn shoot injured by Psylla cratregi.

« shows the injured portion. sucking the juices, the inflated portion clies off, as in fig. $31: 3$ ( 1 ); and neanwhile the tiny larre remove themselves to the foliage, change to winged insects, and remain on the foliage all through the summer. 
The adult insect is greenish in colour, but head and thorax are almost white, abdomen darkish. Antennæ yellowish-green, legs reddish-yellow.

\section{Psylua alni (Limn.)}

About June 1 on an average season the tips of the branches of the common alder (Alnus glutinosa) are thickly covered with a white woolly down, as shown in fig. 344 . These are the larvæ of Psylla alni, and may by inexperienced entomologists be classified as Aphididre, similar to American blight. The woolly covering acts as a protection for the creature during the early stages of its existence. At this stage

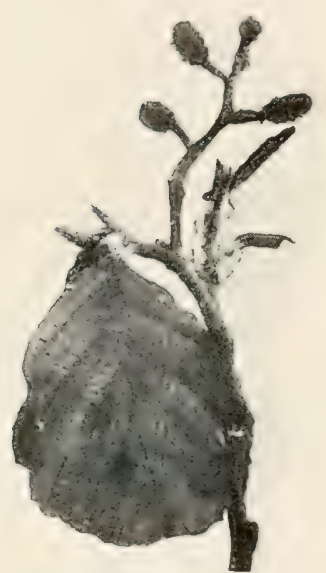

Fig. 344.-Twig of alder injured by Psylla alni. they are very easily disturbed, and set off rapidly as large white moving specks.

The larval and pupal stages cannot be very easily separated; but considering the more advanced stage as pupa, it is, when divested of its white overcoat, rather a handsome insect. The prevailing colour is green, with several dark transverse spots across the body. The anal segment is dark. The body shows "wing humps" at a very young stage. The head is not conspicuously separated from the thorax, nor the abdomen from the thorax. The wax hairs at the anal portion of the body are quite a conspicuous feature.

The perfect insect may be found throughout the whole summer. The prevailing colour is a light-green. Head and thorax yellowish-green, and studded with reddish markings; abdomen green. Wings perfectly clear. Costal and stigma veins green; other veins sometimes darker. Legs green, with dark tibiæ and claws. Length of insect when wings are folded about $5 \mathrm{~mm}$.

The sexes can be very easily distinguished-partly by the abdominal structure, and also on account of the antemne of the male being longer than the antenne of the female.

It cannot be said that this insect is very injurious, as the summer foliage does not seem to have been injured from the effects of the larval and woolly secretions in spring. 


\section{References to Literature consulted.}

Board of Agriculture Leaflet, A $\frac{16-93}{\text { I. }}$

Edwards, James. The Hemiptera-Homoptera (Cicadina and I'syllina) of the British Islands. 1896.

Riley, C. V. Notes on North American Psyllide. Proc. of Biol. Soc. of Washington. 1884.

Witlaczil, Dr Emanuel. Die Anatomie der Psylliden. Wien. 1884.

\section{Part II.}

\section{CICADID丑.}

This family of insects is generally overlooked by the practical man, inasmuch as he groups them along with the Aphidide or "Green-fly."

The injuries are not so conspicuous as to arrest special notice. In fact, the injuries done by these creatures are of such a nature as to suggest asking the question, What is damage? As regards the damage actually done, three very general examples may be given-the first from the nursery, the second from the garden or orchard, and the third in the meadow. With regard to the example from the nursery, a walk alongside a plot of wych-elms, say from 3 to $5 \mathrm{ft}$. high, in August or September, coupled with a little observation, will show that the foliage has entirely lost its green hue, and is of a sulphury-yellow colour. If the leaves are slightly shaken, a shower of tiny active insects of a yellow colour, harmonising with the foliage, will dance about in all directions. These are known as Typllocyba ulmi, and may be taken as the most injurious of forest Cicadidæ. A similar example on pear-trees, more especially those on walls, will suffice for those in the orchard; and as regards those in the meadows, the most common example is that of the "cuckoo-spit"-that froth-like spittle substance which harbours the larva of a common example of a Cicadid.

Many varieties of deciduous trees harbour their own special species of Typhlocyba, and some of them are very beautifully marked, and would therefore form an interesting collection; but the following very 
brief account of them is intended only for a formal introduction to the family as associated with forest trees.

It has been remarked that they are very closely allied to Aphididre, hence Buckton adopts the term Tettigide. The following table, ${ }^{1}$ which is perhaps chiefly of a microscopical character as regards tarsal structure, may therefore be given-viz. :

\section{ORDER RHYNCHOTA.}

\section{Sub-Order homoptera.}

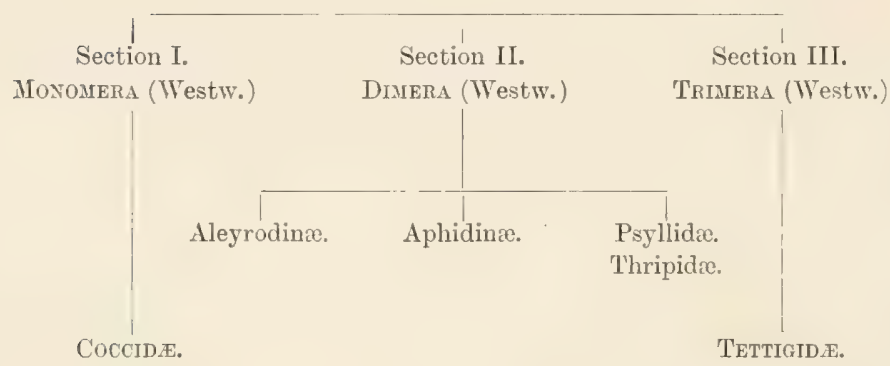

In size the British Cicadidæ show a considerable resemblance to the Aphidide, but the most striking contrast is with regard to the wings, which are coriaceous, more especially the upper wings or elytra. This characteristic almost obliterates the venation. The under wings are also coriaceous, but not so dense as the upper.

The head is always more rounded than in the case of the Aphididæ -in fact, it may be termed frog-shaped. The antennæe are never very long: they are extremely slender, so much so that even under the microscope the joints are very difficult to count.

The insect feeds by means of a short proboseis, which is variable in length but always three-jointed.

No cornicles are ever found on the body, nor any organs for secreting special exudation as a protective covering.

The legs contrast with the Aphididx, inasmuch as they are well adapted for leaping, the femorx and coxe having powerful muscles. The tarsi are three-jointed, lut this is sometimes rather difficult to determine by observation.

${ }^{1}$ From Monograph of the British Cicadæ or Tettigidx, by George Bowdler Buckton, vol. i. p. xxxiv. 
With regard to the life-histony of the Cieaclider, they present some

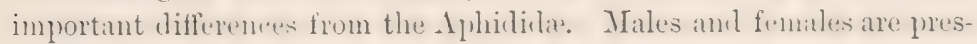
ent throushout the whole seatsm, and the latter are always oviparons. The egrgs, according to Westwood, vary in number from 300 to 400 . They are cleposited in grooves of the leaves, cut by the female insect with her saw or ovipositor. The incision being healed up by the Howing sal, the exgys hatch out in due course into six-legged active litrvit, which feed by means of a proboscis, and after moulting change into pupæ, which are also active and show embryo wings. These finally moult, and betwne active male and female insects. They feed by means of a rostrum, which also forms an anchor when the insects are asleep. The sap pumped up by this organ is ejected by the anus, thus differing from the majority of $A_{\text {phididre, which develop conicles }}$ for this purpose.

It will therefore be seen that the insects undergo incomplete metamorphoses, and are injurious in all stages.

With regard to typical specimens of Cicadidr, I will simply take a few of the most common species.

The most conspicuous species is that known as the "cuckoo-spit," so called because of the white froth or spittle with which the larval form protects itself. In early summer the froth is very common indeer on grasses and low plants. In the mirlst of the froth the larval metamorphosis is passed. The commonest species is known by the name of Phitanens spmaria, sometimes referred to the genus $A_{\mu}$ throphorc or "froth-bearer." The species in this genus are relatively lare, and may be found plentifully on almost all kinds of bushes when beating for other insects.

There is a curious opinion prevalent with regard to cuckoo-spit among gamekeepers. They universally maintain that if a young pheasant swallows this froth it always proves fatal to it. However this may be, I cannot vouch for it other than on the strength of a keeper's opinion.

During the months of July and August a very beautiful and large insect belonging to this group may be heaten in considerable numbers from the oak branches. The insect is about 4 or $5 \mathrm{~mm}$. in length. The head is brownish or a light-chocolate colour, and the body peagreen. It is called Macropsis lanio. 


\section{SUB-FAMILY TYPHLOCYBIDÆ.}

\section{Genus T'rphloctва.}

This genus is perhaps the most important as regards forest insects, and kindred associations in several orchard or garden plants. These may be beaten in showers from the foliage of pear-trees, roses, elm, and alder. They are small yellowish insects, about the usual size of Aphididx, with elytra much larger than the body, but at once show by their active leaping powers that they differ from them. On examination with the lens or microscope they appear beautifully marked, with bright-coloured spots on the light-yellow bodyground.

\section{Trphlocyba Ulmi (Linn.)}

This species may be selected as a typical insect. The head is jellowish or greenish-yellow, with dark conspicuous eyes, and slender antenne which taper to the finest point. The thorax is also yellowish, with dark transverse markings. The abdomen is divided into eight segments or somites, each of which is ornamented with a dark transverse marking, thus giving the insect a general appearance of being black and yellow. The upper wings or elytra are coriaceous, and the veins can only be slightly discerned with the microscope. The wings, or under wings, are lighter in colour and less coriaceous. They are longer than the body. The legs are yellowish, and slightly hairy. (See figs. 345 and 346.)

Mr Fred. V. Theobald has recently worked out the life-history of one of these insects, and the following extract is taken from his writings :-

"The Oak and Fruit Leaf-hopper.

"Trphlocyba quencûs, Fabr.

"Typhlocyba flammigera, Amyot.

"Like all members of this family, the insect passes the winter in either the adult or nymphal stages. Hibernation takes place in any sheltered position. One may find them amongst fallen leaves at the foot of hedgerows, in box hedges, amongst moss and lichens on trees, and abundantly amongst conifers. In spring they appear again, and feed upon the young leaves. In June they were first noticed in numbers: possibly between their exit from winter quarters and June a generation had appeared. It was not until July 
that any marked damage was done to the lenves of apple, plum, and dainson; then all stages of the insect could be found at once, and the life-cycle easily followerl. How many generations vecur in the year could not be decided, but apparently more than two. The arlult may be told by its beautifully marked anterior wings, with six bright-orange and vermilion spots on a milky-white ground, and with a large dusky network at the apex. They are sulject to variation in regard to the markings.

"Their length varies from 3 to $3.9 \mathrm{~mm}$. Thoth nymphs and arlults feed mainly" on the under side of the leaves, but by no means always.

"They are not very active, and can easily be taken at rest on a
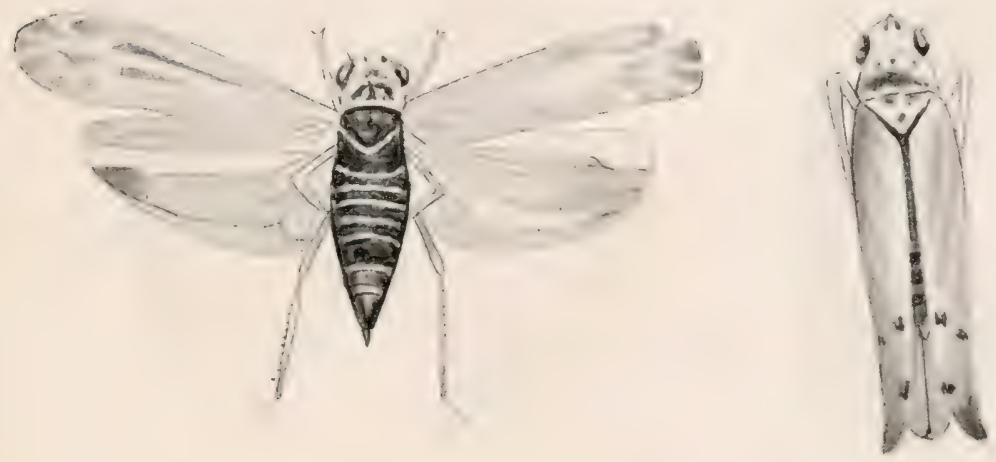

Fig. 345.-Typlılocyba ulmi. (Drawn by

Fig. 346.-Typhlocyba ulmi. P. J. Brown.)

(Drawn by P. J. Brown.)

dull day. When disturbed they take a leap from the leaf, and then use their wings, often flying a couple of feet away.

"Egg-laying seems a laborious task. By means of the saw-like structure the female cuts a slit into the under epidermis, and places one or more eggs just beneath it. A very minute and faint oblong spot marks where they have been laid.

"The ova are very delicate, white, and oblong-oval in form, somewhat curved on one side, and blunt at each end. When nearly ready to hatch they may be seen with a strong lens under the epidermis, their position being plainly marked by the dark eye-spots of the embryos. Length $0.04 \mathrm{~mm}$. 
"Eggs under observation were found to hatch in four days, but how long they had been laid was not known. Lingerland shows that the American Grape-vine Leafhopper (Typhlocyba comes) remains

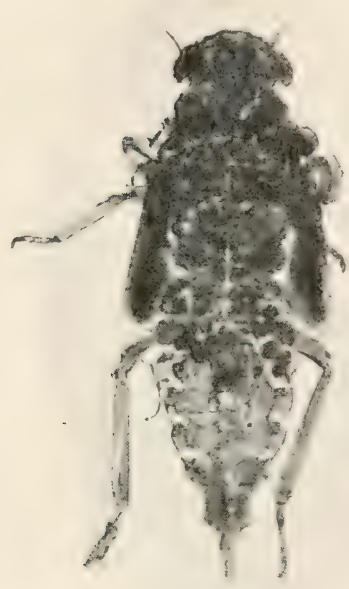

Fig. £47.-Young form of 'Typhlocyba ulni. two weeks in the egg stage, and it is quite likely this is about the period taken by Typhlocyba quercûs.

"The young emerge on the under side of the leaf, and grow rapidly. There are four moults in the nymph stage. At first the young are very pale, but gradually become yellowish as the wing-buds develop. Towards the end of nymphal life they are most ravenous. The whole period of growth lasts from five to six weeks, the complete life-cycle probably taking fifty days. (See fig. 347.)

"They kept on breeding until the first week in October, but in very small numbers after the middle of September.

"Until they are mature these leaf-hoppers are very sedentary, and even when adult do not jump as do other members of their tribe." 1

\section{References to Literature consulted.}

Buckton, George Bowdler. Monograph of the British Cicadæe or Tettigidæ. 1890.

Edwards, James. The Hemiptera-Homoptera (Cicadina and Psyllina) of the British Islands. 1896.

Theobald, Fred. V. "New Hemipterous Fruit Pests in Britain" - The Journal of Economic Biology, 1907, vol. ii., Pt. I.

1 "Nerv Hemipterous Fruit Pests in Eritain," by Fred. T. Theobald, MI.A. --The Journal of Economic Biology, 1907, vol. ii., Pt. I. 


\section{CHAPTER XI.}

\section{HINTS ON (')LLECTING, I'REI'ARATION, ANI) MOUNTING.}

Ix giving a few hints to those about to make a start in the study of forest entomology, perhaps it may be assumed that students can be divided into two classes-viz., those who wish to study the subject partially as a branch of scientific forestry, and those who are anxious to follow it out thoroughly as a division of economic entomology. It is just possible that both classes may at the commencement be undecided how they will follow it up, and it will therefore be advisable to begin in as simple a way as possible. Perhaps it may be said that one of the charms of the study of natural history is to spend as little money, and develop a taste and skill for making as many of the necessary requirements, as possible. Unfortunately, this idea is seldom put in practice.

As a walk through a forest in midsummer will appear to any one not conversint with entomology simply a chatic confusion of insect life, it would be well for all aspiring students outside the guiding influence of a college to join some local field club, or otherwise seek the guidance of a local entomologist. Having done so, they may hegin to collect anything and everything within the forest, and solicit the assistance of local naturalists for naming and classification.

To all those who have not had the benefit of any special course of systematic training, it may be said that in this study, as well as in many others, it is advisable to cultivate at general broal acymaintance with the whole subject of entomology.

It is, of course, necessary to have a simple outfit of that class generally recommended for boys about to begin the collection of moths-viz., a net, chip-boxes, a pocket lens, two killing-bottles,- 
cyanide of potassium and chopped young laurel-leaves, - a few settingboards, with the accompanying entomological pins and braces.

With regard to the killing-bottles, the cyanide should be prepared by a local chemist; and as regards the laurel bottle, only the young leaves, about three-quarters grown, of laurel (Cerasus laurocerasus) should be used. To the rural student, or the young forester enthusiastic of spending his spare time profitably, the above-mentioned outfit will suffice for a season or two. And as regards storage of captures for a time, the collected insects may be placed in store-boxes and labelled.

Having devoted some time to the study in general, it becomes essential to begin the study of pure forest entomology. The student must decide to do so in earnest, and to be prepared for difficulties and failures. It will now be obvious that a more expensive outfit is necessary, but again there will be no harm even if the more or less wealthy student "make haste slowly."

So far as the actual forester is concerned, the one on a small estate has the advantage, inasmuch as he can supervise most of his work on foot, and therefore have greater opportunities for observation, than one on a large property, whose time is largely taken up in travelling.

It is necessary, first of all, to recognise the actual damage, and then ascertain the cause of it. A little practice will soon enable him to distinguish between insect and fungoid damage. It will be necessary to take the damaged portion home, together with the injurious grub or insect, and submit it to some arrangement for development and observation. The observations should be most carefully tabulated in a note-book.

It is, of course, essential to carry a simple outfit of boxes and collecting apparatus in the pocket; but they are so light that they will not in any way interfere with clothing, nor will the placing of a specimen in a box interfere with his duties. On the contrary, the cultivating of this habit of observation will do a very great deal to improve the individual.

In addition to collecting the damaged portion during the actual hours of duty, it is also advisable to go out in the evenings and beat the larvæ or perfect insects from their respective trees. Thus we should have a double method of study-viz., recognising the actual lamaged part, striving to ascertain the cause of it, and also discovering the special insects which attack any particular tree. In the latter method the comparatively young student may place all his captures 
firmm one tree together in a specially prepared cage, and then finally arrange the perfect insects according to the respective trees from which they have been hatched; but, on the other hand, the special portion of damage should be most carefully kept hy itself, and the perfect insects arranged together with the actual damaged portions in entomological order.

As time advances and the student makes progress, it will be advisahle to become more specific and less general. In fact, the correct method of study would probibly be to take a few special insects and work them thoroughly out by means of study and observation. Having regarl to the shortness of human life, and the desire, or necessity, for other subjects, the student of forest entomology must carry on simultaneously a number of observations with special insects and their damage. Hence it is necessary to have separate hatehing-boxes for each species, but with regard to what is the best plan, individuals will naturally differ from one another. The simplest plan, of course, is to collect the larve just as they are about to change to pupa, for then they require little or no attention. However, this is in many cases practically impossible, and it must therefore be remembered that moisture is invariably the most important essential in insect life. This may be obtained either from a bed of damp sand placed in the hatching-case, or from the food-plant itself. Hence two simple methods may he given. The first is, simply to collect as many old glass jam-jars, from a pint to a quart capacity, as may be required, place a little damp sand in the bottom, insert a fresh potato in the sand, stick the stalk of the food-plant into the buried potato, change the food from time to time, liepp doum. the mould, and patiently await the results. Where moisture is not so absolutely important, as, for example, in bark-beetles, the following plan will often suffice-viz., get an empty negative or lantern-slide box, cut out a hole in the top, leaving a little over half an inch of rim all round, get a spoiled negative or lantern-slide (a by no means rare article in the hands of an amateur), glue the cleaned glass to the rim left in the top, and you then have a glass-covered box wherein you can place your specimen and watch the results, noting daily all important points of development, and tabulating the same in a note- and sketch-book kept specially for the purpose. It may be well to remark that the hatching referred to should, if possible, be kept in a shed or outhouse. 
Having hatched or collected the special insects, now comes the question of setting and storing; and to follow this out properly, the student unfortunately requires leisure and money. At the same time, it is no exaggeration to say that the real charm of the study begins at this stage.

With regard to the actual setting, it will, of course, vary with the family of insects, and also with the size of the individuals. Suppose we begin with any of the larger moths, the usual style of settingboards with braces and pins may be aldopted, or the style of setting with glass, sugrested by Mr Newstead and recommended by Mr Day, late of Knutsford, Cheshire. In lieu of the cardboard braces, I would recommend strips of transparent tracing-paper as being lighter, and also as showing the wing in position with more reliable accuracy. The setting of the smaller moths (micros) is more difficult, and it would be well to get a few practical hints from any worker in this group.

It is, of course, advisable to have the smaller moths well relaxed before attempting to set them. They should be handled as carefully as possible, and braced down either with tracing-paper, bristles, or silk thread and pins.

As regards beetles, the larger-sized specimens-the set specimensmay be often seen with a pin through the bcdy, and slightly raised above the surface of the store-box; or otherwise the individual beetles may be mounted on a small card, and a pin placed through the card. The latter method is obviously the neatest. In either case, the setting is practically the same. First of all, see that the insect is well relaxed, brush the legs and antennæe carefully out with a delicate red sable brush, and fix the body and appendages well down on paper with gum-tragacanth or gum-arabic. When it has stood for a considerable time, until the body is perfectly stiff, float it off in water, and then finally transfer it to a clean card, and fix it carefully down with seccotine squeezed out of the tube and thinnerl down with a little glacial acetic acid.

The smaller-sized beetles are, of course, more difficult to deal with, and the following hints may be given. First get the insect well relaxed, and place the creature, under side upwards, on a very soft bed, with a slight depression to receive the insect. There are two classes of beds which may be recommended-viz, a piece of sheet cork, or perhaps better still, a well-dried portion of the white fungus from dead birch, known as Polyporus. The small insect must be tempor- 
arily, hut firmly, held in this position by gentle pressure, either by an entomologrcal pin or stiff bristle inserted in cork, and usirl as a sort of pressure-har, or by the careful manipulation of a soft silk threal. Harings arranged matters so, brush out the legs and antenna with a delicate sable brush, or the "sportsman's feather" from a woodcock's wing. When in correct position, brush them over with a slight moistening of absolute alcohol, and allow it to remain for a short time, say until two or three more insects are similarly treated. The effect of this

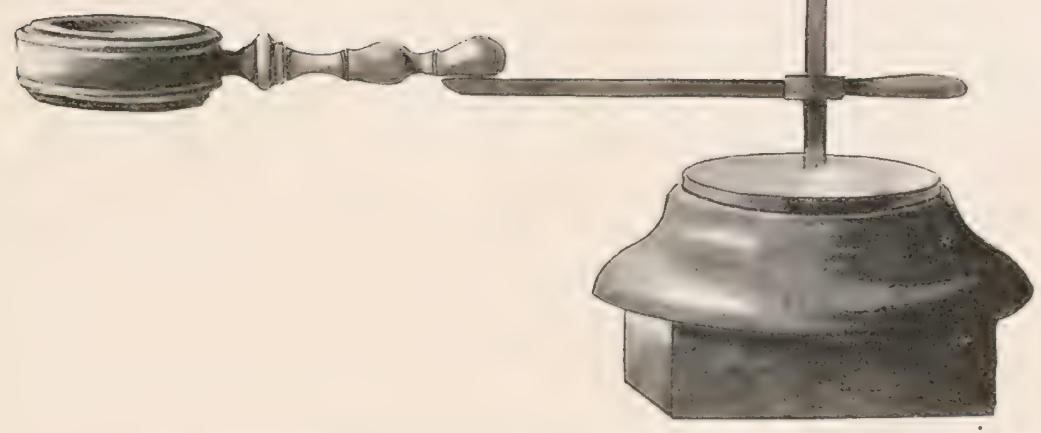

Fig. 34S.-Simple arrangement for dissecting specimens under a magnifying-glass, or for mounting small specimens for the microscope.

brushing with alcohol is to stiffen the legs into their desirer position. Then remove the insect, and place it on a card in seccotine. It is of course advisable to do the preparation referred to under a lens or magnifying-glass, as in fig. 348 .

Hitherto the setting of insects has been considered, but it must be remembered that many of the specific characters are very minute, and also that the major portion of forest entomology is purely a microscopical study. Hence, though it is impossible to give anything like 
a full account of microscopical manipulation, a few general remarks, together with some practical hints as regards special insects, may be helpful to the young student.

As regards the choice of a microscope, it is, of course, best to get what is termed a good stand, as accessories can always be added. The principal lenses required are the inch and quarter-inch objectives. A power lower than the inch is very useful, but the greater portion of practical work is always done with the inch objective. For the examination of opaque objects a bull's-eye condensor is required.

A small outfit of, say, a spirit-lamp, a pair of scissors, a small dissecting-knife, a few slips and cover-glasses, a bottle of balsam and benzole, and a pair of forceps, are about all that are required for a start.

Now let us prepare and mount a slide of some simple object. Take a few slips and cover-glasses, and have them thoroughly cleaned: then select a simple object, say a wing of a house-fly or the scales off a butterfly's wing, gently warm the slip over the spirit-lamp (this is not always done even by experienced workers), place the object in the centre of the slip, drop a little balsam on the object, and with the forceps lift a well-cleaned cover-glass and let it just "feel" the flame of the spirit-lamp, so that any natural moisture may be removed, and let it fall with its own weight on to the balsam on the slip, gently press it, and keep it in position with a clip, lay it aside for a short time, and the operation is completed,- -you have a mounted slide. Great care should be taken to prevent air-bubbles, as they are the deadly enemy of mounts. Such is the simple method of mounting-viz., to fasten the object between two glasses with Canada balsam, as this resinous substance is highly refractive, and brings out the details of structure.

It would, of course, be well for the young student in a rural district to get assistance from a naturalist friend in mounting, \&c. A good useful microscope and simple outfit cost about $£ 8$.

In setting the insects hatching out from oak galls, the following methods, either for microscopic slides or cabinet specimens, may be alopted. First of all, get the insects separated from the galls by the usual method of stupefying by chloroform. When under the influence of the anæsthetic, place them in a clean empty box with a glasscovered top, and when they revive and become active in the box, "tap" them rapidly into a saucer containing boiling-water. When they 
touch the boiling-water, many of them will immediately spreat out their wings in the correct position for setting, — in fact, appearing perfectly set on the surface of the water. Select the best-looking ones, and float each insect on to a separate microseopical cover-glass, am then place the wings, antemne, and legs in the correct position: remore the moisture by means of clean blotting-paper, and then drop nethylated spirits on to the insect: lay them aside, and cover them over with a large inverted glass, - a large champagne-glass which has its foot broken off is a very good thing for this. WVe have then the insects well set either for microscopic slides or cabinet specimens; and it may be noted that the principle of the method adopted is to make the delicate insects as far as possible set themselves.

If specimens are intended for the microscope, it will be necessary to place the insect on the cover-glass with the uncer surface un umrt:; place on it a drop of absolute alcohol, and allow it to evaporate under the bell-jar glass, - which, by the way, should be so arranged as to allow a little air to enter from below. When the alcohol has evaporated, it will be found that the insect adheres firmly to the cover-glass, and when in this condition, immerse it in oil of cloves for twelve hours, and again remove the surplus oil of cloves with blotting-paper. Then place a drop of xylol or benzole, according to the balsam which is used, and allow this partially to evaporate; then place a drop of balsam on the insect again, allow it to stand for, say, twenty-four hours under the bell-jar; prepare a microscopic slip in the usual way, place a drop of balsam on the centre of the slip, and then turn over and press the previously prepared insect on the cover-glass into the balsam on the slip. We have then a well-mounted slide for ordinary purposes.

If, however, a more transparent object is desired, the following method may be adopted: Prepare the insect as previously described, and when it is well set on the cover-glass and thoroughly free from moisture, separate it from the cover-glass and place it in liquorpotasse. It should be borne in mind that when well set in this way, the insect will, with careful handling, always remain in this fixed position. Hence it may be allowed to remain in the liquorpotassæ for one or two days, then float it on to a cover-glass, and place it (by careful floating) on to clean water. Thus it may be gradually washed in this way in water, alcohol, and xylol respectively, until quite transparent. Then float it on to oil of cloves 
and prepare it for mounting, under sicle upwards, as in the previous method. By this method we get a better slide for recognising special structural points.

If a sprecimen of a gall insect be required for general entomologrical cabinet purposes, the following method of mounting may be adopted: In addition to preparing the insect as in the first method, get a piece of clean white cardboard, punch a hole in it with a $\frac{5}{5}$ in. or $\frac{3}{4}$ in. punch, then attach with seccotine a piece of thinner cardboard to the punched portion, and lay the amalgamated cardboard aside to get thoroughly dry. Thus we have a circular cell of cardboard; in this place the previously prepared insects, and according to space fix them neatly in the prepared cell with a very tiny drop of seccotine. Lay the insects aside for a time, see that they are kept free from dust, and then finally seal them over with a microscopical cover-glass, a shade larger than the cell. The latter should be done with considerable care, and either of two fixing mediums may be used-viz., Kay's Coaguline, or "brown cement." In either case place a series of tiny drops around the edge of the cell, but not quite touching one another; then let a cover-glass, well cleaned and warmed over a spirit-lamp, fall on the edges of the previously laid drops, again lay it aside until partially dry, and then warm a glass microscopical slip over a spirit-lamp and press gently on the cover-glass, and finally run a ring of the medium round the edge of the cover-glass, and the whole is completed. This method of preparation makes an excellent opaque microscopical slide for revealing the natural colours of the insect.

The small Cecidomyidæ may also be made to "set themselves" for microscopical slides. First stupefy them with chloroform, then pick a single specimen, male or female, place it on a clean cover-glass, place a drop of absolute alcohol on the insect, allow it to evaporate, and then mount in balsam in the usual way. The placing of the alcohol on to the tiny insect is, however, rather difficult. It should, as it were, be allowed to creep under the insect, and so let the delicate wings adhere gently and properly to the cover-glass. If, on the other hand, the alcohol were allowed to drop on to the tiny insect, the wings would double up, and, as a microscopical slide, we should have a complete failure. The alcohol dehydrates the natural moisture in the body of the insect, and as the insects are very delicate, it is well to move them about as little as possible. As the Cecidomyidre change colour rapidly after death, it is best to examine the unpre- 
pared insect while under the influence of chloroform for specific characters.

In giving a short account of the preparation of Scale-insects for the cabinet and the micruseope, I am not only indebted to Newsteall's

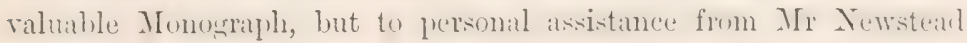
himself long before the book was published.

For cabinet purposes, and for the study of external characters, where the number and variety of species are the chief olijects in view, small cork slips of 3 inch $\times 1$ inch, and covered with white or black paper, according to the colour of the species, may be used. But where it is intender to display the "scale" from an educational point of view, together with the nature of the damage it causes and the more salient details of structure, a suitable space should be allotted to it in the cabinet.

As, however, the scales are almost exclusively a microscopical study, it is indispensable to give a short account of the necessary preparation. In scale-insects we have two great divisions, - one where the body is protected by the scale, the other where the actual body is the scale itself. The former class is well represented by the Diaspinæ, Psendococcus, \&c. ; the latter by the Lecanium and Pulvinaria. Now let us begin with the Diaspinæe, and no better example could be taken than the Chionaspis on ash, willow, \&c., as found in winter. Under a weak lens, reading-glass, or arrangement as in fig. 348 , lift up a female scale, and underneath this we find the dead female surrounded by eggs. Collect a number of those female insects, and place them in a saucer of water. Be it remembered they are mere tiny specks, and can only be lifted with a needle or woodcock's feather. Now we must boil it in, say, a ten per cent solution of caustic potash $(\mathrm{KOH})$. The strength need not be too accurate,- about two penny sticks in a pint of water would do. Place the insects in a portion of this solution contained in a very small tube, and stoppered with cotton-wool. Place this small tube inside a larger one, containing water, and boil the two tubes in a small enamelled cup over a spirit-lamp for about fifteen minutes. Pour out the boiled insects from the inner tube into a saucer of clean water, pick them up with a needle, and re-boil them in clean water for a short time, transfer them to dilute and then to absolute alcohol, anil from this again transfer them into another glass containing absolute alcohol and a weak colouring of one of Crawshaw's dyes, which 
are sold in penny packets, and which form a very good medium for staining scale-insects. Then with the aid of a large but weak lens lift them out of the stain, on the tip of a woodcock's feather, and place them on to a prepared cover-glass. Arrange them as carefully as possible, and absorb the moisture with a clean-cut portion of blotting-paper. Then the specimens may be allowed to remain under oil of cloves for a short time, which may in turn be replaced by a drop of xylol, and this again further replaced with thin balsam and xylol. The latter may be allowed to remain under an inverted glass for a

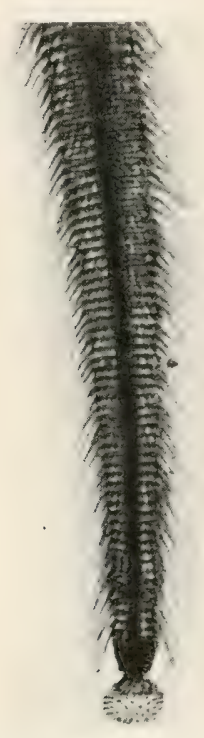

Fig. 349.-Proboscis of honey-bee. (From photo by A. Flatters.)

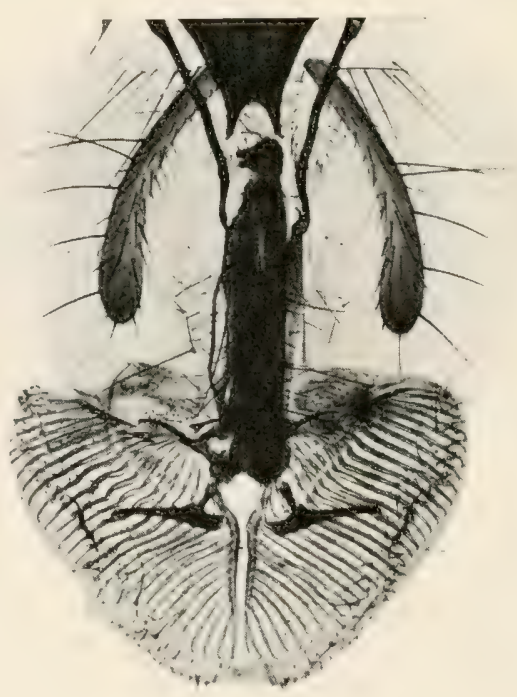

Fig. $350 .-$ Tongue of house-fly. (By A. Flatters.)

short time, and then finally mounted on to a glass-slip by pressing the cover-glass with the scales into the balsam on the slip.

This method may be termed mounting the object on the coverglass, and is certainly, for this class of work, better than mounting on the slip. All workers, more especially beginners, know full well that when an object is mounted on the slip and the cover-glass afterwarls applied, the valuable object has often heen found outside the cover-glass in the superfluous balsam, so that mounting carefully the opposite way generally gives better results. 
With regard to the preparation of the larger specimens, as, for example, the female seales of Lecanimm and Pulvinaria, they may he: boiled in caustic potash in a test-tube (not in an inner one, as with the very small species), then boiled in clean water, then transferrent to absolute alcohol with stain for a day, oil of cloves for another day, and finally mount in xylol balsam.

In addition to studying the more salient points of the anatony of forest insects, the student would do well to study the details of ninute insect structure as revealed hy microscopical investigation. There is obviously no end of oljects outside forest insects, thus giving

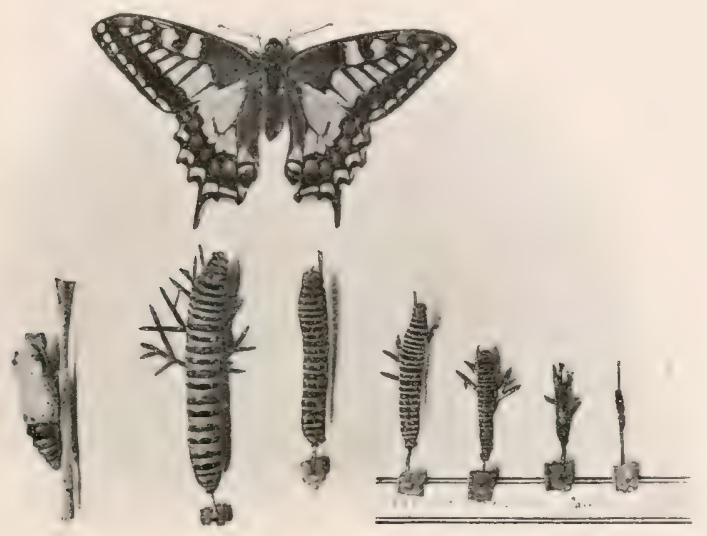

Fig. 351.-Life-history stages of "Suallow-tail" Butterfly (Papilio machaon). (From photo by A. Flatters.)

the student not only a wider outlook, but teaching him many a valuable lesson from indirect subjects. Take, for example, the case of figs. 349 and 350-the proboscis of the honey-bee and the tongue of the house-fiy. Not only do subjects like these show marvellous mechanism, but they throw a strong sidelight on such delicate anittomy as the mouth parts and feeding organs of scale-insects, green-fly, \&c. In the case of all insects which suck the juices from the foodplant, as contrasted with those which eat the vegetalle direct, it is obvious that the vegetable cellular structure must he ruptured, and therefore many disease spores may thus find a really entrance into a favourable host. Hence the obvious necessity of careful investigation 
in many diseases, and the incalculable value of trained laboratory research work.

Such are a few "hints" to the student from the writer's point of view; but it is possible that even advanced enthusiastic students may show a greater desire for life-histories than minute investigation. Hence fig. 351 may be taken as a typical case of the life-history of an insect, inasmuch as we see the successive stages of larval development. In the example given we have, of course, an excellent instance of the correct method for cabinet purposes; but in reality all insects should be worked out on similar lines, and the various stages noted and tabulated in a book kept for the purpose. 


\section{CHAPTER XII.}

\section{INSECTICIDES AND GENERAL REMEDIES.}

WHeN dealing with forest insects and showing them in the cabinet or life-history cases from an educational standpoint, one is generally asked the question by practical men, What is the best way of getting rid of them? It will have been noticed that throughout the whole of this work general and not specific remedies have been given. As regards the latter, or the insects considered, it will be obvious that, while there are some very notable exceptions, as a general rule only sickly or back-going trees are usually attacked. Hence it is apparent that there are two practical methods to be adopted-viz. : (1) to maintain good health or encourage vigour either for trees or shruls incliviclually, and for woods or plantations when considered collectively; and (2) that where we do get certain insects attacking healthy trees in nursery or plantation, special remedial measures must be adopted.

With regard to good cultivation, it may be said that in making the following remarks it is not intended that the methods should be usually adopted in order to lessen insect attacks; but, at the same time, it is certainly true that in many cases bad methods of cultivation, together with careless workmanship or inattention to details, are points very much to the advantage of insects. Hence the absence of insects and good husbandry are often very closely associater. It will perhaps be most practical to consider what may be done in the nursery, the young plantation (ornamental or commercial), the midlleaged wood, or in old woods prior to replanting.

As regards the nursery, more especially the estate nursery, for general plants the first thing to consider is the selection of a good site. The nursery should not, e.\%, he in the neighbourhood of an oll Scots pine wood or where Scots pine branches are likely to lie unburned after heavy falls, as this would endanger young Scots pine or Austrian 
pine to be subjected to attacks of Hylurgus piniperda. Again, the site ought to be considered as regards shelter, for while it is obvious that too much shelter is not advisable for subsequent planting in the open, still it is much better to err on the side of shelter, and then never plant out before young growth is fully matured, as, on the other hand, too much exposure results in an absence of constitution and vigour; hence growth is often not in proportion to anticipations, and insects have an advantage.

Again, it is possible that selection of seed is a point more important than hitherto considered. It is perhaps true, as many scientists have asserted, that the vegetable organism, unlike the animal, does not "hand on" the disease of the parent. Still, there is in all probability an inherent weakness from the parent, and therefore a natural predisposition to disease,-another point in favour of the insect.

So far as the actual management of the nursery is concerned, too many details cannot be given, as such would simply be an epitome of nursery management. Great care should be taken as regards good handling, as the very first thing to be considered is a good root on the plant, and careful lifting of the stock; and as regards the transplanting of seedlings and young trees generally, it is in most cases essential to transplant or sell out always following two years' transplantings.

Nuch may be done to maintain a good constitution in young trees, as prevention against insect attacks by transplanting at the proper age. Take, for example, beech seedlings. If they are transplanted at two years of age, they grow strong and healthy without any insect attack; but if they are transplanted when only one year old, they are often injured by the woolly aphis (Phyllaphis faf $i$ ). On the other hand, ash seedlings are less liable to injuries from the tiny moth, Prays curtisellue, when transplanted at one year old and left for two years in the nursery-line, than when transplanted at two years old and left two years in the nursery-line: besides, the former make the better plants.

The question of cleaning in summer has to some extent a beneficial influence, both as regards the stimulating of the growth and the keeping down of the weeds. As regards the latter, it may be said that weeds not only choke young plants, and therefore weaken them, but it is possible that some species of green-fly may be assisted by weeds.

The method of digging between rows of plants in autumn has a 
very marked effect in producing greater growth, and thus lessening insect attack. Mr J. W. Robson, nurseryman, Hexham,-a nurseryman of nearly fifty years' experience, - informs me that he has often experimented with antumn and winter digrging as a means of stimulating growth and lessening insect attacks. Iy taking a plot of plants, say thoms, and digging and leaving undug alternate patche:, he lias found that the undug portions made less growth and suffered heavily from green-fly, whereas the dug portions male long shoots of srowth and were practically untouched by insects. By autumn digging, too, the frost pulverises the soil, and facilitates the subsernent summer cleaning.

It often happens that many plots of hardwood in the nursery are very much injured by insects. For example, ash plants at three years of age (that is, two years in seed-bed and one year in nurseryline) are injured by Prays curtisellus and other insects-so much so that, with forked and bushy tops, they are practically useless. This may be got over by cutting down to the ground in early spring, and then giving sufficient attention to see that the plants spring away with only a single shoot. The result is that we get very good, healthy plants.

There are several other points which may be attended to with very beneficial results, as, for example, burning of all prinings of hedges, holly bushes, yews, \&c. In the growing of fruit-trees, certain varieties assert themselves as being practically immune from such direful pests as American blight and mussel scale, and perhaps this suggests the advisability of attending to certain species or varieties as regards ornamental trees, shrubs, or willows, \&c. Much might also be done in the way of green cropping, green manuring, and so forth, according to local circumstances or the experience of practical men.

As regards preventive measures against insects in young woods, it is even more important than in the nursery, inasmuch as the majority of reports against forest insects (although perhaps due to better facilities for observation) come from young woods. In the majority of cases the real cause of injury is primarily due to careless or indifferent planting. Practical men, or men who ought to be practical, will write to newspapers stating that certain areas can be planted for sums which cannot even raise the plants. Seeing that a plantation is for a period of a hundred years, why should it not be properly done? Do what is right in principle,- - get the full return of work from the workmen, 
making quality a leading feature,-and the insect pest will often clisappear. What are correct principles in planting? The answer may be varied according to the class of planting. Thus we may have here (1) planting on a large area, chiefly pure or mixed, only by grouping according to soil conditions; (2) a mixed plantation on previously cultivated land; (3) clumps or groups of trees for landscape eflect; and (4) replanting of old woods.

(1) Planting on a large area.-If the ground be quite bare and the herbage not very rough, the usual method of notching may be adopted with very good healthy results; but if, on the other hand, the surface conditions are against using a small plant, then unless some extra care in preparation be adopted, the results will not be so good, and therefore much to the advantage of insect attack.

(2) As regards planting with the object of forming a new plot on previously cultivated land, more especially in a pasture field, the plants are rather difficult to get away, and often hang on for a considerable time. It is from this class of planting that we often get very severe attacks of Chermes on larch, and, in fact, many larch plants are killed with the aphis. This attack might often be considerably reduced if a little more attention were given to a few practical details. In the first place, the wrong size and age of larch plant is used-viz., two years two years, or four years old; and some use one year three years, which is even worse. The plea is that a large plant is used to save expense of cleaning. A smaller plant and attention in keeping lown the grass will give better results. The best results of planting a mixed plantation, including larch for early returns, would be to plant off ploughed land and keep the grass and herbage down for two years. The planting could be cheaper done, both as regards plants and labour; and even if following a green crop, it would pay to allow for "unexhausted improvements," inasmuch as being in every sense better as regards soil conditions there would be comparatively no blanks and no insect attacks. As an experimental comparison, it may be noted that when planting on grass land it is often essential to have fires when preparing for planting, as when burning old hedges and so forth. The larch plants on the burned patches do infinitely better than those on grass, and never show signs of Chermes.

(3) In planting ornamental clumps for landscape effect, the best remedy against insects is to trench the ground. Not only do the 
trees grow ever so much faster as compared with pitting, lunt the more rapid landseape effect and the greater increment amply cempensate for the initial outlay in trenching.

(4) In replanting, it may be noted that careless or indifferent management of the wovdland, in the period intervening letween the ratting of the old erop and the replanting, not only grives every advantages to the dissemination of insects, but the essential conditions of soil are often so much placed out of order that the next crop is weakenerl and more liable to be injured by insects. All branches should either be carted off the ground or bumed on the spot, which of course destroys the breeding-ground for many species of beetles. Then in many eases, more especially pure Scots pine woods, the ground should be well stocked with cattle or sheep three or four years prior to replanting. The effect of this is that the soil is so much trodden away from the old stools that the bark falls off, and the stools are more unfit for hreeling-places. Scrub hushes are prevented from getting up, which also often serve for the propagation of many species.

As regards the advantage of "stocking" with cattle or sheep, it should be noted that, as a result of pasturing, the "spongy" layer unclerlying the rough turf disappears. This is a great innprovement to the soil, inasmuch as the spongy layer is acid in reaction, and contains nitrogrenous matter derived from the decayed plant resilues of which it is composed. In the rough state the nitrogenous matter, however, is not directly available as a plant food, but must be converted into a soluble and available form by the action of the nitrifying organisms always present in the soil. It will therefore be obvious that the ground can be more cheaply and successfully replanted; and as the plants will not only do better and give a more regular crop, as comprared with planting on rough unprepared grounl, the young trees get better over the most critical period against the attacks of insects.

With regard to the prevention of insects in young woods, it may be said that again it is essential to adopt sound sylvicultural principles, and as a rule the insects will not be troublesome. One notable exception is the Retinic or pine-shoot moth, which does not disippear under good management as many others do. In young plantations it is well to see that they are planted "thick" and kept so. Secure

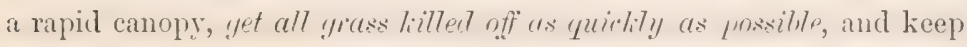
the soil conditions right by having a covering of leaves from the shade-bearers-beech and other trees-and growth will be very much 
stimulated. It has been proved by the Woburn and other experiments that grass has no place in an orchard; and as the case of young woods is practically analogous, it would be well for the health of young woods if the grass could he got rid of as soon as possible by the density of the young thick crops.

In the nursery-lines many species of hardwood trees which may be doing badly, partially owing to insects, after being planted for a few years could be cut down to the ground, and then come away as strong young trees, provided they are well sheltered with the remainder of the crop, or under the protection of netting, and receiving attention for the first year.

In dealing with Insecticides, or the destruction of certain insects by the application of special chemicals and mixtures in varying degrees of strength, or otherwise by the application of special mixtures as sold by respectable firms or individuals, it will be obvious that in a work of this class it would be very improper either to support or condemm any "mixture" in the market. It is therefore considered advisable to simply give a few general principles.

In the first place, it should be remembered that the use of any insecticide should be, as far as possible, applied intelligently (1) as regards the life-history of the insect; (2) what is to be the actual or prospective effect on that particular stage of the insect under the anticipated remedy; and (3) how far such remedies may be practicable.

It is important to bear in mind the structural and physiological functions of an insert (1) as regards the structure of the mouth and method of feeding; (2) the method of respiration or breathing; and (3) in some special cases the method of reproduction. The application of effectual insecticides must be through one or other of these mediums.

As regards the poisoning of the insect through feeding, it must be borne in mind that there are three distinct methods of feeding-viz., biting, piercing, and sucking. The piercing and sucking forms, however, are not always easily separated. Now take a typical case of general insecticide application-viz., spraying; and consider obvious results. The biting form of mouth, as seen in the beetle, would take the liquid along with the full structure of the leaf; or if the insect only ate the upper surface of the leaf, leaving the veins and under surface, it would obviously take more liquid in proportion than the other insects. But if the insect were literally of the piereing type, 
the proboscis would pass through the smallest possible curantity of the poison on the surface, and feed on the pure vegetalle sap underneath. It is therefore obvious that hefore any good results could accrue, we should require to get the vegetable organism to incorporate the poison with its own sap. How far this can be done is still to a large extent a question for future scientists, but nature does give us some very gond suggestions in this direction. Take, for example, the case of some scales with their piercing mouths-viz., Cryptococcus fary or felt scale on beech and Mytilusyis pomorum or mussel scale on fruittrees. In the former case the copper beech often shows itself as practically immune alongside the badly infested trees of the common beech, and in the latter certain varieties of fruit-trees are practically immune while the surrounding trees of other varieties are literally killed. Hence the practical inference is to either raise immune varieties, as in fruit-trees, or if possible to so feed the vegetable organism as to contain some ingredient so amalgamated with the sap as to be inimical to the animal parasite.

With regard to the breathing-apparatus of an insect, it should be remembered that breathing is not effected through the mouth, lut through slits or openings termed breathing-pores or spiracles. If these openings are varnished orer, the insect will be asphyxiated. Thus, therefore, we gret the suggestion of applying insecticides in the form of an emulsion or thick spray. Nothing answers this purpose better than soft-soap, hecause it adheres to the skin, and other ingredients may be alded within certain linits and according to the species of insect and nature of injuries. Such ingredients are cutussia, paraffin, tobacco, sulphur, turpentine, caustic soda, caustic potash, \&c. The addition of any of these ingredients has the effect of corroding the skin, and so intensifying the action of the emulsion. The skin of insects is composed of a substance known as chitine. This substance is more or less of a horny nature, and has the chemical formula of $\mathrm{C}_{9} \mathrm{H}_{15} \mathrm{NO}_{6}$. It is practically unaffected by alcohol, ether, acetic acid, alkalies, or even when boiled in caustic potash. It may, however, be dissolved by concentrated mineral acids, but as the latter would injure the vegetable organism, it follows that insecticides must be so composed as to act on the insect without doing injury to the plant.

The reproduction of insects may to some extent be checked, as for

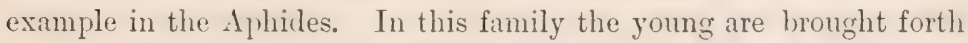
alive, so that by using any insecticide which would so injure the 
creature as to prevent it giving birth to young we should be checking the pest considerably.

Insecticides are now employed with great success, especially in horticulture; but obviously they are more difficult to apply in forestry, particularly in the forest proper. It appears best, therefore, to suggest remedies in a general way for the nursery and individual or ornamental trees.

In the nursery remedial insecticides may be classified under four heads: (1) fumigation; (2) dressing the soil ; (3) spraying; (4) miscellaneous.

As regards fumigation, it may be done in an open shed when removing from the nursery to the plantation, or when foreign plants have been purchased, or with a costly preparation on groups or individual trees.

As fumigation has not been adopted to any great extent in this country, the following account of Mr Lounsbury, Government Entomologist, Cape of Good Hope, ${ }^{1}$ may be given :-

"Fumigation with hydrocyanic acid gas is applicable for the destruction of scale insects on citrus-trees, and to a large extent on other trees. It is without doubt the most efficient remedy for this purpose yet brought into practical use. The eggs of the insect do not succumb to the gas unless this is used at a much greater strength than what is necessary to destroy the insects themselves. One treatment suffices for the destruction of those species in which the young are produced alive. Successive treatments at the ordinary strength are necessary to destroy all stages of egg-laying species, but it is more arlvisable to give several treatments at this strength than a single one which would destroy the eggs, because of the liability of serionsly injuring the trees in the latter case.

"In general, the treatment consists in covering the trees with an air-tight cloth made in the form of a tent or sheet. The gas is then generated beneath this cover by acting on potassium cyanide with sulphuric acid, the amounts of the chemicals used depending upon the dimensions of the tree. The coverings are removed after the expiration of half or three-quarters of an hour, by which time the gas is largely spent. Great care must be taken in the use of the gas, as it is highly poisonous not only to insects but also to the higher forms of life. When proper precautions are taken, however, there need be no

1 Report for the year 1906, p. 130. 
more danger in its use than in the (mpluyment of arsenical sheep-elipls or stryehnine for other farm purposes.

"It is desirable to have various sizes of the coverings ; and withal, the initial outfit demands an outlay so considerable, that not every orchardist will find it economical to provide himself with an equipment for his sole use. But by co-operation among a number of growers, the expense per tree treated may be lowered to a figure which leaves a handsone margin of profit in the henetits which acerne from the operation. After the first expense for the equipment the chief item of cost is the labour, but this expense is not much, if any, greater than the expense of spraying citrus-trees. When purchased in large quantities the chemicals are not expensive. The cyanide may be procured in London at $10 \mathrm{~d}$. per $\mathrm{lb}$. in $224 \mathrm{lb}$. lots, and the sulphuric acid in Cape Town for 50s, per case of $168 \mathrm{lb}$. : one merchant sells the acid at $26 \mathrm{~s}$. per case of $122 \mathrm{lb}$. Estimating the cyanide to cost $1 \mathrm{~s}$. $6 \mathrm{~d}$. per $\mathrm{Ib}$. and the sulphuric acid $4 \mathrm{~d}$., the expense of the chemicals necessary for a tree ten feet in height would be about 3d."

With reference to dressing the soil, various mixtures have been used, but the one which has recently found most favour with practical men is Vaporite. It should be sown broadcast in the soil prior to cligging, and when thus applied it gives off a vapour that destroys the larve of many insects, as, for example, wire-worm, leather-jackets, and others which pass their larval stage in the soil.

As regards spraying in the nursery, various commercial washes may be used, and of course it may be noted that practical men will differ in their opinion. It will therefore, perhaps, be best to give what may be considered a kind of mixture which can be used with the knapsack spraying arrangement or the hand syringe.

Get an old boiler of, say, 16 gallons capacity. Boil about 7 gallons of soft water; add and well mix in this about $10 \mathrm{lb}$. soft-soap, together with alout 1 gallon of paraffin. Then boil in a separate vessel about $5 \mathrm{lb}$. quassia chips. Strain and add to the above. This will form a kind of stock solution, and when quite cold add and mix well. in about 100 gallons of soft water (three old paraffin casks), and apply with syringe.

As it is very difficult to apply any insectieide to trees collectively, it becomes therefore a question how far we can apply any dressing to ornamental or special trees individually, together with the cost of the 
same. The best report I have received bearing on this is given by my friend Mr Thomas Bond, Lambton Park, Co. Durham, regarding treatment on old beech-trees badly infested with Cryptocorrus fagi. Taking as his guide the Board of Agriculture leaflet No. 140, and the treatment No. 2, which is the same as that given in chap. vi., p. 236, of this work, and mixed on a fairly large scale, he says: "We secured a 25-gallon portable boiler and placed in it the following quantitiesviz., 2 gallons soft water, 4 lb. soft-soap, 4 handfuls sulphur, 4 pints paraffin, and 4 pints turpentine. After boiling and mixing these ingredients, we added 16 gallons of soft water, and then allowed it to cool before application. Then after well churning the mixture we placed some in a paint-pot and rubbed it on the stems and large branches with a large paint-brush, which we found better to use than a whitewash-brush. We had, of course, to use ladders, but we brushed it well into all the crevices of the bark. In this way we went over 60 trees at a cost of about $4 \mathrm{~s}$. per tree, including labour and materials. The operation was begun on the 3rd of May, but was not completed till the 28th of the same month, owing to wet weather retarding the work. In the month of August we noticed very small specks of the 'felt' appearing in the crevices of the bark, possibly coming from larva which had been secure from the reach of the mixture. The treatment was certainly a success, and with another slight application the following year we hope to be able to eradicate the pest. Having regard to the size and value of the trees from a park point of view, the expense was not excessive."

There are, of course, many other practical points which might be enlarged upon that go to keep down the injurious species of insects in this country. We rarely hear of any species becoming such alarming pests in this country as on the Continent or in America. This is probably due to the major portion of our forests being "mixed" woods, as contrasted with "pure" woods abroad. The effect of this is that there is no preponderating advantages to any single species of injurious insect.

Another point of importance which should receive special attention is the encouragement of the various species of birds that live, or partially live, on insects. The destruction of certain species of birds is perhaps necessary in order to protect our fruits, our field crops, or our game-preserves; but on the other hand, the preservation of certain kinds of beneficial birds should be rigidly enforced. The question of 
interfering with the "balince of Xature" is always a serions problen, and great caution, combined with intelligent forethought, should lx: exercised. On the one hand we get certain animals preserved by killing their natural enemies, but on the other hand we may have a direful pest unexpectedly asiort itself as the result of killing natural enemies.

\section{References to Literature consulted.}

Board of Agriculture Leaflets, \&c.

Theobald, Fred. V. A Text-Book of Agricultural Zoology. Chiefly chapter on the prevention and destruction of insect pests. 


\section{CHAPTER XIII.}

\section{BENEFICIAL INSECTS.}

Is the foregoing chapters it will have been noted that all insects considered are injurious to a more or less extent, and the inquiring or philosophic student will naturally ask, Are there no benefieial forest insects? In a general way an affirmative answer may be given, but in defining "beneficial" insects it is necessary that some qualification should be made. Thus we may divide our subject into three main divisions-viz., (1) the question whether insects play any part in the fertilisation of flowers; (2) the part which insects may play in aiding the rapid destruction of certain refuse in the woods; and (3) the very great part played by parasitic insects-i.e., insects living on other insects.

As regards the first division, it may be said that the majority of our forest trees are wind-fertilised, but there are, of course, probably others which are not so, together with many flowering-shrubs, and it is just possible that this may be to some extent an unworked field.

With reference to the second division, it is obvious that we can get into closer association with this part of the subject. Thus, much dead wood is often left lying in woods, and the forester desires its early destruction. Many species of insects may be found within rotting wood which douhtless assist in the disintegration of the parts. This, however, may be considered as having a very indirect bearing, inasmuch as many of those insects found in rotting wood may be looked upon as being there purely for shelter or moisture. One notable exception, however, may be given-viz., the case of any insects which may aid in the destruction of roots left in the ground. In Scotland and the north of England it may be observed that in the roots of Scots pine, after being cut for three or four years, very small, clearcut, gimlet-like holes can be seen in the solid roots. It will be obvious 
to the practical man that the effeet of these holes is to let moisture intu the body of the root, and so hasten its decay. Thus the more rapid destruction of the roots accruing from the insect may well be considered as an advantage.

The insect doing the work referred to is a beetle termed Asemum striatum. The larva is about an inch in length, of a whitish colour, broad at the thoracic portion, and tapering very much in the atuluminal segments.

The beetle is of an oblong shape, a dull-black colour, and deeply sculptured. The legs are brownish-black, with deep-black tarsi.

With reference to the third division of our subject, it may be noted that it can be divided into sub-divisions, as it were-viz, insects which prey directly on other insects, and those which are parasitic, or in many cases indirectly kill other insects.

As regards those which feed directly on injurious insects, perhaps the best example is the Coccinellidæ or "lady-bird" beetles. There are several species of them, and they live on insects, more especially Aphides. They feed on these insects both in the larval and beetle stages. Some species pupate on the leaves of trees, and to a beginner in forest entomology the rolled-up pupa is a somewhat puzzling ohject. These beetles should be carefully studied in every letail, for not only are they very good friends, but the males often differ so much from the females that they may at first be mistaken for distinct species.

Many of the Colonial writers give very interesting accounts of the great advantages of introducing a species of lady-bird or Vedalia (Novius cardinalis), the notorious Australian bug destroyer. The bug referred to has been kept in check in many parts of the world by the Vedalia. So that a very good hint is given to encourage ladybird beetles.

The field of beneficial beetles in forest entomology is rather an unworked one, and Mr R. S. Bagnall has recently demonstrated this by showing that the beetle Epurcea angustala is a parasite on the genus Trypodendron, and this obriously suggests that the parasites of the Scolytidæ are entirely an unworked field.

There are many other species of beetles which might be well considered as beneficial, as, for example, many of the ground-beetles, which live on the larvæ of various insects, or other creatures, which in turn feed on the roots of young trees in the nursery.

The larvæ of some species of Diptera are very beneficial in 
keeping down green-fly, \&c., and may often be found amongst these pests.

The most important parasite insects belong to the order Hymenoptera, and the following concise account of the families which may be considered as beneficial is taken from Professor Carpenter's work on 'Insects, their Structure and Life':-

"Ichneumonidæ.-The Icleneumonitle or Ichneumon-flies are an exceedingly large family. The feelers are straight, long, and manyjointed, tapering towards the tip; three ocelli are always present on the crown. The wings have for the Hymenoptera a complex neuration; a distinguishing character is the presence of two cells between the cubitals and the second posterior cell (at the anal angle of the fore-wing). Rarely wings are quite absent. The stalk of the elongate hind-body is attached to the lower or hinder of the first abdominal segment, which is very large, while the metathorax is relatively short, so that the middle and hind pairs of legs are inserted close together. The trochanters have two segments. The females are provided with ovipositors, which in some cases are several times as long as the body: by means of these they lay their eggs in the bodies of caterpillars. The forms with exceptionally long ovipositors, such as Rhyssa, prey upon wood-boring grubs: this species lays her eggs in the burrows of Sirex, on whose grubs her larvæ feed as external parasites. In most cases, however, the Ichneumon maggots feed interually on the juices of their victims. Over 6000 species of Ichneumonidæe are already known, and the family is distributed in all parts of the world.

"Braconidæ.--The Braconitce are a large family, closely allied to the Ichneumonide, but distinguished by having only a single cell on the fore-wing, between the cubitals and the second posterior cell. The larve live like those of the Ichneumons, and the range of the family is equally wide.

"Chalcididæ.-The Chatcididte are a very large family of small Hymenoptera, distinguished from all the preceding families of Petiolata by their elbowed feelers, which have from seven to thirteen segments. The pronotum is partially free, and does not reach back to the insertion of the fore-wings. The neuration is very simple: a single thick nervure runs from the base of the wing to the costa, giving off at its termination a very short branch. The trochanters are divided. The Chalcididæ are frequently of brilliant metallic 
colours. Over 4000 species have already heen deseriberl, and they occur in all parts of the world. The eggs are laid in galls, or in nests of the higher IIymenoptera, so that the larva may feed on the contained maggot. Some species attack the caterpillars of moth:, aml others, like Chalcis ovcta, feed in pupr.

"Proctotrypidæ. - The Proctotrypile" are a lange family of small Hymenoptera, distinguished from the Chaldivlider by the pronotum being closely fused with the mesothorax, and reaching back to the bases of the fore-wings. The neuration varies greatly : in some generat a few nervures and cells are present; in others, none. The hind-holly is pointed at the tip, and the ovipositor is tubular. The trochanters are usually segmented, but in some genera they are simple. The larve live parasitically within the bodies of insects; those of some very minute species find food enough in other insects' egrss. In some Prortotiyluide the larva in its first stage is broad in front, and taper's behind to a point whence spring several tail-processes; this is ultimately changed into the ordinary Hymenopterous maggot. Some genera of the sub-family M!nmarine, tiny and delicate insects with narrow wings fringed with long hairs, are aquatic in their habits, and their larvæ are believed to feed in the eggs of dragon-flies. The Proctotrypidce have a world-wide range, and nust number many thousands of species."

The above remarks are given simply with the idea of suggesting the field of study for the student. As a general rule, the student will find sufticient scope, along with other subjects, in confining himself entirely to the injurious species. If, however, he can possibly study "beneficial insects" as here indicated, he will find the best method of doing so to simply collect the various species in the hatching-boxes. In the case of some insects this is specially interesting, as for example in the "oak-apple" gall, from which various parasites hatch out nearly all the year round. Again, it may be said that it is essential to know something of parasites, as, to a beginner, they may often in the hatching-box be mistaken for the real injurious species. It is also of considerable importance to study parasites, as in certain cases they may change their habits, as, for example, in Megatigmus, which has been long known as a parasite on "oak galls," and recently has been discovered as a deadly enemy to the seeds of Douglas fir. 


\section{CHAPTER XIV.}

\section{LIST OF TREES WITH INJURIOUS INSECTS.}

The following "list" is given in order that the student may more readily identify the insect from the damage. Almost every reader will be able to determine different trees, and the insect may therefore be recognised from the brief note defining the nature of the injury, or otherwise guiding the student as to where to refer for descriptive information.

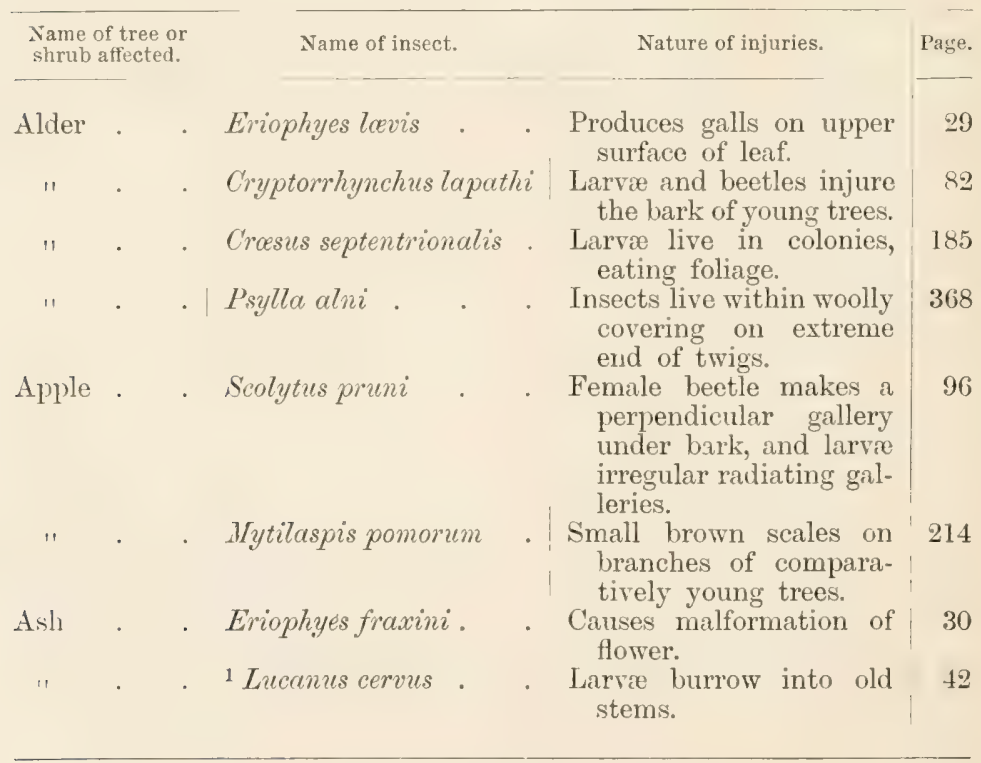

1 Also found on oak, hornbeam, holly, and beech. 


\begin{tabular}{|c|c|c|c|c|c|}
\hline \multicolumn{3}{|c|}{$\begin{array}{l}\text { Name of tree or } \\
\text { shrub affecter. }\end{array}$} & Name of insect. & Nature of injuries & l'age. \\
\hline Ash & . & . & $\begin{array}{l}{ }^{1} \text { Sinodendron cylindri- } \\
\text { cum. }\end{array}$ & Larve burrow in the bark & 43 \\
\hline " & . & . & Rhagium inquisitor. & $\begin{array}{l}\text { Larve live under bark of } \\
\text { decayed logs. }\end{array}$ & 56 \\
\hline$" 1$ & . & . & Hylesinus crenatus & $\begin{array}{l}\text { Female makes short gal- } \\
\text { leries under thick bark } \\
\text { of old trees. Larva } \\
\text { make irregular galleries. }\end{array}$ & 101 \\
\hline " & . & & " fraxini. & $\begin{array}{l}\text { Female beetle makes a } \\
\text { double-armed gallery } \\
\text { under bark. Larve } \\
\text { make galleries at right } \\
\text { angles to mother gallery. }\end{array}$ & 103 \\
\hline$" 1$ & . & . & " oleiperda & $\begin{array}{l}\text { Female beetle burrows in } \\
\text { small twigs and larva } \\
\text { make irregular galleries. }\end{array}$ & 105 \\
\hline 11 & & & Tespa Crabro (hornet). & $\begin{array}{l}\text { Insect damages bark of } \\
\text { young trees. }\end{array}$ & 192 \\
\hline$"$ & - & . & Chionaspis salicis. & $\begin{array}{l}\text { Small white scales on } \\
\text { stems of comparatively } \\
\text { young trees. }\end{array}$ & 209 \\
\hline " & . & . & Apterococcus fraxini & $\begin{array}{l}\text { White scales on bark of } \\
\text { old trees. }\end{array}$ & 238 \\
\hline " & . & . & 2 Zeuzera cesculi. & $\begin{array}{l}\text { Larva burrow in young } \\
\text { stems or branches. }\end{array}$ & 247 \\
\hline " & . & . & Prays curtisellus & $\begin{array}{l}\text { Larva lives in leading bud } \\
\text { of young tree, which it } \\
\text { kills, and thus causes a } \\
\text { forked stem. }\end{array}$ & 273 \\
\hline " & . & . & Diplosis botularice. & $\begin{array}{l}\text { Insects form pea-pod-like } \\
\text { galls through foldings } \\
\text { of leaf. }\end{array}$ & 351 \\
\hline$" 1$ & . & . & Bibio marci. & $\begin{array}{l}\text { Larvæ eat roots of young } \\
\text { plants in nursery. }\end{array}$ & 361 \\
\hline$" 1$ & . & . & Psyllopsis fraxinicola & $\begin{array}{l}\text { Insects found on foliage } \\
\text { during summer. }\end{array}$ & 364 \\
\hline 11 & . & & fraxini & $\begin{array}{l}\text { Insects cause leaflets to } \\
\text { roll. The rollings are } \\
\text { of a brown variegated } \\
\text { colour. }\end{array}$ & $36 \pm$ \\
\hline Beech & . & & Doreus parallelopipedus & $\begin{array}{l}\text { Larva bore into back- } \\
\text { going trees. }\end{array}$ & 43 \\
\hline " & . & & 3 Melolontha vulgaris & Larva feed on roots. & 44 \\
\hline " & . & . & + Agrilus viridis & $\begin{array}{l}\text { Injures the bark of stems } \\
\text { of young trees. }\end{array}$ & 48 \\
\hline
\end{tabular}

1 Also on beech and holly.

2 Also found on elm, sycamore, hawthorn, and several other trees.

3 Injurious to practically all nursery stock. "Rare; found only in south of Fngland. 


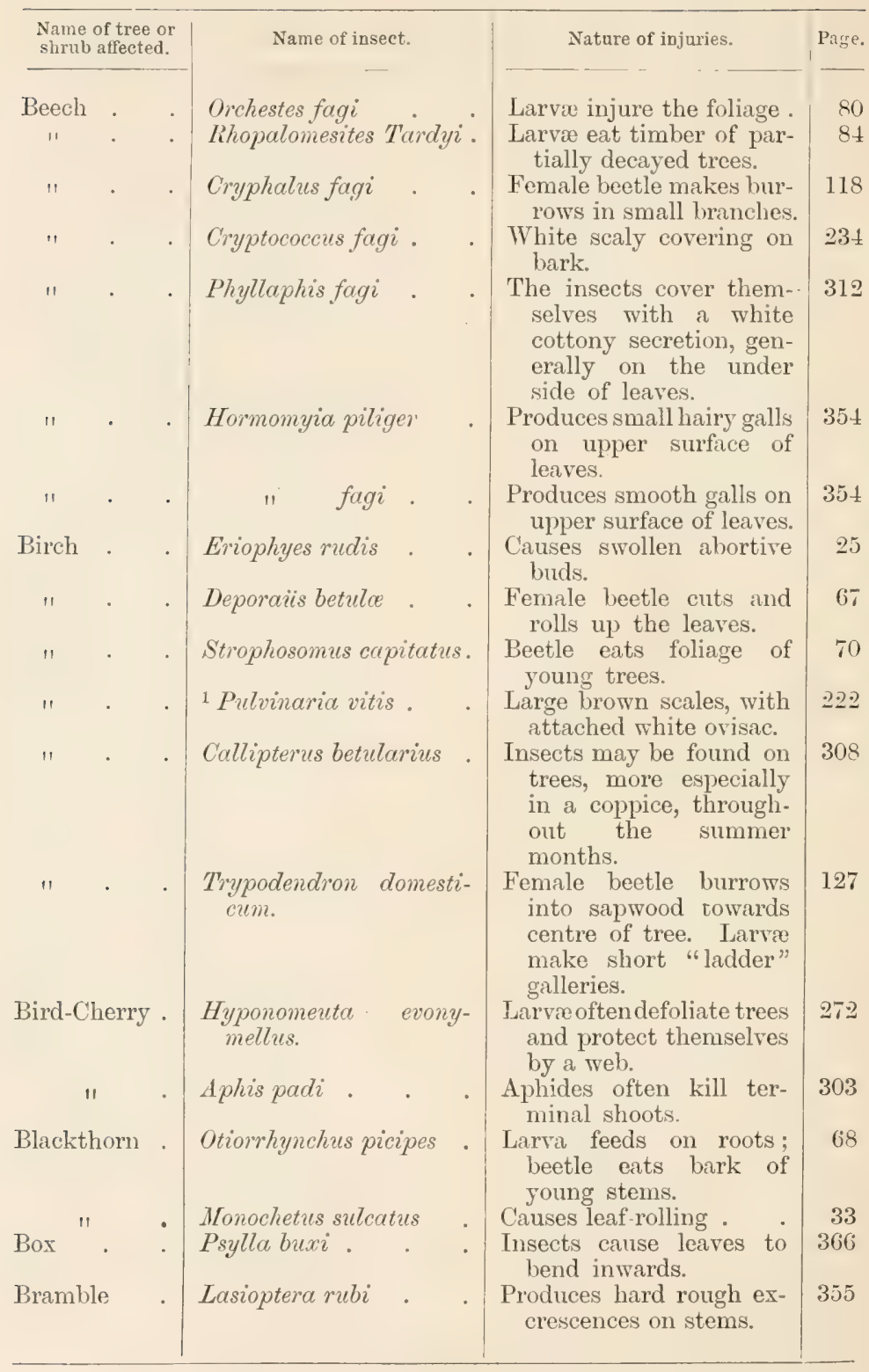

1 Also on hawthorn, hazel, willow, alder, \&c. 


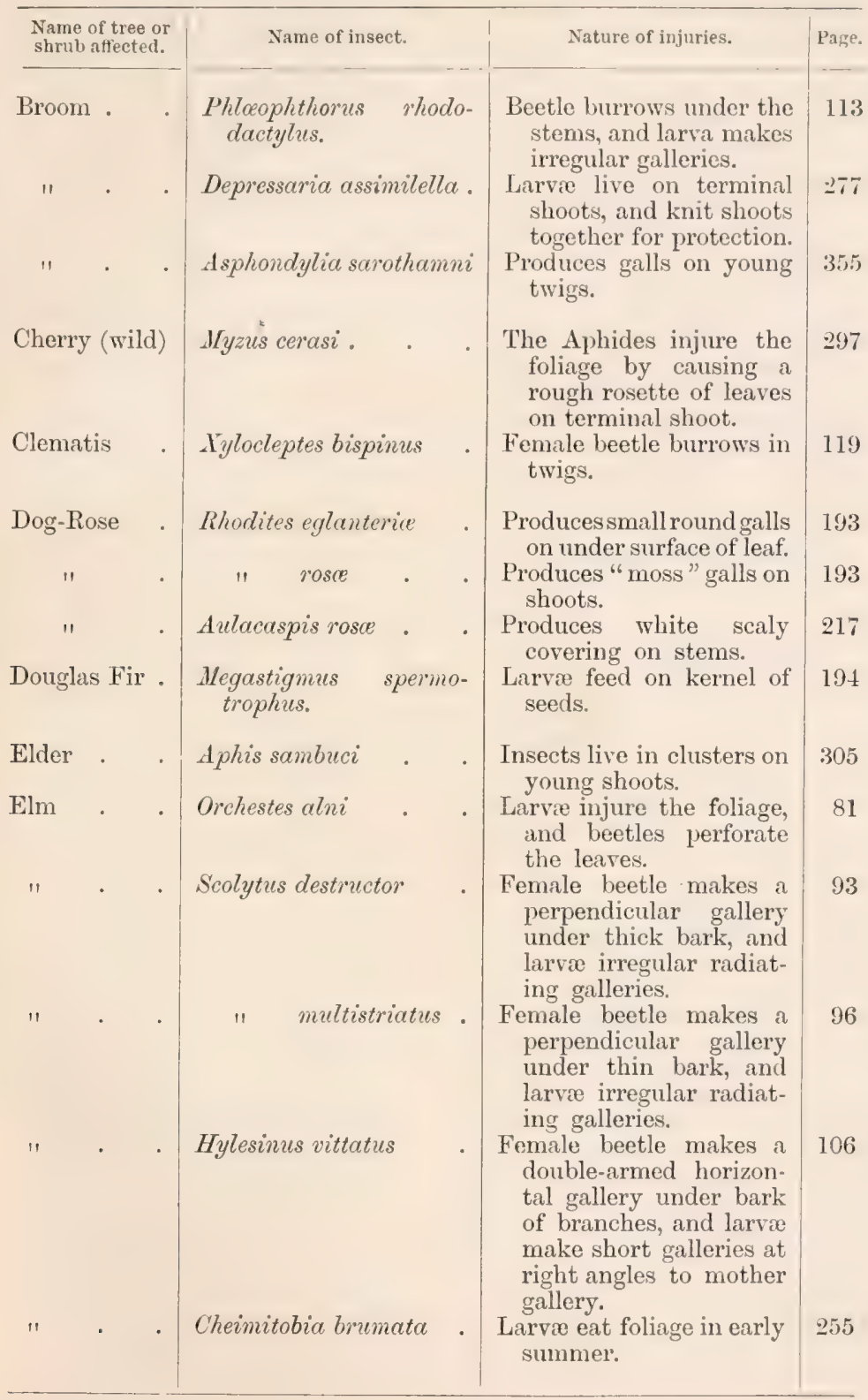




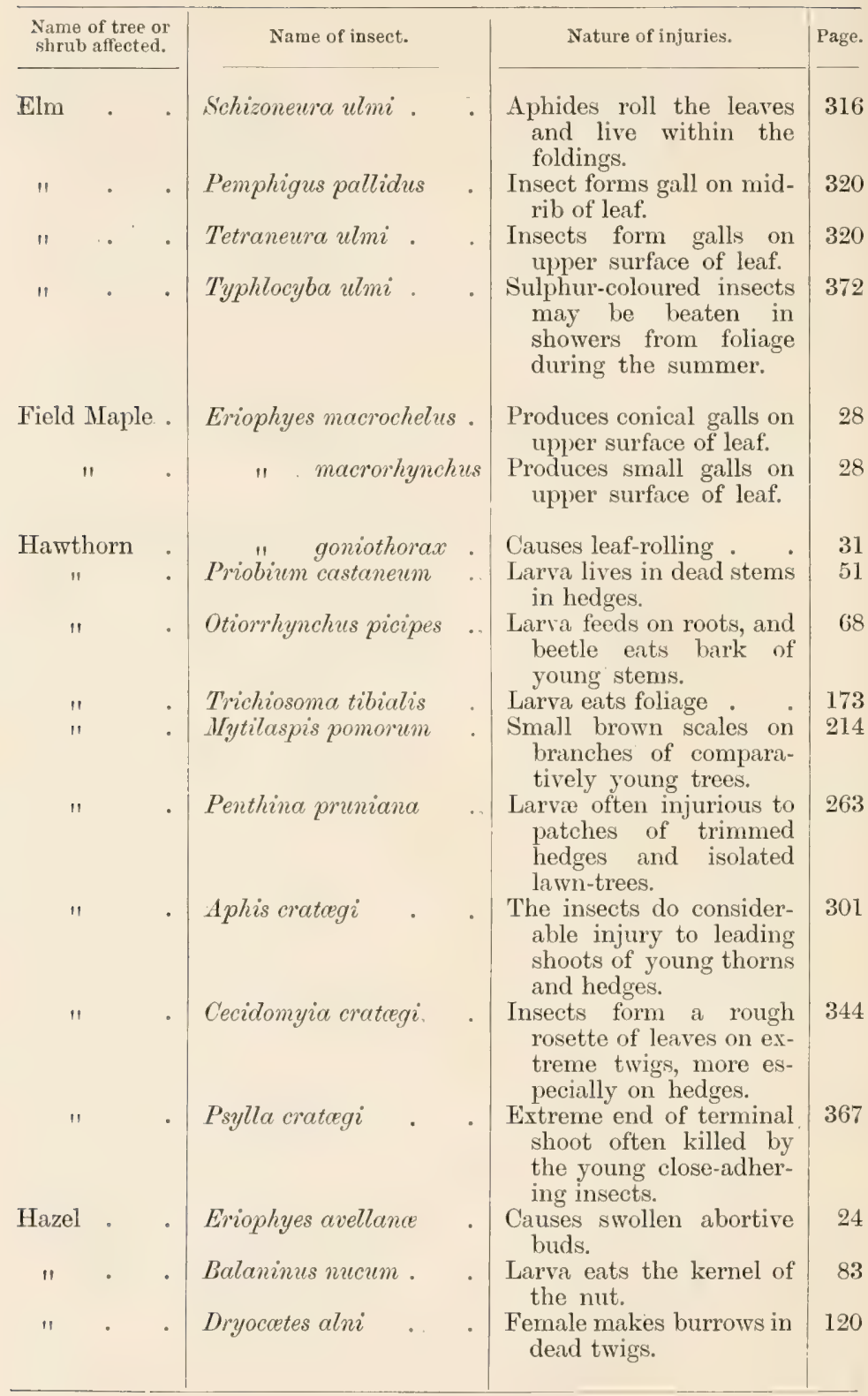




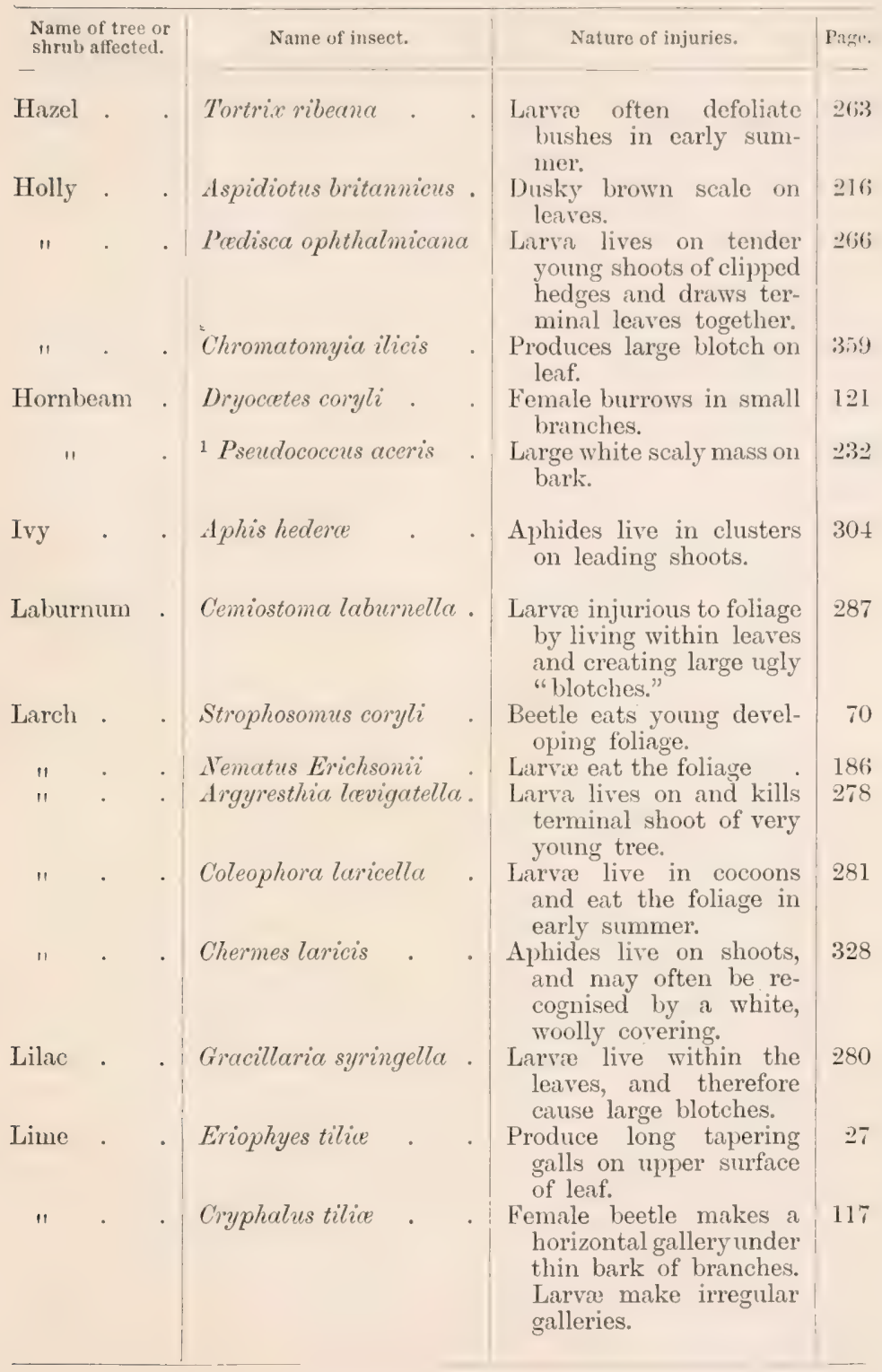

1 Also on sycamore, oak, ash, elm, gorse, \&c. 


\begin{tabular}{|c|c|c|c|c|}
\hline \multicolumn{2}{|c|}{$\begin{array}{l}\text { Name of tree or } \\
\text { shrub affected. }\end{array}$} & Name of insect. & Nature of injuries. & \multirow{2}{*}{$\begin{array}{r}\text { Page. } \\
255\end{array}$} \\
\hline Lime & - & Cheimitobia brumata & $\begin{array}{l}\text { Larvo eat foliage in early } \\
\text { summer. }\end{array}$ & \\
\hline 11 & - & Pterocellis tilice . & $\begin{array}{l}\text { Aphides common under } \\
\text { foliage. }\end{array}$ & 309 \\
\hline 11 & - & Cecidomyia tiliam volens & $\begin{array}{l}\text { Insects roll leaves, or } \\
\text { otherwise form galls } \\
\text { on extreme tips of } \\
\text { twigs. }\end{array}$ & 350 \\
\hline Moun & ain-Ash & Eriophyes aucuparioe . & $\begin{array}{l}\text { Causes surface injuries } \\
\text { to leaves. }\end{array}$ & 32 \\
\hline & 11 & Pliyllobius maculicornis & Beetle feeds on foliage . & 71 \\
\hline Oak & . & ${ }^{1}$ Prionus corarius. & $\begin{array}{l}\text { Larvæ bore into living } \\
\text { trees. }\end{array}$ & 54 \\
\hline$" 1$ & . & Attelabus curculionides. & $\begin{array}{l}\text { Female beetle makes } \\
\text { "thimble case" by roll- } \\
\text { ing up the leaf. }\end{array}$ & 66 \\
\hline " & . & Polydrusus micans & Beetle feeds on leaves & 71 \\
\hline " & . & Orchestes quercits. & $\begin{array}{l}\text { Larva injure the foli- } \\
\text { age. }\end{array}$ & 81 \\
\hline$" 1$ & - & Scolytus intricatus & $\begin{array}{l}\text { Female beetle makes a } \\
\text { short horizontal gallery } \\
\text { under bark, and larvæ } \\
\text { make long galleries at } \\
\text { right angles to mother } \\
\text { gallery. }\end{array}$ & 97 \\
\hline$" 1$ & . & Dryoccetes villosus. & $\begin{array}{l}\text { Female burrows in thick } \\
\text { bark of old dead trees } \\
\text { or under bark of dead } \\
\text { standing trees. }\end{array}$ & 120 \\
\hline 11 & . & $\begin{array}{l}\text { Trypodendron domesti- } \\
\text { cum. }\end{array}$ & $\begin{array}{l}\text { Female beetle burrows } \\
\text { into sapwood towards } \\
\text { centre of tree. Larva } \\
\text { make short ladder } \\
\text { galleries. }\end{array}$ & 127 \\
\hline 11 & . & Iyleborus dispar. & $\begin{array}{l}\text { Female bores into stem } \\
\text { of young tree. Larva } \\
\text { make galleries at right } \\
\text { angles to mother gal- } \\
\text { lery. }\end{array}$ & 128 \\
\hline 11 & . & Neuroterus lenticularis. & $\begin{array}{l}\text { Produces "spangle galls" } \\
\text { on under side of leaf. } \\
\text { Galls raised in centre; } \\
\text { flat at outer edge, and } \\
\text { covered with stellate } \\
\text { hairs. }\end{array}$ & 140 \\
\hline
\end{tabular}

1 Rare; confined to south of England. 


\begin{tabular}{|c|c|c|c|c|c|c|}
\hline \multicolumn{3}{|c|}{$\begin{array}{l}\text { Name of tree or } \\
\text { slirub atfected. }\end{array}$} & \multicolumn{2}{|l|}{ Name of insect. } & Nature of injuries. & l'age. \\
\hline Oak & . & - & Spathegaster bacearum & & $\begin{array}{l}\text { Produces "currant galls" } \\
\text { on flowers or leaves. } \\
\text { Galls globular, soft, } \\
\text { and succulent. }\end{array}$ & 143 \\
\hline 11 & - & . & Neuroterus fumipennis & & $\begin{array}{l}\text { Produces galls on under } \\
\text { side of leaf. Centre of } \\
\text { gall concave, edges con- } \\
\text { spicuously turned up. }\end{array}$ & 144 \\
\hline 11 & $\cdot$ & . & Spathegaster tricolor & - & $\begin{array}{l}\text { Produces galls on under } \\
\text { side of leaf; in clusters, } \\
\text { and hairy. }\end{array}$ & 145 \\
\hline$" 1$ & $\cdot$ & . & Neuroterus leviusculus & . & $\begin{array}{l}\text { Produces galls on under } \\
\text { side of leaf. Galls are } \\
\text { nearly smooth, white } \\
\text { or yellowish, the outer } \\
\text { edge turned up. }\end{array}$ & 145 \\
\hline$" 1$ & · & - & Spathegaster albipes & . & $\begin{array}{l}\text { Produces spindle-shaped, } \\
\text { smooth galls, causing } \\
\text { fairly deep indenta- } \\
\text { tions of leaf. }\end{array}$ & 145 \\
\hline 11 & - & - & Neurotemes numismatis & & $\begin{array}{l}\text { Produces "button galls" } \\
\text { on under side of leaf. } \\
\text { Galls are depressed in } \\
\text { centre, surface covered } \\
\text { like silk velvet. }\end{array}$ & 146 \\
\hline 11 & - & - & ostreus. & - & $\begin{array}{l}\text { Produces small, spotted, } \\
\text { pellet-like gall on mid- } \\
\text { rib of leaf. }\end{array}$ & 146 \\
\hline 11 & • & - & Spathegaster aprilinus & . & $\begin{array}{l}\text { Produces"thin" galls, pre- } \\
\text { senting the appearance } \\
\text { of an undereloped bud. }\end{array}$ & 147 \\
\hline " & - & . & Aphilothrix radicis & - & $\begin{array}{l}\text { Produces large many- } \\
\text { chambered galls at } \\
\text { base of trumk near } \\
\text { surface of roots. }\end{array}$ & 147 \\
\hline 11 & - & . & corticis & - & $\begin{array}{l}\text { Produces galls in young } \\
\text { bark around a pruned } \\
\text { branch. }\end{array}$ & 148 \\
\hline "1 & • & · & globuli & - & $\begin{array}{l}\text { Produces globular green } \\
\text { galls, projecting from } \\
\text { bud scales. }\end{array}$ & 148 \\
\hline$" 1$ & . & - & Andricus inflator. & . & $\begin{array}{l}\text { Produces galls in inflated } \\
\text { portion of the terminal } \\
\text { twig. }\end{array}$ & 149 \\
\hline "1 & $\cdot$ & & curvator. & . & $\begin{array}{l}\text { Produces galls on leaf, } \\
\text { causing an irregu- } \\
\text { lar globular swelling. } \\
\text { These galls have al- } \\
\text { ways an inner gall. }\end{array}$ & 150 \\
\hline
\end{tabular}




\begin{tabular}{|c|c|c|c|c|}
\hline \multicolumn{2}{|c|}{$\begin{array}{l}\text { Name of tree or } \\
\text { shrub affected. }\end{array}$} & Name of insect. & Nature of injuries. & Pagne. \\
\hline Oak & . & $\begin{array}{c}\text { Aphilothrix quadritin- } \\
\text { eata. }\end{array}$ & $\begin{array}{l}\text { Produces small, ovoid, } \\
\text { ribbed galls on flowers. }\end{array}$ & 151 \\
\hline 11 & . & " albopunctata & $\begin{array}{l}\text { Produces ovoid, green, } \\
\text { smooth, hard galls in } \\
\text { buds. }\end{array}$ & 152 \\
\hline "1 & . & Andricus ramuli . & $\begin{array}{l}\text { Produces gall like a ball } \\
\text { of cotton on flowers. }\end{array}$ & 152 \\
\hline$"$ & . & Aphilothrix fecundatrix & $\begin{array}{l}\text { Produces gall wholly en- } \\
\text { veloped in leaf scales. }\end{array}$ & 152 \\
\hline "1 & . & Dryophanta scutellaris & $\begin{array}{l}\text { Produces cherry-like gall } \\
\text { on under surface of } \\
\text { leaf. }\end{array}$ & 153 \\
\hline$"$ & . & longiventris & $\begin{array}{l}\text { Produces a hard, reddish, } \\
\text { striped gall on under } \\
\text { surface of leaf. }\end{array}$ & 154 \\
\hline$" 1$ & - & divisa & $\begin{array}{l}\text { Produces small, hard galls } \\
\text { on under surface of } \\
\text { leaf. }\end{array}$ & 154 \\
\hline " & - & Biorthiza aptera . & $\begin{array}{l}\text { Produces irregular clus- } \\
\text { ters of galls on roots } \\
\text { of old trees. }\end{array}$ & 155 \\
\hline$"$ & . & Teras terminalis. & $\begin{array}{l}\text { Produces large, soft, } \\
\text { apple-like galls on ter- } \\
\text { minal or lateral buds } \\
\text { or terminal shoots. }\end{array}$ & 156 \\
\hline$" 1$ & . & Biorhiza renum. & $\begin{array}{l}\text { Produces kidney-shaped } \\
\text { galls on veins of leaf. }\end{array}$ & 157 \\
\hline 11 & . & Cynips Kollari & $\begin{array}{l}\text { Produces marble - like } \\
\text { galls on twigs of young } \\
\text { trees. }\end{array}$ & 158 \\
\hline "1 & . & Aspidiotus zonatus & $\begin{array}{l}\text { Circular brown scales of } \\
\text { female on stems and } \\
\text { small scales of male on } \\
\text { leaves. }\end{array}$ & 216 \\
\hline$"$ & . & $\begin{array}{l}\text { Asterolecanium vario- } \\
\text { losum. }\end{array}$ & $\begin{array}{l}\text { Scales produce pitted de- } \\
\text { pressions on extreme } \\
\text { twigs. }\end{array}$ & 231 \\
\hline$"$ & - & Cossus ligniperda. & $\begin{array}{l}\text { Larvie burrow in stems } \\
\text { of old trees. }\end{array}$ & 245 \\
\hline " & - & Orgyia antiqua & Larvæ eat foliage : & 248 \\
\hline$" 1$ & . & Pygcera bucephala & $\begin{array}{l}\text { Larva live gregariously, } \\
\text { and often defoliate } \\
\text { isolated branches or } \\
\text { whole trees. }\end{array}$ & 251 \\
\hline$"$ & . & Tortix viridana . & $\begin{array}{l}\text { Larve often defoliate } \\
\text { trees in early summer. }\end{array}$ & 260 \\
\hline $11(\mathrm{er}$ & rgreen) & Lithocolletis messaniella & $\begin{array}{l}\text { Larva lives within a } \\
\text { "blotch," generally on } \\
\text { under side of leaf. }\end{array}$ & 285 \\
\hline
\end{tabular}




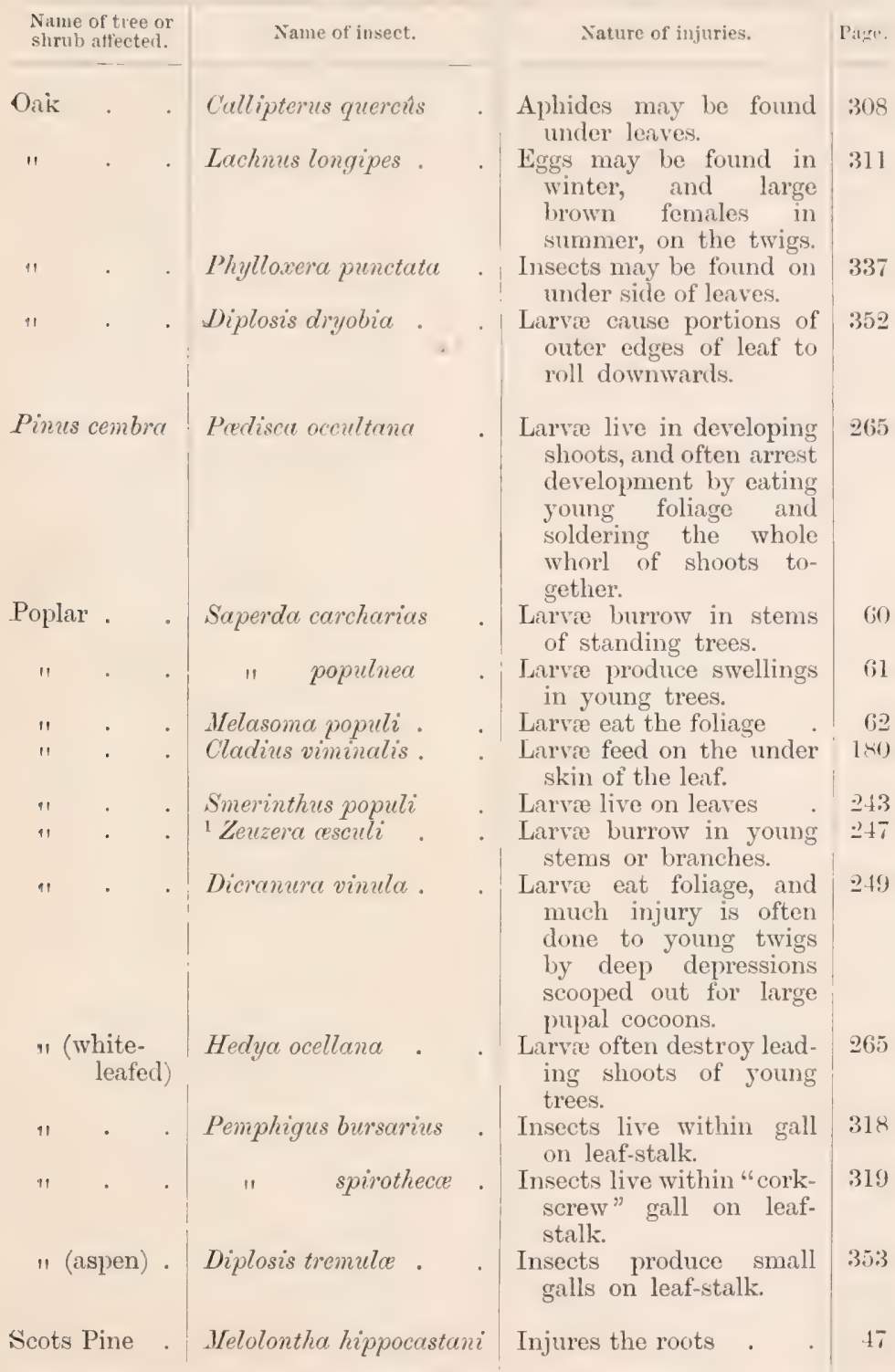

${ }^{1}$ Also on elm, sycamore, hawthorn, and several other trees. 


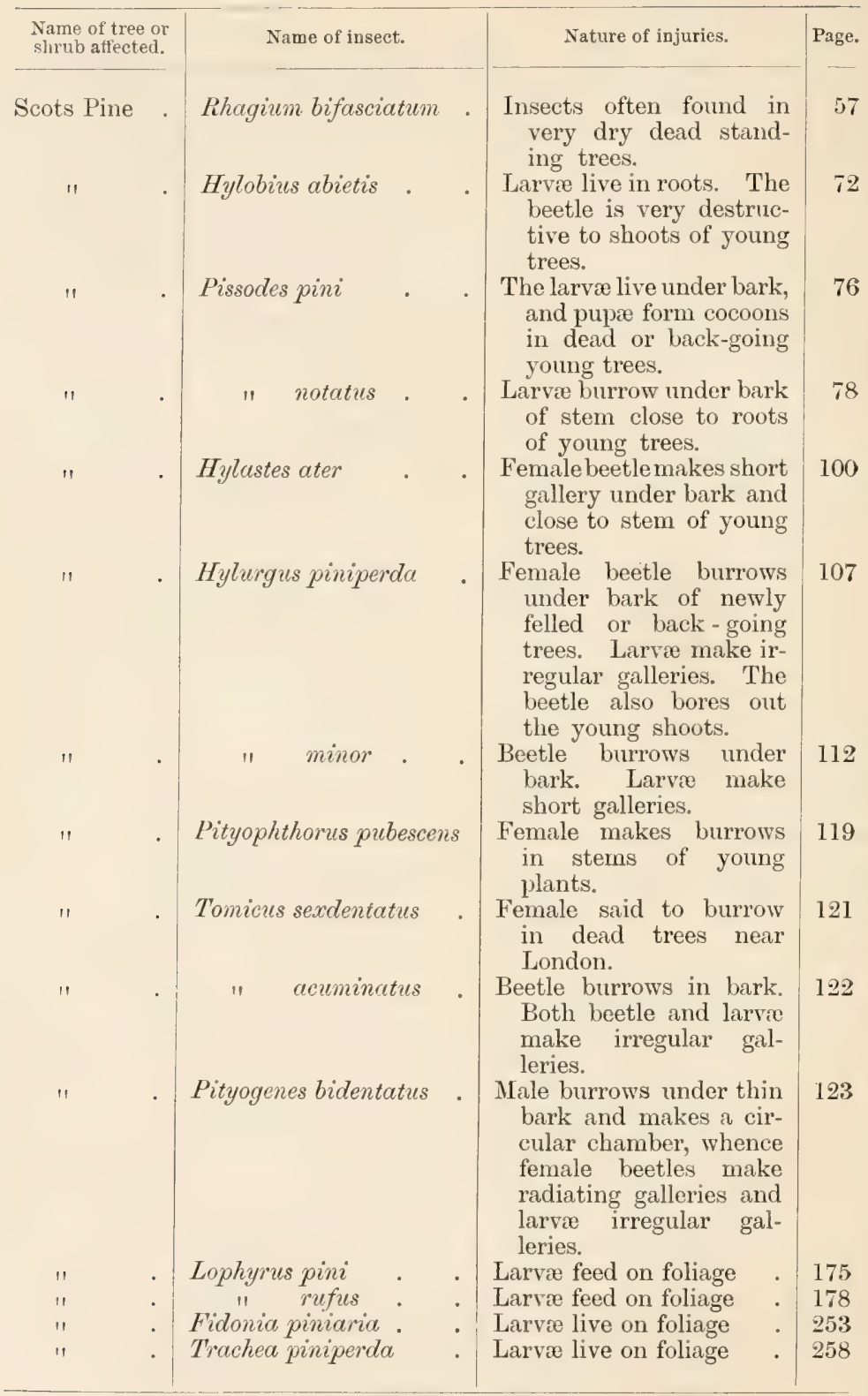




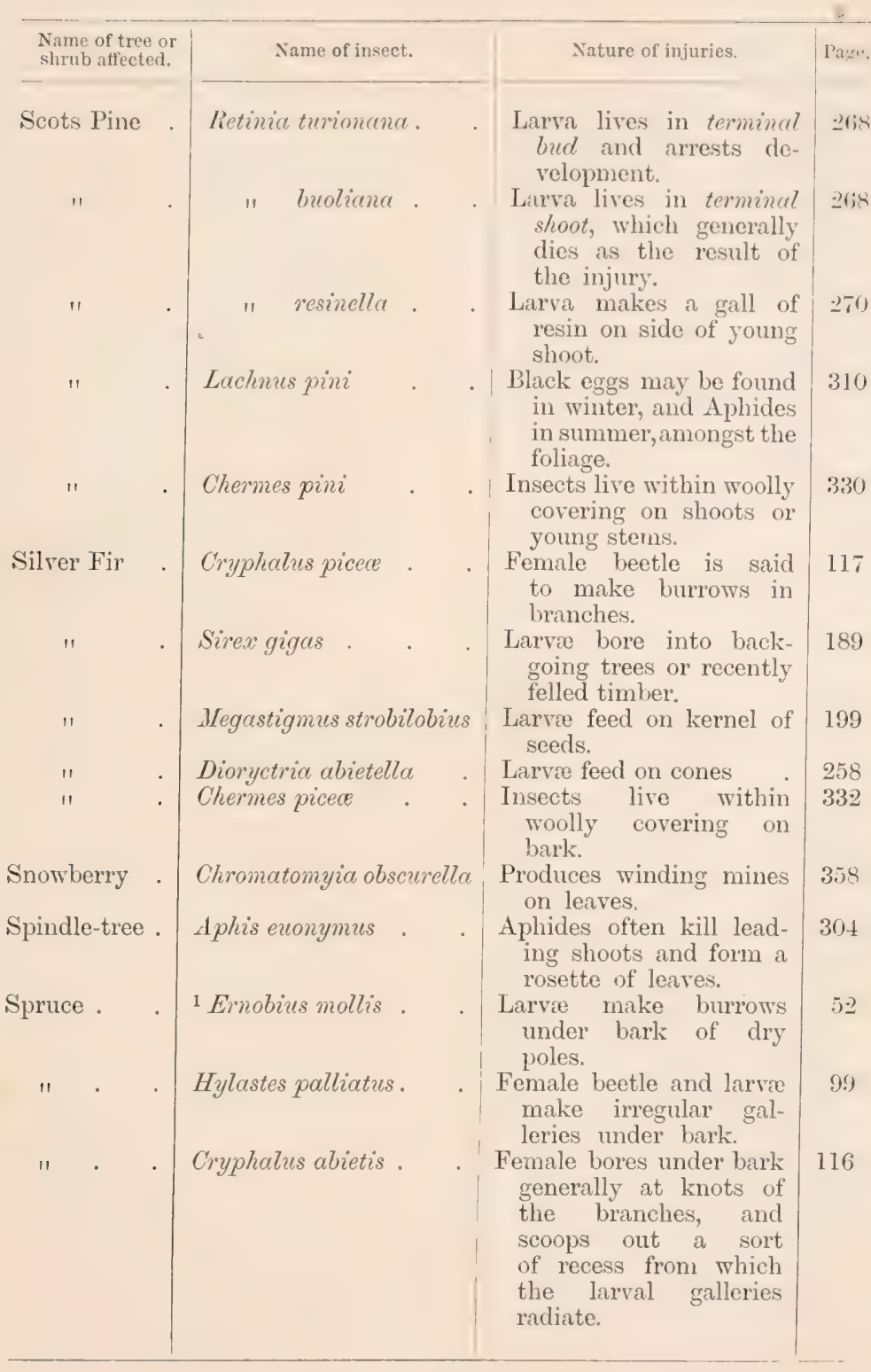

1 Also under bark of larch paling. 


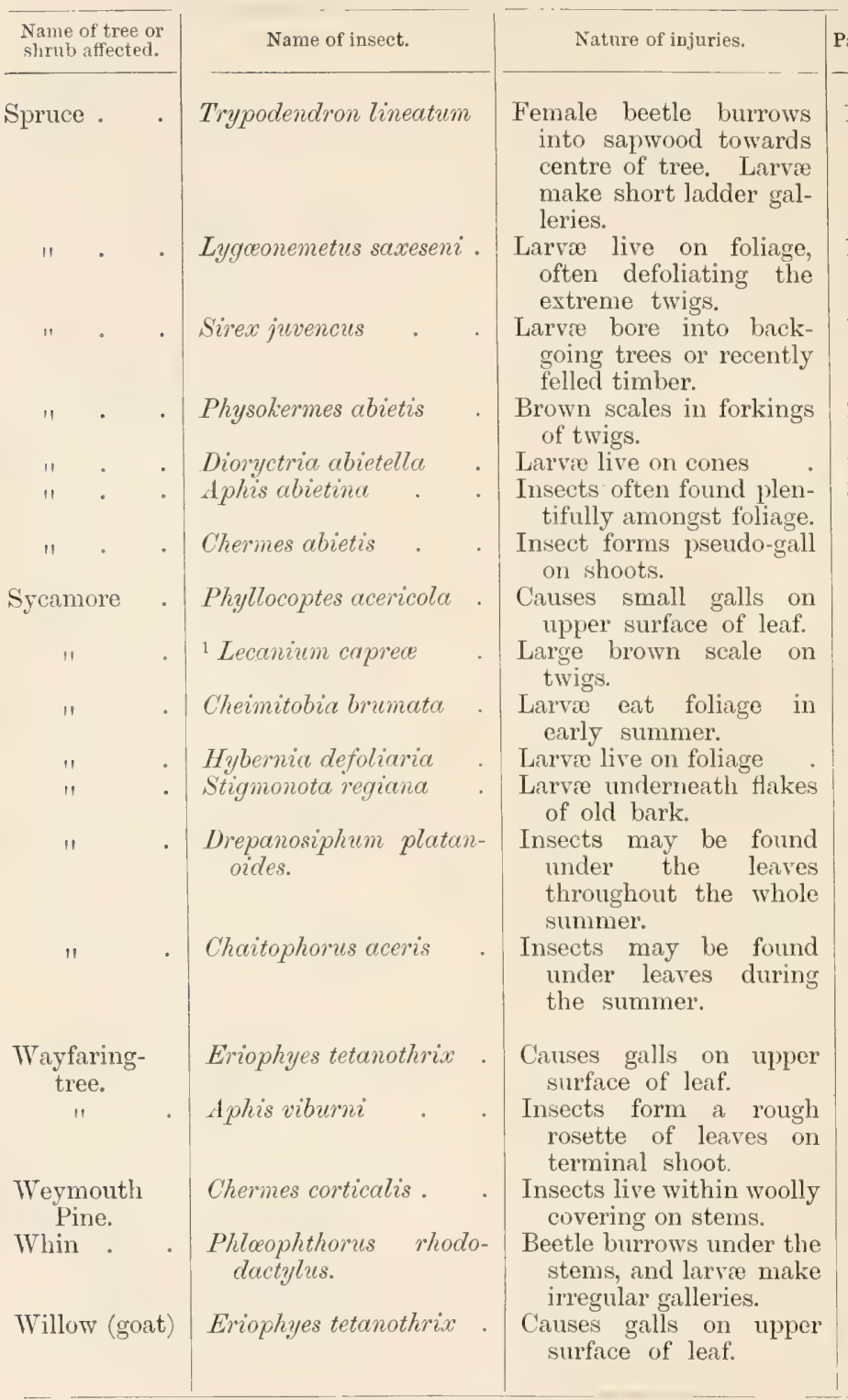

1 Also on hawthorn, apple, oak, elm, chestnut, lime, \&c. 


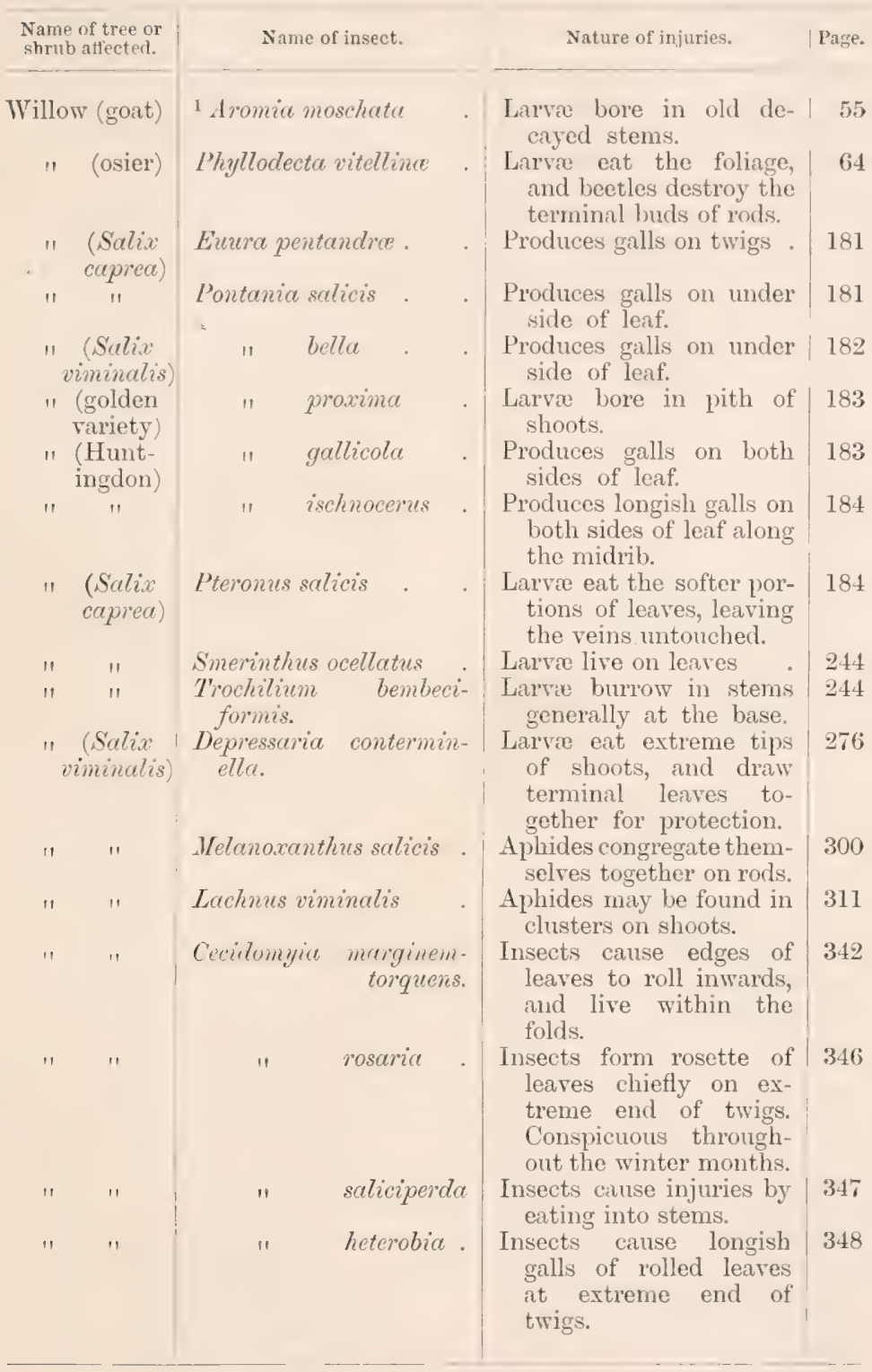

1 Also attacks lime-trees. 
FOREST ENTOMOLOGY.

\begin{tabular}{|c|c|c|c|c|c|}
\hline \multicolumn{2}{|c|}{$\begin{array}{l}\text { Name of tree or } \\
\text { shrub affected. }\end{array}$} & \multicolumn{2}{|l|}{ Name of insect. } & Nature of injuries. & Page. \\
\hline \multicolumn{2}{|c|}{$\begin{array}{l}\text { Willow (Salix } \\
\text { viminalis) }\end{array}$} & Cecidomyia salicis & & $\begin{array}{l}\text { Insects produce galls by } \\
\text { swellings on twigs. }\end{array}$ & 349 \\
\hline$" 1$ & 11 & Hormomyia caprea & & $\begin{array}{l}\text { Produces hard galls on } \\
\text { midrib of leaves. }\end{array}$ & 354 \\
\hline$" 1$ & " & Agromyza schineri & & $\begin{array}{l}\text { Produces irregular galls } \\
\text { on stems. }\end{array}$ & $3 \pi 7$ \\
\hline Yew & & & & $\begin{array}{l}\text { Cause swollen abortive } \\
\text { buds. }\end{array}$ & 26 \\
\hline 11 & . & Batodes angustiorana & & $\begin{array}{l}\text { Larve live throughout } \\
\text { the winter in rough } \\
\text { cocoons on under side } \\
\text { of foliage. In summer } \\
\text { injuries of larvæ are } \\
\text { conspicuous by dead } \\
\text { twigs. }\end{array}$ & 265 \\
\hline 11 & . & Cecidomyia taxi & & $\begin{array}{l}\text { Insects form rosette of } \\
\text { leaves chiefly on ex- } \\
\text { treme end of twigs. }\end{array}$ & 345 \\
\hline
\end{tabular}




\section{N D E X.}

Note. - The names of insects given as synonyms throughout the book and names not at present generally adopted are printed in italics.

Abdomen, 11

Abnormal buds, 20

Acanthocinus æedilis, 58

Agrilus viridis, 48

Agromyzidæ, characters of family, 357

Agromyza schineri, 357

Aleyrodidæ, 204

Andricus curvator, 150

fecundatrix, 152

gemmatus, 148

inflator, 149

noduli, 148

ramuli, 152

Anobiidæe family, 50

Anobiina, generic divisions and characters of, 51

Antennie, typical, 10

Aphididx, general characters of, 290 honey-dew of, 292

oviparous and viviparous, 295

sub-families of, 296

Aphilothrix albopunctata, 152

collaris, 149

corticis, 148

fecundatrix, 152

globuli, 148

quadrilineata, 151

radicis, 147

Aphis, characters of genus, 301

abietina, 304

cratigi, 301

euonymus, 304

hederæ, 304

padi, 303 sambuci, 305

viburni, 305

Apterococcus fraxini, 238

Argyresthia, generic characters of, 278

lævigatella, 278

Aromia moschata, 55

Arthropoda, divisions of, 3

Asemum striatum, 399

Ash-bark beetles, 101

Ash-bud Moth, 273

Asphondylia sarothamni, 355

Aspidiotus, generic characters of, 215 britannicus, 216

zonatus, 216

Asterolecanium, generic characters of, 231

variolosum, 231

Astinomus cedilis, 58

Attelabus curculionides, 66

Aulacaspis rosæ, 217

Balaninus, generic characters of, 83 nucum, 83

Bark beetles, descriptive characters of, 85

Batodes angustiorana, 265

Beech Agrilus, 48

Beetles, descriptive details of, 37 classification of, 40

Beneficial insects, 398

Bibionidre, characters of family, 360

Bibio marei, 361

Biorhiza aptera, 154 renum, 157 
Blind bud of currant, 19

Bordered White Moth, 253

Braconidæ, 400

Breathing organs, 12

Buff-tip Moth, 251

Butterfly, development of, 7

Callipterus, characters of genus, 307 betularius, 308 quercûs, $30 \mathrm{~s}$

Cecidomyidre, characters of family, 341

Cecidomyia, characters of genus, 341 cratægi, 344

marginemtorquens, 342

piceæ, 357

rosaria, 346

saliciperda, 347

salicis, 349

taxi, 345

tiliam volens, 350

Cemiostoma laburnella, 287

Cerambycidie, 55

Cerataphis latanix, 204

Ceratoneon vulgare, 34

Cerura vinula, 249

Chaitophorus, characters of genus, 306

abnormal form of, 306 aceris, 305

Chalcidide, 139, 400

Cheimitobia brumata, 255

Chermesinæ, characters of tribe, 321

Chermes, characters of genus, 323

importance of genus in forestry, 333

abietis, 324

corticalis, 331

laricis, 328

picere, 332

pini, 330

strobilobius, 326

Chionaspis, characters of genus, 208 salicis, 209

Chromatomyia obscurella, 358 ilicis, 359

Chrysomelina, 62

Cicadidæ, 369

Cimbicides, 172

Cladius viminalis, 180

Clay-coloured weevil, $6 \mathrm{~s}$

Clinodiplosis botularia, 351

Clytus arietis, 55
Coccidæ, general characters of, 201, 205

synopsis of sub-families, 205

Cockchafer, 44 preventive and remedial measures against, 46

Coleophora, generic characters of, 281

fuscedinella, 284

laricella, 281

sp., 284

Coleoptera, 37

Collecting, 375

Cossus ligniperda, 245

Crœesus septentrionalis, 185

Cryphalus, characters of genus, 115 abietis, 116

fagi, 118

picere, 117

tiliæ, 117

Cryptocampus pentandre, 181

Cryptococcus fagi, 234

Cryptorrhynchus lapathi, 82

Cynipidæ, details of structure, 138 groups of, 140

Cynips Kollari, 158

Dactylopiinæ, 229

Dasyneura marginemtorquens, 342 cratregi, 344

taxi, 345

tiliam volens, 350

Deporaïs betuli, 67

Depressaria, characters of genus, 276 assimilella, 277 conterminella, 276

Diaspinæ, 206

Diaspis, 217

Dicranura vinula, 249

Digestive organs, 13

Digging in autumn, 388

Dioryctria abietella, 258

Diplosis botulariz, 351 dryobia, 352 tremulre, 353

Diptera, general characters of, $\mathbf{3 3 9}$

Dorcus parallelopipedus, 43

Drepanosiphum, generic characters of, 298 platanoides, 298

Dryobius, characters of genus, 314

Dryocretes, generic characters of, 120

villosus, 120 
Dryocetina, 114

Dryophanta divisa, 154

longiventris, 154

scutellaris, 153

Dryophanta folii, 153

Eccoptogaster scolytus, 93

Eggs of insects, 4

Elm-bark Beetle, 93

Entomology, principal orders, 3

Epurea angustala, 399

Erineum, 19

Eriophyes, life-history and microscopical characters, 21

fastidious as to food, 35

physiological functions, 22

species causing malformation of flowers, fruit, or leaves, 30

species living in buds, 23

species living in galls, 27

aucuparix, 32

avellane, 24

axillaris, 29

fraxini, 30

goniothorax, 31

livis, 29

macrochelus, 28

macrorhynchus, $2 S$

psilaspis, 26

rudis, 25

tetanothrix (levis), 29

tiliæ (typicus), 27

tiliarius, 30

Eriophyidar, 19

Eriophyinæ, sub-family, 23

dissemination of, 36

Ernobius mollis, 52

Euura pentandræ, 181

Eyed Hawk-Moth, the, 244

Eyes of insects, 9

Fidonia piniaria, 253

Forest Entomology, definition of, 1

Fumigation, 394

Gall-flies, setting of, 380

Gall-mites, 19

Geometrina, 253

Goat-moth, 245

Gracillaria syringella, 2s0

Green Tortrix Moth, 260

Harmandia tremule, 353

Head of insect, 9
Heart of insect, 14

Hedya ocellana, 265

Holcocneme Érichsonii, 156

Hormomyia caprex, 354

fagi, 354

piliger, 354

Hornet, 192

clear-wing of the osier, 244

Hybernia defoliaria, 257

Hylastes, characters of genus, 9s

ater, 100

palliatus, 99

Hylesinina, 98

Hylesinus, characters of genus, 101

crenatus, 101

fraxini, 103

oleiperda, 105

vittatus, 106

Hylesinus piniperda, 107

Hylobius abietis, 72

preventive and remedial measures against, 74

Hylurgus, generic characters of, 107 minor, 112

piniperda, 107

piniperda, preventive and remedial measures against, 111

Hymenoptera-oak-galls, 130

characters of, 164

miscellaneous, 192

saw-flies, 164

Hyponomeuta evonymellus, 272

Ichneumonidx, 400

Insect, general definition of, 3

Insecticides, 387

Insects, relative position in the animal kingdom, 2

Lachninæ, characters of tribes, 309

Lachnus, characters of genus, 310

longipes, 311

pini, 310

viminalis, 311

Lamiidre, 58

Larvæ, typical forms of, 5

Lasioptera rubi, 355

Leaf-wasps, 172

Lecanium, general characters of, 219 generic characters of, 221

bituberculatum, 226

caprere, 226

ciliatum, 225

persicæ, var. coryli, 225 
Leg, structure of, 11

Leopard Moth, 247

Lepidoptera, general characters of, 240

Lithocolletis, characters of genus, 285

carpinicolella, 287

coryli, 287

faginella, 287

messaniella, 285

salicicolella, 287

Longicornia, characters of, 53

family divisions of, 54

Lophyrides, 175

Lophyrus, characters of genus, 175 pini, 175 rufus, 178

Lygæonemetus saxeseni, $18 \mathrm{~S}$

Lucanidæ, 42

Lucanus cervus, 42

Macrodiplosis dryobia, 352

Macropsis lanio, 371

Marble gall, 158

Megastigmus spermotrophus, 194 strobilobius, 199

Melanoxanthus, characters of genus, 299

salicis, 300

Melasoma populi, 62

Melolontha, characters of genus, 44 preventive and remedial measures against, 46

hippocastani, 47

vulgaris, 44

Mikiola fagi, 354

Monochetus sulcatus, 33

Mottled Umber Moth, 257

Mounting, microscopic, 380

Musk Beetle, 55

Myelophilus piniperda, 107

Mytilaspis, generic characters of, 214

pomorum, 214

Myzus, generic characters of, 297 cerasi, 297

Nail-galls, 27

Nematinæ, 178

generic divisions, 179

Nematus abietinus, 188

bellus, 181

yallicola, 183

ischnocemus, 184 septentrionalis, 185

vallisnerii, 183

Nematus Erichsonii, 186

Nervous system, 12

Neuroterus fumipennis, 144

læviusculus, 145

lenticularis, 140

numismatis, 146

ostreus, 146

Novius cardinalis, 399

Oak-apple, 156

Oak-galls, 130

alternating generations of, 141

development of, 132

relation to theory of evolution, 134

synoptical table of, 159

their economic interest and teachings, 162

Ocelli, 9

Oligotrophus capree, 354 piliger, 354

Orchestes, generic characters of, 80 alni, 81

fagi, 80

quercûs, 81

Otiorrhynchus picipes, 68

sulcatus, 69

Pædisca occultana, 265

ophthalmicana, 266

Pemphiginæ, characters of tribe, 317

Pemphigus, characters of genus, 317 bursarius, 318

pallidus, 320

spirothecæ, 319

Penthina pruniana, 263

Philaneus spumaria, 371

Phlœophthorus, characters of genus, 113 rhododactylus, 113

Phratora vitelline, 64

Phyllaphis, characters of genus, 312 fagi, 312

Phyllereum, 20

Phyllobius maculicornis, 71

Phyllocoptinæ, 33

Phyllocoptes acericola, 34

Phyllodecta, characters of genus, $6 t$ vitelline, 64

Phylloxera, characters of genus, 336

punctata, 337 
Physokermes, characters of genus, Pulvinaria, characters of, 222

$$
228
$$

abietis, 228

Phytomyzc xylostei, 358

ilicis, 359

Phytomyzidie, characters of family, 358

Phytoptidie, 19

Phytoptus aceris, 34 calycophthirus, 25

myriadeum, 28

ribis, 19

rudis, 25

taxi, 26

Pine-bud Tortrix Moth, 268

Beauty Moth, 258

shoot Tortrix Moth, 268

Pine weevil, 72

Pissodes, characters of genus, 75 notatus, 78 pini, 76

Pityogenes, characters of genus, 122

bidens, 123

bidentatus, 123

Pityophthorus, characters of genus, 118

pubescens, 119

Polyclrusus micans, 71

Pontania bella, 182

gallicola, 183

ischnocerus, 184

proxima, 183

salicis, 181

Poplar Hawk-Moth, 243

Poplar-leaf Beetle, 62 large Longicorn Beetle of, 60 small Longicorn Beetle of, 61

Prays curtisellus, 273

Priobium castaneum, 51

Prionus corarius, 54

Proctotrypide, 401

Pseudococcus aceris, 232

Psyllidie, 363

Psylla alni, 368 buxi, 366 cratægi, 367

Psyllopsis fraxinicola, 364 fraxini, 364

Pterocallis, characters of genus, 309

tilixe, 309

Pteronus, characters of genus, 184 salicis, 184 vitis, 222

var. ribesixe, 223

Pupa, typical, 6

Puss Moth, 249

Pygera bucephala, 251

Reproductive organs of female, 15 organs of male, 17

Respiratory organs, 12

Retinia, characters of genus, 268 buoliana, 268

resinella, 270

turionana, 268

Rhabdophaga heterobia, 348 rosaria, 346

salicis, 349

Rhagium, characters of genus, 56

bifasciatum, 57

inquisitor, 56

Rhodites eglanterix, 193

rosie, 193

Rhopalomesites Tardyi, 84

Rhynchophora, characters of, 66

Rhynchota, 370

Saperda, generic characters of, 59 carcharias, 60

populnea, 61

Scale-insects, 201

Scarabæidæe, 44

Schizoneura, characters of genus, 315

ulmi, 316

Schizoneurinæ, 314

Scolytidi, descriptive characters of, S5

Scolytine, characters of sub-family, 92

Scolytus, characters of genus, 9 destructor, 93

Geotiroyi, 93

intricatus, 97

multistriatus, 96

pruni, 96

Sesia bembeciformis, 244

Sinodendron cylindricum, 43

Sirex gigas, 189 juvencus, 191

Siricidæ, 189

Smerinthus ocellatus, 244 populi, 243

Spathegaster albipes, 145

aprilinus, 147 
INDEX.

baccarum, 143

tricolor, 145

vesicatrix, 146

Spraying in nursery, 395

Stag-beetle, 42

Stigmonota regiana, 267

Stomaphis, characters of genus, 313

Strophosomus, characters of genus, 69

capitatus, 70

coryli, 70

Structure of insects, 8

Taphrina, 20

Tenthredinidæ, 172

Teras terminalis, 156

Tetraneura ulmi, 320

Thorax, 10

Tineæ, 271

Tomicus, characters of genus, 121 acuminatus, 122 sexdentatus, 121

Tortoiseshell butterfly, development of, 7

Tortricidæ, 259

Tortrix ribeana, 263 viridana, 260

Trachea piniperda, 25s

Tracher, 13

Trichiocampus viminalis, 180

Trichiosoma, characters of genus, 172 tibialis, 173

Trochilium bembeciformis, 244
Trypodendron, characters of genus, 125

domesticum, 127

lineatum, 126

quercus, 128

Two-winged flies, 339

Typhlocyba ulmi, 372

flammiger a, 372

quercûs, 372

Typhlocybidie, 372

Typical insect, 4 mouth parts, 9

Vapourer Moth, 248

Vedalia, 399

Vespa Crabro, 192

Volvulifex aceris, 34

Washing large trees, 396

Wasp Beetle, 55

Willow Beetle, 64

twig midge, 349

wood midge, 347

Winter Moth, 255

Wood-Wasps, 189

Xestobium tessellatum, 52

Xyleborus, characters of genus, 128 (lispar, 128

Xylocleptes, characters of genus, 119 bispinus, 119

Zeuzera resculi, 247

THE END. 





